\title{
NEPHELINE FORMATION STUDY FOR SLUDGE BATCH 4 (SB4): PHASE 3 EXPERIMENTAL RESULTS
}

\author{
K.M. Fox \\ T.B. Edwards \\ D.K. Peeler \\ D.R. Best \\ I.A. Reamer \\ R.J. Workman
}

May 2006

Process Science and Engineering Section Savannah River National Laboratory Aiken, SC 29808

Prepared for the U.S. Department of Energy Under Contract Number DEAC09-96SR18500

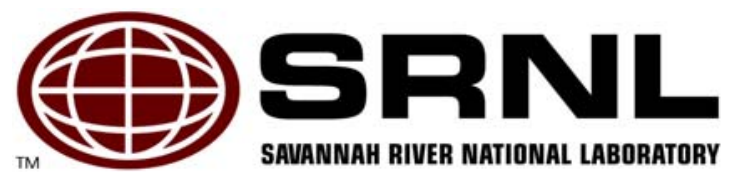


WSRC-TR-2006-00093

Revision 0

\section{DISCLAIMER}

This report was prepared by Washington Savannah River Company (WSRC) for the United States Department of Energy under Contract No. DE-AC09-96SR18500 and is an account of work performed under that contract. Neither the United States Department of Energy, nor WSRC, nor any of their employees makes any warranty, expressed or implied, or assumes any legal liability or responsibility for the accuracy, completeness, or usefulness, of any information, apparatus, or product or process disclosed herein or represents that its use will not infringe privately owned rights. Reference herein to any specific commercial product, process, or service by trademark, name, manufacturer or otherwise does not necessarily constitute or imply endorsement, recommendation, or favoring of same by WSRC or by the United States Government or any agency thereof. The views and opinions of the authors expressed herein do not necessarily state or reflect those of the United States Government or any agency thereof.

Printed in the United States of America

Prepared For U.S. Department of Energy

The Savannah River National Laboratory is operated for the U.S. Department of Energy by Washington Savannah River Company. 
Keywords: glass, durability, crystallization, nepheline

Retention: permanent

\section{NEPHELINE FORMATION STUDY FOR SLUDGE BATCH 4 (SB4): PHASE 3 EXPERIMENTAL RESULTS}

K.M. Fox

T.B. Edwards

D.K. Peeler

D.R. Best

I.A. Reamer

R.J. Workman

May 2006

Process Science and Engineering Section Savannah River National Laboratory Aiken, SC 29808

Prepared for the U.S. Department of Energy Under Contract Number DEAC09-96SR18500

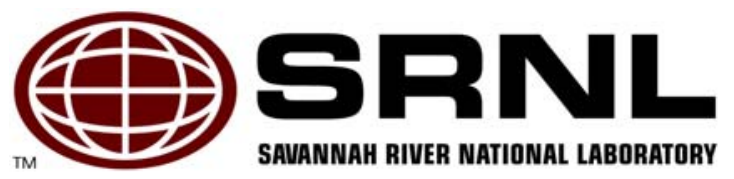




\section{REVIEWS AND APPROVALS}

AUTHORS:

K.M. Fox, Materials Science and Technology Section

Date

T.B. Edwards, Statistical Consulting Section

Date

D.K. Peeler, Process Science and Engineering Section

Date

D.R. Best, Process Science and Engineering Section

Date

I.A. Reamer, Process Science and Engineering Section

Date

R.J. Workman, Process Science and Engineering Section

Date

\section{TECHNICAL REVIEWER:}

M.E. Smith, Process Engineering Technology Group

Date

\section{APPROVERS:}

R.E. Edwards, Manager, Process Science and Engineering Section

Date

C.C. Herman, Manager, Process Engineering Technology Group

Date

J.E. Occhipinti, Manager, Process Cognizant Engineering

Date

Waste Solidification Engineering 


\section{EXECUTIVE SUMMARY}

This Phase 3 study was undertaken to complement the previous phases of the nepheline formation studies ${ }^{1,2}$ by continuing the investigation into the ability of the nepheline discriminator to predict the occurrence of nepheline crystallization in Sludge Batch 4 (SB4) glasses and into the impact of such phases on the durability of the SB4 glasses. The Phase 3 study had two primary objectives. The first was to continue to demonstrate the ability of the discriminator value to adequately predict the nepheline formation potential for specific glass systems of interest. The second was to generate additional data that have a high probability of supporting the SB4 variability study. To support these two objectives, sixteen glasses were selected based on the most recent SB4 compositional projection, Case $15 \mathrm{C}$ Blend $1 .^{3}$ Four different frits were included, based on previous assessments of projected operating windows and melt rate, ${ }^{4,5}$ with four WLs selected for each frit. Eight of these frit-sludge combinations covered WLs which tightly bound the nepheline discriminator value of 0.62 , with the intent of refining this value to a level of confidence where it can be incorporated into offline administrative controls and/or the Process Composition Control System (PCCS) to support Slurry Mix Evaporator (SME) acceptability decisions. The remaining eight frit-sludge combinations targeted lower WLs (35 and 40\%) and were prepared and analyzed to contribute needed data to the ComPro $^{\mathrm{TM}}$ database $^{6}$ to support a potential variability study for SB4.

Each Phase 3 glass was batched and melted following established SRNL procedures. ${ }^{7,8}$ Specimens of each glass were heat-treated to simulate cooling along the centerline of a DWPF-type canister (ccc) ${ }^{9}$ to gauge the effects of thermal history on the product performance. Visual observations on both quenched and ccc glasses were documented. A representative sample from each glass was submitted to the SRNL Process Science Analytical Laboratory (PSAL) for chemical analysis to confirm that the as-fabricated glasses corresponded to the defined target compositions. The Product Consistency Test $(\mathrm{PCT})^{10}$ was performed in triplicate on each Phase 3 quenched and ccc glass to assess chemical durability. The experimental test matrix also included the Environmental Assessment (EA) glass ${ }^{11}$ and the Approved Reference Material (ARM) glass. Representative samples of all Phase $3 \mathrm{ccc}$ glasses were submitted to Analytical Development (AD) for X-ray diffraction (XRD) analysis.

Chemical composition measurements indicated that the experimental glasses were close to their target compositions. The chemical composition data suggest essentially full retention of $\mathrm{SO}_{4}{ }^{2-}$ in the glass (i.e., no volatilization during the fabrication process). There were no signs of a salt layer on any of the Phase 3 glasses upon cooling. These results suggest that the $0.6 \mathrm{wt} \% \mathrm{SO}_{4}{ }^{2-}$ limit is applicable for the SB4 system.

PCT results showed that all of the Phase 3 quenched glasses were acceptable as compared with the EA reference glass. The highest normalized release for boron (NL [B]) for the quenched glasses was $1.26 \mathrm{~g} / \mathrm{L}$, as compared to $16.695 \mathrm{~g} / \mathrm{L}$ for the EA glass. ${ }^{11}$ The durabilities of some of the ccc glasses, particularly those with higher WLs, were statistically greater than their quenched counterparts. However, this was shown to be of little practical significance, as the durabilities of the ccc glasses were also all considerably better than that of the EA reference glass, with the highest NL [B] being $3.23 \mathrm{~g} / \mathrm{L}$. All but one of the glasses in the Phase 3 study had durabilities that were predictable based on the $\Delta \mathrm{G}_{\mathrm{P}}$ model. The glass that was not predicable using the model contained both spinel and nepheline, and had a nepheline discriminator value of less than 0.62 . Since the glass was not homogenous, it is expected that the model will not correctly predict its performance. ${ }^{12}$ Also, a glass with a nepheline discriminator value of less than 0.62 is likely to be screened out from production at DWPF upon implementation of a nepheline discriminator in PCCS. 
Visual observations and PCT results indicated that all of the Phase 3 quenched glasses were amorphous. For the ccc glasses, XRD results indicated that the lower WL glasses (35 and $40 \mathrm{wt} \%$ ) in each frit-sludge group were amorphous. The higher WL glasses in each frit-sludge group were shown by XRD to contain spinel (trevorite, $\mathrm{NiFe}_{2} \mathrm{O}_{4}$ ). XRD showed that two of the highest WL glasses contained nepheline $\left(\mathrm{NaAlSiO}_{4}\right)$ as well. It is possible that some of the other high WL glasses also contained some nepheline, but that the amount of nepheline crystallization was below the detection limit associated with XRD (estimated to be $\sim 0.5 \mathrm{wt} \%$ ). Nepheline crystallization was shown to result in a decrease in durability for some of the high WL glasses. In the worst case (within the glasses studied here), the NL [B] increased from $1.26 \mathrm{~g} / \mathrm{L}$ (quenched) to $3.23 \mathrm{~g} / \mathrm{L}(\mathrm{ccc})$. However, this $\mathrm{NL}[\mathrm{B}]$ is still acceptable as compared to the EA reference glass $(16.695 \mathrm{~g} / \mathrm{L}) .{ }^{11}$

The results of the Phase 3 study concur with the earlier phases of the nepheline studies in that a nepheline discriminator of 0.62 appears to be the appropriate value for screening out glasses with the potential for nepheline crystallization (and therefore reduced chemical durabilities) upon slow cooling. The nepheline discriminator was also useful in screening out a glass that would be unpredictable by the $\Delta \mathrm{G}_{\mathrm{P}}$ model. ${ }^{12}$ Further discussion of a nepheline discriminator for possible inclusion in DWPF process controls will be addressed in a forthcoming report.

With respect to frit selection for SB4, the Phase 3 results indicate that Frits 418, 425, 501 and 502 are all acceptable candidates, based on chemical durability and devitrification upon slow cooling. Differences in chemical durability and devitrification behavior were relatively small between the four frits studied as part of Phase 3. The results also indicate that WLs of 35-40 $\mathrm{wt} \%$ should produce acceptable glasses with these frits. However, melt rate is also an important factor in frit selection. Melt rate studies on these frits are currently underway, and will likely have a significant impact on frit selection due to the high $\mathrm{Al}_{2} \mathrm{O}_{3}$ content of SB4. 


\section{TABLE OF CONTENTS}

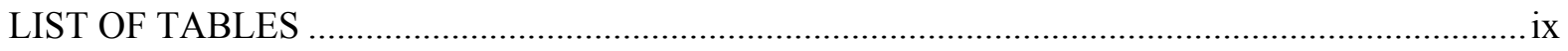

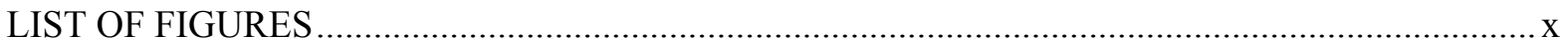

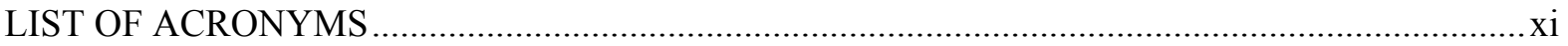

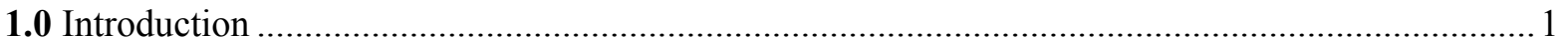

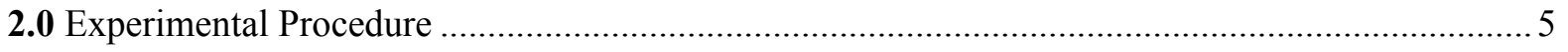

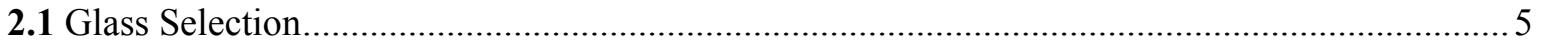

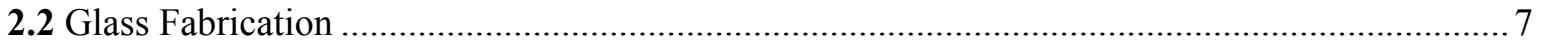

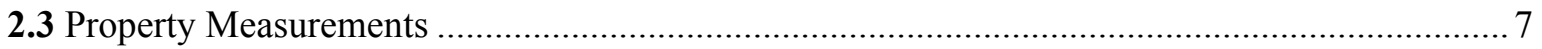

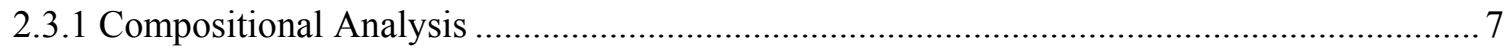

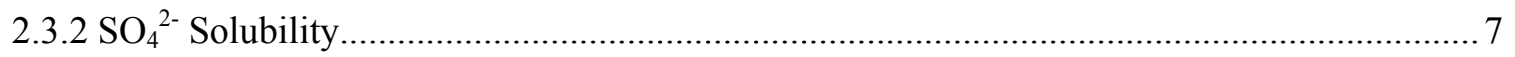

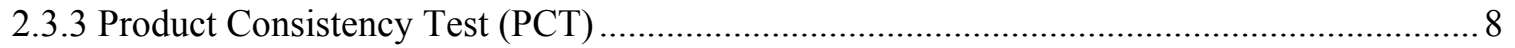

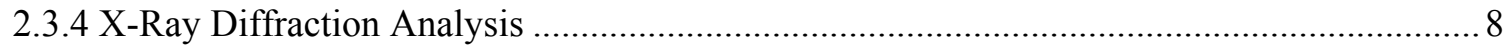

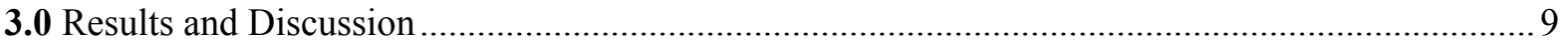

3.1 A Statistical Review of the Chemical Composition Measurements for the Phase 3 Nepheline

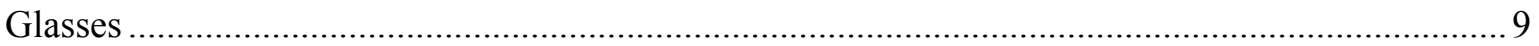

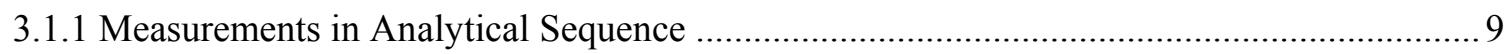

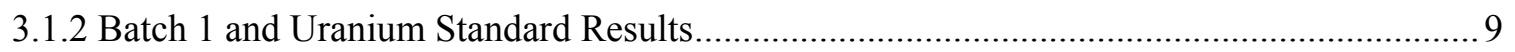

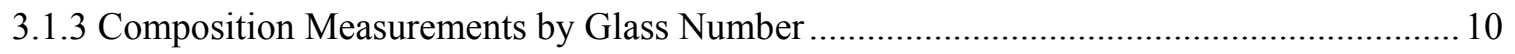

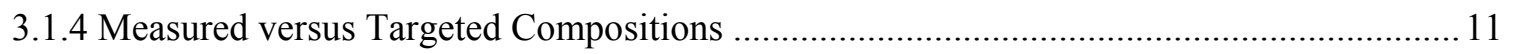

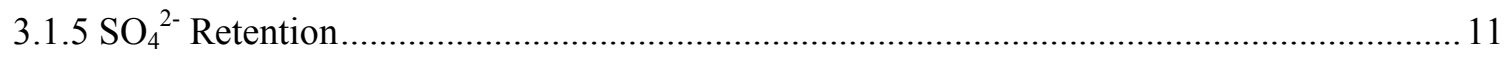

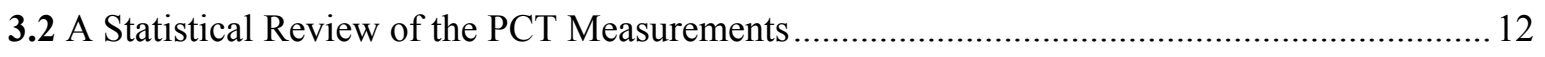

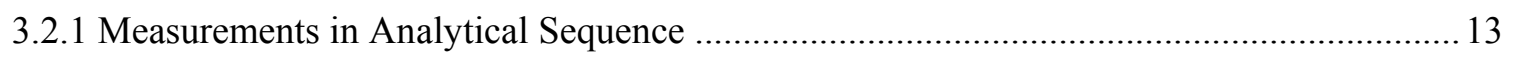

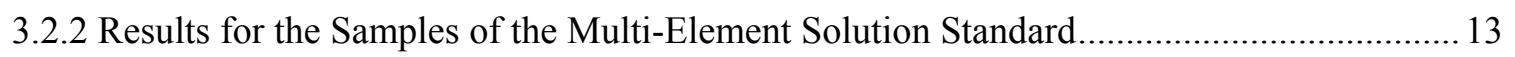

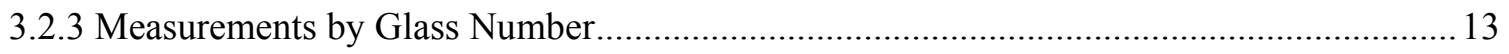

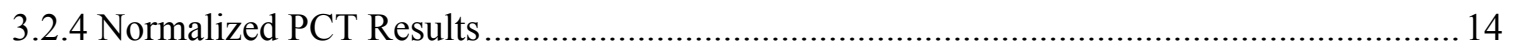

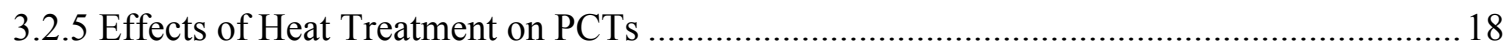

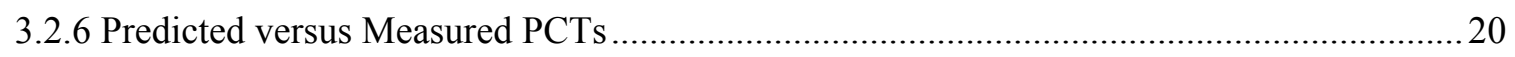

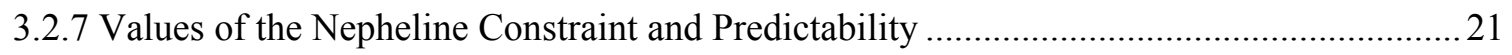

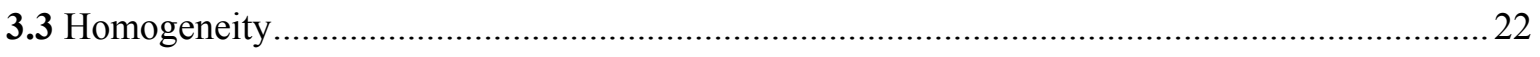

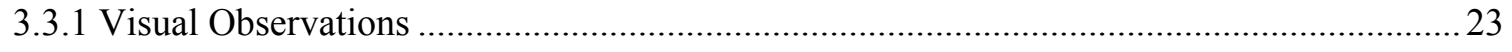

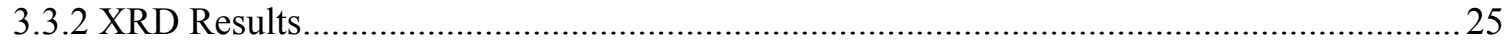

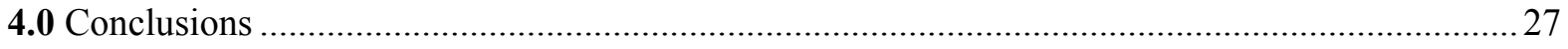




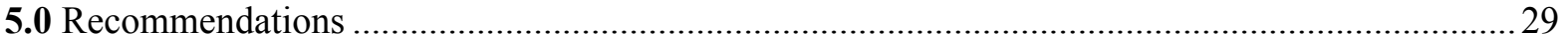

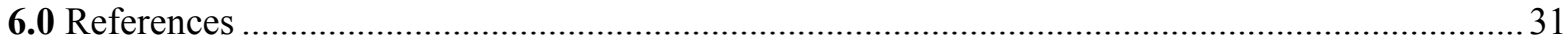

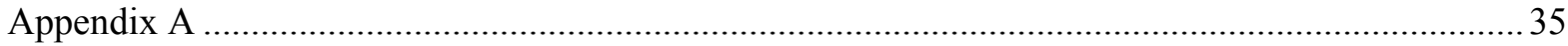

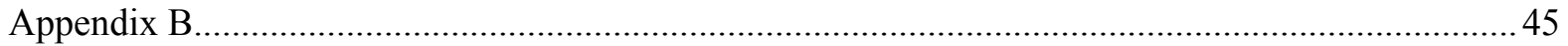

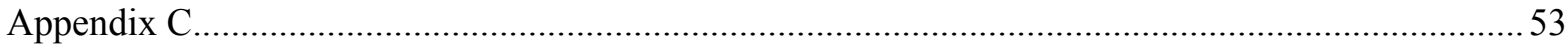

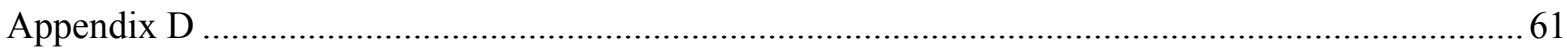

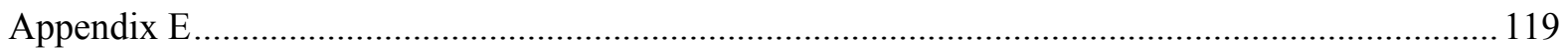




\section{LIST OF TABLES}

Table 2-1. Composition of Candidate Frits 5

Table 2-2. Target Compositions of Glasses Selected for SB4 Case 15C Blend 1 in wt $\%$.................. 6

Table 3-1. Results from Samples of the Multi-Element Solution Standard ...................................... 13

Table 3-2. Normalized Release Values for the Nepheline Phase 3 Glasses ..................................... 15

Table 3-3. Values of the nepheline discriminator calculated for each glass using the measured, measured bias-corrected, and targeted compositions. ............................................................. 20

Table 3-4. Visual observations and XRD results for the Phase 3 glasses. ....................................... 24 


\section{LIST OF FIGURES}

Figure 3-1. Targeted versus measured $\mathrm{SO}_{4}{ }^{2-}$ values for the Phase 3 glasses..................................... 12

Figure 3-2. Normalized boron release and nepheline discriminator values for the quenched and ccc Phase 3 glasses. . 19

Figure 3-3. NL [B] versus $\Delta \mathrm{G}_{\mathrm{P}}$ for the quenched and ccc Phase 3 glasses. .................................... 21

Figure 3-4. Scatter Plot Matrix of $\log \mathrm{NL}\left[\mathrm{B}\right.$ g/L], Nepheline Constraint, and $\Delta \mathrm{G}_{\mathrm{P}} \ldots \ldots \ldots \ldots \ldots \ldots \ldots \ldots . . . . . . . . . . . .22$ 


\section{LIST OF ACRONYMS}

\begin{tabular}{ll} 
AD & Analytical Development \\
ANOVA & Analysis of Variance \\
ARM & Approved Reference Material glass \\
ARP & Actinide Removal Process \\
bc & bias-corrected \\
CBU & Closure Business Unit \\
ccc & centerline canister cooled \\
DWPF & Defense Waste Processing Facility \\
EA & Environmental Assessment glass \\
HLW & High Level Waste \\
ICP-AES & Inductively Coupled Plasma - Atomic Emission Spectroscopy \\
LM & lithium-metaborate dissolution \\
LWO & Liquid Waste Operations \\
MAR & Measurement Acceptability Region \\
PCCS & Product Composition Control System \\
PCT & Product Consistency Test \\
PF & sodium peroxide fusion dissolution \\
PSAL & Process Science Analytical Laboratory \\
SB4 / SB5 & Sludge Batch 4 / Sludge Batch 5 \\
SME & Slurry Mix Evaporator \\
SRL & Savannah River Laboratory \\
SRNL & Savannah River National Laboratory \\
$T_{L}$ & liquidus temperature \\
WL & Waste Loading (weight percent) \\
XRD & \\
& X-Ray Diffraction \\
\hline &
\end{tabular}


WSRC-TR-2006-00093

Revision 0

This page intentionally left blank. 
WSRC-TR-2006-00093

Revision 0

\subsection{Introduction}

Crystallization (or devitrification) is an important factor in the processing and performance of nuclear waste glass. In terms of processing, the Defense Waste Processing Facility (DWPF) uses a liquidus temperature $\left(\mathrm{T}_{\mathrm{L}}\right)$ model $^{13}$ and an imposed $\mathrm{T}_{\mathrm{L}}$ limit for feed acceptability to avoid bulk devitrification within the melter. In terms of product quality or the durability of the waste form, the impact of devitrification depends on the type and extent of crystallization.

Numerous studies ${ }^{9,14-19}$ have assessed the potential for devitrification in various high level waste (HLW) glasses and its impact on durability. These studies generally agree that the impact of devitrification on durability is dependent upon the type and extent of crystallization. For example, a strong increase in the rate of glass dissolution (or decrease in durability) was observed in previous studies ${ }^{16,20,21}$ of glasses that formed aluminum-containing crystals, such as $\mathrm{NaAlSiO}_{4}$ (nepheline) and LiAlSi ${ }_{2} \mathrm{O}_{6}$, or crystalline $\mathrm{SiO}_{2}$. This is in contrast to the results from a study by Bickford and Jantzen. ${ }^{14}$ Their results indicated that the formation of spinel had little or no effect on the durability of Savannah River Laboratory (SRL) 165- or SRL 131-based glasses, while the formation of acmite produced a small but noticeable increase in the rate of dissolution of the matrix glass. The impact of devitrification on durability is complex and depends on several interrelated factors including the change in residual glass composition, the development of internal stress or microcracks, and preferential attack at the glass - crystal interface.

While the addition of $\mathrm{Al}_{2} \mathrm{O}_{3}$ to borosilicate glasses generally enhances the durability of the waste form (through creation of network-forming tetrahedral $\mathrm{Na}^{+}-\left[\mathrm{AlO}_{4 / 2}\right]^{-}$pairs), nepheline formation, which depends in part on the $\mathrm{Al}_{2} \mathrm{O}_{3}$ content, can result in severe deterioration of the chemical durability of the glass through residual glass compositional changes. Three moles of glass forming oxides $\left(\mathrm{Al}_{2} \mathrm{O}_{3}\right.$ and $\left.2 \mathrm{SiO}_{2}\right)$ are removed from the continuous glass phase per each mole of $\mathrm{Na}_{2} \mathrm{O}$ as nepheline crystallizes. Therefore, nepheline formation produces an $\mathrm{Al}_{2} \mathrm{O}_{3}$ and $\mathrm{SiO}_{2}$ deficient continuous glass matrix (relative to the same composition without crystallization) which reduces the durability of the final product. The magnitude of the reduction ultimately depends on the extent (volume fraction) of crystallization.

Li et al. ${ }^{18,22}$ indicated that sodium alumino-borosilicate glasses are prone to nepheline crystallization if their compositions projected on the $\mathrm{Na}_{2} \mathrm{O}-\mathrm{Al}_{2} \mathrm{O}_{3}-\mathrm{SiO}_{2}$ ternary fall within or close to the nepheline primary phase field. In particular, glasses with $\mathrm{SiO}_{2} /\left(\mathrm{SiO}_{2}+\mathrm{Na}_{2} \mathrm{O}+\mathrm{Al}_{2} \mathrm{O}_{3}\right)>0.62$, where the chemical formulae stand for the mass fractions in the glass, do not tend to precipitate nepheline as a primary crystalline phase. The potential for formation of nepheline and/or other aluminum/silicon-containing crystals exists in the Sludge Batch 4 (SB4) system based on the projected compositional views coupled with the initial frit development strategy. Compositional projections of Sludge Batch 4 (SB4) ${ }^{23}$ indicate that the sludge will be enriched in $\mathrm{Al}_{2} \mathrm{O}_{3}$ relative to the $\mathrm{Al}_{2} \mathrm{O}_{3}$ concentrations of previous sludge batches processed through the DWPF. Candidate frits have been identified which range in $\mathrm{Na}_{2} \mathrm{O}$ concentration from $8-13 \%$ by mass for the $\mathrm{SB} 4$ compositional projections. ${ }^{24}$ The combination of high $\mathrm{Al}_{2} \mathrm{O}_{3}$ and $\mathrm{Na}_{2} \mathrm{O}$ concentrations, coupled with lower $\mathrm{SiO}_{2}$ concentrations as waste loadings are increased (given the primary source of $\mathrm{SiO}_{2}$ is from the frit), shifts the composition toward the nepheline phase field, raising the potential for nepheline crystallization. Therefore, strategic frit development efforts ${ }^{4}$ have been made to suppress the development of nepheline formation by lowering the $\mathrm{Na}_{2} \mathrm{O}$ content while increasing $\mathrm{B}_{2} \mathrm{O}_{3}, \mathrm{Fe}_{2} \mathrm{O}_{3}$, and/or $\mathrm{Li}_{2} \mathrm{O}$ concentration in the frit. 
Peeler et al. ${ }^{1,25}$ provided insight into the potential impact of nepheline formation on SB4 glasses based on the Lilliston ${ }^{23}$ SB4 compositional projections. In that study (referred to as Phase 1), twelve SB4-based glasses were fabricated (only two of which were prone to nepheline formation using the 0.62 value $^{22}$ as a guide) and the durability of each was measured. The results indicated that all the glasses in the study (both quenched and centerline canister cooled (ccc)) had a durability as defined by the Product Consistency Test (PCT $)^{10}$ that was acceptable. More specifically, the normalized boron release (NL [B]) values for all the Phase 1 nepheline glasses were much lower than the Environmental Assessment (EA) glass value of $16.695 \mathrm{~g} / \mathrm{L} .{ }^{11}$ The most durable glass was NEPH-04 (quenched) with a NL [B] of $0.61 \mathrm{~g} / \mathrm{L}$, while the least durable glass was NEPH-01 (ccc) with a NL $[\mathrm{B}]$ of $2.47 \mathrm{~g} / \mathrm{L}$ (based on the measured composition).

The Phase 1 PCT results suggested that for the two glasses prone to nepheline formation (NEPH-01 and NEPH-02), a statistically significant difference in PCT response was observed between the quenched and ccc versions but the impact on durability was of little or no practical concern. When the PCT responses were coupled with the X-ray diffraction (XRD) results and/or visual observations, it was concluded that the formation of nepheline in these glasses did have a negative impact on durability. However, the impact (as seen by a difference between the quenched and ccc PCT responses), while statistically significant, was not of practical concern.

The results of the Phase 1 study suggested that the 0.62 value, as proposed by Li et al., ${ }^{22}$ appeared to be a reasonable guide to monitor the potential for nepheline formation in the alumino-borosilicate based SB4 glass system. The results also suggested that the presence of nepheline in the glasses studied during this phase had little or no practical impact on durability as measured by the PCT. This latter statement must be qualified to some extent given that only two glasses were selected which were actually prone to nepheline formation based on the general guide and that the volume fraction of nepheline formed based on XRD results was relatively low $(\sim 0.5$ vol.\%). Given that the waste loadings (WLs) for the Phase 1 glasses were limited to 40\%, if higher WLs were considered, the potential for nepheline formation (and potentially the volume fraction of crystallization) could increase, and the likelihood of observing a significant and practical difference in PCT response could be realized.

After issuance of the Phase 1 report, revised compositional projections from the Closure Business Unit (CBU) for SB4 were issued. ${ }^{26,27}$ These revised projections were framed around three decision areas: the sodium molarity of the sludge (at values of $1 \mathrm{M} \mathrm{Na}^{+}$and $1.6 \mathrm{M} \mathrm{Na}^{+}$), the Sludge Batch 3 (SB3) heel that will be included in the batch (expressed in inches of SB3 sludge with values of 0, 40, and 127"), and the introduction of an Actinide Removal Process (ARP) stream into the sludge (which was represented by six options: no ARP, ARP-A, ARP-E, ARP-K, ARP-M, and ARP-V). In response to these revised projections, candidate frits whose operating windows (i.e., waste loading intervals that meet Product Composition Control System (PCCS) Measurement Acceptability Region (MAR) criteria) are robust to and/or selectively optimal for these sludge options were identified via a paper study approach. ${ }^{28}$ The results of that paper study indicated that candidate frits are available for the various SB4 options which provide relatively large operating windows. Besides the revised compositional projections, the primary difference between this second assessment ${ }^{28}$ and the first ${ }^{24}$ was that the 0.62 nepheline discriminator value was used as a screening tool to evaluate the potential impact of nepheline formation on the projected operating windows. The results of activating the nepheline discriminator ${ }^{28}$ indicated that access to higher WLs for almost all SB4 frit - sludge options was restricted when the nepheline discriminator was applied. That is, a relatively large WL interval was available in which all PCCS MAR criteria were satisfied except for the nepheline discriminator value. This suggested possible issues associated with crystallization and its impact on durability. Therefore, the value of the nepheline discriminator was challenged to determine if access to those higher WLs could be regained without compromising durability. 
Twenty eight glasses were identified for Phase 2 of the nepheline study ${ }^{29}$ that intentionally challenged the nepheline discriminator value based on the $1.6 \mathrm{M} \mathrm{Na}^{+}, 40$ " and $1.6 \mathrm{M} \mathrm{Na}^{+}, 127$ " sludge options. ${ }^{26}$,

${ }^{27}$ These Phase 2 glasses were selected to complement the Phase 1 study ${ }^{1}$ by continuing the investigation into the ability of the nepheline discriminator to predict the crystallization of nepheline in SB4 glasses and the impact of nepheline crystallization on durability. In general, the Phase 2 glasses were selected to cover WLs over which nepheline was the only criterion restricting acceptability. The primary difference between the Phase 1 and Phase 2 nepheline studies is that Phase 2 challenged the nepheline discriminator for all glasses - not just a few select glasses as in Phase 1 . In order to meet this objective, WLs of $\sim 40 \%$ or higher were targeted for the Phase 2 glasses whereas $40 \%$ was the maximum WL used during Phase 1 . As previously mentioned, the probability of nepheline formation increases when WL increases (at higher WLs, $\mathrm{Al}_{2} \mathrm{O}_{3}$ and $\mathrm{Na}_{2} \mathrm{O}$ concentrations increase and the $\mathrm{SiO}_{2}$ concentration decreases).

The Phase 2 glasses were fabricated and the durability of each (as measured by the PCT) was assessed for both quenched and ccc samples. All of the Phase 2 quenched glasses had normalized boron releases of less than $1.19 \mathrm{~g} / \mathrm{L}$, which is approximately an order of magnitude better than the EA benchmark glass. ${ }^{11}$ However, the potential for crystallization was suppressed kinetically in the quenched glasses. That is, the glasses may be prone to nepheline formation but the rapid cooling limited the formation of nepheline (or other crystalline phases).

For the ccc glasses, visual observations suggested that as the targeted WL within a specific frit sludge system was increased, the degree of crystallization became more extensive. This is not unexpected as the slower cooling provides a glass with a composition that is thermodynamically favorable for nepheline formation (i.e., a composition that falls within the nepheline primary phase field) the kinetic opportunity to devitrify. XRD results indicated the presence of nepheline, trevorite $\left(\mathrm{NiFe}_{2} \mathrm{O}_{4}\right)$, and/or lithium silicate $\left(\mathrm{Li}_{2} \mathrm{SiO}_{3}\right)$ in select Phase $2 \mathrm{ccc}$ glasses. In general, as the WL increased within a specific frit - sludge system, the glass transitioned from amorphous or from containing crystalline phase(s) such as spinels at the lowest WL, to spinel and nepheline at the intermediate WL, and ultimately to spinel, nepheline, and lithium silicate at the highest WL. As a result, the difference between the quenched and ccc PCT response for each specific frit system increased as WL increased. Coupling this trend with the crystallization results, one can easily explain the durability responses as a function of WL. As WL increased within a specific frit - sludge system, the durability of the ccc based glasses decreased due to the formation of nepheline and/or lithium silicate. These trends are in agreement with previous observations that the impact on durability is dependent upon the type and extent of crystallization and the resulting change to the residual glass composition.

The results of the Phase 1 and Phase 2 studies suggest that the 0.62 value is a reasonable guide to monitor SB4 - frit systems for potential nepheline formation upon ccc. The significance of "ccc" in this sentence is based on the fact that none of the Phase 1 or Phase 2 quenched glasses showed any sign of nepheline formation (based on the PCT response) although some of the Phase 2 glasses had nepheline discriminator values as low as 0.541 . It was only when the glass was provided the kinetic opportunity to devitrify through the slow ccc schedule that nepheline formed and had an adverse impact on durability.

In Phase 2, the lower WL glasses showed no significant or practical differences in durability when comparing quenched and ccc glasses, which is consistent with the Phase 1 results. It was only at the higher WLs that nepheline formation had a significant impact on durability, where cec glasses had normalized releases for boron that exceeded that of the EA glass. The practical implication to DWPF is that higher WL glasses should be avoided for these types of glass systems (i.e., those containing 
high $\mathrm{Al}_{2} \mathrm{O}_{3}$ and $\mathrm{Na}_{2} \mathrm{O}$ ). The primary question becomes: how can potential nepheline formation regions be avoided or controlled in DWPF if necessary? A formal recommendation of the specific path was not made in the Phase 2 report, ${ }^{2}$ but a general discussion was provided on available options. These included: (1) use of an administrative control on waste loading, (2) implementation of a nepheline discriminator value in the Product Composition Control System (PCCS), or (3) strategic frit development efforts to mitigate nepheline formation.

For Phase 3 of the nepheline study, 16 glasses have been selected to complement the earlier work ${ }^{1,2}$ by continuing the investigation into the ability of the nepheline discriminator to predict the occurrence of nepheline crystallization in SB4 glasses and into the impact of such phases on the durability of the SB4 glasses. The Phase 3 study has two primary objectives. The first is to continue to demonstrate the ability of the discriminator value to adequately predict the nepheline formation potential for specific glass systems of interest. The second is to generate additional data that have a high probability of supporting the SB4 variability study. To support these two objectives, glasses were selected to cover WLs that tightly bound the nepheline discriminator value of 0.62 , with the intent of refining this value to a level of confidence where it can be incorporated into offline administrative controls and/or the PCCS to support Slurry Mix Evaporator (SME) acceptability decisions. In addition, glasses targeting lower WLs (35 and 40\%) were prepared and analyzed to contribute needed data to the ComPro ${ }^{\mathrm{TM}}$ database in anticipation of a variability study for SB4.

The results of this study will provide valuable input for the frit development efforts and subsequent feedback to Liquid Waste Operations (LWO) regarding the viability of four of the frit options under consideration and the need for incorporating a nepheline discriminator into administrative or process controls. Additional data provided through other studies, such as melt rate information, will also influence the frit recommendation decision for SB4 vitrification. The work was initiated by a Technical Task Request ${ }^{30}$ and is covered by a Technical Task and QA Plan. ${ }^{31}$ 
WSRC-TR-2006-00093

Revision 0

\subsection{Experimental Procedure}

\subsection{Glass Selection}

A detailed description of the Phase 3 glass selection process has been given in a previous report. ${ }^{32} \mathrm{~A}$ brief summary is provided below. It should be noted that although the primary focus of these glasses is $\mathrm{SB} 4$, the Phase 3 data will be applicable to other high $\mathrm{Al}_{2} \mathrm{O}_{3}$ waste streams, such as SB5.

In selecting the Phase 3 glasses, a window of nepheline discriminator values was first determined using the Phase 1 and 2 results. The lower end of the window was set at a value of 0.59 , where it was expected that the glasses would begin to have a measurable difference in PCT response between the quenched and ccc specimens, but would not have unacceptable (EA-like) responses. The upper end of the window was set at 0.62 , as the previous phases of the work have shown this value to be a reliable indicator of the potential for nepheline crystallization in ccc glasses.

The frits considered in this study, including two frits (Frit 418 and Frit 425) used for the earlier frit development efforts, ${ }^{28}$ are described in Table $2-1$. These frits are currently primary candidates for use with SB4 based on previous assessments of projected operating windows and melt rate. ${ }^{4,5}$

Table 2-1. Composition (as mass fractions) of Candidate Frits

\begin{tabular}{|c|c|c|c|c|}
\hline Frit ID & $\mathbf{B}_{\mathbf{2}} \mathbf{O}_{\mathbf{3}}$ & $\mathbf{L i}_{\mathbf{2}} \mathbf{O}$ & $\mathbf{N a}_{\mathbf{2}} \mathbf{O}$ & $\mathbf{S i O}_{\mathbf{2}}$ \\
\hline 418 & 0.08 & 0.08 & 0.08 & 0.76 \\
\hline 425 & 0.08 & 0.08 & 0.10 & 0.74 \\
\hline 501 & 0.09 & 0.10 & 0.05 & 0.76 \\
\hline 502 & 0.08 & 0.11 & 0.05 & 0.76 \\
\hline
\end{tabular}

Only one sludge option, Case 15C Blend 1 ( 96 inch SB3 heel, $1.4 \mathrm{M} \mathrm{Na}^{+}$before blending), ${ }^{3}$ was employed in the Phase 3 selection process as this option is seen as providing the most likely representation of SB4. This sludge option was combined with the four frits in Table 2-1 in a paper study where the PCCS MAR assessments and nepheline discriminator values were determined for a WL interval of 25 to $60 \%{ }^{4}$ The WLs for each sludge - frit combination that gave nepheline discriminator values at the upper and lower bounds of the window described above were then chosen for this Phase 3 study. The paper study indicated that some of the higher WLs chosen will produce glasses that have an unacceptable $\mathrm{T}_{\mathrm{L}}$ or viscosity based on the PCCS MAR results. This was intentionally disregarded in favor of concentrating on the potential for nepheline formation.

In addition, glass compositions at WLs of 35 and 40\% (a range more likely to be used by DWPF) were chosen to contribute needed data to the $\mathrm{ComPro}^{\mathrm{TM}}$ database $^{6}$ in anticipation of a variability study for SB4. The 16 glass compositions generated by the selection process are given in Table 2-2. Unique identifiers for these glasses are provided in the first row of the table, and the value of the nepheline discriminator for each glass is also included. 
Table 2-2. Target Compositions of Glasses Selected for SB4 Case 15C Blend 1 in wt\%

\begin{tabular}{|c|c|c|c|c|c|c|c|c|c|c|c|c|c|c|c|c|}
\hline Glass ID & $\begin{array}{c}\text { NEPH } \\
3-41\end{array}$ & $\begin{array}{c}\text { NEPH } \\
3-42\end{array}$ & $\begin{array}{c}\mathrm{NEPH} \\
3-43\end{array}$ & $\begin{array}{c}\text { NEPH } \\
3-44\end{array}$ & $\begin{array}{c}\text { NEPH } \\
3-45\end{array}$ & $\begin{array}{c}\text { NEPH } \\
3-46\end{array}$ & $\begin{array}{c}\text { NEPH } \\
3-47\end{array}$ & $\begin{array}{c}\text { NEPH } \\
3-48\end{array}$ & $\begin{array}{c}\text { NEPH } \\
3-49\end{array}$ & $\begin{array}{c}\text { NEPH } \\
3-50\end{array}$ & $\begin{array}{c}\text { NEPH } \\
3-51\end{array}$ & $\begin{array}{c}\text { NEPH } \\
3-52\end{array}$ & $\begin{array}{c}\text { NEPH } \\
3-53\end{array}$ & $\begin{array}{c}\text { NEPH } \\
3-54\end{array}$ & $\begin{array}{c}\text { NEPH } \\
3-55\end{array}$ & $\begin{array}{c}\text { NEPH } \\
3-56\end{array}$ \\
\hline Frit ID & 418 & 418 & 418 & 418 & 501 & 501 & 501 & 501 & 425 & 425 & 425 & 425 & 502 & 502 & 502 & 502 \\
\hline$\% \mathrm{WL}$ & 35 & 40 & 46 & 50 & 35 & 40 & 47 & 51 & 35 & 40 & 44 & 48 & 35 & 40 & 48 & 51 \\
\hline $\begin{array}{c}\text { neph. } \\
\text { discrim. }\end{array}$ & 0.702 & 0.667 & 0.624 & 0.593 & 0.721 & 0.685 & 0.631 & 0.599 & 0.684 & 0.650 & 0.622 & 0.594 & 0.721 & 0.685 & 0.623 & 0.599 \\
\hline $\mathrm{Al}_{2} \mathrm{O}_{3}$ & 8.682 & 9.922 & 11.411 & 12.403 & 8.682 & 9.922 & 11.659 & 12.651 & 8.682 & 9.922 & 10.915 & 11.907 & 8.682 & 9.922 & 11.907 & 12.651 \\
\hline $\mathrm{B}_{2} \mathrm{O}_{3}$ & 5.200 & 4.800 & 4.320 & 4.000 & 5.850 & 5.400 & 4.770 & 4.410 & 5.200 & 4.800 & 4.480 & 4.160 & 5.200 & 4.800 & 4.160 & 3.920 \\
\hline $\mathrm{BaO}$ & 0.044 & 0.050 & 0.058 & 0.063 & 0.044 & 0.050 & 0.059 & 0.064 & 0.044 & 0.050 & 0.056 & 0.061 & 0.044 & 0.050 & 0.061 & 0.064 \\
\hline $\mathrm{CaO}$ & 0.836 & 0.955 & 1.098 & 1.194 & 0.836 & 0.955 & 1.122 & 1.218 & 0.836 & 0.955 & 1.051 & 1.146 & 0.836 & 0.955 & 1.146 & 1.218 \\
\hline $\mathrm{Ce}_{2} \mathrm{O}_{3}$ & 0.052 & 0.060 & 0.069 & 0.075 & 0.052 & 0.060 & 0.070 & 0.076 & 0.052 & 0.060 & 0.066 & 0.072 & 0.052 & 0.060 & 0.072 & 0.076 \\
\hline $\mathrm{Cr}_{2} \mathrm{O}_{3}$ & 0.074 & 0.085 & 0.098 & 0.106 & 0.074 & 0.085 & 0.100 & 0.108 & 0.074 & 0.085 & 0.093 & 0.102 & 0.074 & 0.085 & 0.102 & 0.108 \\
\hline $\mathrm{CuO}$ & 0.021 & 0.024 & 0.028 & 0.030 & 0.021 & 0.024 & 0.028 & 0.031 & 0.021 & 0.024 & 0.026 & 0.029 & 0.021 & 0.024 & 0.029 & 0.031 \\
\hline $\mathrm{Fe}_{2} \mathrm{O}_{3}$ & 9.298 & 10.626 & 12.220 & 13.283 & 9.298 & 10.626 & 12.486 & 13.548 & 9.298 & 10.626 & 11.689 & 12.751 & 9.298 & 10.626 & 12.751 & 13.548 \\
\hline $\mathrm{K}_{2} \mathrm{O}$ & 0.120 & 0.138 & 0.158 & 0.172 & 0.120 & 0.138 & 0.162 & 0.175 & 0.120 & 0.138 & 0.151 & 0.165 & 0.120 & 0.138 & 0.165 & 0.175 \\
\hline $\mathrm{La}_{2} \mathrm{O}_{3}$ & 0.038 & 0.043 & 0.050 & 0.054 & 0.038 & 0.043 & 0.051 & 0.055 & 0.038 & 0.043 & 0.048 & 0.052 & 0.038 & 0.043 & 0.052 & 0.055 \\
\hline $\mathrm{Li}_{2} \mathrm{O}$ & 5.200 & 4.800 & 4.320 & 4.000 & 6.500 & 6.000 & 5.300 & 4.900 & 5.200 & 4.800 & 4.480 & 4.160 & 7.150 & 6.600 & 5.720 & 5.390 \\
\hline $\mathrm{MgO}$ & 0.873 & 0.998 & 1.148 & 1.248 & 0.873 & 0.998 & 1.173 & 1.273 & 0.873 & 0.998 & 1.098 & 1.198 & 0.873 & 0.998 & 1.198 & 1.273 \\
\hline $\mathrm{MnO}$ & 1.918 & 2.192 & 2.521 & 2.740 & 1.918 & 2.192 & 2.576 & 2.795 & 1.918 & 2.192 & 2.411 & 2.630 & 1.918 & 2.192 & 2.630 & 2.795 \\
\hline $\mathrm{Na}_{2} \mathrm{O}$ & 12.928 & 13.632 & 14.477 & 15.040 & 10.978 & 11.832 & 13.027 & 13.711 & 14.228 & 14.832 & 15.315 & 15.798 & 10.978 & 11.832 & 13.198 & 13.711 \\
\hline $\mathrm{NiO}$ & 0.552 & 0.631 & 0.726 & 0.789 & 0.552 & 0.631 & 0.741 & 0.804 & 0.552 & 0.631 & 0.694 & 0.757 & 0.552 & 0.631 & 0.757 & 0.804 \\
\hline $\mathrm{PbO}$ & 0.032 & 0.036 & 0.042 & 0.045 & 0.032 & 0.036 & 0.043 & 0.046 & 0.032 & 0.036 & 0.040 & 0.043 & 0.032 & 0.036 & 0.043 & 0.046 \\
\hline $\mathrm{SO}_{4}{ }^{2-}$ & 0.468 & 0.535 & 0.615 & 0.669 & 0.468 & 0.535 & 0.629 & 0.682 & 0.468 & 0.535 & 0.589 & 0.642 & 0.468 & 0.535 & 0.642 & 0.682 \\
\hline $\mathrm{SiO}_{2}$ & 50.840 & 47.245 & 42.932 & 40.057 & 50.840 & 47.245 & 42.213 & 39.338 & 49.540 & 46.045 & 43.250 & 40.454 & 50.840 & 47.245 & 41.494 & 39.338 \\
\hline $\mathrm{ThO}_{2}$ & 0.023 & 0.026 & 0.030 & 0.033 & 0.023 & 0.026 & 0.031 & 0.034 & 0.023 & 0.026 & 0.029 & 0.032 & 0.023 & 0.026 & 0.032 & 0.034 \\
\hline $\mathrm{TiO}_{2}$ & 0.009 & 0.011 & 0.012 & 0.013 & 0.009 & 0.011 & 0.013 & 0.014 & 0.009 & 0.011 & 0.012 & 0.013 & 0.009 & 0.011 & 0.013 & 0.014 \\
\hline $\mathrm{U}_{3} \mathrm{O}_{8}$ & 2.674 & 3.056 & 3.515 & 3.820 & 2.674 & 3.056 & 3.591 & 3.897 & 2.674 & 3.056 & 3.362 & 3.667 & 2.674 & 3.056 & 3.667 & 3.897 \\
\hline $\mathrm{ZnO}$ & 0.034 & 0.039 & 0.045 & 0.049 & 0.034 & 0.039 & 0.046 & 0.050 & 0.034 & 0.039 & 0.043 & 0.047 & 0.034 & 0.039 & 0.047 & 0.050 \\
\hline $\mathrm{ZrO}_{2}$ & 0.083 & 0.095 & 0.109 & 0.119 & 0.083 & 0.095 & 0.111 & 0.121 & 0.083 & 0.095 & 0.104 & 0.114 & 0.083 & 0.095 & 0.114 & 0.121 \\
\hline
\end{tabular}




\subsection{Glass Fabrication}

Each Phase 3 glass was prepared from the proper proportions of reagent-grade metal oxides, carbonates, $\mathrm{H}_{3} \mathrm{BO}_{3}$, and salts in 150 -g batches. ${ }^{7}$ The raw materials were thoroughly mixed and placed into a $95 \%$ Platinum $/ 5 \%$ Gold $250-\mathrm{mL}$ crucible. The batch was placed into a high-temperature furnace at the target melt temperature of $1150^{\circ} \mathrm{C}^{8}$ After an isothermal hold at $1150^{\circ} \mathrm{C}$ for $1.0 \mathrm{~h}$, the crucible was removed from the furnace. The glass was poured onto a clean stainless steel plate and allowed to air cool (quench). The glass pour patty was used as a sampling stock for the various property measurements (i.e., chemical composition and durability).

Approximately $25 \mathrm{~g}$ of each glass was heat-treated to simulate cooling along the centerline of a DWPF-type canister ${ }^{9}$ to gauge the effects of thermal history on the product performance. This cooling schedule is referred to as the ccc curve. Visual observations on both quenched and ccc glasses were documented. ${ }^{\mathrm{a}}$

\subsection{Property Measurements}

This section provides a general discussion of the chemical composition analyses, the PCTs, and the XRD analyses of the Phase 3 glasses.

\subsubsection{Compositional Analysis}

To confirm that the as-fabricated glasses corresponded to the defined target compositions, a representative sample from each glass was submitted to the SRNL Process Science Analytical Laboratory (PSAL) for chemical analysis under the auspices of an analytical plan. The plan (see Appendix A) identified the cations to be analyzed and the dissolution techniques (i.e., sodium peroxide fusion $[\mathrm{PF}]$ and lithium-metaborate $[\mathrm{LM}])$ to be used. The samples prepared by LM were used to measure for barium $(\mathrm{Ba})$, calcium $(\mathrm{Ca})$, cerium $(\mathrm{Ce})$, chromium $(\mathrm{Cr})$, copper $(\mathrm{Cu})$, potassium $(\mathrm{K})$, lanthanum $(\mathrm{La})$, magnesium $(\mathrm{Mg})$, sodium $(\mathrm{Na})$, lead $(\mathrm{Pb})$, sulfur $(\mathrm{S})$, thorium $(\mathrm{Th})$, titanium $(\mathrm{Ti})$, zinc $(\mathrm{Zn})$, and zirconium $(\mathrm{Zr})$ concentrations. Samples prepared by PF were used to measure for aluminum (Al), boron (B), iron (Fe), lithium (Li), manganese (Mn), nickel (Ni), silicon ( $\mathrm{Si})$, and uranium (U). Each glass was prepared in duplicate for each cation dissolution technique (PF and LM). All of the prepared samples were analyzed (twice for each element of interest) by Inductively Coupled Plasma - Atomic Emission Spectroscopy (ICP-AES) with the instrumentation being recalibrated between the duplicate analyses. The analytical plan was developed in such a way as to provide the opportunity to evaluate potential sources of error. Glass standards were also intermittently measured to assess the performance of the ICP-AES instrument over the course of these analyses.

\subsection{2 $\mathrm{SO}_{4}{ }^{2-}$ Solubility}

Although not a primary focus of the Phase 3 work, $\mathrm{SO}_{4}{ }^{2-}$ solubility is a secondary concern in this study. The applicability of the current $0.6 \mathrm{wt} \% \mathrm{SO}_{4}{ }^{2-}$ limit (established for the Frit $418-\mathrm{SB} 3$ system ${ }^{33}$ ) to SB4 was investigated. From Table 2-2, the targeted $\mathrm{SO}_{4}{ }^{2-}$ concentrations in the Phase 3 glasses range from 0.468 to $0.682 \mathrm{wt} \%$. Previous tests have suggested that the use of reagent grade raw materials is conservative with respect to $\mathrm{SO}_{4}{ }^{2-}$ retention and/or volatility. ${ }^{\mathrm{b}}$ Since the Phase 3 glasses have both high $\mathrm{SO}_{4}{ }^{2-}$ concentrations and are batched from reagent grade raw materials, the

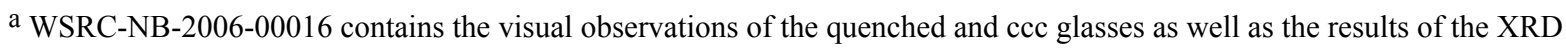
and PCT analyses for the Phase 3 glasses.

$\mathrm{b}$ Previous results have indicated that the use of raw materials (reagent grade chemicals) to produce the glasses minimizes $\mathrm{SO}_{4}{ }^{2-}$ volatilization during the fabrication process. Since volatilization is anticipated in slurry-fed melters, this approach will provide a conservative measure of $\mathrm{SO}_{4}^{2-}$ retention in the glass.
} 
ability of the glasses to retain the targeted $\mathrm{SO}_{4}{ }^{2-}$ concentrations will provide valuable insight into the applicability of the $\mathrm{SO}_{4}{ }^{2-}$ limit to $\mathrm{SB} 4$. Both visual observations (i.e., formation of a salt layer on the surface of the glass indicating that $\mathrm{SO}_{4}{ }^{2-}$ limit has been exceeded) and a comparison of measured versus targeted $\mathrm{SO}_{4}{ }^{2-}$ concentrations were used to support this assessment.

\subsubsection{Product Consistency Test (PCT)}

The $\mathrm{PCT}^{10}$ was performed in triplicate on each Phase 3 quenched and ccc glass to assess chemical durability. Also included in the experimental test matrix was the EA glass, ${ }^{11}$ the Approved Reference Material (ARM) glass, and blanks from the sample cleaning batch. Samples were ground, washed, and prepared according to the standard procedure. ${ }^{10}$ Fifteen milliliters of Type I American Society for Testing and Materials (ASTM) water were added to $1.5 \mathrm{~g}$ of glass in stainless steel vessels. The vessels were closed, sealed, and placed in an oven at $90 \pm 2{ }^{\circ} \mathrm{C}$ where the samples were maintained for 7 days. Once cooled, the resulting solutions were sampled (filtered and acidified), then labeled and analyzed by PSAL under the auspices of two analytical plans (see Appendices B and C). ${ }^{\text {a }}$ The aim of the plans was to provide an opportunity to assess the consistency (repeatability) of the PCT and analytical procedures to evaluate the chemical durability of the Phase 3 glasses. Normalized release rates were calculated based on targeted, measured, and bias-corrected (bc) compositions using the average of the logs of the leachate concentrations.

\subsubsection{X-Ray Diffraction Analysis}

Although visual observations for crystallization were performed and documented, representative samples for all ccc Phase 3 glasses were submitted to Analytical Development (AD) for X-ray diffraction (XRD) analysis. The quenched glasses were not submitted for XRD analyses based on visual observations and the PCT responses. Samples were run under conditions providing a detection limit of approximately $0.5 \mathrm{vol} \%$. That is, if crystals (or undissolved solids) were present at $0.5 \mathrm{vol} \%$ or greater, the diffractometer will not only be capable of detecting the crystals but will also allow a qualitative determination of the type of crystal(s) present. Otherwise, a characteristically high background devoid of crystalline spectral peaks indicates that the glass product is amorphous, suggesting either a completely amorphous product or that the degree of crystallization is below the detection limit.

\footnotetext{
a One analytical plan (SRNL-SCS-2006-00003) was developed to assess the PCT solutions resulting from the NEPH3-41 to NEPH3-48 glasses, while a second plan (SRNL-SCS-2006-00007) was developed for the NEPH3-49 to NEPH3-56 glasses.
} 
WSRC-TR-2006-00093

Revision 0

\subsection{Results and Discussion}

\subsection{A Statistical Review of the Chemical Composition Measurements for the Phase 3 Nepheline Glasses}

In this section, the measured versus targeted compositions of the 16 Phase 3 Nepheline study glasses (NEPH3-41 through NEPH3-56) are presented and compared. The targeted compositions for these glasses are provided in Table 2-2 (also shown in Table D1 of Appendix D). Chemical composition measurements for these glasses were conducted by PSAL following the analytical plan provided in Appendix A as described in Section 2.3.1. For each study glass, measurements were obtained from samples prepared in duplicate by both the LM and PF dissolution methods.

Table D2 in Appendix D provides the elemental concentration measurements derived from the samples prepared using LM, and Table D3 in Appendix D provides the measurements derived from the samples prepared using PF. Measurements for standards (Batch 1 and a uranium standard, $U_{\text {std }}$ ) that were included in the PSAL analytical plan along with the study glasses are also provided in these two tables.

The elemental concentrations were converted to oxide concentrations by multiplying the values for each element by the gravimetric factor for the corresponding oxide. During this process, an elemental concentration that was determined to be below the detection limit of the analytical procedures used by the PSAL was reduced to half of that detection limit as the oxide concentration was determined.

In the sections that follow, the analytical sequences of the measurements are explored, the measurements of the standards are investigated and used for bias correction, the measurements for each glass are reviewed, the average chemical compositions (measured and bias-corrected) for each glass are determined, and comparisons are made between the measurements and the targeted compositions for the glasses.

\subsubsection{Measurements in Analytical Sequence}

Exhibit D1 in Appendix D provides plots of the measurements generated by the PSAL for samples prepared using the LM method. The plots are in analytical sequence with different symbols and colors being used to represent each of the study and standard glasses. Similar plots for the samples prepared using the PF method are provided in Exhibit D2 in Appendix D. These plots include all of the measurement data from Tables D2 and D3. A review of these plots indicates no significant patterns or trends in the analytical process over the course of these measurements, and there appear to be no obvious outliers in these chemical composition measurements. One minor exception is the measurement of $\mathrm{Na}_{2} \mathrm{O}$ concentration in glass NEPH3-44. The $\mathrm{Na}_{2} \mathrm{O}$ measurements for this single glass varied by 2.5 to $3 \mathrm{wt} \%$, which should not cause any difficulty in evaluating the results.

\subsubsection{Batch 1 and Uranium Standard Results}

In this section, the PSAL measurements of the chemical compositions of the Batch 1 and uranium standard $\left(\mathrm{U}_{\text {std }}\right)$ glasses are reviewed. These measurements are investigated across the ICP analytical blocks, and the results are used to bias correct the measurements for the study glasses.

Exhibit D3 in Appendix D provides statistical analyses of the Batch 1 and $\mathrm{U}_{\text {std }}$ results generated by the LM prep method by block for each oxide of interest. The results include analysis of variance (ANOVA) investigations looking for statistically significant differences between the block means for each of the oxides for each of the standards. The results from the statistical tests for the Batch 1 standard may be summarized as follows: $\mathrm{BaO}, \mathrm{CaO}, \mathrm{Ce}_{2} \mathrm{O}_{3}, \mathrm{Cr}_{2} \mathrm{O}_{3}, \mathrm{CuO}, \mathrm{MgO}, \mathrm{Na}_{2} \mathrm{O}, \mathrm{TiO}_{2}$, and $\mathrm{ZrO}_{2}$ 
have measurements that indicate a significant ICP calibration effect on the block averages at the 5\% significance level. For the $\mathrm{U}_{\text {std }}, \mathrm{CaO}, \mathrm{Ce}_{2} \mathrm{O}_{3}, \mathrm{Cr}_{2} \mathrm{O}_{3}, \mathrm{CuO}, \mathrm{MgO}, \mathrm{MnO}, \mathrm{Na}_{2} \mathrm{O}, \mathrm{ThO}_{2}$ (a detection limit effect), and $\mathrm{TiO}_{2}$ have measurements that indicate a significant ICP calibration effect on the block averages at the 5\% significance level. The reference values for the oxide concentrations of the standard are given in the header for each set of measurements in the exhibit.

Exhibit D4 in Appendix D provides a similar set of analyses for the measurements derived from samples prepared via the PF method. The results from the statistical tests for the Batch 1 standard may be summarized as follows: only $\mathrm{B}_{2} \mathrm{O}_{3}$ has measurements that indicate a significant ICP calibration effect on the block averages at the 5\% significance level. For the $U_{\text {std }}$, none of the oxides have measurements that indicate a significant ICP calibration effect on the block averages at the 5\% significance level. The reference values for the oxide concentrations of the standard are given in the headers for each set of measurements in the exhibit.

Some of these results provide incentive for adjusting the measurements by the effect of the ICP calibration. Therefore, the oxide measurements of the study glasses were bias corrected for the effect of the ICP calibration on each of the analytical blocks. The basis for this bias correction is presented as part of Exhibits D3 and D4 - the average measurement for Batch 1 for each ICP block/sub-block for $\mathrm{Al}_{2} \mathrm{O}_{3}, \mathrm{~B}_{2} \mathrm{O}_{3}, \mathrm{BaO}, \mathrm{CaO}, \mathrm{Cr}_{2} \mathrm{O}_{3}, \mathrm{CuO}, \mathrm{Fe}_{2} \mathrm{O}_{3}, \mathrm{~K}_{2} \mathrm{O}, \mathrm{Li}_{2} \mathrm{O}, \mathrm{MgO}, \mathrm{MnO}, \mathrm{Na} 2 \mathrm{O}, \mathrm{NiO}, \mathrm{SiO}_{2}$, and $\mathrm{TiO}_{2}$ and the average measurement for $\mathrm{U}_{\text {std }}$ for each ICP set/block for $\mathrm{U}_{3} \mathrm{O}_{8}$. The Batch 1 results served as the basis for bias correcting all of the oxides (that were bias corrected) except uranium. The $U_{\text {std }}$ results were used to bias correct for uranium. For the other oxides, the Batch 1 results were used to conduct the bias correction as long as the reference value for the oxide concentration in the Batch 1 glass was greater than or equal to $0.1 \mathrm{wt} \%$. Applying this approach and based upon the information in the exhibits, the Batch 1 results were used to bias correct the $\mathrm{Al}_{2} \mathrm{O}_{3}, \mathrm{~B}_{2} \mathrm{O}_{3}, \mathrm{BaO}, \mathrm{CaO}, \mathrm{Cr}_{2} \mathrm{O}_{3}, \mathrm{CuO}$, $\mathrm{Fe}_{2} \mathrm{O}_{3}, \mathrm{~K}_{2} \mathrm{O}, \mathrm{Li}_{2} \mathrm{O}, \mathrm{MgO}, \mathrm{MnO}, \mathrm{Na}_{2} \mathrm{O}, \mathrm{NiO}, \mathrm{SiO}_{2}$, and $\mathrm{TiO}_{2}$ measurements. No bias correction was conducted for $\mathrm{Ce}_{2} \mathrm{O}_{3}, \mathrm{La}_{2} \mathrm{O}_{3}, \mathrm{PbO}, \mathrm{SO}_{4}{ }^{2-}, \mathrm{ThO}_{2}, \mathrm{ZnO}$, or $\mathrm{ZrO}_{2}$.

The bias correction was conducted as follows. For each oxide, let $\bar{a}_{i j}$ be the average measurement for the $i^{\text {th }}$ oxide at analytical block $j$ for Batch 1 (or $\mathrm{U}_{\text {std }}$ for uranium), and let $t_{i}$ be the reference value for the $i^{\text {th }}$ oxide for Batch 1 (or for $\mathrm{U}_{\text {std }}$ if uranium). The averages and reference values are provided in Exhibits D3 and D4. Let $\bar{c}_{i j k}$ be the average measurement for the $i^{\text {th }}$ oxide at analytical block $j$ for the $k^{\text {th }}$ glass. The bias adjustment was conducted as follows:

$$
\bar{c}_{i j k} \bullet\left(1-\frac{\bar{a}_{i j}-t_{i}}{\bar{a}_{i j}}\right)=\bar{c}_{i j k} \bullet \frac{t_{i}}{\bar{a}_{i j}}
$$

Bias-corrected measurements are indicated by a "bc" suffix, and such adjustments were performed for all of the oxides of this study except for $\mathrm{Ce}_{2} \mathrm{O}_{3}, \mathrm{La}_{2} \mathrm{O}_{3}, \mathrm{PbO}, \mathrm{SO}_{4}{ }^{2-}, \mathrm{ThO}_{2}, \mathrm{ZnO}$, and $\mathrm{ZrO}_{2}$. Both measured and measured "bc" values are included in the discussion that follows. In these discussions, the measured values for $\mathrm{Ce}_{2} \mathrm{O}_{3}, \mathrm{La}_{2} \mathrm{O}_{3}, \mathrm{PbO}, \mathrm{SO}_{4}{ }^{2-}, \mathrm{ThO}_{2}, \mathrm{ZnO}$, and $\mathrm{ZrO}_{2}$ are duplicated as the measured-bc values for completeness (e.g., to allow a sum of oxides to be computed for the biascorrected results). These bias-corrected values are the same as the original, measured $\mathrm{Ce}_{2} \mathrm{O}_{3}, \mathrm{La}_{2} \mathrm{O}_{3}$, $\mathrm{PbO}, \mathrm{SO}_{4}{ }^{2-}, \mathrm{ThO}_{2}, \mathrm{ZnO}$, and $\mathrm{ZrO}_{2}$ values.

\subsubsection{Composition Measurements by Glass Number}

Exhibits D5 and D6 in Appendix D provide plots of the oxide concentration measurements by Glass ID \# (including both Batch 1, labeled as glass numbered 100 and $\mathrm{U}_{\text {std, }}$ labeled as glass numbered 200) 
for the measured and bc values for the LM and PF preparation methods, respectively. Different symbols and colors are used to represent the different glasses. These plots show the individual measurements across the duplicates of each preparation method and the two ICP calibrations. A review of the plots presented in these exhibits reveals the repeatability of the four individual oxide values for each glass. The sole exception is the $\mathrm{Na}_{2} \mathrm{O}$ concentration of glass NEPH3-44, which should not have a significant impact on the results presented here. More detailed discussions of the average, measured chemical compositions of the study glasses are provided in the sections that follow.

\subsubsection{Measured versus Targeted Compositions}

The four measurements for each oxide for each glass (over both preparation methods) were averaged to determine a representative chemical composition for each glass. These determinations were conducted both for the measured and for the bias-corrected data. A sum of oxides was also computed for each glass based upon both the measured and bias-corrected values. Exhibit D7 in Appendix D provides plots showing results for each glass for each oxide to help highlight the comparisons among the measured, bias-corrected, and targeted values.

Table D4 in Appendix D provides a summary of the average compositions as well as the targeted compositions and some associated differences and relative differences. Notice that the targeted sums of oxides for the standard glasses do not sum to $100 \%$ due to an incomplete coverage of the oxides in the Batch 1 (glass \# 100) and $U_{\text {std }}$ (glass \# 200) glasses. All of the sums of oxides (both measured and bias-corrected) for the study glasses fall within the interval of 95 to $105 \mathrm{wt} \%$. Entries in Table D4 show the relative differences between the measured or bias-corrected values and the targeted values. These differences are shaded when they are greater than or equal to 5\%. Overall, these comparisons between the measured and targeted compositions suggest only minor difficulties in hitting the targeted compositions for some of the oxides (including $\mathrm{CaO}, \mathrm{Fe}_{2} \mathrm{O}_{3}$, and $\mathrm{NiO}$ ) for some of the glasses. These should have no impact on the conclusions drawn to support the objectives of this report.

\subsection{5 $\mathrm{SO}_{4}{ }^{2-}$ Retention}

Although not the primary focus of the Phase 3 study, a secondary concern is the potential need to redefine the $\mathrm{SO}_{4}{ }^{2-}$ solubility limit for SB4. The compositional analysis, coupled with the visual observations of the as-fabricated glasses (see Section 3.3.1), will serve as primary indicators to determine whether the current $0.6 \mathrm{wt} \% \mathrm{SO}_{4}{ }^{2-}$ limit (established for the Frit $418-\mathrm{SB} 3$ system ${ }^{33}$ ) is still applicable for SB4. From Table 2-2, the targeted $\mathrm{SO}_{4}{ }^{2-}$ concentrations in the Phase 3 glasses range from $0.468 \mathrm{wt} \%$ (NEPH3-41) to $0.682 \mathrm{wt} \%$ (NEPH3-48).

Figure 3-1 summarizes the targeted versus measured $\mathrm{SO}_{4}{ }^{2-}$ concentrations in glass. The purple line represents the targeted concentrations as noted in Table 2-2. The red data points represent the measured $\mathrm{SO}_{4}{ }^{2-}$ concentrations in the glass, while the green data points are the measured, biascorrected values. The data suggest essentially full retention in the glass (i.e., no solubility or volatilization issues during the fabrication process). Although the visual observations are discussed in Section 3.3.1 in more detail, there were no signs of a salt layer on any of the Phase 3 glasses upon fabrication. Coupling the analytical measurements with visual observations of the as-fabricated glasses, the results suggest that the $0.6 \mathrm{wt} \% \mathrm{SO}_{4}{ }^{2-}$ limit is applicable for these frit - SB4 systems. The degree of $\mathrm{SO}_{4}{ }^{2-}$ retention does not appear to be frit-dependent for the systems studied here. If the $\mathrm{SO}_{4}{ }^{2-}$ concentration in the SB4 feed to DWPF contains the projected levels, then no issues with $\mathrm{SO}_{4}{ }^{2-}$ solubility are anticipated. 
Oxide $=\mathrm{SO}_{4}{ }^{2-}(\mathbf{w t} \%)$

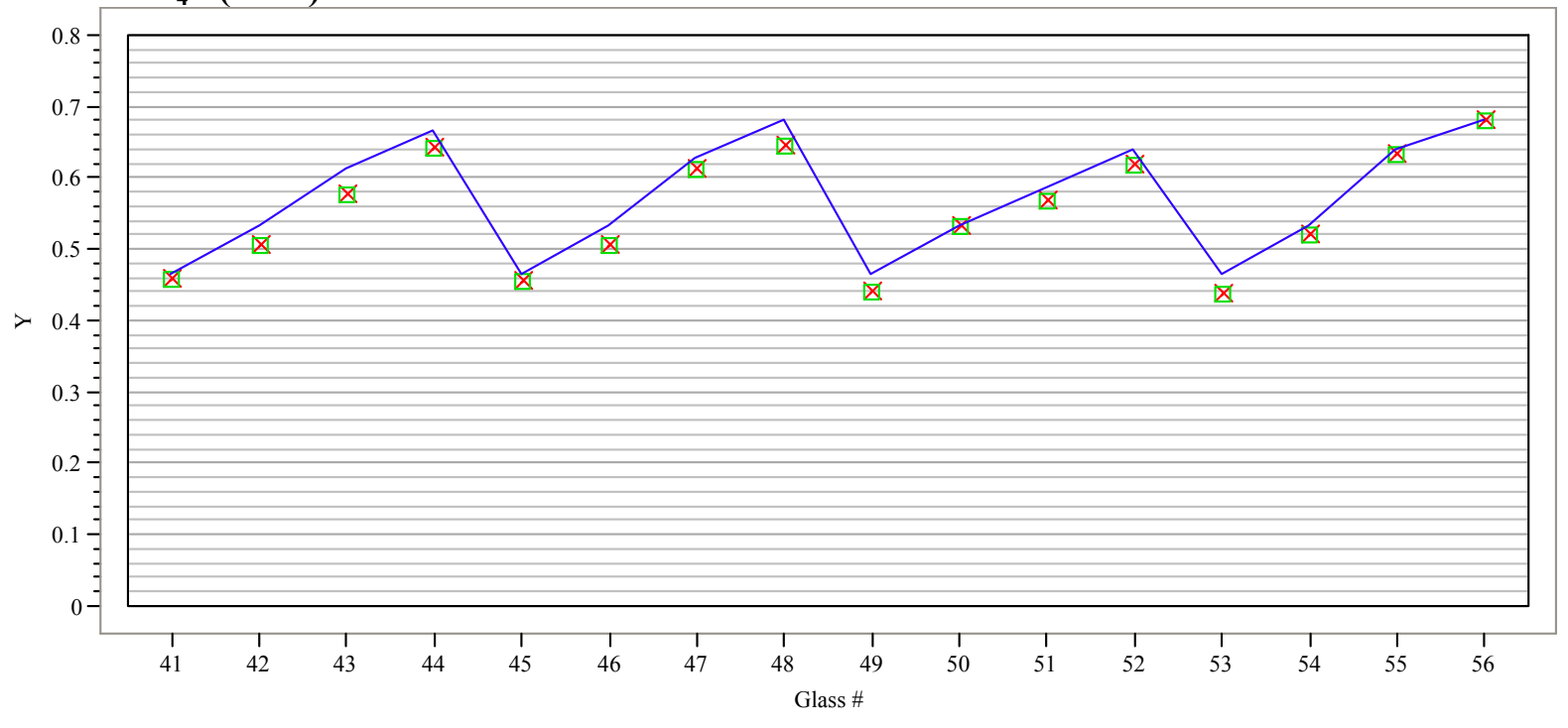

x Measured $\quad$ Measured bc Targeted

Figure 3-1. Targeted versus measured $\mathrm{SO}_{4}{ }^{2-}$ values for the Phase 3 glasses.

\subsection{A Statistical Review of the PCT Measurements}

The nepheline study glasses, after being batched and fabricated, were subjected to the 7-day PCT to assess their durabilities. ${ }^{10}$ Durability is the critical product quality metric for DWPF glass studies. Two heat treatments (quenched and ccc) were used during the fabrication of each of the study glasses. Both heat treatments for each study glass were subjected to the PCT (in triplicate). PCTs were also conducted in triplicate for samples of the EA glass and for samples of the ARM glass. Blanks (samples consisting only of ASTM Type I water) were also submitted for the PCT.

Analytical plans, presented in the appendices, were provided to the PSAL to support the measurement of the compositions of the solutions resulting from the PCTs which were conducted in two parts. Samples of a multi-element, standard solution were also included in the analytical plans as a check of the accuracy of the ICP-AES instrument used for these measurements. In this and the following sections, the measurements generated by the PSAL for these PCTs are presented and reviewed.

Table E1 in Appendix E provides the elemental leachate concentration measurements determined by the PSAL for the solution samples generated by the PCTs. One of the quality control checkpoints for the PCT procedure is solution-weight loss over the course of the 7-day test. None of these PCT results indicated a solution-weight loss problem. Any measurement in Table E1 below the detection limit of the analytical procedure (indicated by a "<") was replaced by $1 / 2$ of the detection limit in subsequent analyses. In addition to adjustments for detection limits, the values were adjusted for the dilution factors: the values for the study glasses, the blanks, and the ARM glass in Table E1 were multiplied by 1.6667 to determine the values in parts per million (ppm) and the values for EA were multiplied by 16.6667. Table E2 in Appendix E provides the resulting measurements.

One of the important objectives of this study is the investigation of the effects of heat treatment on the PCTs. In the sections that follow, the analytical sequence of the measurements is explored, the measurements of the standards are investigated and used to assess the overall accuracy of the ICP 
measurement process, the measurements for each glass are reviewed, plots are provided that explore the effects of heat treatment on the PCTs for these glasses, the PCTs are normalized using the compositions (targeted, measured, and bias-corrected) presented in Table D4, and the normalized PCTs are compared to durability predictions for these compositions generated from the current DWPF models. ${ }^{12}$

\subsubsection{Measurements in Analytical Sequence}

Exhibits E1 and E2 in Appendix E provide plots of the leachate concentrations (ppm) in analytical sequence as generated by the PSAL for all of the data and for the data from only the study glasses, respectively. A different color and symbol are used for each study glass or standard. No problems are seen in these plots.

\subsubsection{Results for the Samples of the Multi-Element Solution Standard}

Exhibit E3 in Appendix E provides analyses of the PSAL measurements of the samples of the multielement solution standard by ICP analytical (or calibration) block. An ANOVA investigating for statistically significant differences among the part/block averages for these samples for each element of interest is included in these exhibits. These results indicate a statistically significant (at approximately a 5\% level) difference among only the B average measurements over these parts/blocks. However, no bias correction of the PCT results for the study glasses was conducted. This approach was taken since the triplicate PCTs for a single study glass were placed in different ICP blocks. Averaging the ppm's for each set of triplicates helps to minimize the impact of the ICP effects.

Table 3-1 summarizes the average measurements and the reference values for the four primary elements of interest. The results indicate consistent and accurate measurements from the PSAL processes used to conduct these analyses.

Table 3-1. Results from Samples of the Multi-Element Solution Standard

\begin{tabular}{|c|c|c|c|c||}
\hline $\begin{array}{c}\text { Analytical } \\
\text { Part/Block }\end{array}$ & $\begin{array}{c}\text { Avg B } \\
\text { (ppm) }\end{array}$ & $\begin{array}{c}\text { Avg Li } \\
\text { (ppm) }\end{array}$ & $\begin{array}{c}\text { Avg Na } \\
\text { (ppm) }\end{array}$ & $\begin{array}{c}\text { Avg Si } \\
\text { (ppm) }\end{array}$ \\
\hline $1 / 1$ & 19.4 & 9.7 & 82.2 & 49.4 \\
\hline $1 / 2$ & 20.8 & 9.6 & 79.3 & 49.4 \\
\hline $1 / 3$ & 21.0 & 9.7 & 80.1 & 49.3 \\
\hline $2 / 1$ & 20.5 & 9.7 & 81.3 & 49.1 \\
\hline $2 / 2$ & 21.1 & 9.7 & 83.3 & 49.6 \\
\hline $2 / 3$ & 21.2 & 9.8 & 77.5 & 49.9 \\
\hline Grand Average & 20.7 & 9.7 & 80.6 & 49.5 \\
\hline Reference Value & 20 & 10 & 81 & 50 \\
\hline \% difference & $3.3 \%$ & $-3.2 \%$ & $-0.5 \%$ & $-1.1 \%$ \\
\hline
\end{tabular}

\subsubsection{Measurements by Glass Number}

Exhibit E4 in Appendix E provides plots of the leachate concentrations for each type of submitted sample: the study glasses and the standards (EA (101), ARM (102), the multi-element solution standard (100), and blanks (103)). Exhibit E5 in Appendix E provides plots of the leachate concentrations for the PCT results of the study glasses only. These plots allow for the assessment of 
the repeatability of the measurements, which suggests some scatter in the triplicate values for some analytes for some of the glasses. Also, note that the results from the two heat treatments are shown for each study glass and that some differences between the two sets of values are evident.

\subsubsection{Normalized PCT Results}

PCT leachate concentrations are typically normalized using the cation composition (expressed as a weight percent) in the glass to obtain a grams-per-liter $(\mathrm{g} / \mathrm{L})$ leachate concentration. The normalization of the PCTs is usually conducted using the measured compositions of the glasses. This is the preferred normalization process for the PCTs. For completeness, the targeted cation and the bias-corrected cation compositions were also used to conduct this normalization.

As is the usual convention, the common logarithm of the normalized PCT (normalized leachate, NL) for each element of interest was determined and used for comparison. To accomplish this computation, one must:

1. Determine the common logarithm of the elemental parts per million (ppm) leachate concentration for each of the triplicates and each of the elements of interest (these values are provided in Table E2 of Appendix E),

2. Average the common logarithms over the triplicates for each element of interest, and then

Normalizing Using Measured Composition (preferred method)

3. Subtract a quantity equal to 1 plus the common logarithm of the average cation measured concentration (expressed as a weight percent of the glass) from the average computed in step 2.

Or Normalizing Using Target Composition

3. Subtract a quantity equal to 1 plus the common logarithm of the target cation concentration (expressed as a weight percent of the glass) from the average computed in step 2.

Or Normalizing Using Measured Bias-Corrected Composition

3. Subtract a quantity equal to 1 plus the common logarithm of the measured bias-corrected cation concentration (expressed as a weight percent of the glass) from the average computed in step 2.

Exhibit E6 in Appendix E provides scatter plots for these results and offers an opportunity to investigate the consistency in the leaching across the elements for the glasses of this study. All combinations of the normalizations of the PCTs (i.e., those generated using the targeted, measured, and bias-corrected compositional views) and both heat treatments are represented in the series of scatter plots. Consistency in the leaching across the elements is typically demonstrated by a high degree of linear correlation among the values for pairs of these elements. For the study glasses, the ccc results demonstrate a higher degree of correlation than do the quenched results. This may be due to the limited range of PCT responses for the quenched glasses as opposed to the ccc glasses, as revealed by the scale of the axes of the two sets of PCT measurements in the scatter plots of Exhibit E6. Table 3-2 summarizes the normalized PCTs for the glasses of this study. 
Table 3-2. Normalized Release Values for the Nepheline Phase 3 Glasses

\begin{tabular}{|c|c|c|c|c|c|c|c|c|c|c|}
\hline $\begin{array}{c}\text { Glass } \\
\text { ID } \\
\end{array}$ & $\begin{array}{c}\text { Heat } \\
\text { Treatment }\end{array}$ & Composition & \begin{tabular}{|c|}
$\log \mathbf{N L}$ \\
{$[\mathbf{B}(\mathrm{g} / \mathrm{L})]$} \\
\end{tabular} & \begin{tabular}{|c|}
$\log \mathbf{~ N L}$ \\
{$[\mathbf{L i}(\mathrm{g} / \mathbf{L})]$} \\
\end{tabular} & $\begin{array}{c}\log \mathbf{N L} \\
{[\mathrm{Na}(\mathrm{g} / \mathrm{L})]}\end{array}$ & \begin{tabular}{|l|}
$\log \mathbf{N L}$ \\
{$[\mathrm{Si}(\mathrm{g} / \mathrm{L})]$} \\
\end{tabular} & \begin{tabular}{|c|} 
NL \\
$\mathrm{B}(\mathrm{g} / \mathrm{L})$ \\
\end{tabular} & \begin{tabular}{|c|}
$\mathbf{N L}$ \\
$\mathbf{L i ( g / L )}$
\end{tabular} & \begin{tabular}{|c|}
$\mathrm{NL}$ \\
$\mathrm{Na}(\mathrm{g} / \mathrm{L})$ \\
\end{tabular} & $\begin{array}{l}N L \\
\text { Si(g/L) } \\
\end{array}$ \\
\hline ARM & - & reference & -0.265 & -0.217 & -0.257 & -0.517 & 0.54 & 0.61 & 0.55 & 0.30 \\
\hline EA & - & reference & 1.243 & 0.956 & 1.120 & 0.576 & 17.51 & 9.03 & 13.17 & 3.77 \\
\hline NEPH3-41 & uenched & measured & -0.170 & -0.112 & -0.131 & -0.282 & 0.68 & 0.77 & 0.74 & 0.52 \\
\hline & denched & measured bc & -0.174 & -0.120 & -0.120 & & 0.67 & 0.76 & 0.76 & 0.52 \\
\hline NEPH3-41 & yenched & target & -0.201 & -0.129 & -0.120 & -0.300 & 0.63 & 0.74 & 0.76 & 0.50 \\
\hline NEPH3-41 & ccc & measured & -0.182 & -0.114 & -0.153 & -0.287 & 0.66 & 0.77 & 0.70 & 0.52 \\
\hline & $\mathrm{ccc}$ & measured bc & -0.186 & -0.121 & -0.142 & -0.292 & 0.65 & 0.76 & 0.72 & 0.51 \\
\hline NEPH3-41 & $\mathrm{ccc}$ & target & -0.213 & -0.130 & -0.141 & -0.305 & 0.61 & 0.74 & 0.72 & 0.50 \\
\hline NEPH3-42 & uenched & measured & -0.062 & -0.089 & -0.068 & & 0.87 & 0.81 & 0.86 & 0.54 \\
\hline & quenc & measured bc & -0.056 & -0.098 & & & 0.88 & 0.80 & 0.88 & 0.53 \\
\hline NEPH3-42 & quenched & target & -0.071 & -0.101 & -0.067 & -0.284 & 0.85 & 0.79 & 0.86 & 0.52 \\
\hline NEPH3-42 & $\mathrm{ccc}$ & measured & -0.107 & -0.091 & -0.085 & -0.275 & 0.78 & 0.81 & 0.82 & 0.53 \\
\hline & $\mathrm{ccc}$ & mea & & & & & 0.79 & 0.80 & 0.84 & 0.52 \\
\hline NEPH3-42 & $\mathrm{ccc}$ & & -0.115 & -0.102 & -0.084 & & 0.77 & 0.79 & 0.82 & 0.51 \\
\hline NEPH3-43 & quenc & & -0.070 & -0.078 & 0.007 & & 0.85 & 0.83 & 1.02 & 0.55 \\
\hline & quenc & meas & -0.064 & -0.0 & & & 0.86 & 0.82 & 1.00 & 0.54 \\
\hline NEPH3-43 & quenched & & -0.064 & -0.086 & 0.000 & & 0.86 & 0.82 & 1.00 & 0.54 \\
\hline & & & & 0.0 & 001 & & 0.90 & 1.01 & 1.00 & 0.59 \\
\hline & $\mathrm{ccc}$ & meas & -0.041 & -0.006 & 05 & & 0.91 & 0.99 & 0.99 & 0.58 \\
\hline NEPH3-43 & $\mathrm{ccc}$ & & -0.041 & -0.005 & -0.005 & & 0.91 & 0.99 & 0.99 & 0.58 \\
\hline & quenc & & & -0. & & & 1.06 & 0.86 & 1.00 & 0.56 \\
\hline NEPH & quenched & meas & 0.021 & -0.074 & 012 & & 1.05 & 0.84 & 1.03 & 0.56 \\
\hline NEPH & quenched & & -0.009 & -0.078 & 34 & & 0.98 & 0.84 & 1.08 & 0.56 \\
\hline & & & 0.036 & 26 & 011 & & 1.09 & 1.06 & 1.03 & 0.60 \\
\hline NEPH & $\mathrm{ccc}$ & meas & 0.032 & 19 & 0.022 & & 1.08 & 1.04 & 1.05 & 0.59 \\
\hline & & & 0.002 & 0.1 & 0.045 & & 1.01 & 1.03 & 1.11 & 0.59 \\
\hline & quenc & & -0.134 & -0.060 & -0.125 & & 0.73 & 0.87 & 0.75 & 0.56 \\
\hline & quenched & measu & \begin{tabular}{|l|}
-0.139 \\
\end{tabular} & -0.068 & & & 0.73 & 0.86 & 0.74 & 0.55 \\
\hline & quenched & & -0.147 & -0.071 & -0.134 & & 0.71 & 0.85 & 0.74 & 0.55 \\
\hline & $\operatorname{ccc}$ & & \begin{tabular}{|l|}
-0.134 \\
\end{tabular} & -0.053 & -0.127 & & 0.73 & 0.89 & 0.75 & 0.56 \\
\hline NEPH3-45 & $\mathrm{ccc}$ & measured bc & -0.139 & -0.060 & -0.133 & 256 & 0.73 & 0.87 & 0.74 & 0.55 \\
\hline & & & -0.147 & -0.064 & & & 0.71 & 0.86 & 0.73 & 0.55 \\
\hline NEPH3-46 & quenched & measured & \begin{tabular}{|l|}
-0.097 \\
\end{tabular} & -0.061 & -0.088 & -0.260 & 0.80 & 0.87 & 0.82 & 0.55 \\
\hline NEPH3-46 & quenched & measured bc & -0.101 & -0.068 & -0.094 & -0.265 & 0.79 & 0.85 & 0.81 & 0.54 \\
\hline NEPH3-46 & quenched & & -0.109 & -0.070 & -0.085 & & 0.78 & 0.85 & 0.82 & 0.55 \\
\hline NEPH3-46 & \begin{tabular}{|c|}
$\mathrm{ccc}$ \\
\end{tabular} & measured & \begin{tabular}{|l|}
-0.071 \\
\end{tabular} & -0.012 & -0.081 & -0.234 & 0.85 & 0.97 & 0.83 & 0.58 \\
\hline NEPH3-46 & $\mathrm{ccc}$ & measured bc & -0.075 & -0.019 & -0.087 & -0.240 & 0.84 & 0.96 & 0.82 & 0.58 \\
\hline NEPH3-46 & & & -0.083 & -0.021 & -0.079 & & 0.83 & 0.95 & 0.83 & 0.58 \\
\hline NEPH3-47 & quenched & measured & -0.001 & -0.019 & 0.003 & -0.230 & 1.00 & 0.96 & 1.01 & 0.59 \\
\hline NEPH3-47 & quenched & measured bc & 0.005 & -0.028 & 0.014 & -0.240 & 1.01 & 0.94 & 1.03 & 0.58 \\
\hline NEPH3-47 & quenched & target & 0.006 & -0.026 & 0.015 & -0.234 & 1.01 & 0.94 & 1.03 & 0.58 \\
\hline
\end{tabular}


Table 3-2. Normalized Release Values for the Nepheline Phase 3 Glasses (continued)

\begin{tabular}{|c|c|c|c|c|c|c|c|c|c|c|}
\hline $\begin{array}{c}\text { Glass } \\
\text { ID } \\
\end{array}$ & $\begin{array}{c}\text { Heat } \\
\text { Treatment }\end{array}$ & Composition & \begin{tabular}{|l|}
$\log \mathrm{NL}$ \\
{$[\mathrm{B}(\mathrm{g} / \mathrm{L})]$}
\end{tabular} & \begin{tabular}{|l}
$\log N \mathrm{~L}$ \\
{$[\mathrm{Li}(\mathrm{g} / \mathrm{L})]$}
\end{tabular} & $\begin{array}{c}\log \mathbf{N L} \\
{[\mathrm{Na}(\mathrm{g} / \mathrm{L})]}\end{array}$ & \begin{tabular}{|l|}
$\log \mathrm{NL}$ \\
{$[\mathrm{Si}(\mathrm{g} / \mathrm{L})]$} \\
\end{tabular} & \begin{tabular}{|c|}
$\mathbf{N L}$ \\
$\mathrm{B}(\mathrm{g} / \mathbf{L})$ \\
\end{tabular} & \begin{tabular}{|c|}
$\mathbf{N L}$ \\
$\mathbf{L i}(\mathrm{g} / \mathrm{L})$ \\
\end{tabular} & \begin{tabular}{|c|}
$\mathrm{NL}$ \\
$\mathrm{Na}(\mathrm{g} / \mathrm{L})$ \\
\end{tabular} & \begin{tabular}{|l}
$\mathrm{NL}$ \\
$\mathrm{Si}(\mathrm{g} / \mathrm{L})$
\end{tabular} \\
\hline NEPH3-47 & $\operatorname{ccc}$ & measured & -0.040 & 0.024 & -0.014 & -0.213 & 0.91 & 1.06 & 0.97 & 0.61 \\
\hline NEPH3-47 & $\mathrm{ccc}$ & measured bc & -0.033 & 0.015 & -0.002 & -0.223 & 0.93 & 1.04 & 0.99 & 0.60 \\
\hline NEPH3-47 & $\mathrm{ccc}$ & target & -0.032 & 0.016 & -0.002 & -0.217 & 0.93 & 1.04 & 1.00 & 0.61 \\
\hline NEPH3-48 & quenched & measured & -0.002 & -0.001 & 0.078 & -0.199 & 1.00 & 1.00 & 1.20 & 0.63 \\
\hline NEPH3-48 & quenched & measured bc & 0.005 & -0.010 & 0.072 & -0.209 & 1.01 & 0.98 & 1.18 & 0.62 \\
\hline NEPH3-48 & quenched & & 0.014 & -0.010 & 0.076 & -0.205 & 1.03 & 0.98 & 1.19 & 0.62 \\
\hline NEPH3-48 & ccc & measured & 0.170 & 0.214 & 0.126 & -0.115 & 1.48 & 1.64 & 1.34 & 0.77 \\
\hline NEPH3-48 & $\mathrm{ccc}$ & measured bc & 0.177 & 0.205 & 0.120 & -0.125 & 1.50 & 1.60 & 1.32 & 0.75 \\
\hline NEPH3-48 & $\mathrm{ccc}$ & & 0.186 & 0.204 & 0.125 & & 1.54 & 1.60 & 1.33 & 0.76 \\
\hline NEPH3-49 & quenched & sured & -0.117 & -0.100 & -0.044 & -0.266 & 0.76 & 0.79 & 0.90 & 0.54 \\
\hline NEPH3-49 & quenched & measured bc & -0.110 & -0.109 & -0.051 & -0.275 & 0.78 & 0.78 & 0.89 & 0.53 \\
\hline NEPH3-49 & quenched & & -0.118 & -0.112 & -0.025 & & 0.76 & 0.77 & 0.95 & 0.53 \\
\hline NEPH3-49 & ccc & mea & \begin{tabular}{|l|}
-0.106 \\
\end{tabular} & -0.063 & & & 0.78 & 0.87 & 0.86 & 0.56 \\
\hline NEPH3-49 & $\mathrm{ccc}$ & measured bc & -0.099 & -0.072 & -0.070 & -0.265 & 0.80 & 0.85 & 0.85 & 0.54 \\
\hline NEPH3-49 & $\mathrm{ccc}$ & & \begin{tabular}{|l|}
-0.107 \\
\end{tabular} & -0.075 & -0.044 & -0.264 & 0.78 & 0.84 & 0.90 & 0.54 \\
\hline NEPH3-50 & quenched & mes & -0.064 & -0.079 & 0.006 & & 0.86 & 0.83 & 1.01 & 0.58 \\
\hline NEPH3-50 & quenched & meas & -0.058 & -0.087 & 0.017 & 247 & 0.88 & 0.82 & 1.04 & 0.57 \\
\hline NEPH3-50 & quenched & & \begin{tabular}{|l|}
-0.059 \\
\end{tabular} & -0.0 & 0.012 & & 0.87 & 0.81 & 1.03 & 0.57 \\
\hline NEPH3-50 & ccc & $\mathrm{me}$ & \begin{tabular}{|l|}
-0.059 \\
\end{tabular} & -0.047 & -0.017 & & 0.87 & 0.90 & 0.96 & 0.58 \\
\hline NEPH3-50 & $\mathrm{ccc}$ & meas & -0.052 & -0.055 & -0.006 & & 0.89 & 0.88 & 0.99 & 0.57 \\
\hline NEPH & & & -0.053 & -0.0 & & & 0.88 & 0.88 & 0.98 & 0.57 \\
\hline NEPH3-51 & quenched & $\mathrm{me}$ & 0.023 & -0.045 & & & 1.05 & 0.90 & 1.16 & 0.60 \\
\hline NEPH3-51 & quenched & meas & 0.019 & -0.052 & & & 1.04 & 0.89 & 1.14 & 0.59 \\
\hline $\mathrm{NEPH}$ & lench & & & -0.0 & & & 0.98 & 0.87 & 1.14 & 0.59 \\
\hline NEPH3-51 & $\mathrm{ccc}$ & me: & 0.153 & 0.087 & 0.071 & 70 & 1.42 & 1.22 & 1.18 & 0.68 \\
\hline NEPH3-51 & $\mathrm{ccc}$ & meas & 0.149 & 0.080 & 0.0 & 176 & 1.41 & 1.20 & 1.16 & 0.67 \\
\hline NEPI & $\mathrm{ccc}$ & & 0.121 & 0.072 & 0.067 & & 1.32 & 1.18 & 1.17 & 0.66 \\
\hline NEPH3-52 & quenched & mea & 0.032 & -0.033 & 0.097 & & 1.08 & 0.93 & 1.25 & 0.64 \\
\hline NEPH3-52 & quenched & measu & 0.039 & -0.041 & 0.090 & & 1.09 & 0.91 & 1.23 & 0.63 \\
\hline $\mathrm{NEPH}$ & quenched & & 0.036 & -0.043 & 0.095 & -0.207 & 1.09 & 0.91 & 1.24 & 0.62 \\
\hline NEPH3-52 & ccc & meas & 0.045 & & & & 1.11 & 1.08 & 1.24 & 0.67 \\
\hline NEPH3-52 & $\mathrm{ccc}$ & measu & 0.052 & & 0.088 & & 1.13 & 1.06 & 1.22 & 0.66 \\
\hline NEPH3-52 & $\mathrm{ccc}$ & target & 0.049 & 0.022 & 0.092 & -0.188 & 1.12 & 1.05 & 1.24 & 0.65 \\
\hline NEPH3-53 & quenched & measured & -0.051 & -0.020 & -0.045 & -0.213 & 0.89 & 0.96 & 0.90 & 0.61 \\
\hline NEPH3-53 & quenched & measu & -0.056 & -0.027 & & & 0.88 & 0.94 & 0.89 & 0.61 \\
\hline NEPH3-53 & quenched & target & -0.065 & -0.031 & -0.044 & -0.223 & 0.86 & 0.93 & 0.90 & 0.60 \\
\hline NEPH3-53 & $\operatorname{ccc}$ & measured & 0.048 & 0.252 & 0.029 & -0.029 & 1.12 & 1.79 & 1.07 & 0.94 \\
\hline NEPH3-53 & $\mathrm{ccc}$ & measured bc & 0.044 & 0.245 & 0.023 & -0.034 & 1.11 & 1.76 & 1.05 & 0.93 \\
\hline NEPH3-53 & $\mathrm{ccc}$ & target & 0.035 & 0.241 & 0.030 & -0.039 & 1.08 & 1.74 & 1.07 & 0.91 \\
\hline NEPH3-54 & quenched & measured & -0.016 & 0.023 & -0.020 & -0.198 & 0.96 & 1.05 & 0.96 & 0.63 \\
\hline NEPH3-54 & quenched & measured bc & -0.010 & 0.014 & -0.008 & -0.208 & 0.98 & 1.03 & 0.98 & 0.62 \\
\hline NEPH3-54 & quenched & target & \begin{tabular}{|l|}
-0.014 \\
\end{tabular} & 0.011 & -0.014 & -0.204 & 0.97 & 1.02 & 0.97 & 0.63 \\
\hline NEPH3-54 & $\mathrm{ccc}$ & measured & 0.007 & 0.080 & 0.004 & -0.160 & 1.02 & 1.20 & 1.01 & 0.69 \\
\hline NEPH3-54 & $\mathrm{ccc}$ & measured bc & 0.013 & 0.071 & 0.016 & -0.169 & 1.03 & 1.18 & 1.04 & 0.68 \\
\hline NEPH3-54 & $\mathrm{ccc}$ & target & 0.009 & 0.068 & 0.010 & -0.165 & 1.02 & 1.17 & 1.02 & 0.68 \\
\hline
\end{tabular}


Table 3-2. Normalized Release Values for the Nepheline Phase 3 Glasses (continued)

\begin{tabular}{|c|c|c|c|c|c|c|c|c|c|c|}
\hline $\begin{array}{l}\text { Glass } \\
\text { ID }\end{array}$ & $\begin{array}{c}\text { Heat } \\
\text { Treatment }\end{array}$ & Composition & $\begin{array}{c}\log \mathbf{N L} \\
{[\mathbf{B}(\mathrm{g} / \mathrm{L})]}\end{array}$ & \begin{tabular}{|c|}
$\log N \mathrm{~L}$ \\
{$[\mathrm{Li}(\mathrm{g} / \mathrm{L})]$}
\end{tabular} & $\begin{array}{c}\log \mathbf{N L} \\
{[\mathrm{Na}(\mathrm{g} / \mathrm{L})]}\end{array}$ & $\begin{array}{c}\log N \mathrm{~L} \\
{[\mathrm{Si}(\mathrm{g} / \mathrm{L})]}\end{array}$ & \begin{tabular}{|c|}
$N L$ \\
$B(g / L)$
\end{tabular} & \begin{tabular}{|c|}
$\mathbf{N L}$ \\
$\mathbf{L i}(\mathbf{g} / \mathbf{L})$
\end{tabular} & $\begin{array}{c}\mathrm{NL} \\
\mathrm{Na}(\mathrm{g} / \mathrm{L})\end{array}$ & \begin{tabular}{|c|}
$\mathbf{N L}$ \\
$\mathrm{Si}(\mathrm{g} / \mathrm{L})$ \\
\end{tabular} \\
\hline NEPH3-55 & quenched & measured & 0.074 & 0.022 & 0.055 & -0.181 & 1.19 & 1.05 & 1.14 & 0.66 \\
\hline NEPH3-55 & quenched & measured bc & 0.070 & 0.015 & 0.067 & -0.186 & 1.18 & 1.03 & 1.17 & 0.65 \\
\hline $\mathrm{NEPH}$ & uenched & & 45 & & & & 1.11 & 1.01 & 1.16 & 0.64 \\
\hline $\mathrm{NEPH}$ & $\mathrm{ccc}$ & $\mathrm{me}$ & 18 & 50 & & -0.066 & 1.65 & 1.78 & 1.26 & 0.86 \\
\hline NEPH3-55 & $\mathrm{ccc}$ & meas & 0.214 & 0.2 & 0.110 & -0.071 & 1.64 & 1.75 & 1.29 & 0.85 \\
\hline $\mathrm{NE}$ & & & & & & & 1.55 & 1.70 & 1.28 & 0.83 \\
\hline NEPH3-56 & quenched & measured & 0.099 & 0.031 & 0.086 & -0.162 & 1.26 & 1.07 & 1.22 & 0.69 \\
\hline NEPH3-56 & quenched & measur & 096 & & 098 & -0 . & 1.25 & 1.06 & 1.25 & 0.68 \\
\hline NEPH3-56 & quenched & roct & 0.066 & 0.015 & 0.096 & -0.174 & 1.17 & 1.04 & 1.25 & 0.67 \\
\hline NEPH3-56 & $\mathrm{ccc}$ & measured & 0.509 & 0.494 & 0.208 & 0.083 & 3.23 & 3.12 & 1.61 & 1.21 \\
\hline NEPH3-56 & $\mathrm{ccc}$ & measured bc & 0.506 & 0.487 & 0.219 & & 3.20 & 3.07 & 1.66 & 1.20 \\
\hline NEPH3-56 & $\mathrm{ccc}$ & target & 0.476 & 0.479 & 0.218 & 0.071 & 2.99 & 3.01 & 1.65 & 1.18 \\
\hline
\end{tabular}




\subsubsection{Effects of Heat Treatment on PCTs}

Exhibit E7 in Appendix E provides a series of plots and statistical comparisons that show the effects of heat treatment on the common logarithm ppm-responses of interest of the triplicate PCTs for each element for each study glass. The ccc version of a given glass yielded measurements indicating a significantly (at the 5\% significance level) larger mean $\log (\mathrm{ppm})$ response than the quenched version of the glass for a given element if the Prob $>\mathbf{t}$ value in the exhibit is 0.05 or smaller.

As shown in Table 3-2, all of the Phase 3 quenched glasses have normalized boron releases less than $1.20 \mathrm{~g} / \mathrm{L}$, which in terms of acceptability are approximately an order of magnitude better than the EA benchmark glass that has a reported NL [B] of $16.695 \mathrm{~g} / \mathrm{L} .{ }^{11}$ The range of measured, normalized boron releases for the quenched glasses is from $0.67 \mathrm{~g} / \mathrm{L}$ (NEPH3-41) to $1.25 \mathrm{~g} / \mathrm{L}$ (NEPH3-56). The results suggest that even though some of the glasses may be prone to nepheline formation based on the 0.62 nepheline discriminator value, all Phase 3 quenched glasses are acceptable. However, the potential for crystallization was suppressed in the quenched glasses in terms of kinetics. That is, the glasses may be prone to nepheline formation but the rapid cooling limited or prevented the formation of nepheline or other crystalline phases. As observed in the Phase 1 and 2 glasses, it was only in the slowly cooled (ccc) glasses where the impact of nepheline on durability response was observed.

Also shown in Table 3-2 are the normalized releases based on the ccc version of each Phase 3 glass for each compositional view. As will be discussed further in Sections 3.3.1 (Visual Observations) and 3.3.2 (XRD Results), the ccc cooling schedule generally resulted in devitrification, with the extent of crystallization generally increasing with increasing WL. This is not unexpected, as the slower cooling rate provides a thermodynamically favorable (compositional-wise) glass the kinetic opportunity to devitrify. The measured, normalized boron releases for the Phase $3 \mathrm{ccc}$ glasses range from $0.65 \mathrm{~g} / \mathrm{L}$ (NEPH3-41) to $3.20 \mathrm{~g} / \mathrm{L}$ (NEPH3-56). While these values span a wider PCT response as compared to the quenched versions of these glasses, their responses are still well below that of the EA glass $(16.695 \mathrm{~g} / \mathrm{L}){ }^{11}$

Figure 3-2 shows the PCT responses for boron, normalized based on measured compositions, for both the quenched and ccc glasses. The value of the nepheline discriminator (calculated from the measured compositions) for each glass is also shown. The PCT responses are indicated by the symbol $(\square)$ for the quenched glasses and the symbol (•) for the ccc glasses. 


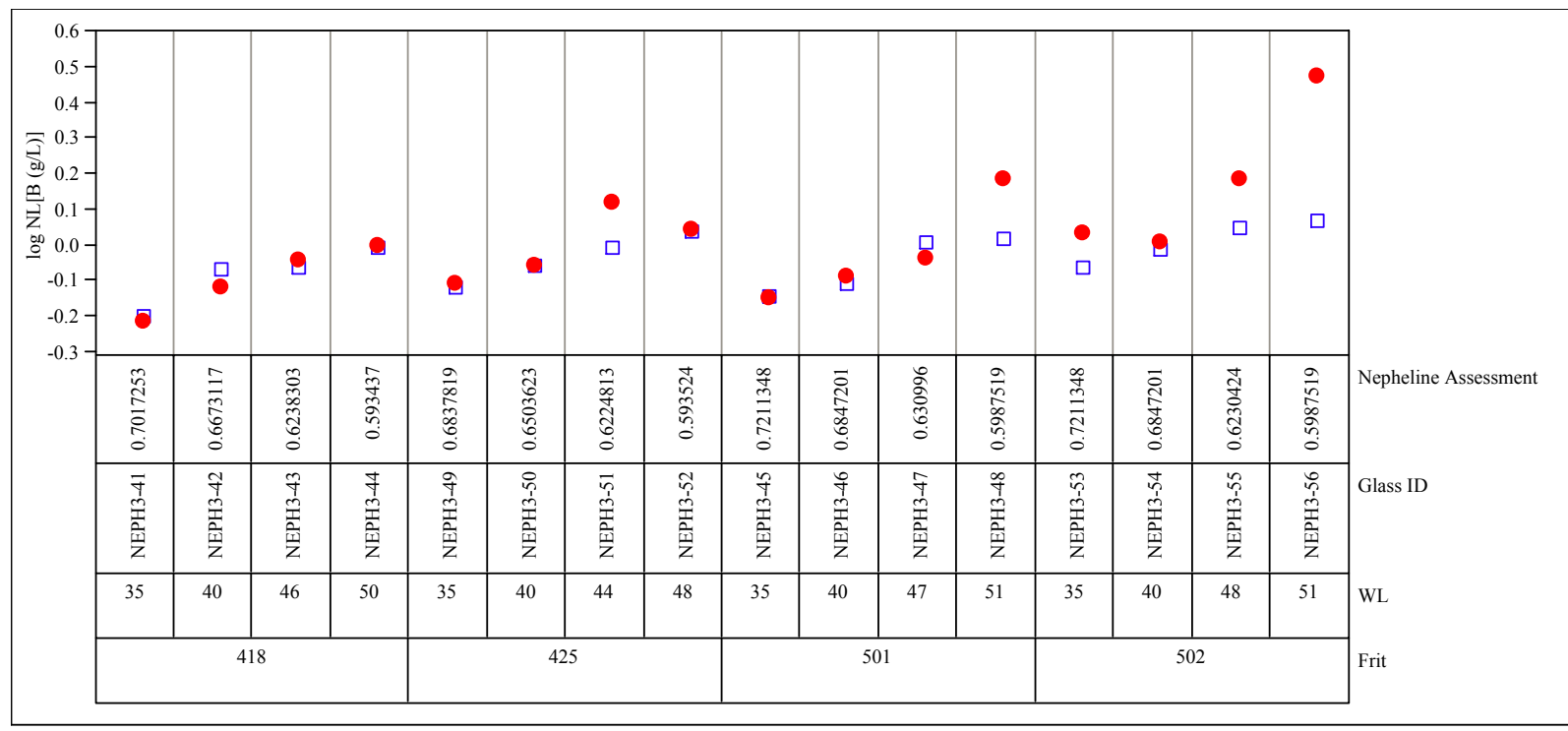

$(\square)$ quenched glasses, $(\bullet)$ ccc glasses

\section{Figure 3-2. Normalized boron release and nepheline discriminator values for the quenched and cce Phase 3 glasses.}

Some general trends are evident upon examination of Figure 3-2. For the quenched glasses, the NL [B] values generally increase with increasing WL for each of the sludge-frit systems. A similar trend is seen for the ccc glasses, with a few exceptions in the Frit 425 and Frit 502 systems. Though troubling from a visual perspective, these variations in the trend are of little practical importance, since all of the normalized release values are still well below that of the EA reference glass.

Glasses NEPH3-48, NEPH3-51, NEPH3-53, NEPH3-55 and NEPH3-56 show statistically significant differences in the quenched versus ccc normalized boron release. However, these differences are of little practical importance due to the relatively low values of NL [B].

Table 3-3 lists the nepheline discriminator values for each of the Phase 3 glasses, calculated using either the target, measured, or measured-bc compositions. If a nepheline discriminator value of 0.62 were to be implemented, based on the target compositions, two of the ccc glasses with high NL [B] responses (NEPH3-48 and NEPH3-56) would be screened out by the discriminator. The highest NL [B] response for the Phase 3 glasses would then be $1.65 \mathrm{~g} / \mathrm{L}$ (glass NEPH3-55ccc), which is an order of magnitude less than the EA reference glass. ${ }^{11}$ If the nepheline discriminator values calculated using the measured compositions were used in the screening, the highest NL [B] response for the Phase 3 ccc glasses would then be $1.12 \mathrm{~g} / \mathrm{L}$ (glass NEPH3-53). 
WSRC-TR-2006-00093

Revision 0

Table 3-3. Values of the nepheline discriminator calculated for each glass using the measured, measured bias-corrected, and targeted compositions.

(Values below 0.62 are highlighted.)

\begin{tabular}{||c|c|c|c||}
\hline \multirow{2}{*}{ Glass ID } & \multicolumn{3}{|c|}{ Nepheline Discriminator Values } \\
\cline { 2 - 4 } & Measured & Measured bc & Targeted \\
\hline NEPH3-41 & 0.688 & 0.694 & 0.702 \\
\hline NEPH3-42 & 0.656 & 0.664 & 0.667 \\
\hline NEPH3-43 & 0.620 & 0.623 & 0.624 \\
\hline NEPH3-44 & 0.580 & 0.587 & 0.593 \\
\hline NEPH3-45 & 0.718 & 0.719 & 0.721 \\
\hline NEPH3-46 & 0.681 & 0.682 & 0.685 \\
\hline NEPH3-47 & 0.621 & 0.629 & 0.631 \\
\hline NEPH3-48 & 0.594 & 0.598 & 0.599 \\
\hline NEPH3-49 & 0.670 & 0.673 & 0.684 \\
\hline NEPH3-50 & 0.640 & 0.649 & 0.650 \\
\hline NEPH3-51 & 0.617 & 0.619 & 0.622 \\
\hline NEPH3-52 & 0.584 & 0.587 & 0.594 \\
\hline NEPH3-53 & 0.713 & 0.714 & 0.721 \\
\hline NEPH3-54 & 0.677 & 0.685 & 0.685 \\
\hline NEPH3-55 & 0.612 & 0.618 & 0.623 \\
\hline NEPH3-56 & 0.588 & 0.595 & 0.599 \\
\hline
\end{tabular}

Use of a value of 0.62 and the measured compositions for screening with the nepheline discriminator eliminates all but one of the glasses that showed a statistical difference in NL [B] between the quenched and ccc specimens. This one remaining glass (NEPH3-53) showed only a small difference in NL [B], $0.89 \mathrm{~g} / \mathrm{L}$ versus $1.12 \mathrm{~g} / \mathrm{L}$, between the quenched and ccc samples, respectively.

Exhibit E8 in Appendix E provides a series of plots that show the effects of heat treatment on the PCT response based on the three different compositional views: measured, measured bias-corrected, and targeted. These plots allow for an assessment of the differences in PCT responses from a practical perspective, and reinforce the above discussion.

\subsubsection{Predicted versus Measured PCTs}

As seen in Table 3-2, the durabilities for the Phase 3 glasses are all acceptable (i.e. NL [B] less than $3.24 \mathrm{~g} / \mathrm{L}$ ) as compared to the EA reference glass. It should be noted though that some of the ccc glasses exhibited varying amounts of crystallization. Since the current durability model ${ }^{12}$ is only applicable to homogeneous glasses, the inability of the model to predict the PCT response for those ccc glasses which resulted in devitrification is not surprising.

Exhibit E9 in Appendix E provides plots of the DWPF models that relate the logarithm of the normalized PCT (for each element of interest) to a linear function of a free energy of hydration term $\left(\Delta \mathrm{G}_{\mathrm{p}}, \mathrm{kcal} / 100 \mathrm{~g}\right.$ glass $)$ derived from all of the glass compositional views and heat treatments. ${ }^{12}$ Prediction limits (at a 95\% confidence) for an individual PCT result are also plotted along with the linear fit. The EA and ARM results are also indicated on these plots. Exhibit E10 in Appendix E provides a version of these plots for the quenched glasses only while Exhibit E11 in Appendix E 
provides a version for ccc glasses only. Figure 3-3 shows the log NL [B] versus $\Delta \mathrm{G}_{\mathrm{P}}$ for the quenched and ccc glasses.

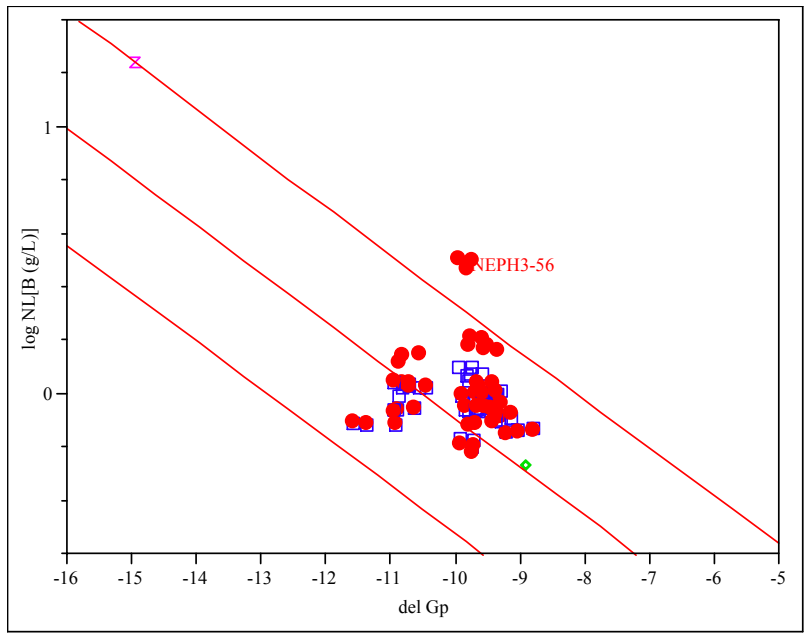

Figure 3-3. NL $[\mathrm{B}]$ versus $\Delta \mathrm{G}_{\mathrm{P}}$ for the quenched ( $\square$ ) and cec (•) Phase 3 glasses.

As shown in Figure 3-3, all of the quenched Phase 3 glasses are predictable by the $\Delta \mathrm{G}_{\mathrm{P}}$ model. Also, with the exception of NEPH3-56, all of the ccc glasses are predictable by the $\Delta G_{P}$ model. Since NEPH3-56ccc is not a homogeneous glass (and contains nepheline, as will be shown below in Section 3.3), it is not surprising that the model is not able to predict its durability. While the PCT response of NEPH3-56ccc is acceptable, it is not predictable. All of the Phase 3 glasses remaining after a nepheline discriminator screening would be both acceptable as compared to the EA reference glass and predictable using the $\Delta \mathrm{G}_{\mathrm{P}}$ model. The relationship between predictability and the nepheline discriminator is explored in the next section.

\subsubsection{Values of the Nepheline Constraint and Predictability}

Li et al. proposed 0.62 as the critical value for the nepheline discriminator. ${ }^{22}$ Glass compositions with a nepheline discriminator value of less than 0.62 are prone to nepheline crystallization. ${ }^{22}$ Figure 3-4 provides a scatter plot matrix of the values for PCT response for boron, for the nepheline constraint, and for $\Delta \mathrm{G}_{\mathrm{P}}$. In this plot, the PCT response is provided for both the quenched $(\square)$ and $\operatorname{ccc}(\bullet$ or $\bullet)$ versions of the glass. The two different colors used to represent the ccc results allow for the distinction between those glasses that satisfy the nepheline constraint $(\bullet)$ and those that fail it $(\bullet)$.

Based on Figure 3-4, the PCT results for the ccc version of NEPH3-56 (i.e., the three compositional views of the ccc version of NEPH3-56), while unpredictable by the $\Delta \mathrm{G}_{\mathrm{P}}$ model (see Figure 3-3), also correspond to compositional views that fail the nepheline constraint. As discussed earlier, this glass would be screened out of DWPF processing if a nepheline discriminator value of 0.62 were to be implemented. 


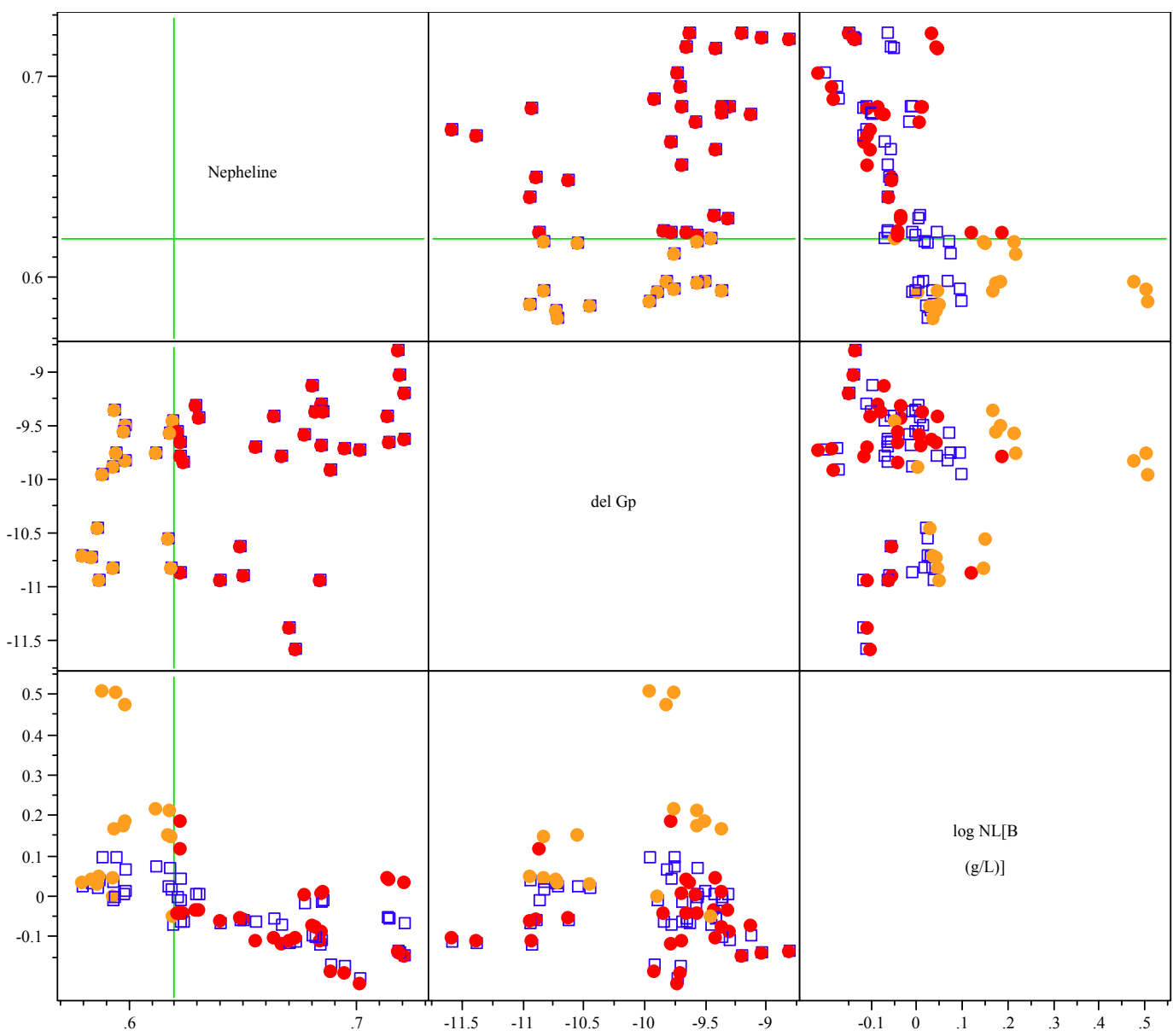

$(\square)$ quenched glasses, $(\bullet)$ ccc glasses that satisfy the nepheline constraint, $(\bullet)$ ccc glasses that do not satisfy the nepheline constraint

Figure 3-4. Scatter Plot Matrix of $\log$ NL[B g/L], Nepheline Constraint, and $\Delta G_{P}$

\subsection{Homogeneity}

In this section, the primary interest is the possible formation of nepheline (and/or other crystalline phases) in the Phase $3 \mathrm{ccc}$ glasses which could be responsible for the measurable and sometimes statistically significant differences in PCT responses as compared to their quenched counterparts. Table 3-4 summarizes the visual and XRD results for the quenched and ccc Phase 3 glasses. It should be noted that only the ccc versions of the glasses were submitted for XRD analysis given that the visual observations and durability responses suggested no significant crystallization in the quenched glasses. That is, with normalized boron releases ranging from $0.67 \mathrm{~g} / \mathrm{L}$ to $1.26 \mathrm{~g} / \mathrm{L}$, there is no evidence of nepheline formation in the quenched glasses - even if present, the impact is of no practical concern.

Prior to discussing the results, a few words regarding the terminology used in the tables are warranted. The use of "homogeneous" for visual observations indicates that the sample was classified as a single-phase system (i.e., no evidence of crystallization). The term "surface crystals" (used as a descriptor for visual observations) implies that the surface of the glass was characterized by the presence of crystallization while the cross-section of bulk glass appeared homogeneous (i.e., singlephase, black and shiny). Surface crystallization in the Phase 3 glasses was apparent through the 
presence of a "textured" surface that ranged in appearance from a "dull or matte" surface to a "highly metallic-like" surface.

The XRD results are more qualitative in nature. As previously mentioned, only the ccc glasses were submitted for XRD analysis based on both the PCT responses as well as visual observations of the quenched glasses. The PCT responses of the quenched glasses were "acceptable and predictable" and visual observations suggested only the presence of surface devitrification on the higher WL glasses. Historically, surface devitrification occurs as WLs increase, and this is typically the result of spinel formation for DWPF type glasses. The Phase 3 PCT responses suggested that for those quenched glasses that were classified as having "surface crystallization" or a "metallic haze on the surface", spinel formation was highly probable - which is consistent with recent observations and the inert effect on the PCT response. For the ccc glasses, the XRD results suggested that the glass was either amorphous or contained some degree of crystallization. The presence of a characteristically high background devoid of crystalline spectral lines indicates that the glass product is amorphous (suggesting either a completely amorphous product or that the degree of crystallization is below the detection limit - approximately $0.5 \mathrm{vol} \%$ in glass). In terms of crystallization, the XRD results indicated the presence of spinel (Trevorite, $\left.\mathrm{NiFe}_{2} \mathrm{O}_{4}\right)$ and nepheline $\left(\mathrm{NaAlSiO}_{4}\right)$. For a more detailed description of the visual observations and XRD results of both the quenched and ccc glasses, see WSRC-NB-2006-00016.

\subsubsection{Visual Observations}

Visual observations of the quenched Phase 3 glasses indicate that nine glasses were homogeneous, while the remaining seven glasses were characterized by a metallic haze on the surface with the bulk (cross-section) being homogeneous. The nine quenched glasses classified as visually homogeneous were generally lower WL glasses within their respective frit series.

The noted surface crystallization on the seven quenched, high WL glasses is consistent with historical, visual observations of DWPF-based glasses, especially those targeting higher waste loadings. More specifically, use of descriptions such as a dull or matte texture and/or metallic-like surface is common for DWPF-type glasses targeting higher WLs and/or having undergone a slow cooling schedule. Previous XRD analyses have indicated that the textured or metallic-like surfaces are typically a result of spinels that precipitate during the cooling process. This is in-line with glass theory which suggests that as WL increases, the concentrations of $\mathrm{Fe}_{2} \mathrm{O}_{3}, \mathrm{NiO}, \mathrm{Cr}_{2} \mathrm{O}_{3}$, and/or $\mathrm{MnO}$ also increase, enhancing the likelihood of spinel devitrification. Based on the PCT responses for the quenched glasses, spinel formation resulting in the metallic haze is reasonable as spinels have been shown to have no impact on the durability response. ${ }^{14}$

A metallic haze, either somewhat shiny or dull, characterized the surface of all $16 \mathrm{ccc}$ glasses. The primary difference among the ccc glasses is the degree of devitrification visually observed within the bulk glass. That is, when examining the cross-sections of the heat treated samples, visual observations ranged from "shiny and clean" (indicating a homogeneous glass) to "devitrified". In general, the transition from homogeneous to partially devitrified and completely devitrified resulted as WL increased within a specific frit - sludge system. For example, consider NEPH3-46ccc through NEPH3-48ccc (from Table 3-4). The visual observations suggest that the bulk of the heat treated sample was homogeneous at 40\% WL (NEPH3-46ccc), partially devitrified at 47\% WL (NEPH3-47ccc), and completely devitrified at 51\% WL (NEPH3-48ccc).

In general, visual observations indicate that devitrification was more prevalent in the ccc glasses than in the quenched glasses, as expected, given kinetics are more favorable for devitrification during the slower cooling cycle. 
Table 3-4. Visual observations and XRD results for the Phase 3 glasses.

\begin{tabular}{|c|c|c|c|c|c|}
\hline Glass & Frit ID & $\begin{array}{l}\text { Target } \\
\text { WL }\end{array}$ & $\begin{array}{c}\text { Heat } \\
\text { Treatment }\end{array}$ & Visual & XRD \\
\hline NEPH3-41 & 418 & 35 & quenched & Patty - black, shiny, homogeneous; Crucible - clean with bubbles & - \\
\hline NEPH3-41 & 418 & 35 & $\mathrm{ccc}$ & Surface - shiny, metallic; Bulk - shiny and clean & Amorphous \\
\hline NEPH3-42 & 418 & 40 & quenched & Patty - black, shiny, homogeneous; Crucible - clean with bubbles & - \\
\hline NEPH3-42 & 418 & 40 & $\mathrm{ccc}$ & Surface - shiny, metallic with crystals; Bulk - black, shiny, clean & Amorphous \\
\hline NEPH3-43 & 418 & 46 & quenched & Patty - black, shiny, homogeneous; Crucible - clean with bubbles & - \\
\hline NEPH3-43 & 418 & 46 & $\mathrm{ccc}$ & Surface - dull metallic with crystals; Bulk - shiny, black, some crystals & $\mathrm{NiFe}_{2} \mathrm{O}_{4}$ \\
\hline NEPH3-44 & 418 & 50 & quenched & Patty - shiny metallic haze; Crucible - clean with bubbles & - \\
\hline NEPH3-44 & 418 & 50 & $\mathrm{ccc}$ & Surface - crusty, metallic with crystals; Bulk - black matte, crystals & $\mathrm{NiFe}_{2} \mathrm{O}_{4}, \mathrm{NaAlSiO}_{4}$ \\
\hline NEPH3-45 & 501 & 35 & quenched & Patty - black, shiny, homogeneous; Crucible - clean with bubbles & - \\
\hline NEPH3-45 & 501 & 35 & $\mathrm{ccc}$ & Surface - metallic haze; Bulk - black, shiny, clean & Amorphous \\
\hline NEPH3-46 & 501 & 40 & quenched & Patty - black, shiny, homogeneous; Crucible - clean with bubbles & - \\
\hline NEPH3-46 & 501 & 40 & $\mathrm{ccc}$ & Surface - metallic haze with crystals; Bulk - black, shiny, clean & Amorphous \\
\hline NEPH3-47 & 501 & 47 & quenched & Patty - black, shiny with a few hazy swirls; Crucible - clean with bubbles & - \\
\hline NEPH3-47 & 501 & 47 & $\mathrm{ccc}$ & Surface - dull, metallic haze with crystals; Bulk - black, shiny with crystals & $\mathrm{NiFe}_{2} \mathrm{O}_{4}$ \\
\hline NEPH3-48 & 501 & 51 & quenched & Patty - a few shiny, metallic spots; Crucible - clean with bubbles & - \\
\hline NEPH3-48 & 501 & 51 & $\mathrm{ccc}$ & Surface - dull and crusty; Bulk - black matte with crystals, devitrified & $\mathrm{NiFe}_{2} \mathrm{O}_{4}$ \\
\hline NEPH3-49 & 425 & 35 & quenched & Patty - black, shiny, homogeneous; Crucible - clean with bubbles & - \\
\hline NEPH3-49 & 425 & 35 & $\mathrm{ccc}$ & Surface - metallic haze; Bulk - clean & Amorphous \\
\hline NEPH3-50 & 425 & 40 & quenched & Patty - black, shiny, homogeneous; Crucible - clean with bubbles & - \\
\hline NEPH3-50 & 425 & 40 & $\mathrm{ccc}$ & Surface - metallic haze with many crystals; Bulk - clean & Amorphous \\
\hline NEPH3-51 & 425 & 44 & quenched & Patty - black, shiny with a few milky swirls; Crucible - clean with bubbles & - \\
\hline NEPH3-51 & 425 & 44 & $\mathrm{ccc}$ & Surface - dull and crusty; Bulk - clean & $\mathrm{NiFe}_{2} \mathrm{O}_{4}$ \\
\hline NEPH3-52 & 425 & 48 & quenched & Patty - shiny metallic surface; Crucible - clean with bubbles & - \\
\hline NEPH3-52 & 425 & 48 & $\mathrm{ccc}$ & Surface - metallic haze with heavy crystallization; Bulk - crystals & $\mathrm{NiFe}_{2} \mathrm{O}_{4}$ \\
\hline NEPH3-53 & 502 & 35 & quenched & Patty - black, shiny, homogeneous; Crucible - clean with bubbles & - \\
\hline NEPH3-53 & 502 & 35 & $\mathrm{ccc}$ & Surface - metallic haze with crystals; Bulk - clean & Amorphous \\
\hline NEPH3-54 & 502 & 40 & quenched & Patty - black, shiny, homogeneous; Crucible - clean with bubbles & - \\
\hline NEPH3-54 & 502 & 40 & $\operatorname{ccc}$ & Surface - dull, metallic haze with some crystals; Bulk - clean & Amorphous \\
\hline NEPH3-55 & 502 & 48 & quenched & Patty - shiny, metallic surface; Crucible - clean with bubbles & - \\
\hline NEPH3-55 & 502 & 48 & $\mathrm{ccc}$ & Surface - dull metallic haze with crystals; Bulk - crystals & $\mathrm{NiFe}_{2} \mathrm{O}_{4}$ \\
\hline NEPH3-56 & 502 & 51 & quenched & Patty - shiny, metallic surface; Crucible - clean with bubbles & - \\
\hline NEPH3-56 & 502 & 51 & $\operatorname{ccc}$ & Surface - dull and crusty; Bulk - crystals & $\mathrm{NiFe}_{2} \mathrm{O}_{4}, \mathrm{NaAlSiO}_{4}$ \\
\hline
\end{tabular}




\subsubsection{XRD Results}

The XRD results shown in Table 3-4 provide a technical basis for making decisions regarding the impact of nepheline formation on durability. The PCT data (as shown in Figure 3-2) indicate that, in general, as WL increased within a given frit-sludge system, the difference in NL [B] between quenched and ccc glasses increased. This same type of response was seen in the Phase 2 study. ${ }^{2}$ Since the higher WL glasses challenge the nepheline discriminator value of 0.62 , it is not surprising that nepheline crystallization and a reduction in durability occurred in some of the Phase 3 glasses.

XRD results indicated that the low WL glasses (i.e. 35 and $40 \mathrm{wt} \%$ ) were amorphous in each of the four frit-sludge groups. This agrees well with the PCT data, in that no statistical or practical difference in NL [B] response was seen between the quenched and ccc versions of each glass, with the exception of NEPH3-53. This exception is not of practical concern, as the NL [B] for NEPH3-53ccc was only $1.12 \mathrm{~g} / \mathrm{L}$ (based on measured composition), which is more than an order of magnitude below that of the EA reference glass and which fell within the prediction uncertainty of the $\Delta \mathrm{G}_{\mathrm{P}}$ model for boron.

The higher WL ccc glasses ( $>40 \% \mathrm{WL})$ in each frit-sludge group were shown by XRD to contain spinel (trevorite, $\mathrm{NiFe}_{2} \mathrm{O}_{4}$ ). This is expected, since as WL increases, the spinel formers ( $\mathrm{Fe}, \mathrm{Mn}, \mathrm{Ni}$ and $\mathrm{Cr}$ ) increase in concentration, resulting in precipitation of spinels in the glass upon slow cooling. Two of the highest WL glasses, NEPH3-44 and NEPH3-56, also contained nepheline $\left(\mathrm{NaAlSiO}_{4}\right)$. It is possible that some of the other high WL glasses, such as NEPH3-48, NEPH3-51 and NEPH3-55 also contain some nepheline, but that the amount of nepheline crystallization was below the detection limit of the XRD instrument. The presence of small amounts of nepheline would explain the difference in PCT responses between the quenched and ccc versions of these glasses. While a statistical difference in NL [B] response for these three glasses between the two cooling conditions was seen, the difference is small and of little practical concern, since the NL [B] values for the ccc glasses are well below that of the EA reference glass and the PCT responses fell within the uncertainty bands of the $\Delta \mathrm{G}_{\mathrm{P}}$ models.

The effect of nepheline crystallization is shown most clearly by NEPH3-56ccc. For this glass, the PCT response shows a significant difference between the quenched and ccc specimens, and XRD indicates that nepheline crystallization has occurred. As previously noted, nepheline formation can result in a severe deterioration of the chemical durability of the glass through changes in the composition of the residual glass (i.e., a continuous glass matrix which is $\mathrm{Al}_{2} \mathrm{O}_{3}$ and/or $\mathrm{SiO}_{2}$ deficient). The primary driver for the reduction in durability is the removal of three moles of glass forming oxides $\left(\mathrm{Al}_{2} \mathrm{O}_{3}\right.$ and $\left.2 \mathrm{SiO}_{2}\right)$ per each mole of $\mathrm{Na}_{2} \mathrm{O}$ from the continuous glass phase when nepheline crystallizes. Therefore, nepheline formation produces an $\mathrm{Al}_{2} \mathrm{O}_{3}$ and $\mathrm{SiO}_{2}$ deficient continuous glass matrix (relative to the same composition which is void of crystals) which reduces the durability of the final product. The magnitude of the reduction ultimately depends on the extent of crystallization. For NEPH3-56ccc, the NL [B] is still acceptable as compared to the EA reference glass (3.23 vs.

$16.695 \mathrm{~g} / \mathrm{L})$. However, the glass's unpredictability by the $\Delta \mathrm{G}_{\mathrm{P}}$ model suggests, once again, that glasses with nepheline discriminator values below the 0.62 limit may be of concern for processing at the DWPF. 
WSRC-TR-2006-00093

Revision 0

This page intentionally left blank. 


\subsection{Conclusions}

The results of this Phase 3 study concur with the earlier phases in that a nepheline discriminator of 0.62 appears to be the appropriate value for screening out glasses with the potential for nepheline crystallization upon slow cooling (and therefore reduced chemical durability). For the glasses studied here, the nepheline discriminator was also successful in screening out glasses that would be unpredictable by the $\Delta \mathrm{G}_{\mathrm{P}}$ model. Further discussion of a nepheline discriminator for possible inclusion in DWPF process controls will be addressed in a forthcoming report.

Chemical composition measurements indicated that the experimental glasses were close to their target compositions. The targeted $\mathrm{SO}_{4}{ }^{2-}$ concentrations in the Phase 3 glasses ranged from 0.468 to $0.682 \mathrm{wt} \%$. The chemical composition data suggest essentially full retention of $\mathrm{SO}_{4}{ }^{2-}$ in the glass (i.e., no solubility or volatilization issues during the fabrication process). There were no signs of a salt layer on any of the Phase 3 glasses. The degree of $\mathrm{SO}_{4}{ }^{2-}$ retention did not appear to be frit-dependent for these four frits. Coupling the analytical measurements with visual observations of the asfabricated glasses, the results suggest that the $0.6 \mathrm{wt} \% \mathrm{SO}_{4}{ }^{2-}$ limit is applicable for the $\mathrm{SB} 4$ systems evaluated in this study.

PCT results showed that all of the Phase 3 quenched glasses were acceptable as compared with the EA reference glass. The durabilities of some of the ccc glasses, particularly those with higher WLs, were statistically greater than their quenched counterparts. However, this was shown to be of little practical significance, as the durabilities of the ccc glasses were also all below that of the EA reference glass.

The glass that was not predicable contained both spinel and nepheline, had a nepheline discriminator value of less than 0.62 and was slow cooled. Since the glass was not homogenous, it is expected that the $\Delta \mathrm{G}_{\mathrm{P}}$ models will not correctly predict its performance.

Visual observations and PCT results indicated that all of the Phase 3 quenched glasses were amorphous. For the ccc glasses, XRD results indicated that the lower WL glasses (35 and $40 \mathrm{wt} \%$ ) in each frit-sludge group were amorphous, which was consistent with visual observations and PCT response.

The higher WL glasses ( $>40 \% \mathrm{WL}$ ) in each frit-sludge group were shown by XRD to contain spinel (trevorite, $\mathrm{NiFe}_{2} \mathrm{O}_{4}$ ). XRD showed that two of the highest WL glasses contained nepheline $\left(\mathrm{NaAlSiO}_{4}\right)$ as well. It is possible that some of the other high WL glasses also contained some nepheline, but that the amount of nepheline crystallization was below the detection limit associated with XRD. Nepheline crystallization was shown to result in a decrease in durability for some of the high WL ccc glasses. In the worst case (for the glasses studied here), the NL [B] increased from $1.26 \mathrm{~g} / \mathrm{L}$ (quenched) to $3.23 \mathrm{~g} / \mathrm{L}$ (ccc) for glass NEPH3-56. However, this NL [B] is still acceptable as compared to the EA reference glass $(16.695 \mathrm{~g} / \mathrm{L}) .{ }^{11}$

With respect to frit selection for SB4, the Phase 3 results indicate that Frits 418, 425, 501, and 502 are all good candidates, based on chemical durability and devitrification upon slow cooling. Differences in chemical durability and devitrification behavior were relatively small between the four frits studied as part of Phase 3. The results also indicate that WLs of 35-40 wt $\%$ are attainable with these frits, producing glasses with acceptable durability responses. However, melt rate is also an important factor in frit selection. Melt rate studies on these frits are currently underway and will likely have a significant impact on frit selection due to the high $\mathrm{Al}_{2} \mathrm{O}_{3}$ content of SB4. 
WSRC-TR-2006-00093

Revision 0

This page intentionally left blank. 


\subsection{Recommendations}

The path forward for evaluating the impact of nepheline formation on SB4-based glasses should include an assessment of the impact of implementing a nepheline discriminator value of 0.62 as an administrative control at DWPF, based on the results of the Phase $1-3$ studies and the on-going Frit 503 study. A determination should be made as to whether the nepheline discriminator would screen out all of the existing data that are either unacceptable (based on PCT responses) and/or unpredictable (using the $\Delta \mathrm{G}_{\mathrm{P}}$ models).

In addition, the impact of measurement uncertainty (MAR) on the projected operating windows for the frit-SB4 systems of interest must be made. The nepheline discriminator value of 0.62 does not yet have a measurement uncertainty associated with it. An assessment must be made to determine whether the inclusion of measurement uncertainty in the nepheline discriminator will restrict the range of WLs available to DWPF.

Finally, the impact of applying a nepheline discriminator to process controls must be evaluated for glasses that have already been fabricated at DWPF. Future work should identify what impact, if any, implementation of the nepheline discriminator would have on acceptability of historical glass compositions. 
WSRC-TR-2006-00093

Revision 0

This page intentionally left blank. 
WSRC-TR-2006-00093

Revision 0

\subsection{References}

1. Peeler, D. K., T. B. Edwards, I. A. Reamer and R. J. Workman, Nepheline Formation Study for Sludge Batch 4 (SB4): Phase 1 Experimental Results, WSRC-TR-2005-00371, Revision 0, Westinghouse Savannah River Company, Aiken, South Carolina (2005).

2. Peeler, D. K., T. B. Edwards, D. R. Best, I. A. Reamer and R. J. Workman, Nepheline Formation Study for Sludge Batch 4 (SB4): Phase 2 Experimental Results, WSRC-TR-2006-00006, Revision 0, Westinghouse Savannah River Company, Aiken, South Carolina (2006).

3. Shah, H. B., Estimate of Sludge Batch 4 Calcine Composition: Additional Cases for Final

Recommendation, CBU-PIT-2006-0001, Westinghouse Savannah River Company, Aiken, South Carolina (2006).

4. Peeler, D. K. and T. B. Edwards, Model Based Assessments for the Baseline Sludge Batch 4 (Case 15C) Flowsheet, WSRC-TR-2006-00049, Revision 0, Washington Savannah River Company, Aiken, South Carolina (2006).

5. Stone, M. E. and J. E. Josephs, Melt Rate Improvement for DWPF MB3: Melt Rate Furnace Testing (U), WSRC-TR-2001-00146, Revision 0, Westinghouse Savannah River Company, Aiken, South Carolina (2001).

6. Taylor, A. S., T. B. Edwards, J. C. George, T. K. Snyder and D. K. Peeler, The SRNL Composition Properties (ComPro ${ }^{\mathrm{TM}}$ ) Database, WSRC-RP-2004-00704, Revision 0, Westinghouse Savannah River Company, Aiken, South Carolina (2004).

7. SRNL, Glass Batching, SRTC Procedure Manual, L29, ITS-0001, Westinghouse Savannah River Company, Aiken, South Carolina (2002).

8. SRNL, Glass Melting, SRTC Procedure Manual, L29, ITS-0003, Westinghouse Savannah River Company, Aiken, South Carolina (2002).

9. Marra, S. L. and C. M. Jantzen, Characterization of Projected DWPF Glass Heat Treated to Simulate Canister Centerline Cooling, WSRC-TR-92-142, Revision 1, Westinghouse Savannah River Company, Aiken, South Carolina (1993).

10. ASTM, Standard Test Methods for Determining Chemical Durability of Nuclear Waste Glasses: The Product Consistency Test (PCT), ASTM C-1285-2002, (2002).

11. Jantzen, C. M., N. E. Bibler, D. C. Beam, C. L. Crawford and M. A. Pickett, Characterization of the Defense Waste Processing Facility (DWPF) Environmental Assessment (EA) Glass Standard Reference Material, WSRC-TR-92-346, Revision 1, Westinghouse Savannah River Company, Aiken, South Carolina (1993).

12. Jantzen, C. M., J. B. Picket, K. G. Brown, T. B. Edwards and D. C. Beam, Process/Product Models for the Defense Waste Processing Facility (DWPF): Part I. Predicting Glass Durability from Composition Using a Thermodynamic Hydration Energy Reaction Model (THERMO), WSRC-TR-93-672, Revision 1, Westinghouse Savannah River Company, Aiken, South Carolina (1995).

13. Brown, K. G., R. L. Postles and T. B. Edwards, SME Acceptability Determination for DWPF Process Control, WSRC-TR-95-00364, Revision 4, Westinghouse Savannah River Company, Aiken, South Carolina (2002).

14. Bickford, D. F. and C. M. Jantzen, "Devitrification of SRL Defense Waste Glass," Sci. Basis for Nuclear Waste Management VII, edited by G. L. McVay. Elsevier, New York, pp. 557-565 (1984). 
15. Bickford, D. F. and C. M. Jantzen, "Devitrification of Defense Nuclear Waste Glasses: Role of Melt Insolubles," J. Non-Crystalline Solids, 84 [1-3] 299-307 (1986).

16. Jantzen, C. M., D. F. Bickford, D. G. Karraker and G. G. Wicks, "Time-Temperature-Transformation Kinetics in SRL Waste Glass," pp. 30-38 in Advances in Ceramics, Vol. 8, American Ceramic Society, Westerville, OH (1984).

17. Spilman, D. B., L. L. Hench and D. E. Clark, "Devitrification and Subsequent Effects on the Leach Behavior of a Simulated Borosilicate Nuclear Waste Glass," Nuclear and Chemical Waste Management, 6 107119 (1986).

18. Li, H., J. D. Vienna, P. Hrma, D. E. Smith and M. J. Schwieger, "Nepheline Precipitation in High-Level Waste Glasses - Compositional Effects and Impact on the Waste Form Acceptability," Mat. Res. Soc. Proc., Vol. 465, pp. 261-268 (1997).

19. Riley, B. J., J. A. Rosario and P. Hrma, Impact of HLW Glass Crystallinity on the PCT Response, PNNL-13491, Pacific Northwest National Laboratory, Richland, Washington (2001).

20. Cicero, C. A., S. L. Marra and M. K. Andrews, Phase Stability Determinations of DWPF Waste Glasses (U), WSRC-TR-93-00227, Revision 0, Westinghouse Savannah River Company, Aiken, South Carolina (1993).

21. Kim, D. S., D. K. Peeler and P. Hrma, "Effect of Crystallization on the Chemical Durability of Simulated Nuclear Waste Glasses," Environmental Issues and Waste Management Technologies in the Ceramic and Nuclear Industries, Vol. 61, pp. 177-185 (1995).

22. Li, H., P. Hrma, J. D. Vienna, M. Qian, Y. Su and D. E. Smith, "Effects of $\mathrm{Al}_{2} \mathrm{O}_{3}, \mathrm{~B}_{2} \mathrm{O}_{3}, \mathrm{Na}_{2} \mathrm{O}$, and $\mathrm{SiO}_{2}$ on Nepheline Formation in Borosilicate Glasses: Chemical and Physical Correlations," Journal of Non-Crystalline Solids, 331 202-216 (2003).

23. Lilliston, G. R., Development of Elemental Sludge Compositions for Variations of Sludge Batch 4 (SB4), CBU-PIT-2004-00011, Revision 1, Westinghouse Savannah River Company, Aiken, South Carolina (2005).

24. Peeler, D. K. and T. B. Edwards, Frit Development Efforts for Sludge Batch 4: Model-Based Assessments, WSRC-TR-2005-00103, Revision 0, Westinghouse Savannah River Company, Aiken, South Carolina (2005).

25. Peeler, D. K., T. B. Edwards and T. H. Lorier, Nepheline Formation Potential in Sludge Batch (SB4)

Glasses, WSRC-TR-2005-00153, Revision 0, Westinghouse Savannah River Company, Aiken, South Carolina (2005).

26. Elder, H. H., Estimate of Sludge Batch 4 Calcine Composition, CBU-PIT-2005-00134, Revision 0, Westinghouse Savannah River Company, Aiken, South Carolina (2005).

27. Elder, H. H., Estimate of Sludge Batch 4 Calcine Composition Additional Cases, CBU-PIT-2005-00176, Revision 0, Westinghouse Savannah River Company, Aiken, South Carolina (2005).

28. Peeler, D. K. and T. B. Edwards, Frit Development Effort for SB4: Nominal and Variation Stage Assessments, WSRC-TR-2005-00372, Revision 0, Westinghouse Savannah River Company, Aiken, South Carolina (2005).

29. Edwards, T. B. and D. K. Peeler, Nepheline Formation Potential in Sludge Batch 4 (SB4) and Its Impact on Durability: Selecting Glasses for a Phase 2 Study, WSRC-TR-2005-00370, Revision 0, Westinghouse Savannah River Company, Aiken, South Carolina (2005). 
30. Washburn, F. A., Technical Task Request: Sludge Batch 4 and MCU Frit Optimization,

HLW/DWPF/TTR-2004-0025, Revision 0, Westinghouse Savannah River Company, Aiken, South Carolina (2004).

31. Peeler, D. K., Task Technical \& QA Plan: Sludge Batch and MCU Frit Optimization, WSRC-RP2004-00746, Revision 0, Westinghouse Savannah River Company, Aiken, South Carolina (2004).

32. Fox, K. M., T. B. Edwards and D. K. Peeler, Nepheline Formation Potential in Sludge Batch 4 (SB4) and Its Impact on Durability: Selecting Glases for a Phase 3 Study, WSRC-TR-2006-00053, Revision 0, Washington Savannah River Company, Aiken, South Carolina (2006).

33. Peeler, D. K., C. C. Herman, M. E. Smith, T. H. Lorier, D. R. Best, T. B. Edwards and M. A. Baich, An Assessment of the Sulfate Solubility Limit for the Frit 418 - Sludge Batch 2/3 System, WSRC-TR-200400081, Revision 0, Westinghouse Savannah River Company, Aiken, South Carolina (2004). 
WSRC-TR-2006-00093

Revision 0

This page intentionally left blank. 


\section{Appendix A}

\section{An Analytical Plan for Measuring the Chemical Compositions of the Nepheline Phase 3 Study Glasses (SRNL-SCS-2006-00006)}


WSRC-TR-2006-00093

Revision 0

Appendix A (SRNL-SCS-2006-00006)

This page intentionally left blank. 
February 14, 2006

To: $\quad$ K. M. Fox, SRNL

cc: $\quad$ R. A. Baker, 773-42A

I. A. Reamer, 999-1W

D. R. Best, 786-1A (wo)

P. A. Toole, 786-1A (wo)

C. C. Herman, 999-W

R. C. Tuckfield, 773-42A

D. K. Peeler, 999-W

R. J. Workman, 999-1 W

From: T. B. Edwards, 773-42A (5-5148)

Statistical Consulting Section

wo - without glass identifiers
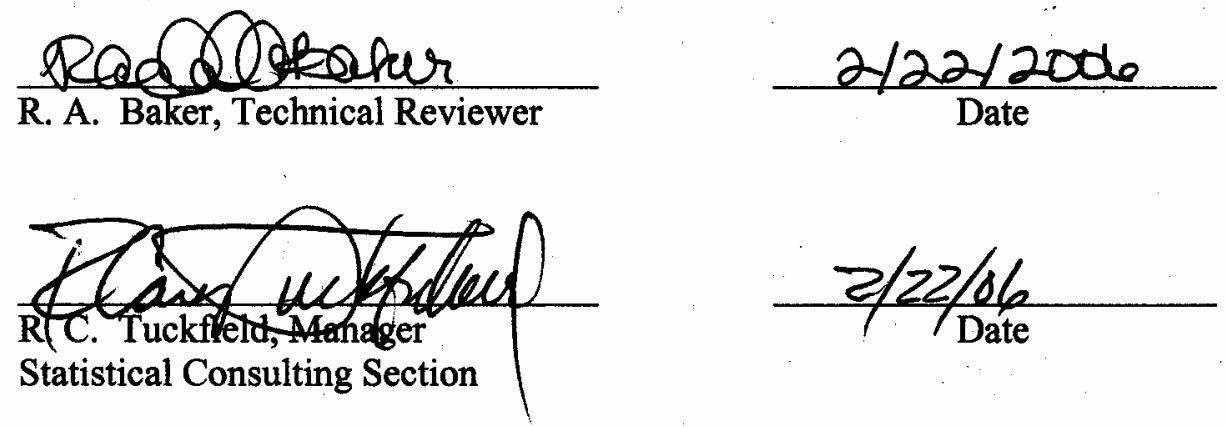

\section{An Analytical Plan for Measuring THE CHEMICAL COMPOSITIONS OF THE Nepheline Phase 3 Study Glasses (U)}




\subsection{EXECUTIVE SUMMARY}

A study is being conducted by the Savannah River National Laboratory (SRNL) for the Defense Waste Processing Facility (DWPF) that involves investigating the potential impact of nepheline formation on the durability of high level waste glasses. To address this issue, several glass compositions were identified for their potential for the formation of nepheline as part of the frit development activities for Sludge Batch 4 (SB4). Sixteen of these glasses were selected to be batched and fabricated as Phase 3 of the nepheline study. These glasses complemented the earlier studies by continuing the investigation into the ability of the nepheline discriminator to predict the occurrence of a nepheline primary crystalline phase for SB4 glasses and into the impact of such phases on the durability of the SB4 glasses.

The chemical compositions of these 16 Phase 3 glasses are to be determined by SRNL's Process Science Analytical Laboratory (PSAL). This memorandum provides an analytical plan to direct and support these measurements at PSAL. 


\subsection{INTRODUCTION}

Appendix A (SRNL-SCS-2006-00006)

A study is being conducted by the Savannah River National Laboratory (SRNL) for the Defense Waste Processing Facility (DWPF) that involves investigating the potential impact of nepheline formation on the durability of high level waste glasses [1]. To address this issue, sixteen glass compositions were identified for their potential for the formation of nepheline as part of the frit development activities for Sludge Batch 4 (SB4). These glasses make up the Phase 3 study, which has two primary objectives. The first is to continue to demonstrate the ability of the discriminator value to adequately predict nepheline formation potential for specific glass systems of interest. The second is to generate additional data that have a high probability of supporting the SB4 variability study. To support these two objectives, glasses were selected to cover waste loadings (WLs) that tightly bound the nepheline discriminator value of 0.62 [2], with the intent of refining this value to a level of confidence where it can be incorporated into offline administrative controls and/or the Product Composition Control System (PCCS) to support Slurry Mix Evaporator (SME) acceptability decisions. In addition, glasses targeting lower WLs (35 and 40\%) will be prepared and analyzed to contribute needed data to the ComPro ${ }^{\mathrm{TM}}$ database [3] in anticipation of a variability study for SB4.

The chemical compositions of the 16 Phase 3 glasses are to be determined by SRNL's Process Science Analytical Laboratory (PSAL). This memorandum provides an analytical plan to direct and support these measurements at PSAL.

\subsection{Analytical Plan}

The analytical procedures used by PSAL to determine cation concentrations for a glass sample include steps for sample preparation and for instrument calibration. Each glass is to be prepared in duplicate by each of two dissolution methods: lithium metaborate fusion (LM) and sodium peroxide fusion (PF).

The primary measurements of interest are to be acquired as follows. The samples prepared by LM are to be measured for barium $(\mathrm{Ba})$, calcium $(\mathrm{Ca})$, cerium $(\mathrm{Ce})$, chromium $(\mathrm{Cr})$, copper $(\mathrm{Cu})$, potassium $(\mathrm{K})$, lanthanum $(\mathrm{La})$, magnesium $(\mathrm{Mg})$, manganese $(\mathrm{Mn})$, sodium $(\mathrm{Na})$, lead $(\mathrm{Pb})$, sulfur (S), thorium (Th), titanium (Ti), zinc $(\mathrm{Zn})$, and zirconium $(\mathrm{Zr})$ concentrations. Samples prepared by $\mathrm{PF}$ are to be measured for aluminum (Al), boron (B), iron (Fe), lithium ( $\mathrm{Li})$, nickel (Ni), silicon ( $\mathrm{Si}$ ), and uranium (U). Samples dissolved by both preparation methods are to be measured using Inductively Coupled Plasma - Atomic Emission Spectrometry (ICP-AES). It should be noted that some of these elements are minor components that may be near detection limits for most, if not all, of the study glasses.

Randomizing the preparation steps and blocking and randomizing the measurements for the ICP-AES are of primary concern in the development of this analytical plan. The sources of uncertainty for the analytical procedure used by PSAL to determine the cation concentrations for the submitted glass samples are dominated by the dissolution step in the preparation of the sample and by the calibrations of the ICP-AES.

Samples of glass standards will be included in the analytical plan to provide an opportunity for checking the performance of the instrumentation over the course of the analyses and for potential bias correction. Specifically, several samples of Waste Compliance Plan (WCP) Batch 1 (BCH) [4] and a uranium standard glass (Ustd) are included in this analytical plan. The reference compositions of these glasses are provided in Table 1. 
WSRC-TR-2006-00093

Revision 0

Appendix A (SRNL-SCS-2006-00006)

Table 1: Oxide Compositions of WCP Batch 1 (BCH) and of Ustd (wt\%)

\begin{tabular}{|c|c|c|}
\hline $\begin{array}{c}\text { Oxide/ } \\
\text { Anion }\end{array}$ & $\begin{array}{c}\text { BCH } \\
\text { (wt \%) }\end{array}$ & $\begin{array}{c}\text { Ustd } \\
\text { (wt \%) }\end{array}$ \\
\hline $\mathrm{Al}_{2} \mathrm{O}_{3}$ & 4.877 & 4.1 \\
\hline $\mathrm{B}_{2} \mathrm{O}_{3}$ & 7.777 & 9.209 \\
\hline $\mathrm{BaO}$ & 0.151 & 0 \\
\hline $\mathrm{CaO}$ & 1.22 & 1.301 \\
\hline $\mathrm{Cr}_{2} \mathrm{O}_{3}$ & 0.107 & 0 \\
\hline $\mathrm{Cs}_{2} \mathrm{O}$ & 0.06 & 0 \\
\hline $\mathrm{CuO}$ & 0.399 & 0 \\
\hline $\mathrm{Fe}_{2} \mathrm{O}_{3}$ & 12.839 & 13.196 \\
\hline $\mathrm{K}_{2} \mathrm{O}$ & 3.327 & 2.999 \\
\hline $\mathrm{Li}_{2} \mathrm{O}$ & 4.429 & 3.057 \\
\hline $\mathrm{MgO}_{\mathrm{MnO}}$ & 1.419 & 1.21 \\
\hline $\mathrm{MnO}_{2} \mathrm{O}$ & 1.726 & 2.892 \\
\hline $\mathrm{Na}_{2} \mathrm{O}$ & 9.003 & 11.795 \\
\hline $\mathrm{Nd}_{2} \mathrm{O}_{3}$ & 0.147 & 0 \\
\hline $\mathrm{NiO}$ & 0.751 & 1.12 \\
\hline $\mathrm{RuO}_{2}$ & 0.0214 & 0 \\
\hline $\mathrm{SiO}_{2}$ & 50.22 & 45.353 \\
\hline $\mathrm{SO}_{3}$ & 0 & 0 \\
\hline $\mathrm{TiO}_{2}$ & 0.677 & 1.049 \\
\hline $\mathrm{U}_{3} \mathrm{O}_{8}$ & 0 & 2.406 \\
\hline $\mathrm{ZrO}_{2}$ & 0.098 & 0 \\
\hline
\end{tabular}

Each glass sample submitted to PSAL will be prepared in duplicate by the LM and PF dissolution methods. Every prepared sample will be read twice by ICP-AES, with the instrument being calibrated before each of these two sets of readings. This will lead to four measurements for each cation of interest for each submitted glass.

Table 2 presents identifying codes, G01 through G16, for the 16 glasses fabricated for this nepheline study. The table provides a naming convention that is to be used in analyzing the glasses and reporting the measurements of their compositions. ${ }^{\mathrm{a}}$

a Renaming these samples helps to ensure that they will be processed as blind samples within PSAL. Table 2 is not shown in its entirety in the copies going to PSAL. 
WSRC-TR-2006-00093

Revision 0

Appendix A (SRNL-SCS-2006-00006)

Table 2: Glass Identifiers ${ }^{a}$ to Establish Blind Samples for PSAL

\begin{tabular}{||c|c||c|c||}
\hline $\begin{array}{c}\text { Glass } \\
\text { ID }\end{array}$ & $\begin{array}{c}\text { Sample } \\
\text { ID }\end{array}$ & $\begin{array}{c}\text { Glass } \\
\text { ID }\end{array}$ & $\begin{array}{c}\text { Sample } \\
\text { ID }\end{array}$ \\
\hline NEPH3-41 & G06 & NEPH3-49 & G13 \\
\hline NEPH3-42 & G08 & NEPH3-50 & G04 \\
\hline NEPH3-43 & G14 & NEPH3-51 & G03 \\
\hline NEPH3-44 & G01 & NEPH3-52 & G09 \\
\hline NEPH3-45 & G12 & NEPH3-53 & G05 \\
\hline NEPH3-46 & G07 & NEPH3-54 & G16 \\
\hline NEPH3-47 & G15 & NEPH3-55 & G10 \\
\hline NEPH3-48 & G02 & NEPH3-56 & G11 \\
\hline
\end{tabular}

\subsection{PREPARATION OF THE SAMPLES}

Each of the 16 glasses included in this analytical plan is to be prepared in duplicate by the LM and PF dissolution methods. Thus, the total number of prepared glass samples is determined by $16 \cdot 2 \cdot 2=64$, not including the samples of the $\mathrm{BCH}$ and Ustd glass standards that are to be prepared.

Table 3 provides blocking and (random) sequencing schema for conducting the preparation steps of the analytical procedures. One block of preparation work is provided for each preparation method to facilitate the scheduling of activities by work shift. The identifier for each of the prepared samples indicates the sample identifier (ID), preparation method, and duplicate number.

\footnotetext{
a The nomenclature NEPH3-41 stands for a nepheline glass ("NEPH”), Phase 3 ("3"), with the identifying number 41 ("-41"). The Phase 1 and Phase 2 studied glasses with numbers 1 through 12 and 13 through 40, respectively.
} 
Table 3: Preparation Blocks by Dissolution Method

\begin{tabular}{|c|c|}
\hline LM (Lithium Metaborate) & PF (Peroxide Fusion) \\
\hline G14LM1 & G07PF1 \\
\hline G04LM1 & G13PF1 \\
\hline G16LM1 & G10PF1 \\
\hline G07LM1 & G09PF1 \\
\hline G02LM1 & G15PF1 \\
\hline G14LM2 & G03PF1 \\
\hline G04LM2 & G06PF1 \\
\hline G16LM2 & G04PF1 \\
\hline G07LM2 & G07PF2 \\
\hline G10LM1 & G14PF1 \\
\hline G13LM1 & G01PF1 \\
\hline G06LM1 & G08PF1 \\
\hline G05LM1 & G05PF1 \\
\hline G02LM2 & G02PF1 \\
\hline G12LM1 & G16PF1 \\
\hline G05LM2 & G12PF1 \\
\hline G11LM1 & G14PF2 \\
\hline G09LM1 & G11PF1 \\
\hline G01LM1 & G06PF2 \\
\hline G10LM2 & G08PF2 \\
\hline G08LM1 & G12PF2 \\
\hline G13LM2 & G09PF2 \\
\hline G15LM1 & G15PF2 \\
\hline G03LM1 & G13PF2 \\
\hline G09LM2 & G10PF2 \\
\hline G15LM2 & G04PF2 \\
\hline G06LM2 & G03PF2 \\
\hline G08LM2 & G01PF2 \\
\hline G12LM2 & G11PF2 \\
\hline G01LM2 & G16PF2 \\
\hline G11LM2 & G05PF2 \\
\hline G03LM2 & G02PF2 \\
\hline
\end{tabular}

\subsection{ICP-AES CALIBRATION BLOCKS}

The glass samples prepared by the LM and PF dissolution methods are to be analyzed using ICP-AES instrumentation calibrated for the particular preparation method. After the initial set of cation concentration measurements, the ICP-AES instrumentation is to be recalibrated and a second set of concentration measurements for the cations determined.

Randomized plans for measuring cation concentrations in the LM-prepared and PF-prepared samples are provided in Table 4. The cations to be measured are specified as part of the table. In the tables, the sample identifiers for the 16 study glasses have been modified by the addition of a suffix (a " 1 "or a " 2 ") to indicate whether the measurement was made during the first or second (respectively) 
calibration of the ICP-AES instrumentation. The identifiers for the $\mathrm{BCH}$ and Ustd samples have been modified to indicate the ICP-AES calibration and that each of these prepared samples is to be read 3 times (mirrored in the corresponding suffix of 1,2, or 3) per block and calibration.

Table 4: ICP-AES Blocks \& Calibration Groups by Preparation Method

\begin{tabular}{|c|c|c|c|c|c|c|c|}
\hline \multicolumn{4}{|c|}{ LM Glass Samples } & \multicolumn{4}{|c|}{ PF Glass Samples } \\
\hline \multicolumn{4}{|c|}{$\begin{array}{c}\text { Used to Measure Elemental Ba, } \mathrm{Ca}, \mathrm{Ce}, \mathrm{Cr}, \mathrm{Cu}, \mathrm{K}, \mathrm{La}, \mathrm{Mg}, \mathrm{Mn}, \mathrm{Na}, \mathrm{Pb} \\
\mathrm{S}, \mathrm{Th}, \mathrm{Ti}, \mathrm{Zn}, \& \mathrm{Zr} \\
\end{array}$} & \multicolumn{4}{|c|}{ Used to Measure Elemental Al, B, Fe, Li, Ni, Si, \& U } \\
\hline \multicolumn{2}{|c|}{ Block 1 } & \multicolumn{2}{|c|}{\begin{tabular}{|l|} 
Block 2 \\
\end{tabular}} & \multicolumn{2}{|c|}{ Block 1} & \multicolumn{2}{|c|}{ Block 2} \\
\hline Calibration 1 & Calibration 2 & Calibration 1 & Calibration 2 & Calibration 1 & Calibration 2 & \begin{tabular}{|l|} 
Calibration 1 \\
\end{tabular} & Calibration 2 \\
\hline BCHLM111 & BCHLM121 & BCHLM211 & BCHLM221 & BCHPF111 & BCHPF121 & BCHPF211 & BCHPF221 \\
\hline UstdLM111 & UstdLM121 & UstdLM211 & UstdLM221 & UstdPF111 & UstdPF121 & UstdPF211 & UstdPF221 \\
\hline G14LM21 & G07LM22 & G04LM21 & G08LM22 & G10PF21 & G10PF12 & G15PF11 & G02PF22 \\
\hline G13LM21 & G03LM12 & G06LM21 & G06LM12 & G06PF21 & G11PF22 & G08PF11 & G04PF22 \\
\hline G05LM21 & G14LM22 & G16LM11 & G16LM22 & G11PF21 & G05PF12 & G13PF11 & G16PF22 \\
\hline G12LM21 & G09LM12 & G08LM21 & G08LM12 & G03PF21 & G12PF22 & G14PF21 & G14PF22 \\
\hline G03LM11 & G12LM22 & G11LM21 & G01LM22 & G07PF21 & G06PF12 & G16PF21 & G09PF12 \\
\hline G13LM11 & G05LM22 & G06LM11 & G06LM22 & G05PF11 & G01PF12 & G04PF21 & G02PF12 \\
\hline G09LM21 & G12LM12 & G10LM11 & G15LM12 & G06PF11 & G07PF22 & G14PF11 & G14PF12 \\
\hline G07LM21 & G13LM22 & G01LM21 & G04LM22 & G11PF11 & G06PF22 & G09PF21 & G16PF12 \\
\hline BCHLM112 & BCHLM122 & BCHLM212 & BCHLM222 & BCHPF112 & BCHPF122 & BCHPF212 & BCHPF222 \\
\hline UstdLM112 & UstdLM122 & UstdLM212 & UstdLM222 & UstdPF112 & UstdPF122 & UstdPF212 & UstdPF222 \\
\hline G02LM21 & G02LM12 & G04LM11 & G16LM12 & G12PF21 & G11PF12 & G02PF11 & G09PF22 \\
\hline G09LM11 & G03LM22 & G11LM11 & G04LM12 & G05PF21 & G05PF22 & G02PF21 & G08PF12 \\
\hline G02LM11 & G02LM22 & G10LM21 & G10LM22 & G01PF21 & G12PF12 & G09PF11 & G04PF12 \\
\hline G05LM11 & G09LM22 & G01LM11 & G15LM22 & G01PF11 & G07PF12 & G04PF11 & G08PF22 \\
\hline G12LM11 & G14LM12 & G15LM11 & G10LM12 & G12PF11 & G03PF22 & G15PF21 & G15PF22 \\
\hline G07LM11 & G13LM12 & G08LM11 & G11LM22 & G10PF11 & G03PF12 & G08PF21 & G13PF12 \\
\hline G03LM21 & G05LM12 & G16LM21 & G11LM12 & G07PF11 & G10PF22 & G13PF21 & G15PF12 \\
\hline G14LM11 & G07LM12 & G15LM21 & G01LM12 & G03PF11 & G01PF22 & G16PF11 & G13PF22 \\
\hline BCHLM113 & BCHLM123 & BCHLM213 & BCHLM223 & BCHPF113 & BCHPF123 & BCHPF213 & BCHPF223 \\
\hline UstdLM113 & UstdLM123 & UstdLM213 & UstdLM223 & UstdPF113 & UstdPF123 & UstdPF213 & UstdPF223 \\
\hline
\end{tabular}

\subsection{Concluding Comments}

In summary, this analytical plan identifies two preparation blocks in Table 3 and eight ICP-AES calibration blocks in Table 4 for use by PSAL. The sequencing of the activities associated with each of the steps in the analytical procedures has been randomized. The size of each of the blocks was selected so that it could be completed in a single work shift.

If a problem is discovered while measuring samples in a calibration block, the instrument should be re-calibrated and the block of samples re-measured in its entirety. If for some reason the measurements are not conducted in the sequences presented in this report, a record should be made of the actual order used along with any explanative comments.

The analytical plan indicated in the preceding tables should be modified by the personnel of PSAL to include any calibration check standards and/or other standards that are part of their routine operating procedures. It is also recommended that the solutions resulting from each of the prepared samples be archived for some period, considering the "shelf-life" of the solutions, in case questions arise during 
data analysis. This would allow for the solutions to be rerun without additional preparations, thus minimizing cost.

\subsection{REFERENCES}

[1] Fox, K.M., T.B. Edwards, and D.K. Peeler, "Nepheline Formation Potential in Sludge Batch 4 (SB4) and its Impact on Durability: Selecting Glasses for a Phase 3 Study," WSRC-TR-2006-00053, Revision 0, 2006.

[2] Li, H., P. Hrma, J.D. Vienna, M. Qian, Y. Su, and D.E. Smith, "Effects of $\mathrm{Al}_{2} \mathrm{O}_{3}, \mathrm{~B}_{2} \mathrm{O}_{3}$, $\mathrm{Na}_{2} \mathrm{O}$, and $\mathrm{SiO}_{2}$ on Nepheline Formation in Borosilicate Glasses: Chemical and Physical Correlations," Journal of Non-Crystalline Solids, 331, pgs. 202-216, 2003.

[3] Taylor, A.S., T.B. Edwards, J.C. George, T.K. Snyder, and D.K. Peeler, "The SRNL Glass Composition - Properties (ComPro) Database," WSRC-RP-2004-00704, Revision $0,2004$.

[4] Jantzen, C.M., J.B. Pickett, K.G. Brown, T.B. Edwards, and D.C. Beam, "Process/ Product Models for the Defense Waste Processing Facility (DWPF): Part I. Predicting Glass Durability from Composition Using a Thermodynamic Hydration Energy Reaction Model (THERMO ${ }^{\mathrm{TM}}$ ) (U)," WSRC-TR-93-673, Revision 1, Volume 2, Table B.1, pp. B.9, 1995. 


\section{Appendix B}

\section{An Analytical Plan for Measuring PCT Solutions for the First Set of Glasses from the Phase 3 Nepheline Study (SRNL-SCS-2006-00003)}


WSRC-TR-2006-00093

Revision 0

Appendix B (SRNL-SCS-2006-00003)

This page intentionally left blank. 


\section{SRNL-SCS-2006-00003}

February 8, 2006

To:

K. M. Fox, SRNL

cc:

R. A. Baker, 773-42A

D. R. Best, 786-1A (wo)

I. A. Reamer, 999-1W

C. C. Herman, $999-W$

P. A. Toole, 786-1A (wo)

D. K. Peeler, 999-W

R. C. Tuckfield, 773-42A

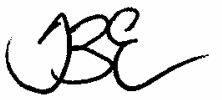

From: T. B. Edwards, 773-42A (5-5148)

Statistical Consulting Section

R. J. Workman, 999-1W

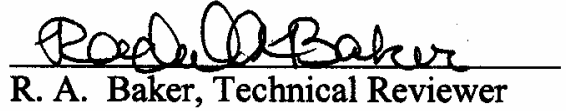

wo - without glass identifiers

R. A. Baker, Technical Reviewer
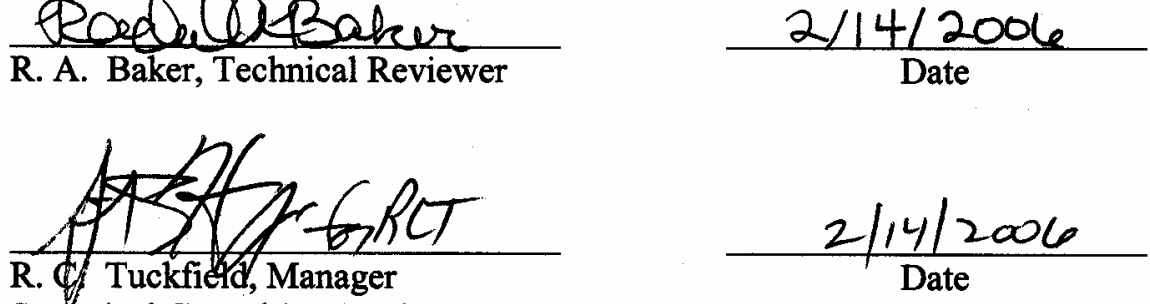

Statístical Consulting Section

$\frac{2 / 14 / 2006}{\text { Date }}$

\section{An Analytical Plan for Measuring PCT SOLUTIONS FOR THE FIRST SET OF Glasses from the Phase 3 NePheline STUDY (U)}




\subsection{EXECUTIVE SUMMARY}

A study is being conducted by the Savannah River National Laboratory (SRNL) for the Defense Waste Processing Facility (DWPF) that involves investigating the potential impact of nepheline formation on the durability of high level waste glasses. To address this issue, several glass compositions were identified for their potential for the formation of nepheline as part of the frit development activities for Sludge Batch 4 (SB4). Sixteen of these glasses were selected to be batched and fabricated as Phase 3 of the nepheline study; the durability of the glasses is to be measured using the Product Consistency Test (PCT) as defined in ASTM C-1285-2002. Two heat treatments were utilized during the fabrication of each of these glasses. Specifically, each of the 16 glasses was quenched (i.e., rapidly cooled) and cooled in accordance with the centerline-canister-cooling (ccc) regime. Both heat treatments of each glass are to be subjected to the PCT.

To complete the full complement of PCTs, the 16 glasses were grouped into two sets based on the frits that were combined with SB4. The first set of PCTs covered the glasses that were developed using Frits 418 and 501, while the second set of PCTs covered the glasses that were developed using Frits 425 and 502. Both sets of PCTs are to be submitted to SRNL's Process Science Analytical Laboratory (PSAL) for measurement. This memorandum provides an analytical plan for the measurement of the first set of PCTs by PSAL. 
WSRC-TR-2006-00093

Revision 0

Appendix B (SRNL-SCS-2006-00003)

\subsection{INTRODUCTION}

A study is being conducted by the Savannah River National Laboratory (SRNL) for the Defense Waste Processing Facility (DWPF) that involves investigating the potential impact of nepheline formation on the durability of high level waste glasses [1]. To address this issue, 16 glass compositions were selected for their potential for the formation of nepheline as part of the frit development activities for Sludge Batch 4 (SB4). The specific SB4 option being considered is Case $15 \mathrm{C}$ Blend 1 as defined by Shah [2]. The glasses were selected to be batched and fabricated as Phase 3 of the nepheline study; the durability of the glasses is to be measured using the Product Consistency Test (PCT) as defined in ASTM C-1285-2002 [3]. Two heat treatments were utilized during the fabrication of each of these glasses. Specifically, each of the 16 glasses was quenched (i.e., rapidly cooled) and cooled in accordance with the centerline-canister-cooling (ccc) regime. Both heat treatments of each glass are to be subjected to the PCT.

To complete the full complement of PCTs, the 16 glasses were grouped into two sets based on the frits that were combined with SB4. The first set of PCTs covered the glasses (NEPH3-41 through NEPH3-48) that were developed using Frits 418 and 501, while the second set of PCTs covered the glasses (NEPH3-49 through NEPH3-56) that were developed using Frits 425 and 502. This analytical study plan addresses the PCT solutions for NEPH3-41 through NEPH3-48 (or set \#1) for both quenched and ccc heat treatments. A separate analytical plan will be developed for the second set (NEPH3-49 through NEPH3-56). Both sets of PCTs are to be submitted to SRNL's Process Science Analytical Laboratory (PSAL) for measurement. Table 1 presents a listing of the glasses covered by this memorandum.

Table 1: Identifiers for Glasses Covered by this Plana

\begin{tabular}{|c|c|}
\hline NEPH3-41 & NEPH3-45 \\
\hline NEPH3-41ccc & NEPH3-45ccc \\
\hline NEPH3-42 & NEPH3-46 \\
\hline NEPH3-42ccc & NEPH3-46ccc \\
\hline NEPH3-43 & NEPH3-47 \\
\hline NEPH3-43ccc & NEPH3-47ccc \\
\hline NEPH3-44 & NEPH3-48 \\
\hline NEPH3-44ccc & NEPH3-48ccc \\
\hline
\end{tabular}

\subsection{DisCUSSION}

Each of the study glasses of Table 1 is to be subjected to the PCT in triplicate. In addition to PCTs for the study glasses, triplicate PCTs are to be conducted on a sample of the Approved Reference Material - One (ARM-1) glass and a sample of the Environmental Assessment (EA) glass. Two reagent blank samples are also to be included in these tests. This results in 56 sample solutions being required to complete these PCTs.

The leachates from these tests will be diluted by adding $4 \mathrm{~mL}$ of $0.4 \mathrm{M} \mathrm{HNO}_{3}$ to $6 \mathrm{~mL}$ of the leachate (a 6:10 volume to volume, v:v, dilution) before being submitted to PSAL. The leachates of EA will

a The nomenclature NEPH3-41 stands for a nepheline glass ("NEPH"), Phase 3 ("3"), with the identifying number 41 ("41"). The Phase 1 and 2 studies contained glasses 1 through 12 and 13 through 40, respectively. 
be further diluted (1:10 v:v) with deionized water prior to submission to PSAL in order to prevent problems with the nebulizer. Note that additional dilutions for the ccc versions of one or more of the study glasses may be needed due to a possibly low durability of some of the glasses. Upon termination of the PCT, a decision is to be made (by the technicians and a PSAL representative, if called by the technician) as to whether any other dilution is needed for these solutions to mitigate any potential gelling issues. Any extra dilutions are to be reported, and guidance is to be given as to how the dilutions are to be handled in the statistical assessment of the measurement data. More specifically, PSAL will be responsible for indicating if any additional dilutions were made and how they were, or how they should be, accounted for in the reported measurements.

Table 2 presents identifying codes, F01 through F56, for the individual solutions required for the PCTs of the select study glasses and of the standards (EA, ARM-1, and blanks). This provides a naming convention that is to be used by PSAL in analyzing the solutions and reporting the relevant concentration measurements. ${ }^{\mathrm{a}}$

Table 2: Identifiers for the PCT Solutions Covered by this Plan

\begin{tabular}{|cc|cc|cc|}
\hline $\begin{array}{c}\text { Original } \\
\text { Sample }\end{array}$ & $\begin{array}{c}\text { Solution } \\
\text { Identifier }\end{array}$ & $\begin{array}{c}\text { Original } \\
\text { Sample }\end{array}$ & $\begin{array}{c}\text { Solution } \\
\text { Identifier }\end{array}$ & $\begin{array}{c}\text { Original } \\
\text { Sample }\end{array}$ & $\begin{array}{c}\text { Solution } \\
\text { Identifier }\end{array}$ \\
NEPH3-41 & F37 & NEPH3-44ccc & F36 & NEPH3-48 & F38 \\
NEPH3-41 & F09 & NEPH3-44ccc & F22 & NEPH3-48 & F14 \\
NEPH3-41 & F17 & NEPH3-44ccc & F42 & NEPH3-48 & F18 \\
NEPH3-41ccc & F32 & NEPH3-45 & F55 & NEPH3-48ccc & F47 \\
NEPH3-41ccc & F11 & NEPH3-45 & F16 & NEPH3-48ccc & F20 \\
NEPH3-41ccc & F41 & NEPH3-45 & F40 & NEPH3-48ccc & F33 \\
NEPH3-42 & F52 & NEPH3-45ccc & F28 & EA & F50 \\
NEPH3-42 & F05 & NEPH3-45ccc & F02 & EA & F53 \\
NEPH3-42 & F06 & NEPH3-45ccc & F04 & EA & F46 \\
NEPH3-42ccc & F39 & NEPH3-46 & F25 & ARM-1 & F08 \\
NEPH3-42ccc & F30 & NEPH3-46 & F35 & ARM-1 & F29 \\
NEPH3-42ccc & F23 & NEPH3-46 & F45 & ARM-1 & F13 \\
NEPH3-43 & F10 & NEPH3-46ccc & F07 & blank & F26 \\
NEPH3-43 & F49 & NEPH3-46ccc & F19 & blank & F12 \\
NEPH3-43 & F54 & NEPH3-46ccc & F56 & & \\
NEPH3-43ccc & F34 & NEPH3-47 & F01 & & \\
NEPH3-43ccc & F44 & NEPH3-47 & F27 & & \\
NEPH3-43ccc & F51 & NEPH3-47 & F31 & & \\
NEPH3-44 & F15 & NEPH3-47ccc & F48 & & \\
NEPH3-44 & F24 & NEPH3-47ccc & F03 & & \\
NEPH3-44 & F21 & NEPH3-47ccc & F43 & & \\
\hline
\end{tabular}

\subsection{Analytical Plan}

The analytical plan for PSAL is provided in this section. Each of the solution samples submitted to PSAL is to be analyzed only once for each of the following: boron (B), barium (Ba), cadmium (Cd),

a Renaming these samples ensures that they will be processed as blind samples by PSAL. This table does not contain the solution identifiers for those on the distribution list with a "wo" following their names. 
chromium $(\mathrm{Cr})$, iron $(\mathrm{Fe})$, lithium $(\mathrm{Li})$, sodium $(\mathrm{Na})$, lead $(\mathrm{Pb})$, silicon $(\mathrm{Si})$, thorium $(\mathrm{Th})$, and uranium (U). $\mathrm{B}, \mathrm{Li}, \mathrm{Na}$, and $\mathrm{Si}$ are the elements that are to be used in the assessment of glass durability; the other elements are being monitored to address solution disposal issues in SRNL upon termination of the PCTs. The measurements are to be made in parts per million (ppm).

The analytical procedure used by PSAL to determine the concentrations utilizes an Inductively Coupled Plasma - Atomic Emission Spectrometer (ICP-AES). The PCT solutions (as identified in Table 2) are grouped in three ICP-AES blocks for processing by PSAL in Table 3. Each block requires a different calibration of the ICP-AES.

Table 3: ICP-AES Calibration Blocks for Leachate Measurements

\begin{tabular}{|ccc|}
\hline Block 1 & Block 2 & Block 3 \\
std-b1-1 & std-b2-1 & std-b3-1 \\
F52 & F05 & F06 \\
F39 & F30 & F23 \\
F08 & F27 & F46 \\
F01 & F03 & F31 \\
F48 & F35 & F43 \\
F26 & F19 & F45 \\
F25 & F09 & F56 \\
F07 & F11 & F17 \\
F37 & F29 & F41 \\
F32 & F53 & F12 \\
std-b1-2 & std-b2-2 & std-b3-2 \\
F15 & F24 & F21 \\
F36 & F22 & F42 \\
F38 & F14 & F18 \\
F47 & F20 & F33 \\
F50 & F49 & F13 \\
F10 & F44 & F54 \\
F34 & F16 & F51 \\
F55 & F02 & F40 \\
F28 & std-b2-3 & F04 \\
std-b1-3 & & std-b3-3 \\
\hline
\end{tabular}

A multi-element solution standard (denoted by "std-bi-j" where $\mathrm{i}=1$ to 3 represents the block number and $\mathrm{j}=1,2$, and 3 represents the position in the block) was added at the beginning, middle, and end of each of the three blocks. This standard may be useful in checking and correcting for bias in the concentration measurements arising from the ICP calibrations.

\subsection{SUMMARY}

In summary, this analytical plan provides identifiers for the PCT solutions in Table 2 and three ICPAES calibration blocks in Table 3 for PSAL to use in conducting the boron (B), barium (Ba), cadmium $(\mathrm{Cd})$, chromium $(\mathrm{Cr})$, iron $(\mathrm{Fe})$, lithium $(\mathrm{Li})$, sodium $(\mathrm{Na})$, lead $(\mathrm{Pb})$, silicon $(\mathrm{Si})$, thorium $(\mathrm{Th})$, and uranium $(\mathrm{U})$ concentration measurements for the PCT study of this select subset of the Phase 3 nepheline glasses. The sequencing of the activities associated with each of the steps in the analytical procedure has been randomized. The size of the blocks was selected so that the block 
WSRC-TR-2006-00093

Revision 0

Appendix B (SRNL-SCS-2006-00003)

could be completed in a single work shift. If for some reason the measurements are not conducted in the sequence presented in this memorandum, the actual order should be recorded along with any explanative comments.

The analytical plan indicated in the preceding tables should be modified by the personnel of PSAL to include any calibration check standards and/or other standards that are part of their standard operating procedures.

\subsection{REFERENCES}

[1] Fox, K.M., T.B. Edwards, and D.K. Peeler, "Nepheline Formation Potential in Sludge Batch 4 (SB4) and its Impact on Durability: Selecting Glasses for a Phase 3 Study," WSRC-TR2006-00053, Revision 0, 2006.

[2] Shah, H.B., "Estimate of Sludge Batch 4 Calcine Composition Additional Cases for Final Recommendation," CBU-PIT-2006-00011, Revision 0, 2006.

[3] ASTM C-1285-2002, "Standard Test Methods for Determining Chemical Durability of Nuclear Waste Glasses: The Product Consistency Test (PCT),” ASTM, 2002. 


\section{Appendix C}

\section{An Analytical Plan for Measuring PCT Solutions for the Second Set of Glasses from the Phase 3 Nepheline Study SRNL-SCS-2006-00007}


WSRC-TR-2006-00093

Revision 0

Appendix C (SRNL-SCS-2006-00007)

This page intentionally left blank. 
February 27, 2006

To:

K. M. Fox, SRNL

cc:
R. A. Baker, 773-42A
D. R. Best, 786-1A (wo)
C. C. Herman, 999-W
D. K. Peeler, 999-W

I. A. Reamer, 999-1W

P. A. Toole, 786-1A (wo)

R. C. Tuckfield, 773-42A

R. J. Workman, 999-1W

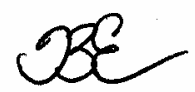

From: $\quad$ T. B. Edwards, 773-42A (5-5148)

Statistical Consulting Section

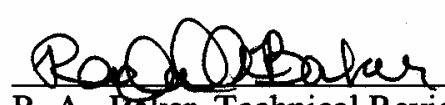

R. A. Baker, Technical Reviewer

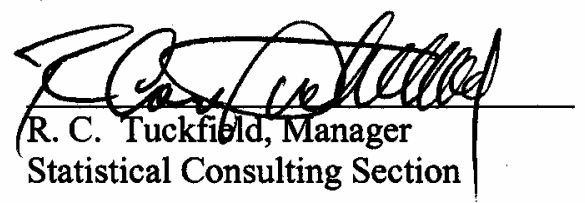

wo - without glass identifiers

\section{An Analytical Plan for Measuring PCT Solutions for the Second Set of Glasses from the Phase 3 Nepheline Study (U)}




\subsection{EXECUTIVE SUMMARY}

A study is being conducted by the Savannah River National Laboratory (SRNL) for the Defense Waste Processing Facility (DWPF) that involves investigating the potential impact of nepheline formation on the durability of high level waste glasses. To address this issue, several glass compositions were identified for their potential for the formation of nepheline as part of the frit development activities for Sludge Batch 4 (SB4). Sixteen of these glasses were selected to be batched and fabricated as Phase 3 of the nepheline study; the durability of the glasses is to be measured using the Product Consistency Test (PCT) as defined in ASTM C-1285-2002. Two heat treatments were utilized during the fabrication of each of these glasses. Specifically, each of the 16 glasses was quenched (i.e., rapidly cooled) and cooled in accordance with the centerline-canister-cooling (ccc) regime. Both heat treatments of each glass are to be subjected to the PCT.

To complete the full complement of PCTs, the 16 glasses were grouped into two sets based on the frits that were combined with SB4. The first set of PCTs covered the glasses that were developed using Frits 418 and 501, while the second set of PCTs covered the glasses that were developed using Frits 425 and 502. Both sets of PCTs are to be submitted to SRNL's Process Science Analytical Laboratory (PSAL) for measurement. This memorandum provides an analytical plan for the measurement of the second set of PCTs by PSAL. 
WSRC-TR-2006-00093

Revision 0

Appendix C (SRNL-SCS-2006-00007)

\subsection{INTRODUCTION}

A study is being conducted by the Savannah River National Laboratory (SRNL) for the Defense Waste Processing Facility (DWPF) that involves investigating the potential impact of nepheline formation on the durability of high level waste glasses [1]. To address this issue, 16 glass compositions were selected for their potential for the formation of nepheline as part of the frit development activities for Sludge Batch 4 (SB4). The specific SB4 option being considered is Case $15 \mathrm{C}$ Blend 1 as defined by Shah [2]. The glasses were selected to be batched and fabricated as Phase 3 of the nepheline study [1]; the durability of the glasses is to be measured using the Product Consistency Test (PCT) as defined in ASTM C-1285-2002 [3]. Two heat treatments were utilized during the fabrication of each of these glasses. Specifically, each of the 16 glasses was quenched (i.e., rapidly cooled) and cooled in accordance with the centerline-canister-cooling (ccc) regime. Both heat treatments of each glass are to be subjected to the PCT.

To complete the full complement of PCTs, the 16 glasses were grouped into two sets based on the frits that were combined with SB4. The first set of PCTs covered the glasses (NEPH3-41 through NEPH3-48)a that were developed using Frits 418 and 501, while the second set of PCTs covered the glasses (NEPH3-49 through NEPH3-56) that were developed using Frits 425 and 502. This analytical study plan addresses the PCT solutions for NEPH3-49 through NEPH3-56 (or set \#2) for both quenched and ccc heat treatments. A separate analytical plan was previously developed for the first set (NEPH3-41 through NEPH3-48) [4]. Both sets of PCTs are to be submitted to SRNL's Process Science Analytical Laboratory (PSAL) for measurement. Table 1 presents a listing of the glasses covered by this memorandum.

\section{Table 1: Identifiers for Glasses Covered by this Plan}

\begin{tabular}{|c|c|}
\hline NEPH3-49 & NEPH3-53 \\
\hline NEPH3-49ccc & NEPH3-53ccc \\
\hline NEPH3-50 & NEPH3-54 \\
\hline NEPH3-50ccc & NEPH3-54ccc \\
\hline NEPH3-51 & NEPH3-55 \\
\hline NEPH3-51ccc & NEPH3-55ccc \\
\hline NEPH3-52 & NEPH3-56 \\
\hline NEPH3-52ccc & NEPH3-56ccc \\
\hline
\end{tabular}

\subsection{DisCUSSION}

Each of the study glasses of Table 1 is to be subjected to the PCT in triplicate. In addition to PCTs for the study glasses, triplicate PCTs are to be conducted on a sample of the Approved Reference Material - One (ARM-1) glass and a sample of the Environmental Assessment (EA) glass. Two reagent blank samples are also to be included in these tests. This results in 56 sample solutions being required to complete these PCTs.

The leachates from these tests will be diluted by adding $4 \mathrm{~mL}$ of $0.4 \mathrm{M} \mathrm{HNO}_{3}$ to $6 \mathrm{~mL}$ of the leachate (a 6:10 volume to volume, v:v, dilution) before being submitted to PSAL. The leachates of EA will

a The nomenclature NEPH3-41 stands for a nepheline glass ("NEPH”), Phase 3 (“3”), with the identifying number 41 ("41"). The Phase 1 and 2 studies contained glasses 1 through 12 and 13 through 40, respectively. Phase 3 covers glasses 41 through 56. 
be further diluted (1:10 v:v) with deionized water prior to submission to PSAL in order to prevent problems with the nebulizer. Note that additional dilutions for the ccc versions of one or more of the study glasses may be needed due to a possibly low durability of some of the glasses. Upon termination of the PCT, a decision is to be made (by the technicians and a PSAL representative, if called by the technician) as to whether any other dilution is needed for these solutions to mitigate any potential gelling issues. Any extra dilutions are to be reported, and guidance is to be given as to how the dilutions are to be handled in the statistical assessment of the measurement data. More specifically, PSAL will be responsible for indicating if any additional dilutions were made and how they were, or how they should be, accounted for in the reported measurements.

Table 2 presents identifying codes, H01 through H56, for the individual solutions required for the PCTs of the select study glasses and of the standards (EA, ARM-1, and blanks). This provides a naming convention that is to be used by PSAL in analyzing the solutions and reporting the relevant concentration measurements. ${ }^{\mathrm{a}}$

Table 2: Identifiers for the PCT Solutions

\begin{tabular}{|cc|cc|cc|}
\hline $\begin{array}{c}\text { Original } \\
\text { Sample }\end{array}$ & $\begin{array}{c}\text { Solution } \\
\text { Identifier }\end{array}$ & $\begin{array}{c}\text { Original } \\
\text { Sample }\end{array}$ & $\begin{array}{c}\text { Solution } \\
\text { Identifier }\end{array}$ & $\begin{array}{c}\text { Original } \\
\text { Sample }\end{array}$ & $\begin{array}{c}\text { Solution } \\
\text { Identifier }\end{array}$ \\
NEPH3-49 & H31 & NEPH3-52ccc & H47 & NEPH3-56 & H04 \\
NEPH3-49 & H44 & NEPH3-52ccc & H32 & NEPH3-56 & H14 \\
NEPH3-49 & H06 & NEPH3-52ccc & H16 & NEPH3-56 & H48 \\
NEPH3-49ccc & H53 & NEPH3-53 & H37 & NEPH3-56ccc & H07 \\
NEPH3-49ccc & H52 & NEPH3-53 & H29 & NEPH3-56ccc & H35 \\
NEPH3-49ccc & H55 & NEPH3-53 & H13 & NEPH3-56ccc & H45 \\
NEPH3-50 & H38 & NEPH3-53ccc & H36 & EA & H43 \\
NEPH3-50 & H24 & NEPH3-53ccc & H50 & EA & H54 \\
NEPH3-50 & H46 & NEPH3-53ccc & H02 & EA & H11 \\
NEPH3-50ccc & H05 & NEPH3-54 & H33 & ARM-1 & H17 \\
NEPH3-50ccc & H22 & NEPH3-54 & H15 & ARM-1 & H49 \\
NEPH3-50ccc & H41 & NEPH3-54 & H20 & blank & H19 \\
NEPH3-51 & H03 & NEPH3-54ccc & H26 & blank & H56 \\
NEPH3-51 & H34 & NEPH3-54ccc & H18 & & \\
NEPH3-51 & H39 & NEPH3-54ccc & H21 & & \\
NEPH3-51ccc & H40 & NEPH3-55 & H23 & & \\
NEPH3-51ccc & H10 & NEPH3-55 & H08 & & \\
NEPH3-51ccc & H51 & NEPH3-55 & H27 & & \\
NEPH3-52 & H42 & NEPH3-55ccc & H25 & & \\
NEPH3-52 & H30 & NEPH3-55ccc & H28 & & \\
NEPH3-52 & H01 & NEPH3-55ccc & H12 & & \\
\hline
\end{tabular}

\subsection{Analytical Plan}

The analytical plan for PSAL is provided in this section. Each of the solution samples submitted to PSAL is to be analyzed only once for each of the following: boron (B), barium (Ba), cadmium (Cd),

a Renaming these samples ensures that they will be processed as blind samples by PSAL. This table does not contain the solution identifiers for those on the distribution list with a "wo" following their names. 
chromium $(\mathrm{Cr})$, iron $(\mathrm{Fe})$, lithium $(\mathrm{Li})$, sodium $(\mathrm{Na})$, lead $(\mathrm{Pb})$, silicon $(\mathrm{Si})$, thorium $(\mathrm{Th})$, and uranium (U). $\mathrm{B}, \mathrm{Li}, \mathrm{Na}$, and $\mathrm{Si}$ are the elements that are to be used in the assessment of glass durability; the other elements are being monitored to address solution disposal issues in SRNL upon termination of the PCTs. The measurements are to be made in parts per million (ppm). The analytical procedure used by PSAL to determine the concentrations utilizes an Inductively Coupled Plasma - Atomic Emission Spectrometer (ICP-AES). The PCT solutions (as identified in Table 2) are grouped in three ICP-AES blocks for processing by PSAL in Table 3. Each block requires a different calibration of the ICP-AES.

Table 3: ICP-AES Calibration Blocks for Leachate Measurements

\begin{tabular}{|ccc|}
\hline Block 1 & Block 2 & Block 3 \\
std-b1-1 & std-b2-1 & std-b3-1 \\
H43 & H52 & H55 \\
H07 & H15 & H21 \\
H09 & H22 & H39 \\
H26 & H34 & H11 \\
H04 & H18 & H01 \\
H47 & H50 & H27 \\
H23 & H28 & H41 \\
H33 & H24 & H13 \\
H19 & H30 & H20 \\
H31 & H29 & H49 \\
std-b1-2 & std-b2-2 & std-b3-2 \\
H40 & H54 & H56 \\
H38 & H14 & H46 \\
H05 & H17 & H48 \\
H53 & H44 & H12 \\
H37 & H35 & H16 \\
H42 & H10 & H06 \\
H36 & H32 & H02 \\
H03 & H08 & H51 \\
H25 & std-b2-3 & H45 \\
std-b1-3 & & std-b3-3 \\
\hline
\end{tabular}

A multi-element solution standard (denoted by "std-bi-j" where $\mathrm{i}=1$ to 3 represents the block number and $\mathrm{j}=1,2$, and 3 represents the position in the block) was added at the beginning, middle, and end of each of the three blocks. This standard may be useful in checking and correcting for bias in the concentration measurements arising from the ICP calibrations.

\subsection{SUMMARY}

In summary, this analytical plan provides identifiers for the PCT solutions in Table 2 and three ICPAES calibration blocks in Table 3 for PSAL to use in conducting the boron (B), barium (Ba), cadmium $(\mathrm{Cd})$, chromium $(\mathrm{Cr})$, iron $(\mathrm{Fe})$, lithium $(\mathrm{Li})$, sodium $(\mathrm{Na})$, lead $(\mathrm{Pb})$, silicon $(\mathrm{Si})$, thorium (Th), and uranium (U) concentration measurements for the PCT study of this select subset of the Phase 3 nepheline glasses. The sequencing of the activities associated with each of the steps in the analytical procedure has been randomized. The size of the blocks was selected so that the block 
WSRC-TR-2006-00093

Revision 0

Appendix C (SRNL-SCS-2006-00007)

could be completed in a single work shift. If for some reason the measurements are not conducted in the sequence presented in this memorandum, the actual order should be recorded along with any explanative comments.

The analytical plan indicated in the preceding tables should be modified by the personnel of PSAL to include any calibration check standards and/or other standards that are part of their standard operating procedures.

\subsection{REFERENCES}

[1] Fox, K.M., T.B. Edwards, and D.K. Peeler, "Nepheline Formation Potential in Sludge Batch 4 (SB4) and its Impact on Durability: Selecting Glasses for a Phase 3 Study," WSRC-TR-2006-00053, Revision 0, 2006.

[2] Shah, H.B., "Estimate of Sludge Batch 4 Calcine Composition Additional Cases for Final Recommendation," CBU-PIT-2006-00011, Revision 0, 2006.

[3] ASTM C-1285-2002, "Standard Test Methods for Determining Chemical Durability of Nuclear Waste Glasses: The Product Consistency Test (PCT)," ASTM, 2002.

[4] Edwards, T.B., "An Analytical Plan for Measuring PCT Solutions for the First Set of Glasses from the Phase 3 Nepheline Study (U)," SRNL-SCS-2006-00003, February 8, 2006 


\section{Appendix D}

\section{Tables and Exhibits Supporting the Analysis of the Chemical Composition Measurements of the Nepheline Phase 3 Study Glasses}


WSRC-TR-2006-00093

Revision 0

This page intentionally left blank. 
Table D1. Targeted Oxide Concentrations (as wt \%'s) for the Phase 3 Nepheline Study Glasses

\begin{tabular}{|c|c|c|c|c|c|c|c|c|c|c|c|c|c|c|c|c|c|c|c|c|c|c|c|c|}
\hline & $\mathrm{Al2O3}$ & B2O3 & $\mathrm{BaO}$ & $\mathrm{CaO}$ & $\mathrm{Ce} 2 \mathrm{O3}$ & Cr2O3 & $\mathrm{CuO}$ & $\mathrm{Fe} 2 \mathrm{O3}$ & $\mathrm{K2O}$ & La2O3 & Li2O & MgO & MnO & $\mathrm{Na2O}$ & $\mathrm{NiO}$ & PbO & SO4 & $\mathrm{SiO2}$ & \begin{tabular}{|l|} 
ThO2 \\
\end{tabular} & TiO2 & \begin{tabular}{|l|} 
U3O8 \\
\end{tabular} & $\mathrm{ZnO}$ & $\mathrm{ZrO2}$ & Sum \\
\hline NEPH3-41 & 682 & .200 & 044 & .836 & .052 & 074 & 021 & 9.298 & 120 & 0.038 & 5.200 & .873 & 1.918 & 2.928 & 0.552 & 0.032 & 0.468 & 0.840 & 0.023 & 0.009 & 2.674 & 0.034 & .083 & 100.000 \\
\hline NEPH3-42 & .922 & 4.800 & 050 & .955 & 060 & 885 & .024 & 10.626 & .138 & .043 & 4.800 & .998 & 2.192 & 13.632 & .631 & 0.036 & .535 & 47.245 & 0.026 & 0.011 & 3.056 & 0.039 & 0.095 & 00.000 \\
\hline & .411 & 320 & 058 & 098 & & & & & & & & & & & .726 & & & & & & & 0.045 & & \\
\hline & & 000 & 63 & 194 & & & & & & & & & & & 789 & & & & 033 & & & .049 & & \\
\hline & & & 044 & 836 & & & & & & & 5.500 & & & & .552 & & 0.408 & 840 & & & 2.674 & .034 & & \\
\hline-46 & 92 & 5.400 & .050 & .955 & 0. & 85 & 0.024 & 10.6 & .138 & .043 & 6.000 & 0.998 & 2.192 & 11.832 & 0.631 & 0.036 & 0.535 & 47.245 & 0.026 & 0.011 & 3.056 & 0.039 & .095 & \\
\hline NEPH3-47 & 11.659 & 4.770 & 0.059 & 1.122 & & & 0.028 & & 0.162 & & 5.300 & 1.173 & 2.576 & & 0.741 & 0.043 & 0.629 & 42.213 & 0.031 & 0.013 & 3.591 & 0.046 & & \\
\hline NEPH3-48 & 2.651 & 4.410 & 0.064 & 1.218 & 0.076 & 0.108 & 0.031 & 13.5 & 0.175 & 0.055 & 4.900 & 1.273 & 2.795 & 13.711 & 0.804 & 0.046 & 0.682 & 39.338 & 0.034 & 0.014 & 3.897 & 0.050 & & \\
\hline & & & 044 & & & & & & & & 5.200 & & 1.5 & & .552 & & & 49.540 & & & 2.674 & .034 & & \\
\hline & & 800 & 050 & 955 & & & 024 & & & & 4.800 & 0.998 & 2.192 & & 0.631 & 0.036 & .535 & 46.045 & 0.026 & 0.0 & 3.056 & 0.039 & 95 & \\
\hline & 10.915 & 4.480 & 0.056 & 1.051 & 0.066 & 0.093 & 0.026 & 11.689 & 0.151 & 0.048 & 4.480 & 1.098 & 2.411 & 15.315 & 0.694 & 0.040 & 0.589 & 43.250 & 0.029 & 0.012 & 3.362 & 0.043 & .104 & \\
\hline NEPH3-52 & 11.907 & 4.160 & 0.061 & 1.146 & 0.072 & 0.102 & 0.029 & 12.751 & 0.165 & 0.052 & 4.160 & 1.198 & 2.630 & 15.798 & 0.757 & 0.043 & 0.642 & 40.454 & 0.032 & 0.013 & 3.667 & 0.047 & 0.114 & 100.000 \\
\hline NEPH3-53 & 8.682 & 5.200 & 0.044 & 0.836 & 0.052 & 0.074 & 0.021 & 9.298 & 0.120 & 0.038 & 7.150 & 0.873 & 1.918 & 10.978 & 0.552 & 0.032 & 0.468 & 50.840 & 0.023 & 0.009 & 2.674 & 0.034 & .083 & \\
\hline NEPH & & 4.800 & 0.050 & 0.955 & & & & & & & 6.600 & 0.998 & 2.192 & & 0.631 & 0.036 & & 47.245 & 0.026 & 0.011 & 3.056 & 0.039 & .095 & \\
\hline & 11007 & 4.160 & 0.061 & 1.146 & & & & & 016 & & 5.720 & 1.198 & 2.630 & 13.198 & 0.757 & 0.043 & & 41.494 & 0.032 & 0.013 & 3.667 & 0.047 & 0.114 & \\
\hline NEPH3-56 & 12.651 & 3.920 & 0.064 & 1.218 & 0.076 & 0.108 & 0.031 & 13.548 & 0.175 & 0.055 & 5.390 & 1.273 & 2.795 & 13.711 & 0.804 & 0.046 & 0.682 & 39.338 & \begin{tabular}{|l|}
0.034 \\
\end{tabular} & 0.014 & 3.897 & 0.050 & 0.121 & 100.000 \\
\hline
\end{tabular}


Table D2. Measured Elemental Concentrations (wt\%) for Samples Prepared Using Lithium Metaborate

\begin{tabular}{|c|c|c|c|c|c|c|c|c|c|c|c|c|c|c|c|c|c|c|c|c|}
\hline Glass ID & $\begin{array}{c}\text { Laboratory } \\
\text { ID }\end{array}$ & Block & Sub-Block & $\begin{array}{l}\text { Analytical } \\
\text { Sequence }\end{array}$ & Ba & $\mathrm{Ca}$ & $\mathrm{Ce}$ & $\mathrm{Cr}$ & $\mathrm{Cu}$ & $\mathbf{K}$ & La & Mg & Mn & $\mathrm{Na}$ & $\mathbf{P b}$ & $\mathbf{S}$ & Th & $\mathbf{T i}$ & $\mathbf{Z n}$ & $\mathbf{Z r}$ \\
\hline Batch 1 & BCHLM111 & 1 & 1 & 1 & 0.136 & 0.874 & 0.023 & 0.068 & 0.339 & 2.96 & $<0.010$ & 0.851 & 1.32 & 6.69 & $<0.020$ & $<0.100$ & $<0.010$ & 0.415 & $<0.010$ & 0.061 \\
\hline Ustd & UstdLM111 & 1 & 1 & 2 & $<0.010$ & 0.942 & 0.017 & 0.165 & 0.034 & 2.67 & $<0.010$ & 0.715 & 2.14 & 8.79 & $<0.020$ & $<0.100$ & 0.063 & 0.588 & $<0.010$ & $<0.010$ \\
\hline NEPH3-43 & G14LM21 & 1 & 1 & 3 & \begin{tabular}{|l|}
0.051 \\
\end{tabular} & 0.707 & 0.037 & 0.068 & 0.033 & 0.136 & 0.041 & 0.668 & 1.88 & 10.3 & 0.038 & 0.192 & 0.096 & 0.013 & 0.039 & 0.082 \\
\hline NEPH3-49 & G13LM21 & 1 & 1 & 4 & 0.037 & 0.538 & 0.031 & 0.049 & 0.026 & 0.106 & 0.029 & 0.505 & 1.47 & 10.4 & 0.030 & 0.143 & 0.072 & 0.011 & 0.050 & 0.059 \\
\hline NEPH3-53 & G05LM21 & 1 & 1 & 5 & 0.038 & 0.549 & 0.033 & 0.049 & 0.027 & 0.100 & 0.030 & 0.521 & 1.48 & 8.08 & 0.029 & 0.146 & 0.076 & 0.011 & 0.030 & 0.062 \\
\hline NEPH3-45 & G12LM21 & 1 & 1 & 6 & 0.039 & 0.550 & 0.034 & 0.046 & 0.028 & 0.106 & 0.032 & 0.511 & 1.48 & 8.00 & 0.034 & 0.150 & 0.075 & 0.011 & 0.039 & 0.058 \\
\hline NEPH3-51 & G03LM11 & 1 & 1 & 7 & 0.047 & 0.685 & 0.041 & 0.062 & 0.032 & 0.131 & 0.039 & 0.644 & 1.84 & 11.1 & 0.034 & 0.190 & 0.095 & 0.014 & 0.036 & 0.072 \\
\hline NEPH3-49 & G13LM11 & $\overline{1}$ & 1 & 8 & 0.040 & 0.690 & 0.035 & 0.050 & 0.025 & 0.120 & 0.031 & 0.571 & 1.46 & 11.3 & 0.030 & 0.148 & 0.073 & 0.011 & 0.030 & 0.064 \\
\hline NEPH3-52 & G09LM21 & 1 & 1 & 9 & 0.054 & 0.752 & 0.049 & 0.068 & 0.033 & 0.146 & 0.042 & 0.723 & 2.00 & 11.7 & 0.039 & 0.208 & 0.099 & 0.012 & 0.042 & 0.082 \\
\hline NEPH3-46 & G07LM21 & 1 & 1 & 10 & 0.043 & 0.608 & 0.040 & 0.057 & 0.031 & 0.120 & 0.037 & 0.582 & 1.68 & 8.49 & 0.038 & 0.166 & 0.084 & 0.013 & 0.032 & 0.054 \\
\hline Batch 1 & BCHLM112 & 1 & 1 & 11 & 0.138 & 0.894 & 0.022 & 0.069 & 0.336 & 2.88 & $<0.010$ & 0.863 & 1.30 & 6.34 & $<0.020$ & $<0.100$ & $<0.010$ & 0.418 & $<0.010$ & 0.061 \\
\hline Ustd & UstdLM112 & 1 & 1 & 12 & $<0.010$ & 0.933 & 0.017 & 0.166 & 0.033 & 2.59 & $<0.010$ & 0.716 & 2.12 & 8.39 & $<0.020$ & $<0.100$ & 0.064 & 0.597 & $<0.010$ & $<0.010$ \\
\hline NEPH3-48 & G02LM21 & 1 & 1 & 13 & 0.053 & 0.784 & 0.043 & 0.067 & 0.037 & 0.164 & 0.043 & 0.705 & 2.08 & 9.99 & 0.043 & 0.212 & 0.105 & 0.014 & 0.054 & 0.086 \\
\hline NEPH3-52 & G09LM11 & 1 & 1 & 14 & 0.052 & 0.743 & 0.048 & 0.070 & 0.032 & 0.145 & 0.041 & 0.670 & 1.99 & 11.0 & 0.037 & 0.201 & 0.097 & 0.012 & 0.041 & 0.080 \\
\hline NEPH3-48 & G02LM11 & 1 & 1 & 15 & 0.054 & 0.791 & 0.044 & 0.067 & 0.035 & 0.158 & 0.044 & 0.726 & 2.14 & 9.74 & 0.044 & 0.216 & 0.107 & 0.014 & 0.043 & 0.088 \\
\hline NEPH3-53 & G05LM11 & 1 & 1 & 16 & 0.036 & 0.546 & 0.033 & 0.050 & 0.025 & 0.106 & 0.029 & 0.496 & 1.48 & 7.78 & 0.027 & 0.145 & 0.073 & 0.010 & 0.029 & 0.059 \\
\hline NEPH3-45 & G12LM11 & 1 & 1 & 17 & 0.040 & 0.559 & 0.035 & 0.046 & 0.027 & 0.103 & 0.032 & 0.518 & 1.51 & 7.52 & 0.034 & 0.153 & 0.076 & 0.011 & 0.046 & 0.057 \\
\hline NEPH3-46 & G07LM11 & 1 & 1 & 18 & 0.045 & 0.654 & 0.041 & 0.057 & 0.032 & 0.127 & 0.037 & 0.595 & 1.75 & 8.47 & 0.038 & 0.169 & 0.087 & 0.013 & 0.033 & 0.057 \\
\hline NEPH3-51 & G03LM21 & $\overline{1}$ & 1 & 19 & 0.046 & 0.689 & 0.040 & 0.059 & 0.031 & 0.146 & 0.038 & 0.619 & 1.87 & 10.7 & 0.031 & 0.189 & 0.092 & 0.013 & 0.034 & 0.069 \\
\hline NEPH3-43 & G14LM11 & 1 & 1 & 20 & 0.050 & 0.730 & 0.037 & 0.066 & 0.034 & 0.140 & 0.040 & 0.669 & 1.96 & 10.2 & 0.037 & 0.191 & 0.096 & 0.013 & 0.050 & 0.079 \\
\hline Batch 1 & BCHLM113 & 1 & 1 & 21 & 0.139 & 0.913 & 0.022 & 0.070 & 0.343 & 2.81 & $<0.010$ & 0.864 & 1.33 & 6.17 & $<0.020$ & $<0.100$ & $<0.010$ & 0.423 & $<0.010$ & 0.063 \\
\hline Ustd & UstdLM113 & 1 & 1 & 22 & $<0.010$ & 0.948 & 0.016 & 0.164 & 0.033 & 2.58 & $<0.010$ & 0.712 & 2.21 & 8.37 & $<0.020$ & $<0.100$ & 0.063 & 0.600 & $<0.010$ & $<0.010$ \\
\hline Batch 1 & BCHLM121 & 1 & 2 & 1 & \begin{tabular}{|l|}
0.139 \\
\end{tabular} & 0.871 & $<0.010$ & 0.062 & 0.339 & 2.98 & $<0.010$ & 0.848 & 1.34 & 6.82 & $<0.020$ & $<0.100$ & $<0.010$ & 0.406 & $<0.010$ & 0.045 \\
\hline Ustd & UstdLM121 & 1 & 2 & 2 & $<0.010$ & 0.930 & $<0.010$ & 0.156 & 0.028 & 2.67 & $<0.010$ & 0.706 & 2.18 & 9.03 & $<0.020$ & $<0.100$ & 0.048 & 0.585 & $<0.010$ & $<0.010$ \\
\hline NEPH3-46 & G07LM22 & 1 & 2 & 3 & 0.043 & 0.613 & 0.040 & 0.056 & 0.031 & 0.120 & 0.037 & 0.584 & 1.72 & 9.07 & 0.037 & 0.166 & 0.083 & 0.011 & 0.031 & 0.052 \\
\hline NEPH3-51 & G03LM12 & 1 & 2 & 4 & 0.047 & 0.691 & 0.040 & 0.061 & 0.031 & 0.131 & 0.039 & 0.649 & 1.90 & 11.5 & 0.032 & 0.189 & 0.094 & 0.012 & 0.035 & 0.071 \\
\hline NEPH3-43 & G14LM22 & 1 & 2 & 5 & 0.049 & 0.718 & 0.036 & 0.067 & 0.032 & 0.136 & 0.040 & 0.672 & 1.97 & 10.8 & 0.036 & 0.189 & 0.095 & 0.011 & 0.037 & 0.081 \\
\hline NEPH3-52 & G09LM12 & 1 & 2 & 6 & 0.051 & 0.754 & 0.048 & 0.070 & 0.031 & 0.145 & 0.041 & 0.680 & 2.04 & 11.9 & 0.036 & 0.206 & 0.097 & 0.010 & 0.040 & 0.079 \\
\hline NEPH3-45 & G12LM22 & 1 & 2 & 7 & 0.039 & 0.562 & 0.033 & 0.045 & 0.027 & 0.107 & 0.031 & 0.518 & 1.52 & 8.24 & 0.032 & 0.152 & 0.073 & 0.009 & 0.038 & 0.057 \\
\hline NEPH3-53 & G05LM22 & $\overline{1}$ & 2 & 8 & 0.038 & 0.558 & 0.033 & 0.048 & 0.026 & 0.101 & 0.030 & 0.531 & 1.53 & 8.26 & 0.028 & 0.147 & 0.075 & 0.008 & 0.029 & 0.061 \\
\hline NEPH3-45 & G12LM12 & 1 & 2 & 9 & 0.039 & 0.553 & 0.033 & 0.045 & 0.025 & 0.101 & 0.032 & 0.524 & 1.52 & 8.17 & 0.032 & 0.151 & 0.074 & 0.009 & 0.045 & 0.055 \\
\hline NEPH3-49 & G13LM22 & 1 & 2 & 10 & 0.037 & 0.555 & 0.031 & 0.049 & 0.026 & 0.110 & 0.029 & 0.512 & 1.51 & 10.7 & 0.028 & 0.151 & 0.071 & 0.008 & 0.050 & 0.058 \\
\hline Batch 1 & BCHLM122 & 1 & 2 & 11 & 0.129 & 0.862 & $<0.010$ & 0.052 & 0.321 & 2.92 & $<0.010$ & 0.839 & 1.34 & 6.67 & $<0.020$ & $<0.100$ & $<0.010$ & 0.397 & $<0.010$ & 0.036 \\
\hline Ustd & UstdLM122 & 1 & 2 & 12 & $<0.010$ & 0.936 & $<0.010$ & 0.152 & 0.023 & 2.61 & $<0.010$ & 0.699 & 2.17 & 8.82 & $<0.020$ & $<0.100$ & 0.038 & 0.578 & $<0.010$ & $<0.010$ \\
\hline NEPH3-48 & G02LM12 & 1 & 2 & 13 & 0.054 & 0.802 & 0.044 & 0.067 & 0.035 & 0.160 & 0.044 & 0.731 & 2.15 & 10.3 & 0.043 & \begin{tabular}{|l|}
0.214 \\
\end{tabular} & 0.106 & 0.013 & 0.042 & 0.086 \\
\hline NEPH3-51 & G03LM22 & 1 & 2 & 14 & 0.045 & 0.690 & 0.039 & 0.059 & 0.030 & 0.145 & 0.037 & 0.621 & 1.87 & 11.7 & 0.031 & 0.190 & 0.089 & 0.010 & 0.033 & 0.068 \\
\hline NEPH3-48 & G02LM22 & 1 & 2 & 15 & 0.052 & 0.812 & 0.043 & 0.067 & 0.036 & 0.170 & 0.043 & 0.721 & 2.11 & 10.5 & 0.042 & 0.219 & 0.104 & 0.012 & 0.053 & 0.086 \\
\hline NEPH3-52 & G09LM22 & 1 & 2 & 16 & 0.053 & 0.765 & 0.049 & 0.068 & 0.032 & 0.147 & 0.042 & 0.727 & 2.07 & 12.1 & 0.036 & 0.209 & 0.098 & 0.010 & 0.041 & 0.082 \\
\hline NEPH3-43 & G14LM12 & 1 & 2 & 17 & 0.049 & 0.739 & 0.036 & 0.066 & 0.034 & 0.141 & 0.040 & 0.677 & 1.94 & 11.0 & 0.036 & 0.199 & 0.095 & 0.011 & 0.048 & 0.078 \\
\hline
\end{tabular}


Table D2. Measured Elemental Concentrations (wt\%) for Samples Prepared Using Lithium Metaborate (continued)

\begin{tabular}{|c|c|c|c|c|c|c|c|c|c|c|c|c|c|c|c|c|c|c|c|c|}
\hline NEPH3-49 & G13LM12 & 1 & 2 & 18 & 0.040 & 0.709 & 0.034 & 0.049 & 0.024 & 0.122 & 0.030 & 0.576 & 1.51 & 11.8 & 0.027 & 0.147 & 0.072 & 0.009 & 0.029 & 0.063 \\
\hline NEPH3-53 & G05LM12 & 1 & 2 & 19 & 0.036 & 0.552 & 0.032 & 0.050 & 0.024 & 0.106 & 0.029 & 0.500 & 1.46 & 8.49 & 0.026 & 0.147 & 0.071 & 0.008 & 0.028 & 0.057 \\
\hline NEPH3-46 & G07LM12 & 1 & 2 & 20 & 0.044 & 0.661 & 0.041 & 0.056 & 0.032 & 0.128 & 0.037 & 0.602 & 1.73 & 9.28 & 0.037 & 0.172 & 0.085 & 0.011 & 0.032 & 0.055 \\
\hline Batch 1 & BCHLM123 & 1 & 2 & 21 & 0.129 & 0.856 & $<0.010$ & 0.053 & 0.320 & 3.02 & $<0.010$ & 0.839 & 1.31 & 6.81 & $<0.020$ & $<0.100$ & $<0.010$ & 0.397 & $<0.010$ & 0.037 \\
\hline Ustd & UstdLM123 & 1 & 2 & 22 & $<0.010$ & 0.940 & $<0.010$ & 0.152 & 0.023 & 2.71 & $<0.010$ & 0.701 & 2.14 & 9.09 & $<0.020$ & $<0.100$ & 0.039 & 0.588 & $<0.010$ & $<0.010$ \\
\hline Batch 1 & BCHLM211 & 2 & 1 & 1 & 0.120 & 0.823 & $<0.010$ & 0.053 & 0.304 & 2.96 & $<0.010$ & 0.847 & 1.34 & 6.83 & $<0.020$ & $<0.100$ & $<0.010$ & 0.397 & $<0.010$ & 0.032 \\
\hline Ustd & UstdLM211 & 2 & 1 & 2 & $<0.010$ & 0.892 & $<0.010$ & 0.146 & $<0.010$ & 2.69 & $<0.010$ & 0.698 & 2.16 & 8.99 & $<0.020$ & $<0.100$ & 0.034 & 0.572 & $<0.010$ & $<0.010$ \\
\hline NEPH3-50 & G04LM21 & 2 & 1 & 3 & 0.042 & 0.597 & 0.031 & 0.057 & 0.026 & 0.118 & 0.033 & 0.582 & 1.71 & 11.3 & 0.031 & 0.183 & 0.079 & 0.009 & 0.034 & 0.062 \\
\hline NEPH3-41 & G06LM21 & 2 & 1 & 4 & 0.036 & 0.519 & 0.031 & 0.049 & 0.024 & 0.099 & 0.027 & 0.510 & 1.50 & 9.92 & 0.026 & 0.157 & 0.069 & 0.008 & 0.034 & 0.056 \\
\hline NEPH3-54 & G16LM11 & 2 & 1 & 5 & 0.045 & 0.599 & 0.011 & 0.051 & 0.025 & 0.109 & 0.033 & 0.598 & 1.70 & 9.16 & 0.034 & 0.180 & 0.081 & 0.010 & 0.033 & 0.064 \\
\hline NEPH3-42 & G08LM21 & 2 & 1 & 6 & 0.041 & 0.592 & 0.037 & 0.056 & 0.023 & 0.107 & 0.031 & 0.576 & 1.67 & 10.4 & 0.031 & 0.172 & 0.078 & 0.009 & 0.036 & 0.065 \\
\hline NEPH3-56 & G11LM21 & 2 & 1 & 7 & 0.054 & 0.761 & 0.051 & 0.060 & 0.031 & 0.145 & 0.039 & 0.728 & 2.09 & 10.6 & 0.039 & 0.233 & 0.102 & 0.009 & 0.042 & 0.081 \\
\hline NEPH3-41 & G06LM11 & 2 & 1 & 8 & 0.036 & 0.532 & 0.031 & 0.049 & 0.026 & 0.103 & 0.026 & 0.511 & 1.46 & 9.95 & 0.026 & 0.159 & 0.069 & 0.008 & 0.035 & 0.055 \\
\hline NEPH3-55 & G10LM11 & 2 & 1 & 9 & 0.050 & 0.723 & 0.025 & 0.061 & 0.027 & 0.137 & 0.040 & 0.691 & 1.95 & 10.4 & 0.038 & 0.219 & 0.096 & 0.009 & 0.039 & 0.078 \\
\hline NEPH3-44 & G01LM21 & 2 & 1 & 10 & 0.052 & 0.740 & 0.039 & 0.062 & 0.029 & 0.143 & 0.040 & 0.708 & 2.06 & 13.1 & 0.038 & 0.219 & 0.097 & 0.009 & 0.040 & 0.077 \\
\hline Batch 1 & BCHLM212 & 2 & 1 & 11 & 0.111 & 0.813 & $<0.010$ & 0.043 & 0.291 & 2.88 & $<0.010$ & 0.841 & 1.29 & 7.05 & $<0.020$ & $<0.100$ & $<0.010$ & 0.374 & $<0.010$ & 0.017 \\
\hline Ustd & UstdLM212 & 2 & 1 & 12 & $<0.010$ & 0.874 & $<0.010$ & 0.140 & $<0.010$ & 2.62 & $<0.010$ & 0.701 & 2.12 & 9.11 & $<0.020$ & $<0.100$ & 0.025 & 0.542 & $<0.010$ & $<0.010$ \\
\hline NEPH3-50 & G04LM11 & 2 & 1 & 13 & 0.041 & 0.613 & 0.032 & 0.056 & 0.024 & 0.124 & 0.033 & 0.580 & 1.65 & 11.2 & 0.031 & \begin{tabular}{|l|l|}
0.190 \\
\end{tabular} & 0.080 & 0.008 & 0.031 & 0.063 \\
\hline NEPH3-56 & G11LM11 & 2 & 1 & 14 & 0.054 & 0.780 & 0.051 & 0.062 & 0.032 & 0.149 & 0.040 & 0.728 & 2.06 & 10.6 & 0.039 & 0.239 & 0.103 & 0.009 & 0.044 & 0.083 \\
\hline NEPH3-55 & G10LM21 & 2 & 1 & 15 & 0.050 & 0.725 & 0.025 & 0.061 & 0.030 & 0.136 & 0.040 & 0.696 & 1.98 & 10.1 & 0.038 & 0.221 & 0.096 & 0.009 & 0.043 & 0.078 \\
\hline NEPH3-44 & G01LM11 & 2 & 1 & 16 & 0.053 & 0.765 & 0.040 & 0.060 & 0.030 & 0.144 & 0.041 & 0.720 & 2.01 & 11.2 & 0.039 & 0.225 & 0.102 & 0.009 & 0.044 & 0.079 \\
\hline NEPH3-47 & G15LM11 & 2 & 1 & 17 & 0.048 & 0.719 & 0.039 & 0.057 & 0.028 & 0.140 & 0.037 & 0.679 & 1.95 & 9.95 & 0.040 & 0.212 & 0.091 & 0.009 & 0.034 & 0.076 \\
\hline NEPH3-42 & G08LM11 & 2 & 1 & 18 & 0.042 & 0.614 & 0.038 & 0.057 & 0.024 & 0.111 & 0.031 & 0.583 & 1.67 & 10.0 & 0.031 & 0.179 & 0.079 & 0.009 & 0.034 & 0.067 \\
\hline NEPH3-54 & G16LM21 & 2 & 1 & 19 & 0.045 & 0.604 & 0.011 & 0.050 & 0.025 & 0.111 & 0.033 & 0.588 & 1.68 & 8.96 & 0.033 & 0.180 & 0.081 & 0.010 & 0.033 & 0.064 \\
\hline NEPH3-47 & G15LM21 & 2 & 1 & 20 & 0.049 & 0.721 & 0.039 & 0.058 & 0.029 & 0.138 & 0.037 & 0.683 & 1.96 & 10.1 & 0.039 & 0.212 & 0.092 & 0.010 & 0.039 & 0.077 \\
\hline Batch 1 & BCHLM213 & 2 & 1 & 21 & 0.112 & 0.826 & $<0.010$ & 0.043 & 0.298 & 2.97 & $<0.010$ & 0.847 & 1.29 & 6.76 & $<0.020$ & $<0.100$ & $<0.010$ & 0.376 & $<0.010$ & 0.021 \\
\hline Ustd & UstdLM213 & 2 & 1 & 22 & $<0.010$ & 0.886 & $<0.010$ & 0.139 & $<0.010$ & 2.67 & $<0.010$ & 0.698 & 2.07 & 9.05 & $<0.020$ & $<0.100$ & \begin{tabular}{|l|}
0.025 \\
\end{tabular} & 0.540 & $<0.010$ & $<0.010$ \\
\hline Batch 1 & BCHLM 221 & 2 & 2 & 1 & 0.128 & 0.839 & 0.016 & 0.061 & 0.320 & 2.98 & $<0.010$ & 0.850 & 1.35 & 6.67 & $<0.020$ & $<0.100$ & $<0.010$ & 0.375 & $<0.010$ & 0.036 \\
\hline Ustd & UstdLM221 & 2 & 2 & 2 & $<0.010$ & 0.914 & $<0.010$ & 0.156 & 0.021 & 2.69 & $<0.010$ & 0.707 & 2.21 & 8.97 & $<0.020$ & $<0.100$ & 0.044 & 0.553 & $<0.010$ & $<0.010$ \\
\hline NEPH3-42 & G08LM22 & 2 & 2 & 3 & 0.042 & 0.610 & 0.040 & 0.058 & 0.026 & 0.111 & 0.032 & 0.574 & 1.75 & 10.0 & 0.032 & \begin{tabular}{|l|}
0.161 \\
\end{tabular} & 0.082 & 0.006 & 0.036 & 0.066 \\
\hline NEPH3-41 & G06LM12 & 2 & 2 & 4 & 0.036 & 0.536 & 0.033 & 0.050 & 0.028 & 0.103 & 0.027 & 0.500 & 1.55 & 9.59 & 0.027 & 0.149 & 0.070 & 0.005 & 0.034 & 0.057 \\
\hline NEPH3-54 & G16LM22 & 2 & 2 & 5 & 0.046 & 0.618 & 0.013 & 0.052 & 0.028 & 0.112 & 0.034 & 0.591 & 1.78 & 8.96 & 0.034 & 0.168 & 0.085 & 0.007 & 0.033 & 0.066 \\
\hline NEPH3-42 & G08LM12 & 2 & 2 & 6 & 0.042 & 0.622 & 0.040 & 0.059 & 0.026 & 0.110 & 0.032 & 0.580 & 1.73 & 10.1 & 0.032 & 0.163 & 0.081 & 0.006 & 0.034 & 0.068 \\
\hline NEPH3-44 & G01LM22 & 2 & 2 & 7 & 0.053 & 0.778 & 0.042 & 0.064 & 0.032 & 0.151 & 0.042 & 0.711 & 2.17 & 12.9 & 0.041 & 0.209 & 0.104 & 0.007 & 0.041 & 0.079 \\
\hline NEPH3-41 & G06LM22 & 2 & 2 & 8 & 0.037 & 0.545 & 0.033 & 0.050 & 0.026 & 0.105 & 0.028 & 0.512 & 1.53 & 9.96 & 0.028 & 0.148 & 0.072 & 0.005 & 0.034 & 0.058 \\
\hline NEPH3-47 & G15LM12 & 2 & 2 & 9 & 0.049 & 0.732 & 0.041 & 0.059 & 0.031 & 0.141 & 0.037 & 0.670 & 2.06 & 10.0 & 0.040 & 0.197 & 0.094 & 0.006 & 0.034 & 0.078 \\
\hline NEPH3-50 & G04LM22 & 2 & 2 & 10 & 0.042 & 0.626 & 0.033 & 0.058 & 0.028 & 0.122 & 0.034 & 0.578 & 1.77 & 11.4 & 0.032 & 0.170 & 0.082 & 0.006 & 0.033 & 0.064 \\
\hline Batch 1 & BCHLM222 & 2 & 2 & 11 & 0.122 & 0.859 & 0.011 & 0.056 & 0.317 & 3.02 & $<0.010$ & 0.840 & 1.35 & 6.99 & $<0.020$ & $<0.100$ & $<0.010$ & 0.370 & $<0.010$ & 0.026 \\
\hline Ustd & UstdLM222 & 2 & 2 & 12 & $<0.010$ & 0.917 & $<0.010$ & 0.152 & 0.020 & 2.70 & $<0.010$ & 0.698 & 2.23 & 9.08 & $<0.020$ & $<0.100$ & 0.040 & 0.553 & $<0.010$ & $<0.010$ \\
\hline NEPH3-54 & G16LM12 & 2 & 2 & 13 & 0.045 & 0.617 & 0.013 & 0.052 & 0.027 & 0.112 & 0.033 & 0.584 & 1.83 & 8.50 & 0.035 & \begin{tabular}{|l|l|}
0.167 \\
\end{tabular} & 0.084 & 0.007 & 0.033 & 0.066 \\
\hline NEPH3-50 & G04LM12 & 2 & 2 & 14 & 0.041 & 0.615 & 0.033 & 0.056 & 0.025 & 0.122 & 0.033 & 0.566 & 1.79 & 10.8 & 0.030 & 0.169 & 0.079 & 0.005 & 0.030 & 0.063 \\
\hline
\end{tabular}


Table D2. Measured Elemental Concentrations (wt\%) for Samples Prepared Using Lithium Metaborate (continued)

\begin{tabular}{|c|c|c|c|c|c|c|c|c|c|c|c|c|c|c|c|c|c|c|c|c|}
\hline NEPH3-55 & G10LM22 & 2 & 2 & 15 & 0.050 & 0.747 & 0.027 & 0.061 & 0.032 & 0.138 & 0.041 & 0.683 & 2.15 & 9.74 & 0.039 & 0.202 & 0.098 & 0.006 & 0.042 & 0.080 \\
\hline NEPH3-47 & G15LM22 & 2 & 2 & 16 & 0.049 & 0.729 & 0.041 & 0.059 & 0.031 & 0.138 & 0.037 & 0.672 & 2.12 & 9.69 & 0.040 & 0.194 & 0.094 & 0.007 & 0.038 & 0.078 \\
\hline NEPH3-55 & G10LM12 & 2 & 2 & 17 & 0.050 & 0.742 & 0.027 & 0.061 & 0.028 & 0.140 & 0.040 & 0.680 & 2.17 & 9.63 & 0.038 & 0.201 & 0.098 & 0.006 & 0.037 & 0.079 \\
\hline NEPH3-56 & G11LM22 & 2 & 2 & 18 & 0.053 & 0.785 & 0.053 & 0.060 & 0.033 & 0.149 & 0.040 & 0.712 & 2.21 & 10.2 & 0.039 & 0.217 & 0.105 & 0.006 & 0.041 & 0.083 \\
\hline NEPH3-56 & G11LM12 & 2 & 2 & 19 & 0.053 & 0.781 & 0.053 & 0.062 & 0.033 & 0.149 & 0.040 & 0.709 & 2.23 & 10.2 & 0.039 & 0.217 & 0.103 & 0.006 & 0.042 & 0.084 \\
\hline NEPH3-44 & G01LM12 & 2 & 2 & 20 & 0.053 & 0.770 & 0.042 & 0.061 & 0.031 & 0.144 & 0.041 & 0.703 & 2.14 & 11.0 & 0.040 & 0.202 & 0.103 & 0.007 & 0.043 & 0.080 \\
\hline Batch 1 & BCHLM223 & 2 & 2 & 21 & 0.122 & 0.838 & 0.011 & 0.055 & 0.313 & 2.98 & $<0.010$ & 0.836 & 1.38 & 6.82 & $<0.020$ & $<0.100$ & $<0.010$ & 0.362 & $<0.010$ & 0.030 \\
\hline Ustd & UstdLM223 & 2 & 2 & 22 & $<0.010$ & 0.898 & $<0.010$ & 0.149 & 0.019 & 2.65 & $<0.010$ & 0.687 & 2.28 & 8.86 & $<0.020$ & $<0.100$ & 0.039 & 0.541 & $<0.010$ & $<0.010$ \\
\hline
\end{tabular}




\section{Table D3. Measured Elemental Concentrations (wt\%) for Samples Prepared Using Peroxide Fusion}

\begin{tabular}{|c|c|c|c|c|c|c|c|c|c|c|c|}
\hline Glass ID & PSAL ID & Block & Sub-Block & $\begin{array}{l}\text { Analytical } \\
\text { Sequence }\end{array}$ & Al & B & $\mathbf{F e}$ & $\mathbf{L i}$ & $\mathbf{N i}$ & $\mathbf{S i}$ & $\mathbf{U}$ \\
\hline Batch 1 & Batch 1 & 1 & 1 & 1 & 2.51 & 2.25 & 9.00 & 2.02 & 0.539 & 22.6 & $<0.100$ \\
\hline Ustd & Ustd & 1 & 1 & 2 & 2.13 & 2.87 & 8.85 & 1.40 & 0.767 & 19.8 & 1.90 \\
\hline NEPH3-55 & G10 & 1 & 1 & 3 & 6.25 & 1.08 & 8.52 & 2.56 & 0.475 & 18.5 & 3.00 \\
\hline NEPH3-41 & G06 & 1 & 1 & 4 & 4.63 & 1.38 & 6.11 & 2.31 & 0.385 & 22.4 & 2.18 \\
\hline NEPH3-56 & G11 & 1 & 1 & 5 & 6.72 & 1.03 & 8.96 & 2.43 & 0.542 & 18.1 & 3.16 \\
\hline NEPH3-51 & G03 & 1 & 1 & 6 & 5.79 & 1.22 & 8.20 & 1.99 & 0.512 & 19.7 & 2.78 \\
\hline NEPH3-46 & G07 & 1 & 1 & 7 & 5.37 & 1.55 & 7.33 & 2.72 & 0.477 & 22.2 & 2.60 \\
\hline NEPH3-53 & G05 & 1 & 1 & 8 & 4.72 & 1.43 & 6.42 & 3.21 & 0.407 & 23.2 & 2.18 \\
\hline NEPH3-41 & G06 & 1 & 1 & 9 & 4.63 & 1.42 & 6.28 & 2.31 & 0.391 & 22.8 & 2.27 \\
\hline NEPH3-56 & G11 & 1 & 1 & 10 & 6.64 & 0.97 & 8.50 & 2.37 & 0.511 & 17.5 & 3.06 \\
\hline Batch 1 & Batch 1 & 1 & 1 & 11 & 2.54 & 2.20 & 8.94 & 1.98 & 0.551 & 22.7 & $<0.100$ \\
\hline Ustd & Ustd & 1 & 1 & 12 & 2.13 & 2.64 & 9.12 & 1.39 & 0.788 & 20.0 & 1.96 \\
\hline NEPH3-45 & G12 & 1 & 1 & 13 & 4.73 & 1.80 & 6.54 & 2.97 & 0.416 & 23.8 & 2.21 \\
\hline NEPH3-53 & G05 & 1 & 1 & 14 & 4.74 & 1.52 & 6.66 & 3.25 & 0.426 & 23.4 & 2.17 \\
\hline NEPH3-44 & G01 & 1 & 1 & 15 & 6.69 & 1.09 & 8.62 & 1.81 & 0.561 & 18.5 & 3.16 \\
\hline NEPH3-44 & G01 & 1 & 1 & 16 & 6.60 & 1.06 & 8.76 & 1.79 & 0.578 & 18.6 & 3.14 \\
\hline NEPH3-45 & G12 & 1 & 1 & 17 & 4.67 & 1.60 & 6.23 & 2.90 & 0.394 & 23.2 & 2.16 \\
\hline NEPH3-55 & G10 & 1 & 1 & 18 & 6.23 & 1.12 & 9.00 & 2.51 & 0.489 & 19.0 & 3.05 \\
\hline NEPH3-46 & G07 & 1 & 1 & 19 & 5.37 & 1.54 & 7.35 & 2.70 & 0.482 & 22.1 & 2.61 \\
\hline NEPH3-51 & G03 & 1 & 1 & 20 & 5.87 & 1.21 & 8.32 & 2.02 & 0.513 & 20.2 & 2.75 \\
\hline Batch 1 & Batch 1 & 1 & 1 & 21 & 2.56 & 2.30 & 9.65 & 2.02 & 0.600 & 23.8 & $<0.100$ \\
\hline Ustd & Ustd & 1 & 1 & 22 & 2.17 & 2.72 & 9.38 & 1.41 & 0.818 & 20.7 & 1.96 \\
\hline Batch 1 & Batch 1 & 1 & 2 & 1 & 2.58 & 2.69 & 9.39 & 2.03 & 0.571 & 23.3 & $<0.100$ \\
\hline Ustd & Ustd & 1 & 2 & 2 & 2.17 & 2.94 & 8.98 & 1.41 & 0.767 & 19.9 & 1.94 \\
\hline NEPH3-55 & G10 & 1 & 2 & 3 & 6.24 & 1.37 & 8.70 & 2.52 & 0.475 & 18.5 & 2.99 \\
\hline NEPH3-56 & G11 & 1 & 2 & 4 & 6.74 & 1.25 & 8.95 & 2.42 & 0.522 & 17.8 & 3.13 \\
\hline NEPH3-53 & G05 & 1 & 2 & 5 & 4.71 & 1.65 & 6.45 & 3.22 & 0.397 & 23.1 & 2.09 \\
\hline NEPH3-45 & G12 & 1 & 2 & 6 & 4.73 & 1.82 & 6.26 & 2.93 & 0.380 & 23.2 & 2.15 \\
\hline NEPH3-41 & G06 & 1 & 2 & 7 & 4.68 & 1.65 & 6.64 & 2.34 & 0.402 & 23.3 & 2.17 \\
\hline NEPH3-44 & G01 & 1 & 2 & 8 & 6.74 & 1.24 & 9.04 & 1.83 & 0.590 & 19.0 & 3.18 \\
\hline NEPH3-46 & G07 & 1 & 2 & 9 & 5.45 & 1.70 & 7.22 & 2.75 & 0.474 & 22.0 & 2.52 \\
\hline NEPH3-41 & G06 & 1 & 2 & 10 & 4.72 & 1.56 & 6.17 & 2.34 & 0.376 & 22.8 & 2.17 \\
\hline Batch 1 & Batch 1 & 1 & 2 & 11 & 2.72 & 2.42 & 9.11 & 2.03 & 0.561 & 23.0 & $<0.100$ \\
\hline Ustd & Ustd & 1 & 2 & 12 & 2.16 & 2.84 & 9.07 & 1.41 & 0.781 & 20.1 & 1.92 \\
\hline NEPH3-56 & G11 & 1 & 2 & 13 & 6.86 & 1.27 & 9.06 & 2.45 & 0.547 & 18.1 & 3.06 \\
\hline NEPH3-53 & G05 & 1 & 2 & 14 & 4.79 & 1.66 & 6.56 & 3.26 & 0.414 & 23.1 & 2.12 \\
\hline NEPH3-45 & G12 & 1 & 2 & 15 & 4.84 & 1.83 & 6.43 & 2.97 & 0.392 & 23.7 & 2.18 \\
\hline NEPH3-46 & G07 & 1 & 2 & 16 & 5.49 & 1.73 & 7.33 & 2.75 & 0.466 & 22.0 & 2.58 \\
\hline NEPH3-51 & G03 & 1 & 2 & 17 & 5.82 & 1.37 & 7.90 & 1.99 & 0.493 & 19.5 & 2.72 \\
\hline NEPH3-51 & G03 & 1 & 2 & 18 & 5.91 & 1.37 & 7.96 & 2.03 & 0.484 & 19.7 & 2.76 \\
\hline NEPH3-55 & G10 & 1 & 2 & 19 & 6.88 & 1.27 & 8.78 & 2.59 & 0.473 & 19.2 & 3.02 \\
\hline NEPH3-44 & G01 & 1 & 2 & 20 & 6.75 & 1.21 & 8.79 & 1.81 & 0.556 & 18.5 & 3.10 \\
\hline Batch 1 & Batch 1 & 1 & 2 & 21 & 2.62 & 2.49 & 9.70 & 2.06 & 0.588 & 23.8 & $<0.100$ \\
\hline Ustd & Ustd & 1 & 2 & 22 & 2.20 & 2.93 & 9.65 & 1.44 & 0.829 & 20.9 & 1.90 \\
\hline Batch 1 & Batch 1 & 2 & 1 & 1 & 2.52 & 2.46 & 8.88 & 2.00 & 0.544 & 22.5 & $<0.100$ \\
\hline Ustd & Ustd & 2 & 1 & 2 & 2.17 & 3.01 & 9.39 & 1.41 & 0.795 & 20.3 & 1.90 \\
\hline NEPH3-47 & G15 & 2 & 1 & 3 & 6.39 & 1.57 & 8.21 & 2.42 & 0.508 & 19.5 & 2.92 \\
\hline NEPH3-42 & G08 & 2 & 1 & 4 & 5.36 & 1.47 & 6.90 & 2.14 & 0.425 & 20.9 & 2.39 \\
\hline NEPH3-49 & G13 & 2 & 1 & 5 & 4.65 & 1.62 & 6.22 & 2.30 & 0.387 & 22.0 & 2.24 \\
\hline NEPH3-43 & G14 & 2 & 1 & 6 & 6.22 & 1.36 & 8.31 & 1.95 & 0.530 & 19.5 & 2.77 \\
\hline NEPH3-54 & G16 & 2 & 1 & 7 & 5.38 & 1.50 & 7.48 & 2.97 & 0.453 & 21.7 & 2.48 \\
\hline NEPH3-50 & G04 & 2 & 1 & 8 & 5.43 & 1.51 & 7.62 & 2.19 & 0.457 & 21.3 & 2.45 \\
\hline NEPH3-43 & G14 & 2 & 1 & 9 & 6.27 & 1.39 & 8.81 & 1.99 & 0.538 & 20.4 & 2.94 \\
\hline NEPH3-52 & G09 & 2 & 1 & 10 & 6.37 & 1.26 & 8.71 & 1.87 & 0.535 & 18.2 & 3.02 \\
\hline Batch 1 & Batch 1 & 2 & 1 & 11 & 2.53 & 2.35 & 8.70 & 1.98 & 0.529 & 22.4 & $<0.100$ \\
\hline
\end{tabular}


Table D3. Measured Elemental Concentrations (wt\%) for Samples Prepared Using Peroxide Fusion (continued)

\begin{tabular}{|c|c|c|c|c|c|c|c|c|c|c|c|}
\hline Glass ID & PSAL ID & Block & Sub-Block & $\begin{array}{l}\text { Analytical } \\
\text { Sequence }\end{array}$ & Al & B & $\mathbf{F e}$ & $\mathbf{L i}$ & $\mathbf{N i}$ & Si & $\mathbf{U}$ \\
\hline Ustd & Ustd & 2 & 1 & 12 & 2.12 & 2.75 & 8.60 & 1.38 & 0.733 & 19.6 & 1.85 \\
\hline NEPH3-48 & G02 & 2 & 1 & 13 & 6.76 & 1.48 & 9.07 & 2.22 & 0.560 & 18.1 & 3.25 \\
\hline NEPH3-48 & G02 & 2 & 1 & 14 & 6.85 & 1.41 & 9.13 & 2.24 & 0.568 & 18.3 & 3.17 \\
\hline NEPH3-52 & G09 & 2 & 1 & 15 & 6.38 & 1.33 & 9.19 & 1.89 & 0.563 & 18.5 & 3.02 \\
\hline NEPH3-50 & G04 & 2 & 1 & 16 & 5.47 & 1.52 & 7.63 & 2.19 & 0.480 & 21.3 & 2.51 \\
\hline NEPH3-47 & G15 & 2 & 1 & 17 & 6.46 & 1.52 & 8.63 & 2.42 & 0.534 & 19.8 & 2.97 \\
\hline NEPH3-42 & G08 & 2 & 1 & 18 & 5.47 & 1.49 & 7.61 & 2.21 & 0.481 & 22.0 & 2.50 \\
\hline NEPH3-49 & G13 & 2 & 1 & 19 & 4.80 & 1.65 & 6.88 & 2.38 & 0.418 & 23.3 & 2.25 \\
\hline NEPH3-54 & G16 & 2 & 1 & 20 & 5.50 & 1.52 & 7.78 & 3.03 & 0.475 & 22.4 & 2.52 \\
\hline Batch 1 & Batch 1 & 2 & 1 & 21 & 2.62 & 2.52 & 9.67 & 2.05 & 0.588 & 23.8 & $<0.100$ \\
\hline Ustd & Ustd & 2 & 1 & 22 & 2.19 & 2.93 & 9.62 & 1.42 & 0.828 & 20.7 & 1.94 \\
\hline Batch 1 & Batch 1 & 2 & 2 & 1 & 2.55 & 2.59 & 9.19 & 2.01 & 0.548 & 22.9 & $<0.100$ \\
\hline Ustd & Ustd & 2 & 2 & 2 & 2.12 & 2.90 & 9.01 & 1.39 & 0.755 & 19.9 & 1.92 \\
\hline NEPH3-48 & G02 & 2 & 2 & 3 & 6.85 & 1.44 & 8.88 & 2.23 & 0.547 & 18.1 & 3.24 \\
\hline NEPH3-50 & G04 & 2 & 2 & 4 & 5.37 & 1.52 & 7.37 & 2.16 & 0.445 & 20.8 & 2.50 \\
\hline NEPH3-54 & G16 & 2 & 2 & 5 & 5.35 & 1.52 & 7.45 & 2.95 & 0.455 & 21.5 & 2.53 \\
\hline NEPH3-43 & G14 & 2 & 2 & 6 & 6.31 & 1.35 & 8.43 & 1.98 & 0.511 & 19.7 & 2.84 \\
\hline NEPH3-52 & G09 & 2 & 2 & 7 & 6.38 & 1.29 & 8.91 & 1.89 & 0.529 & 18.2 & 3.09 \\
\hline NEPH3-48 & G02 & 2 & 2 & 8 & 6.78 & 1.36 & 9.00 & 2.22 & 0.546 & 18.1 & 3.27 \\
\hline NEPH3-43 & G14 & 2 & 2 & 9 & 6.20 & 1.35 & 8.47 & 1.97 & 0.510 & 19.8 & 2.98 \\
\hline NEPH3-54 & G16 & 2 & 2 & 10 & 5.40 & 1.46 & 7.37 & 2.97 & 0.432 & 21.6 & 2.54 \\
\hline Batch 1 & Batch 1 & 2 & 2 & 11 & 2.70 & 2.42 & 9.31 & 2.05 & 0.551 & 23.3 & $<0.100$ \\
\hline Ustd & Ustd & 2 & 2 & 12 & 2.17 & 2.79 & 8.99 & 1.41 & 0.759 & 20.0 & 1.97 \\
\hline NEPH3-52 & G09 & 2 & 2 & 13 & 6.36 & 1.33 & 8.50 & 1.89 & 0.514 & 18.0 & 3.04 \\
\hline NEPH3-42 & G08 & 2 & 2 & 14 & 5.37 & 1.45 & 6.95 & 2.15 & 0.409 & 20.8 & 2.45 \\
\hline NEPH3-50 & G04 & 2 & 2 & 15 & 5.40 & 1.49 & 7.32 & 2.17 & 0.460 & 20.8 & 2.49 \\
\hline NEPH3-42 & G08 & 2 & 2 & 16 & 5.38 & 1.44 & 7.17 & 2.18 & 0.433 & 21.2 & 2.53 \\
\hline NEPH3-47 & G15 & 2 & 2 & 17 & 6.40 & 1.48 & 8.24 & 2.41 & 0.504 & 19.4 & 3.04 \\
\hline NEPH3-49 & G13 & 2 & 2 & 18 & 4.74 & 1.59 & 6.54 & 2.35 & 0.392 & 22.8 & 2.33 \\
\hline NEPH3-47 & G15 & 2 & 2 & 19 & 6.41 & 1.46 & 8.18 & 2.43 & 0.494 & 19.5 & 2.98 \\
\hline NEPH3-49 & G13 & 2 & 2 & 20 & 4.76 & 1.58 & 6.52 & 2.37 & 0.386 & 22.6 & 2.31 \\
\hline Batch 1 & Batch 1 & 2 & 2 & 21 & 2.57 & 2.38 & 8.94 & 2.01 & 0.539 & 22.9 & $<0.100$ \\
\hline Ustd & Ustd & 2 & 2 & 22 & 2.16 & 2.74 & 8.59 & 1.40 & 0.732 & 19.5 & 1.94 \\
\hline
\end{tabular}


Table D4. Average Measured and Bias-Corrected Chemical Compositions Versus Targeted Compositions by Oxide by Nepheline Study Glass

(100-Batch 1; $200-U$ std)

\begin{tabular}{|c|c|c|c|c|c|c|c|c|}
\hline Glass \# & Oxide & $\begin{array}{c}\text { Measured } \\
(\mathrm{wt} \%)\end{array}$ & $\begin{array}{c}\text { Measured-bc } \\
(w t \%)\end{array}$ & $\begin{array}{c}\text { Targeted } \\
(\mathbf{w t} \%)\end{array}$ & $\begin{array}{c}\text { Diff of } \\
\text { Measured }\end{array}$ & $\begin{array}{c}\text { Diff of } \\
\text { Meas-bc }\end{array}$ & $\begin{array}{l}\text { \% Diff of } \\
\text { Measured }\end{array}$ & $\begin{array}{l}\text { \% Diff of } \\
\text { Meas-bc }\end{array}$ \\
\hline 41 & $\mathrm{~A} 12 \mathrm{O} 3(\mathrm{wt} \%)$ & 8.8145 & 8.7921 & 8.6820 & 0.1325 & 0.1101 & $1.5 \%$ & $1.3 \%$ \\
\hline 41 & $\mathrm{~B} 2 \mathrm{O} 3(\mathrm{wt} \%)$ & 4.8379 & 4.8831 & 5.2000 & -0.3621 & -0.3169 & $-7.0 \%$ & $-6.1 \%$ \\
\hline 41 & $\mathrm{BaO}(\mathrm{wt} \%)$ & 0.0405 & 0.0460 & 0.0440 & -0.0035 & 0.0020 & $-8.0 \%$ & $4.5 \%$ \\
\hline 41 & $\mathrm{CaO}(\mathrm{wt} \%)$ & 0.7458 & 0.7806 & 0.8360 & -0.0902 & -0.0554 & $-10.8 \%$ & $-6.6 \%$ \\
\hline 41 & $\mathrm{Ce} 2 \mathrm{O} 3(\mathrm{wt} \%)$ & 0.0375 & 0.0375 & 0.0520 & -0.0145 & -0.0145 & $-27.9 \%$ & $-27.9 \%$ \\
\hline 41 & $\mathrm{Cr} 2 \mathrm{O} 3(\mathrm{wt} \%)$ & 0.0723 & 0.1032 & 0.0740 & -0.0017 & 0.0292 & $-2.2 \%$ & $39.5 \%$ \\
\hline 41 & $\mathrm{CuO}\left(\mathrm{wt}^{\circ} \%\right)$ & 0.0325 & 0.0338 & 0.0210 & 0.0115 & 0.0128 & $55.0 \%$ & $60.8 \%$ \\
\hline 41 & $\mathrm{Fe} 2 \mathrm{O} 3(\mathrm{wt} \%)$ & 9.0071 & 8.6984 & 9.2980 & -0.2909 & -0.5996 & $-3.1 \%$ & $-6.4 \%$ \\
\hline 41 & $\mathrm{~K} 2 \mathrm{O}(\mathrm{wt} \%)$ & 0.1235 & 0.1150 & 0.1200 & 0.0035 & -0.0050 & $2.9 \%$ & $-4.2 \%$ \\
\hline 41 & La2O3 (wt $\%)$ & 0.0317 & 0.0317 & 0.0380 & -0.0063 & -0.0063 & $-16.7 \%$ & $-16.7 \%$ \\
\hline 41 & $\mathrm{Li} 2 \mathrm{O}(\mathrm{wt} \%)$ & 5.0055 & 5.0894 & 5.2000 & -0.1945 & -0.1106 & $-3.7 \%$ & $-2.1 \%$ \\
\hline 41 & $\mathrm{MgO}(\mathrm{wt} \%)$ & 0.8428 & 0.8550 & 0.8730 & -0.0302 & -0.0180 & $-3.5 \%$ & $-2.1 \%$ \\
\hline 41 & $\mathrm{MnO}(\mathrm{wt} \%)$ & 1.9497 & 1.9547 & 1.9180 & 0.0317 & 0.0367 & $1.7 \%$ & $1.9 \%$ \\
\hline 41 & $\mathrm{Na} 2 \mathrm{O}(\mathrm{wt} \%)$ & 13.2845 & 12.9460 & 12.9280 & 0.3565 & 0.0180 & $2.8 \%$ & $0.1 \%$ \\
\hline 41 & $\mathrm{NiO}(\mathrm{wt} \%)$ & 0.4944 & 0.5134 & 0.5520 & -0.0576 & -0.0386 & $-10.4 \%$ & $-7.0 \%$ \\
\hline 41 & $\mathrm{PbO}(\mathrm{wt} \%)$ & 0.0288 & 0.0288 & 0.0320 & -0.0032 & -0.0032 & $-10.0 \%$ & $-10.0 \%$ \\
\hline 41 & SO4 (wt\%) & 0.4591 & 0.4591 & 0.4680 & -0.0089 & -0.0089 & $-1.9 \%$ & $-1.9 \%$ \\
\hline 41 & $\mathrm{SiO} 2(\mathrm{wt} \%)$ & 48.8295 & 49.4073 & 50.8400 & -2.0105 & -1.4327 & $-4.0 \%$ & $-2.8 \%$ \\
\hline 41 & ThO2 (wt $\%)$ & 0.0797 & 0.0797 & 0.0230 & 0.0567 & 0.0567 & $246.3 \%$ & $246.3 \%$ \\
\hline 41 & $\mathrm{TiO} 2(\mathrm{wt} \%)$ & 0.0108 & 0.0117 & 0.0090 & 0.0018 & 0.0027 & $20.5 \%$ & $29.7 \%$ \\
\hline 41 & U3O8 (wt $\%)$ & 2.5913 & 2.7394 & 2.6740 & -0.0827 & 0.0654 & $-3.1 \%$ & $2.4 \%$ \\
\hline 41 & $\mathrm{ZnO}(\mathrm{wt} \%)$ & 0.0426 & 0.0426 & 0.0340 & 0.0086 & 0.0086 & $25.4 \%$ & $25.4 \%$ \\
\hline 41 & $\mathrm{ZrO} 2(\mathrm{wt} \%)$ & 0.0763 & 0.0763 & 0.0830 & -0.0067 & -0.0067 & $-8.0 \%$ & $-8.0 \%$ \\
\hline 41 & Sum (wt $\%)$ & 97.4384 & 97.7247 & 99.9990 & -2.5606 & -2.2743 & $-2.6 \%$ & $-2.3 \%$ \\
\hline 42 & $\mathrm{~A} 12 \mathrm{O} 3(\mathrm{wt} \%)$ & 10.1939 & 10.1930 & 9.9220 & 0.2719 & 0.2710 & $2.7 \%$ & $2.7 \%$ \\
\hline 42 & $\mathrm{~B} 2 \mathrm{O} 3(\mathrm{wt} \%)$ & 4.7091 & 4.6364 & 4.8000 & -0.0909 & -0.1636 & $-1.9 \%$ & $-3.4 \%$ \\
\hline 42 & $\mathrm{BaO}(\mathrm{wt} \%)$ & 0.0466 & 0.0530 & 0.0500 & -0.0034 & 0.0030 & $-6.8 \%$ & $6.0 \%$ \\
\hline 42 & $\mathrm{CaO}(\mathrm{wt} \%)$ & 0.8528 & 0.8927 & 0.9550 & -0.1022 & -0.0623 & $-10.7 \%$ & $-6.5 \%$ \\
\hline 42 & $\mathrm{Ce} 2 \mathrm{O} 3(\mathrm{wt} \%)$ & 0.0454 & 0.0454 & 0.0600 & -0.0146 & -0.0146 & $-24.4 \%$ & $-24.4 \%$ \\
\hline 42 & $\mathrm{Cr} 2 \mathrm{O} 3(\mathrm{wt} \%)$ & 0.0840 & 0.1198 & 0.0850 & -0.0010 & 0.0348 & $-1.1 \%$ & $41.0 \%$ \\
\hline 42 & $\mathrm{CuO}(\mathrm{wt} \%)$ & 0.0310 & 0.0321 & 0.0240 & 0.0070 & 0.0081 & $29.1 \%$ & $33.9 \%$ \\
\hline 42 & $\mathrm{Fe} 2 \mathrm{O} 3(\mathrm{wt} \%)$ & 10.2331 & 10.0824 & 10.6260 & -0.3929 & -0.5436 & $-3.7 \%$ & $-5.1 \%$ \\
\hline 42 & $\mathrm{~K} 2 \mathrm{O}(\mathrm{wt} \%)$ & 0.1322 & 0.1232 & 0.1380 & -0.0058 & -0.0148 & $-4.2 \%$ & $-10.8 \%$ \\
\hline 42 & $\mathrm{La} 2 \mathrm{O} 3(\mathrm{wt} \%)$ & 0.0369 & 0.0369 & 0.0430 & -0.0061 & -0.0061 & $-14.1 \%$ & $-14.1 \%$ \\
\hline 42 & $\mathrm{Li} 2 \mathrm{O}(\mathrm{wt} \%)$ & 4.6718 & 4.7658 & 4.8000 & -0.1282 & -0.0342 & $-2.7 \%$ & $-0.7 \%$ \\
\hline 42 & $\mathrm{MgO}(\mathrm{wt} \%)$ & 0.9589 & 0.9728 & 0.9980 & -0.0391 & -0.0252 & $-3.9 \%$ & $-2.5 \%$ \\
\hline 42 & $\mathrm{MnO}(\mathrm{wt} \%)$ & 2.2015 & 2.2071 & 2.1920 & 0.0095 & 0.0151 & $0.4 \%$ & $0.7 \%$ \\
\hline 42 & $\mathrm{Na} 2 \mathrm{O}(\mathrm{wt} \%)$ & 13.6485 & 13.3007 & 13.6320 & 0.0165 & -0.3313 & $0.1 \%$ & $-2.4 \%$ \\
\hline 42 & $\mathrm{NiO}(\mathrm{wt} \%)$ & 0.5561 & 0.5968 & 0.6310 & -0.0749 & -0.0342 & $-11.9 \%$ & $-5.4 \%$ \\
\hline 42 & $\mathrm{PbO}(\mathrm{wt} \%)$ & 0.0339 & 0.0339 & 0.0360 & $\begin{array}{l}-0.0021 \\
\end{array}$ & $\begin{array}{l}-0.0021 \\
\end{array}$ & $-5.7 \%$ & $-5.7 \%$ \\
\hline 42 & SO4 (wt\%) & 0.5056 & 0.5056 & 0.5350 & -0.0294 & $\begin{array}{l}-0.0294 \\
\end{array}$ & $-5.5 \%$ & $-5.5 \%$ \\
\hline 42 & $\mathrm{SiO} 2(\mathrm{wt} \%)$ & 45.4066 & 46.4134 & 47.2450 & -1.8384 & -0.8316 & $-3.9 \%$ & $-1.8 \%$ \\
\hline 42 & ThO2 (wt\%) & 0.0910 & 0.0910 & 0.0260 & 0.0650 & 0.0650 & $250.1 \%$ & $250.1 \%$ \\
\hline 42 & $\mathrm{TiO} 2(\mathrm{wt} \%)$ & 0.0125 & 0.0135 & 0.0110 & 0.0015 & 0.0025 & $13.7 \%$ & $22.5 \%$ \\
\hline 42 & U3O8 (wt $\%)$ & 2.9097 & 3.0922 & 3.0560 & -0.1463 & 0.0362 & $-4.8 \%$ & $1.2 \%$ \\
\hline 42 & $\mathrm{ZnO}(\mathrm{wt} \%)$ & 0.0436 & 0.0436 & 0.0390 & 0.0046 & 0.0046 & $11.7 \%$ & $11.7 \%$ \\
\hline 42 & $\mathrm{ZrO} 2(\mathrm{wt} \%)$ & 0.0898 & 0.0898 & 0.0950 & -0.0052 & -0.0052 & $-5.4 \%$ & $-5.4 \%$ \\
\hline 42 & Sum $(w t \%)$ & 97.4946 & 98.3410 & 99.9990 & -2.5044 & -1.6580 & $-2.5 \%$ & $-1.7 \%$ \\
\hline 43 & $\mathrm{Al} 2 \mathrm{O} 3(\mathrm{wt} \%)$ & 11.8094 & 11.8078 & 11.4110 & 0.3984 & 0.3968 & $3.5 \%$ & $3.5 \%$ \\
\hline 43 & $\mathrm{~B} 2 \mathrm{O} 3(\mathrm{wt} \%)$ & 4.3871 & 4.3193 & 4.3200 & 0.0671 & -0.0007 & $1.6 \%$ & $0.0 \%$ \\
\hline 43 & $\mathrm{BaO}(\mathrm{wt} \%)$ & 0.0555 & 0.0557 & 0.0580 & -0.0025 & -0.0023 & $-4.2 \%$ & $-4.0 \%$ \\
\hline 43 & $\mathrm{CaO}(\mathrm{wt} \%)$ & 1.0123 & 1.0054 & 1.0980 & -0.0857 & -0.0926 & $-7.8 \%$ & $-8.4 \%$ \\
\hline 43 & $\mathrm{Ce} 2 \mathrm{O} 3(\mathrm{wt} \%)$ & 0.0428 & 0.0428 & 0.0690 & -0.0262 & -0.0262 & $-38.0 \%$ & $-38.0 \%$ \\
\hline 43 & $\mathrm{Cr} 2 \mathrm{O} 3(\mathrm{wt} \%)$ & 0.0976 & 0.1159 & 0.0980 & -0.0004 & 0.0179 & $-0.4 \%$ & $18.2 \%$ \\
\hline 43 & $\mathrm{CuO}(\mathrm{wt} \%)$ & 0.0416 & 0.0398 & 0.0280 & 0.0136 & 0.0118 & $48.7 \%$ & $42.3 \%$ \\
\hline 43 & $\mathrm{Fe} 2 \mathrm{O} 3(\mathrm{wt} \%)$ & 12.1596 & 11.9802 & 12.2200 & -0.0604 & -0.2398 & $-0.5 \%$ & $-2.0 \%$ \\
\hline
\end{tabular}


Table D4. Average Measured and Bias-Corrected Chemical Compositions Versus Targeted Compositions by Oxide by Nepheline Study Glass (continued)

(100 -Batch 1; 200 -U std)

\begin{tabular}{|c|c|c|c|c|c|c|c|c|}
\hline Glass \# & Oxide & $\begin{array}{c}\text { Measured } \\
(w t \%)\end{array}$ & $\begin{array}{c}\text { Measured-bc } \\
(w \mathrm{t} \%)\end{array}$ & $\begin{array}{c}\text { Targeted } \\
(\mathbf{w t} \%)\end{array}$ & $\begin{array}{c}\text { Diff of } \\
\text { Measured }\end{array}$ & $\begin{array}{c}\text { Diff of } \\
\text { Meas-bc }\end{array}$ & $\begin{array}{l}\text { \% Diff of } \\
\text { Measured }\end{array}$ & $\begin{array}{l}\text { \% Diff of } \\
\text { Meas-bc }\end{array}$ \\
\hline 43 & $\mathrm{~K} 2 \mathrm{O}(\mathrm{wt} \%)$ & 0.1665 & 0.1571 & 0.1580 & 0.0085 & -0.0009 & $5.4 \%$ & $-0.6 \%$ \\
\hline 43 & La2O3 (wt $\%)$ & 0.0472 & 0.0472 & 0.0500 & -0.0028 & -0.0028 & $-5.6 \%$ & $-5.6 \%$ \\
\hline 43 & $\mathrm{Li} 2 \mathrm{O}(\mathrm{wt} \%)$ & 4.2466 & 4.3320 & 4.3200 & -0.0734 & 0.0120 & $-1.7 \%$ & $0.3 \%$ \\
\hline 43 & $\mathrm{MgO}\left(\mathrm{wt}^{\circ} \%\right)$ & 1.1135 & 1.1203 & 1.1480 & -0.0345 & -0.0277 & $-3.0 \%$ & $-2.4 \%$ \\
\hline 43 & $\mathrm{MnO}(\mathrm{wt} \%)$ & 2.5017 & 2.5270 & 2.5210 & -0.0193 & 0.0060 & $-0.8 \%$ & $0.2 \%$ \\
\hline 43 & $\mathrm{Na} 2 \mathrm{O}(\mathrm{wt} \%)$ & 14.2551 & 14.4606 & 14.4770 & -0.2219 & -0.0164 & $-1.5 \%$ & $-0.1 \%$ \\
\hline 43 & $\mathrm{NiO}\left(\mathrm{wt}^{\circ} \%\right)$ & 0.6646 & 0.7132 & 0.7260 & -0.0614 & -0.0128 & $-8.5 \%$ & $-1.8 \%$ \\
\hline 43 & $\mathrm{PbO}(\mathrm{wt} \%)$ & 0.0396 & 0.0396 & 0.0420 & -0.0024 & -0.0024 & $-5.7 \%$ & $-5.7 \%$ \\
\hline 43 & SO4 (wt $\%)$ & 0.5775 & 0.5775 & 0.6150 & -0.0375 & -0.0375 & $-6.1 \%$ & $-6.1 \%$ \\
\hline 43 & $\mathrm{SiO} 2(\mathrm{wt} \%)$ & 42.4651 & 43.4059 & 42.9320 & -0.4669 & 0.4739 & $-1.1 \%$ & $1.1 \%$ \\
\hline 43 & ThO2 (wt $\%)$ & 0.1087 & 0.1087 & 0.0300 & 0.0787 & 0.0787 & $262.2 \%$ & $262.2 \%$ \\
\hline 43 & $\mathrm{TiO} 2(\mathrm{wt} \%)$ & 0.0200 & 0.0198 & 0.0120 & 0.0080 & 0.0078 & $66.8 \%$ & $65.2 \%$ \\
\hline 43 & U3O8 (wt\%) & 3.3990 & 3.6122 & 3.5150 & -0.1160 & 0.0972 & $-3.3 \%$ & $2.8 \%$ \\
\hline 43 & $\mathrm{ZnO}(\mathrm{wt} \%)$ & 0.0541 & 0.0541 & 0.0450 & 0.0091 & 0.0091 & $20.3 \%$ & $20.3 \%$ \\
\hline 43 & $\mathrm{ZrO} 2(\mathrm{wt} \%)$ & 0.1081 & 0.1081 & 0.1090 & -0.0009 & -0.0009 & $-0.9 \%$ & $-0.9 \%$ \\
\hline 43 & Sum (wt $\%)$ & 99.3732 & 100.6503 & 100.0020 & -0.6288 & 0.6483 & $-0.6 \%$ & $0.6 \%$ \\
\hline 44 & $\mathrm{Al} 2 \mathrm{O} 3(\mathrm{wt} \%)$ & 12.6502 & 12.6180 & 12.4030 & 0.2472 & 0.2150 & $2.0 \%$ & $1.7 \%$ \\
\hline 44 & $\mathrm{~B} 2 \mathrm{O} 3(\mathrm{wt} \%)$ & 3.7029 & 3.7381 & 4.0000 & -0.2971 & -0.2619 & $-7.4 \%$ & $-6.5 \%$ \\
\hline 44 & $\mathrm{BaO}\left(\mathrm{wt}^{2} \%\right)$ & 0.0589 & 0.0669 & 0.0630 & -0.0041 & 0.0039 & $-6.5 \%$ & $6.3 \%$ \\
\hline 44 & $\mathrm{CaO}(\mathrm{wt} \%)$ & 1.0679 & 1.1179 & 1.1940 & -0.1261 & -0.0761 & $-10.6 \%$ & $-6.4 \%$ \\
\hline 44 & $\mathrm{Ce} 2 \mathrm{O} 3(\mathrm{wt} \%)$ & 0.0477 & 0.0477 & 0.0750 & -0.0273 & -0.0273 & $-36.4 \%$ & $-36.4 \%$ \\
\hline 44 & $\mathrm{Cr} 2 \mathrm{O} 3(\mathrm{wt} \%)$ & 0.0903 & 0.1288 & 0.1060 & -0.0157 & 0.0228 & $-14.9 \%$ & $21.5 \%$ \\
\hline 44 & $\mathrm{CuO}(\mathrm{wt} \%)$ & 0.0382 & 0.0396 & 0.0300 & 0.0082 & 0.0096 & $27.3 \%$ & $32.1 \%$ \\
\hline 44 & $\mathrm{Fe} 2 \mathrm{O} 3(\mathrm{wt} \%)$ & 12.5849 & 12.1541 & 13.2830 & -0.6981 & -1.1289 & $-5.3 \%$ & $-8.5 \%$ \\
\hline 44 & $\mathrm{~K} 2 \mathrm{O}(\mathrm{wt} \%)$ & 0.1753 & 0.1633 & 0.1720 & 0.0033 & -0.0087 & $1.9 \%$ & $-5.1 \%$ \\
\hline 44 & La2O3 (wt $\%)$ & 0.0481 & 0.0481 & 0.0540 & -0.0059 & -0.0059 & $-11.0 \%$ & $-11.0 \%$ \\
\hline 44 & Li2O (wt $\%)$ & 3.8967 & 3.9621 & 4.0000 & -0.1033 & -0.0379 & $-2.6 \%$ & $-0.9 \%$ \\
\hline 44 & $\mathrm{MgO}\left(\mathrm{wt}^{\circ} \%\right)$ & 1.1782 & 1.1953 & 1.2480 & -0.0698 & -0.0527 & $-5.6 \%$ & $-4.2 \%$ \\
\hline 44 & $\mathrm{MnO}(\mathrm{wt} \%)$ & 2.7051 & 2.7115 & 2.7400 & -0.0349 & -0.0285 & $-1.3 \%$ & $-1.0 \%$ \\
\hline 44 & $\mathrm{Na} 2 \mathrm{O}(\mathrm{wt} \%)$ & 16.2434 & 15.8294 & 15.0400 & 1.2034 & 0.7894 & $8.0 \%$ & $5.2 \%$ \\
\hline 44 & $\mathrm{NiO}(\mathrm{wt} \%)$ & 0.7269 & 0.7549 & 0.7890 & -0.0621 & -0.0341 & $-7.9 \%$ & $-4.3 \%$ \\
\hline 44 & $\mathrm{PbO}(\mathrm{wt} \%)$ & 0.0425 & 0.0425 & 0.0450 & -0.0025 & -0.0025 & $-5.4 \%$ & $-5.4 \%$ \\
\hline 44 & SO4 (wt $\%)$ & 0.6404 & 0.6404 & 0.6690 & -0.0286 & -0.0286 & $-4.3 \%$ & $-4.3 \%$ \\
\hline 44 & $\mathrm{SiO} 2(\mathrm{wt} \%)$ & 39.8979 & 40.3714 & 40.0570 & -0.1591 & 0.3144 & $-0.4 \%$ & $0.8 \%$ \\
\hline 44 & ThO2 (wt $\%)$ & 0.1155 & 0.1155 & 0.0330 & 0.0825 & 0.0825 & $250.0 \%$ & $250.0 \%$ \\
\hline 44 & $\mathrm{TiO} 2(\mathrm{wt} \%)$ & 0.0133 & 0.0144 & 0.0130 & 0.0003 & 0.0014 & $2.6 \%$ & $10.7 \%$ \\
\hline 44 & U3O8 (wt\%) & 3.7086 & 3.9207 & 3.8200 & -0.1114 & 0.1007 & $-2.9 \%$ & $2.6 \%$ \\
\hline 44 & $\mathrm{ZnO}(\mathrm{wt} \%)$ & 0.0523 & 0.0523 & 0.0490 & 0.0033 & 0.0033 & $6.7 \%$ & $6.7 \%$ \\
\hline 44 & $\mathrm{ZrO} 2(\mathrm{wt} \%)$ & 0.1064 & 0.1064 & 0.1190 & -0.0126 & -0.0126 & $-10.6 \%$ & $-10.6 \%$ \\
\hline 44 & Sum $(w t \%)$ & 99.7917 & 99.8392 & 100.0020 & -0.2103 & -0.1628 & $-0.2 \%$ & $-0.2 \%$ \\
\hline 45 & $\mathrm{~A} 12 \mathrm{O} 3(\mathrm{wt} \%)$ & 8.9610 & 8.9379 & 8.6820 & 0.2790 & 0.2559 & $3.2 \%$ & $2.9 \%$ \\
\hline 45 & $\mathrm{~B} 2 \mathrm{O} 3(\mathrm{wt} \%)$ & 5.6751 & 5.7392 & 5.8500 & -0.1749 & -0.1108 & $-3.0 \%$ & $-1.9 \%$ \\
\hline 45 & $\mathrm{BaO}(\mathrm{wt} \%)$ & 0.0438 & 0.0439 & 0.0440 & -0.0002 & -0.0001 & $-0.4 \%$ & $-0.2 \%$ \\
\hline 45 & $\mathrm{CaO}(\mathrm{wt} \%)$ & 0.7780 & 0.7726 & 0.8360 & -0.0580 & -0.0634 & $-6.9 \%$ & $-7.6 \%$ \\
\hline 45 & $\mathrm{Ce} 2 \mathrm{O} 3(\mathrm{wt} \%)$ & 0.0395 & 0.0395 & 0.0520 & -0.0125 & -0.0125 & $-24.0 \%$ & $-24.0 \%$ \\
\hline 45 & $\mathrm{Cr} 2 \mathrm{O} 3(\mathrm{wt} \%)$ & 0.0665 & 0.0789 & 0.0740 & -0.0075 & 0.0049 & $-10.1 \%$ & $6.6 \%$ \\
\hline 45 & $\mathrm{CuO}(\mathrm{wt} \%)$ & 0.0335 & 0.0320 & 0.0210 & 0.0125 & 0.0110 & $59.5 \%$ & $52.6 \%$ \\
\hline 45 & $\mathrm{Fe} 2 \mathrm{O} 3(\mathrm{wt} \%)$ & 9.1000 & 8.7900 & 9.2980 & -0.1980 & -0.5080 & $-2.1 \%$ & $-5.5 \%$ \\
\hline 45 & $\mathrm{~K} 2 \mathrm{O}(\mathrm{wt} \%)$ & 0.1256 & 0.1185 & 0.1200 & 0.0056 & -0.0015 & $4.6 \%$ & $-1.3 \%$ \\
\hline 45 & $\mathrm{La} 2 \mathrm{O} 3(w \mathrm{t} \%)$ & 0.0372 & 0.0372 & 0.0380 & -0.0008 & -0.0008 & $-2.0 \%$ & $-2.0 \%$ \\
\hline 45 & $\mathrm{Li} 2 \mathrm{O}(\mathrm{wt} \%)$ & 6.3349 & 6.4413 & 6.5000 & -0.1651 & -0.0587 & $-2.5 \%$ & $-0.9 \%$ \\
\hline 45 & $\mathrm{MgO}(\mathrm{wt} \%)$ & 0.8586 & 0.8638 & 0.8730 & -0.0144 & -0.0092 & $-1.7 \%$ & $-1.1 \%$ \\
\hline 45 & $\mathrm{MnO}(\mathrm{wt} \%)$ & 1.9465 & 1.9662 & 1.9180 & 0.0285 & 0.0482 & $1.5 \%$ & $2.5 \%$ \\
\hline 45 & $\mathrm{Na} 2 \mathrm{O}(\mathrm{wt} \%)$ & 10.7604 & 10.9164 & 10.9780 & -0.2176 & -0.0616 & $-2.0 \%$ & $-0.6 \%$ \\
\hline 45 & $\mathrm{NiO}(\mathrm{wt} \%)$ & 0.5033 & 0.5228 & 0.5520 & -0.0487 & -0.0292 & $-8.8 \%$ & $-5.3 \%$ \\
\hline 45 & $\mathrm{PbO}(\mathrm{wt} \%)$ & 0.0355 & 0.0355 & 0.0320 & 0.0035 & 0.0035 & $11.1 \%$ & $11.1 \%$ \\
\hline 45 & SO4 (wt $\%)$ & 0.4539 & 0.4539 & 0.4680 & -0.0141 & -0.0141 & $-3.0 \%$ & $-3.0 \%$ \\
\hline 45 & $\mathrm{SiO} 2(\mathrm{wt} \%)$ & 50.2201 & 50.8183 & 50.8400 & -0.6199 & -0.0217 & $-1.2 \%$ & $0.0 \%$ \\
\hline
\end{tabular}


Table D4. Average Measured and Bias-Corrected Chemical Compositions Versus Targeted Compositions by Oxide by Nepheline Study Glass (continued)

(100 -Batch 1; 200 -U std)

\begin{tabular}{|c|c|c|c|c|c|c|c|c|}
\hline Glass \# & Oxide & $\begin{array}{c}\text { Measured } \\
(w t \%)\end{array}$ & $\begin{array}{c}\text { Measured-bc } \\
(w \mathrm{t} \%)\end{array}$ & $\begin{array}{c}\text { Targeted } \\
(w \mathrm{t} \%)\end{array}$ & $\begin{array}{c}\text { Diff of } \\
\text { Measured }\end{array}$ & $\begin{array}{c}\text { Diff of } \\
\text { Meas-bc }\end{array}$ & $\begin{array}{l}\text { \% Diff of } \\
\text { Measured }\end{array}$ & $\begin{array}{l}\text { \% Diff of } \\
\text { Meas-bc }\end{array}$ \\
\hline 45 & ThO2 (wt\%) & 0.0848 & 0.0848 & 0.0230 & 0.0618 & 0.0618 & $268.6 \%$ & $268.6 \%$ \\
\hline 45 & $\mathrm{TiO} 2\left(\mathrm{wt}^{\circ} \%\right)$ & 0.0167 & 0.0165 & 0.0090 & 0.0077 & 0.0075 & $85.3 \%$ & $83.4 \%$ \\
\hline 45 & U3O8 (wt\%) & 2.5648 & 2.7114 & 2.6740 & -0.1092 & 0.0374 & $-4.1 \%$ & $1.4 \%$ \\
\hline 45 & $\mathrm{ZnO}(\mathrm{wt} \%)$ & 0.0523 & 0.0523 & 0.0340 & 0.0183 & 0.0183 & $53.8 \%$ & $53.8 \%$ \\
\hline 45 & $\mathrm{ZrO} 2(\mathrm{wt} \%)$ & 0.0767 & 0.0767 & 0.0830 & -0.0063 & -0.0063 & $-7.6 \%$ & $-7.6 \%$ \\
\hline 45 & Sum (wt\%) & 98.7685 & 99.5497 & 99.9990 & -1.2305 & -0.4493 & $-1.2 \%$ & $-0.4 \%$ \\
\hline 46 & $\mathrm{~A} 12 \mathrm{O} 3(\mathrm{wt} \%)$ & 10.2411 & 10.2147 & 9.9220 & 0.3191 & 0.2927 & $3.2 \%$ & $2.9 \%$ \\
\hline 46 & $\mathrm{~B} 2 \mathrm{O} 3(\mathrm{wt} \%)$ & 5.2484 & 5.3025 & 5.4000 & -0.1516 & -0.0975 & $-2.8 \%$ & $-1.8 \%$ \\
\hline 46 & $\mathrm{BaO}(\mathrm{wt} \%)$ & 0.0488 & 0.0489 & 0.0500 & -0.0012 & -0.0011 & $-2.3 \%$ & $-2.1 \%$ \\
\hline 46 & $\mathrm{CaO}\left(\mathrm{wt}^{\circ} \%\right)$ & 0.8871 & 0.8810 & 0.9550 & -0.0679 & -0.0740 & $-7.1 \%$ & $-7.8 \%$ \\
\hline 46 & $\mathrm{Ce} 2 \mathrm{O} 3(\mathrm{wt} \%)$ & 0.0474 & 0.0474 & 0.0600 & -0.0126 & -0.0126 & $-20.9 \%$ & $-20.9 \%$ \\
\hline 46 & $\mathrm{Cr} 2 \mathrm{O} 3(\mathrm{wt} \%)$ & 0.0826 & 0.0980 & 0.0850 & -0.0024 & 0.0130 & $-2.8 \%$ & $15.3 \%$ \\
\hline 46 & $\mathrm{CuO}\left(\mathrm{wt}^{\circ} \%\right)$ & 0.0394 & 0.0378 & 0.0240 & 0.0154 & 0.0138 & $64.3 \%$ & $57.3 \%$ \\
\hline 46 & $\mathrm{Fe} 2 \mathrm{O} 3(\mathrm{wt} \%)$ & 10.4475 & 10.0918 & 10.6260 & -0.1785 & -0.5342 & $-1.7 \%$ & $-5.0 \%$ \\
\hline 46 & $\mathrm{~K} 2 \mathrm{O}(\mathrm{wt} \%)$ & 0.1491 & 0.1406 & 0.1380 & 0.0111 & 0.0026 & $8.0 \%$ & $1.9 \%$ \\
\hline 46 & La2O3 (wt\%) & 0.0434 & 0.0434 & 0.0430 & 0.0004 & 0.0004 & $0.9 \%$ & $0.9 \%$ \\
\hline 46 & $\mathrm{Li} 2 \mathrm{O}(\mathrm{wt} \%)$ & 5.8774 & 5.9759 & 6.0000 & -0.1226 & -0.0241 & $-2.0 \%$ & $-0.4 \%$ \\
\hline 46 & $\mathrm{MgO}(\mathrm{wt} \%)$ & 0.9796 & 0.9856 & 0.9980 & -0.0184 & -0.0124 & $-1.8 \%$ & $-1.2 \%$ \\
\hline 46 & $\mathrm{MnO}\left(\mathrm{wt}^{\circ} \%\right)$ & 2.2209 & 2.2434 & 2.1920 & 0.0289 & 0.0514 & $1.3 \%$ & $2.3 \%$ \\
\hline 46 & $\mathrm{Na} 2 \mathrm{O}(\mathrm{wt} \%)$ & 11.8995 & 12.0681 & 11.8320 & 0.0675 & 0.2361 & $0.6 \%$ & $2.0 \%$ \\
\hline 46 & $\mathrm{NiO}(\mathrm{wt} \%)$ & 0.6041 & 0.6274 & 0.6310 & -0.0269 & -0.0036 & $-4.3 \%$ & $-0.6 \%$ \\
\hline 46 & $\mathrm{PbO}(\mathrm{wt} \%)$ & 0.0404 & 0.0404 & 0.0360 & 0.0044 & 0.0044 & $12.2 \%$ & $12.2 \%$ \\
\hline 46 & SO4 (wt\%) & 0.5041 & 0.5041 & 0.5350 & -0.0309 & -0.0309 & $-5.8 \%$ & $-5.8 \%$ \\
\hline 46 & $\mathrm{SiO} 2(\mathrm{wt} \%)$ & 47.2250 & 47.7884 & 47.2450 & -0.0200 & 0.5434 & $0.0 \%$ & $1.2 \%$ \\
\hline 46 & $\mathrm{ThO} 2(\mathrm{wt} \%)$ & 0.0964 & 0.0964 & 0.0260 & 0.0704 & 0.0704 & $270.9 \%$ & $270.9 \%$ \\
\hline 46 & $\mathrm{TiO} 2(\mathrm{wt} \%)$ & 0.0200 & 0.0198 & 0.0110 & 0.0090 & 0.0088 & $82.0 \%$ & $80.2 \%$ \\
\hline 46 & U3O8 (wt\%) & 3.0394 & 3.2131 & 3.0560 & -0.0166 & 0.1571 & $-0.5 \%$ & $5.1 \%$ \\
\hline 46 & $\mathrm{ZnO}(\mathrm{wt} \%)$ & 0.0398 & 0.0398 & 0.0390 & 0.0008 & 0.0008 & $2.1 \%$ & $2.1 \%$ \\
\hline 46 & $\mathrm{ZrO} 2(\mathrm{wt} \%)$ & 0.0736 & 0.0736 & 0.0950 & -0.0214 & -0.0214 & $-22.5 \%$ & $-22.5 \%$ \\
\hline 46 & Sum $(w t \%)$ & 99.8552 & 100.5822 & 99.9990 & -0.1438 & 0.5832 & $-0.1 \%$ & $0.6 \%$ \\
\hline 47 & $\mathrm{~A} 12 \mathrm{O} 3(\mathrm{wt} \%)$ & 12.1211 & 12.1198 & 11.6590 & 0.4621 & 0.4608 & $4.0 \%$ & $4.0 \%$ \\
\hline 47 & $\mathrm{~B} 2 \mathrm{O} 3(\mathrm{wt} \%)$ & 4.8540 & 4.7793 & 4.7700 & 0.0840 & 0.0093 & $1.8 \%$ & $0.2 \%$ \\
\hline 47 & $\mathrm{BaO}(\mathrm{wt} \%)$ & 0.0544 & 0.0619 & 0.0590 & -0.0046 & 0.0029 & $-7.7 \%$ & $4.9 \%$ \\
\hline 47 & $\mathrm{CaO}(\mathrm{wt} \%)$ & 1.0148 & 1.0623 & 1.1220 & -0.1072 & -0.0597 & $-9.6 \%$ & $-5.3 \%$ \\
\hline 47 & $\mathrm{Ce} 2 \mathrm{O} 3(\mathrm{wt} \%)$ & 0.0469 & 0.0469 & 0.0700 & -0.0231 & -0.0231 & $-33.1 \%$ & $-33.1 \%$ \\
\hline 47 & $\mathrm{Cr} 2 \mathrm{O} 3(\mathrm{wt} \%)$ & 0.0851 & 0.1214 & 0.1000 & -0.0149 & 0.0214 & $-14.9 \%$ & $21.4 \%$ \\
\hline 47 & $\mathrm{CuO}(\mathrm{wt} \%)$ & 0.0372 & 0.0386 & 0.0280 & 0.0092 & 0.0106 & $33.0 \%$ & $38.0 \%$ \\
\hline 47 & $\mathrm{Fe} 2 \mathrm{O} 3(\mathrm{wt} \%)$ & 11.8880 & 11.7128 & 12.4860 & -0.5980 & -0.7732 & $-4.8 \%$ & $-6.2 \%$ \\
\hline 47 & $\mathrm{~K} 2 \mathrm{O}(\mathrm{wt} \%)$ & 0.1677 & 0.1563 & 0.1620 & 0.0057 & -0.0057 & $3.5 \%$ & $-3.5 \%$ \\
\hline 47 & La2O3 (wt $\%)$ & 0.0434 & 0.0434 & 0.0510 & -0.0076 & -0.0076 & $-14.9 \%$ & $-14.9 \%$ \\
\hline 47 & $\mathrm{Li} 2 \mathrm{O}(\mathrm{wt} \%)$ & 5.2100 & 5.3149 & 5.3000 & -0.0900 & 0.0149 & $-1.7 \%$ & $0.3 \%$ \\
\hline 47 & $\mathrm{MgO}\left(\mathrm{wt}^{\circ} \%\right)$ & 1.1210 & 1.1372 & 1.1730 & -0.0520 & -0.0358 & $-4.4 \%$ & $-3.1 \%$ \\
\hline 47 & $\mathrm{MnO}\left(\mathrm{wt}^{\circ} \%\right)$ & 2.6115 & 2.6174 & 2.5760 & 0.0355 & 0.0414 & $1.4 \%$ & $1.6 \%$ \\
\hline 47 & $\mathrm{Na} 2 \mathrm{O}(\mathrm{wt} \%)$ & 13.3924 & 13.0510 & 13.0270 & 0.3654 & 0.0240 & $2.8 \%$ & $0.2 \%$ \\
\hline 47 & $\mathrm{NiO}(\mathrm{wt} \%)$ & 0.6490 & 0.6965 & 0.7410 & -0.0920 & -0.0445 & $-12.4 \%$ & $-6.0 \%$ \\
\hline 47 & $\mathrm{PbO}(\mathrm{wt} \%)$ & 0.0428 & 0.0428 & 0.0430 & -0.0002 & -0.0002 & $-0.4 \%$ & $-0.4 \%$ \\
\hline 47 & $\mathrm{SO} 4(\mathrm{wt} \%)$ & 0.6104 & 0.6104 & 0.6290 & -0.0186 & -0.0186 & $-3.0 \%$ & $-3.0 \%$ \\
\hline 47 & $\mathrm{SiO} 2(\mathrm{wt} \%)$ & 41.8233 & 42.7499 & 42.2130 & -0.3897 & 0.5369 & $-0.9 \%$ & $1.3 \%$ \\
\hline 47 & ThO2 $\left(\mathrm{wt}^{\circ} \%\right)$ & 0.1055 & 0.1055 & 0.0310 & 0.0745 & 0.0745 & $240.5 \%$ & $240.5 \%$ \\
\hline 47 & $\mathrm{TiO} 2(\mathrm{wt} \%)$ & 0.0133 & 0.0144 & 0.0130 & 0.0003 & 0.0014 & $2.6 \%$ & $10.6 \%$ \\
\hline 47 & U3O8 (wt\%) & 3.5111 & 3.7312 & 3.5910 & -0.0799 & 0.1402 & $-2.2 \%$ & $3.9 \%$ \\
\hline 47 & $\mathrm{ZnO}(\mathrm{wt} \%)$ & 0.0451 & 0.0451 & 0.0460 & -0.0009 & -0.0009 & $-1.9 \%$ & $-1.9 \%$ \\
\hline 47 & $\mathrm{ZrO} 2(\mathrm{wt} \%)$ & 0.1043 & 0.1043 & 0.1110 & -0.0067 & -0.0067 & $-6.0 \%$ & $-6.0 \%$ \\
\hline 47 & Sum (wt $\%)$ & 99.5525 & 100.3635 & 100.0010 & -0.4485 & 0.3625 & $-0.4 \%$ & $0.4 \%$ \\
\hline 48 & $\mathrm{Al} 2 \mathrm{O} 3(\mathrm{wt} \%)$ & 12.8675 & 12.8658 & 12.6510 & 0.2165 & 0.2148 & $1.7 \%$ & $1.7 \%$ \\
\hline 48 & $\mathrm{~B} 2 \mathrm{O} 3(\mathrm{wt} \%)$ & 4.5803 & 4.5097 & 4.4100 & 0.1703 & 0.0997 & $3.9 \%$ & $2.3 \%$ \\
\hline 48 & $\mathrm{BaO}\left(\mathrm{wt}^{\circ} \%\right)$ & 0.0595 & 0.0596 & 0.0640 & -0.0045 & -0.0044 & $-7.1 \%$ & $-6.9 \%$ \\
\hline 48 & $\mathrm{CaO}(\mathrm{wt} \%)$ & 1.1155 & 1.1079 & 1.2180 & -0.1025 & -0.1101 & $-8.4 \%$ & $-9.0 \%$ \\
\hline
\end{tabular}


Table D4. Average Measured and Bias-Corrected Chemical Compositions Versus Targeted Compositions by Oxide by Nepheline Study Glass (continued)

(100 -Batch 1; 200 -U std)

\begin{tabular}{|c|c|c|c|c|c|c|c|c|}
\hline Glass \# & Oxide & $\begin{array}{c}\text { Measured } \\
(w t \%)\end{array}$ & $\begin{array}{c}\text { Measured-bc } \\
(w t \%)\end{array}$ & $\begin{array}{c}\text { Targeted } \\
(\mathbf{w t} \%)\end{array}$ & $\begin{array}{c}\text { Diff of } \\
\text { Measured }\end{array}$ & $\begin{array}{c}\text { Diff of } \\
\text { Meas-bc }\end{array}$ & $\begin{array}{l}\% \text { Diff of } \\
\text { Measured }\end{array}$ & $\begin{array}{l}\% \text { Diff of } \\
\text { Meas-bc }\end{array}$ \\
\hline 48 & $\mathrm{Ce} 2 \mathrm{O} 3(\mathrm{wt} \%)$ & 0.0510 & 0.0510 & 0.0760 & -0.0250 & -0.0250 & $-33.0 \%$ & $-33.0 \%$ \\
\hline 48 & $\mathrm{Cr} 2 \mathrm{O} 3(\mathrm{wt} \%)$ & 0.0979 & 0.1163 & 0.1080 & -0.0101 & 0.0083 & $-9.3 \%$ & $7.7 \%$ \\
\hline 48 & $\mathrm{CuO}(\mathrm{wt} \%)$ & 0.0448 & 0.0428 & 0.0310 & 0.0138 & 0.0118 & $44.4 \%$ & $38.2 \%$ \\
\hline 48 & $\mathrm{Fe} 2 \mathrm{O} 3(\mathrm{wt} \%)$ & 12.8959 & 12.7057 & 13.5480 & -0.6521 & -0.8423 & $-4.8 \%$ & $-6.2 \%$ \\
\hline 48 & $\mathrm{~K} 2 \mathrm{O}(\mathrm{wt} \%)$ & 0.1963 & 0.1852 & 0.1750 & 0.0213 & 0.0102 & $12.2 \%$ & $5.8 \%$ \\
\hline 48 & $\mathrm{La} 2 \mathrm{O} 3(\mathrm{wt} \%)$ & 0.0510 & 0.0510 & 0.0550 & -0.0040 & -0.0040 & $-7.2 \%$ & $-7.2 \%$ \\
\hline 48 & $\mathrm{Li} 2 \mathrm{O}(\mathrm{wt} \%)$ & 4.7956 & 4.8921 & 4.9000 & -0.1044 & -0.0079 & $-2.1 \%$ & $-0.2 \%$ \\
\hline 48 & $\mathrm{MgO}\left(\mathrm{wt}^{\circ} \%\right)$ & 1.1952 & 1.2025 & 1.2730 & -0.0778 & -0.0705 & $-6.1 \%$ & $-5.5 \%$ \\
\hline 48 & $\mathrm{MnO}\left(\mathrm{wt}^{\circ} \%\right)$ & 2.7373 & 2.7651 & 2.7950 & -0.0577 & -0.0299 & $-2.1 \%$ & $-1.1 \%$ \\
\hline 48 & $\mathrm{Na} 2 \mathrm{O}(\mathrm{wt} \%)$ & 13.6586 & 13.8572 & 13.7110 & -0.0524 & 0.1462 & $-0.4 \%$ & $1.1 \%$ \\
\hline 48 & $\mathrm{NiO}(\mathrm{wt} \%)$ & 0.7066 & 0.7584 & 0.8040 & -0.0974 & -0.0456 & $-12.1 \%$ & $-5.7 \%$ \\
\hline 48 & $\mathrm{PbO}\left(\mathrm{wt}^{\circ} \%\right)$ & 0.0463 & 0.0463 & 0.0460 & 0.0003 & 0.0003 & $0.7 \%$ & $0.7 \%$ \\
\hline 48 & SO4 (wt $\%)$ & 0.6449 & 0.6449 & 0.6820 & -0.0371 & -0.0371 & $-5.4 \%$ & $-5.4 \%$ \\
\hline 48 & $\mathrm{SiO} 2(\mathrm{wt} \%)$ & 38.8283 & 39.6883 & 39.3380 & -0.5097 & 0.3503 & $-1.3 \%$ & $0.9 \%$ \\
\hline 48 & ThO2 (wt $\%)$ & 0.1200 & 0.1200 & 0.0340 & 0.0860 & 0.0860 & $253.1 \%$ & $253.1 \%$ \\
\hline 48 & $\mathrm{TiO} 2(\mathrm{wt} \%)$ & 0.0221 & 0.0219 & 0.0140 & 0.0081 & 0.0079 & $57.9 \%$ & $56.4 \%$ \\
\hline 48 & U3O8 (wt $\%)$ & 3.8118 & 4.0510 & 3.8970 & -0.0852 & 0.1540 & $-2.2 \%$ & $4.0 \%$ \\
\hline 48 & $\mathrm{ZnO}(\mathrm{wt} \%)$ & 0.0598 & 0.0598 & 0.0500 & 0.0098 & 0.0098 & $19.5 \%$ & $19.5 \%$ \\
\hline 48 & $\mathrm{ZrO} 2(\mathrm{wt} \%)$ & 0.1168 & 0.1168 & 0.1210 & -0.0042 & -0.0042 & $-3.4 \%$ & $-3.4 \%$ \\
\hline 48 & Sum (wt\%) & 98.7030 & 99.9193 & 100.0010 & -1.2980 & -0.0817 & $-1.3 \%$ & $-0.1 \%$ \\
\hline 49 & $\mathrm{~A} 12 \mathrm{O} 3(\mathrm{wt} \%)$ & 8.9515 & 8.9502 & 8.6820 & 0.2695 & 0.2682 & $3.1 \%$ & $3.1 \%$ \\
\hline 49 & $\mathrm{~B} 2 \mathrm{O} 3(\mathrm{wt} \%)$ & 5.1840 & 5.1041 & 5.2000 & -0.0160 & -0.0959 & $-0.3 \%$ & $-1.8 \%$ \\
\hline 49 & $\mathrm{BaO}(\mathrm{wt} \%)$ & 0.0430 & 0.0431 & 0.0440 & -0.0010 & -0.0009 & $-2.3 \%$ & $-2.1 \%$ \\
\hline 49 & $\mathrm{CaO}\left(\mathrm{wt}^{\circ} \%\right)$ & 0.8717 & 0.8658 & 0.8360 & 0.0357 & 0.0298 & $4.3 \%$ & $3.6 \%$ \\
\hline 49 & $\mathrm{Ce} 2 \mathrm{O} 3(\mathrm{wt} \%)$ & 0.0384 & 0.0384 & 0.0520 & -0.0136 & -0.0136 & $-26.2 \%$ & $-26.2 \%$ \\
\hline 49 & $\mathrm{Cr} 2 \mathrm{O} 3(\mathrm{wt} \%)$ & 0.0720 & 0.0855 & 0.0740 & -0.0020 & 0.0115 & $-2.7 \%$ & $15.5 \%$ \\
\hline 49 & $\mathrm{CuO}\left(\mathrm{wt}^{\circ} \%\right)$ & 0.0316 & 0.0303 & 0.0210 & 0.0106 & 0.0093 & $50.5 \%$ & $44.1 \%$ \\
\hline 49 & $\mathrm{Fe} 2 \mathrm{O} 3(\mathrm{wt} \%)$ & 9.3502 & 9.2121 & 9.2980 & 0.0522 & -0.0859 & $0.6 \%$ & $-0.9 \%$ \\
\hline 49 & $\mathrm{~K} 2 \mathrm{O}(\mathrm{wt} \%)$ & 0.1379 & 0.1301 & 0.1200 & 0.0179 & 0.0101 & $14.9 \%$ & $8.4 \%$ \\
\hline 49 & $\mathrm{La} 2 \mathrm{O} 3(\mathrm{wt} \%)$ & 0.0349 & 0.0349 & 0.0380 & -0.0031 & -0.0031 & $-8.2 \%$ & $-8.2 \%$ \\
\hline 49 & $\mathrm{Li} 2 \mathrm{O}(\mathrm{wt} \%)$ & 5.0593 & 5.1611 & 5.2000 & -0.1407 & -0.0389 & $-2.7 \%$ & $-0.7 \%$ \\
\hline 49 & $\mathrm{MgO}\left(\mathrm{wt}^{0} \%\right)$ & 0.8971 & 0.9026 & 0.8730 & 0.0241 & 0.0296 & $2.8 \%$ & $3.4 \%$ \\
\hline 49 & $\mathrm{MnO}\left(\mathrm{wt}^{\circ} \%\right)$ & 1.9207 & 1.9400 & 1.9180 & 0.0027 & 0.0220 & $0.1 \%$ & $1.1 \%$ \\
\hline 49 & $\mathrm{Na} 2 \mathrm{O}(\mathrm{wt} \%)$ & 14.8954 & 15.1155 & 14.2280 & 0.6674 & 0.8875 & $4.7 \%$ & $6.2 \%$ \\
\hline 49 & $\mathrm{NiO}(\mathrm{wt} \%)$ & 0.5036 & 0.5405 & 0.5520 & -0.0484 & -0.0115 & $-8.8 \%$ & $-2.1 \%$ \\
\hline 49 & $\mathrm{PbO}(\mathrm{wt} \%)$ & 0.0310 & 0.0310 & 0.0320 & -0.0010 & -0.0010 & $-3.2 \%$ & $-3.2 \%$ \\
\hline 49 & $\mathrm{SO} 4(\mathrm{wt} \%)$ & 0.4411 & 0.4411 & 0.4680 & -0.0269 & -0.0269 & $-5.7 \%$ & $-5.7 \%$ \\
\hline 49 & $\mathrm{SiO} 2(\mathrm{wt} \%)$ & 48.5086 & 49.5825 & 49.5400 & -1.0314 & 0.0425 & $-2.1 \%$ & $0.1 \%$ \\
\hline 49 & ThO2 (wt $\%)$ & 0.0819 & 0.0819 & 0.0230 & 0.0589 & 0.0589 & $256.2 \%$ & $256.2 \%$ \\
\hline 49 & $\mathrm{TiO} 2\left(\mathrm{wt}^{\circ} \%\right)$ & 0.0163 & 0.0161 & 0.0090 & 0.0073 & 0.0071 & $80.7 \%$ & $78.7 \%$ \\
\hline 49 & U3O8 (wt\%) & 2.6915 & 2.8601 & 2.6740 & 0.0175 & 0.1861 & $0.7 \%$ & $7.0 \%$ \\
\hline 49 & $\mathrm{ZnO}(\mathrm{wt} \%)$ & 0.0495 & 0.0495 & 0.0340 & 0.0155 & 0.0155 & $45.5 \%$ & $45.5 \%$ \\
\hline 49 & $\mathrm{ZrO} 2(\mathrm{wt} \%)$ & 0.0824 & 0.0824 & 0.0830 & -0.0006 & -0.0006 & $-0.7 \%$ & $-0.7 \%$ \\
\hline 49 & Sum $(w t \%)$ & 99.8937 & 101.2986 & 99.9990 & -0.1053 & 1.2996 & $-0.1 \%$ & $1.3 \%$ \\
\hline 50 & $\mathrm{Al} 2 \mathrm{O} 3(\mathrm{wt} \%)$ & 10.2364 & 10.2357 & 9.9220 & 0.3144 & 0.3137 & $3.2 \%$ & $3.2 \%$ \\
\hline 50 & $\mathrm{~B} 2 \mathrm{O} 3(\mathrm{wt} \%)$ & 4.8620 & 4.7868 & 4.8000 & 0.0620 & -0.0132 & $1.3 \%$ & $-0.3 \%$ \\
\hline 50 & $\mathrm{BaO}(\mathrm{wt} \%)$ & 0.0463 & 0.0527 & 0.0500 & -0.0037 & 0.0027 & $-7.3 \%$ & $5.3 \%$ \\
\hline 50 & $\mathrm{CaO}(\mathrm{wt} \%)$ & 0.8574 & 0.8975 & 0.9550 & -0.0976 & -0.0575 & $-10.2 \%$ & $-6.0 \%$ \\
\hline 50 & $\mathrm{Ce} 2 \mathrm{O} 3(\mathrm{wt} \%)$ & 0.0378 & 0.0378 & 0.0600 & -0.0222 & -0.0222 & $-37.0 \%$ & $-37.0 \%$ \\
\hline 50 & $\mathrm{Cr} 2 \mathrm{O} 3(\mathrm{wt} \%)$ & 0.0829 & 0.1184 & 0.0850 & -0.0021 & 0.0334 & $-2.4 \%$ & $39.3 \%$ \\
\hline 50 & $\mathrm{CuO}(\mathrm{wt} \%)$ & 0.0322 & 0.0335 & 0.0240 & 0.0082 & 0.0095 & $34.3 \%$ & $39.4 \%$ \\
\hline 50 & $\mathrm{Fe} 2 \mathrm{O} 3(\mathrm{wt} \%)$ & 10.7013 & 10.5439 & 10.6260 & 0.0753 & -0.0821 & $0.7 \%$ & $-0.8 \%$ \\
\hline 50 & $\mathrm{~K} 2 \mathrm{O}(\mathrm{wt} \%)$ & 0.1464 & 0.1363 & 0.1380 & 0.0084 & -0.0017 & $6.1 \%$ & $-1.2 \%$ \\
\hline 50 & $\mathrm{La} 2 \mathrm{O} 3(\mathrm{wt} \%)$ & 0.0390 & 0.0390 & 0.0430 & -0.0040 & -0.0040 & $-9.3 \%$ & $-9.3 \%$ \\
\hline 50 & $\mathrm{Li} 2 \mathrm{O}(\mathrm{wt} \%)$ & 4.6879 & 4.7824 & 4.8000 & -0.1121 & -0.0176 & $-2.3 \%$ & $-0.4 \%$ \\
\hline 50 & $\mathrm{MgO}\left(\mathrm{wt}^{\circ} \%\right)$ & 0.9560 & 0.9698 & 0.9980 & -0.0420 & -0.0282 & $-4.2 \%$ & $-2.8 \%$ \\
\hline 50 & $\mathrm{MnO}\left(\mathrm{wt}^{\circ} \%\right)$ & 2.2338 & 2.2391 & 2.1920 & 0.0418 & 0.0471 & $1.9 \%$ & $2.1 \%$ \\
\hline 50 & $\mathrm{Na} 2 \mathrm{O}(\mathrm{wt} \%)$ & 15.0639 & 14.6801 & 14.8320 & 0.2319 & -0.1519 & $1.6 \%$ & $-1.0 \%$ \\
\hline
\end{tabular}


Table D4. Average Measured and Bias-Corrected Chemical Compositions Versus Targeted Compositions by Oxide by Nepheline Study Glass (continued)

(100-Batch 1; 200 -U std)

\begin{tabular}{|c|c|c|c|c|c|c|c|c|}
\hline Glass \# & Oxide & $\begin{array}{c}\text { Measured } \\
(w t \%)\end{array}$ & $\begin{array}{c}\text { Measured-bc } \\
(w \mathrm{t} \%)\end{array}$ & $\begin{array}{c}\text { Targeted } \\
(\mathbf{w t} \%)\end{array}$ & $\begin{array}{c}\text { Diff of } \\
\text { Measured }\end{array}$ & $\begin{array}{c}\text { Diff of } \\
\text { Meas-bc }\end{array}$ & $\begin{array}{l}\text { \% Diff of } \\
\text { Measured }\end{array}$ & $\begin{array}{l}\text { \% Diff of } \\
\text { Meas-bc }\end{array}$ \\
\hline 50 & $\mathrm{NiO}(\mathrm{wt} \%)$ & 0.5860 & 0.6289 & 0.6310 & -0.0450 & -0.0021 & $-7.1 \%$ & $-0.3 \%$ \\
\hline 50 & $\mathrm{PbO}(\mathrm{wt} \%)$ & 0.0334 & 0.0334 & 0.0360 & -0.0026 & -0.0026 & $-7.2 \%$ & $-7.2 \%$ \\
\hline 50 & SO4 (wt $\%)$ & 0.5333 & 0.5333 & 0.5350 & -0.0017 & -0.0017 & $-0.3 \%$ & $-0.3 \%$ \\
\hline 50 & $\mathrm{SiO} 2(\mathrm{wt} \%)$ & 45.0323 & 46.0309 & 46.0450 & -1.0127 & -0.0141 & $-2.2 \%$ & $0.0 \%$ \\
\hline 50 & ThO2 (wt $\%)$ & 0.0910 & 0.0910 & 0.0260 & 0.0650 & 0.0650 & $250.1 \%$ & $250.1 \%$ \\
\hline 50 & $\mathrm{TiO} 2(\mathrm{wt} \%)$ & 0.0117 & 0.0126 & 0.0110 & 0.0007 & 0.0016 & $6.1 \%$ & $14.3 \%$ \\
\hline 50 & U3O8 (wt\%) & 2.9333 & 3.1175 & 3.0560 & -0.1227 & 0.0615 & $-4.0 \%$ & $2.0 \%$ \\
\hline 50 & $\mathrm{ZnO}(\mathrm{wt} \%)$ & 0.0398 & 0.0398 & 0.0390 & 0.0008 & 0.0008 & $2.1 \%$ & $2.1 \%$ \\
\hline 50 & $\mathrm{ZrO} 2(\mathrm{wt} \%)$ & 0.0851 & 0.0851 & 0.0950 & -0.0099 & -0.0099 & $-10.4 \%$ & $-10.4 \%$ \\
\hline 50 & Sum (wt $\%)$ & 99.3292 & 100.1254 & 99.9990 & -0.6698 & 0.1264 & $-0.7 \%$ & $0.1 \%$ \\
\hline 51 & $\mathrm{~A} 12 \mathrm{O} 3(\mathrm{wt} \%)$ & 11.0489 & 11.0217 & 10.9150 & 0.1339 & 0.1067 & $1.2 \%$ & $1.0 \%$ \\
\hline 51 & $\mathrm{~B} 2 \mathrm{O} 3(\mathrm{wt} \%)$ & 4.1617 & 4.2026 & 4.4800 & -0.3183 & -0.2774 & $-7.1 \%$ & $-6.2 \%$ \\
\hline 51 & $\mathrm{BaO}\left(\mathrm{wt}^{\circ} \%\right)$ & 0.0516 & 0.0517 & 0.0560 & -0.0044 & -0.0043 & $-7.8 \%$ & $-7.6 \%$ \\
\hline 51 & $\mathrm{CaO}(\mathrm{wt} \%)$ & 0.9637 & 0.9570 & 1.0510 & -0.0873 & -0.0940 & $-8.3 \%$ & $-8.9 \%$ \\
\hline 51 & $\mathrm{Ce} 2 \mathrm{O} 3(\mathrm{wt} \%)$ & 0.0469 & 0.0469 & 0.0660 & -0.0191 & -0.0191 & $-29.0 \%$ & $-29.0 \%$ \\
\hline 51 & $\mathrm{Cr} 2 \mathrm{O} 3(\mathrm{wt} \%)$ & 0.0881 & 0.1046 & 0.0930 & -0.0049 & 0.0116 & $-5.3 \%$ & $12.4 \%$ \\
\hline 51 & $\mathrm{CuO}\left(\mathrm{wt}^{\circ} \%\right)$ & 0.0388 & 0.0371 & 0.0260 & 0.0128 & 0.0111 & $49.3 \%$ & $42.9 \%$ \\
\hline 51 & $\mathrm{Fe} 2 \mathrm{O} 3(\mathrm{wt} \%)$ & 11.5734 & 11.1813 & 11.6890 & -0.1156 & -0.5077 & $-1.0 \%$ & $-4.3 \%$ \\
\hline 51 & $\mathrm{~K} 2 \mathrm{O}(\mathrm{wt} \%)$ & 0.1665 & 0.1571 & 0.1510 & 0.0155 & 0.0061 & $10.3 \%$ & $4.0 \%$ \\
\hline 51 & La2O3 (wt\%) & 0.0449 & 0.0449 & 0.0480 & -0.0031 & -0.0031 & $-6.5 \%$ & $-6.5 \%$ \\
\hline 51 & $\mathrm{Li} 2 \mathrm{O}(\mathrm{wt} \%)$ & 4.3219 & 4.3946 & 4.4800 & -0.1581 & -0.0854 & $-3.5 \%$ & $-1.9 \%$ \\
\hline 51 & $\mathrm{MgO}\left(\mathrm{wt}^{\circ} \%\right)$ & 1.0501 & 1.0565 & 1.0980 & -0.0479 & -0.0415 & $-4.4 \%$ & $-3.8 \%$ \\
\hline 51 & $\mathrm{MnO}(\mathrm{wt} \%)$ & 2.4145 & 2.4390 & 2.4110 & 0.0035 & 0.0280 & $0.1 \%$ & $1.2 \%$ \\
\hline 51 & $\mathrm{Na} 2 \mathrm{O}(\mathrm{wt} \%)$ & 15.1650 & 15.3835 & 15.3150 & -0.1500 & 0.0685 & $-1.0 \%$ & $0.4 \%$ \\
\hline 51 & $\mathrm{NiO}(\mathrm{wt} \%)$ & 0.6369 & 0.6616 & 0.6940 & -0.0571 & -0.0324 & $-8.2 \%$ & $-4.7 \%$ \\
\hline 51 & $\mathrm{PbO}(\mathrm{wt} \%)$ & 0.0345 & 0.0345 & 0.0400 & -0.0055 & -0.0055 & $-13.8 \%$ & $-13.8 \%$ \\
\hline 51 & SO4 (wt $\%)$ & 0.5677 & 0.5677 & 0.5890 & -0.0213 & -0.0213 & $-3.6 \%$ & $-3.6 \%$ \\
\hline 51 & $\mathrm{SiO} 2\left(\mathrm{wt}^{\circ} \%\right)$ & 42.3047 & 42.8110 & 43.2500 & -0.9453 & -0.4390 & $-2.2 \%$ & $-1.0 \%$ \\
\hline 51 & ThO2 (wt $\%)$ & 0.1053 & 0.1053 & 0.0290 & 0.0763 & 0.0763 & $263.0 \%$ & $263.0 \%$ \\
\hline 51 & $\mathrm{TiO} 2(\mathrm{wt} \%)$ & 0.0204 & 0.0202 & 0.0120 & 0.0084 & 0.0082 & $70.3 \%$ & $68.5 \%$ \\
\hline 51 & U3O8 (wt\%) & 3.2457 & 3.4314 & 3.3620 & -0.1163 & 0.0694 & $-3.5 \%$ & $2.1 \%$ \\
\hline 51 & $\mathrm{ZnO}(\mathrm{wt} \%)$ & 0.0429 & 0.0429 & 0.0430 & -0.0001 & -0.0001 & $-0.1 \%$ & $-0.1 \%$ \\
\hline 51 & $\mathrm{ZrO} 2\left(\mathrm{wt}^{\circ} \%\right)$ & 0.0946 & 0.0946 & 0.1040 & -0.0094 & -0.0094 & $-9.1 \%$ & $-9.1 \%$ \\
\hline 51 & Sum (wt $\%)$ & 98.1887 & 98.8475 & 100.0020 & -1.8133 & -1.1545 & $-1.8 \%$ & $-1.2 \%$ \\
\hline 52 & $\mathrm{Al} 2 \mathrm{O} 3(\mathrm{wt} \%)$ & 12.0408 & 12.0394 & 11.9070 & 0.1338 & 0.1324 & $1.1 \%$ & $1.1 \%$ \\
\hline 52 & $\mathrm{~B} 2 \mathrm{O} 3(\mathrm{wt} \%)$ & 4.1939 & 4.1289 & 4.1600 & 0.0339 & -0.0311 & $0.8 \%$ & $-0.7 \%$ \\
\hline 52 & $\mathrm{BaO}\left(\mathrm{wt}^{\circ} \%\right)$ & 0.0586 & 0.0587 & 0.0610 & -0.0024 & -0.0023 & $-3.9 \%$ & $-3.7 \%$ \\
\hline 52 & $\mathrm{CaO}\left(\mathrm{wt}^{0} \%\right)$ & 1.0543 & 1.0471 & 1.1460 & -0.0917 & -0.0989 & $-8.0 \%$ & $-8.6 \%$ \\
\hline 52 & $\mathrm{Ce} 2 \mathrm{O} 3(\mathrm{wt} \%)$ & 0.0568 & 0.0568 & 0.0720 & -0.0152 & -0.0152 & $-21.1 \%$ & $-21.1 \%$ \\
\hline 52 & $\mathrm{Cr} 2 \mathrm{O} 3(\mathrm{wt} \%)$ & 0.1009 & 0.1198 & 0.1020 & -0.0011 & 0.0178 & $-1.1 \%$ & $17.5 \%$ \\
\hline 52 & $\mathrm{CuO}(\mathrm{wt} \%)$ & 0.0401 & 0.0383 & 0.0290 & 0.0111 & 0.0093 & $38.1 \%$ & $32.2 \%$ \\
\hline 52 & $\mathrm{Fe} 2 \mathrm{O} 3(\mathrm{wt} \%)$ & 12.6207 & 12.4348 & 12.7510 & -0.1303 & -0.3162 & $-1.0 \%$ & $-2.5 \%$ \\
\hline 52 & $\mathrm{~K} 2 \mathrm{O}(\mathrm{wt} \%)$ & 0.1756 & 0.1656 & 0.1650 & 0.0106 & 0.0006 & $6.4 \%$ & $0.4 \%$ \\
\hline 52 & $\mathrm{La} 2 \mathrm{O} 3(\mathrm{wt} \%)$ & 0.0487 & 0.0487 & 0.0520 & -0.0033 & -0.0033 & $-6.4 \%$ & $-6.4 \%$ \\
\hline 52 & $\mathrm{Li} 2 \mathrm{O}(\mathrm{wt} \%)$ & 4.0582 & 4.1398 & 4.1600 & -0.1018 & -0.0202 & $-2.4 \%$ & $-0.5 \%$ \\
\hline 52 & $\mathrm{MgO}(\mathrm{wt} \%)$ & 1.1608 & 1.1679 & 1.1980 & -0.0372 & -0.0301 & $-3.1 \%$ & $-2.5 \%$ \\
\hline 52 & $\mathrm{MnO}(\mathrm{wt} \%)$ & 2.6147 & 2.6410 & 2.6300 & -0.0153 & 0.0110 & $-0.6 \%$ & $0.4 \%$ \\
\hline 52 & $\mathrm{Na} 2 \mathrm{O}(\mathrm{wt} \%)$ & 15.7379 & 15.9661 & 15.7980 & -0.0601 & 0.1681 & $-0.4 \%$ & $1.1 \%$ \\
\hline 52 & $\mathrm{NiO}(\mathrm{wt} \%)$ & 0.6811 & 0.7310 & 0.7570 & -0.0759 & -0.0260 & $-10.0 \%$ & $-3.4 \%$ \\
\hline 52 & $\mathrm{PbO}(\mathrm{wt} \%)$ & 0.0399 & 0.0399 & 0.0430 & -0.0031 & -0.0031 & $-7.3 \%$ & $-7.3 \%$ \\
\hline 52 & SO4 (wt $\%)$ & 0.6172 & 0.6172 & 0.6420 & -0.0248 & -0.0248 & $-3.9 \%$ & $-3.9 \%$ \\
\hline 52 & $\mathrm{SiO} 2(\mathrm{wt} \%)$ & 38.9887 & 39.8528 & 40.4540 & -1.4653 & -0.6012 & $-3.6 \%$ & $-1.5 \%$ \\
\hline 52 & ThO2 (wt $\%)$ & 0.1112 & 0.1112 & 0.0320 & 0.0792 & 0.0792 & $247.6 \%$ & $247.6 \%$ \\
\hline 52 & $\mathrm{TiO} 2(\mathrm{wt} \%)$ & 0.0183 & 0.0182 & 0.0130 & 0.0053 & 0.0052 & $41.1 \%$ & $39.7 \%$ \\
\hline 52 & $\mathrm{U} 3 \mathrm{O} 8(\mathrm{wt} \%)$ & 3.5877 & 3.8129 & 3.6670 & -0.0793 & 0.1459 & $-2.2 \%$ & $4.0 \%$ \\
\hline 52 & $\mathrm{ZnO}(\mathrm{wt} \%)$ & 0.0510 & 0.0510 & 0.0470 & 0.0040 & 0.0040 & $8.6 \%$ & $8.6 \%$ \\
\hline 52 & $\mathrm{ZrO} 2(\mathrm{wt} \%)$ & 0.1091 & 0.1091 & 0.1140 & -0.0049 & -0.0049 & $-4.3 \%$ & $-4.3 \%$ \\
\hline 52 & Sum $(w t \%)$ & 98.1662 & 99.3961 & 100.0000 & -1.8338 & -0.6039 & $-1.8 \%$ & $-0.6 \%$ \\
\hline
\end{tabular}


Table D4. Average Measured and Bias-Corrected Chemical Compositions Versus Targeted Compositions by Oxide by Nepheline Study Glass (continued)

(100 -Batch 1; 200 -U std)

\begin{tabular}{|c|c|c|c|c|c|c|c|c|}
\hline Glass \# & Oxide & $\begin{array}{c}\text { Measured } \\
(w t \%)\end{array}$ & $\begin{array}{c}\text { Measured-bc } \\
(w \mathrm{t} \%)\end{array}$ & $\begin{array}{c}\text { Targeted } \\
(\mathbf{w t} \%)\end{array}$ & $\begin{array}{c}\text { Diff of } \\
\text { Measured }\end{array}$ & $\begin{array}{c}\text { Diff of } \\
\text { Meas-bc }\end{array}$ & $\begin{array}{l}\text { \% Diff of } \\
\text { Measured }\end{array}$ & $\begin{array}{l}\text { \% Diff of } \\
\text { Meas-bc }\end{array}$ \\
\hline 53 & $\mathrm{Al} 2 \mathrm{O} 3(\mathrm{wt} \%)$ & 8.9562 & 8.9344 & 8.6820 & 0.2742 & 0.2524 & $3.2 \%$ & $2.9 \%$ \\
\hline 53 & $\mathrm{~B} 2 \mathrm{O} 3(\mathrm{wt} \%)$ & 5.0391 & 5.0894 & 5.2000 & -0.1609 & -0.1106 & $-3.1 \%$ & $-2.1 \%$ \\
\hline 53 & $\mathrm{BaO}(\mathrm{wt} \%)$ & 0.0413 & 0.0414 & 0.0440 & -0.0027 & -0.0026 & $-6.1 \%$ & $-5.9 \%$ \\
\hline 53 & $\mathrm{CaO}\left(\mathrm{wt}^{\circ} \%\right)$ & 0.7713 & 0.7660 & 0.8360 & -0.0647 & -0.0700 & $-7.7 \%$ & $-8.4 \%$ \\
\hline 53 & $\mathrm{Ce} 2 \mathrm{O} 3(\mathrm{wt} \%)$ & 0.0384 & 0.0384 & 0.0520 & -0.0136 & -0.0136 & $-26.2 \%$ & $-26.2 \%$ \\
\hline 53 & $\mathrm{Cr} 2 \mathrm{O} 3(\mathrm{wt} \%)$ & 0.0720 & 0.0855 & 0.0740 & -0.0020 & 0.0115 & $-2.7 \%$ & $15.5 \%$ \\
\hline 53 & $\mathrm{CuO}\left(\mathrm{wt}^{\circ} \%\right)$ & 0.0319 & 0.0306 & 0.0210 & 0.0109 & 0.0096 & $52.0 \%$ & $45.5 \%$ \\
\hline 53 & $\mathrm{Fe} 2 \mathrm{O} 3(\mathrm{wt} \%)$ & 9.3252 & 9.0075 & 9.2980 & 0.0272 & -0.2905 & $0.3 \%$ & $-3.1 \%$ \\
\hline 53 & $\mathrm{~K} 2 \mathrm{O}(\mathrm{wt} \%)$ & 0.1244 & 0.1173 & 0.1200 & 0.0044 & -0.0027 & $3.6 \%$ & $-2.2 \%$ \\
\hline 53 & La2O3 (wt $\%)$ & 0.0346 & 0.0346 & 0.0380 & -0.0034 & -0.0034 & $-9.0 \%$ & $-9.0 \%$ \\
\hline 53 & Li2O (wt\%) & 6.9646 & 7.0817 & 7.1500 & -0.1854 & -0.0683 & $-2.6 \%$ & $-1.0 \%$ \\
\hline 53 & $\mathrm{MgO}\left(\mathrm{wt}^{\circ} \%\right)$ & 0.8490 & 0.8542 & 0.8730 & -0.0240 & -0.0188 & $-2.7 \%$ & $-2.2 \%$ \\
\hline 53 & $\mathrm{MnO}(\mathrm{wt} \%)$ & 1.9207 & 1.9401 & 1.9180 & 0.0027 & 0.0221 & $0.1 \%$ & $1.2 \%$ \\
\hline 53 & $\mathrm{Na} 2 \mathrm{O}(\mathrm{wt} \%)$ & 10.9896 & 11.1491 & 10.9780 & 0.0116 & 0.1711 & $0.1 \%$ & $1.6 \%$ \\
\hline 53 & $\mathrm{NiO}\left(\mathrm{wt}^{2} \%\right)$ & 0.5230 & 0.5432 & 0.5520 & -0.0290 & -0.0088 & $-5.3 \%$ & $-1.6 \%$ \\
\hline 53 & $\mathrm{PbO}(\mathrm{wt} \%)$ & 0.0296 & 0.0296 & 0.0320 & -0.0024 & -0.0024 & $-7.4 \%$ & $-7.4 \%$ \\
\hline 53 & SO4 (wt $\%)$ & 0.4382 & 0.4382 & 0.4680 & -0.0298 & -0.0298 & $-6.4 \%$ & $-6.4 \%$ \\
\hline 53 & $\mathrm{SiO} 2\left(\mathrm{wt}^{0} \%\right)$ & 49.6318 & 50.2242 & 50.8400 & -1.2082 & -0.6158 & $-2.4 \%$ & $-1.2 \%$ \\
\hline 53 & ThO2 $(\mathrm{wt} \%)$ & 0.0839 & 0.0839 & 0.0230 & 0.0609 & 0.0609 & $264.9 \%$ & $264.9 \%$ \\
\hline 53 & $\mathrm{TiO} 2(\mathrm{wt} \%)$ & 0.0154 & 0.0153 & 0.0090 & 0.0064 & 0.0063 & $71.4 \%$ & $69.5 \%$ \\
\hline 53 & U3O8 (wt\%) & 2.5235 & 2.6676 & 2.6740 & -0.1505 & -0.0064 & $-5.6 \%$ & $-0.2 \%$ \\
\hline 53 & $\mathrm{ZnO}(\mathrm{wt} \%)$ & 0.0361 & 0.0361 & 0.0340 & 0.0021 & 0.0021 & $6.2 \%$ & $6.2 \%$ \\
\hline 53 & $\mathrm{ZrO} 2(\mathrm{wt} \%)$ & 0.0807 & 0.0807 & 0.0830 & -0.0023 & -0.0023 & $-2.8 \%$ & $-2.8 \%$ \\
\hline 53 & Sum $(w t \%)$ & 98.5205 & 99.2889 & 99.9990 & -1.4785 & -0.7101 & $-1.5 \%$ & $-0.7 \%$ \\
\hline 54 & $\mathrm{Al} 2 \mathrm{O} 3(\mathrm{wt} \%)$ & 10.2175 & 10.2168 & 9.9220 & 0.2955 & 0.2948 & $3.0 \%$ & $3.0 \%$ \\
\hline 54 & $\mathrm{~B} 2 \mathrm{O} 3(\mathrm{wt} \%)$ & 4.8299 & 4.7552 & 4.8000 & 0.0299 & -0.0448 & $0.6 \%$ & $-0.9 \%$ \\
\hline 54 & $\mathrm{BaO}(\mathrm{wt} \%)$ & 0.0505 & 0.0574 & 0.0500 & 0.0005 & 0.0074 & $1.0 \%$ & $14.8 \%$ \\
\hline 54 & $\mathrm{CaO}\left(\mathrm{wt}^{\circ} \%\right)$ & 0.8528 & 0.8927 & 0.9550 & -0.1022 & -0.0623 & $-10.7 \%$ & $-6.5 \%$ \\
\hline 54 & $\mathrm{Ce} 2 \mathrm{O} 3(\mathrm{wt} \%)$ & 0.0141 & 0.0141 & 0.0600 & -0.0459 & -0.0459 & $-76.6 \%$ & $-76.6 \%$ \\
\hline 54 & $\mathrm{Cr} 2 \mathrm{O} 3(\mathrm{wt} \%)$ & 0.0749 & 0.1068 & 0.0850 & -0.0101 & 0.0218 & $-11.9 \%$ & $25.7 \%$ \\
\hline 54 & $\mathrm{CuO}(\mathrm{wt} \%)$ & 0.0329 & 0.0341 & 0.0240 & 0.0089 & 0.0101 & $36.9 \%$ & $42.0 \%$ \\
\hline 54 & $\mathrm{Fe} 2 \mathrm{O} 3(\mathrm{wt} \%)$ & 10.7513 & 10.5930 & 10.6260 & 0.1253 & -0.0330 & $1.2 \%$ & $-0.3 \%$ \\
\hline 54 & $\mathrm{~K} 2 \mathrm{O}(\mathrm{wt} \%)$ & 0.1337 & 0.1246 & 0.1380 & -0.0043 & -0.0134 & $-3.1 \%$ & $-9.7 \%$ \\
\hline 54 & La2O3 (wt $\%)$ & 0.0390 & 0.0390 & 0.0430 & -0.0040 & -0.0040 & $-9.3 \%$ & $-9.3 \%$ \\
\hline 54 & $\mathrm{Li} 2 \mathrm{O}(\mathrm{wt} \%)$ & 6.4156 & 6.5449 & 6.6000 & -0.1844 & -0.0551 & $-2.8 \%$ & $-0.8 \%$ \\
\hline 54 & $\mathrm{MgO}\left(\mathrm{wt}^{\circ} \%\right)$ & 0.9788 & 0.9930 & 0.9980 & -0.0192 & -0.0050 & $-1.9 \%$ & $-0.5 \%$ \\
\hline 54 & $\mathrm{MnO}\left(\mathrm{wt}^{\circ} \%\right)$ & 2.2564 & 2.2616 & 2.1920 & 0.0644 & 0.0696 & $2.9 \%$ & $3.2 \%$ \\
\hline 54 & $\mathrm{Na} 2 \mathrm{O}(\mathrm{wt} \%)$ & 11.9905 & 11.6844 & 11.8320 & 0.1585 & -0.1476 & $1.3 \%$ & $-1.2 \%$ \\
\hline 54 & $\mathrm{NiO}(\mathrm{wt} \%)$ & 0.5774 & 0.6197 & 0.6310 & -0.0536 & -0.0113 & $-8.5 \%$ & $-1.8 \%$ \\
\hline 54 & $\mathrm{PbO}(\mathrm{wt} \%)$ & 0.0366 & 0.0366 & 0.0360 & 0.0006 & 0.0006 & $1.7 \%$ & $1.7 \%$ \\
\hline 54 & $\mathrm{SO} 4(\mathrm{wt} \%)$ & 0.5205 & 0.5205 & 0.5350 & -0.0145 & -0.0145 & $-2.7 \%$ & $-2.7 \%$ \\
\hline 54 & $\mathrm{SiO} 2\left(\mathrm{wt}^{\circ} \%\right)$ & 46.6367 & 47.6709 & 47.2450 & -0.6083 & 0.4259 & $-1.3 \%$ & $0.9 \%$ \\
\hline 54 & ThO2 (wt $\%)$ & 0.0942 & 0.0942 & 0.0260 & 0.0682 & 0.0682 & $262.2 \%$ & $262.2 \%$ \\
\hline 54 & $\mathrm{TiO} 2(\mathrm{wt} \%)$ & 0.0142 & 0.0153 & 0.0110 & 0.0032 & 0.0043 & $28.9 \%$ & $38.9 \%$ \\
\hline 54 & U3O8 (wt\%) & 2.9686 & 3.1549 & 3.0560 & -0.0874 & 0.0989 & $-2.9 \%$ & $3.2 \%$ \\
\hline 54 & $\mathrm{ZnO}(\mathrm{wt} \%)$ & 0.0411 & 0.0411 & 0.0390 & 0.0021 & 0.0021 & $5.3 \%$ & $5.3 \%$ \\
\hline 54 & $\mathrm{ZrO} 2(\mathrm{wt} \%)$ & 0.0878 & 0.0878 & 0.0950 & -0.0072 & -0.0072 & $-7.6 \%$ & $-7.6 \%$ \\
\hline 54 & Sum $(w t \%)$ & 99.6150 & 100.5584 & 99.9990 & -0.3840 & 0.5594 & $-0.4 \%$ & $0.6 \%$ \\
\hline 55 & $\mathrm{~A} 12 \mathrm{O} 3(\mathrm{wt} \%)$ & 12.0928 & 12.0578 & 11.9070 & 0.1858 & 0.1508 & $1.6 \%$ & $1.3 \%$ \\
\hline 55 & $\mathrm{~B} 2 \mathrm{O} 3(\mathrm{wt} \%)$ & 3.8961 & 3.9272 & 4.1600 & -0.2639 & -0.2328 & $-6.3 \%$ & $-5.6 \%$ \\
\hline 55 & $\mathrm{BaO}(\mathrm{wt} \%)$ & 0.0558 & 0.0635 & 0.0610 & -0.0052 & 0.0025 & $-8.5 \%$ & $4.0 \%$ \\
\hline 55 & $\mathrm{CaO}\left(\mathrm{wt}^{\circ} \%\right)$ & 1.0274 & 1.0754 & 1.1460 & -0.1186 & -0.0706 & $-10.4 \%$ & $-6.2 \%$ \\
\hline 55 & $\mathrm{Ce} 2 \mathrm{O} 3(\mathrm{wt} \%)$ & 0.0305 & 0.0305 & 0.0720 & -0.0415 & -0.0415 & $-57.7 \%$ & $-57.7 \%$ \\
\hline 55 & $\mathrm{Cr} 2 \mathrm{O} 3(\mathrm{wt} \%)$ & 0.0892 & 0.1274 & 0.1020 & -0.0128 & 0.0254 & $-12.6 \%$ & $24.9 \%$ \\
\hline 55 & $\mathrm{CuO}(\mathrm{wt} \%)$ & 0.0366 & 0.0380 & 0.0290 & 0.0076 & 0.0090 & $26.3 \%$ & $31.0 \%$ \\
\hline 55 & $\mathrm{Fe} 2 \mathrm{O} 3(\mathrm{wt} \%)$ & 12.5099 & 12.0834 & 12.7510 & -0.2411 & -0.6676 & $-1.9 \%$ & $-5.2 \%$ \\
\hline 55 & $\mathrm{~K} 2 \mathrm{O}(\mathrm{wt} \%)$ & 0.1659 & 0.1546 & 0.1650 & 0.0009 & -0.0104 & $0.6 \%$ & $-6.3 \%$ \\
\hline 55 & La2O3 (wt $\%)$ & 0.0472 & 0.0472 & 0.0520 & -0.0048 & -0.0048 & $-9.2 \%$ & $-9.2 \%$ \\
\hline
\end{tabular}


Table D4. Average Measured and Bias-Corrected Chemical Compositions Versus Targeted Compositions by Oxide by Nepheline Study Glass (continued)

(100 -Batch 1; 200 -U std)

\begin{tabular}{|c|c|c|c|c|c|c|c|c|}
\hline Glass \# & Oxide & $\begin{array}{c}\text { Measured } \\
(\mathrm{wt} \%)\end{array}$ & $\begin{array}{c}\text { Measured-bc } \\
(w \mathrm{t} \%)\end{array}$ & $\begin{array}{c}\text { Targeted } \\
(\mathbf{w t} \%)\end{array}$ & $\begin{array}{c}\text { Diff of } \\
\text { Measured }\end{array}$ & $\begin{array}{c}\text { Diff of } \\
\text { Meas-bc }\end{array}$ & $\begin{array}{l}\text { \% Diff of } \\
\text { Measured }\end{array}$ & $\begin{array}{l}\text { \% Diff of } \\
\text { Meas-bc }\end{array}$ \\
\hline 55 & $\mathrm{Li} 2 \mathrm{O}(\mathrm{wt} \%)$ & 5.4791 & 5.5711 & 5.7200 & -0.2409 & -0.1489 & $-4.2 \%$ & $-2.6 \%$ \\
\hline 55 & $\mathrm{MgO}\left(\mathrm{wt}^{\circ} \%\right)$ & 1.1401 & 1.1566 & 1.1980 & -0.0579 & -0.0414 & $-4.8 \%$ & $-3.5 \%$ \\
\hline 55 & $\mathrm{MnO}(\mathrm{wt} \%)$ & 2.6631 & 2.6684 & 2.6300 & 0.0331 & 0.0384 & $1.3 \%$ & $1.5 \%$ \\
\hline 55 & $\mathrm{Na} 2 \mathrm{O}(\mathrm{wt} \%)$ & 13.4362 & 13.0927 & 13.1980 & 0.2382 & -0.1053 & $1.8 \%$ & $-0.8 \%$ \\
\hline 55 & $\mathrm{NiO}(\mathrm{wt} \%)$ & 0.6083 & 0.6317 & 0.7570 & -0.1487 & -0.1253 & $-19.6 \%$ & $-16.5 \%$ \\
\hline 55 & $\mathrm{PbO}(\mathrm{wt} \%)$ & 0.0412 & 0.0412 & 0.0430 & -0.0018 & -0.0018 & $-4.2 \%$ & $-4.2 \%$ \\
\hline 55 & $\mathrm{SO} 4\left(\mathrm{wt}^{\circ} \%\right)$ & 0.6314 & 0.6314 & 0.6420 & -0.0106 & -0.0106 & $-1.7 \%$ & $-1.7 \%$ \\
\hline 55 & $\mathrm{SiO} 2(\mathrm{wt} \%)$ & 40.2188 & 40.6968 & 41.4940 & -1.2752 & -0.7972 & $-3.1 \%$ & $-1.9 \%$ \\
\hline 55 & ThO2 (wt $\%)$ & 0.1104 & 0.1104 & 0.0320 & 0.0784 & 0.0784 & $244.9 \%$ & $244.9 \%$ \\
\hline 55 & $\mathrm{TiO} 2(\mathrm{wt} \%)$ & 0.0125 & 0.0135 & 0.0130 & -0.0005 & 0.0005 & $-3.8 \%$ & $3.6 \%$ \\
\hline 55 & U3O8 (wt $\%)$ & 3.5553 & 3.7586 & 3.6670 & -0.1117 & 0.0916 & $-3.0 \%$ & $2.5 \%$ \\
\hline 55 & $\mathrm{ZnO}(\mathrm{wt} \%)$ & 0.0501 & 0.0501 & 0.0470 & 0.0031 & 0.0031 & $6.6 \%$ & $6.6 \%$ \\
\hline 55 & $\mathrm{ZrO} 2(\mathrm{wt} \%)$ & 0.1064 & 0.1064 & 0.1140 & -0.0076 & -0.0076 & $-6.7 \%$ & $-6.7 \%$ \\
\hline 55 & Sum (wt\%) & 98.0041 & 98.1338 & 100.0000 & -1.9959 & -1.8662 & $-2.0 \%$ & $-1.9 \%$ \\
\hline 56 & $\mathrm{~A} 12 \mathrm{O} 3(\mathrm{wt} \%)$ & 12.7352 & 12.7025 & 12.6510 & 0.0842 & 0.0515 & $0.7 \%$ & $0.4 \%$ \\
\hline 56 & $\mathrm{~B} 2 \mathrm{O} 3(\mathrm{wt} \%)$ & 3.6385 & 3.6622 & 3.9200 & -0.2815 & -0.2578 & $-7.2 \%$ & $-6.6 \%$ \\
\hline 56 & $\mathrm{BaO}(\mathrm{wt} \%)$ & 0.0597 & 0.0679 & 0.0640 & -0.0043 & 0.0039 & $-6.7 \%$ & $6.1 \%$ \\
\hline 56 & $\mathrm{CaO}\left(\mathrm{wt}^{\circ} \%\right)$ & 1.0868 & 1.1377 & 1.2180 & -0.1312 & -0.0803 & $-10.8 \%$ & $-6.6 \%$ \\
\hline 56 & $\mathrm{Ce} 2 \mathrm{O} 3(\mathrm{wt} \%)$ & 0.0609 & 0.0609 & 0.0760 & -0.0151 & -0.0151 & $-19.9 \%$ & $-19.9 \%$ \\
\hline 56 & $\mathrm{Cr} 2 \mathrm{O} 3(\mathrm{wt} \%)$ & 0.0892 & 0.1274 & 0.1080 & -0.0188 & 0.0194 & $-17.4 \%$ & $17.9 \%$ \\
\hline 56 & $\mathrm{CuO}(\mathrm{wt} \%)$ & 0.0404 & 0.0419 & 0.0310 & 0.0094 & 0.0109 & $30.2 \%$ & $35.2 \%$ \\
\hline 56 & $\mathrm{Fe} 2 \mathrm{O} 3(\mathrm{wt} \%)$ & 12.6779 & 12.2435 & 13.5480 & -0.8701 & -1.3045 & $-6.4 \%$ & $-9.6 \%$ \\
\hline 56 & $\mathrm{~K} 2 \mathrm{O}(\mathrm{wt} \%)$ & 0.1783 & 0.1661 & 0.1750 & 0.0033 & -0.0089 & $1.9 \%$ & $-5.1 \%$ \\
\hline 56 & $\mathrm{La} 2 \mathrm{O} 3(\mathrm{wt} \%)$ & 0.0466 & 0.0466 & 0.0550 & -0.0084 & -0.0084 & $-15.2 \%$ & $-15.2 \%$ \\
\hline 56 & $\mathrm{Li} 2 \mathrm{O}(\mathrm{wt} \%)$ & 5.2046 & 5.2919 & 5.3900 & -0.1854 & -0.0981 & $-3.4 \%$ & $-1.8 \%$ \\
\hline 56 & $\mathrm{MgO}(\mathrm{wt} \%)$ & 1.1927 & 1.2100 & 1.2730 & -0.0803 & -0.0630 & $-6.3 \%$ & $-5.0 \%$ \\
\hline 56 & $\mathrm{MnO}\left(\mathrm{wt}^{\circ} \%\right)$ & 2.7729 & 2.7792 & 2.7950 & -0.0221 & -0.0158 & $-0.8 \%$ & $-0.6 \%$ \\
\hline 56 & $\mathrm{Na} 2 \mathrm{O}(\mathrm{wt} \%)$ & 14.0192 & 13.6613 & 13.7110 & 0.3082 & -0.0497 & $2.2 \%$ & $-0.4 \%$ \\
\hline 56 & $\mathrm{NiO}(\mathrm{wt} \%)$ & 0.6751 & 0.7010 & 0.8040 & -0.1289 & -0.1030 & $-16.0 \%$ & $-12.8 \%$ \\
\hline 56 & $\mathrm{PbO}(\mathrm{wt} \%)$ & 0.0420 & 0.0420 & 0.0460 & -0.0040 & -0.0040 & $-8.7 \%$ & $-8.7 \%$ \\
\hline 56 & $\mathrm{SO} 4(\mathrm{wt} \%)$ & 0.6786 & 0.6786 & 0.6820 & -0.0034 & -0.0034 & $-0.5 \%$ & $-0.5 \%$ \\
\hline 56 & $\mathrm{SiO} 2(\mathrm{wt} \%)$ & 38.2400 & 38.6940 & 39.3380 & -1.0980 & -0.6440 & $-2.8 \%$ & $-1.6 \%$ \\
\hline 56 & ThO2 (wt $\%)$ & 0.1175 & 0.1175 & 0.0340 & 0.0835 & 0.0835 & $245.6 \%$ & $245.6 \%$ \\
\hline 56 & $\mathrm{TiO} 2(\mathrm{wt} \%)$ & 0.0125 & 0.0135 & 0.0140 & -0.0015 & -0.0005 & $-10.6 \%$ & $-3.8 \%$ \\
\hline 56 & U3O8 (wt\%) & 3.6585 & 3.8677 & 3.8970 & -0.2385 & -0.0293 & $-6.1 \%$ & $-0.8 \%$ \\
\hline 56 & $\mathrm{ZnO}(\mathrm{wt} \%)$ & 0.0526 & 0.0526 & 0.0500 & 0.0026 & 0.0026 & $5.2 \%$ & $5.2 \%$ \\
\hline 56 & $\mathrm{ZrO} 2(\mathrm{wt} \%)$ & 0.1118 & 0.1118 & 0.1210 & -0.0092 & -0.0092 & $-7.6 \%$ & $-7.6 \%$ \\
\hline 56 & Sum $(w t \%)$ & 97.3914 & 97.4777 & 100.0010 & -2.6096 & -2.5233 & $-2.6 \%$ & $-2.5 \%$ \\
\hline 100 & $\mathrm{Al} 2 \mathrm{O} 3(\mathrm{wt} \%)$ & 4.8844 & 4.8770 & 4.8770 & 0.0074 & 0.0000 & $0.2 \%$ & $0.0 \%$ \\
\hline 100 & $\mathrm{~B} 2 \mathrm{O} 3(\mathrm{wt} \%)$ & 7.8002 & 7.7770 & 7.7770 & 0.0232 & 0.0000 & $0.3 \%$ & $0.0 \%$ \\
\hline 100 & $\mathrm{BaO}(\mathrm{wt} \%)$ & 0.1419 & 0.1510 & 0.1510 & -0.0091 & 0.0000 & $-6.0 \%$ & $0.0 \%$ \\
\hline 100 & $\mathrm{CaO}\left(\mathrm{wt}^{\circ} \%\right)$ & 1.1972 & 1.2200 & 1.2200 & -0.0228 & 0.0000 & $-1.9 \%$ & $0.0 \%$ \\
\hline 100 & $\mathrm{Ce} 2 \mathrm{O} 3(\mathrm{wt} \%)$ & 0.0132 & 0.0132 & 0.0000 & 0.0132 & 0.0132 & & \\
\hline 100 & $\mathrm{Cr} 2 \mathrm{O} 3(\mathrm{wt} \%)$ & 0.0834 & 0.1070 & 0.1070 & -0.0236 & 0.0000 & $-22.0 \%$ & $0.0 \%$ \\
\hline 100 & $\mathrm{CuO}(\mathrm{wt} \%)$ & 0.4007 & 0.3990 & 0.3990 & 0.0017 & 0.0000 & $0.4 \%$ & $0.0 \%$ \\
\hline 100 & $\mathrm{Fe} 2 \mathrm{O} 3(\mathrm{wt} \%)$ & 13.1628 & 12.8390 & 12.8390 & 0.3238 & 0.0000 & $2.5 \%$ & $0.0 \%$ \\
\hline 100 & $\mathrm{~K} 2 \mathrm{O}(\mathrm{wt} \%)$ & 3.5496 & 3.3270 & 3.3270 & 0.2226 & 0.0000 & $6.7 \%$ & $0.0 \%$ \\
\hline 100 & $\mathrm{La} 2 \mathrm{O} 3(\mathrm{wt} \%)$ & 0.0059 & 0.0059 & 0.0000 & 0.0059 & 0.0059 & & \\
\hline 100 & $\mathrm{Li} 2 \mathrm{O}(\mathrm{wt} \%)$ & 4.3489 & 4.4290 & 4.4290 & -0.0801 & 0.0000 & $-1.8 \%$ & $0.0 \%$ \\
\hline 100 & $\mathrm{MgO}(\mathrm{wt} \%)$ & 1.4047 & 1.4190 & 1.4190 & -0.0143 & 0.0000 & $-1.0 \%$ & $0.0 \%$ \\
\hline 100 & $\mathrm{MnO}(\mathrm{wt} \%)$ & 1.7151 & 1.7260 & 1.7260 & -0.0109 & 0.0000 & $-0.6 \%$ & $0.0 \%$ \\
\hline 100 & $\mathrm{Na} 2 \mathrm{O}(\mathrm{wt} \%)$ & 9.0563 & 9.0030 & 9.0030 & 0.0533 & 0.0000 & $0.6 \%$ & $0.0 \%$ \\
\hline 100 & $\mathrm{NiO}(\mathrm{wt} \%)$ & 0.7114 & 0.7510 & 0.7510 & -0.0396 & 0.0000 & $-5.3 \%$ & $0.0 \%$ \\
\hline 100 & $\mathrm{PbO}\left(\mathrm{wt}^{\circ} \%\right)$ & 0.0108 & 0.0108 & 0.0000 & 0.0108 & 0.0108 & & \\
\hline 100 & $\mathrm{SO} 4\left(\mathrm{wt}^{\circ} \%\right)$ & 0.1498 & 0.1498 & 0.0000 & 0.1498 & 0.1498 & & \\
\hline 100 & $\mathrm{SiO} 2(\mathrm{wt} \%)$ & 49.3822 & 50.2200 & 50.2200 & -0.8378 & 0.0000 & $-1.7 \%$ & $0.0 \%$ \\
\hline 100 & ThO2 (wt $\%)$ & 0.0057 & 0.0057 & 0.0000 & 0.0057 & 0.0057 & & \\
\hline 100 & $\mathrm{TiO} 2(\mathrm{wt} \%)$ & 0.6547 & 0.6770 & 0.6770 & -0.0223 & 0.0000 & $-3.3 \%$ & $0.0 \%$ \\
\hline
\end{tabular}


WSRC-TR-2006-00093

Revision 0

Table D4. Average Measured and Bias-Corrected Chemical Compositions Versus Targeted Compositions by Oxide by Nepheline Study Glass (continued)

(100-Batch 1; $200-U$ std)

\begin{tabular}{|c|c|c|c|c|c|c|c|c|}
\hline Glass \# & Oxide & $\begin{array}{c}\text { Measured } \\
(w t \%)\end{array}$ & $\begin{array}{l}\text { Measured-bc } \\
(w \mathrm{w} \%)\end{array}$ & $\begin{array}{c}\text { Targeted } \\
(\mathrm{wt} \%)\end{array}$ & $\begin{array}{c}\text { Diff of } \\
\text { Measured }\end{array}$ & $\begin{array}{c}\text { Diff of } \\
\text { Meas-bc }\end{array}$ & $\begin{array}{l}\text { \% Diff of } \\
\text { Measured }\end{array}$ & $\begin{array}{l}\text { \% Diff of } \\
\text { Meas-bc }\end{array}$ \\
\hline 100 & U3O8 (wt\%) & 0.0590 & 0.0625 & 0.0000 & 0.0590 & 0.0625 & & \\
\hline 100 & $\mathrm{ZnO}(\mathrm{wt} \%)$ & 0.0062 & 0.0062 & 0.0000 & 0.0062 & 0.0062 & & \\
\hline 100 & $\mathrm{ZrO} 2(\mathrm{wt} \%)$ & 0.0523 & 0.0523 & 0.0980 & -0.0457 & -0.0457 & $-46.6 \%$ & $-46.6 \%$ \\
\hline 100 & $\begin{array}{c}\text { Sum of Oxides } \\
(\mathrm{wt} \%)\end{array}$ & 98.7963 & 99.2284 & 99.0200 & -0.2237 & 0.2084 & $-0.2 \%$ & $0.2 \%$ \\
\hline 200 & $\mathrm{Al} 2 \mathrm{O} 3(\mathrm{wt} \%)$ & 4.0766 & 4.0712 & 4.1000 & -0.0234 & -0.0288 & $-0.6 \%$ & $-0.7 \%$ \\
\hline 200 & $\mathrm{~B} 2 \mathrm{O} 3(\mathrm{wt} \%)$ & 9.1391 & 9.1216 & 9.2090 & -0.0699 & -0.0874 & $-0.8 \%$ & $-0.9 \%$ \\
\hline 200 & $\mathrm{BaO}(\mathrm{wt} \%)$ & 0.0056 & 0.0060 & 0.0000 & 0.0056 & 0.0060 & & \\
\hline 200 & $\mathrm{CaO}(\mathrm{wt} \%)$ & 1.2838 & 1.3085 & 1.3010 & -0.0172 & 0.0075 & $-1.3 \%$ & $0.6 \%$ \\
\hline 200 & $\mathrm{Ce} 2 \mathrm{O} 3(\mathrm{wt} \%)$ & 0.0093 & 0.0093 & 0.0000 & 0.0093 & 0.0093 & & \\
\hline 200 & $\mathrm{Cr} 2 \mathrm{O} 3(\mathrm{wt} \%)$ & 0.2237 & 0.2905 & 0.0000 & 0.2237 & 0.2905 & & \\
\hline 200 & $\mathrm{CuO}(\mathrm{wt} \%)$ & 0.0260 & 0.0253 & 0.0000 & 0.0260 & 0.0253 & & \\
\hline 200 & $\mathrm{Fe} 2 \mathrm{O} 3(\mathrm{wt} \%)$ & 13.0162 & 12.6971 & 13.1960 & -0.1798 & -0.4989 & $-1.4 \%$ & $-3.8 \%$ \\
\hline 200 & $\mathrm{~K} 2 \mathrm{O}(\mathrm{wt} \%)$ & 3.1972 & 2.9970 & 2.9990 & 0.1982 & -0.0020 & $6.6 \%$ & $-0.1 \%$ \\
\hline 200 & $\mathrm{La} 2 \mathrm{O} 3(\mathrm{wt} \%)$ & 0.0059 & 0.0059 & 0.0000 & 0.0059 & 0.0059 & & \\
\hline 200 & $\mathrm{Li} 2 \mathrm{O}(\mathrm{wt} \%)$ & 3.0266 & 3.0824 & 3.0570 & -0.0304 & 0.0254 & $-1.0 \%$ & $0.8 \%$ \\
\hline 200 & $\mathrm{MgO}\left(\mathrm{wt}^{2} \%\right)$ & 1.1661 & 1.1779 & 1.2100 & -0.0439 & -0.0321 & $-3.6 \%$ & $-2.7 \%$ \\
\hline 200 & $\mathrm{MnO}\left(\mathrm{wt}^{\circ} \%\right)$ & 2.8008 & 2.8183 & 2.8920 & -0.0912 & -0.0737 & $-3.2 \%$ & $-2.5 \%$ \\
\hline 200 & $\mathrm{Na} 2 \mathrm{O}(\mathrm{wt} \%)$ & 11.9691 & 11.9002 & 11.7950 & 0.1741 & 0.1052 & $1.5 \%$ & $0.9 \%$ \\
\hline 200 & $\mathrm{NiO}(\mathrm{wt} \%)$ & 0.9917 & 1.0468 & 1.1200 & -0.1283 & -0.0732 & $-11.5 \%$ & $-6.5 \%$ \\
\hline 200 & $\mathrm{PbO}(\mathrm{wt} \%)$ & 0.0108 & 0.0108 & 0.0000 & 0.0108 & 0.0108 & & \\
\hline 200 & $\mathrm{SO} 4(\mathrm{wt} \%)$ & 0.1498 & 0.1498 & 0.0000 & 0.1498 & 0.1498 & & \\
\hline 200 & $\mathrm{SiO} 2(w \mathrm{t} \%)$ & 43.0356 & 43.7670 & 45.3530 & -2.3174 & -1.5860 & $-5.1 \%$ & $-3.5 \%$ \\
\hline 200 & ThO2 (wt\%) & 0.0495 & 0.0495 & 0.0000 & 0.0495 & 0.0495 & & \\
\hline 200 & $\mathrm{TiO} 2(\mathrm{wt} \%)$ & 0.9503 & 0.9834 & 1.0490 & -0.0987 & -0.0656 & $-9.4 \%$ & $-6.3 \%$ \\
\hline 200 & U3O8 (wt\%) & 2.2700 & 2.4060 & 2.4060 & -0.1360 & 0.0000 & $-5.7 \%$ & $0.0 \%$ \\
\hline 200 & $\mathrm{ZnO}(\mathrm{wt} \%)$ & 0.0062 & 0.0062 & 0.0000 & 0.0062 & 0.0062 & & \\
\hline 200 & $\mathrm{ZrO} 2(\mathrm{wt} \%)$ & 0.0068 & 0.0068 & 0.0000 & 0.0068 & 0.0068 & & \\
\hline 200 & Sum $(w t \%)$ & 97.4166 & 97.9374 & 99.6870 & -2.2704 & -1.7496 & $-2.3 \%$ & $-1.8 \%$ \\
\hline
\end{tabular}




\section{Exhibit D1. Oxide Measurements in Analytical Sequence for Samples Prepared Using the LM Method}
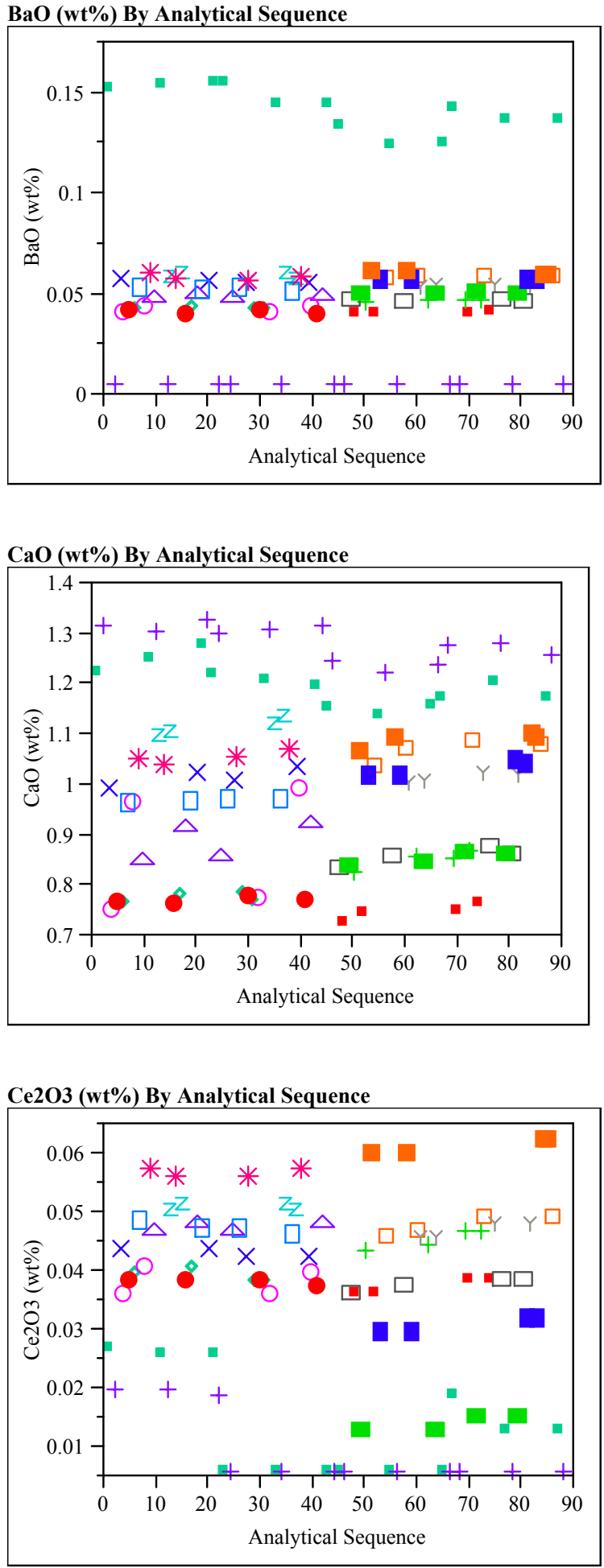

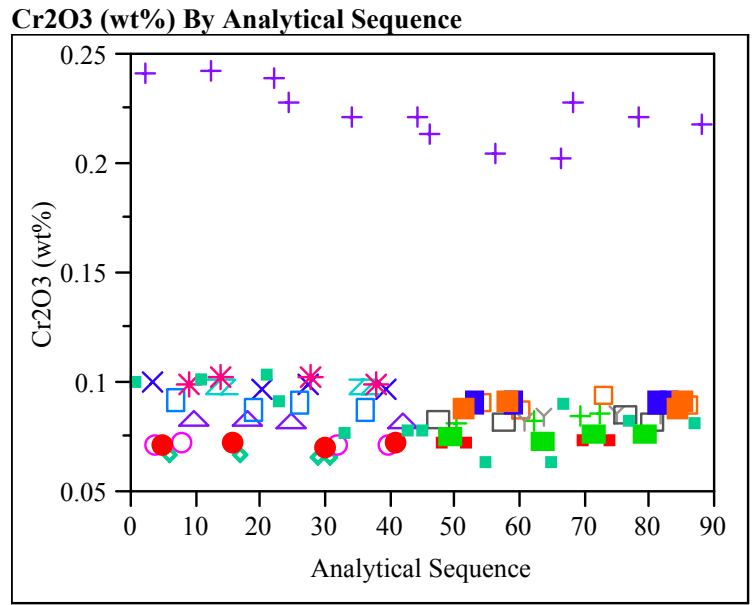

$\mathrm{CuO}(\mathrm{wt} \%)$ By Analytical Sequence

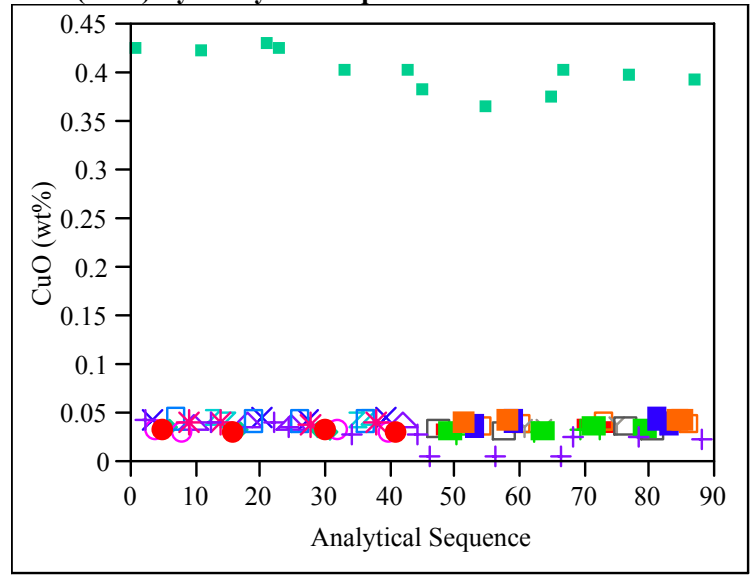

K2O (wt\%) By Analytical Sequence

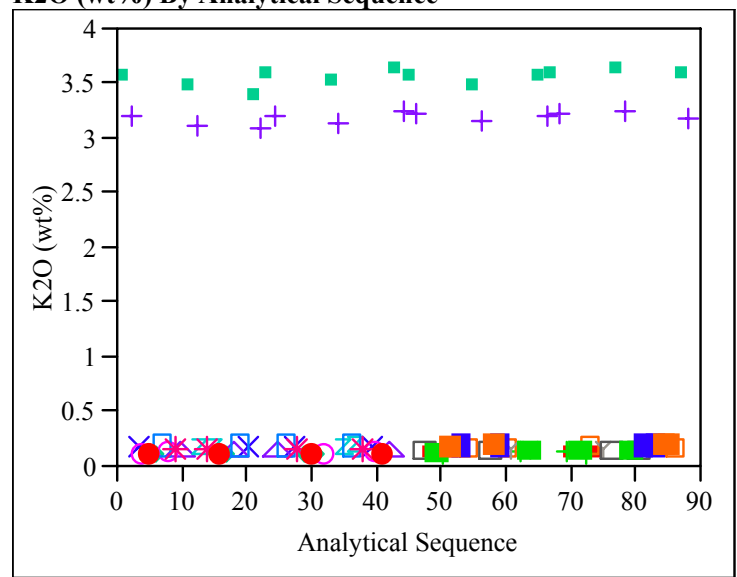




\section{Exhibit D1. Oxide Measurements in Analytical Sequence for Samples Prepared Using the LM Method (continued)}
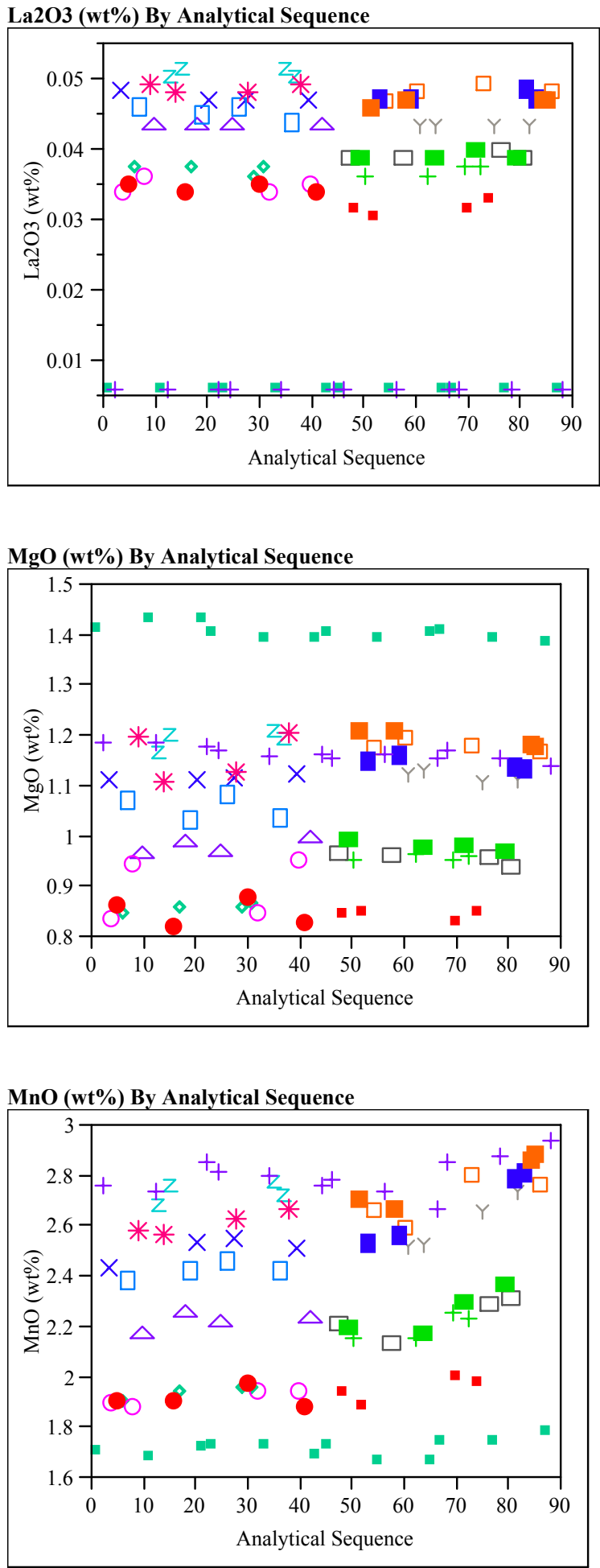

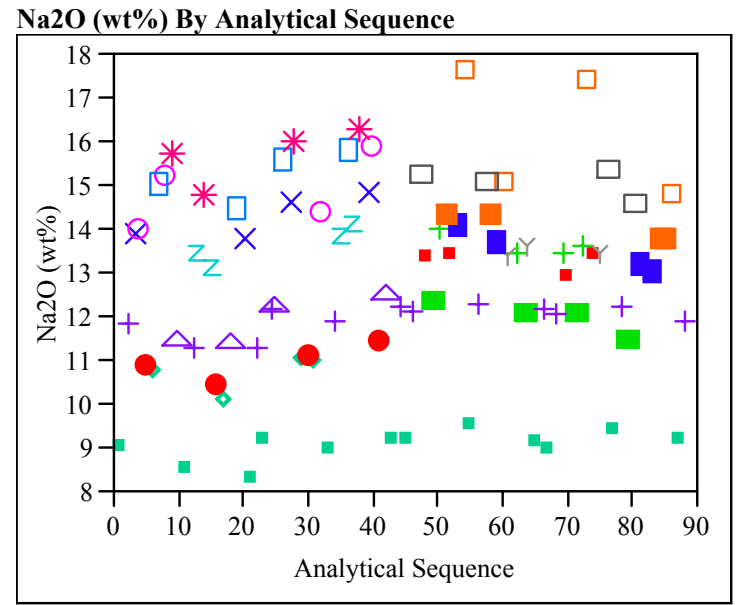

PbO (wt\%) By Analytical Sequence

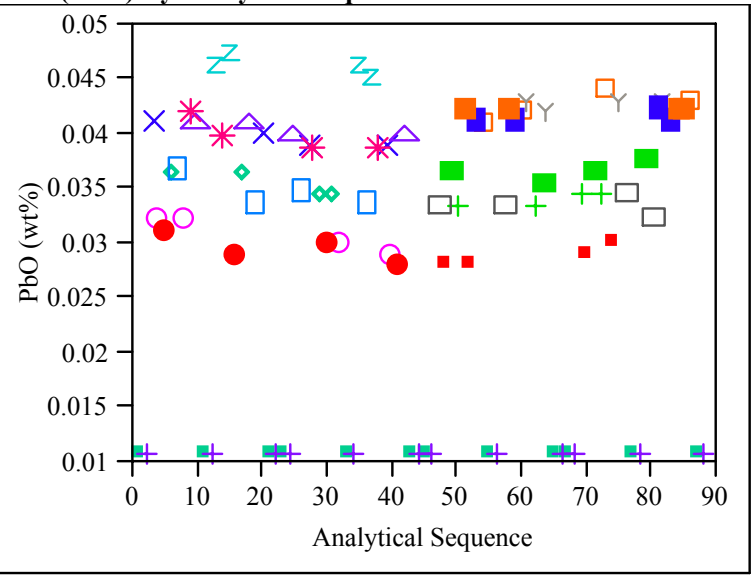

SO4 (wt\%) By Analytical Sequence

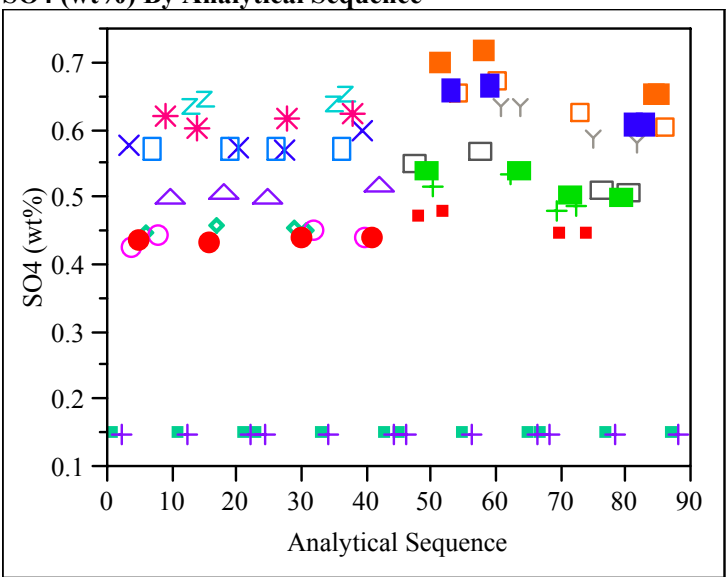




\section{Exhibit D1. Oxide Measurements in Analytical Sequence for Samples Prepared Using the LM Method (continued)}
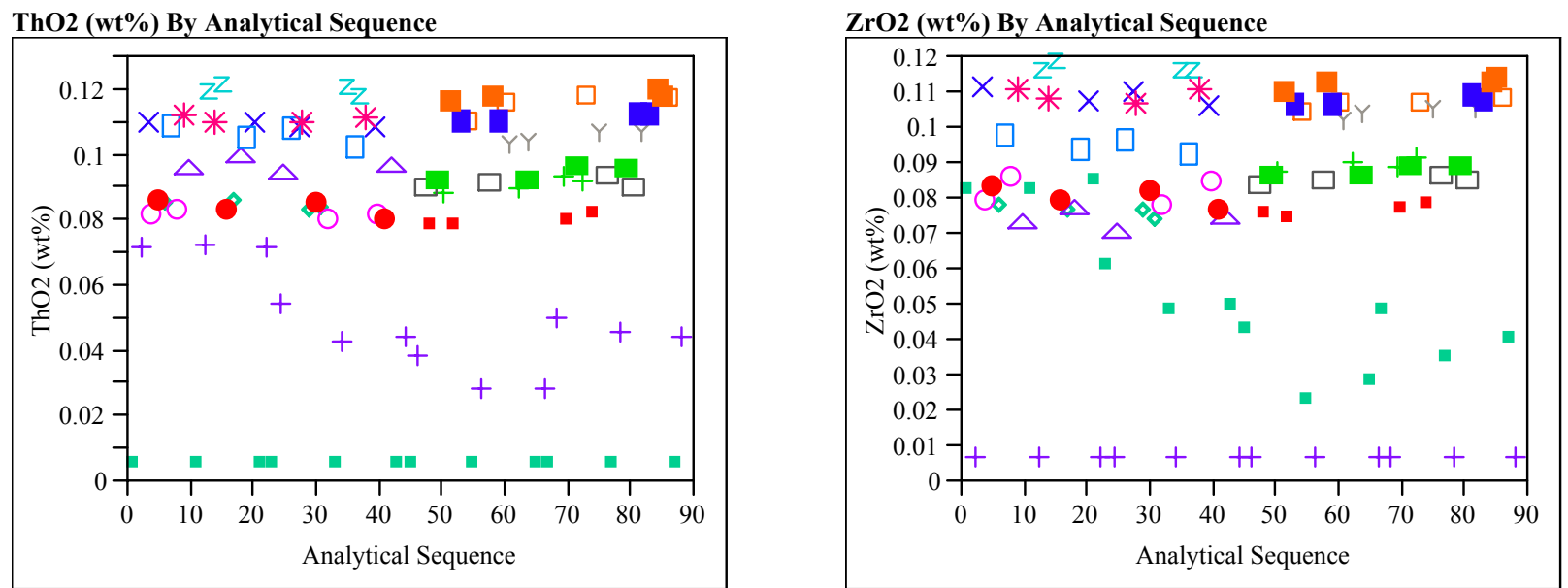

TiO2 (wt\%) By Analytical Sequence

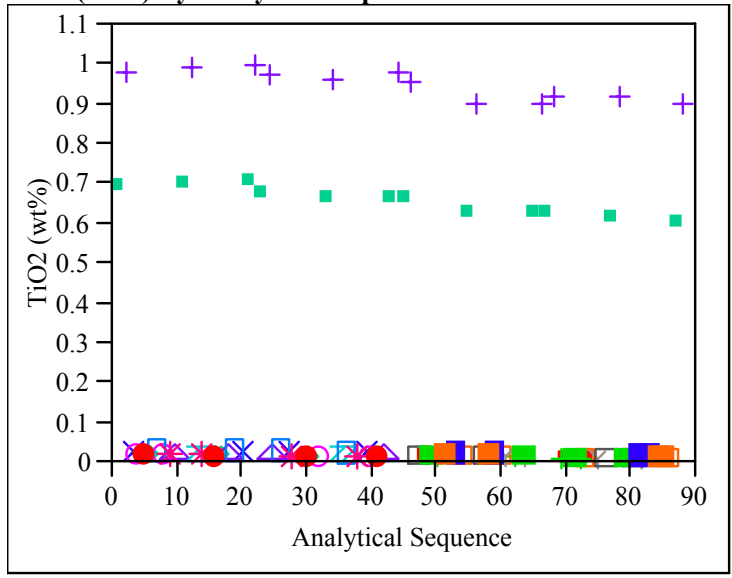

ZnO (wt\%) By Analytical Sequence

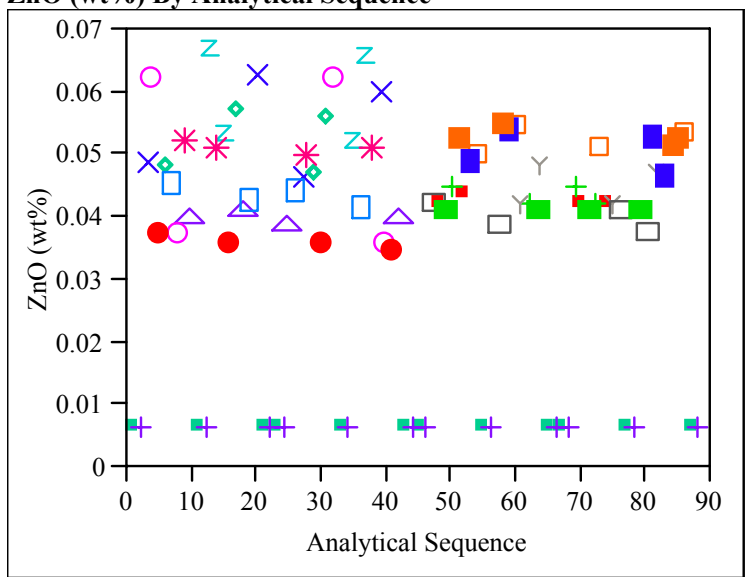




\section{Exhibit D2. Oxide Measurements in Analytical Sequence for Samples Prepared Using the PF Method}

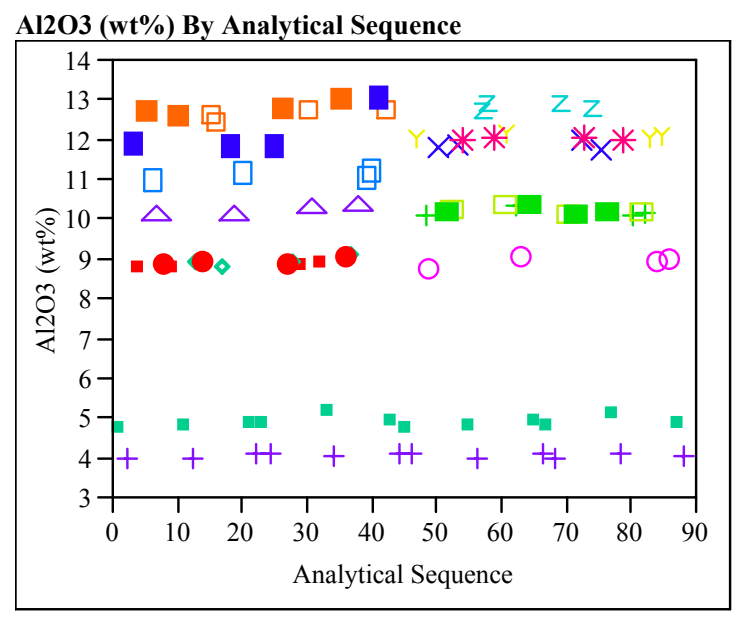

B2O3 (wt\%) By Analytical Sequence

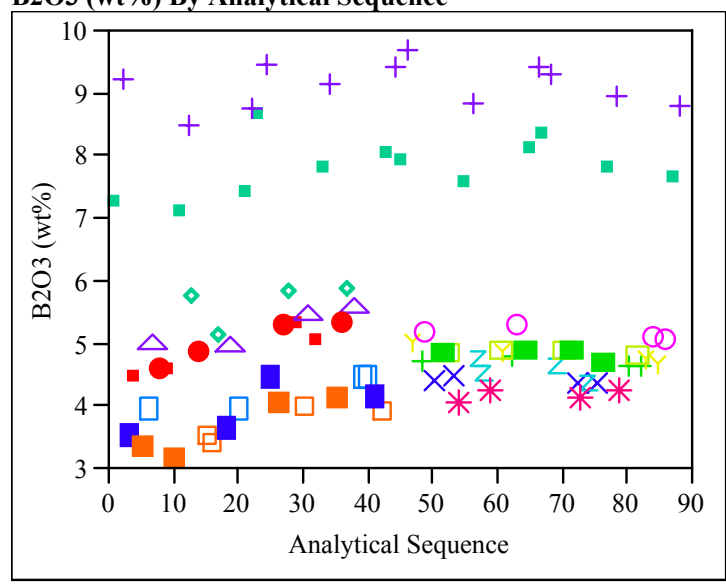

Fe2O3 (wt\%) By Analytical Sequence

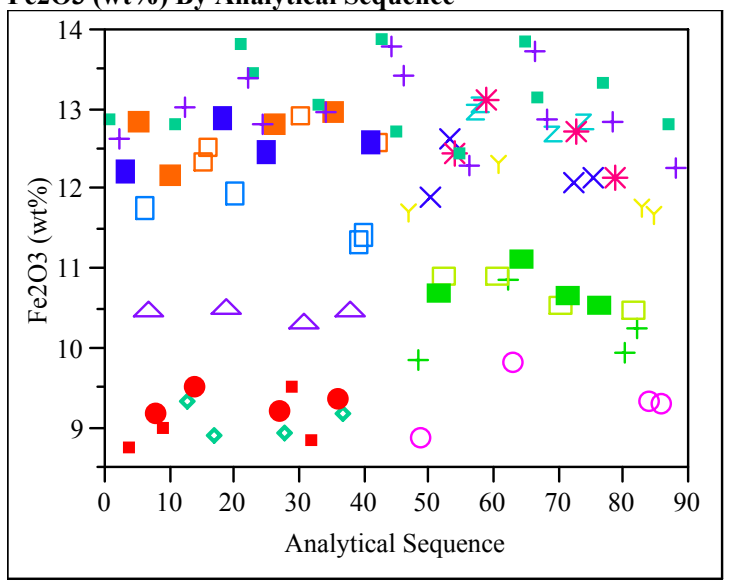

Li2O (wt\%) By Analytical Sequence

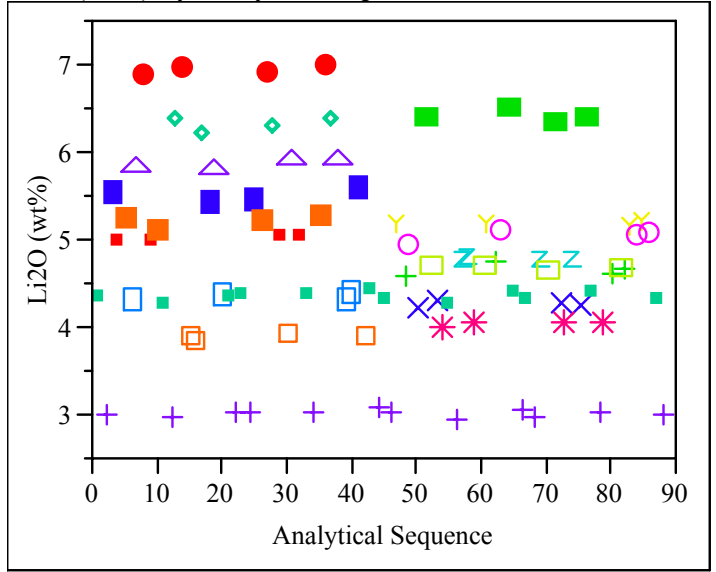

NiO (wt\%) By Analytical Sequence

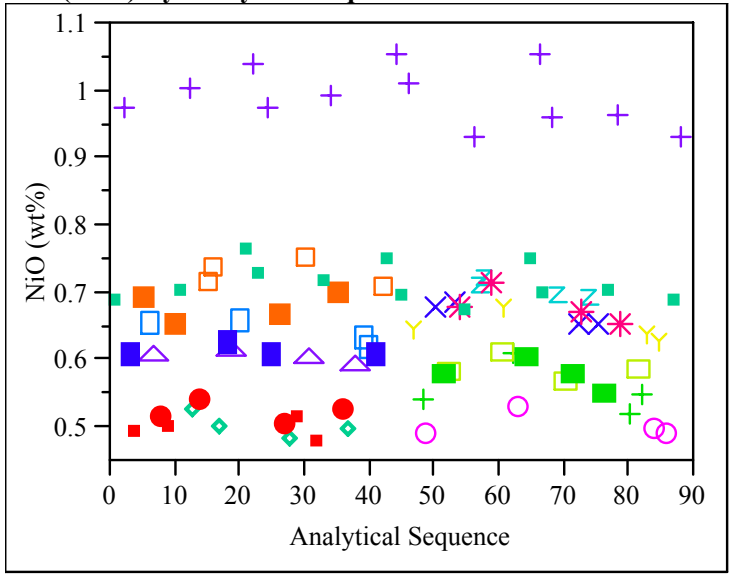

$\mathrm{SiO2}(w \mathrm{t} \%)$ By Analytical Sequence

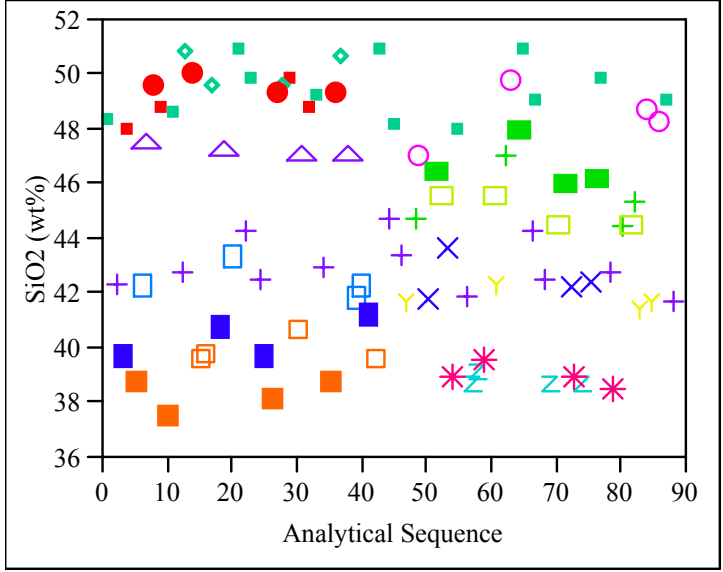


WSRC-TR-2006-00093

Revision 0

\section{Exhibit D2. Oxide Measurements in Analytical Sequence for Samples Prepared Using the PF Method (continued)}

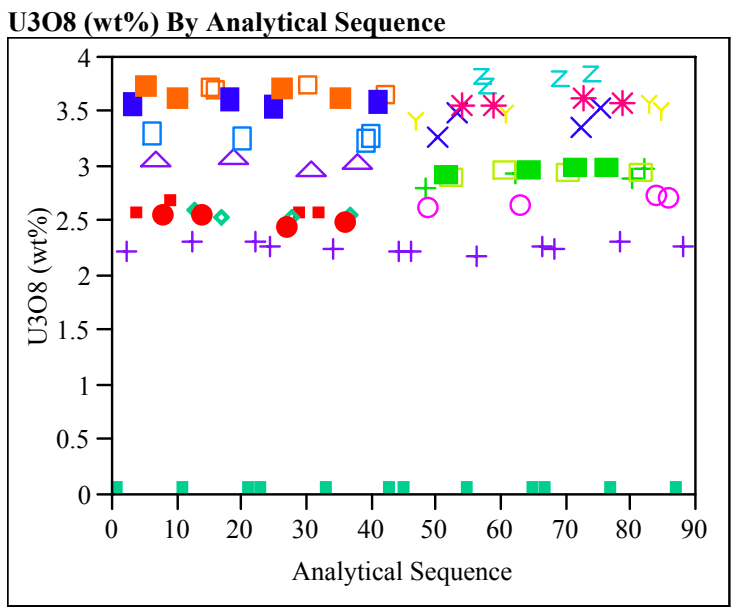




\section{Exhibit D3. PSAL Measurements by Analytical Block for Samples of the Standard Glasses Prepared Using the LM Method}

Glass ID=Batch 1

Oneway Analysis of $\mathrm{BaO}(\mathrm{wt} \%)$ By Block/Sub-Block Reference Value $=0.151 \mathbf{w t} \%$

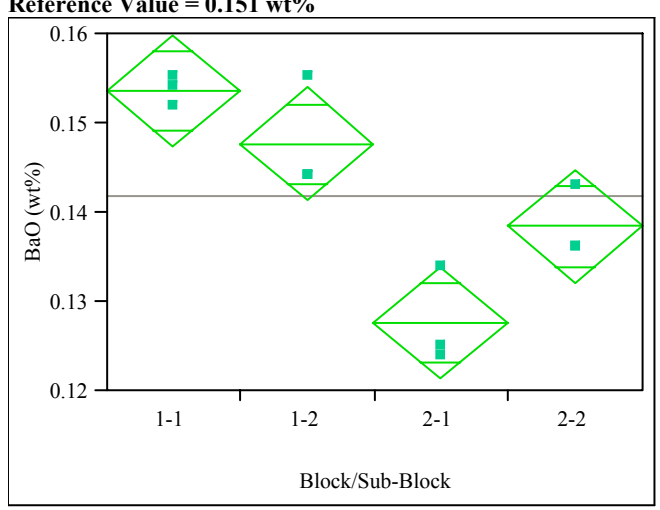

Oneway Anova
Summary of Fit

$\begin{array}{ll}\text { Rsquare } & 0.866533 \\ \text { Adj Rsquare } & 0.816483\end{array}$

Root Mean Square Error $\quad 0.004737$

Mean of Response $\quad 0.141889$

Observations (or Sum Wgts)

Source DF Sum of Squares Mean Square F Ratio Prob $>$ F $\begin{array}{llllll}\text { Block/Sub-Block } & 3 & 0.00116544 & 0.000388 & 17.3133 & 0.0007\end{array}$ $\begin{array}{lll}\text { Error } & 8 & 0.0001795 \\ \text { C. } & 11 & 0.0013495\end{array}$

Error $\begin{array}{rr}8 & 0.00017951 \\ 11 & 0.00134495\end{array}$

Means for Oneway Anova

Level Number Mean Std Error Lower 95\% Upper 95\%

$\begin{array}{llllll}1-1 & 3 & 0.153705 & 0.00273 & 0.14740 & 0.16001\end{array}$

$\begin{array}{llllll}1-2 & 3 & 0.147750 & 0.00273 & 0.14144 & 0.15406\end{array}$

$\begin{array}{llllll}2-1 & 3 & 0.127653 & 0.00273 & 0.12135 & 0.13396\end{array}$

$\begin{array}{llllll}2-2 & 3 & 0.138446 & 0.00273 & 0.13214 & 0.14475\end{array}$

Std Error uses a pooled estimate of error variance
Oneway Analysis of $\mathrm{CaO}(\mathrm{wt} \%)$ By Block/Sub-Block Reference Value $=1.220 \mathrm{wt}^{\circ} \%$

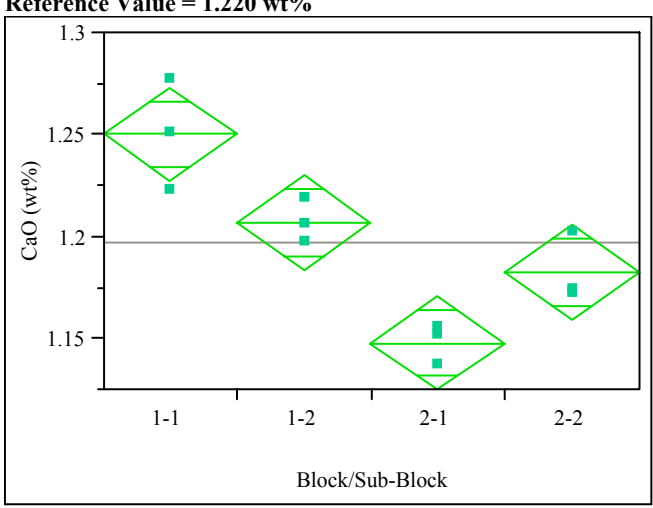

\section{Oneway Anova}

Summary of Fit

Rsquare

$\begin{array}{ll}\text { Adj Rsquare } & 0.823759 \\ \text { Root Mean Square Error } & 0.017476\end{array}$

Mean of Response 1.197249

Observations (or Sum Wgts)

Analysis of Variance

Source DF Sum of Squares Mean Square F Ratio Prob $>$ F Block/Sub-Block $33 \quad 0.01661878$ $\begin{array}{rr}3 & 0.01661878 \\ 8 & 0.00244329\end{array}$

$\begin{array}{lll}\text { C. Total } & 11 & 0.01906206\end{array}$

Means for Oneway Anova

Level Number Mean Std Error Lower 95\% Upper 95\%

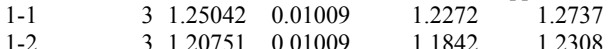

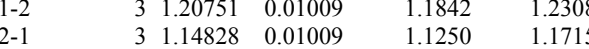

$\begin{array}{llllll}2-2 & 3 & 1.18279 & 0.01009 & 1.1595 & 1.2061\end{array}$

Std Error uses a pooled estimate of error variance
Oneway Analysis of Ce2O3 (wt\%) By Block/Sub-Block

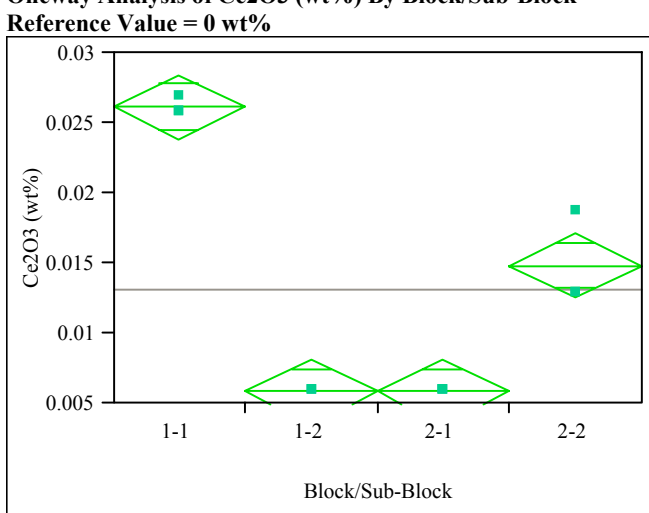

Oneway Anova

Summary of Fit

Adj Rsquare $\quad 0.972322$

Root Mean Square Error $\quad 0.001724$

$\begin{array}{lr}\text { Mean of Response } & 0.013177 \\ \text { Observations (or Sum Wgts) } & 12\end{array}$

Observations (or Sum Wgts)

Analysis of Variance

Source DF Sum of Squares Mean Square F Ratio Prob $>$ F

$\begin{array}{llllllll}\text { Block/Sub-Block } 3 & 0.00083540 & 0.000278 & 93.6795 & <.0001\end{array}$

$\begin{array}{lll}\text { Error } & 8 & 0.00002378\end{array}$

0.000003

C. Total $11 \quad 0$

Level Number Mean Std Error Lower 95\% Upper 95\%

$\begin{array}{llllll}1-1 & 3 & 0.026159 & 0.00100 & 0.02386 & 0.02845\end{array}$

$\begin{array}{llllll}1-2 & 3 & 0.005857 & 0.00100 & 0.00356 & 0.00815\end{array}$

$\begin{array}{llllll}2-1 & 3 & 0.005857 & 0.00100 & 0.00356 & 0.00815\end{array}$

$\begin{array}{llllll}2-2 & 3 & 0.014836 & 0.00100 & 0.01254 & 0.01713\end{array}$ 


\section{Exhibit D3. PSAL Measurements by Analytical Block for Samples of the \\ Standard Glasses Prepared Using the LM Method (continued)}

Oneway Analysis of $\mathrm{Cr} 2 \mathrm{O} 3$ (wt\%) By Block/Sub-Block

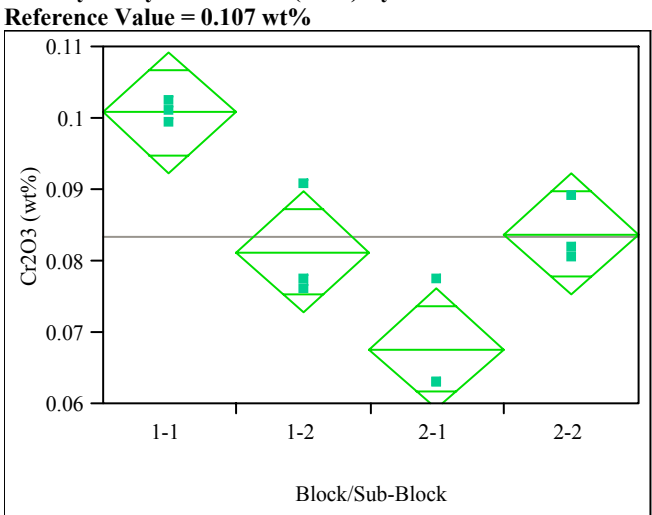

\section{Oneway Anova}

Summary of Fit

Rsquare

Adj Rsquare $\quad 0.838522$

Root Mean Square Error $\quad 0.006329$

Mean of Response $\quad 0.083433$

Observations (or Sum Wgts)

Analysis of Variance

Source DF Sum of Squares Mean Square F Ratio Prob $>$ F $\begin{array}{lllllll}\text { Block/Sub-Block } & 3 & 0.00166398 & 0.000555 & 13.8474 & 0.0016\end{array}$

$\begin{array}{lrr}\text { Error } & 8 & 0.00032044 \\ \text { C. Total } & 11 & 0.00198442\end{array}$

Means for Oneway Anova

Level Number Mean Std Error Lower 95\% Upper 95\%

$\begin{array}{llllll}1-1 & 3 & 0.100850 & 0.00365 & 0.09242 & 0.10928\end{array}$

$\begin{array}{llllll}1-2 & 3 & 0.081362 & 0.00365 & 0.07294 & 0.08979\end{array}$

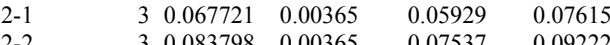

Std Error uses a pooled estimate of error variance
Oneway Analysis of $\mathrm{CuO}(\mathrm{wt} \%)$ By Block/Sub-Block Reference Value $=0.399 \mathbf{w t} \%$

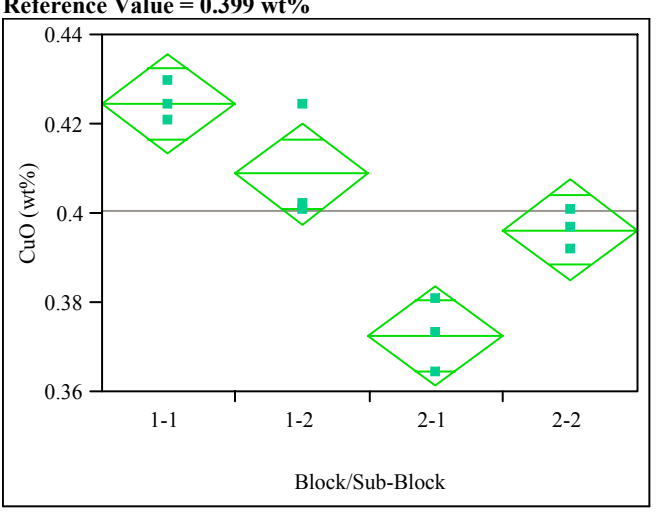

Oneway Anova
Summary of Fit

Rsquare

Adj Rsquare

Mean of Response

Analysis of Variance

Source DF Sum of Squares Mean Square F Ratio Prob $>$ F Block/Sub-Block 330.00436293

$\begin{array}{lrr}\text { Error } & 8 & 0.00056830 \\ \text { C. Total } & 11 & 0.00493123\end{array}$

Means for Oneway Anova

Level Number Mean Std Error Lower 95\% Upper 95\%

$\begin{array}{lllllll}1-1 & & 3 & 0.424777 & 0.00487 & 0.41356 & 0.43600\end{array}$

$\begin{array}{llllll}1-2 & 3 & 0.408921 & 0.00487 & 0.39770 & 0.42014\end{array}$

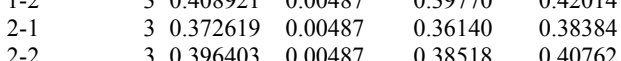

Std Error uses a pooled estimate of error variance
Oneway Analysis of K2O (wt\%) By Block/Sub-Block Reference Value $=3.327 \mathrm{wt} \%$

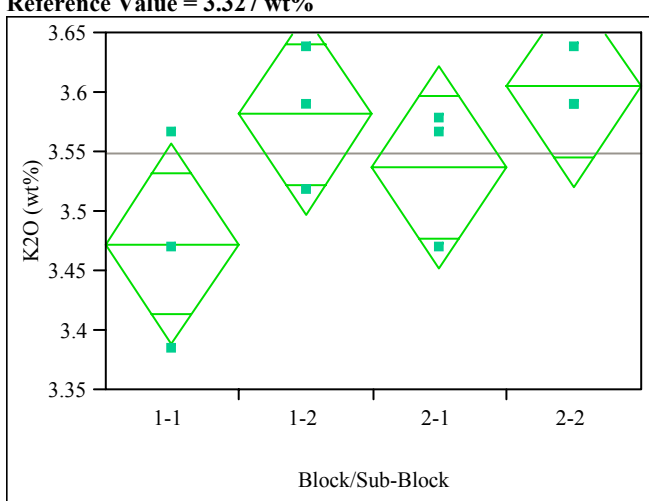

\section{Oneway Anova}

Summary of Fit

$\begin{array}{lr}\text { Rsquare } & 0.485362 \\ \text { Adj Rsquare } & 0.292373 \\ \text { Root Mean Square Error } & 0.063551 \\ \text { Mean of Response } & 3.549555 \\ \text { Obervations (or Sum Wgts) } & 12\end{array}$

Observations (or Sum

Source DF Sum of Squares Mean Square F Ratio Prob $>$ F $\begin{array}{llllll}\text { Block/Sub-Block } & 3 & 0.03047228 & 0.010157 & 2.5150 & 0.1321\end{array}$ $\begin{array}{lrrr}\text { Error } & 8 & 0.03231030 & 0.004039\end{array}$

Means for Oneway Anova

Level Number Mean Std Error Lower 95\% Upper 95\%

$\begin{array}{llllrr}1-1 & 3 & 3.47326 & 0.03669 & 3.3887 & 3.5579\end{array}$

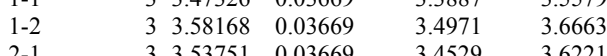

$\begin{array}{llllll}2-1 & 3 & 3.5357 & 0.03669 & 3.4529 & 3.6221 \\ 2-2 & 3.60577 & 0.03669 & 3.5212 & 3.6904\end{array}$

Std Error uses a pooled estimate of error variance 


\section{Exhibit D3. PSAL Measurements by Analytical Block for Samples of the \\ Standard Glasses Prepared Using the LM Method (continued)}

Oneway Analysis of La2O3 (wt\%) By Block/Sub-Block

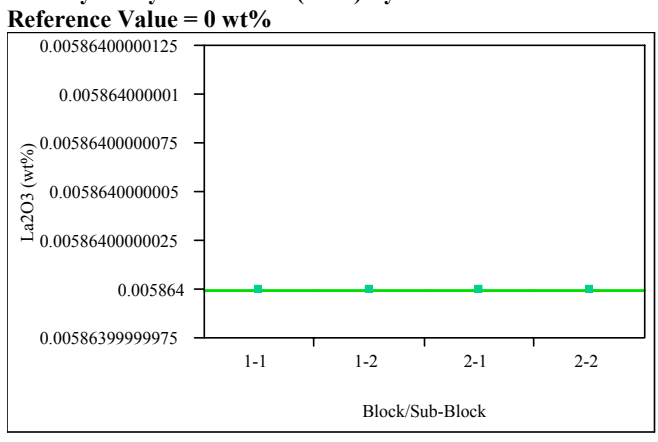

Oneway Anova

Rsquare

Adj Rsquare

Root Mean Square Error $\quad 0$

Mean of Response $\quad 0.005864$

Observations (or Sum

Source $\quad$ DF Sum of Squares Mean Square F Ratio Prob $>$ F Block/Sub-Block

$\begin{array}{rrr}3 & 0 & 0 \\ 8 & 0 & 0\end{array}$

C. Total 11

Means for Oneway Anova

Level Number Mean Std Error Lower 95\% Upper 95\%

$\begin{array}{llllll}1-1 & 3 & 0.005864 & 0 & 0.00586 & 0.00586\end{array}$

$\begin{array}{llllll}1-2 & 3 & 0.005864 & 0 & 0.00586 & 0.00586\end{array}$

$\begin{array}{llllll}2-1 & 3 & 0.005864 & 0 & 0.00586 & 0.00586 \\ 2-2 & 3 & 0.005864 & 0 & 0.00586 & 0.00586\end{array}$

Std Error uses a pooled estimate of error variance
Oneway Analysis of $\mathrm{MgO}(\mathrm{wt} \%)$ By Block/Sub-Block Reference Value $=1.419 \mathrm{wt} \%$

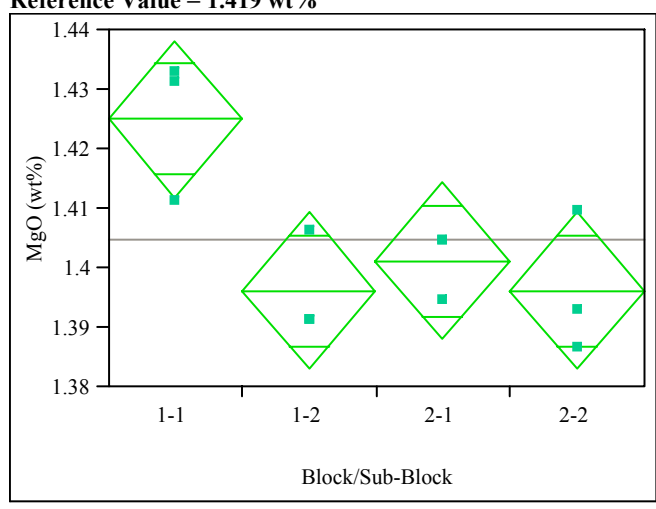

\section{Oneway Anova}

Summary of Fit

Rsquare

$\begin{array}{ll}\text { Rsquare } & 0.683212 \\ \text { Adj Rsquare } & 0.564417 \\ \text { Root Mean Square Error } & 0.009927\end{array}$

Mean of Response

Observations (or Sum Wgts) 1.40478

Analysis of Variance

Source DF Sum of Squares Mean Square F Ratio Prob $>$ F $\begin{array}{lllllll}\text { Block/Sub-Block } & 3 & 0.00170016 & 0.000567 & 5.7512 & 0.0214\end{array}$ $\begin{array}{lll}\text { Error } & 8 & 0.00078832\end{array}$

$\begin{array}{lrr}\text { C. Total } & 11 & 0.00248848\end{array}$

Means for Oneway Anova

Level Number Mean Std Error Lower 95\% Upper 95\%

$\begin{array}{llllll}1-1 & 3 & 1.42503 & 0.00573 & 1.4118 & 1.4382\end{array}$

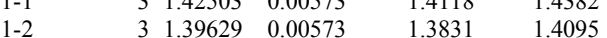

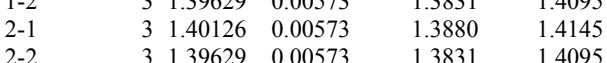

Std Error uses a pooled estimate of error variance
Oneway Analysis of $\mathrm{MnO}$ (wt\%) By Block/Sub-Block Reference Value $=1.726 \mathrm{wt} \%$

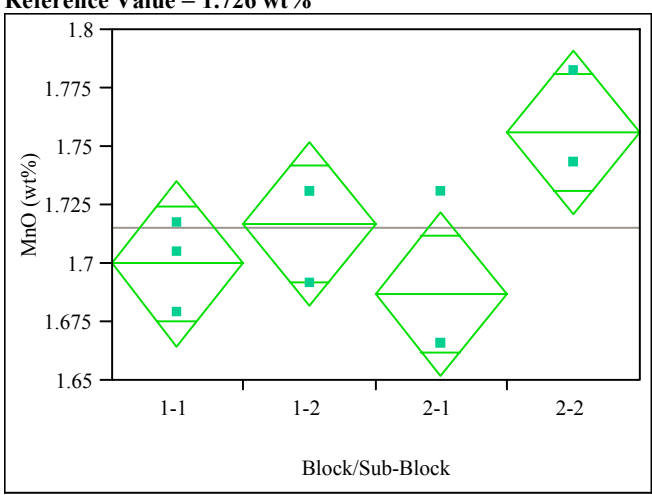

Oneway Anova

Summary of Fit

Adj Rsquare $\quad 0.591837$

Root Mean Square Error $\quad 0.026357$

$\begin{array}{lr}\text { Mean of Response } & 1.715144 \\ 12\end{array}$

Observations (or Sum Wgts)

ares

Sum of Squares Mean Square F Ratio Prob > $\begin{array}{llllll}\text { Block/Sub-Block } 3 & 0.00805812 & 0.002686 & 3.8667 & 0.0560\end{array}$

$\begin{array}{lrr}\text { Error } & 8 & 0.00555732\end{array}$ 0.000695

C. Total

$11 \quad 0.01361545$

Means for Oneway Anova

Level Number Mean Std Error Lower 95\% Upper 95\%

$\begin{array}{llllll}1-1 & 3 & 1.70008 & 0.01522 & 1.6650 & 1.7352\end{array}$

$\begin{array}{llllll}1-2 & 3 & 1.71730 & 0.01522 & 1.6822 & 1.7524\end{array}$

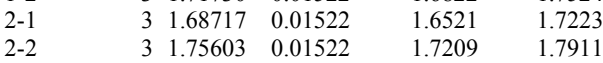

Std Error uses a pooled estimate of error variance 


\section{Exhibit D3. PSAL Measurements by Analytical Block for Samples of the Standard Glasses Prepared Using the LM Method (continued)}

Oneway Analysis of $\mathrm{Na2O}$ (wt\%) By Block/Sub-Block

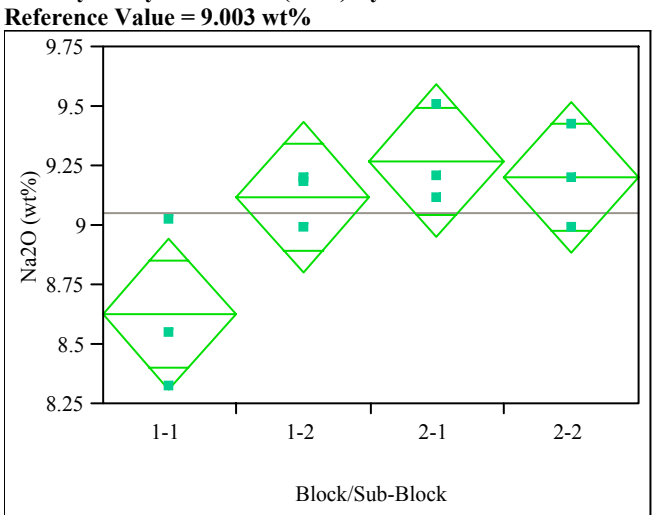

\section{Oneway Anova}

Summary of Fit

Rsquare

Adj Rsquare

Mean of Response

0.488246
0.23912

9.056313

Analysis of Variance

Source DF Sum of Squares Mean Square F Ratio Prob $>$ F $\begin{array}{llllll}\text { Block/Sub-Block } & 3 & 0.7716029 & 0.257201 & 4.4982 & 0.0395\end{array}$ $\begin{array}{lrr}\text { Error } & 8 & 0.4574256 \\ \text { C. Total } & 11 & 12290286\end{array}$

Means for Oneway Anova

Level Number Mean Std Error Lower 95\% Upper 95\%

$\begin{array}{llllll}1-1 & 3 & 8.62720 & 0.13806 & 8.3088 & 8.9456\end{array}$

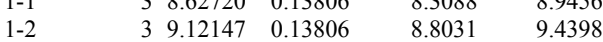

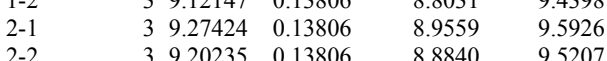

Std Error uses a pooled estimate of error variance
Oneway Analysis of PbO (wt\%) By Block/Sub-Block

Reference Value $=0 \mathrm{wt} \%$

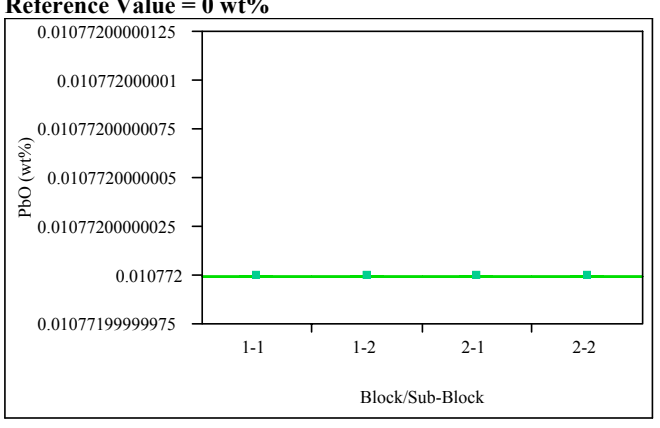

Oneway Anova

Rsquare

Adj Rsquare

Root Mean Square Error $\quad \begin{array}{r}-0.375 \\ \quad 2.12 \mathrm{e}-18\end{array}$

Mean of Response $\quad 0.010772$

Observations (or Sum Wgts)

Analysis of Variance

Source DF Sum of Squares Mean Square F Ratio Prob $>$ F Block/Sub-Block

3 Sum of Squares

$\begin{array}{rrr}0 & 0.0000 \quad 1.0000\end{array}$

C. Total $\begin{array}{rr}8 & 3.6111 \mathrm{e}-35 \\ 11 & 3.6111 \mathrm{e}-35\end{array}$

$4.514 \mathrm{e}-36$

Means for Oneway Anova

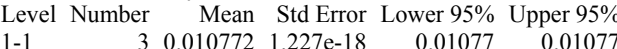

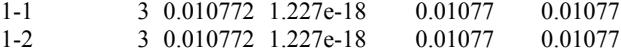

$\begin{array}{llllll}2-1 & 3 & 0.010772 & 1.227 \mathrm{e}-18 & 0.01077 & 0.01077 \\ 2-2 & 3 & 0.010772 & 1.227 \mathrm{e}-18 & 0.01077 & 0.01077\end{array}$

Std Error uses a pooled estimate of error variance
Oneway Analysis of SO4 (wt\%) By Block/Sub-Block Reference Value $=\mathbf{0} \mathbf{w t} \%$

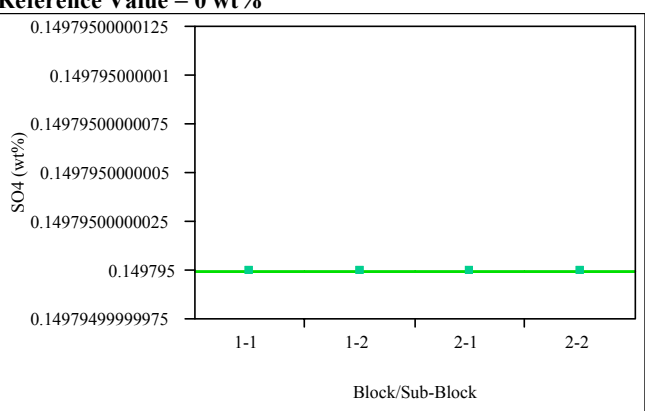

Oneway Anova

Summary of Fit

Rsquare

Root Mean Square Error $\quad 0$

$\begin{array}{lr}\text { Mean of Response } & 0.149795 \\ \text { Observations (or Sum Wgts) } & 12\end{array}$

Observations (or Sum W

Source DF Sum of Squares Mean Square F Ratio Prob > F

Block/Sub-Block

Error

$\begin{array}{ll}0 & 0 \\ 0 & 0\end{array}$

Means for Oneway Anova

Level Number Mean Std Error Lower 95\% Upper 95\%

$\begin{array}{llllll}1-1 & 3 & 0.149795 & 0 & 0.14979 & 0.14979\end{array}$

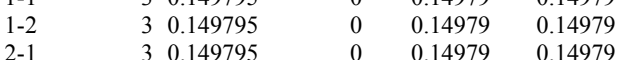

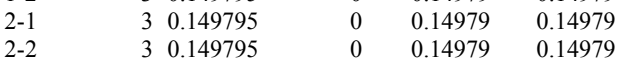

Std Error uses a pooled estimate of error variance 


\section{Exhibit D3. PSAL Measurements by Analytical Block for Samples of the Standard Glasses Prepared Using the LM Method (continued)}

Oneway Analysis of ThO2 (wt\%) By Block/Sub-Block Reference Value $=0 \mathbf{~ w t} \%$

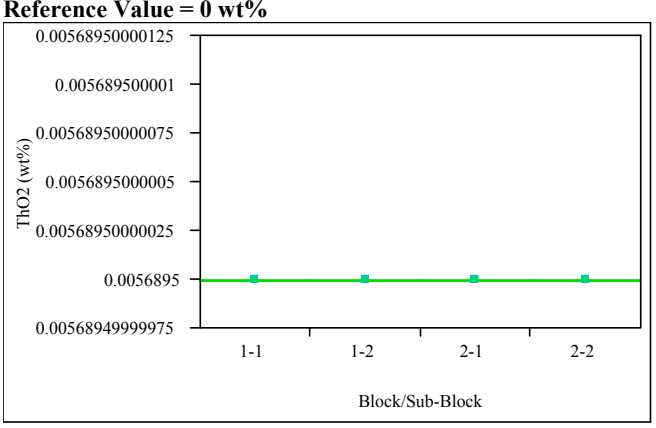

Oneway Anova

Summary of Fit

Rsquare

Adj Rsquare

0
0.005689

Observations (or Sum

Source DF Sum of Squares Mean Square F Ratio Prob > F Block/Sub-Block 3

$\begin{array}{rrr}3 & 0 & 0 \\ 8 & 0 & 0\end{array}$

C. Total 11

Level Number Mean Std Error Lower 95\% Upper 95\%

$\begin{array}{llllll}1-1 & 3 & 0.005689 & 0 & 0.00569 & 0.00569\end{array}$

$\begin{array}{llllll}1-2 & 3 & 0.005689 & 0 & 0.00569 & 0.00569\end{array}$

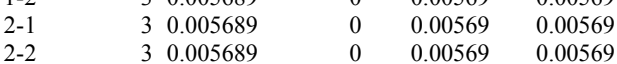

Std Error uses a pooled estimate of error variance
Oneway Analysis of TiO2 (wt\%) By Block/Sub-Block

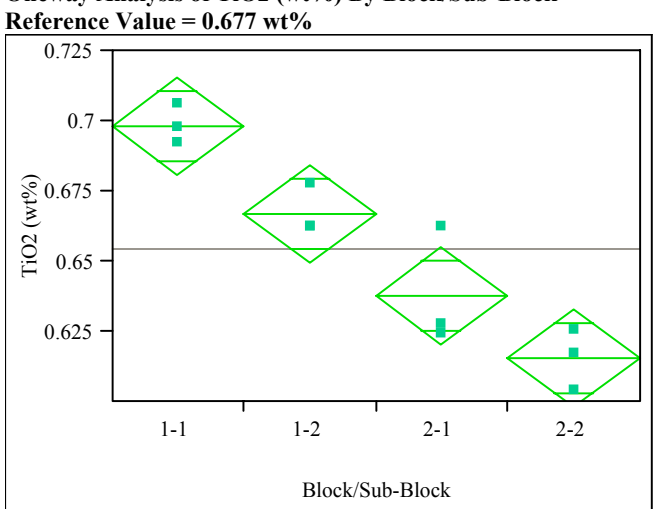

Oneway Anova

Summary of Fit

Rsquare

Adj Rsquare

0.893891

Root Mean Squ

0.8541
0.013151

0.65469

Observations (or Sum Wgts) $\quad 12$

Analysis of Variance

Source

DF Sum of Squares Mean Square F Ratio Prob $>$ F

Block/Sub-Block

$3 \quad 0.0116565$

$\begin{array}{lll}0.003886 & 22.4647 & 0.0003\end{array}$

C. Total

$\begin{array}{ll}8 & 0.00138369 \\ 1 & 0.01304028\end{array}$

Means for Oneway Anova

Level Number Mean Std Error Lower 95\% Upper 95\%

$\begin{array}{llllll}1-1 & 3 & 0.698336 & 0.00759 & 0.68083 & 0.71585\end{array}$

$\begin{array}{llllll}1-2 & 3 & 0.667200 & 0.00759 & 0.64969 & 0.68471\end{array}$

$\begin{array}{llllll}2-1 & 3 & 0.637732 & 0.00759 & 0.62022 & 0.65524\end{array}$

$\begin{array}{llllll}2-2 & 3 & 0.615492 & 0.00759 & 0.59798 & 0.63300\end{array}$
Oneway Analysis of ZnO (wt\%) By Block/Sub-Block

Reference Value $=0 \mathbf{w t} \%$

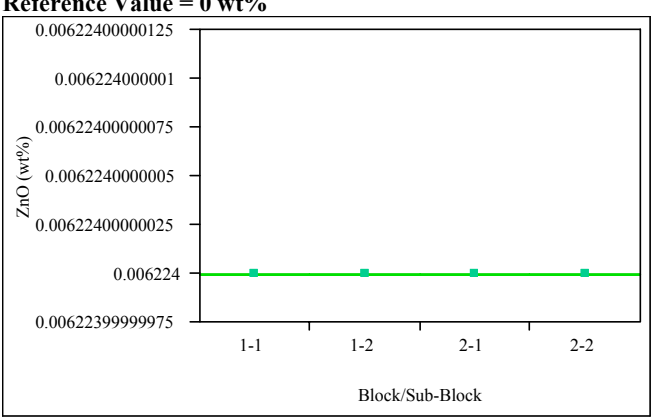

Oneway Anova

ummary of Fit

Rsquare

Root Mean Square Error $\quad 0$

$\begin{array}{lr}\text { Mean of Response } & 0.006224 \\ \text { Observations (or Sum Wgts) } & 12\end{array}$

Analysis of Variance

Source DF Sum of Squares Mean Square F Ratio Prob $>$ Block/Sub-Block

$\begin{array}{ll}0 & 0 \\ 0 & 0\end{array}$

C. Total

8
11

Means for Oneway Anova

Level Number Mean Std Error Lower 95\% Upper 95\%

$\begin{array}{lllllll}1-1 & 3 & 0.006224 & 0 & 0.00622 & 0.00622\end{array}$

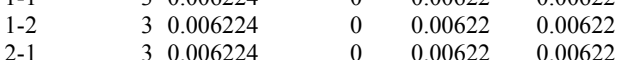

$\begin{array}{llllll}2-1 & 3 & 0.006224 & 0 & 0.00622 & 0.00622 \\ 2-2 & 3 & 0.006224 & 0 & 0.00622 & 0.00622\end{array}$

Std Error uses a pooled estimate of error variance 


\section{Exhibit D3. PSAL Measurements by Analytical Block for Samples of the Standard Glasses Prepared Using the LM Method (continued)}

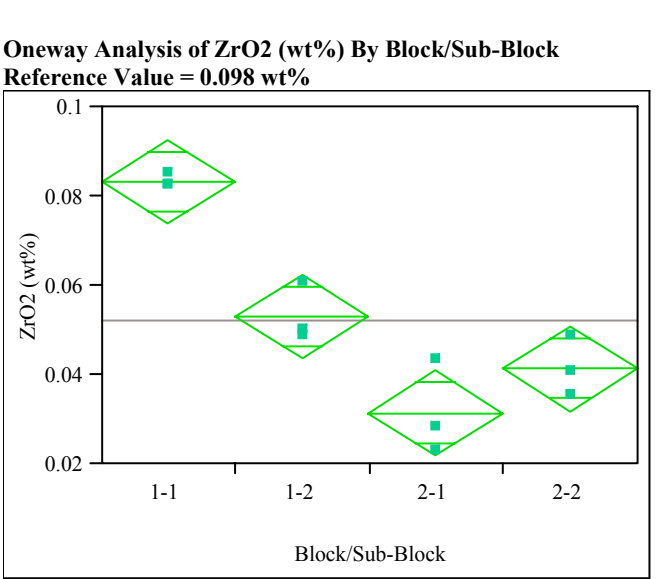

\section{Oneway Anova}

$\begin{array}{lr}\text { Rsquare } & 0.917782 \\ \text { Adj Rsquare } & 0.88695\end{array}$

Root Mean Square Error $\quad 0.007126$

Mean of Response

Observations (or Sum Wgts)

Analysis of Variance

Source DF Sum of Squares Mean Square F Ratio Prob $>$ F

$\begin{array}{llllll}\text { Block/Sub-Block } & 3 & 0.00453535 & 0.001512 & 29.7675 & 0.0001\end{array}$

Error

\begin{tabular}{lll} 
C. Total & 11 & 0.00040629 \\
\hline & 0.00494164
\end{tabular}

Level Number Mean Std Error Lower 95\% Upper 95\%

$\begin{array}{llllll}1-1 & 3 & 0.083299 & 0.00411 & 0.07381 & 0.09279\end{array}$

$\begin{array}{llllll}1-2 & 3 & 0.053131 & 0.00411 & 0.04364 & 0.06262\end{array}$

$\begin{array}{llllll}2-1 & 3 & 0.031519 & 0.00411 & 0.02203 & 0.04101 \\ 2-2 & 3 & 0.041425 & 0.00411 & 0.03194 & 0.05091\end{array}$

Std Error uses a pooled estimate of error variance
Glass ID $=$ Ustd

Oneway Analysis of $\mathrm{BaO}(\mathrm{wt} \%)$ By Block/Sub-Block

Reference Value $=\mathbf{0} \mathbf{w t} \%$

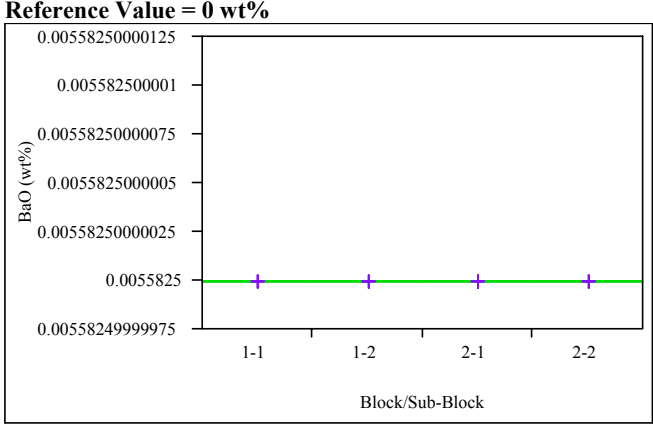

Oneway Anova

Summary of Fit

Rsquare

Adj Rsquare

Mean of Response

0.005583

Analysis of Variance

Source DF Sum of Squares Mean Square F Ratio Prob > F Block/Sub-Block

Error

$\begin{array}{lll}3 & 0 & 0 \\ 8 & 0 & 0\end{array}$

C. Total

11

Level Number Mean Std Error Lower 95\% Upper 95\%

$\begin{array}{llllll}1-1 & 3 & 0.005583 & 0 & 0.00558 & 0.00558\end{array}$

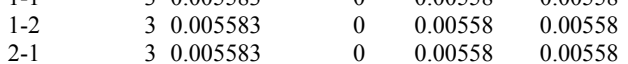

$\begin{array}{llllll}2-2 & 3 & 0.005583 & 0 & 0.00558 & 0.00558\end{array}$

Std Error uses a pooled estimate of error variance
Oneway Analysis of $\mathrm{CaO}(\mathrm{wt} \%)$ By Block/Sub-Block

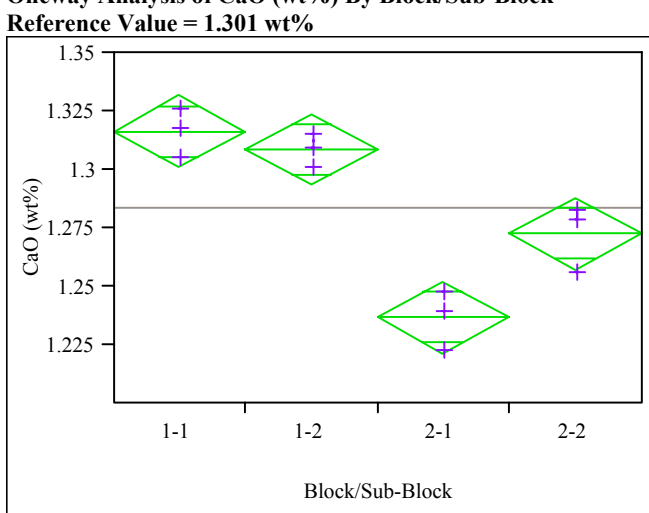

Oneway Anova

Summary of Fit

Adj Rsquare $\quad 0.91924$

Root Mean Square Error $\quad 0.01151$

Mean of Response $\quad 1.283766$

Observations (or Sum Wgts) 12

Analysis of Variance

Source DF Sum of Squares Mean Square F Ratio Prob $>$ F

$\begin{array}{llllll}\text { Block/Sub-Block } & 3 & 0.01206307 & 0.004021 & 30.3530 & 0.0001\end{array}$

$\begin{array}{lll}\text { Error } & 8 & 0.00105980\end{array}$

$\begin{array}{lll}\text { C. Total } & 11 & 0.01312287\end{array}$

Means for Oneway Anova

Level Number Mean Std Error Lower 95\% Upper 95\%

$\begin{array}{llllll}1-1 & 3 & 1.31665 & 0.00665 & 1.3013 & 1.3320\end{array}$

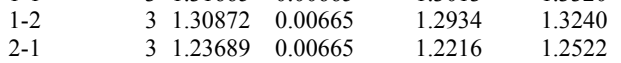

$\begin{array}{llllll}2-2 & 3 & 1.27281 & 0.00665 & 1.2575 & 1.2881\end{array}$

Std Error uses a pooled estimate of error variance 


\section{Exhibit D3. PSAL Measurements by Analytical Block for Samples of the \\ Standard Glasses Prepared Using the LM Method (continued)}

Oneway Analysis of Ce2O3 (wt\%) By Block/Sub-Block

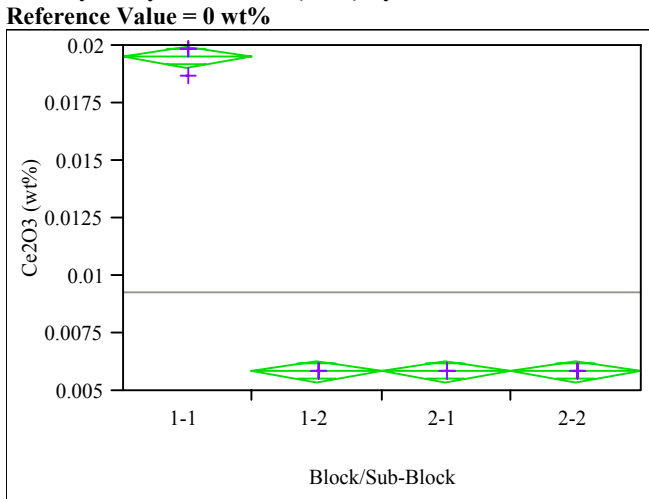

Oneway Anova

Summary of Fit

Rsquare

Adj Rsquare 0.997828

0.997013

$\begin{array}{lr}\text { Mean of Response } & 0.009273 \\ \text { Observations (or Sum Wgts) } & 12\end{array}$

$\begin{array}{lll}\text { Analysis of Variance } & \\ \text { Source DF Sum of Squares Mean Square F Ratio Prob }>\text { F }\end{array}$

$\begin{array}{llllll}\text { Block/Sub-Block } & 3 & 0.00042016 & 0.000140 & 1225 & <.000\end{array}$

$8 \quad 0.0000009$

$1.143 \mathrm{e}-7$

C. Total $11 \quad 0.0004210$

Means for Oneway Anova

Level Number Mean Std Error Lower 95\% Upper 95\%

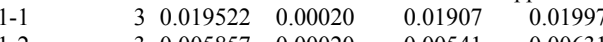

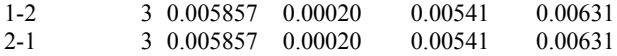

$\begin{array}{llllll}3 & 0.005857 & 0.00020 & 0.00541 & 0.00631\end{array}$

Std Error uses a pooled estimate of error variance
Oneway Analysis of $\mathrm{Cr} 2 \mathrm{O} 3$ (wt\%) By Block/Sub-Block

Reference Value $=\mathbf{0} \mathbf{w t} \%$

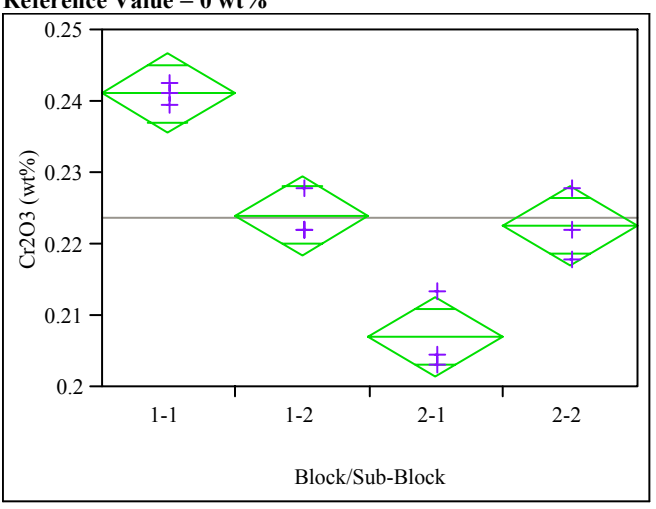

\section{Oneway Anova}

Summary of Fit

Rsquare

Adj Rsquare

Mean of Response

Analysis of Variance

Source DF Sum of Squares Mean Square F Ratio Prob $>$ F $\begin{array}{lll}\text { Block/Sub-Block } & 3 & 0.00174943 \\ \text { Error } & 8 & 0.00014099\end{array}$ $\begin{array}{lrr}\text { C. Total } & 11 & 0.00014099 \\ \text { Meror } & 11 & 0.00189042\end{array}$

Means for Oneway Anova

Level Number Mean Std Error Lower 95\% Upper 95\%

$\begin{array}{lllllll}1-1 & 3 & 0.241164 & 0.00242 & 0.23557 & 0.24675\end{array}$

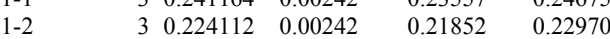

$\begin{array}{llllll}2-1 & 3 & 0.207060 & 0.00242 & 0.20147 & 0.21265\end{array}$

$\begin{array}{llllll}2-2 & 3 & 0.222650 & 0.00242 & 0.21706 & 0.22824\end{array}$
Oneway Analysis of $\mathrm{CuO}$ (wt\%) By Block/Sub-Block

Reference Value $=0 \mathbf{w t} \%$

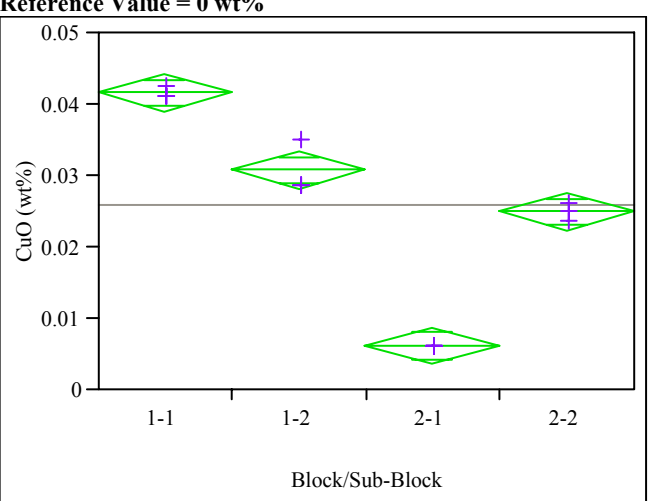

\section{Oneway Anova}

Summary of Fit

Rsquare

Root Mean Square Error $\quad 0.001946$

Mean of Response $\quad 0.025975$

Observations (or Sum Wgts)

Analysis of Variance

Source DF Sum of Squares Mean Square F Ratio Prob $>$ F $\begin{array}{llllll}\text { Block/Sub-Block } & 3 & 0.00198526 & 0.000662 & 174.7471 & <.0001\end{array}$ $\begin{array}{lll}\text { Error } & 8 & 0.00003030\end{array}$ $\begin{array}{lrr}\text { C. Total } & 11 & 0.000203030 \\ \text { Metror } & & 0.0020156\end{array}$

Means for Oneway Anova

Level Number Mean Std Error Lower 95\% Upper 95\%

$\begin{array}{lllllll}1-1 & 3 & 0.041727 & 0.00112 & 0.03914 & 0.04432\end{array}$

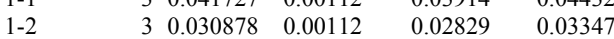

$\begin{array}{llllll}2-1 & 3 & 0.006259 & 0.00112 & 0.00367 & 0.00885\end{array}$

$\begin{array}{llllll}2-2 & 3 & 0.025036 & 0.00112 & 0.02245 & 0.02763\end{array}$ 


\section{Exhibit D3. PSAL Measurements by Analytical Block for Samples of the Standard Glasses Prepared Using the LM Method (continued)}

Oneway Analysis of K2O (wt\%) By Block/Sub-Block

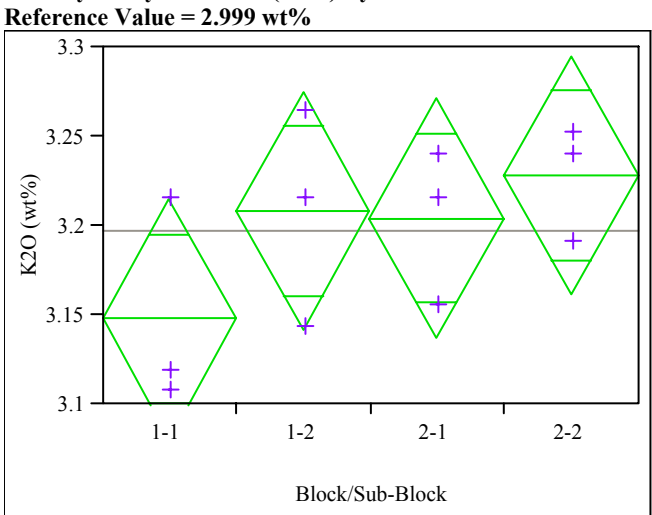

\section{Oneway Anova}

Summary of Fit

$\begin{array}{ll}\text { Rsquare } & 0.345597 \\ \text { Adj Rsquare } & 0.100196\end{array}$

Root Mean Square Error $\quad 0.050272$

Mean of Response $\quad 3.197209$

Observations (or Sum Wgts)

Analysis of Variance

Source DF Sum of Squares Mean Square F Ratio Prob $>$ F $\begin{array}{llllll}\text { Block/Sub-Block } & 3 & 0.01067739 & 0.003559 & 1.4083 & 0.3097\end{array}$ Error

C. Total $8 \quad 0.02021812$ 0.002527

Level Number Mean Std Error Lower 95\% Upper 95\%

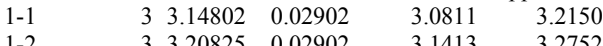

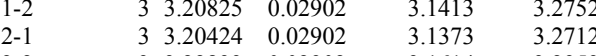

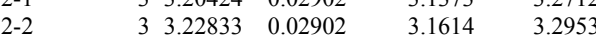

Std Error uses a pooled estimate of error variance
Oneway Analysis of La2O3 (wt\%) By Block/Sub-Block Reference Value $=\mathbf{0} \mathbf{w t} \%$

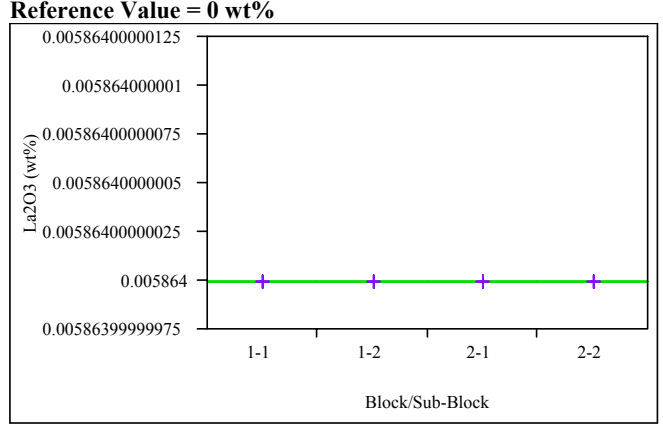

Oneway Anova

Summary of Fit

Rsquare
Adj Rsquare

Adj Rsquare

Mean of Response

Analysis of Variance

Source DF Sum of Squares Mean Square F Ratio Prob $>$ F Block/Sub-Block

Error

$\begin{array}{lll}3 & 0 & 0 \\ 8 & 0 & 0\end{array}$

C. Total

11

Level Number Mean Std Error Lower 95\% Upper 95\%

$\begin{array}{llllll}1-1 & 3 & 0.005864 & 0 & 0.00586 & 0.00586\end{array}$

$\begin{array}{llllll}1-2 & 3 & 0.005864 & 0 & 0.00586 & 0.00586\end{array}$

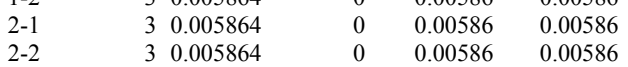

Std Error uses a pooled estimate of error variance
Oneway Analysis of $\mathrm{MgO}(\mathrm{wt} \%)$ By Block/Sub-Block Reference Value $=1.21 \mathrm{wt} \%$

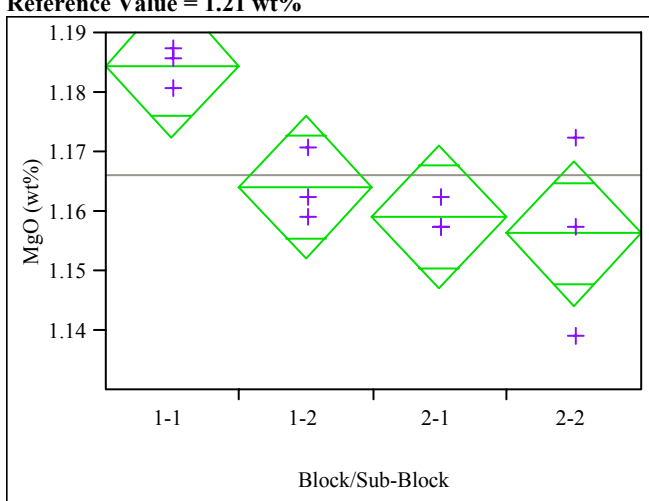

\section{Oneway Anova}

Summary of Fit

$\begin{array}{lr}\text { Rsquare } & 0.688065 \\ \text { Adj Rsquare } & 0.57109\end{array}$

Root Mean Square Error $\quad \begin{array}{r}0.57109 \\ 0.009108\end{array}$

Mean of Response 1.166061

Observations (or Sum Wgts) 12

Analysis of Variance

Source DF Sum of Squares Mean Square F Ratio Prob $>$ F $\begin{array}{llllll}\text { Block/Sub-Block } & 3 & 0.00146389 & 0.000488 & 5.8821 & 0.0202\end{array}$ $\begin{array}{lrr}\text { Error } & 8 & 0.00066366 \\ \text { C. Total } & 11 & 0.00212755\end{array}$

Means for Oneway Anova

Level Number Mean Std Error Lower 95\% Upper 95\%

$\begin{array}{llllll}1-1 & 3 & 1.18458 & 0.00526 & 1.1725 & 1.1967\end{array}$

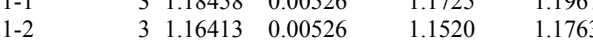

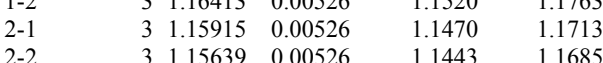

Std Error uses a pooled estimate of error variance 


\section{Exhibit D3. PSAL Measurements by Analytical Block for Samples of the Standard Glasses Prepared Using the LM Method (continued)}

Oneway Analysis of MnO (wt\%) By Block/Sub-Block

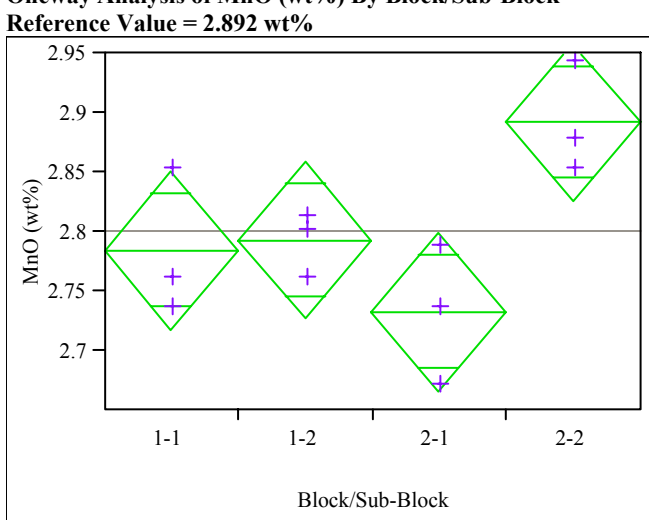

\section{Oneway Anova}

Summary of Fit

\begin{tabular}{lr} 
Rsquare & 0.665661 \\
Adj Rsquare & 0.540283 \\
Root Mean Square Error & 0.050008 \\
Mean of Response & 2.800828 \\
\hline Ore
\end{tabular}

Mean of Response 2.800828

Observations (or Sum Wg

Analysis of Variance

Source DF Sum of Squares Mean Square F Ratio Prob $>$ F $\begin{array}{llllll}\text { Block/Sub-Block } 3 & 0.03983213 & 0.013277 & 5.3093 & 0.0263\end{array}$ Error

$\begin{array}{lll}\text { C. Total } & 11 & 0.05983849\end{array}$

Means for Oneway Anova

Level Number Mean Std Error Lower 95\% Upper 95\%

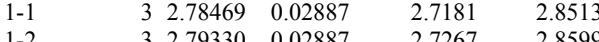

$\begin{array}{llllll}1-1 & 3 & 2.79330 & 0.02887 & 2.7267 & 2.8599 \\ 2-1 & 3 & 2.73304 & 0.02887 & 2.6665 & 2.7996\end{array}$

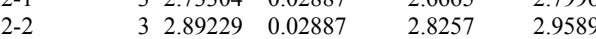

Std Error uses a pooled estimate of error variance
Oneway Analysis of Na2O (wt\%) By Block/Sub-Block Reference Value $=11.795 \mathrm{wt} \%$

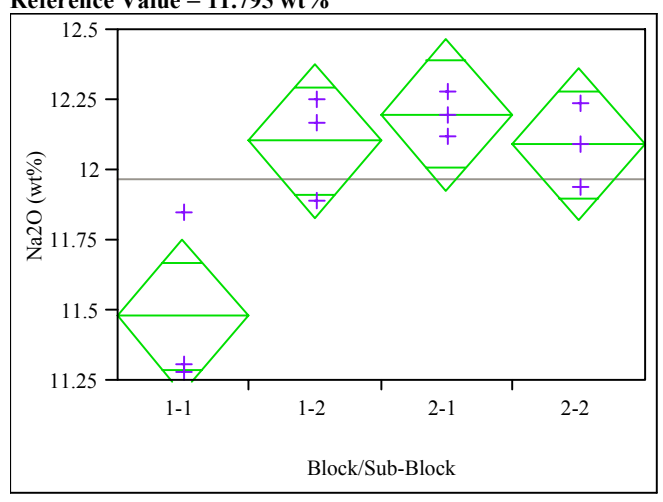

Oneway Anova
Summary of Fit

ummary of Fit

Rsquare

0.744945

$\begin{array}{lr}\text { Adj Rsquare } & 0.6493 \\ \text { Root Mean Square Error } & 0.20436\end{array}$

0.6493

Mean of Response

11.96912
12

Analysis of Variance

Source DF Sum of Squares Mean Square F Ratio Prob $>$ F

Block/Sub-Block 30.9758303

$\begin{array}{lrr}\text { Error } & 8 & 0.3341049 \\ \text { C. } & 11 & 1.309351\end{array}$

0.3341049
1.3099351

Means for Oneway Anova

Level Number Mean Std Error Lower 95\% Upper 95\%

$\begin{array}{lllrrr}1-1 & 3 & 11.4805 & 0.11799 & 11.208 & 11.753 \\ 1-2 & 3 & 12.1050 & 0.11799 & 11.83 & 12.377\end{array}$

$\begin{array}{llllll}1-2 & 3 & 12.1050 & 0.11799 & 11.833 & 12.377\end{array}$

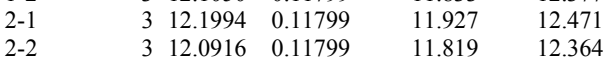

Std Error uses a pooled estimate of error variance
Oneway Analysis of PbO (wt\%) By Block/Sub-Block

Reference Value $=\mathbf{0} \mathbf{w t} \%$

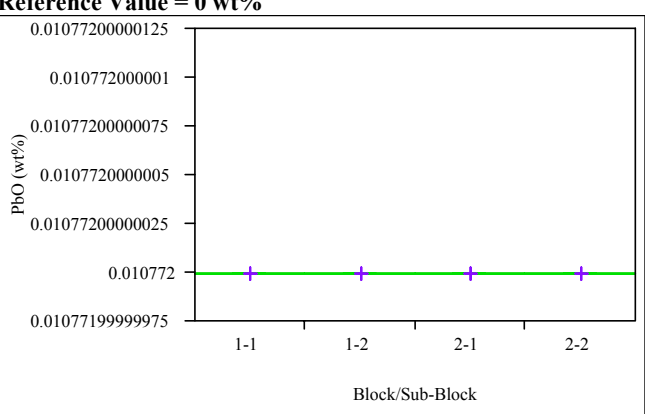

Oneway Anova

Rsquare

Adj Rsquare $\quad-0.375$

Root Mean Square Error $\quad 2.12 \mathrm{e}-18$

Mean of Response $\quad 0.010772$

Observations (or Sum Wg

Source DF Sum of Squares Mean Square F Ratio Prob $>$ F

$\begin{array}{lrrr}\text { Error } & 8 & 3.6111 \mathrm{e}-35 & 4.514 \mathrm{e}-36\end{array}$

$\begin{array}{ll}\text { C. Total } & 11 \\ \text { Means for Oneway Anova }\end{array}$

Level Number Mean Std Error Lower 95\% Upper 95\%

$\begin{array}{lllllll}1-1 & 3 & 0.010772 & 1.227 \mathrm{e}-18 & 0.01077 & 0.01077\end{array}$

$\begin{array}{llllll}1-2 & 3 & 0.010772 & 1.227 \mathrm{e}-18 & 0.01077 & 0.01077\end{array}$

$\begin{array}{llllll}2-1 & 3 & 0.010772 & 1.227 \mathrm{e}-18 & 0.01077 & 0.01077 \\ 2-2 & 3 & 0.010772 & 1.227 \mathrm{e}-18 & 0.01077 & 0.01077\end{array}$

Std Error uses a pooled estimate of error variance 


\section{Exhibit D3. PSAL Measurements by Analytical Block for Samples of the Standard Glasses Prepared Using the LM Method (continued)}

Oneway Analysis of SO4 (wt\%) By Block/Sub-Block

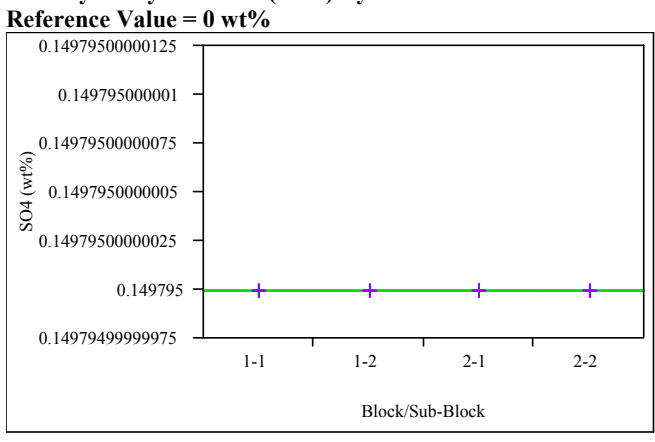

Oneway Anova

Summary of Fit

Rsquare
Adj Rsquare

Root Mean Square Error $\quad 0$

$\begin{array}{lr}\text { Mean of Response } & 0.149795 \\ \text { Observations (or Sum Wgts) } & 12\end{array}$

Analysis of Variance

Source DF Sum of Squares Mean Square F Ratio Prob > F Block/Sub-Block

C. Tot $\begin{array}{rrr}3 & 0 & 0 \\ 8 & 0 & 0\end{array}$

Means for Oneway Anova

Level Number Mean Std Error Lower 95\% Upper 95\% $\begin{array}{llllll}1-1 & 3 & 0.149795 & 0 & 0.14979 & 0.14979\end{array}$

$\begin{array}{llllll}1-2 & 3 & 0.149795 & 0 & 0.14979 & 0.14979\end{array}$

$\begin{array}{lllllll}2-1 & 3 & 0.149795 & 0 & 0.14979 & 0.14979 \\ 2-2 & & 3 & 0.149795 & 0 & 0.14979 & 0.14979\end{array}$

Std Error uses a pooled estimate of error variance
Oneway Analysis of ThO2 (wt\%) By Block/Sub-Block

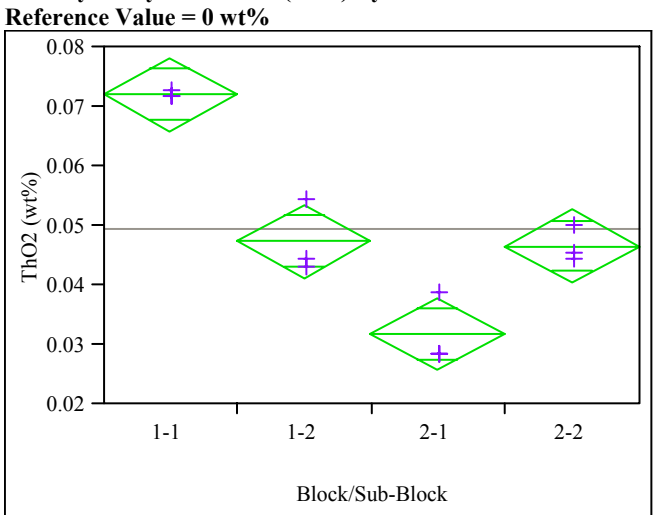

\section{Oneway Anova}

Summary of Fit

Rsquare

$\begin{array}{ll}\text { Adj Rsquare } & 0.913631 \\ \text { Rot } & 0.004575\end{array}$

Mean of Response $\quad 0.049499$

Observations (or Sum Wgts)

Analysis of Variance

Source DF Sum of Squares Mean Square F Ratio Prob $>$ F

Block/Sub-Block $3 \quad 0.00249856$

$\begin{array}{lrr}\text { Error } & 8 & 0.00016746 \\ \text { C. Total } & 11 & 0.00266603\end{array}$

Means for Oneway Anova

Level Number Mean Std Error Lower 95\% Upper 95\%

$\begin{array}{lllllll}1-1 & 3 & 0.072067 & 0.00264 & 0.06598 & 0.07816\end{array}$

$\begin{array}{llllll}1-2 & 3 & 0.047412 & 0.00264 & 0.04132 & 0.05350\end{array}$

$\begin{array}{lllllll}2-1 & 3 & 0.031861 & 0.00264 & 0.02577 & 0.033795\end{array}$

$\begin{array}{llllll}2-2 & 3 & 0.046654 & 0.00264 & 0.04056 & 0.05275\end{array}$

Std Error uses a pooled estimate of error variance
Oneway Analysis of TiO2 (wt\%) By Block/Sub-Block Reference Value $=1.049 \mathrm{wt} \%$

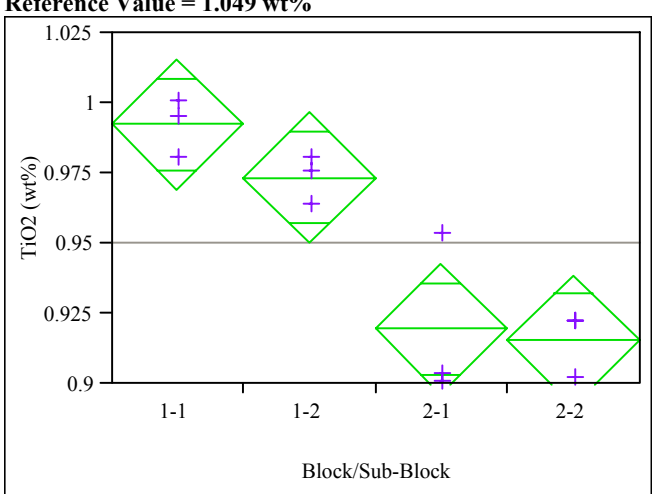

Oneway Anova

Summary of Fit

Adj Rsquare $\quad 0.846926$

Root Mean Square Error $\quad 0.017388$

Mean of Response $\quad 0.950343$

Observations (or Sum Wg

Analysis of Variance

Source DF Sum of Squares Mean Square F Ratio Prob $>$ F

$\begin{array}{lllllll}\text { Block/Sub-Block } & 3 & 0.01336279 & 0.004454 & 14.7329 & 0.0013\end{array}$

$\begin{array}{lll}\text { Error } & 8 & 0.00241868\end{array}$

$\begin{array}{lll}\text { C. Total } & 11 & 0.01578147\end{array}$

Means for Oneway Anova

Level Number Mean Std Error Lower 95\% Upper 95\%

$\begin{array}{llllrr}1-1 & 3 & 0.992460 & 0.01004 & 0.96931 & 1.0156\end{array}$

$\begin{array}{llllll}1-2 & 3 & 0.973556 & 0.01004 & 0.95041 & 0.9967\end{array}$

$\begin{array}{llllll}2-1 & 3 & 0.919624 & 0.01004 & 0.89647 & 0.9428\end{array}$

$\begin{array}{llllll}2-2 & 3 & 0.915732 & 0.01004 & 0.89258 & 0.9389\end{array}$ 


\section{Exhibit D3. PSAL Measurements by Analytical Block for Samples of the} Standard Glasses Prepared Using the LM Method (continued)

Oneway Analysis of $\mathrm{ZnO}$ (wt\%) By Block/Sub-Block

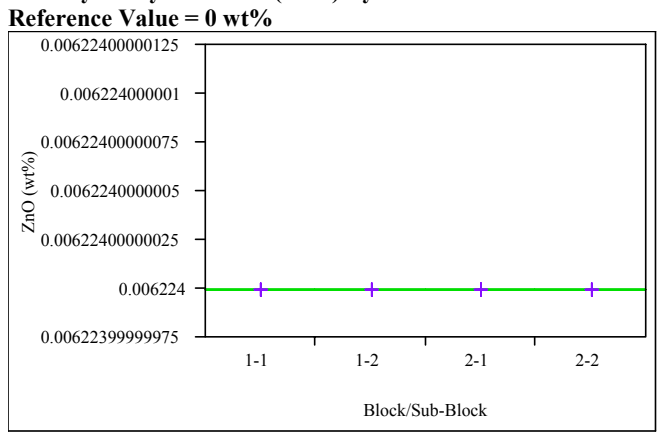

Oneway Anova

Summary of Fit

Rsquare
Adj Rsquare

Mean of Response

Analysis of Variance

Source DF Sum of Squares Mean Square F Ratio Prob $>$ F

Block/Sub-Block 3

Error

$\begin{array}{lll}3 & 0 & 0 \\ 8 & 0 & 0\end{array}$

C. Total

11

Level Number Mean Std Error Lower 95\% Upper 95\%

$\begin{array}{lllll}-1 & 3 & 0.006224 \\ 1 & 3 & 0.006 & 0\end{array}$

$\begin{array}{llllll}1-2 & 3 & 0.006224 & 0 & 0.00622 & 0.00622\end{array}$

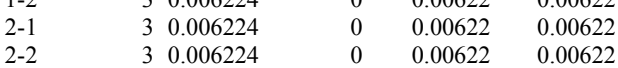

Std Error uses a pooled estimate of error variance
Oneway Analysis of ZrO2 (wt\%) By Block/Sub-Block

Reference Value $=\mathbf{0 ~ w t} \%$

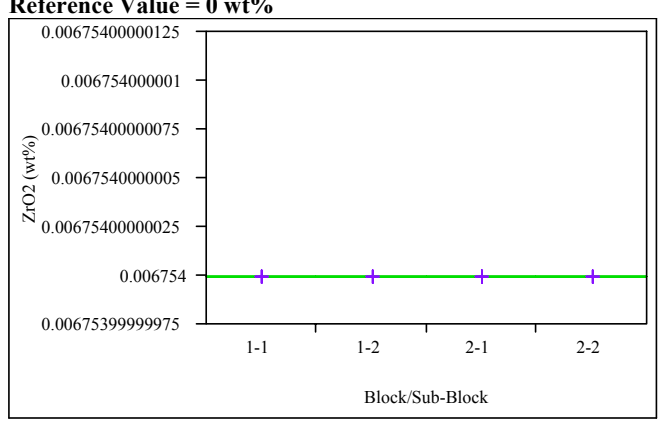

Oneway Anova

Summary of Fit

Rsquare

Adj Rsquare

Root Mean Square Error $\quad 0$
0.006754

$\begin{array}{lr}\text { Mean of Response } & 0.006754 \\ \text { Observations (or Sum Wgts) } & 12\end{array}$

Analysis of Variance

Source DF Sum of Squares Mean Square F Ratio Prob > F

$\begin{array}{lrrr}\text { Block/Sub-Block } & 3 & 0 & 0 \\ \text { Error } & 8 & 0 & 0 \\ \text { C. Total } & 11 & 0 & \end{array}$

Means for Oneway Anova

Level Number Mean Std Error Lower 95\% Upper 95\%

$\begin{array}{llllll}1-1 & 3 & 0.006754 & 0 & 0.00675 & 0.00675\end{array}$

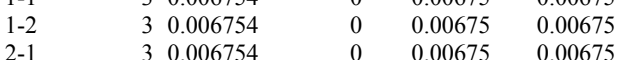

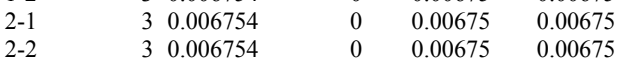

Std Error uses a pooled estimate of error variance 


\section{Exhibit D4: PSAL Measurements by Analytical Block for Samples of the Standard Glasses Prepared Using the PF Method}

Glass ID=Batch 1

Oneway Analysis of Al2O3 (wt\%) By Block/Sub-Block Reference Value $=4.877 \mathrm{wt} \%$

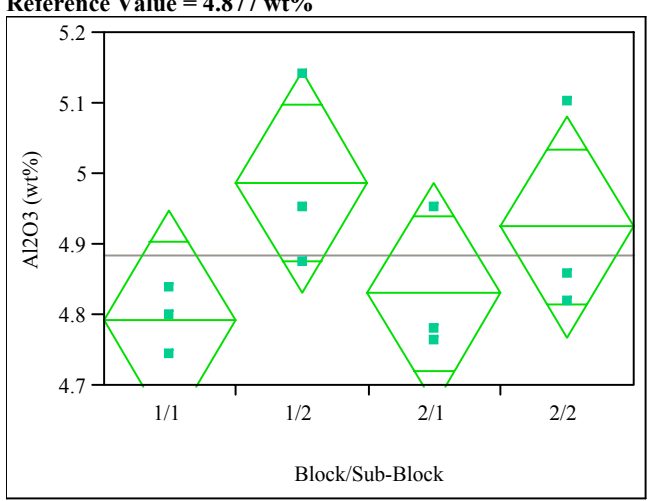

Oneway Anova

Rsquare

Adj Rsquare

Root Mean Square Error

0.390963

0.162574
0.11762

Mean of Response

4.884358
12

Observations (or Sum Wgts)

Analysis of Variance

DF Sum of Squares Mean Square F Ratio Prob $>$ F

$\begin{array}{lrrrrr}\text { Block/Sub-Block } & 3 & 0.07104718 & 0.023682 & 1.7118 & 0.2414\end{array}$

Error

$8 \quad 0.11067652$

0.013835

C. Total $11 \quad 0.18172370$

Level Number Mean Std Error Lower 95\% Upper 95\%

$\begin{array}{llllll}1 / 1 & 3 & 4.79303 & 0.06791 & 4.6364 & 4.9496\end{array}$

$\begin{array}{llllll}1 / 2 & 3 & 4.98828 & 0.06791 & 4.8317 & 5.1449\end{array}$

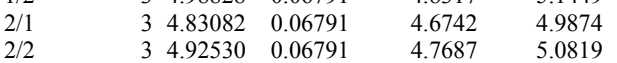

Std Error uses a pooled estimate of error variance
Oneway Analysis of B2O3 (wt\%) By Block/Sub-Block Reference Value $=7.777 \mathrm{wt} \%$

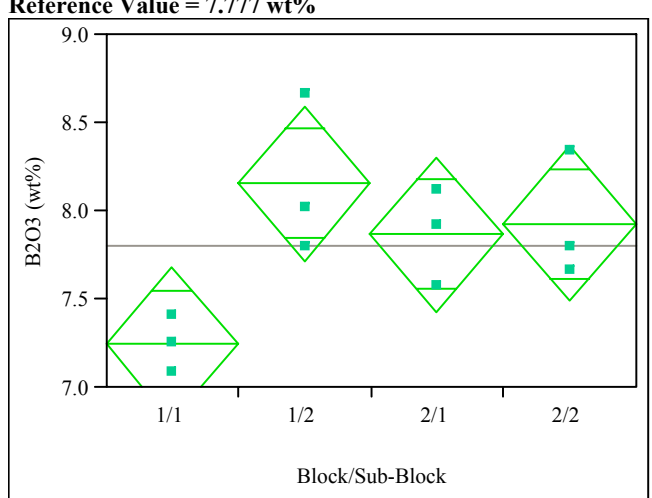

Oneway Anova

Summary of Fi

Rsquare

Adj Rsquare

Root Mean Square E

Mean of Response

0.611875
0.466328

Error $\quad 0.329942$

Sum Wgts)
7.800

Analysis of Variance

$\begin{array}{llll}\text { Source } & \text { DF Sum of Squares Mean Square F Ratio Prob }>\text { F } \\ \text { Block/Sub-Block } & 3\end{array}$

$\begin{array}{lrr} & 1.3729501 \\ \text { Error } & 8 & 0.8708915 \\ \text { C. Tolock } & 3 & 2.2438416\end{array}$

C. Total

$\begin{array}{rr}11 & 2.8738416\end{array}$

Means for Oneway Anova

Level Number Mean Std Error Lower 95\% Upper 95\%

$\begin{array}{llrrrr}1 / 1 & 3 & 7.24478 & 0.19049 & 6.8055 & 7.6841 \\ 1 / 2 & 3 & 8.15708 & 0.19049 & 7.7178 & 8.5964 \\ 2 / 1 & 3 & 7.86729 & 0.19049 & 7.4280 & 8.3066 \\ 2 / 2 & 3 & 7.93169 & 0.19049 & 7.4924 & 8.3710\end{array}$

Std Error uses a pooled estimate of error variance
Oneway Analysis of Fe2O3 (wt\%) By Block/Sub-Block Reference Value $=12.839 \mathrm{wt} \%$

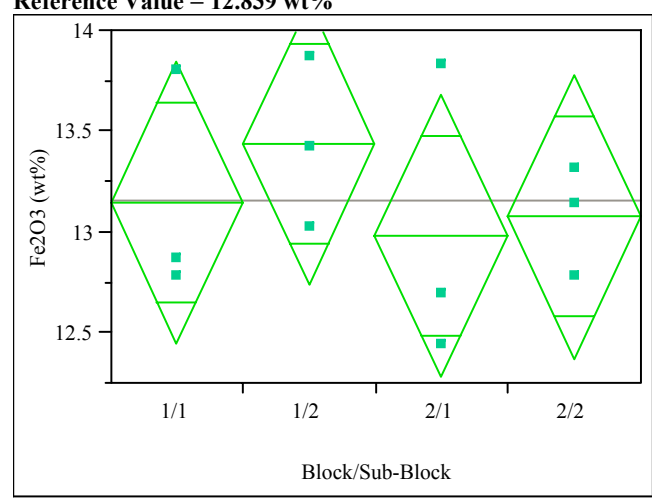

Oneway Anova

Rsquare

Adj Rsquare $\quad 0.134355$

Root Mean Square Error $\quad 0.527247$

$\begin{array}{lr}\text { Mean of Response } & 13.16277 \\ \text { Observations (or Sum Wgts) } & 12\end{array}$

Analysis of Variance

Source DF Sum of Squares Mean Square F Ratio Prob $>$ F $\begin{array}{llllll}\text { Block/Sub-Block } & 3 & 0.3451706 & 0.115057 & 0.4139 & 0.7477\end{array}$ $\begin{array}{lrrr}\text { Error } & 8 & 2.2239178 & 0.277990\end{array}$

$\begin{array}{lll}\text { C. Total } & 11 & 2.5690884\end{array}$

Means for Oneway Anova

Level Number Mean Std Error Lower 95\% Upper 95\% $\begin{array}{llllll}1 / 1 & 3 & 13.1485 & 0.30441 & 12.447 & 13.850 \\ 1 / 2 & 3 & 13.4392 & 0.30441 & 12.737 & 14.141\end{array}$

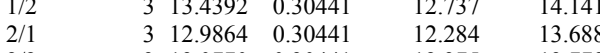

$\begin{array}{llllll}2 / 2 & 3 & 13.0770 & 0.30441 & 12.375 & 13.779\end{array}$

Std Error uses a pooled estimate of error variance 


\section{Exhibit D4: PSAL Measurements by Analytical Block for Samples of the Standard Glasses Prepared Using the PF Method (continued)}

Oneway Analysis of Li2O (wt\%) By Block/Sub-Block

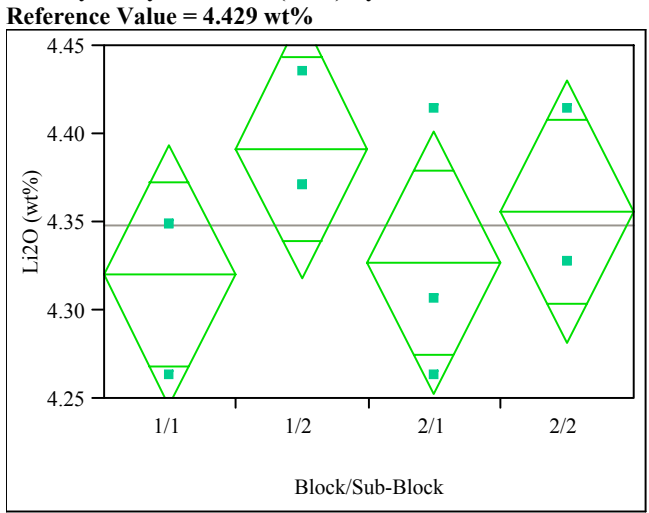

Oneway Anova

Summary of

Rsquare

Adj Rsquare $\quad 0.279279$

Root Mean Square Error $\quad 0.055588$

Mean of Response 4.348858

Observations (or Sum Wgts)

Analysis of Variance

$\begin{array}{lrrrrrr}\text { Source } & \text { DF } & \text { Sum of Squares } & \text { Mean Square } & \text { F Ratio } & \text { Prob }>\text { F } \\ \text { Block/Sub-Block } & 3 & 0.00957896 & 0.003193 & 1.0333 & 0.4282\end{array}$

Error

$8 \quad 0.02471988$

0.003090

Means for Oneway Anova

Level Number Mean Std Error Lower 95\% Upper 95\%

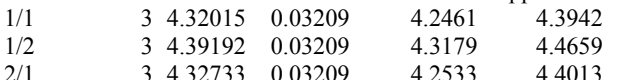

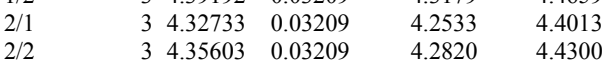

Std Error uses a pooled estimate of error variance
Oneway Analysis of NiO (wt\%) By Block/Sub-Block

Reference Value $=0.751 \mathbf{w t}^{\circ}$

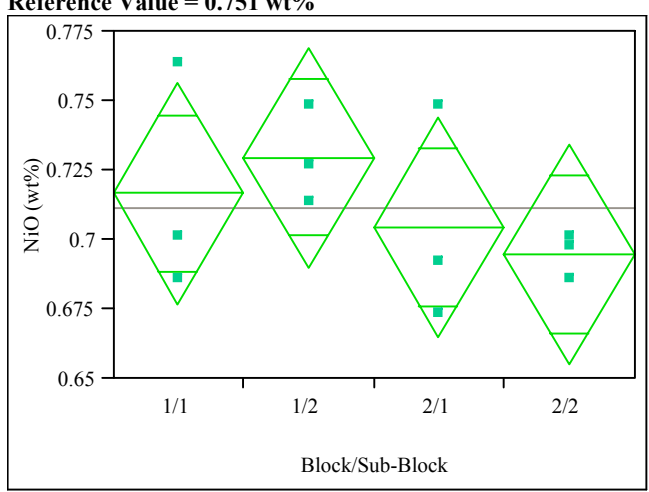

Oneway Anova

Summary of Fit

Rsquare

Adj Rsquare

Sub-Block

Roor $\quad 0.02991$

$\begin{array}{lr}\text { Mean of Response } & 0.711434 \\ \text { Observations (or Sum Wgts) } & 12\end{array}$

Analysis of Variance

Source DF Sum of Squares Mean Square F Ratio Prob $>$ F

$\begin{array}{lrrrrr}\text { Block/Sub-Block } & 3 & 0.00204822 & 0.000683 & 0.7631 & 0.5458\end{array}$

Error

$8 \quad 0.00715711$

0.000895

C. Total $11 \quad 0.0092053$

Level Number Mean Std Error Lower 95\% Upper 95\%

$\begin{array}{lllllll}1 / 1 & 3 & 0.716842 & 0.01727 & 0.67702 & 0.75666\end{array}$

$\begin{array}{llllll}1 / 2 & 3 & 0.729567 & 0.01727 & 0.68974 & 0.76939 \\ 2 / 1 & 3 & 0.704541 & 0.01727 & 0.66472 & 0.74366\end{array}$

$\begin{array}{lllllll}2 / 1 & 3 & 0.704541 & 0.01727 & 0.66472 & 0.74436 \\ 2 / 2 & 3 & 0.694785 & 0.01727 & 0.65496 & 0.73461\end{array}$

Std Error uses a pooled estimate of error variance
Oneway Analysis of SiO2 (wt\%) By Block/Sub-Block Reference Value $=50.22$ wt\%

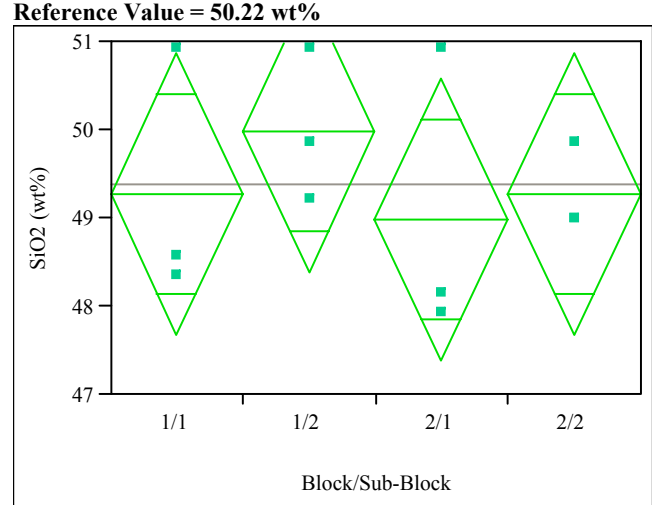

Oneway Anova

Summary of Fit

Rsquare

Root Mean Square Error $\quad 1.205434$

Mean of Response

49.38217
12

Observations (or Sum Wgts)

Source DF Sum of Squares Mean Square F Ratio Prob $>$ F

$\begin{array}{lrrrrr}\text { Block/Sub-Block } & 3 & 1.632322 & 0.54411 & 0.3745 & 0.7740 \\ \text { Error } & 8 & 11.624575 & 1.45307 & & \end{array}$

Error 1.45307

Means for Oneway Anova

Level Number Mean Std Error Lower 95\% Upper 95\% $\begin{array}{llllll}1 / 1 & 3 & 49.2752 & 0.69596 & 47.670 & 50.880\end{array}$

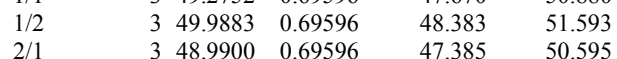

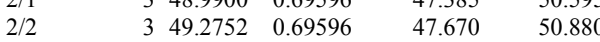

Std Error uses a pooled estimate of error variance 


\section{Exhibit D4: PSAL Measurements by Analytical Block for Samples of the Standard Glasses Prepared Using the PF Method (continued)}

Oneway Analysis of U3O8 (wt\%) By Block/Sub-Block Reference Value $=0 \mathrm{wt} \%$

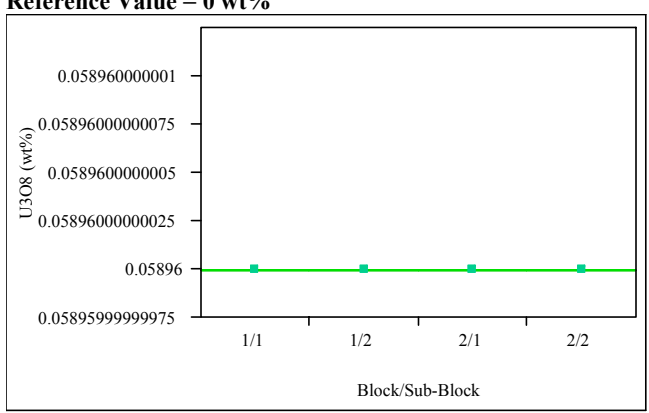

Oneway Anova

Rsquare

Adj Rsquare

Root Mean Square Erro

Mean of Response

Observations (or Sum Wgs)

Analysis of Variance

Source Block/Sub-Block

Sum of Squares Mean Square F Ratio Prob > F

Erro

$\begin{array}{rrr}3 & 0 & 0 \\ 8 & 0 & 0\end{array}$

C. Total

11

Means for Oneway Anova

Level Number Mean Std Error Lower 95\% Upper 95\%

$\begin{array}{llllll}1 / 1 & 3 & 0.058960 & 0 & 0.05896 & 0.05896\end{array}$

$\begin{array}{llllll}1 / 2 & 3 & 0.058960 & 0 & 0.05896 & 0.05896 \\ 2 / 1 & 3 & 0.058960 & 0 & 0.05896 & 0.05896\end{array}$

$\begin{array}{llllll}2 / 2 & 3 & 0.058960 & 0 & 0.05896 & 0.05896 \\ & & 0.058960 & 0 & 0.05896 & 0.05896\end{array}$

Std Error uses a pooled estimate of error variance
Glass ID $=$ Ustd

(wt\%) By Block/Sub-Block

Reference Value $=4.1 \mathrm{wt}^{\circ}$

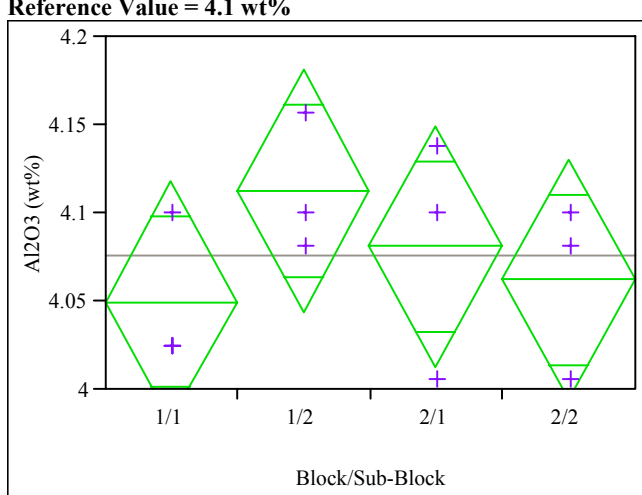

Oneway Anova

Block/Sub-Block

Summary of Fit

Rsquare

Adj Rsquare

Root Mean Square Er

Mean of Response
Observations (or S

0.241747
-0.0426

Analysis of Variance

$\begin{array}{lrrrrr}\text { Source } & \text { DF } & \text { Sum of Squares } & \text { Mean Square } & \text { F Ratio } & \text { Prob }>\text { F } \\ \text { Block/Sub-Block } & 3 & 0.00675365 & 0.002251 & 0.8502 & 0.5045 \\ \text { Error } & 8 & 0.02118325 & 0.002648 & & \end{array}$

0.02118325
0.02793690

C. Total $11 \quad 0$

0.002648

Level Number Mean Std Error Lower 95\% Upper 95\%

$\begin{array}{llllll}1 / 1 & 3 & 4.04983 & 0.02971 & 3.9813 & 4.1183\end{array}$

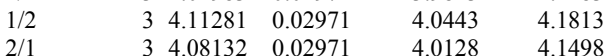

$\begin{array}{llllll}2 / 2 & 3 & 4.06243 & 0.02971 & 3.9939 & 4.1309\end{array}$

Std Error uses a pooled estimate of error variance
Oneway Analysis of B2O3 (wt\%) By Block/Sub-Block

Reference Value $=9.209 \mathbf{w t}$

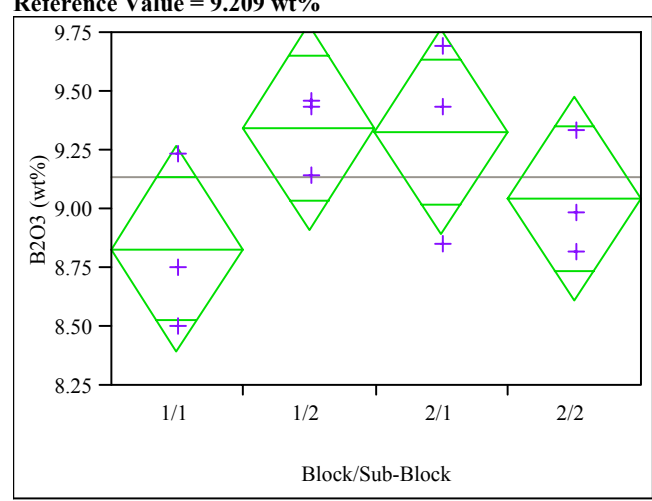

Oneway Anova

Rsquare

Adj Rsquare $\quad 0.38915$

Root Mean Square Error $\quad 0.326387$

$\begin{array}{lr}\text { Mean of Response } & 9.13915 \\ \text { Observations (or Sum Wgts) } & 12\end{array}$

Analysis of Variance

Source DF Sum of Squares Mean Square F Ratio Prob $>$ F $\begin{array}{llllll}\text { Block/Sub-Block } & 3 & 0.5429248 & 0.180975 & 1.6988 & 0.2439\end{array}$ $\begin{array}{lrrr}\text { Error } & 8 & 0.8522295 & 0.106529\end{array}$

$\begin{array}{lll}\text { C. Total } & 11 & 1.3951544\end{array}$

Means for Oneway Anova

Level Number Mean Std Error Lower 95\% Upper 95\%

$\begin{array}{llllll}1 / 1 & 3 & 8.83326 & 0.18844 & 8.3987 & 9.2678\end{array}$

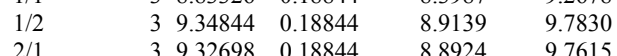

$\begin{array}{llllll}2 / 2 & 3 & 9.04792 & 0.18844 & 8.6134 & 9.4825\end{array}$

Std Error uses a pooled estimate of error variance 


\section{Exhibit D4: PSAL Measurements by Analytical Block for Samples of the Standard Glasses Prepared Using the PF Method (continued)}

Oneway Analysis of Fe2O3 (wt\%) By Block/Sub-Block Reference Value $=13.196 \mathrm{wt} \%$

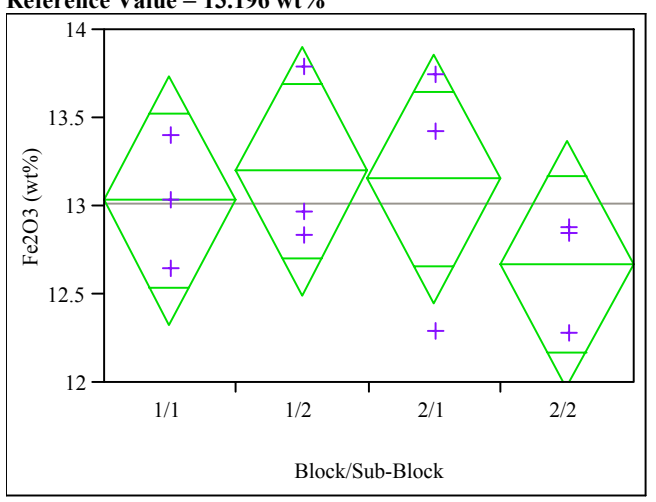

Oneway Anova

Summary of Fit

Rsquare

Adj Rsquare

Root Mean Square Error $\quad-0.11506$

Mean of Response

13.01623
12

Observations (or Sum Wg

Source DF Sum of Squares Mean Square F Ratio Prob > F $\begin{array}{llllll}\text { Block/Sub-Block } & 3 & 0.5192378 & 0.173079 & 0.6217 & 0.6206\end{array}$ Error 8 \begin{tabular}{ll}
3 & 0.5192378 \\
8 & 2.2273245 \\
\hline
\end{tabular} 0.278416

C. Total $\begin{array}{ll}11 & 2.7465623\end{array}$

Level Number Mean Std Error Lower 95\% Upper 95\%

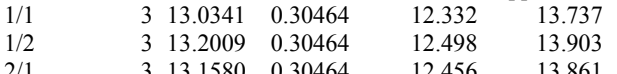

$\begin{array}{llllrr}1 / 2 & 3 & 13.1580 & 0.30464 & 12.456 & 13.861 \\ 2 / 2 & 3 & 12.6719 & 0.30464 & 11.969 & 13.374\end{array}$

Std Error uses a pooled estimate of error variance
Oneway Analysis of Li2O (wt\%) By Block/Sub-Block Reference Value $=3.057 \mathrm{wt} \%$

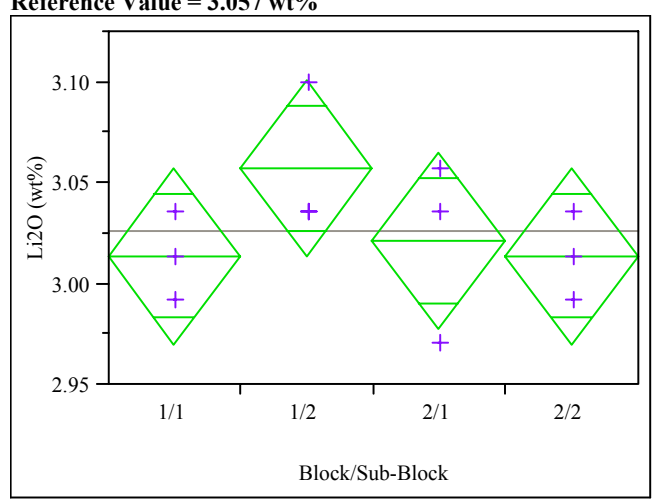

Oneway Anova

Summary of Fit

\section{Rsquare}

Adj Rsquare $\quad 0.04644$

Root Mean Square Error $\quad 0.032886$

$\begin{array}{lr}\text { Mean of Response } & 3.026619 \\ \text { Observations (or Sum Wgts) } & 12\end{array}$

Analysis of Variance

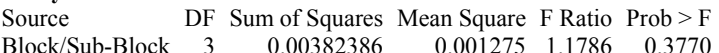

Block/Sub-Block $3 \quad 0.00382386$

$\begin{array}{lrr}\text { Error } & 8 & 0.00865196 \\ \text { C. Total } & 11 & 0.01247582\end{array}$

Means for Oneway Anova

Level Number Mean Std Error Lower 95\% Upper 95\%

$\begin{array}{llrrrr}1 / 1 & 3 & 3.01406 & 0.01899 & 2.9703 & 3.0578 \\ 1 / 2 & 3 & 3.05712 & 0.01899 & 3.0133 & 3.1009 \\ 2 / 1 & 3 & 3.02124 & 0.01899 & 2.9775 & 3.0650 \\ 2 / 2 & 3 & 3.01406 & 0.01899 & 2.9703 & 3.0578\end{array}$

Std Error uses a pooled estimate of error variance
Oneway Analysis of $\mathrm{NiO}(\mathrm{wt} \%)$ By Block/Sub-Block Reference Value $=1.12 \mathrm{wt} \%$

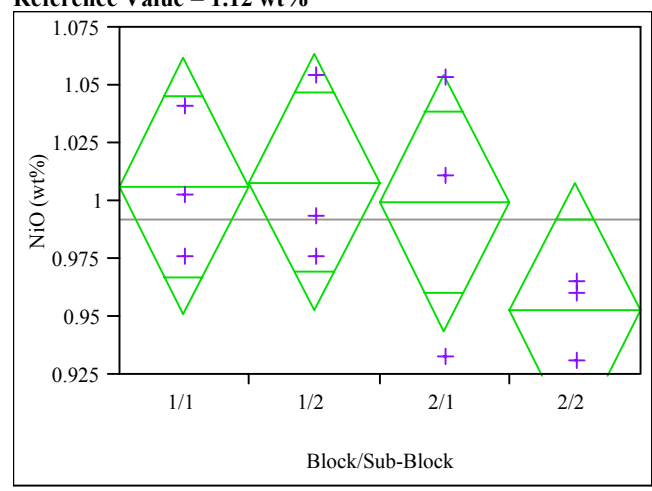

Oneway Anova

Summary of Fit

Rsquare

Adj Rsquare $\quad 0.311292$

Root Mean Square Eror 0.053027

Mean of Respors

Observations (or Sum Wgts) $\quad 12$

Analysis of Variance

Source DF Sum of Squares Mean Square F Ratio Prob $>$ F $\begin{array}{llllll}\text { Block/Sub-Block } & 3 & 0.00622550 & 0.002075 & 1.2053 & 0.3683\end{array}$ $\begin{array}{lrrr}\text { Error } & 8 & 0.01377339 & 0.00172\end{array}$

C. Total $\quad 11 \quad 0.0199988$

Means for Oneway Anova

Level Number Mean Std Error Lower 95\% Upper 95\%

$\begin{array}{llllll}1 / 1 & 3 & 1.00655 & 0.02396 & 0.95130 & 1.0618\end{array}$

$\begin{array}{lllllll}1 / 2 & & 3 & 1.00824 & 0.02396 & 0.95300 & 1.0635\end{array}$

$\begin{array}{llllll}2 / 1 & 3 & 0.99934 & 0.02396 & 0.94409 & 1.0546 \\ 2 / 2 & 3 & 0.95268 & 0.02396 & 0.89744 & 1.009\end{array}$

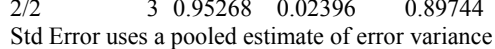




\section{Exhibit D4: PSAL Measurements by Analytical Block for Samples of the Standard Glasses Prepared Using the PF Method (continued)}

Oneway Analysis of SiO2 (wt\%) By Block/Sub-Block

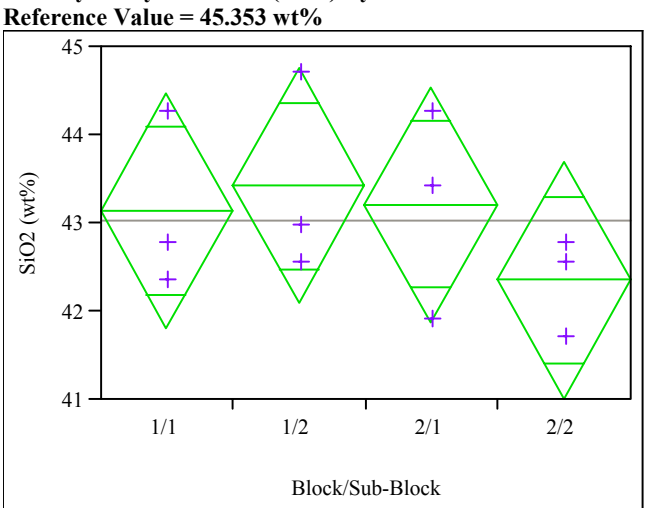

Oneway Anova

Summary of Fit

Rsquare

$-0.10584$

Root Mean Square Error 1.005319

Mean of Response

43.03558
$\quad 12$

Observations (or Sum Wgts)

Source DF Sum of Squares Mean Square F Ratio Prob > F

$\begin{array}{llllll}\text { Block/Sub-Block } & 3 & 1.967940 & 0.65598 & 0.6491 & 0.6053\end{array}$

Error

1.01067

C. Total

$11 \quad 10.053275$

Level Number Mean Std Error Lower 95\% Upper 95\%

$\begin{array}{llllll}1 / 1 & 3 & 43.1426 & 0.58042 & 41.804 & 44.481\end{array}$

$\begin{array}{llllll}1 / 2 & 3 & 43.4278 & 0.58042 & 42.089 & 44.766\end{array}$

$\begin{array}{llllll}2 / 1 & 3 & 43.2139 & 0.58042 & 41.875 & 44.552\end{array}$

$\begin{array}{lllll}2 / 2 & 3 & 42.3581 & 0.58042 & 41.020\end{array}$

43.697
Oneway Analysis of U3O8 (wt\%) By Block/Sub-Block

Reference Value $=\mathbf{2 . 4 0 6} \mathrm{wt} \%$

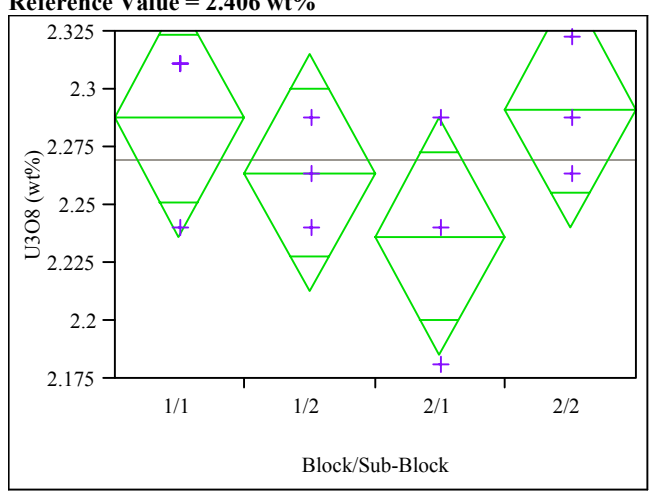

Oneway Anova

Summary of Fit

Rsquare

Adj Rsquare

Mean of Response $\quad 2.26996$

0.076115

0.038513

Observations (or Sum Wgts)

Analysis of Variance

Source DF Sum of Squares Mean Square F Ratio Prob $>$ F

$\begin{array}{lrrrrr}\text { Block/Sub-Block } & 3 & 0.00579380 & 0.001931 & 1.3021 & 0.3389\end{array}$

$\begin{array}{lrr}\text { Error } & 8 & 0.01186571 \\ \text { C. Total } & 11 & 0.0176595\end{array}$

$\begin{array}{lll}\text { C. Total } & 11 & 0.01765951\end{array}$

Means for Oneway Anova

Level Number Mean Std Error Lower 95\% Upper 95\%

$\begin{array}{llllll}1 / 1 & 3 & 2.28765 & 0.02224 & 2.2364 & 2.3389 \\ 1 / 2 & & 3 & 2.2606 & 0.0224 & 2.218\end{array}$

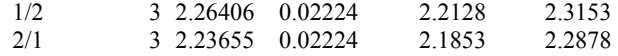

$\begin{array}{lllllll}2 / 2 & 3 & 2.29158 & 0.02224 & 2.2403 & 2.3429\end{array}$

Std Error uses a pooled estimate of error variance 
Exhibit D5. Measured and Measured Bias-Corrected Oxide Weight Percents by Glass \# for the Glasses Prepared Using the LM Method

$$
\text { (100 - Batch 1; } 200 \text { - Ustd) }
$$

BaO (wt \%) By Study Glass \#

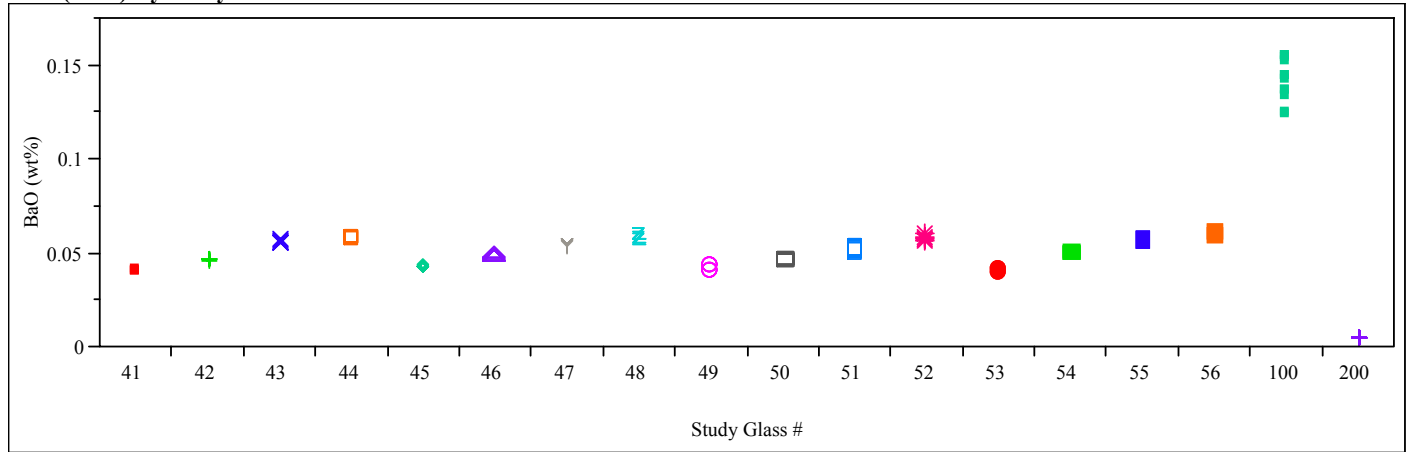

BaO bc (wt\%) By Study Glass \#

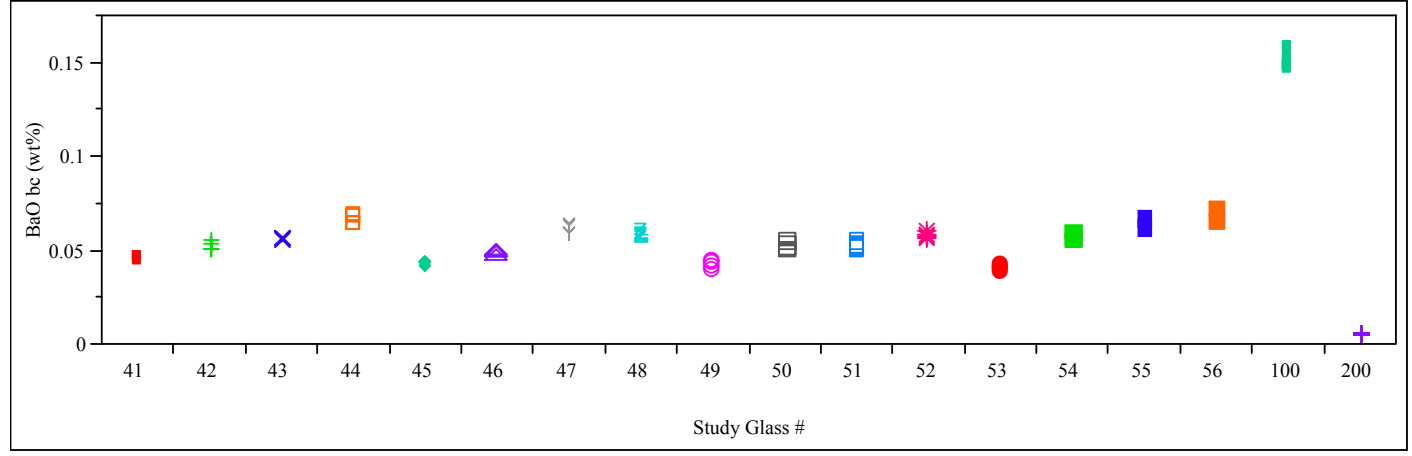

CaO (wt\%) By Study Glass \#

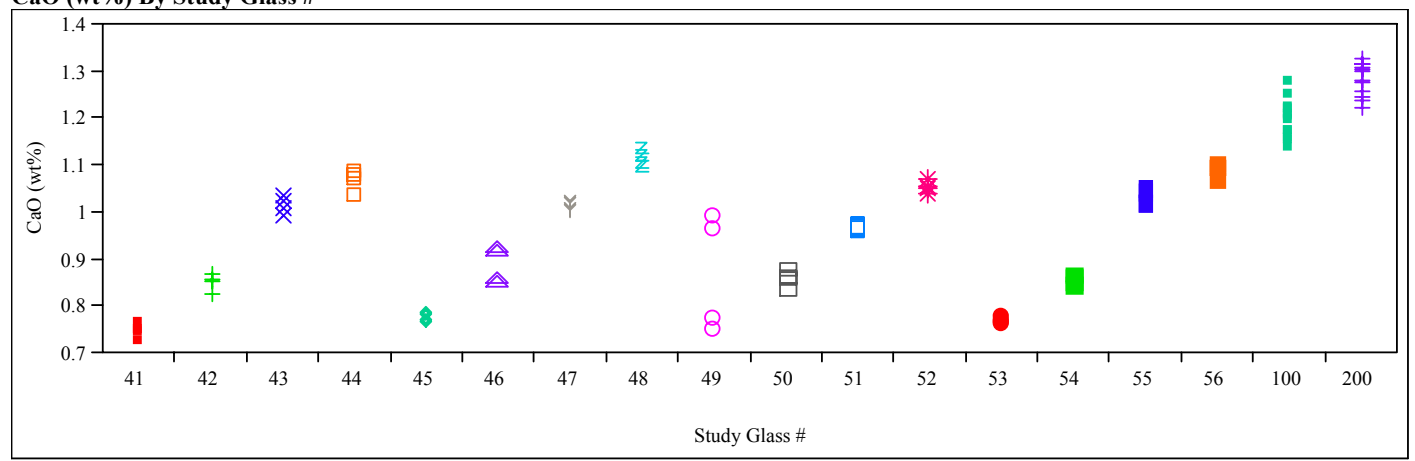

CaO bc (wt\%) By Study Glass \#

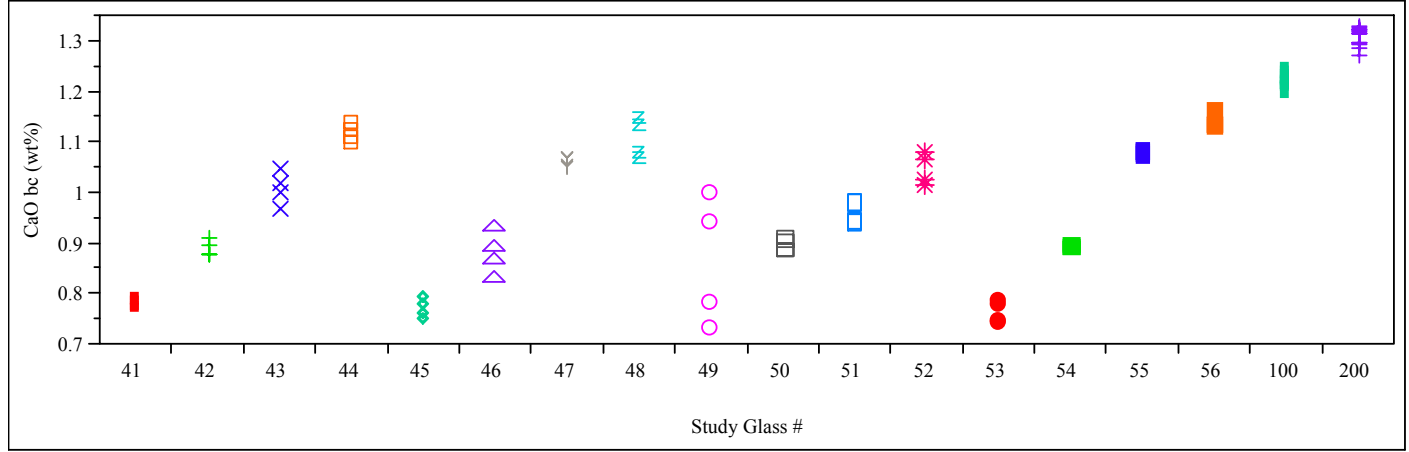




\section{Exhibit D5. Measured and Measured Bias-Corrected Oxide Weight Percents by Glass \# for the Glasses Prepared Using the LM Method (continued)}

(100 - Batch 1; 200 - Ustd)

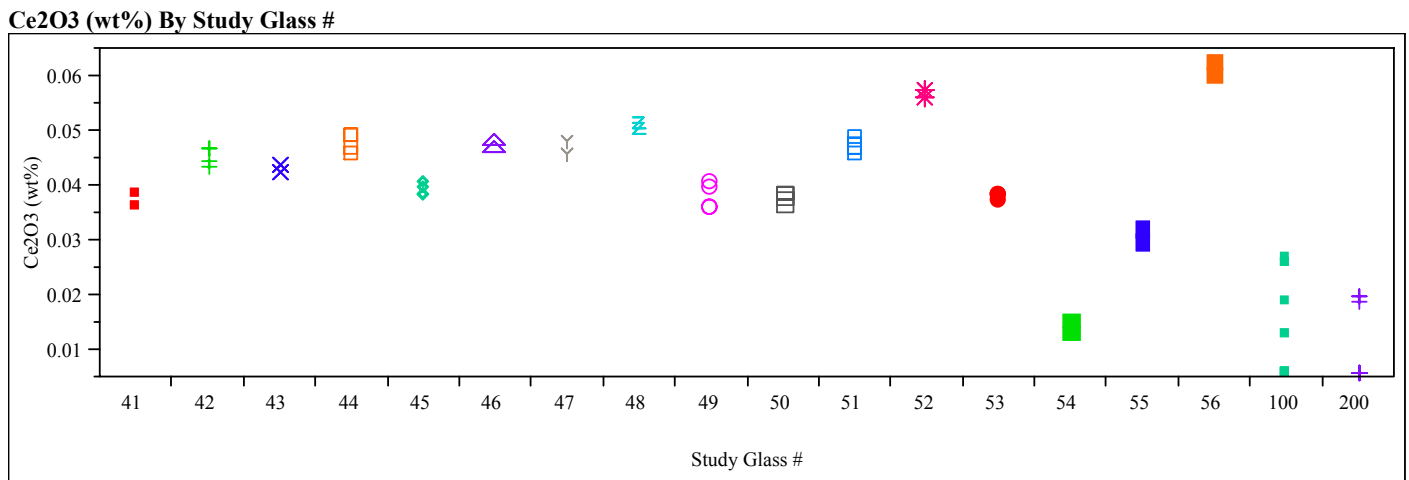

Ce2O3 bc (wt\%) By Study Glass \#
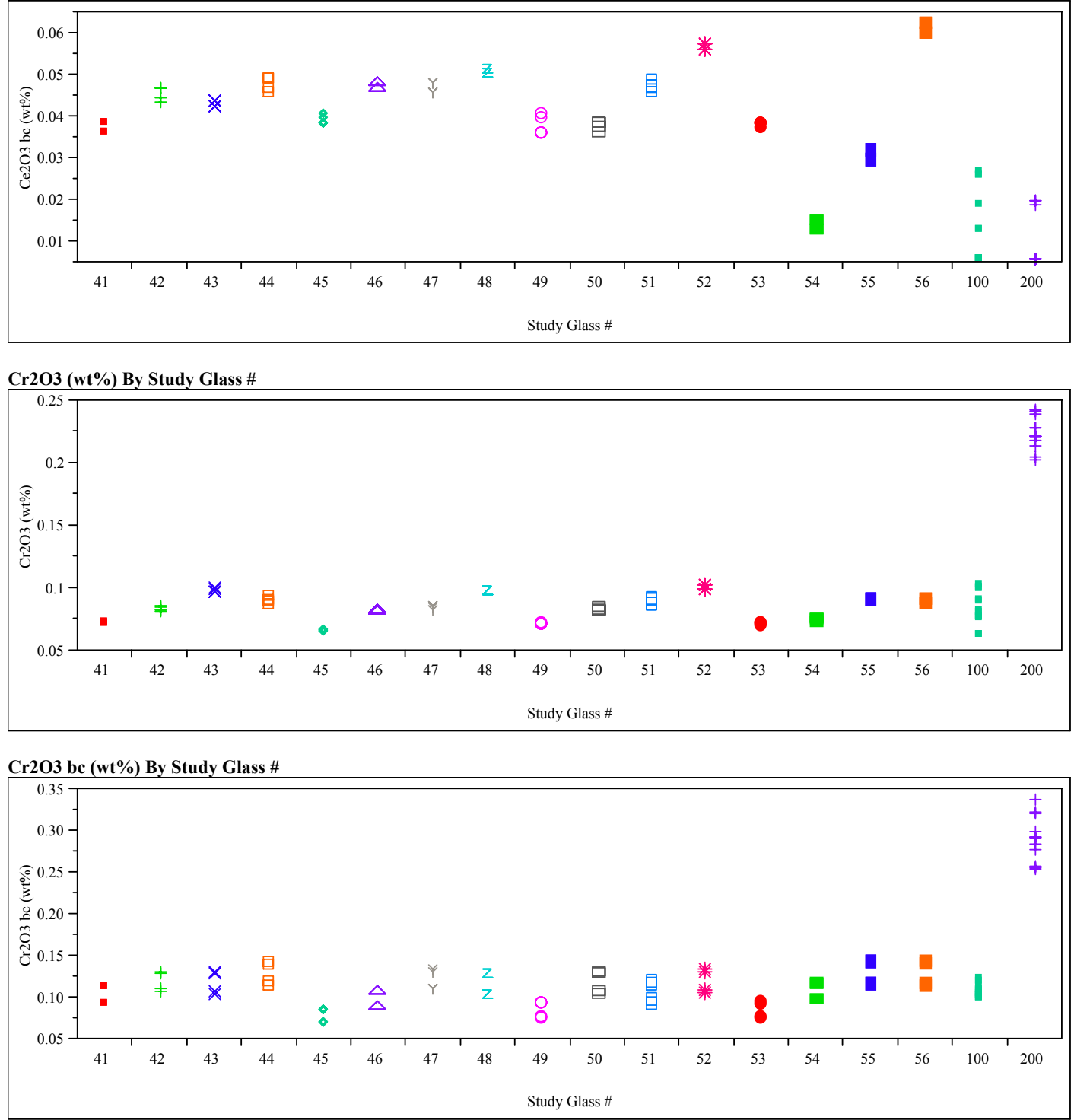
Exhibit D5. Measured and Measured Bias-Corrected Oxide Weight Percents by Glass \# for the Glasses Prepared Using the LM Method (continued)

$$
\text { (100 - Batch 1; } 200 \text { - Ustd) }
$$
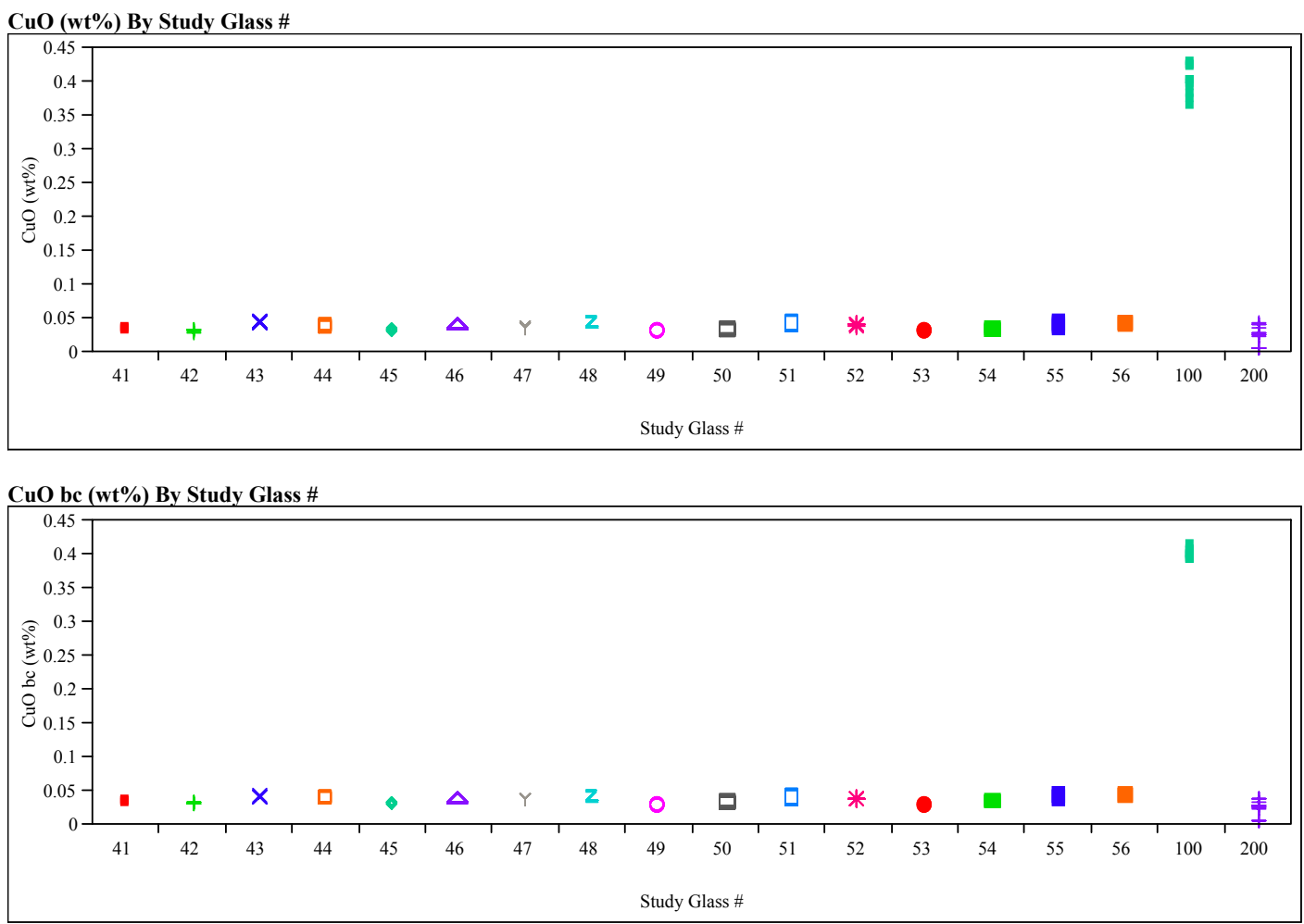

K2O (wt\%) By Study Glass \#

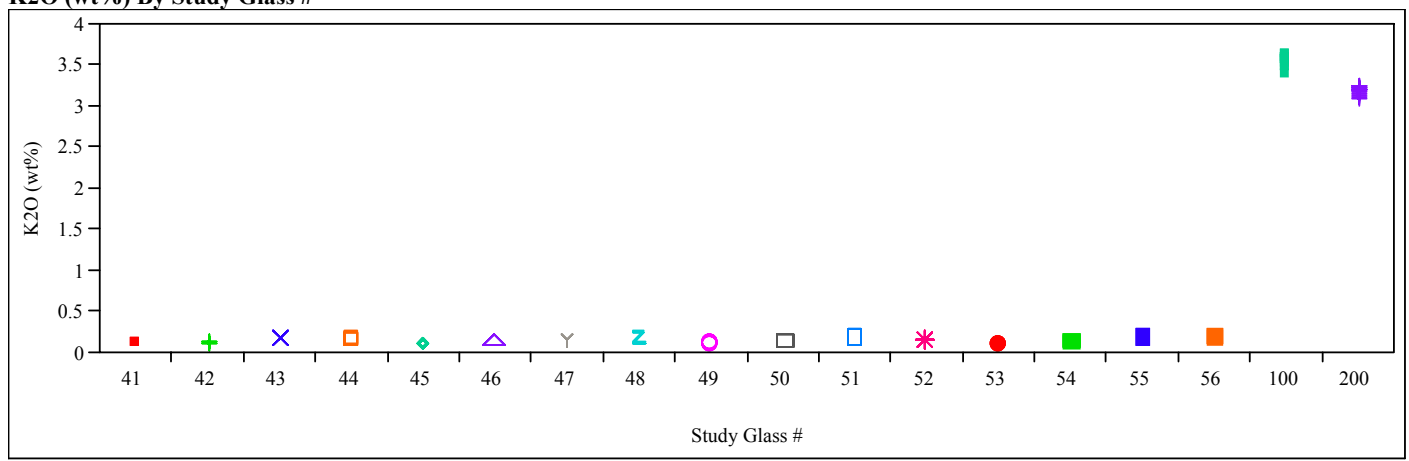

K2O bc (wt\%) By Study Glass \#

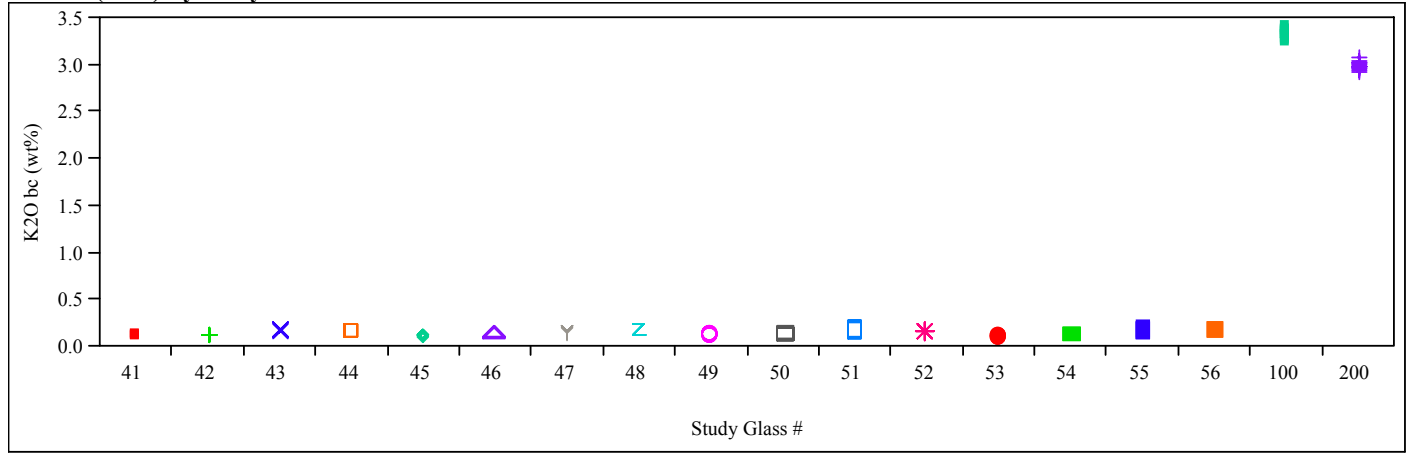




\section{Exhibit D5. Measured and Measured Bias-Corrected Oxide Weight Percents by} Glass \# for the Glasses Prepared Using the LM Method (continued)

$$
\text { (100 - Batch 1; } 200 \text { - Ustd) }
$$

La2O3 (wt\%) By Study Glass \#

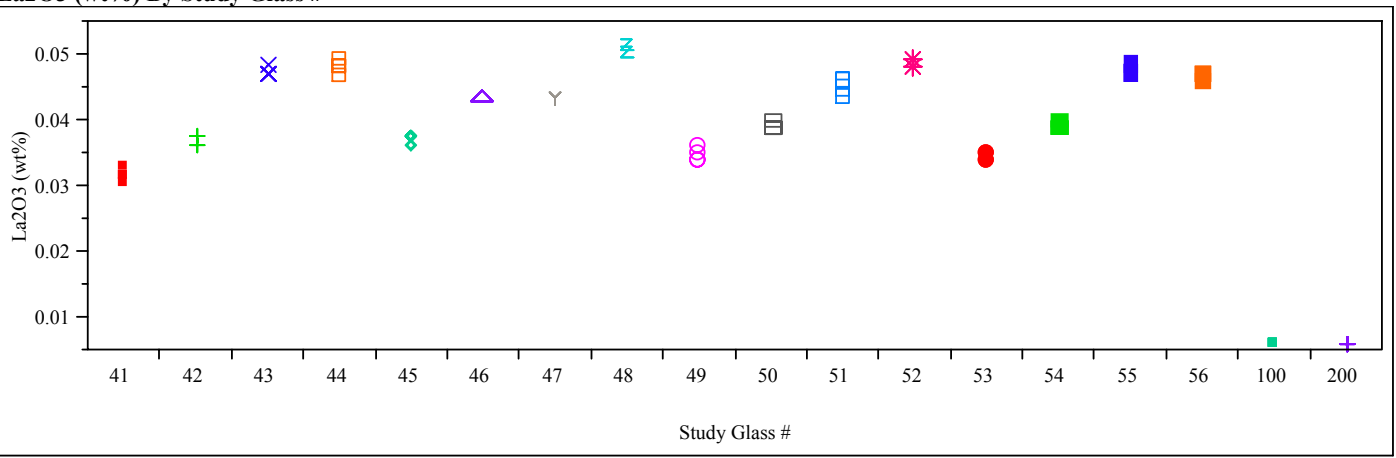

La2O3 bc (wt\%) By Study Glass \#
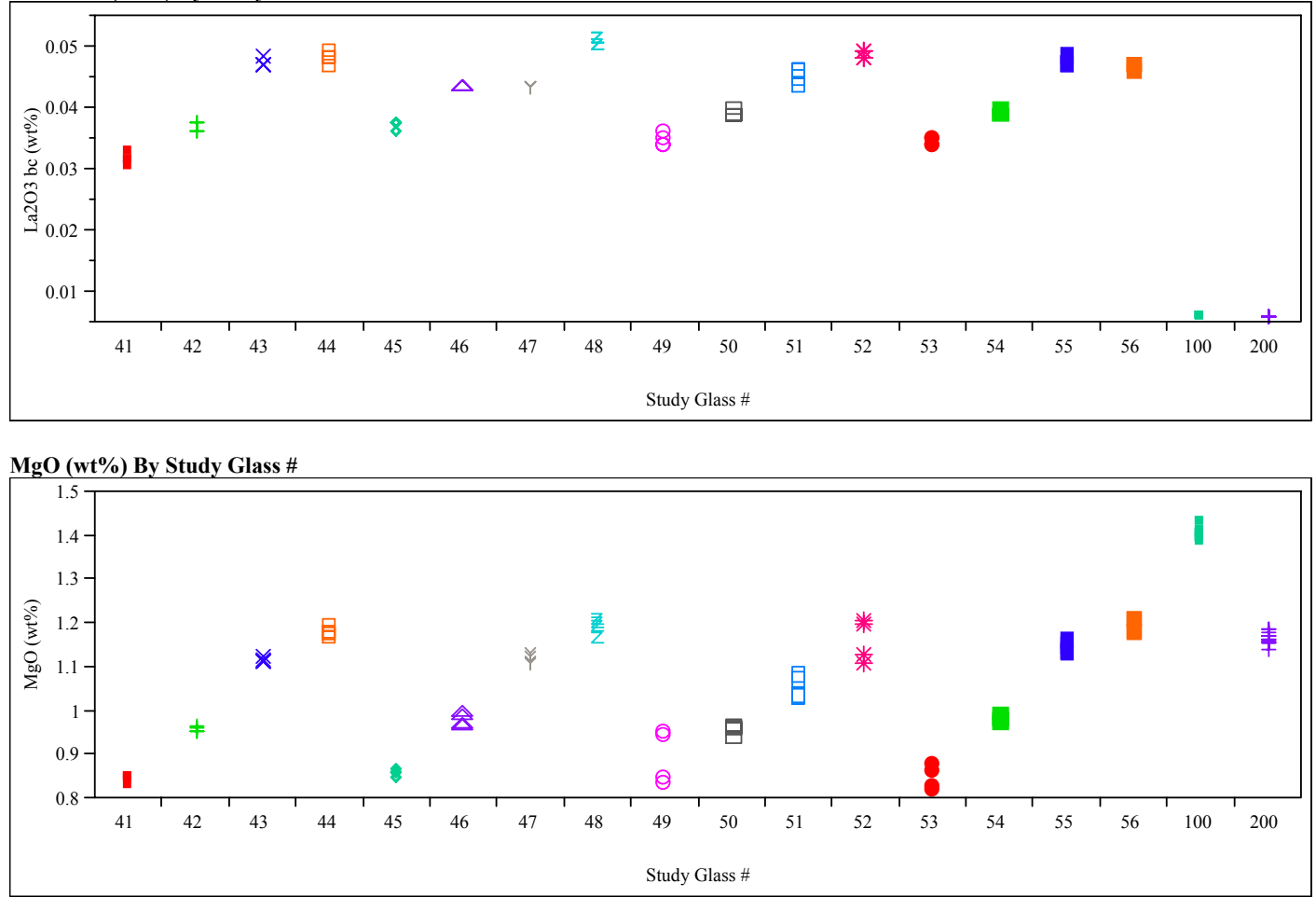

MgO bc (wt\%) By Study Glass \#

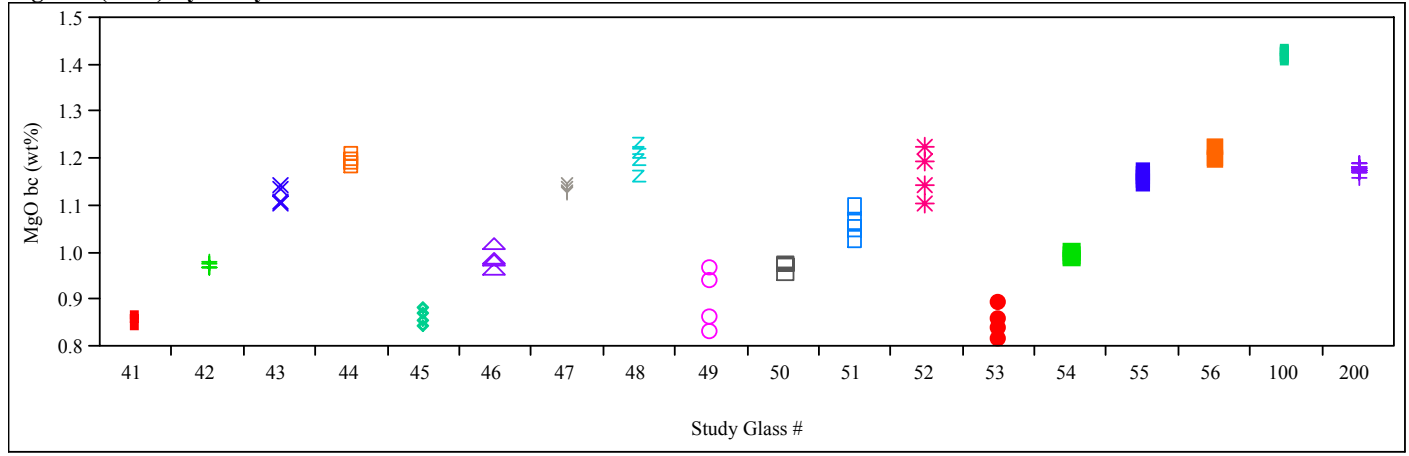


Exhibit D5. Measured and Measured Bias-Corrected Oxide Weight Percents by Glass \# for the Glasses Prepared Using the LM Method (continued)

(100 - Batch 1; 200 - Ustd)

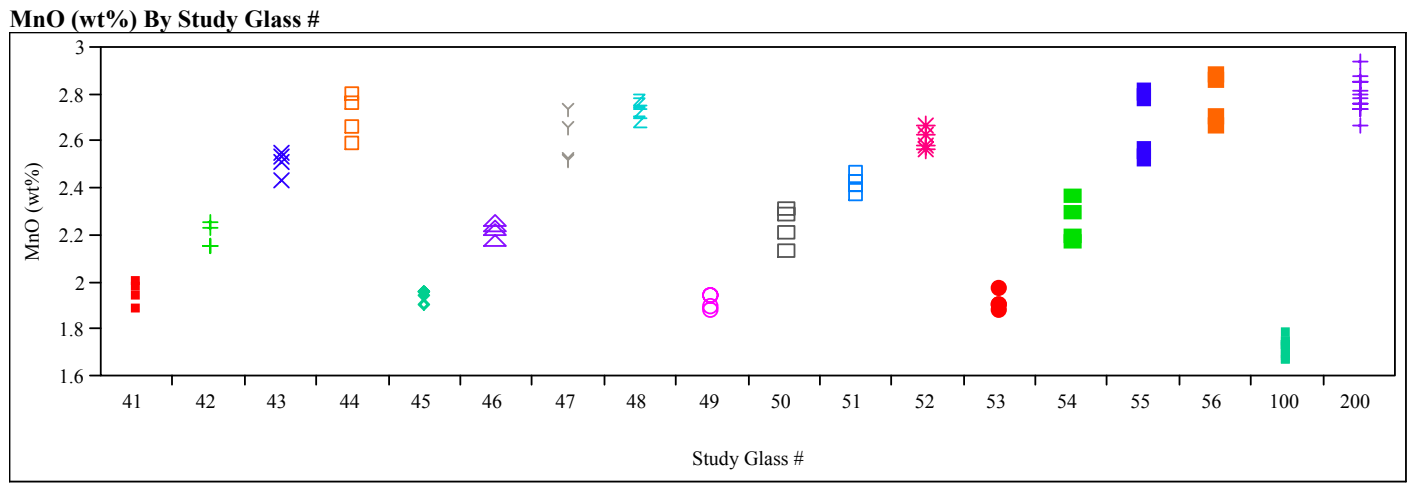

MnO bc (wt\%) By Study Glass \#
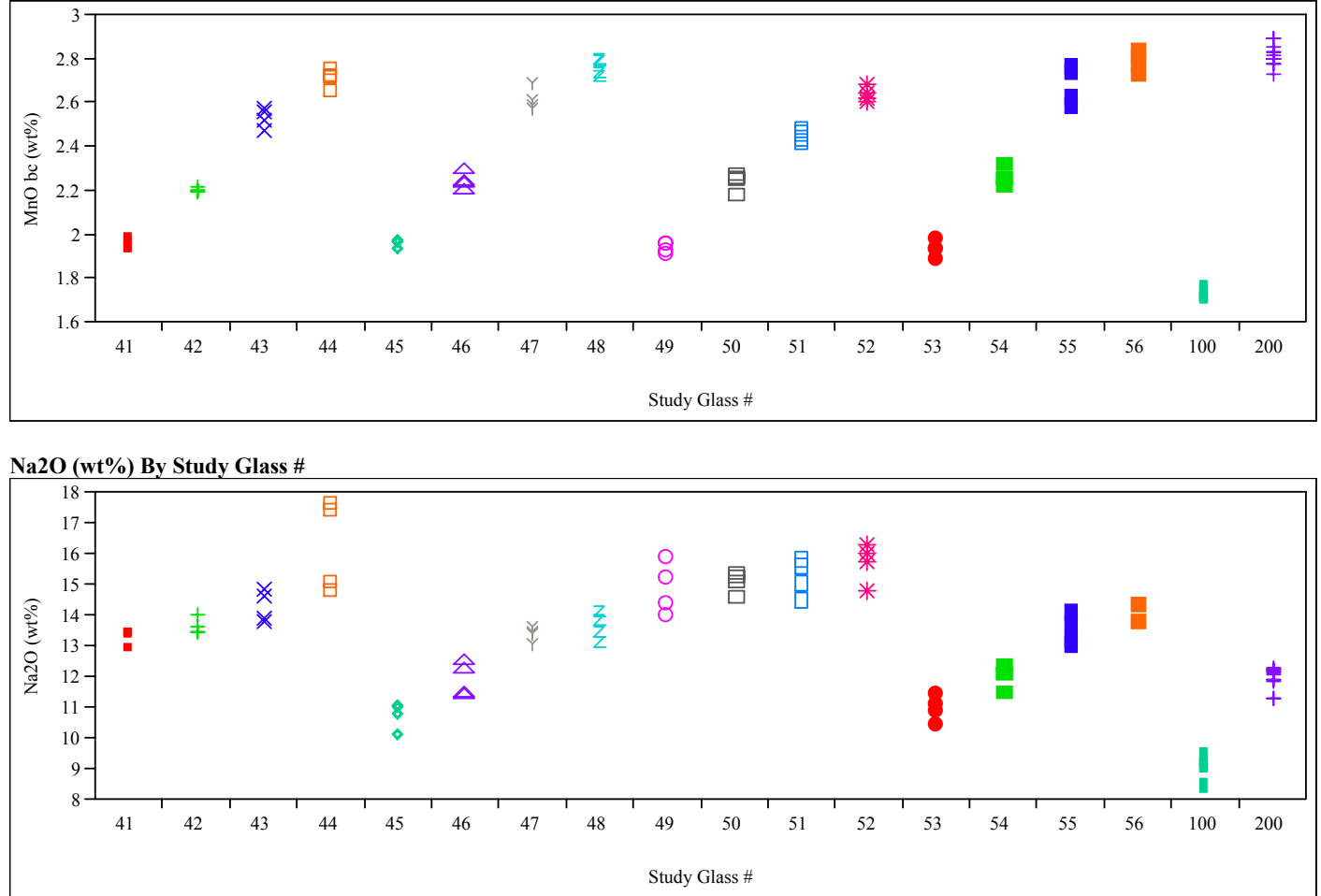

Na2O bc (wt\%) By Study Glass \#

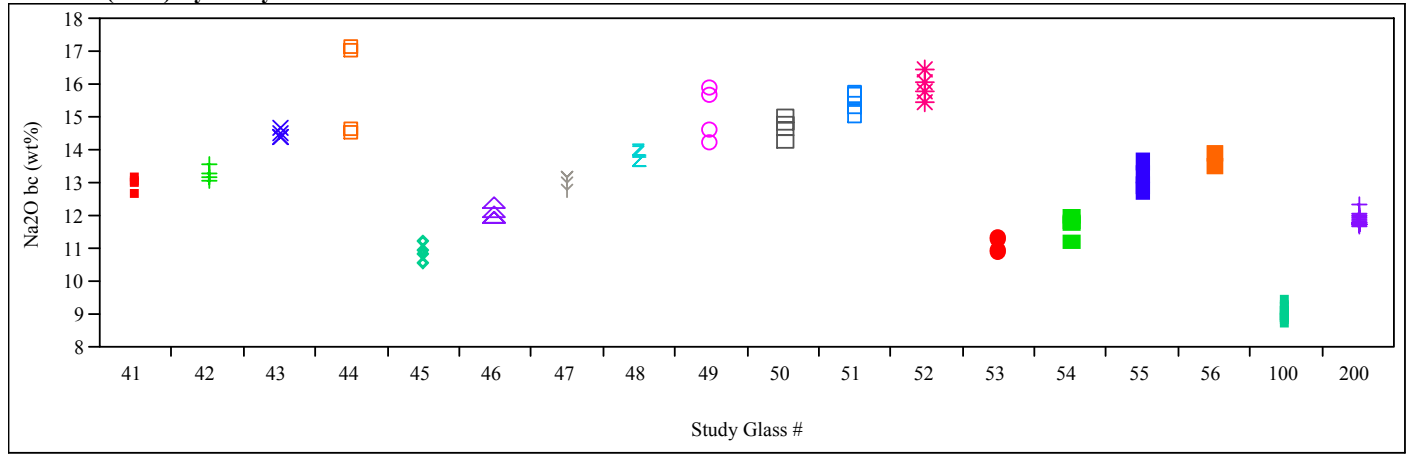


Exhibit D5. Measured and Measured Bias-Corrected Oxide Weight Percents by Glass \# for the Glasses Prepared Using the LM Method (continued)

$$
\text { (100 - Batch 1; } 200-\text { Ustd) }
$$

PbO (wt\%) By Study Glass \#
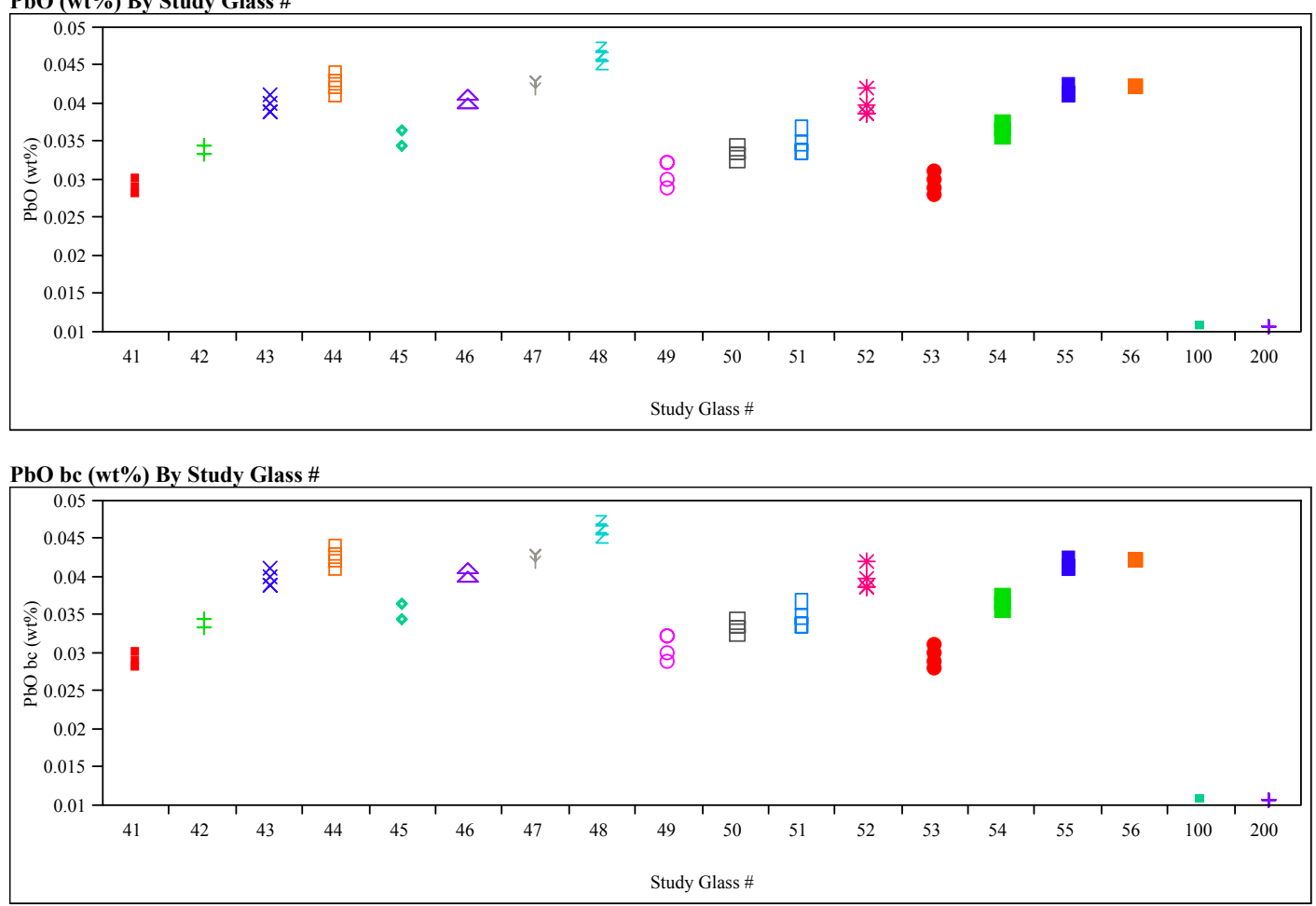

SO4 (wt \%) By Study Glass \#

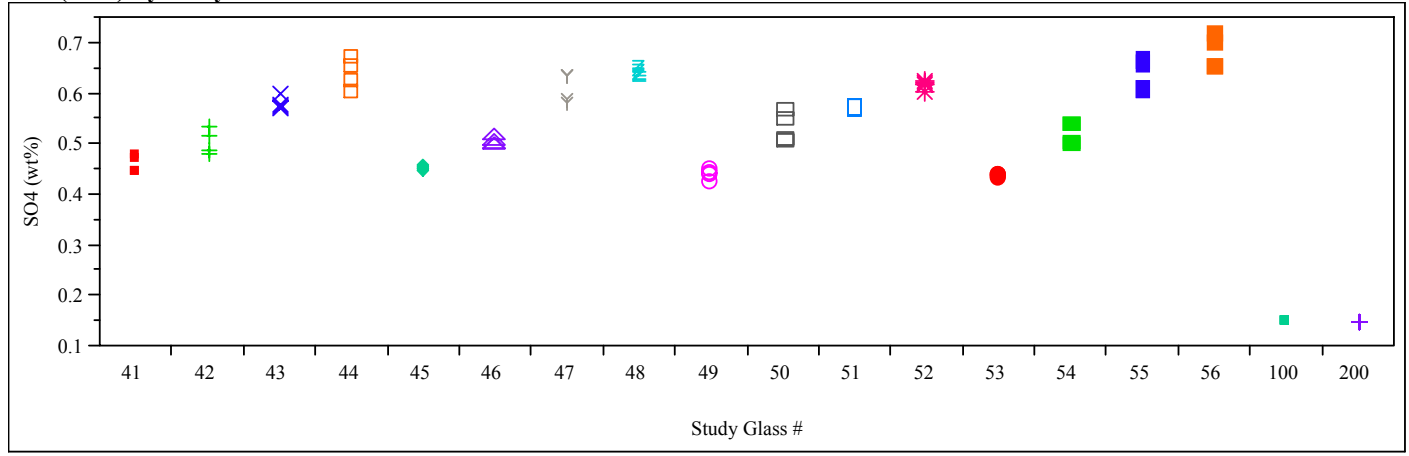

SO4 bc (wt\%) By Study Glass \#

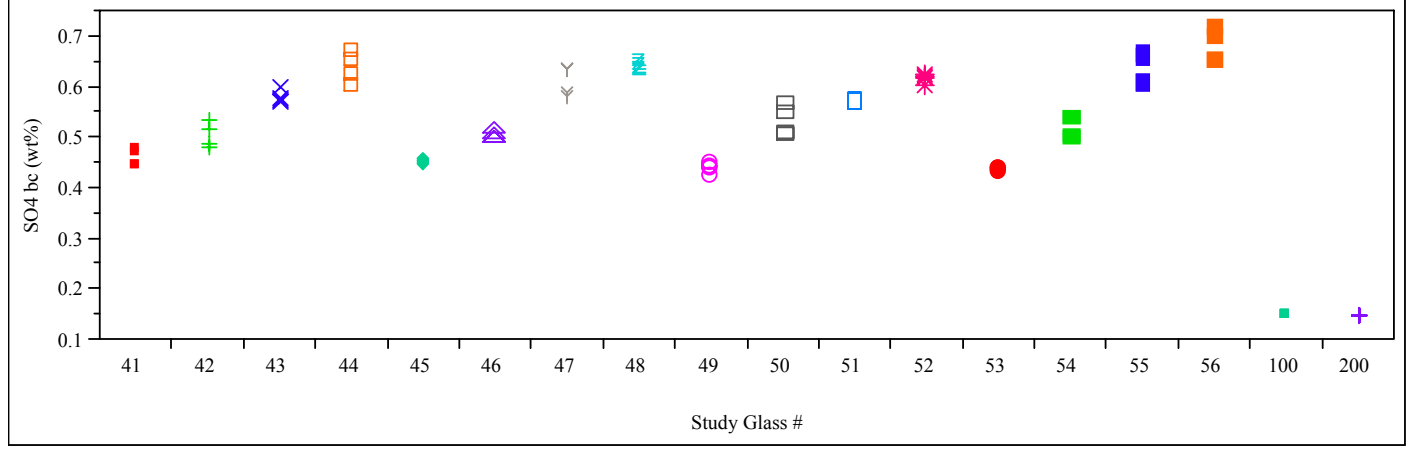


Exhibit D5. Measured and Measured Bias-Corrected Oxide Weight Percents by Glass \# for the Glasses Prepared Using the LM Method (continued)

$$
\text { (100 - Batch 1; } 200 \text { - Ustd) }
$$

ThO2 (wt \%) By Study Glass \#

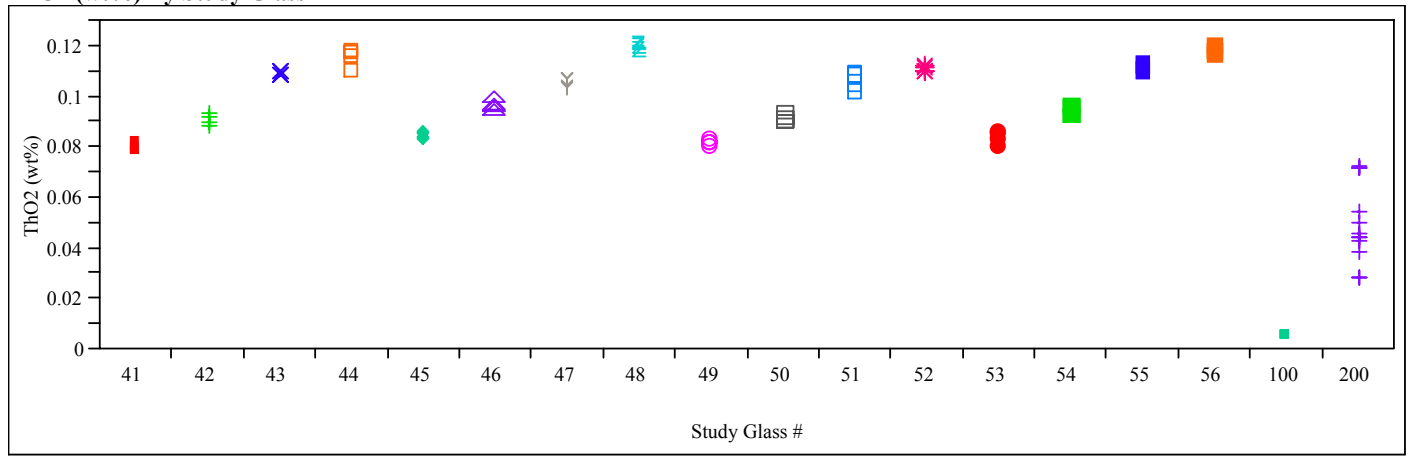

ThO2 bc (wt\%) By Study Glass \#

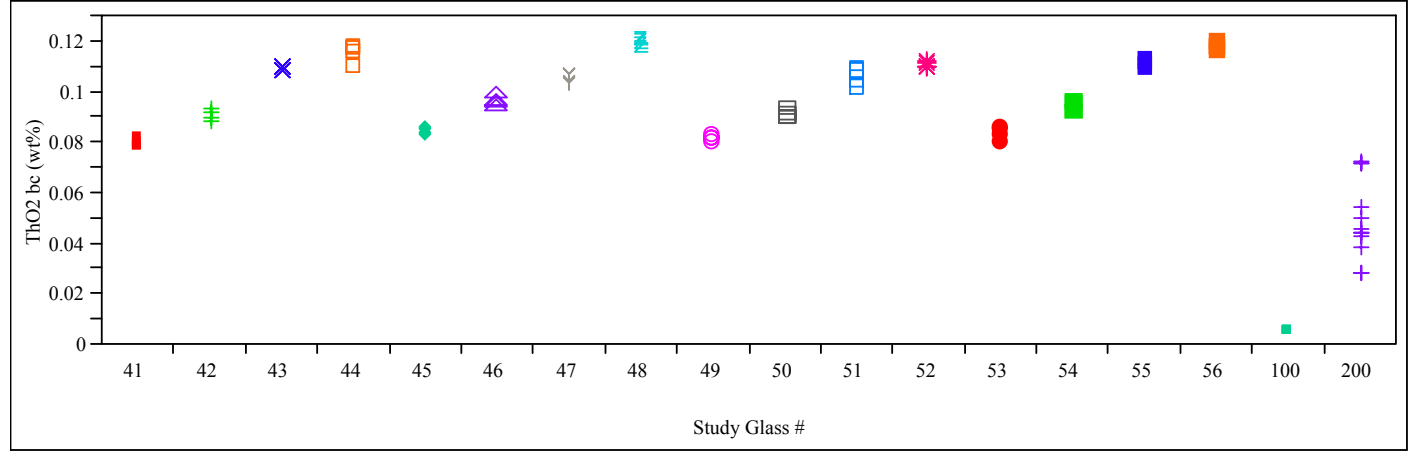

TiO2 (wt\%) By Study Glass \#

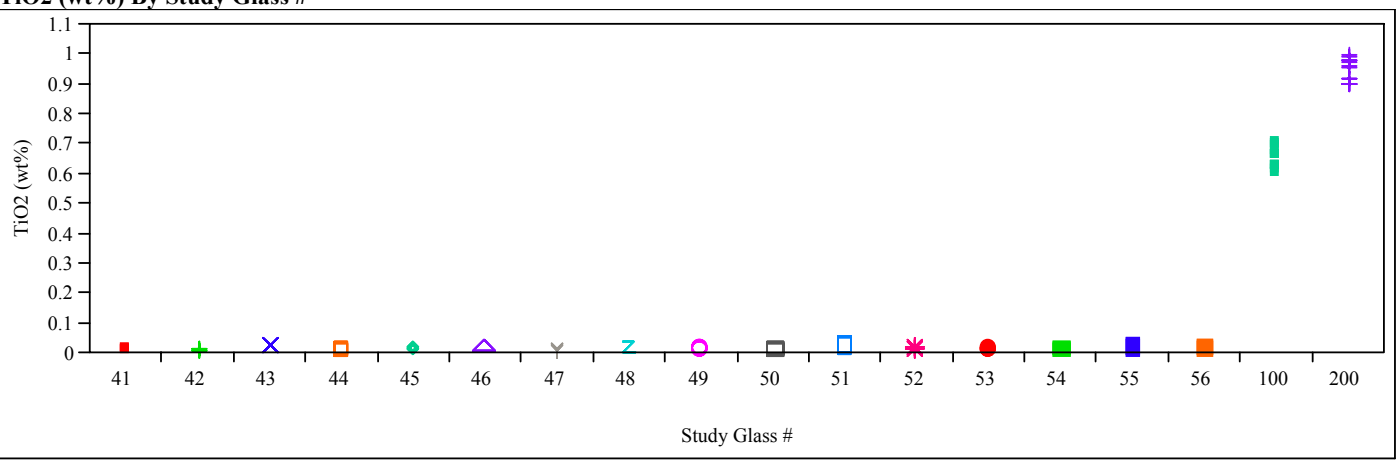

TiO2 bc (wt\%) By Study Glass \#

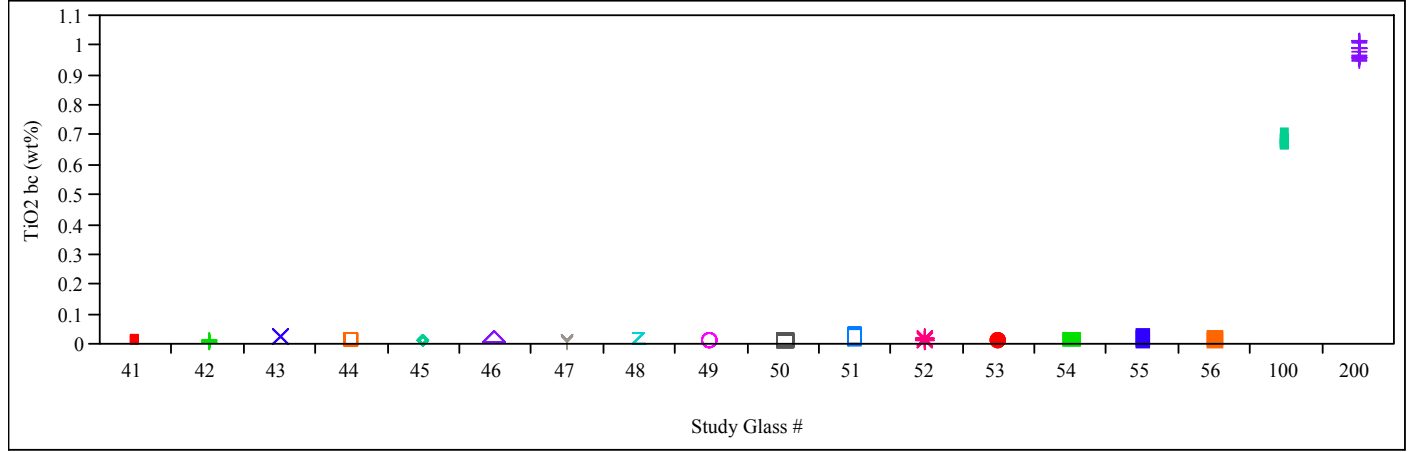


Exhibit D5. Measured and Measured Bias-Corrected Oxide Weight Percents by Glass \# for the Glasses Prepared Using the LM Method (continued)

$$
\text { (100 - Batch 1; } 200-\text { Ustd) }
$$
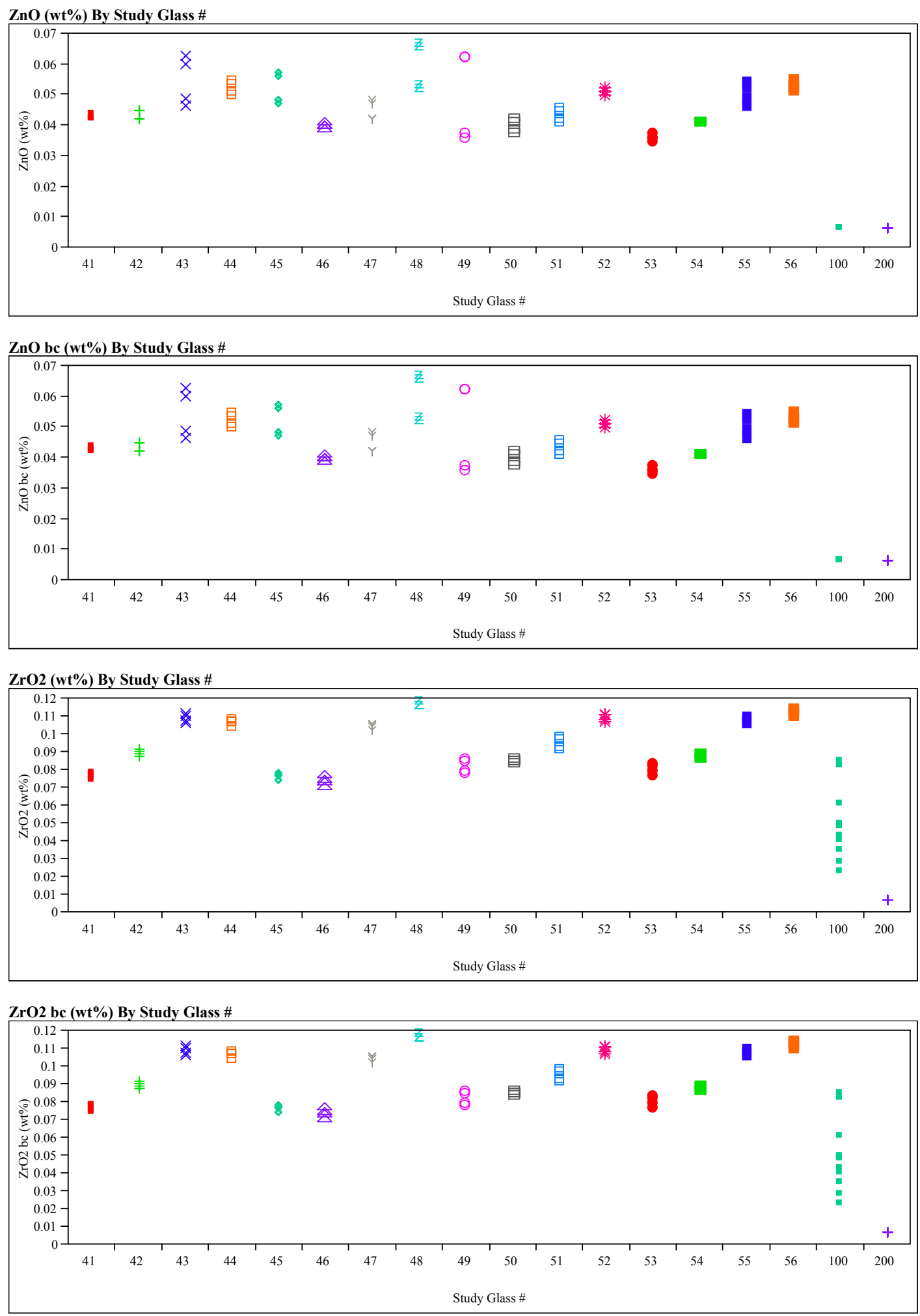
Exhibit D6. Measured and Measured Bias-Corrected Oxide Weight Percents by Glass \# for the Glasses Prepared Using the PF Method

(100 - Batch 1; 200 - Ustd)
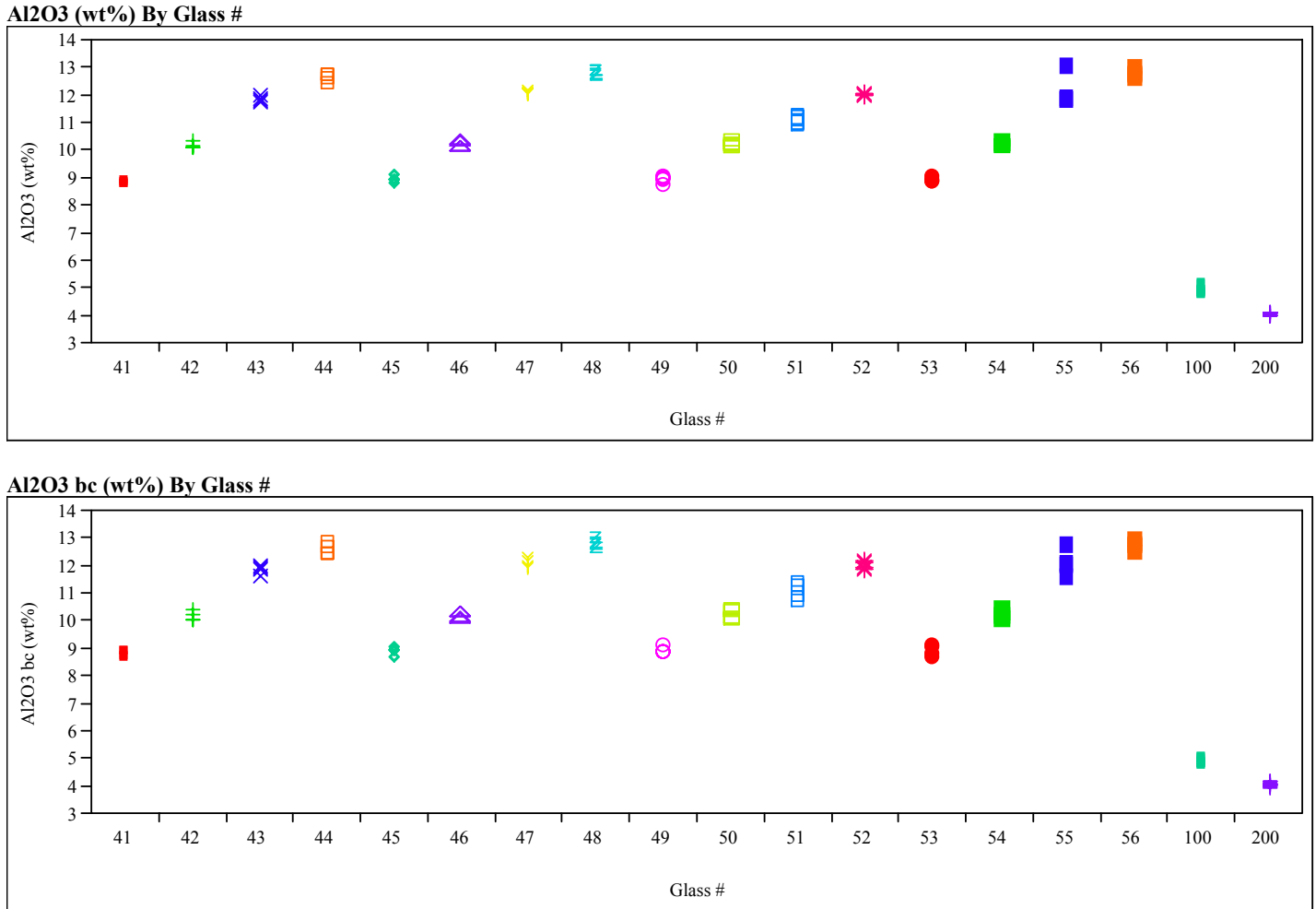

B2O3 (wt\%) By Glass \#

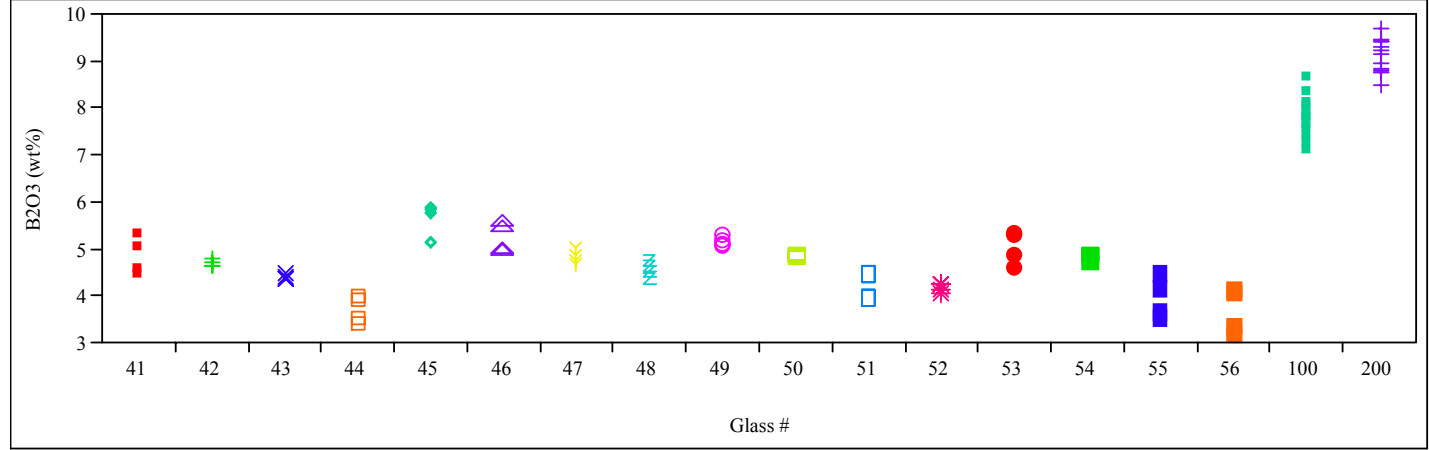


Exhibit D6. Measured and Measured Bias-Corrected Oxide Weight Percents by Glass \# for the Glasses Prepared Using the PF Method (continued)

$$
\text { (100 - Batch 1; } 200 \text { - Ustd) }
$$

B2O3 bc (wt\%) By Glass \#

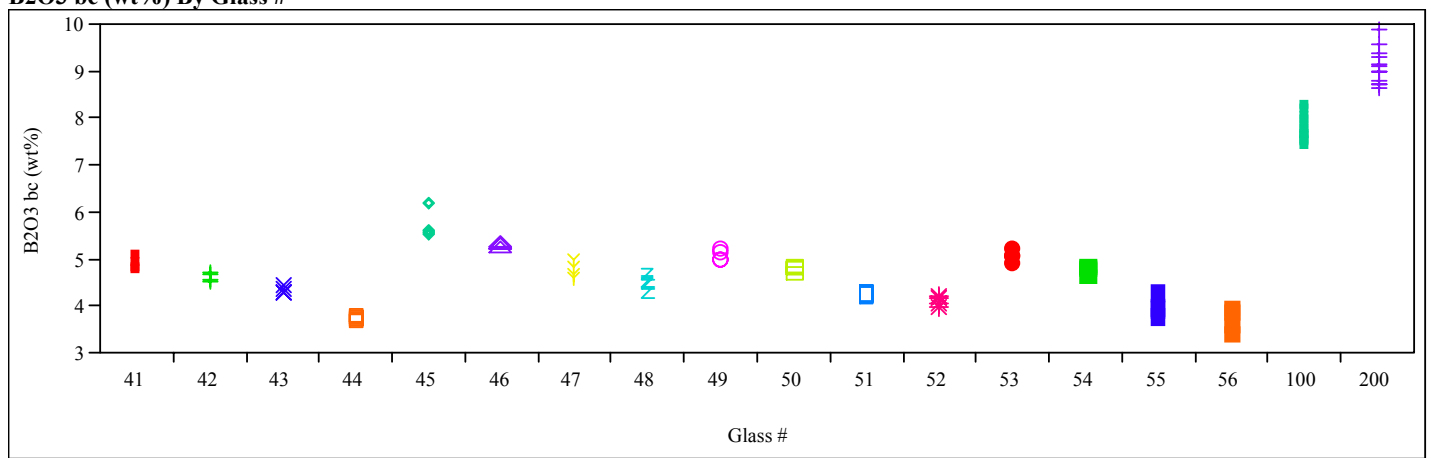

Fe2O3 (wt\%) By Glass \#

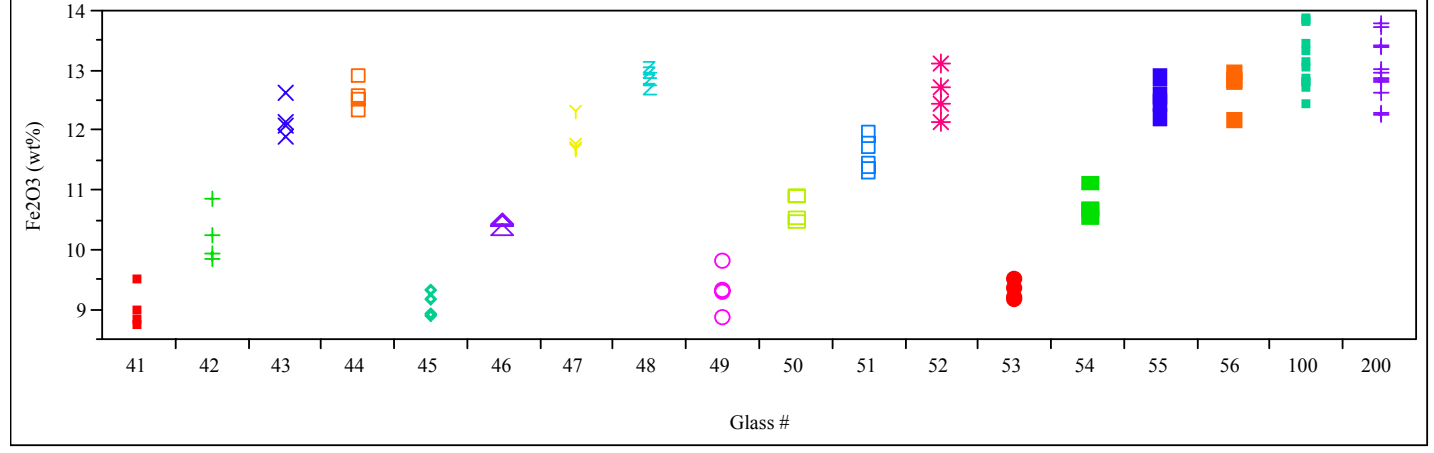

Fe2O3 bc (wt\%) By Glass \#

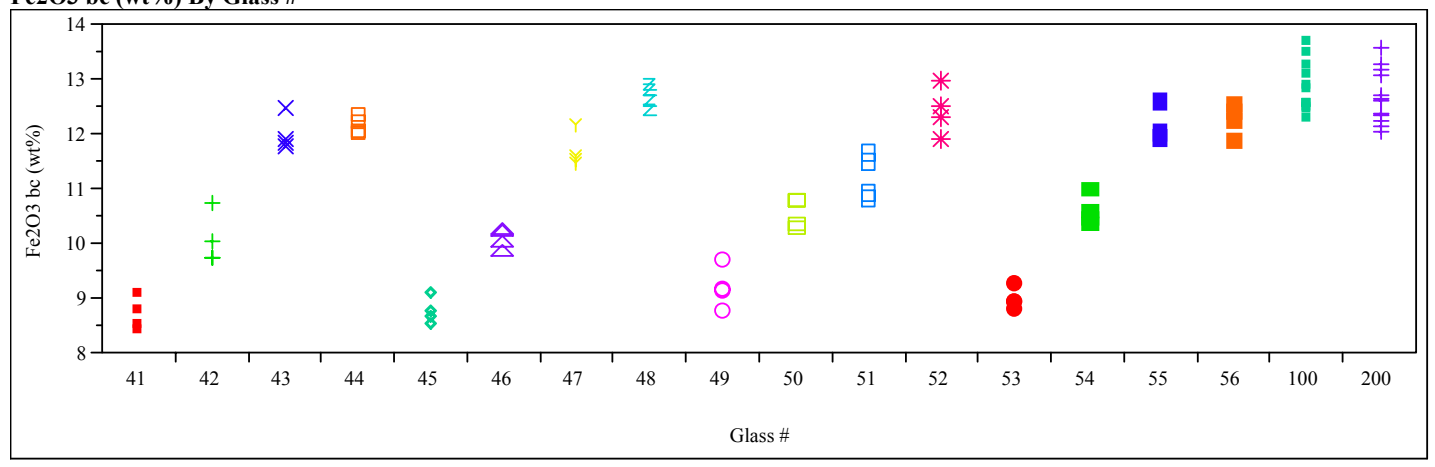

Li2O (wt\%) By Glass \#

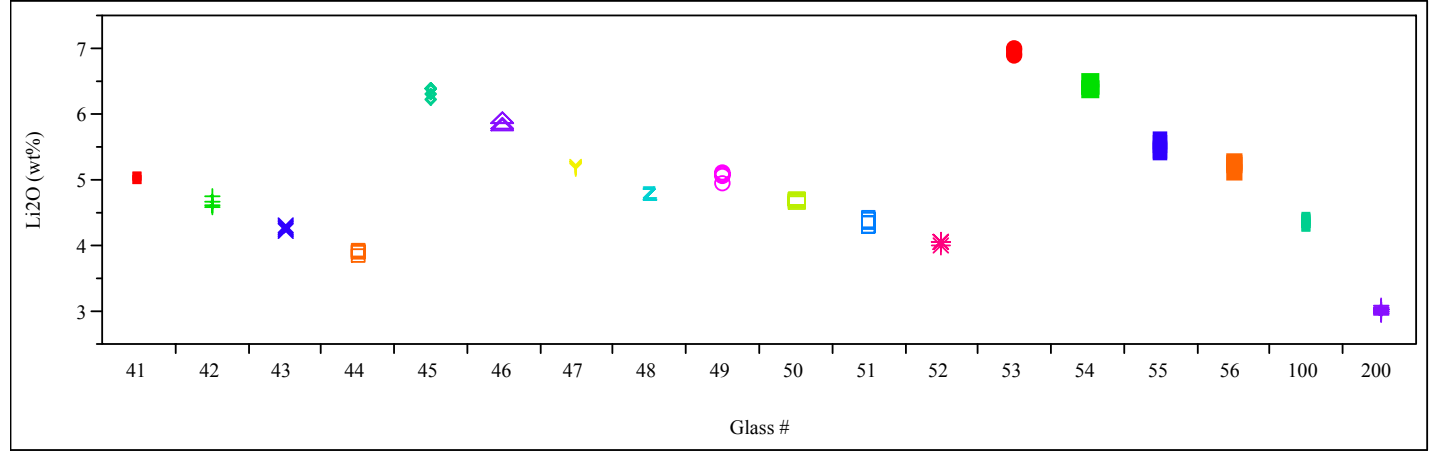


Exhibit D6. Measured and Measured Bias-Corrected Oxide Weight Percents by Glass \# for the Glasses Prepared Using the PF Method (continued)

$$
\text { (100 - Batch 1; } 200-\text { Ustd) }
$$
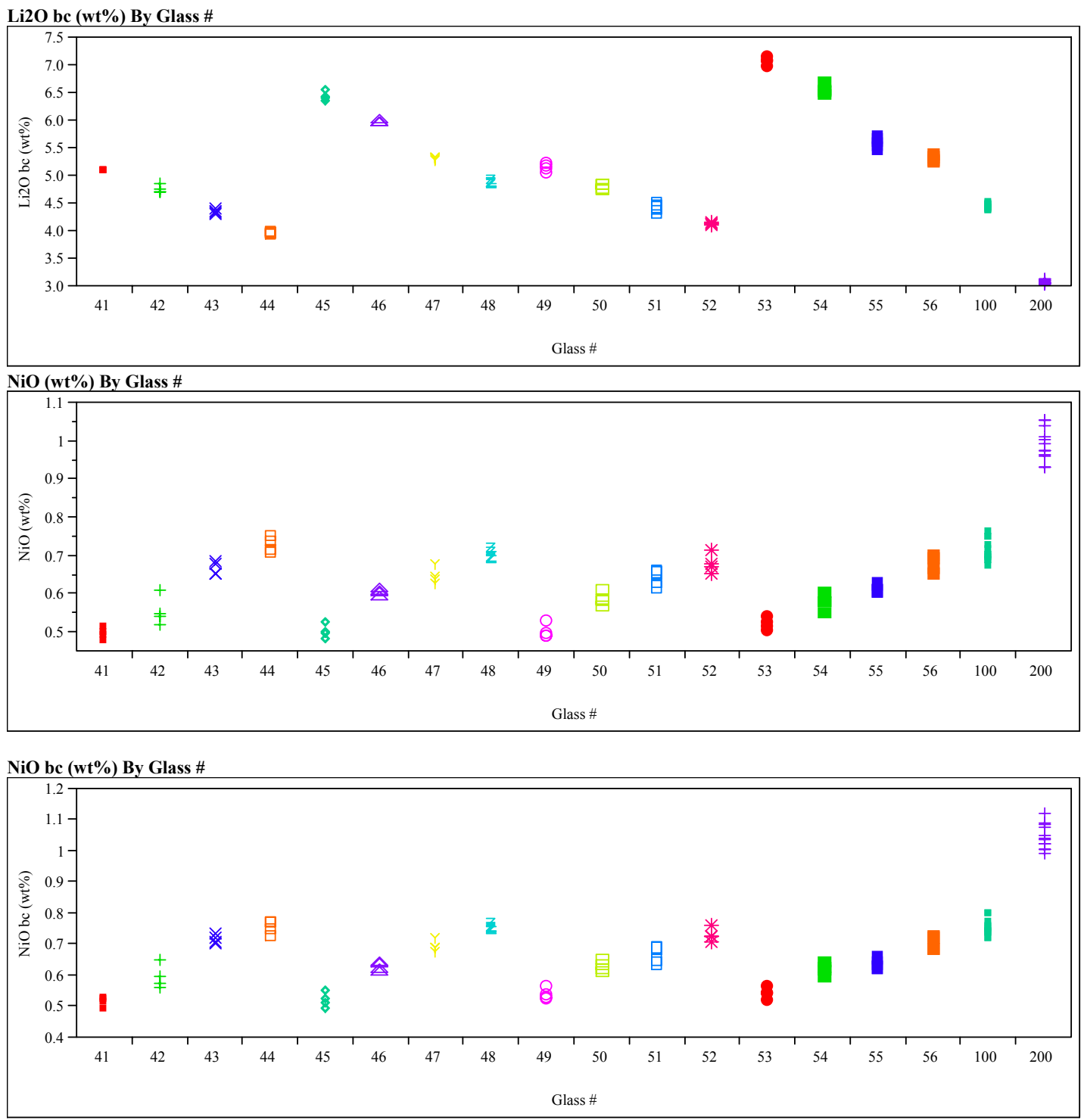
Exhibit D6. Measured and Measured Bias-Corrected Oxide Weight Percents by Glass \# for the Glasses Prepared Using the PF Method (continued)

$$
\text { (100 - Batch 1; } 200-\text { Ustd) }
$$

SiO2 (wt\%) By Glass \#

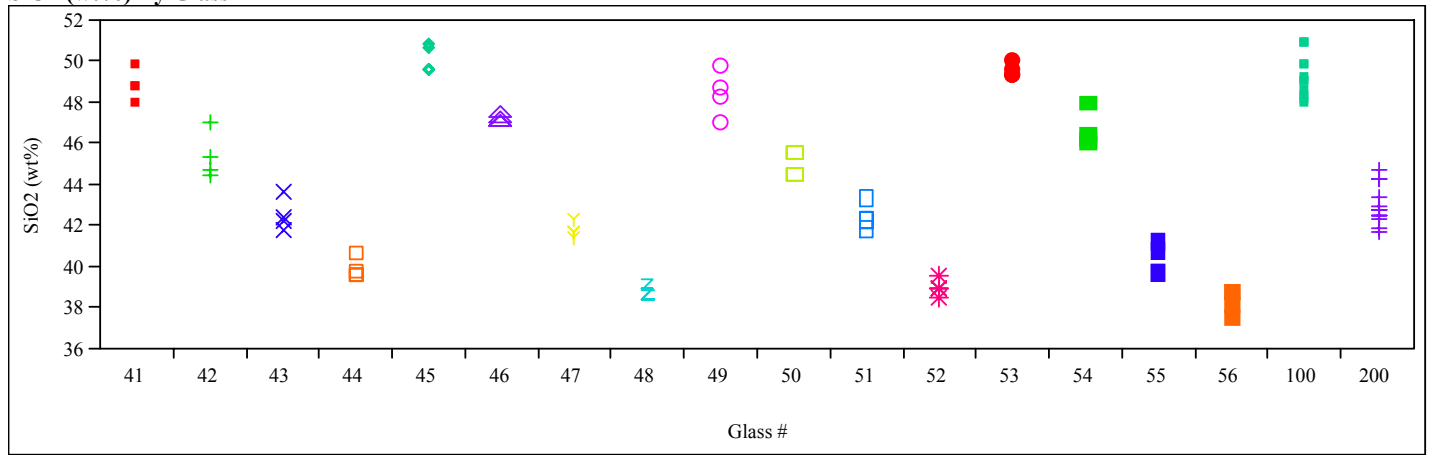

SiO2 bc (wt\%) By Glass \#

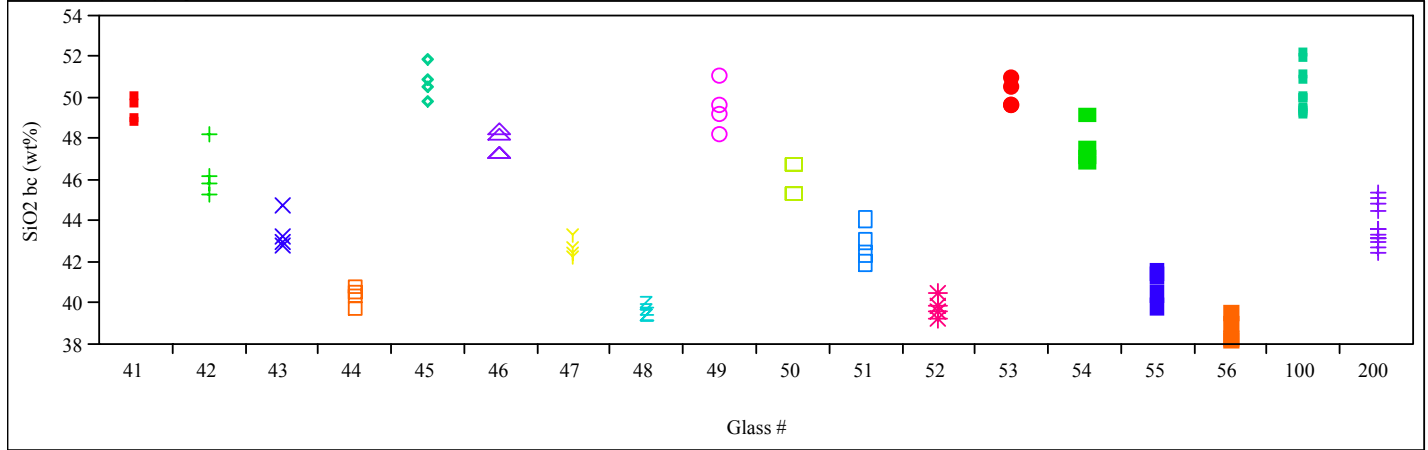

U3O8 (wt \%) By Glass \#

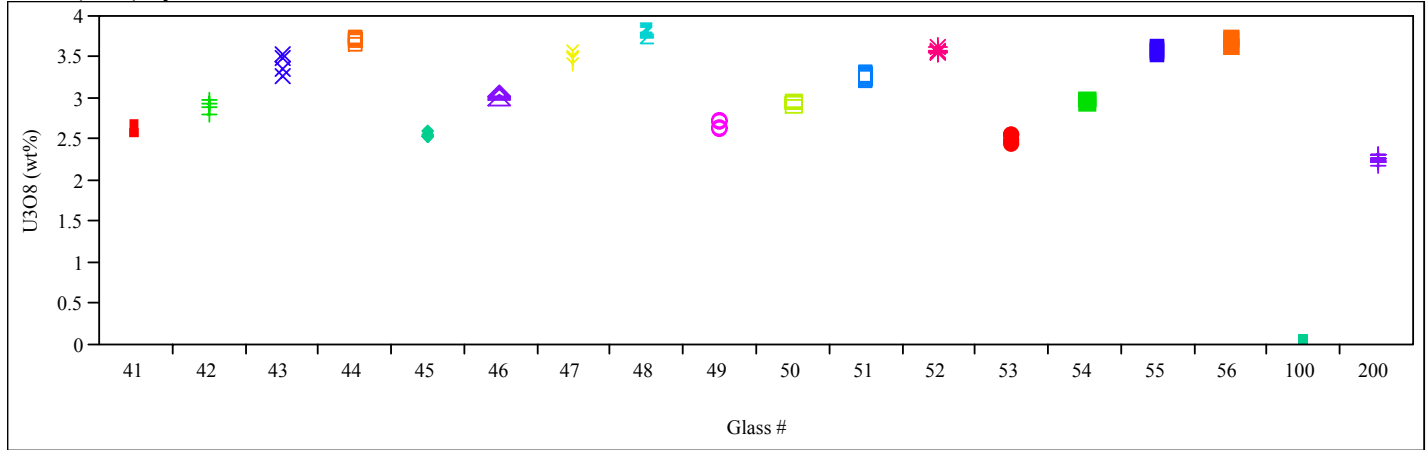


Exhibit D6. Measured and Measured Bias-Corrected Oxide Weight Percents by Glass \# for the Glasses Prepared Using the PF Method (continued)

$$
\text { (100 - Batch 1; } 200 \text { - Ustd) }
$$

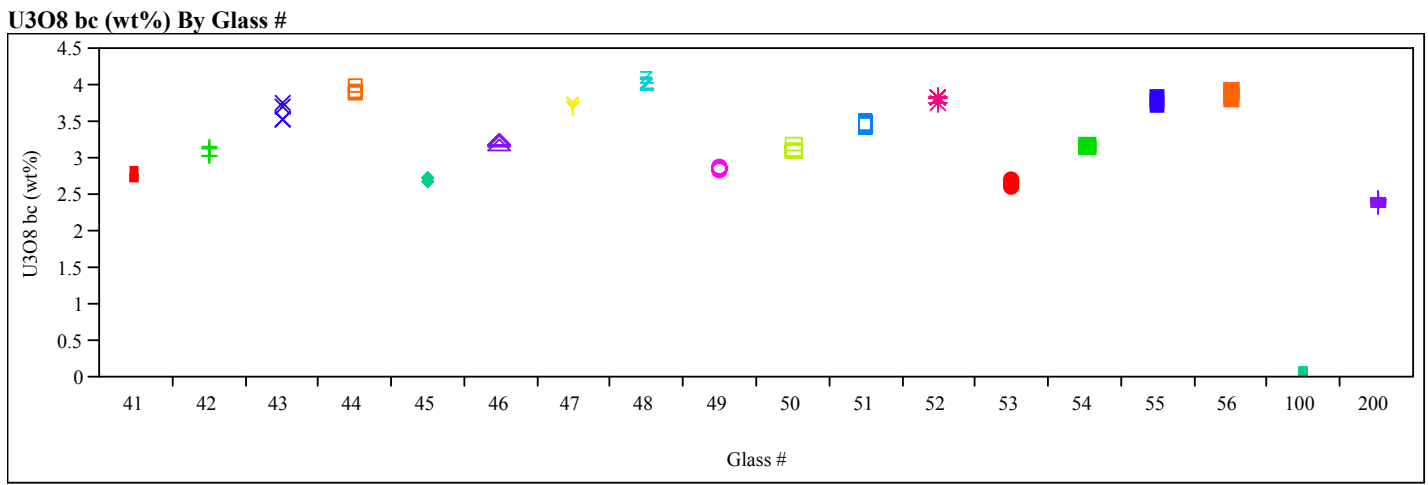


Exhibit D7. Average Measured and Bias-Corrected (bc) Versus Targeted Compositions by Glass \# by Oxide

(100 - Batch 1; 200 - Ustd)

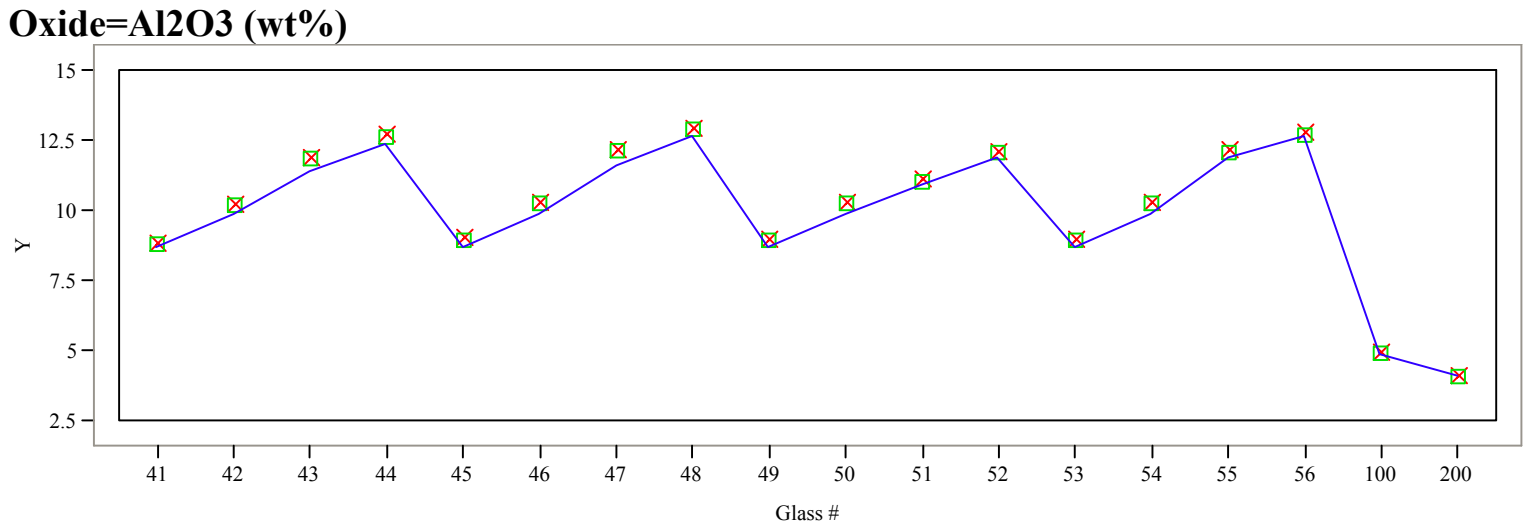

Oxide $=$ B2O3 (wt\%)

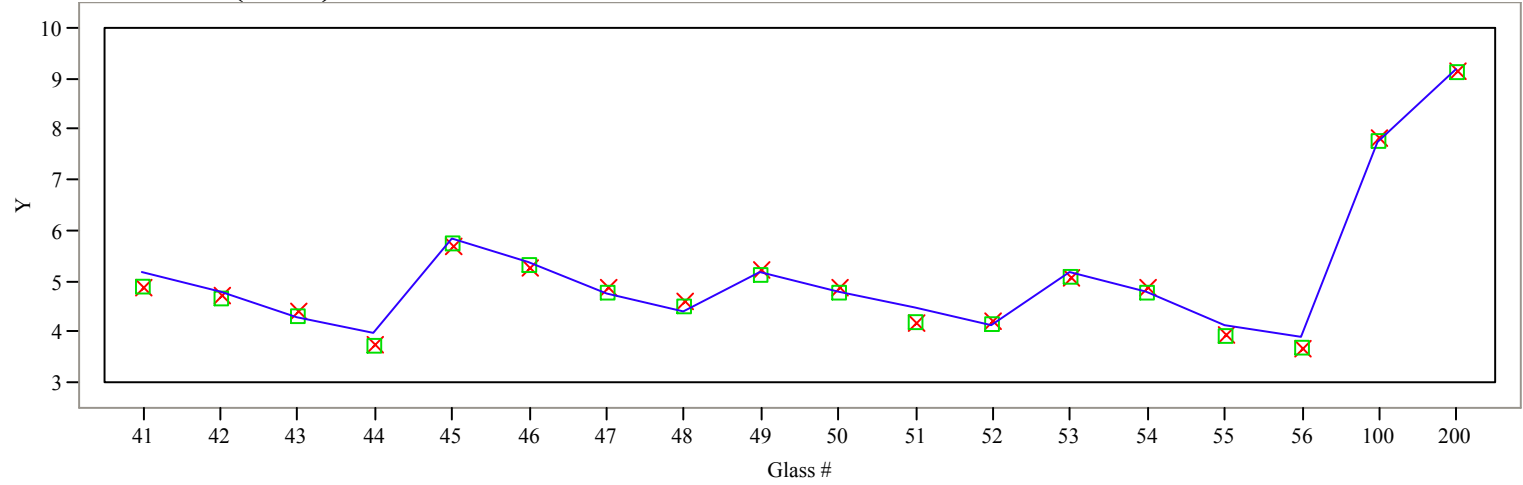

Oxide $=\mathrm{BaO}($ wt $\%)$

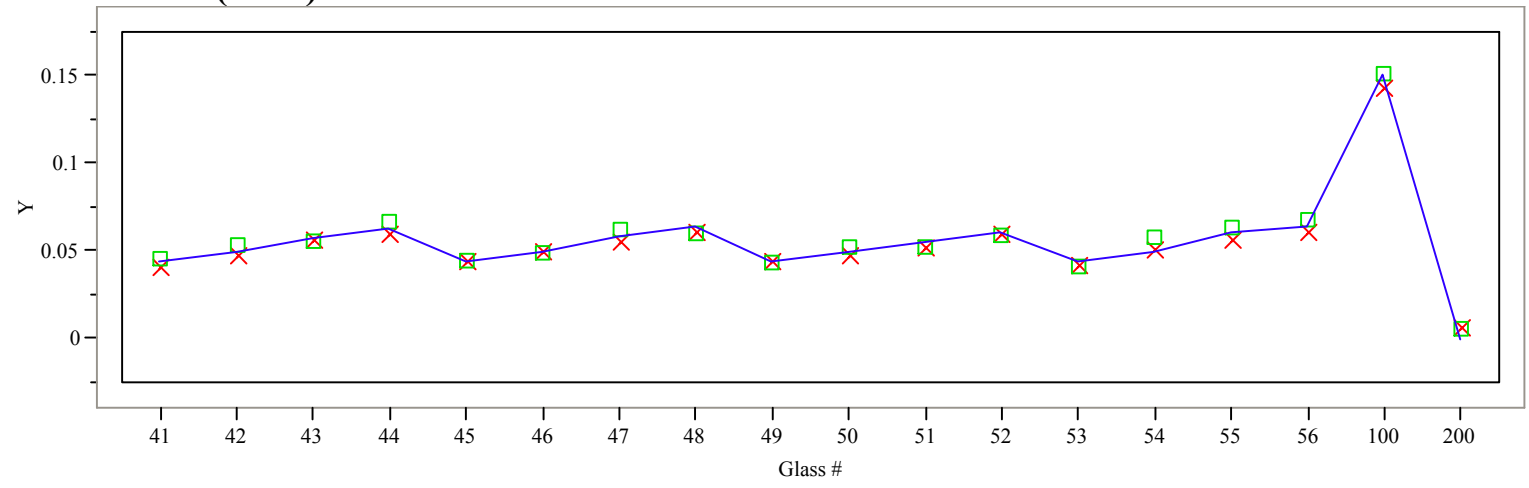

$\mathrm{Y} \times$ Measured $\square$ Measured bc - Targeted 
Exhibit D7. Average Measured and Bias-Corrected (bc) Versus Targeted Compositions by Glass \# by Oxide (continued)

$$
\text { (100 - Batch 1; } 200 \text { - Ustd) }
$$

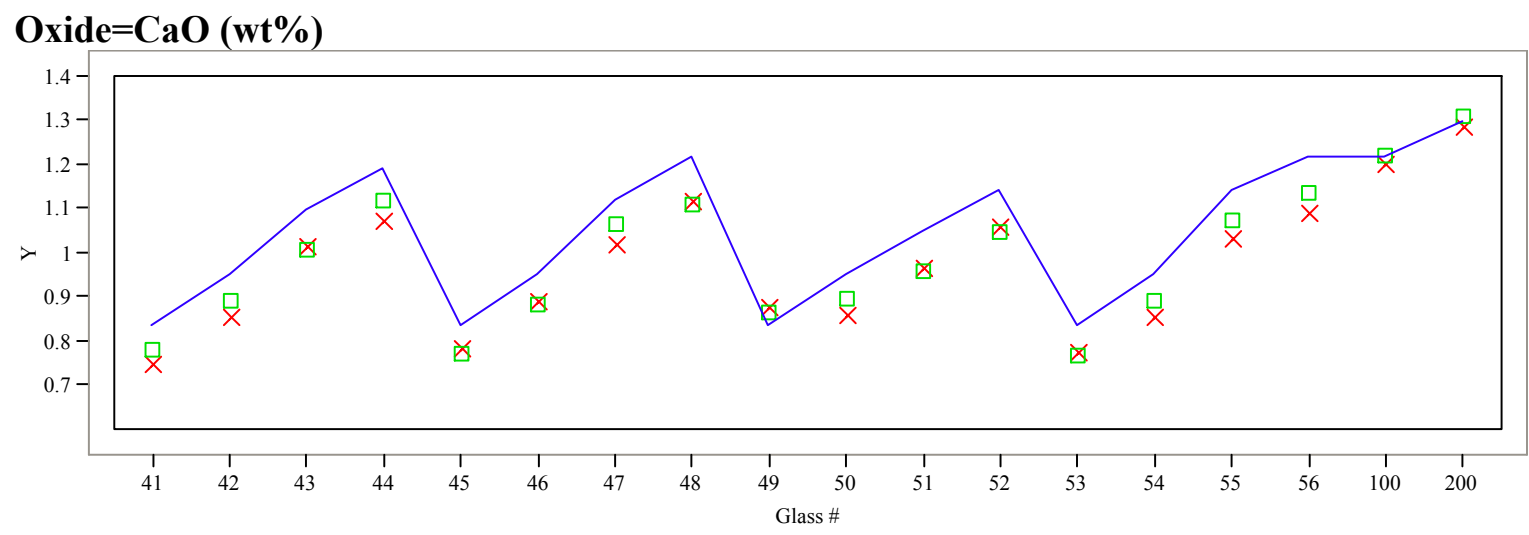

\section{Oxide $=\operatorname{Ce2O3}(w t \%)$}

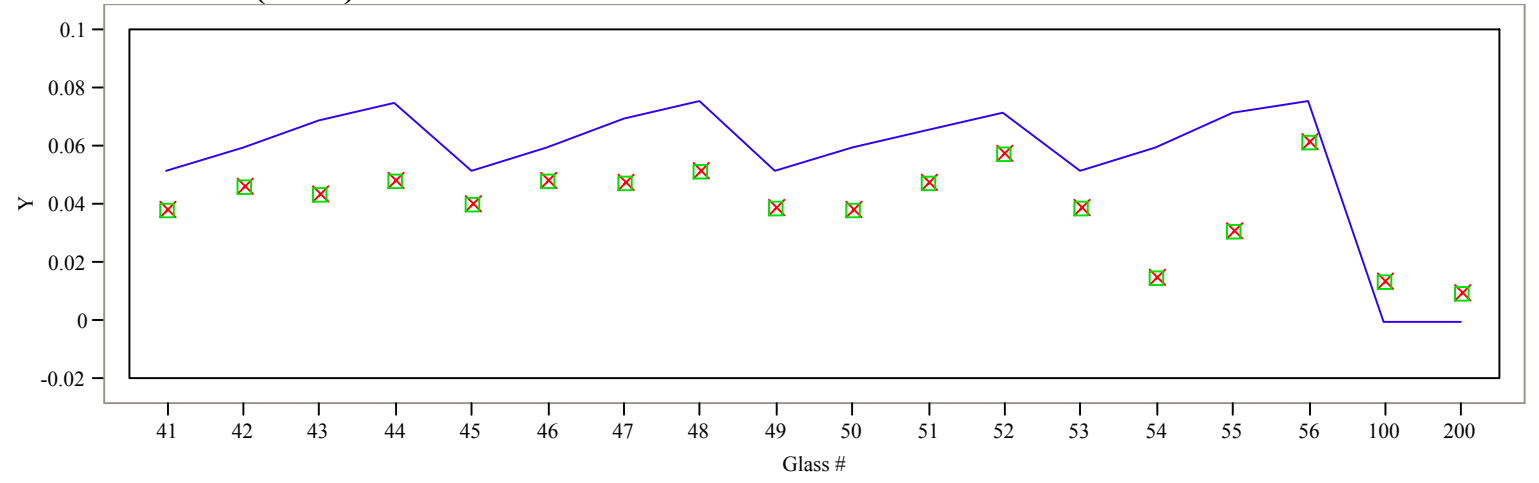

Oxide $=\operatorname{Cr2O3}(\mathbf{w t} \%)$

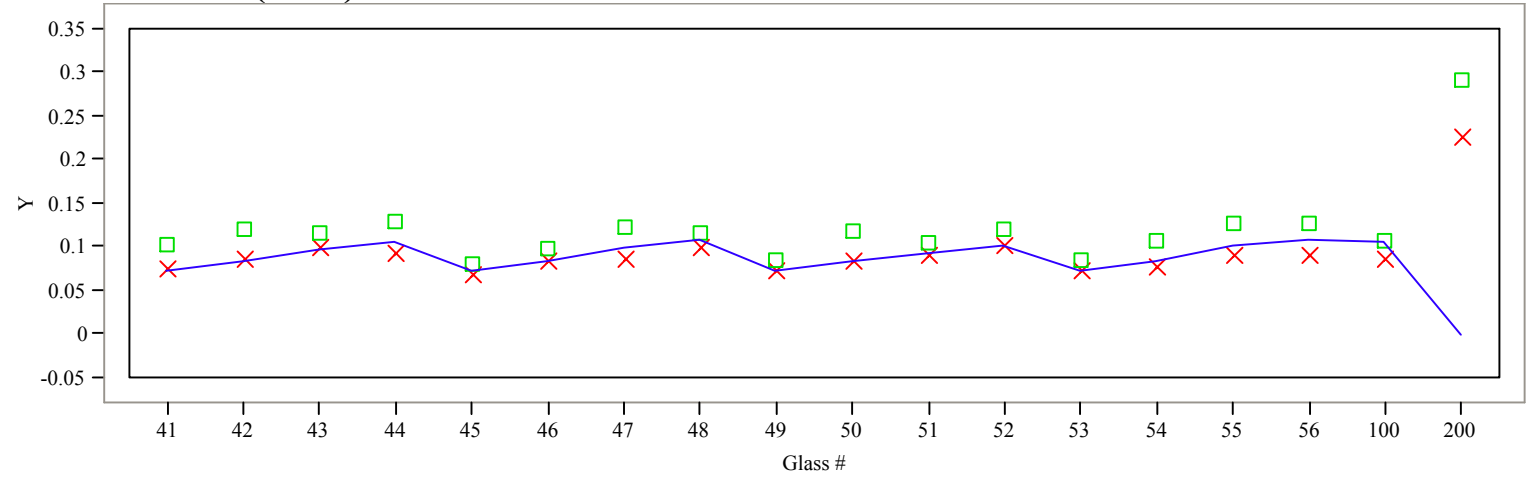

$\mathrm{Y} \times$ Measured Measured bc - Targeted 
Exhibit D7. Average Measured and Bias-Corrected (bc) Versus Targeted Compositions by Glass \# by Oxide (continued)

$$
\text { (100 - Batch 1; } 200 \text { - Ustd) }
$$

\section{Oxide $=\mathrm{CuO}(\mathbf{w t} \%)$}

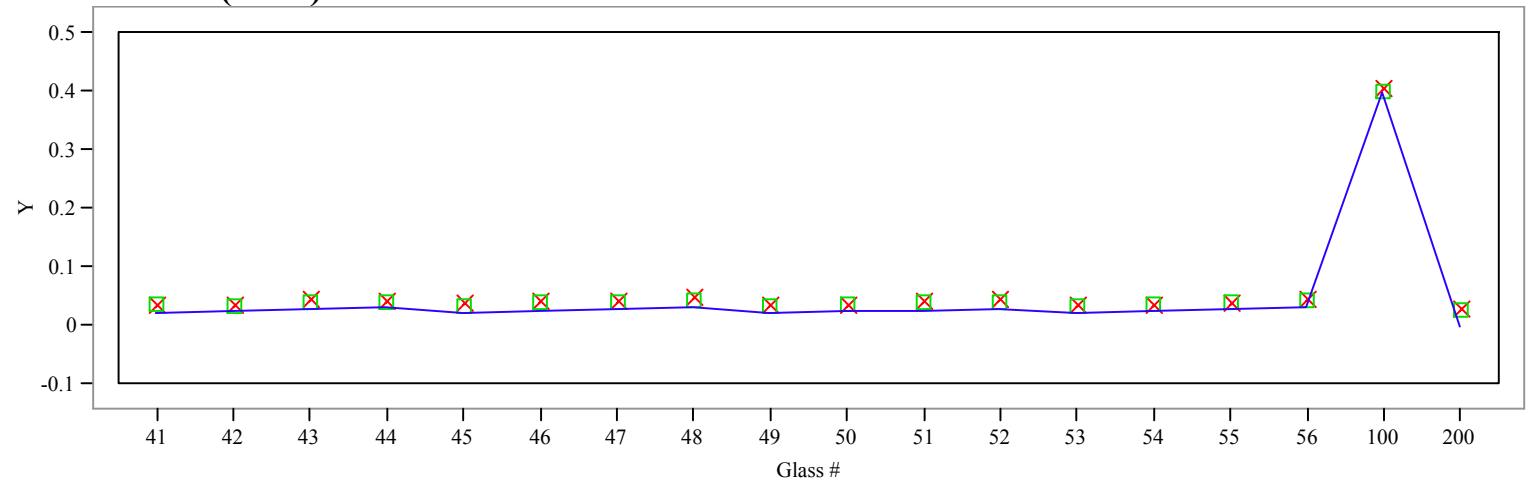

Oxide $=\mathrm{Fe} 2 \mathrm{O} 3(\mathrm{wt} \%)$

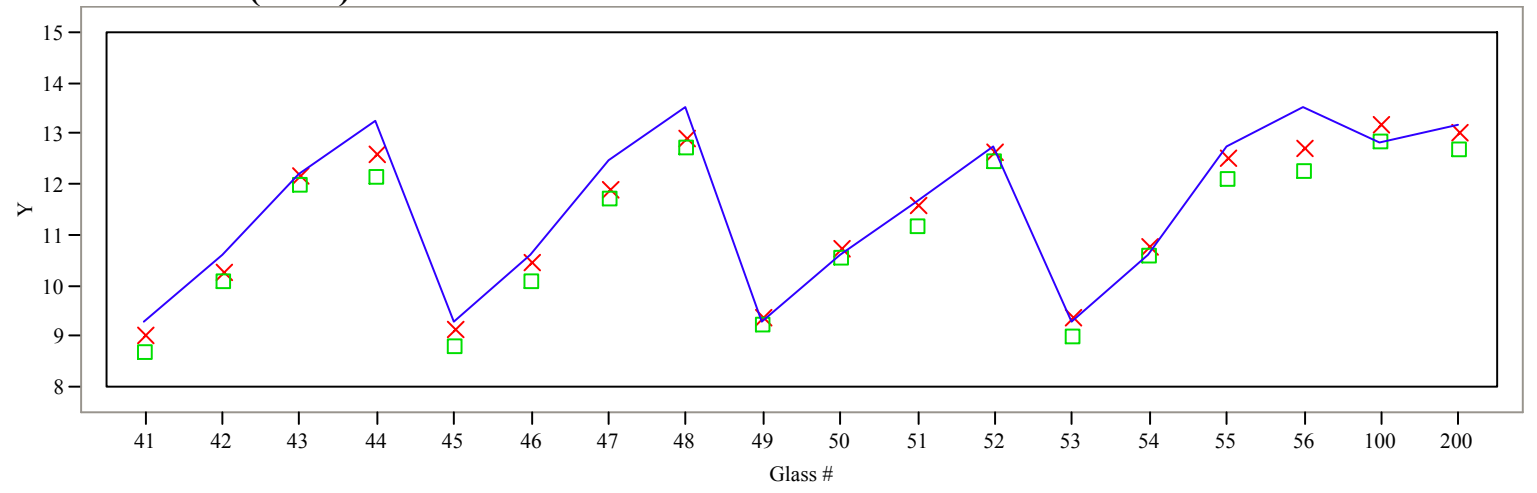

\section{Oxide $=K 2 O(w t \%)$}

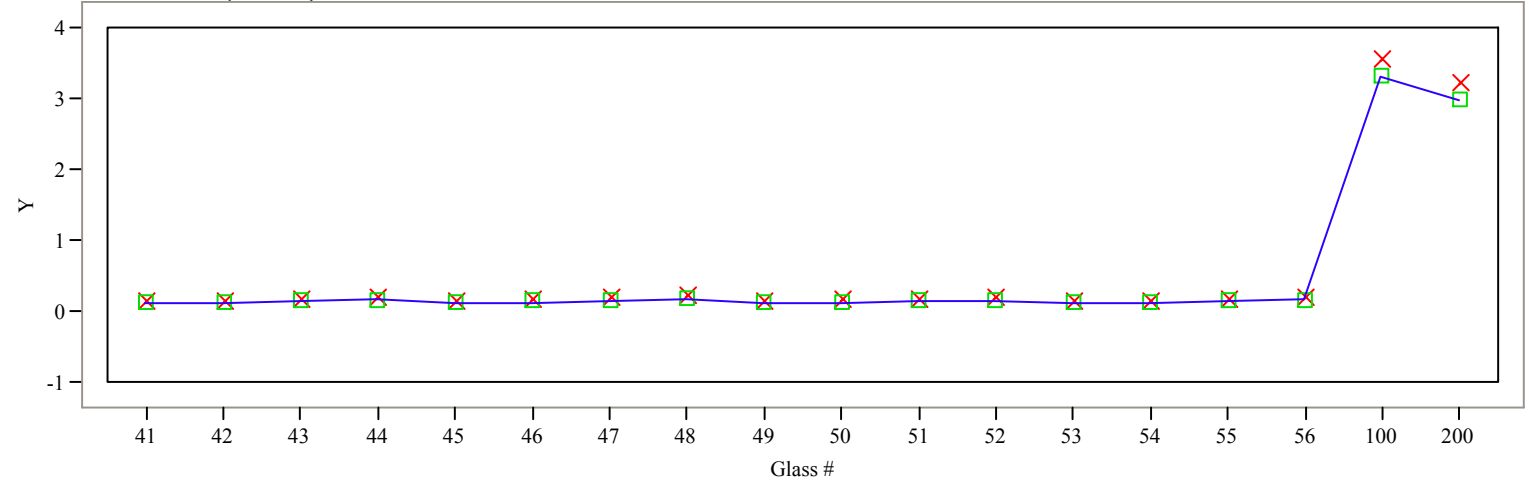

$\mathrm{Y} \times$ Measured $\square$ Measured bc $\quad$ Targeted 
Exhibit D7. Average Measured and Bias-Corrected (bc) Versus Targeted Compositions by Glass \# by Oxide (continued)

$$
\text { (100 - Batch 1; } 200 \text { - Ustd) }
$$

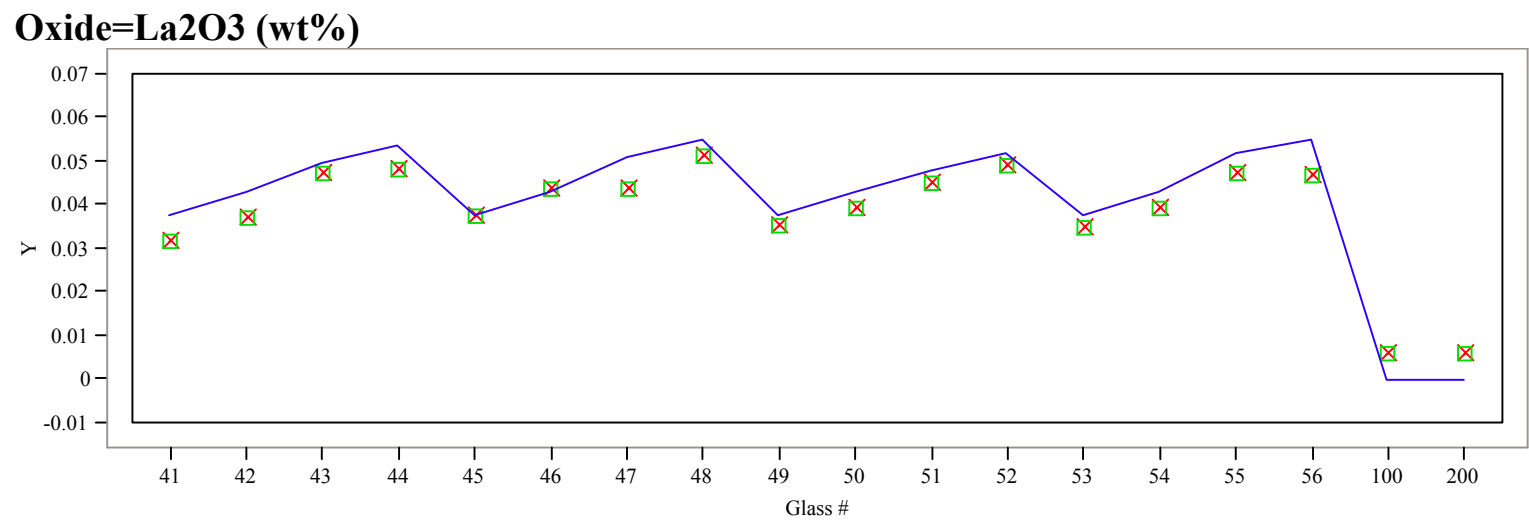

Oxide $=\mathrm{Li2O}(\mathrm{wt} \%)$

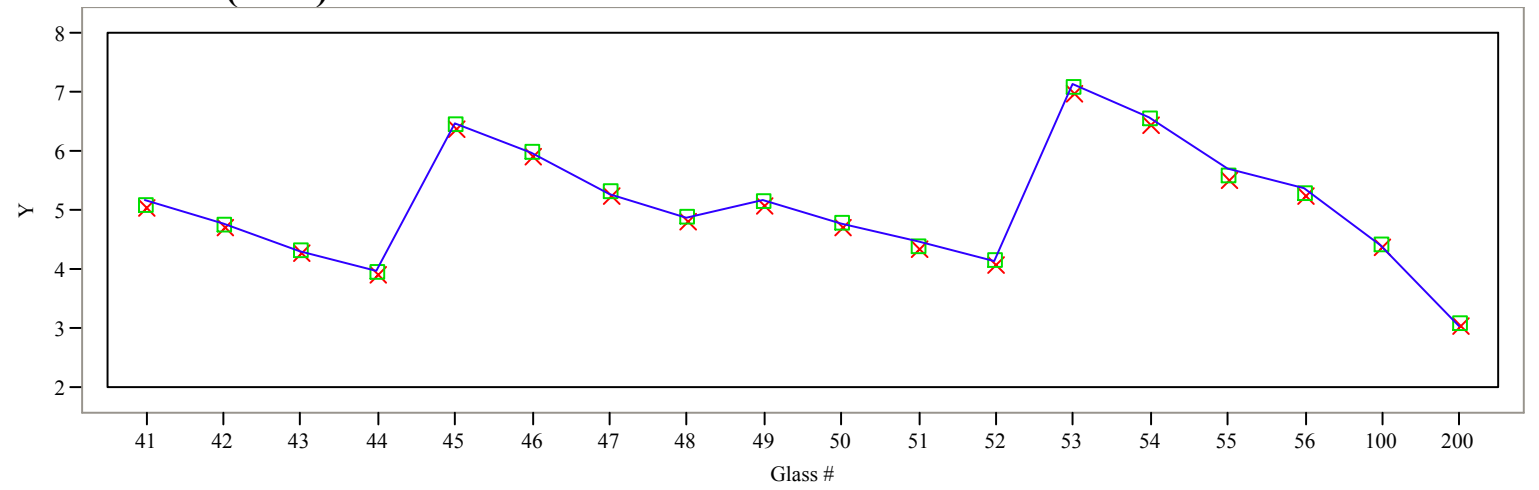

Oxide $=\operatorname{MgO}(\mathbf{w t} \%)$

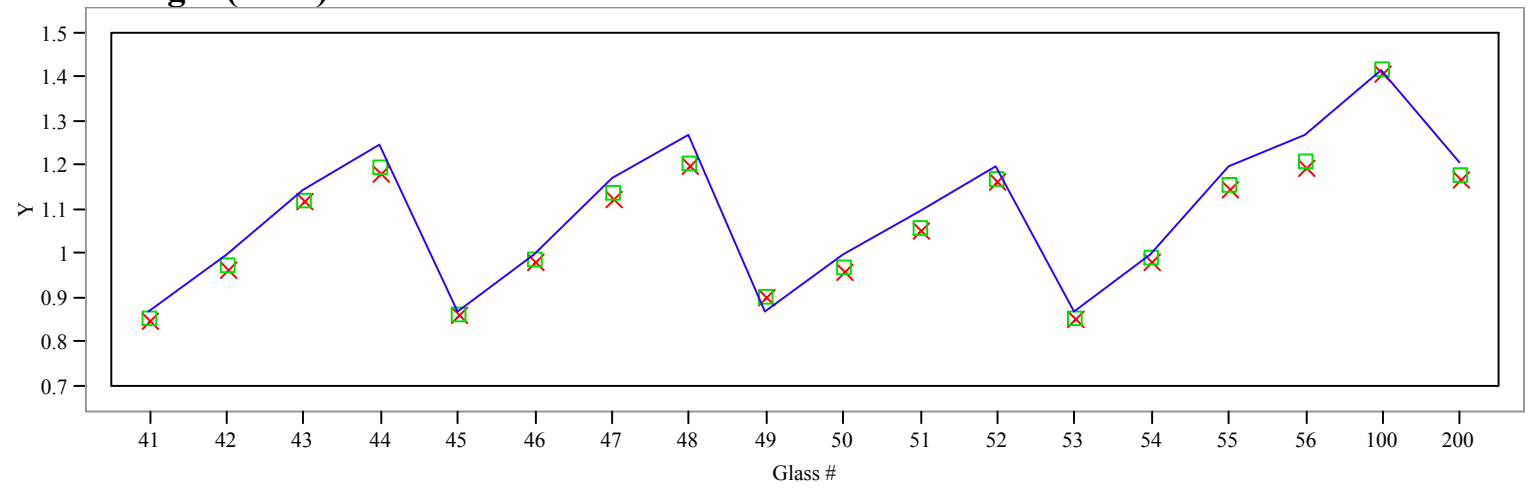

Y $\times$ Measured Measured bc - Targeted 
Exhibit D7. Average Measured and Bias-Corrected (bc) Versus Targeted Compositions by Glass \# by Oxide (continued)

$$
\text { (100 - Batch 1; } 200 \text { - Ustd) }
$$

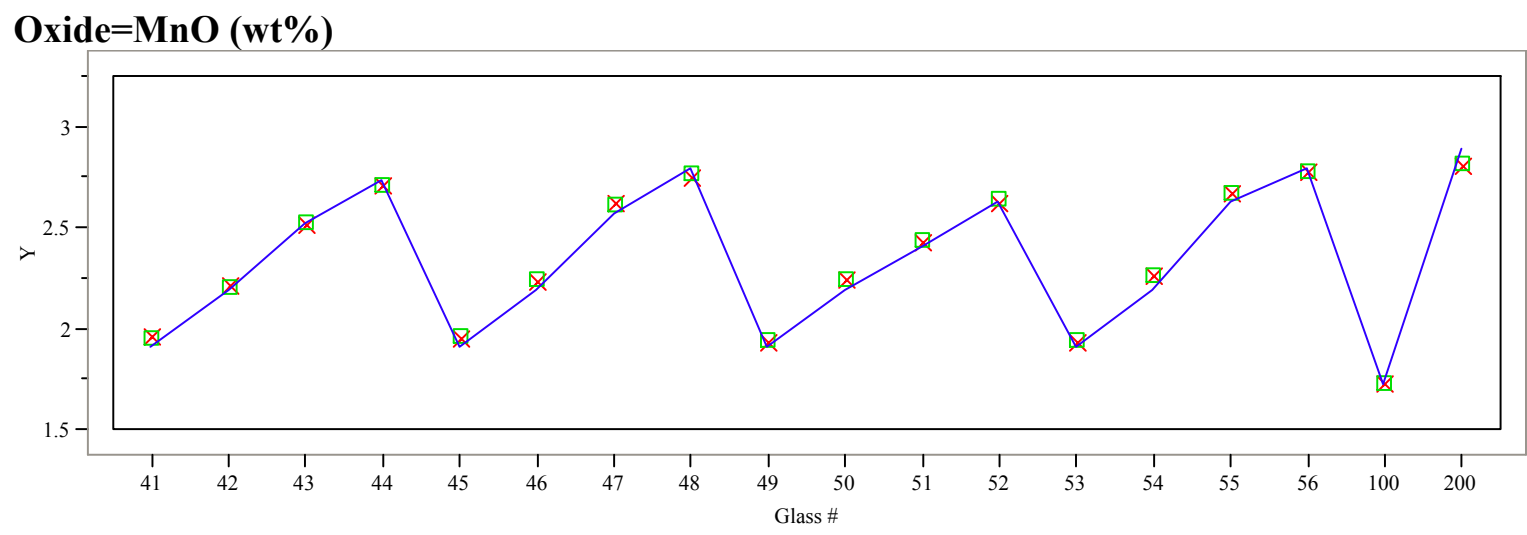

Oxide $=\mathrm{Na2O}(\mathrm{wt} \%)$

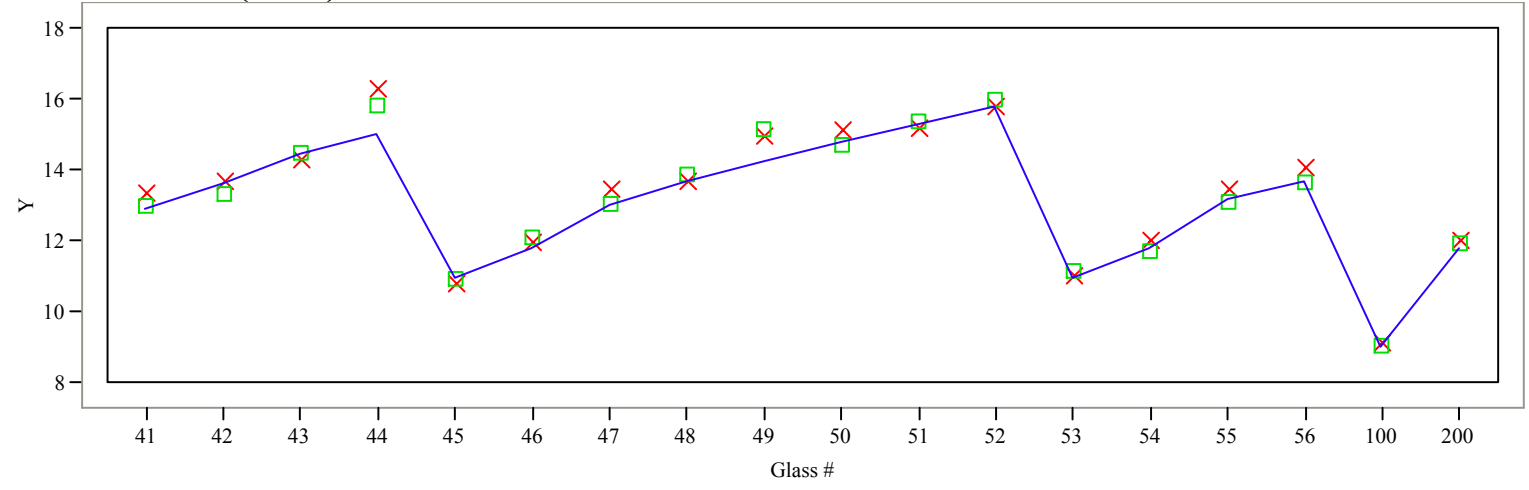

Oxide $=\mathrm{NiO}(\mathrm{wt} \%)$

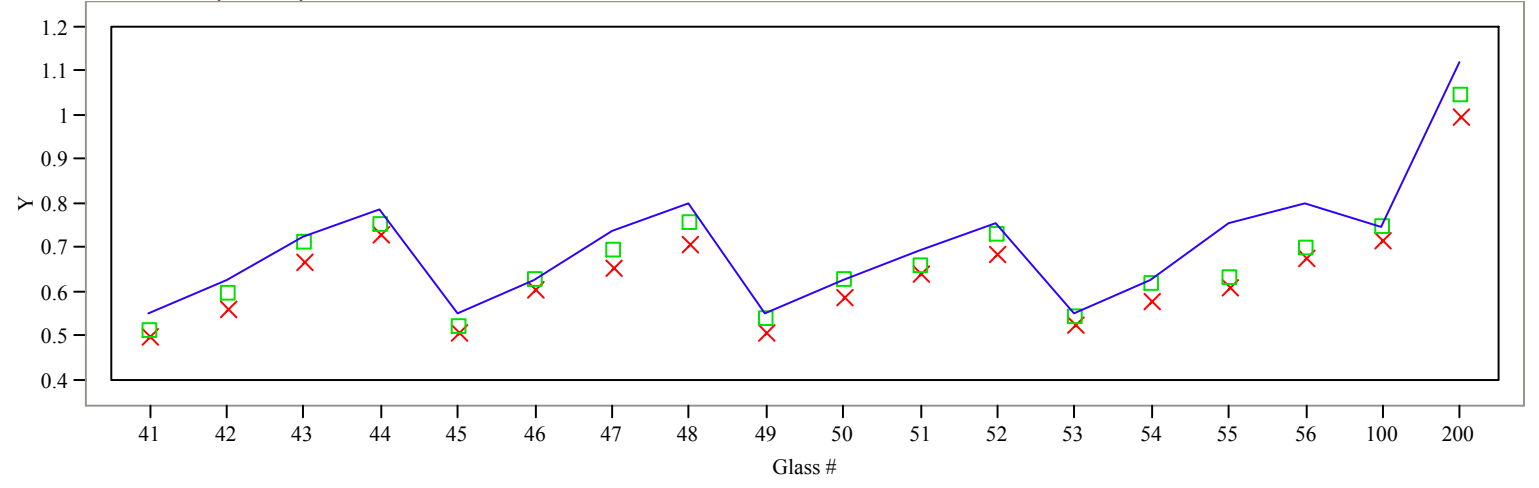

$\mathrm{Y} \times$ Measured Measured bc $\quad$ Targeted 
Exhibit D7. Average Measured and Bias-Corrected (bc) Versus Targeted Compositions by Glass \# by Oxide (continued)

$$
\text { (100 - Batch 1; } 200 \text { - Ustd) }
$$

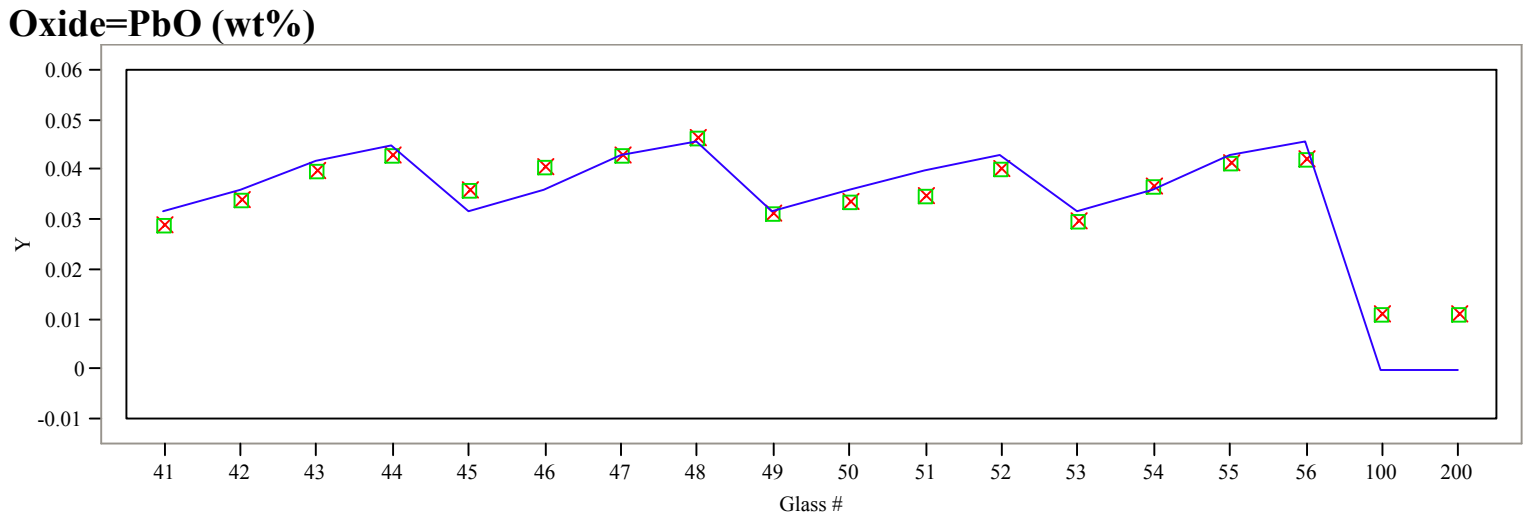

Oxide $=\mathrm{SO} 4(\mathrm{wt} \%)$

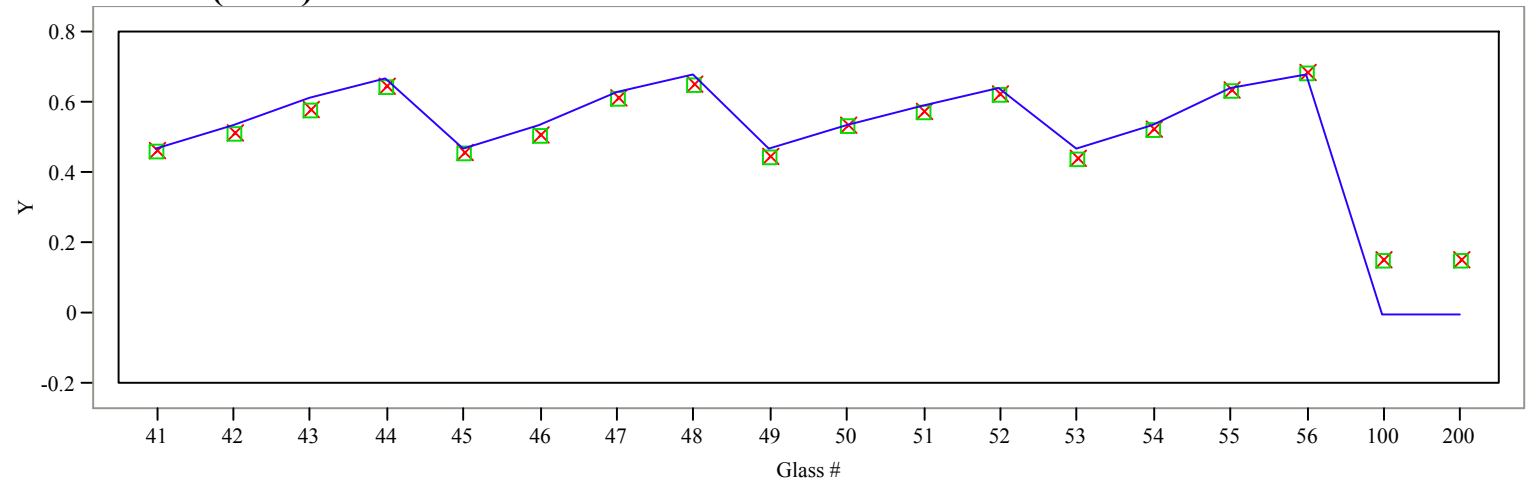

Oxide $=\mathrm{SiO} 2(\mathbf{w t} \%)$

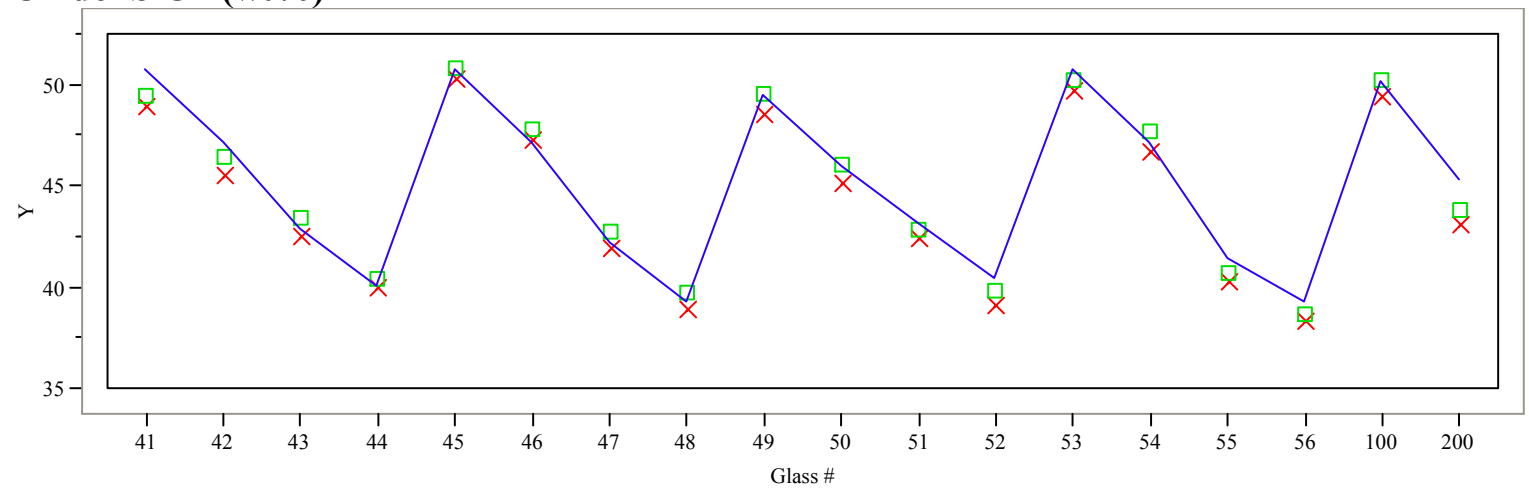

$\mathrm{Y} \times$ Measured Measured bc $\square$ Targeted 
Exhibit D7. Average Measured and Bias-Corrected (bc) Versus Targeted Compositions by Glass \# by Oxide (continued)

$$
\text { (100 - Batch 1; } 200 \text { - Ustd) }
$$

Oxide $=$ ThO2 $(w t \%)$

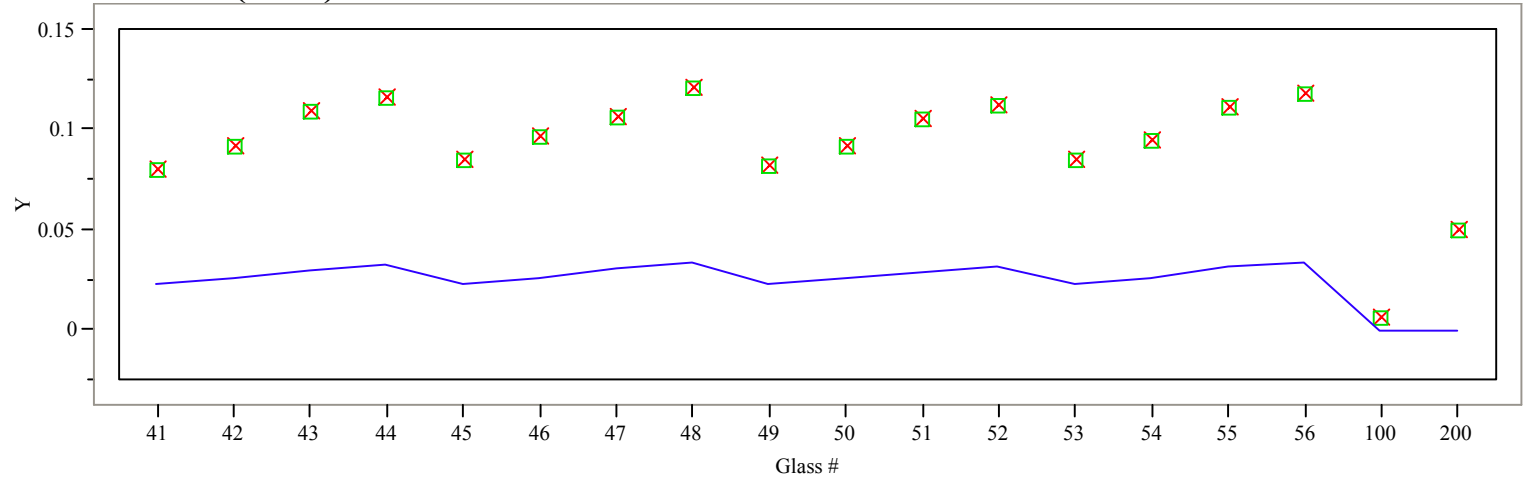

Oxide $=\mathrm{TiO} 2(\mathrm{wt} \%)$

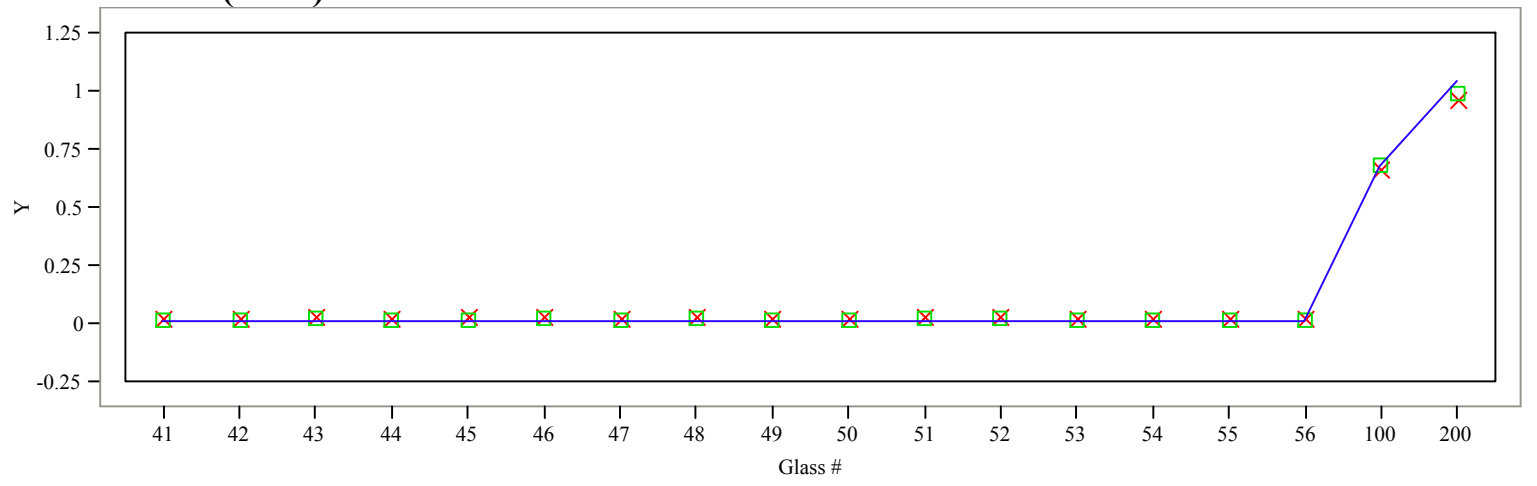

Oxide $=\mathrm{U} 308(\mathrm{wt} \%)$

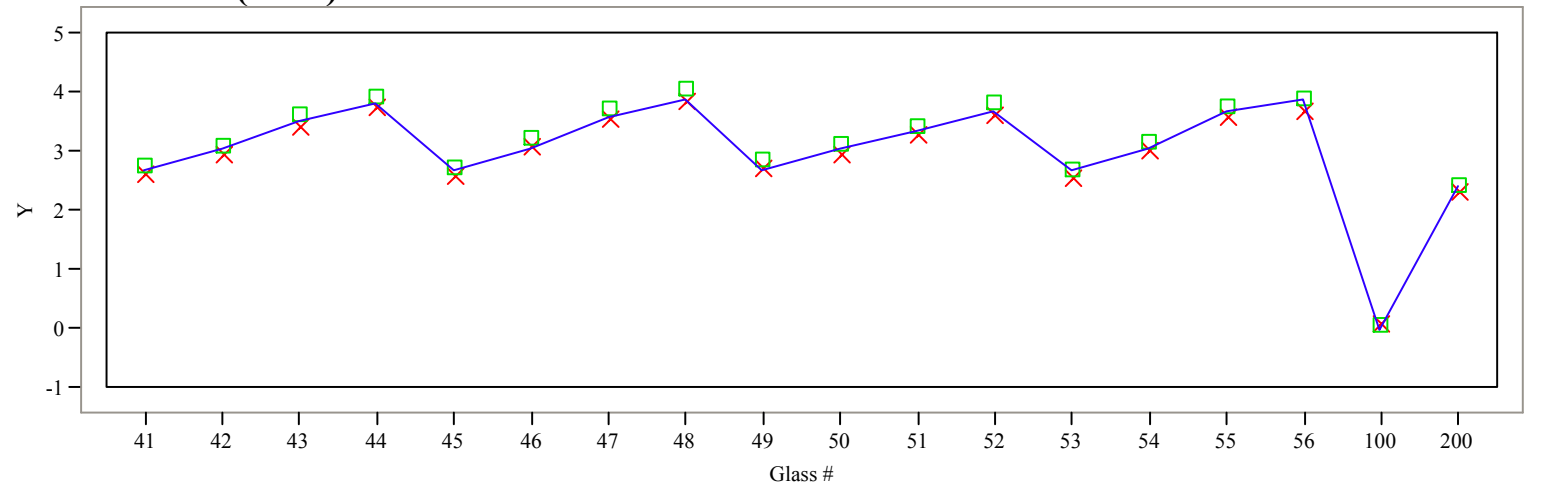

Y X Measured $\square$ Measured bc —Targeted 
Exhibit D7. Average Measured and Bias-Corrected (bc) Versus

Targeted Compositions by Glass \# by Oxide (continued)

$$
\text { (100 - Batch 1; } 200-\text { Ustd) }
$$

Oxide $=\mathbf{Z n O}($ wt $\%)$

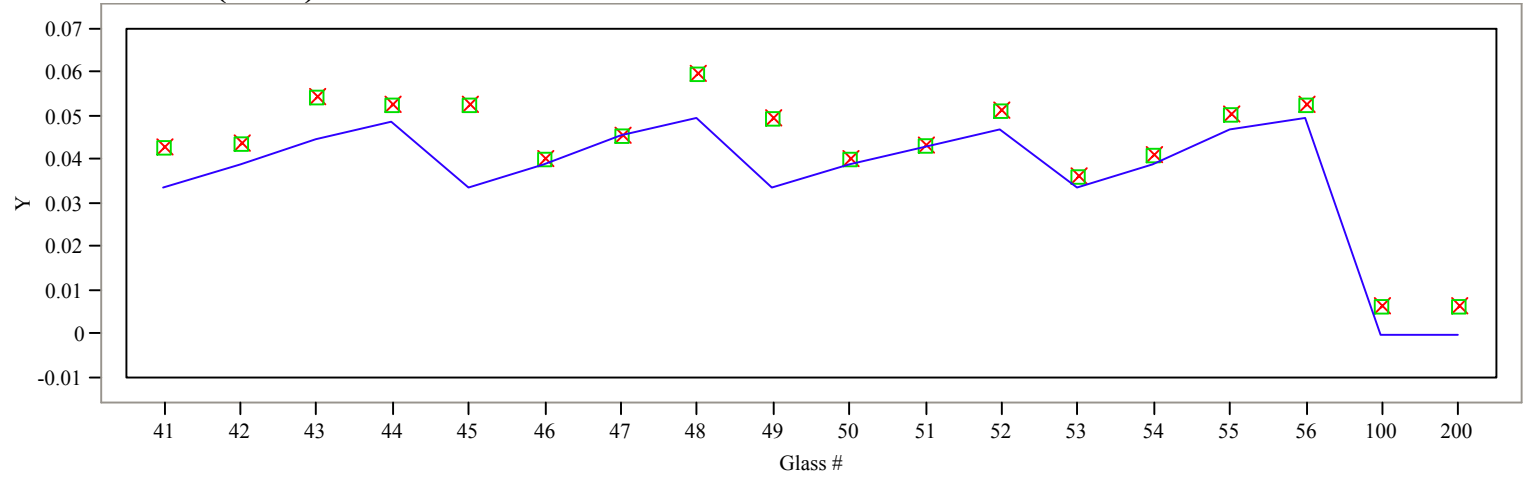

Oxide $=\mathrm{ZrO} 2(\mathrm{wt} \%)$

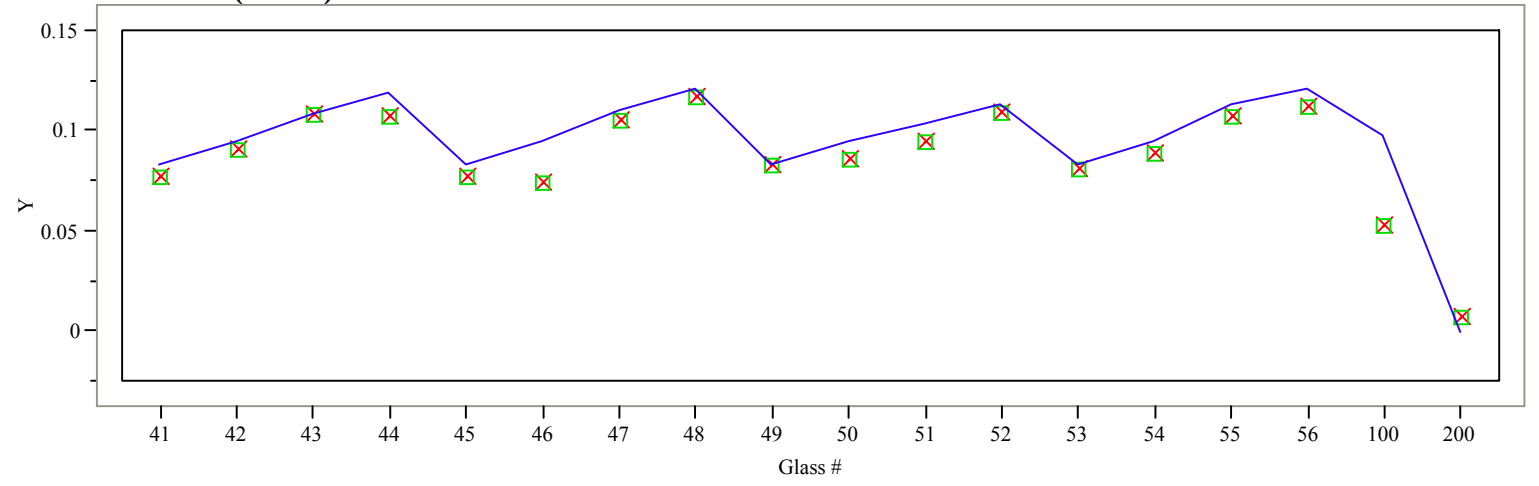

Oxide $=$ Sum of Oxides $(w t \%)$

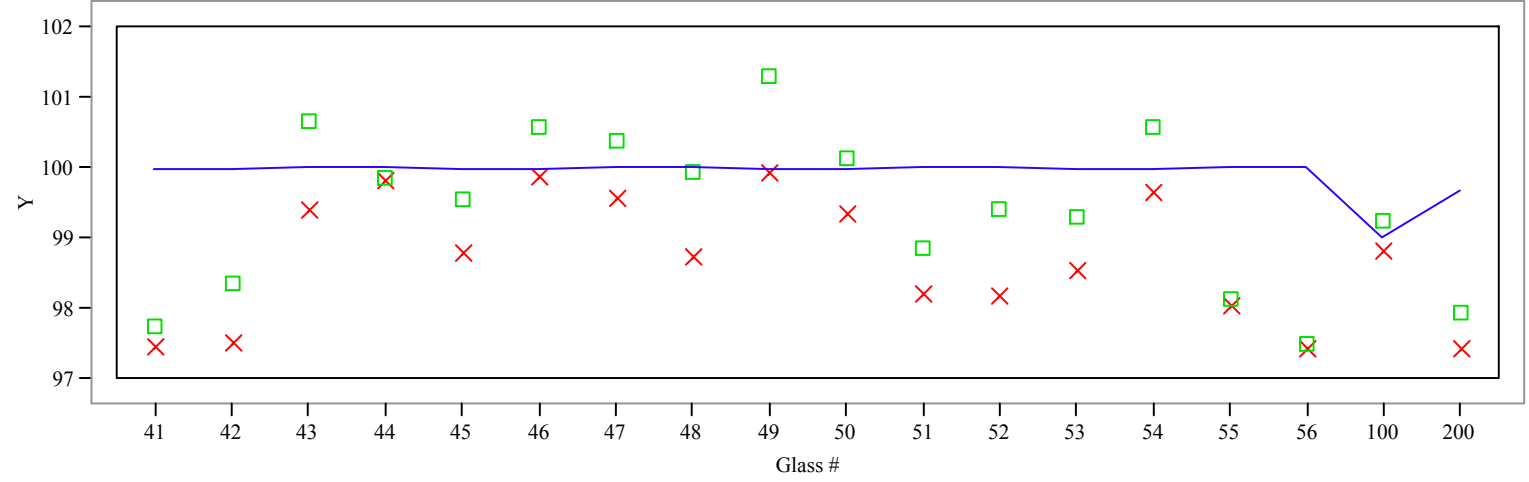

$\mathrm{Y} \times$ Measured (wt\%) $\square$ Measured bc (wt \%) - Targeted (wt $\%)$ 


\section{Appendix E}

\section{Tables and Exhibits Supporting the Analysis of the PCT Results for the Nepheline Phase 3 Study Glasses}


WSRC-TR-2006-00093

Revision 0

This page intentionally left blank. 
Table E1. Laboratory Measurements of the PCT Solutions for the Nepheline Study Glasses

\begin{tabular}{|c|c|c|c|c|c|c|c|c|c|c|c|c|c|c|c|c|}
\hline Part & Glass ID & $\begin{array}{c}\text { Heat } \\
\text { Treatment }\end{array}$ & $\begin{array}{c}\text { Laboratory } \\
\text { ID }\end{array}$ & Block & Seq & B ar & Ba ar & Cd ar & $\mathrm{Cr}$ ar & Fe ar & Li ar & Na ar & $\mathrm{Pb}$ ar & Si ar & Th ar & $\mathbf{U}$ ar \\
\hline 1 & Soln Std & & STD-B1-1 Cs & 1 & 1 & 19.4 & $<0.010$ & $<0.080$ & $<0.010$ & 4.10 & 9.79 & 83.1 & $<0.020$ & 50.0 & $<0.100$ & $<0.200$ \\
\hline 1 & NEPH3-42 & quenched & F52 & 1 & 2 & 6.97 & $<0.010$ & $<0.080$ & $<0.010$ & 4.07 & 10.3 & 51.4 & $<0.020$ & 67.8 & $<0.100$ & 1.80 \\
\hline 1 & NEPH3-42ccc & $\mathrm{ccc}$ & F39 & 1 & 3 & 6.29 & $<0.010$ & $<0.080$ & $<0.010$ & 3.40 & 10.4 & 49.0 & $<0.020$ & 67.1 & $<0.100$ & 1.79 \\
\hline 1 & ARM-1 & & F08 & 1 & 4 & 10.7 & $<0.010$ & $<0.080$ & $<0.010$ & $<0.004$ & 8.24 & 23.4 & $<0.020$ & 38.7 & $<0.100$ & $<0.200$ \\
\hline 1 & NEPH3-47 & quenched & F01 & 1 & 5 & 8.26 & $<0.010$ & $<0.080$ & $<0.010$ & 4.27 & 13.8 & 60.0 & $<0.020$ & 68.6 & $<0.100$ & 1.70 \\
\hline 1 & NEPH3-47ccc & $\mathrm{ccc}$ & F48 & 1 & 6 & 7.61 & $<0.010$ & $<0.080$ & $<0.010$ & 3.98 & 15.3 & 58.6 & $<0.020$ & 71.7 & $<0.100$ & 1.67 \\
\hline 1 & blank & & F26 & 1 & 7 & $<0.080$ & $<0.010$ & $<0.080$ & $<0.010$ & $<0.004$ & $<0.500$ & 0.247 & $<0.020$ & $<0.200$ & $<0.100$ & $<0.200$ \\
\hline 1 & NEPH3-46 & quenched & F25 & 1 & 8 & 7.04 & $<0.010$ & $<0.080$ & $<0.010$ & 4.26 & 14.2 & 44.1 & $<0.020$ & 72.5 & $<0.100$ & 1.70 \\
\hline 1 & NEPH3-46ccc & $\mathrm{ccc}$ & F07 & 1 & 9 & 7.64 & $<0.010$ & $<0.080$ & $<0.010$ & 4.72 & 15.9 & 45.2 & $<0.020$ & 76.9 & $<0.100$ & 1.80 \\
\hline 1 & NEPH3-41 & quenched & F37 & 1 & 10 & 5.45 & $<0.010$ & $<0.080$ & $<0.010$ & 4.18 & 10.7 & 44.9 & $<0.020$ & 70.6 & $<0.100$ & 2.05 \\
\hline 1 & NEPH3-41ccc & $\mathrm{ccc}$ & F32 & $\frac{1}{1}$ & 11 & 5.26 & $<0.010$ & $<0.080$ & $<0.010$ & 4.40 & 10.6 & 43.0 & $<0.020$ & 69.6 & $<0.100$ & 1.89 \\
\hline 1 & Soln Std & & STD-B1-2 & 1 & 12 & 19.4 & $<0.010$ & $<0.080$ & $<0.010$ & 3.87 & 9.62 & 81.1 & $<0.020$ & 48.8 & $<0.100$ & $<0.200$ \\
\hline 1 & NEPH3-44 & quenched & F15 & 1 & 13 & 6.60 & $<0.010$ & $<0.080$ & $<0.010$ & 4.19 & 9.16 & 72.4 & $<0.020$ & 62.5 & $<0.100$ & 1.77 \\
\hline 1 & NEPH3-44ccc & $\mathrm{ccc}$ & F36 & 1 & 14 & 6.84 & $<0.010$ & $<0.080$ & $<0.010$ & 3.04 & 11.5 & 74.6 & $<0.020$ & 66.5 & $<0.100$ & 1.54 \\
\hline 1 & NEPH3-48 & quenched & F38 & 1 & 15 & 7.77 & $<0.010$ & $<0.080$ & $<0.010$ & 5.41 & 13.3 & 73.2 & $<0.020$ & 68.4 & $<0.100$ & 1.64 \\
\hline 1 & NEPH3-48ccc & $\mathrm{ccc}$ & F47 & 1 & 16 & 12.0 & $<0.010$ & $<0.080$ & $<0.010$ & 3.14 & 21.9 & 82.3 & $<0.020$ & 83.0 & $<0.100$ & 1.96 \\
\hline 1 & EA & & F50 & 1 & 17 & 37.5 & $<0.010$ & $<0.080$ & $<0.010$ & $<0.004$ & 11.0 & 103 & $<0.020$ & 53.0 & $<0.100$ & $<0.200$ \\
\hline 1 & NEPH3-43 & quenched & F10 & 1 & 18 & 6.70 & $<0.010$ & $<0.080$ & $<0.010$ & 4.20 & 10.1 & 66.0 & $<0.020$ & 66.1 & $<0.100$ & 1.63 \\
\hline 1 & NEPH3-43ccc & $\mathrm{ccc}$ & F34 & 1 & 19 & 6.87 & $<0.010$ & $<0.080$ & $<0.010$ & 5.14 & 12.1 & 65.4 & $<0.020$ & 71.1 & $<0.100$ & 1.90 \\
\hline 1 & NEPH3-45 & quenched & F55 & 1 & 20 & 7.15 & $<0.010$ & $<0.080$ & $<0.010$ & 4.68 & 15.4 & 36.4 & $<0.020$ & 78.5 & $<0.100$ & 2.40 \\
\hline 1 & NEPH3-45ccc & $\mathrm{ccc}$ & F28 & 1 & 21 & 7.20 & $<0.010$ & $<0.080$ & $<0.010$ & 4.32 & 15.8 & 36.8 & $<0.020$ & 79.3 & $<0.100$ & 2.08 \\
\hline 1 & Soln Std & & STD-B1-3 & 1 & 22 & 19.4 & $<0.010$ & $<0.080$ & $<0.010$ & 3.90 & 9.71 & 82.4 & $<0.020$ & 49.4 & $<0.100$ & $<0.200$ \\
\hline 1 & Soln Std & & STD-B2-1 & 2 & 1 & 21.8 & $<0.010$ & $<0.080$ & $<0.010$ & 4.21 & 9.66 & 79.0 & $<0.020$ & 49.5 & $<0.100$ & $<0.200$ \\
\hline 1 & NEPH3-42 & quenched & F05 & 2 & 2 & 7.91 & $<0.010$ & $<0.080$ & $<0.010$ & 3.70 & 10.9 & 52.5 & $<0.020$ & 71.0 & $<0.100$ & 1.72 \\
\hline 1 & NEPH3-42ccc & $\mathrm{ccc}$ & $\mathrm{F} 30$ & 2 & 3 & 7.01 & $<0.010$ & $<0.080$ & $<0.010$ & 3.78 & 10.7 & 48.8 & $<0.020$ & 68.9 & $<0.100$ & 1.71 \\
\hline 1 & NEPH3-47 & quenched & F27 & 2 & 4 & 9.08 & $<0.010$ & $<0.080$ & $<0.010$ & 4.43 & 14.1 & 60.9 & $<0.020$ & 69.7 & $<0.100$ & 1.73 \\
\hline 1 & NEPH3-47ccc & $\mathrm{ccc}$ & F03 & 2 & 5 & 8.32 & $<0.010$ & $<0.080$ & $<0.010$ & 4.05 & 15.4 & 57.0 & $<0.020$ & 72.5 & $<0.100$ & 1.67 \\
\hline 1 & NEPH3-46 & quenched & F35 & 2 & 6 & 7.95 & $<0.010$ & $<0.080$ & $<0.010$ & 4.33 & 14.2 & 43.2 & $<0.020$ & 72.7 & $<0.100$ & 1.72 \\
\hline 1 & NEPH3-46ccc & $\mathrm{ccc}$ & F19 & 2 & 7 & 8.45 & $<0.010$ & $<0.080$ & $<0.010$ & 4.70 & 16.0 & 43.5 & $<0.020$ & 77.1 & $<0.100$ & 1.83 \\
\hline 1 & NEPH3-41 & quenched & F09 & 2 & 8 & 6.15 & $<0.010$ & $<0.080$ & $<0.010$ & 3.92 & 10.8 & 42.7 & $<0.020$ & 71.4 & $<0.100$ & 2.23 \\
\hline 1 & NEPH3-41ccc & $\mathrm{ccc}$ & F11 & 2 & 9 & 6.12 & $<0.010$ & $<0.080$ & $<0.010$ & 3.63 & 10.8 & 40.9 & $<0.020$ & 70.4 & $<0.100$ & 1.86 \\
\hline 1 & ARM-1 & & F29 & 2 & 10 & 11.3 & $<0.010$ & $<0.080$ & $<0.010$ & $<0.004$ & 8.67 & 23.7 & $<0.020$ & 39.8 & $<0.100$ & $<0.200$ \\
\hline 1 & EA & & F53 & 2 & 11 & 38.3 & $<0.010$ & $<0.080$ & $<0.010$ & $<0.004$ & 11.1 & 101 & $<0.020$ & 53.7 & $<0.100$ & $<0.200$ \\
\hline 1 & Soln Std & & STD-B2-2 & 2 & 12 & 20.7 & $<0.010$ & $<0.080$ & $<0.010$ & 4.02 & 9.70 & 79.2 & $<0.020$ & 50.0 & $<0.100$ & $<0.200$ \\
\hline 1 & NEPH3-44 & quenched & F24 & 2 & 13 & 7.53 & $<0.010$ & $<0.080$ & $<0.010$ & 4.59 & 9.32 & 72.1 & $<0.020$ & 63.2 & $<0.100$ & 1.63 \\
\hline 1 & NEPH3-44ccc & $\mathrm{ccc}$ & F22 & 2 & 14 & 7.54 & $<0.010$ & $<0.080$ & $<0.010$ & 2.69 & 11.4 & 73.7 & $<0.020$ & 66.0 & $<0.100$ & 1.59 \\
\hline 1 & NEPH3-48 & quenched & F14 & 2 & 15 & 8.73 & $<0.010$ & $<0.080$ & $<0.010$ & 5.52 & 13.4 & 72.0 & $<0.020$ & 69.2 & $<0.100$ & 1.82 \\
\hline 1 & NEPH3-48ccc & $\mathrm{ccc}$ & F20 & 2 & 16 & 12.7 & $<0.010$ & $<0.080$ & $<0.010$ & 3.34 & 21.7 & 81.2 & $<0.020$ & 83.3 & $<0.100$ & 1.92 \\
\hline 1 & NEPH3-43 & quenched & F49 & 2 & 17 & 6.96 & $<0.010$ & $<0.080$ & $<0.010$ & 5.40 & 10.0 & 65.6 & $<0.020$ & 66.7 & $<0.100$ & 1.97 \\
\hline
\end{tabular}


Table E1. Laboratory Measurements of the PCT Solutions for the Nepheline Study Glasses (continued)

\begin{tabular}{|c|c|c|c|c|c|c|c|c|c|c|c|c|c|c|c|c|}
\hline Part & Glass ID & $\begin{array}{c}\text { Heat } \\
\text { Treatment } \\
\end{array}$ & $\begin{array}{c}\text { Laboratory } \\
\text { ID }\end{array}$ & Block & Seq & B ar & Ba ar & Cd ar & $\mathrm{Cr}$ ar & Fe ar & Li ar & $\mathrm{Na}$ ar & $\mathrm{Pb}$ ar & Si ar & Th ar & $\mathbf{U}$ ar \\
\hline 1 & NEPH3-43ccc & $\mathrm{ccc}$ & F44 & 2 & 18 & 7.41 & $<0.010$ & $<0.080$ & $<0.010$ & 5.36 & 11.9 & 63.8 & $<0.020$ & 70.6 & $<0.100$ & 1.87 \\
\hline 1 & NEPH3-45 & quenched & F16 & 2 & 19 & 7.95 & $<0.010$ & $<0.080$ & $<0.010$ & 4.98 & 15.5 & 36.1 & $<0.020$ & 79.2 & $<0.100$ & 2.16 \\
\hline 1 & NEPH3-45ccc & $\mathrm{ccc}$ & F02 & 2 & 20 & 7.81 & $<0.010$ & $<0.080$ & $<0.010$ & 5.19 & 15.5 & 35.4 & $<0.020$ & 79.1 & $<0.100$ & 2.18 \\
\hline 1 & Soln Std & & STD-B2-3 & 2 & 21 & 19.8 & $<0.010$ & $<0.080$ & $<0.010$ & 4.10 & 9.55 & 79.6 & $<0.020$ & 48.8 & $<0.100$ & $<0.200$ \\
\hline 1 & Soln Std & & STD-B3-1 & 3 & 1 & 22.1 & $<0.010$ & $<0.080$ & $<0.010$ & 3.92 & 9.77 & 80.5 & $<0.020$ & 49.4 & $<0.100$ & 0.25 \\
\hline 1 & NEPH3-42 & quenched & F06 & 3 & 2 & 7.96 & $<0.010$ & $<0.080$ & $<0.010$ & 3.45 & 10.6 & 52.1 & $<0.020$ & 68.0 & $<0.100$ & 1.96 \\
\hline 1 & NEPH3-42ccc & $\mathrm{ccc}$ & F23 & 3 & 3 & 7.34 & $<0.010$ & $<0.080$ & $<0.010$ & 3.82 & 10.6 & 52.2 & $<0.020$ & 67.0 & $<0.100$ & 1.90 \\
\hline 1 & EA & & F46 & 3 & 4 & 34.9 & $<0.010$ & $<0.080$ & $<0.010$ & $<0.004$ & 10.1 & 91.8 & $<0.020$ & 48.0 & $<0.100$ & $<0.200$ \\
\hline 1 & NEPH3-47 & quenched & F31 & 3 & 5 & 9.77 & $<0.010$ & $<0.080$ & $<0.010$ & 4.71 & 13.8 & 59.1 & $<0.020$ & 68.8 & $<0.100$ & 1.91 \\
\hline 1 & NEPH3-47ccc & $\mathrm{ccc}$ & F43 & 3 & 6 & 8.89 & $<0.010$ & $<0.080$ & $<0.010$ & 4.30 & 15.3 & 57.7 & $<0.020$ & 71.2 & $<0.100$ & 1.81 \\
\hline 1 & NEPH3-46 & quenched & F45 & 3 & 7 & 8.57 & $<0.010$ & $<0.080$ & $<0.010$ & 4.19 & 14.3 & 42.6 & $<0.020$ & 73.1 & $<0.100$ & 1.92 \\
\hline 1 & NEPH3-46ccc & $\mathrm{ccc}$ & F56 & 3 & 8 & 8.88 & $<0.010$ & $<0.080$ & $<0.010$ & 4.85 & 15.9 & 43.1 & $<0.020$ & 77.6 & $<0.100$ & 2.03 \\
\hline 1 & NEPH3-41 & quenched & F17 & 3 & 9 & 6.75 & $<0.010$ & $<0.080$ & $<0.010$ & 4.55 & 10.8 & 43.5 & $<0.020$ & 72.4 & $<0.100$ & 2.28 \\
\hline 1 & NEPH3-41 ccc & $\mathrm{ccc}$ & F41 & 3 & 10 & 6.47 & $<0.010$ & $<0.080$ & $<0.010$ & 3.86 & 10.8 & 40.8 & $<0.020$ & 72.2 & $<0.100$ & 2.34 \\
\hline 1 & blank & & F12 & 3 & 11 & $<0.080$ & $<0.010$ & $<0.080$ & $<0.010$ & $<0.004$ & $<0.500$ & $<0.080$ & $<0.020$ & $<0.200$ & $<0.100$ & $<0.200$ \\
\hline 1 & Soln Std & & STD-B3-2 & 3 & 12 & 20.4 & $<0.010$ & $<0.080$ & $<0.010$ & 3.96 & 9.62 & 79.8 & $<0.020$ & 49.0 & $<0.100$ & $<0.200$ \\
\hline 1 & NEPH3-44 & quenched & F21 & 3 & 13 & 7.84 & $<0.010$ & $<0.080$ & $<0.010$ & 4.88 & 9.47 & 72.6 & $<0.020$ & 63.3 & $<0.100$ & 2.06 \\
\hline 1 & NEPH3-44ccc & $\mathrm{ccc}$ & F42 & 3 & 14 & 8.16 & $<0.010$ & $<0.080$ & $<0.010$ & 2.82 & 11.7 & 74.3 & $<0.020$ & 67.3 & $<0.100$ & 1.95 \\
\hline 1 & NEPH3-48 & quenched & F18 & 3 & 15 & 9.03 & $<0.010$ & $<0.080$ & $<0.010$ & 5.64 & 13.3 & 73.0 & $<0.020$ & 69.0 & $<0.100$ & 1.97 \\
\hline 1 & NEPH3-48ccc & $\mathrm{ccc}$ & F33 & 3 & 16 & 13.2 & $<0.010$ & $<0.080$ & $<0.010$ & 3.43 & 22.0 & 80.4 & $<0.020$ & 84.2 & $<0.100$ & 2.11 \\
\hline 1 & ARM-1 & & F13 & 3 & 17 & 12.4 & $<0.010$ & $<0.080$ & $<0.010$ & $<0.004$ & 8.85 & 24.3 & $<0.020$ & 40.5 & $<0.100$ & $<0.200$ \\
\hline 1 & NEPH3-43 & quenched & F54 & 3 & 18 & 7.21 & $<0.010$ & $<0.080$ & $<0.010$ & 5.34 & 9.55 & 61.9 & $<0.020$ & 64.0 & $<0.100$ & 2.45 \\
\hline 1 & NEPH3-43ccc & $\mathrm{ccc}$ & F51 & 3 & 19 & 7.73 & $<0.010$ & $<0.080$ & $<0.010$ & 5.30 & 11.7 & 61.8 & $<0.020$ & 68.8 & $<0.100$ & 2.00 \\
\hline 1 & NEPH3-45 & quenched & F40 & 3 & 20 & 8.25 & $<0.010$ & $<0.080$ & $<0.010$ & 5.67 & 15.2 & 35.3 & $<0.020$ & 77.0 & $<0.100$ & 2.30 \\
\hline 1 & NEPH3-45ccc & $\mathrm{ccc}$ & F04 & 3 & 21 & 8.34 & $<0.010$ & $<0.080$ & $<0.010$ & 4.79 & 15.6 & 35.1 & $<0.020$ & 78.8 & $<0.100$ & 2.45 \\
\hline 1 & Soln Std & & STD-B-3-3 & 3 & 22 & 20.5 & $<0.010$ & $<0.080$ & $<0.010$ & 3.89 & 9.62 & 80.1 & $<0.020$ & 49.6 & $<0.100$ & $<0.200$ \\
\hline 2 & Soln Std & & STD-B1-1 & 1 & 1 & 21.8 & $<0.010$ & $<0.080$ & $<0.010$ & 4.44 & 9.67 & 81.0 & $<0.020$ & 49.4 & $<0.100$ & 1.88 \\
\hline 2 & EA & & $\mathrm{H} 43$ & 1 & 2 & 38.6 & $<0.010$ & $<0.080$ & $<0.010$ & $<0.004$ & 11.0 & 97.7 & $<0.020$ & 53.2 & $<0.100$ & $<0.200$ \\
\hline 2 & NEPH3-56ccc & ccc & $\mathrm{H} 07$ & 1 & 3 & 22.1 & $<0.010$ & $<0.080$ & $<0.010$ & 5.57 & 44.7 & 101 & $<0.020$ & 128 & 0.116 & 1.81 \\
\hline 2 & ARM-1 & & H09 & 1 & 4 & 12.7 & $<0.010$ & $<0.080$ & $<0.010$ & $<0.004$ & 9.09 & 25.4 & $<0.020$ & 39.2 & $<0.100$ & 1.94 \\
\hline 2 & NEPH3-54ccc & $\mathrm{ccc}$ & $\mathrm{H} 26$ & 1 & 5 & 9.53 & $<0.010$ & $<0.080$ & $<0.010$ & 9.15 & 23.8 & 54.7 & $<0.020$ & 96.9 & $<0.100$ & 1.72 \\
\hline 2 & NEPH3-56 & quenched & $\mathrm{H} 04$ & 1 & 6 & 8.25 & $<0.010$ & $<0.080$ & $<0.010$ & 7.31 & 15.3 & 75.9 & $<0.020$ & 72.1 & $<0.100$ & $<0.200$ \\
\hline 2 & NEPH3-52ccc & $\mathrm{ccc}$ & $\mathrm{H} 47$ & 1 & 7 & 8.64 & $<0.010$ & $<0.080$ & $<0.010$ & 4.15 & 12.3 & 86.8 & $<0.020$ & 72.9 & $<0.100$ & 1.58 \\
\hline 2 & NEPH3-55 & quenched & $\mathrm{H} 23$ & 1 & 8 & 8.47 & $<0.010$ & $<0.080$ & $<0.010$ & 5.80 & 15.8 & 67.1 & $<0.020$ & 72.8 & $<0.100$ & $<0.200$ \\
\hline 2 & NEPH3-54 & quenched & $\mathrm{H} 33$ & 1 & 9 & 8.05 & $<0.010$ & $<0.080$ & $<0.010$ & 5.32 & 16.9 & 49.1 & $<0.020$ & 78.0 & $<0.100$ & 2.16 \\
\hline 2 & blank & & H19 & 1 & 10 & 0.251 & $<0.010$ & $<0.080$ & $<0.010$ & $<0.004$ & $<0.500$ & $<0.100$ & $<0.020$ & $<0.200$ & $<0.100$ & 3.08 \\
\hline 2 & NEPH3-49 & quenched & H31 & 1 & 11 & 7.02 & $<0.010$ & $<0.080$ & $<0.010$ & 5.74 & 10.9 & 58.8 & $<0.020$ & 71.6 & $<0.100$ & 2.20 \\
\hline 2 & Soln Std & & STD-B1-2 & 1 & 12 & 20.0 & $<0.010$ & $<0.080$ & $<0.010$ & 4.36 & 9.64 & 80.6 & $<0.020$ & 49.3 & $<0.100$ & 1.85 \\
\hline 2 & NEPH3-51ccc & $\mathrm{ccc}$ & $\mathrm{H} 40$ & 1 & 13 & 10.6 & $<0.010$ & $<0.080$ & $<0.010$ & 5.56 & 14.5 & 78.7 & $<0.020$ & 78.3 & $<0.100$ & 1.97 \\
\hline 2 & NEPH3-50 & quenched & H38 & 1 & 14 & 7.63 & $<0.010$ & $<0.080$ & $<0.010$ & 5.96 & 10.7 & 68.4 & $<0.020$ & 71.8 & $<0.100$ & 2.30 \\
\hline 2 & NEPH3-50 ccc & $\mathrm{ccc}$ & $\mathrm{H} 05$ & 1 & 15 & 7.72 & $<0.010$ & $<0.080$ & $<0.010$ & 4.95 & 11.6 & 65.7 & $<0.020$ & 72.3 & $<0.100$ & 2.23 \\
\hline
\end{tabular}


Table E1. Laboratory Measurements of the PCT Solutions for the Nepheline Study Glasses (continued)

\begin{tabular}{|c|c|c|c|c|c|c|c|c|c|c|c|c|c|c|c|c|}
\hline Part & Glass ID & $\begin{array}{c}\text { Heat } \\
\text { Treatment }\end{array}$ & $\begin{array}{c}\text { Laboratory } \\
\text { ID }\end{array}$ & Block & Seq & B ar & Ba ar & Cd ar & Crar & $\mathrm{Fe}$ ar & Li ar & Na ar & Pb ar & Si ar & Th ar & $\mathbf{U}$ ar \\
\hline 2 & NEPH3-49ccc & ccc & $\mathrm{H} 53$ & 1 & 16 & 7.41 & $<0.010$ & $<0.080$ & $<0.010$ & 5.74 & 11.9 & 56.5 & $<0.020$ & 74.5 & $<0.100$ & 2.06 \\
\hline 2 & NEPH3-53 & quenched & H37 & 1 & 17 & 7.86 & $<0.010$ & $<0.080$ & $<0.010$ & 6.66 & 17.8 & 42.8 & $<0.020$ & 82.1 & $<0.100$ & $<0.200$ \\
\hline 2 & NEPH3-52 & quenched & $\mathrm{H} 42$ & 1 & 18 & 8.22 & $<0.010$ & $<0.080$ & $<0.010$ & 6.47 & 10.6 & 88.6 & $<0.020$ & 70.8 & $<0.100$ & 1.83 \\
\hline 2 & NEPH3-53 ccc & ccc & H36 & 1 & 19 & 10.1 & $<0.010$ & $<0.080$ & $<0.010$ & 13.8 & 34.6 & 53.1 & $<0.020$ & 130 & $<0.100$ & 1.88 \\
\hline 2 & NEPH3-51 & quenched & $\mathrm{H} 03$ & 1 & 20 & 8.07 & $<0.010$ & $<0.080$ & $<0.010$ & 5.21 & 10.8 & 78.1 & $<0.020$ & 71.0 & $<0.100$ & 3.24 \\
\hline 2 & NEPH3-55ccc & ccc & $\mathrm{H} 25$ & 1 & 21 & 11.2 & $<0.010$ & $<0.080$ & $<0.010$ & 5.51 & 26.8 & 76.0 & $<0.020$ & 95.0 & $<0.100$ & 1.88 \\
\hline 2 & Soln Std & & STD-B1-3 & 1 & 22 & 19.7 & $<0.010$ & $<0.080$ & $<0.010$ & 4.28 & 9.66 & 82.4 & $<0.020$ & 48.7 & $<0.100$ & 2.06 \\
\hline 2 & Soln Std & & STD-B2-1 & 2 & 1 & 21.9 & $<0.010$ & $<0.080$ & $<0.010$ & 4.40 & 9.69 & 81.6 & $<0.020$ & 49.5 & $<0.100$ & 1.99 \\
\hline 2 & NEPH3-49ccc & $\mathrm{ccc}$ & H52 & 2 & 2 & 7.61 & $<0.010$ & $<0.080$ & $<0.010$ & 5.92 & 12.2 & 58.9 & $<0.020$ & 76.3 & $<0.100$ & 2.25 \\
\hline 2 & NEPH3-54 & quenched & $\mathrm{H} 15$ & 2 & 3 & 8.01 & $<0.010$ & $<0.080$ & $<0.010$ & 5.29 & 16.5 & 50.9 & $<0.020$ & 76.7 & $<0.100$ & 1.79 \\
\hline 2 & NEPH3-50ccc & $\mathrm{ccc}$ & $\mathrm{H} 22$ & 2 & 4 & 7.87 & $<0.010$ & $<0.080$ & $<0.010$ & 5.34 & 11.6 & 65.4 & $<0.020$ & 72.9 & $<0.100$ & $<0.200$ \\
\hline 2 & NEPH3-51 & quenched & $\mathrm{H} 34$ & 2 & 5 & 8.11 & $<0.010$ & $<0.080$ & $<0.010$ & 5.72 & 10.8 & 78.7 & $<0.020$ & 71.3 & $<0.100$ & $<0.200$ \\
\hline 2 & NEPH3-54ccc & $\mathrm{ccc}$ & $\mathrm{H} 18$ & 2 & 6 & 8.24 & $<0.010$ & $<0.080$ & $<0.010$ & 5.57 & 17.1 & 51.3 & $<0.020$ & 79.2 & $<0.100$ & 1.86 \\
\hline 2 & NEPH3-53ccc & $\mathrm{ccc}$ & $\mathrm{H} 50$ & 2 & 7 & 10.4 & $<0.010$ & $<0.080$ & $<0.010$ & 14.2 & 34.2 & 53.8 & $<0.020$ & 129 & $<0.100$ & 1.87 \\
\hline 2 & NEPH3-55ccc & $\mathrm{ccc}$ & $\mathrm{H} 28$ & 2 & 8 & 12.2 & $<0.010$ & $<0.080$ & $<0.010$ & 6.00 & 26.8 & 77.3 & $<0.020$ & 95.6 & $<0.100$ & 1.85 \\
\hline 2 & NEPH3-50 & quenched & $\mathrm{H} 24$ & 2 & 9 & 7.86 & $<0.010$ & $<0.080$ & $<0.010$ & 6.23 & 10.9 & 70.3 & $<0.020$ & 72.5 & $<0.100$ & 2.31 \\
\hline 2 & NEPH3-52 & quenched & $\mathrm{H} 30$ & 2 & 10 & 8.00 & $<0.010$ & $<0.080$ & $<0.010$ & 8.12 & 10.0 & 87.2 & $<0.020$ & 68.6 & $<0.100$ & 2.26 \\
\hline 2 & NEPH3-53 & quenched & $\mathrm{H} 29$ & 2 & 11 & 8.42 & $<0.010$ & $<0.080$ & $<0.010$ & 6.46 & 18.6 & 46.7 & $<0.020$ & 85.6 & $<0.100$ & 3.21 \\
\hline 2 & Soln Std & & STD-B2-2 & 2 & 12 & 20.7 & $<0.010$ & $<0.080$ & $<0.010$ & 4.32 & 9.68 & 83.8 & $<0.020$ & 49.7 & $<0.100$ & 2.14 \\
\hline 2 & EA & & H54 & 2 & 13 & 38.9 & $<0.010$ & $<0.080$ & $<0.010$ & $<0.004$ & 11.1 & 102 & $<0.020$ & 53.7 & $<0.100$ & $<0.200$ \\
\hline 2 & NEPH3-56 & quenched & H14 & 2 & 14 & 8.75 & $<0.010$ & $<0.080$ & $<0.010$ & 6.52 & 15.5 & 79.7 & $<0.020$ & 72.8 & $<0.100$ & 2.10 \\
\hline 2 & ARM-1 & & H17 & 2 & 15 & 13.1 & $<0.010$ & $<0.080$ & $<0.010$ & 0.039 & 9.27 & 27.5 & $<0.020$ & 39.9 & $<0.100$ & 2.68 \\
\hline 2 & NEPH3-49 & quenched & $\mathrm{H} 44$ & 2 & 16 & 7.32 & $<0.010$ & $<0.080$ & $<0.010$ & 5.84 & 11.1 & 63.4 & $<0.020$ & 72.8 & $<0.100$ & $<0.200$ \\
\hline 2 & NEPH3-56 ccc & $\operatorname{ccc}$ & H35 & 2 & 17 & 21.5 & $<0.010$ & $<0.080$ & $<0.010$ & 5.72 & 45.1 & 107 & $<0.020$ & 128 & 0.115 & $<0.200$ \\
\hline 2 & NEPH3-51 ccc & $\mathrm{ccc}$ & $\mathrm{H} 10$ & 2 & 18 & 11.2 & $<0.010$ & $<0.080$ & $<0.010$ & 5.80 & 14.7 & 82.8 & $<0.020$ & 79.7 & $<0.100$ & $<0.200$ \\
\hline 2 & NEPH3-52ccc & $\mathrm{ccc}$ & H32 & 2 & 19 & 8.55 & $<0.010$ & $<0.080$ & $<0.010$ & 4.22 & 12.3 & 91.9 & $<0.020$ & 74.3 & $<0.100$ & 2.41 \\
\hline 2 & NEPH3-55 & quenched & $\mathrm{H} 08$ & 2 & 20 & 8.42 & $<0.010$ & $<0.080$ & $<0.010$ & 6.63 & 16.0 & 71.2 & $<0.020$ & 74.3 & $<0.100$ & 2.00 \\
\hline 2 & Soln Std & & STD-B2-3 & 2 & 21 & 20.8 & $<0.010$ & $<0.080$ & $<0.010$ & 4.27 & 9.70 & 84.6 & $<0.020$ & 49.7 & $<0.100$ & 3.05 \\
\hline 2 & Soln Std & & STD-B3-1 & 3 & 1 & 21.2 & $<0.010$ & $<0.080$ & $<0.010$ & 4.26 & 9.72 & 80.0 & $<0.020$ & 48.8 & $<0.100$ & 1.82 \\
\hline 2 & NEPH3-49ccc & $\mathrm{ccc}$ & $\mathrm{H} 55$ & 3 & 2 & 7.68 & $<0.010$ & $<0.080$ & $<0.010$ & 5.82 & 12.5 & 56.5 & $<0.020$ & 76.0 & $<0.100$ & $<0.200$ \\
\hline 2 & NEPH3-54ccc & $\operatorname{ccc}$ & $\mathrm{H} 21$ & 3 & 3 & 9.71 & $<0.010$ & $<0.080$ & $<0.010$ & 7.92 & 24.4 & 55.8 & $<0.020$ & 96.7 & $<0.100$ & 2.28 \\
\hline 2 & NEPH3-51 & quenched & H39 & 3 & 4 & 8.36 & $<0.010$ & $<0.080$ & $<0.010$ & 4.78 & 11.0 & 77.1 & $<0.020$ & 71.0 & $<0.100$ & 3.14 \\
\hline 2 & EA & & $\mathrm{H} 11$ & 3 & 5 & 39.0 & $<0.010$ & $<0.080$ & $<0.010$ & $<0.004$ & 11.1 & 99.1 & $<0.020$ & 53.8 & $<0.100$ & 2.22 \\
\hline 2 & NEPH3-52 & quenched & $\mathrm{H} 01$ & 3 & 6 & 9.06 & $<0.010$ & $<0.080$ & $<0.010$ & 6.15 & 10.9 & 86.7 & $<0.020$ & 71.9 & $<0.100$ & $<0.200$ \\
\hline 2 & NEPH3-55 & quenched & $\mathrm{H} 27$ & 3 & 7 & 8.94 & $<0.010$ & $<0.080$ & $<0.010$ & 7.46 & 16.4 & 65.6 & $<0.020$ & 76.1 & $<0.100$ & 1.75 \\
\hline 2 & NEPH3-50ccc & $\mathrm{ccc}$ & $\mathrm{H} 41$ & 3 & 8 & 8.15 & $<0.010$ & $<0.080$ & $<0.010$ & 4.90 & 12.0 & 62.3 & $<0.020$ & 74.4 & $<0.100$ & 1.77 \\
\hline 2 & NEPH3-53 & quenched & $\mathrm{H} 13$ & 3 & 9 & 8.77 & $<0.010$ & $<0.080$ & $<0.010$ & 6.55 & 19.3 & 43.0 & $<0.020$ & 88.4 & $<0.100$ & 1.96 \\
\hline 2 & NEPH3-54 & quenched & $\mathrm{H} 20$ & 3 & 10 & 10.1 & $<0.010$ & $<0.080$ & $<0.010$ & 8.28 & 24.0 & 53.1 & $<0.020$ & 95.2 & $<0.100$ & 1.70 \\
\hline 2 & ARM-1 & & H49 & 3 & 11 & 12.7 & $<0.010$ & $<0.080$ & $<0.010$ & $<0.004$ & 9.23 & 24.6 & $<0.020$ & 40.0 & $<0.100$ & 1.73 \\
\hline 2 & Soln Std & & STD-B3-2 & 3 & 12 & 21.0 & $<0.010$ & $<0.080$ & $<0.010$ & 4.20 & 9.74 & 78.4 & $<0.020$ & 50.1 & $<0.100$ & 3.04 \\
\hline 2 & blank & & H56 & 3 & 13 & 0.279 & $<0.010$ & $<0.080$ & $<0.010$ & $<0.004$ & $<0.500$ & $<0.100$ & $<0.020$ & $<0.200$ & $<0.100$ & $<0.200$ \\
\hline
\end{tabular}


Table E1. Laboratory Measurements of the PCT Solutions for the Nepheline Study Glasses (continued)

\begin{tabular}{|c|c|c|c|c|c|c|c|c|c|c|c|c|c|c|c|c|}
\hline Part & Glass ID & $\begin{array}{c}\text { Heat } \\
\text { Treatment }\end{array}$ & $\begin{array}{c}\text { Laboratory } \\
\text { ID }\end{array}$ & Block & Seq & B ar & Ba ar & Cd ar & Cr ar & $\mathrm{Fe}$ ar & Li ar & $\mathrm{Na}$ ar & Pb ar & Si ar & Th ar & $\mathbf{U}$ ar \\
\hline 2 & NEPH3-50 & quenched & $\mathrm{H} 46$ & 3 & 14 & 7.95 & $<0.010$ & $<0.080$ & $<0.010$ & 5.75 & 11.1 & 65.2 & $<0.020$ & 75.0 & $<0.100$ & 2.03 \\
\hline 2 & NEPH3-56 & quenched & $\mathrm{H} 48$ & 3 & 15 & 8.54 & $<0.010$ & $<0.080$ & $<0.010$ & 7.37 & 15.9 & 72.9 & $<0.020$ & 76.8 & $<0.100$ & $<0.200$ \\
\hline 2 & NEPH3-55ccc & $\mathrm{ccc}$ & $\mathrm{H} 12$ & 3 & 16 & 12.6 & $<0.010$ & $<0.080$ & $<0.010$ & 6.22 & 27.8 & 72.1 & $<0.020$ & 100 & $<0.100$ & $<0.200$ \\
\hline 2 & NEPH3-52ccc & $\mathrm{ccc}$ & H16 & 3 & 17 & 8.83 & $<0.010$ & $<0.080$ & $<0.010$ & 4.35 & 12.0 & 82.4 & $<0.020$ & 73.4 & $<0.100$ & 2.21 \\
\hline 2 & NEPH3-49 & quenched & H06 & 3 & 18 & 7.81 & $<0.010$ & $<0.080$ & $<0.010$ & 6.04 & 11.6 & 57.5 & $<0.020$ & 77.0 & $<0.100$ & 1.95 \\
\hline 2 & NEPH3-53ccc & $\mathrm{ccc}$ & $\mathrm{H} 02$ & 3 & 19 & 11.0 & $<0.010$ & $<0.080$ & $<0.010$ & 14.5 & 35.3 & 50.1 & $<0.020$ & 132 & $<0.100$ & $<0.200$ \\
\hline 2 & NEPH3-51 ccc & $\mathrm{ccc}$ & H51 & 3 & 20 & 11.3 & $<0.010$ & $<0.080$ & $<0.010$ & 5.59 & 15.0 & 77.0 & $<0.020$ & 82.5 & $<0.100$ & 1.57 \\
\hline 2 & NEPH3-56ccc & $\mathrm{ccc}$ & $\mathrm{H} 45$ & 3 & 21 & 22.0 & $<0.010$ & $<0.080$ & $<0.010$ & 6.12 & 45.9 & 94.5 & $<0.020$ & 134 & 0.103 & 2.19 \\
\hline 2 & Soln Std & & STD-B-3-3 & 3 & 22 & 21.3 & $<0.010$ & $<0.080$ & $<0.010$ & 4.32 & 9.79 & 74.0 & $<0.020$ & 50.8 & $<0.100$ & $<0.200$ \\
\hline
\end{tabular}


Table E2. PSAL Measurements of the PCT Solutions for the Study Glasses After Appropriate Adjustments

\begin{tabular}{|c|c|c|c|c|c|c|c|c|c|c|c|c|c|c|c|c|}
\hline Part & Glass ID & $\begin{array}{c}\text { Heat } \\
\text { Treatment }\end{array}$ & Laboratory ID & Block & Seq & B (ppm) & Ba (ppm) & Cd (ppm) & $\mathrm{Cr}(\mathrm{pp})$ & $\mathrm{Fe}(\mathrm{ppm})$ & Li (ppm) & Na (ppm) & $\mathrm{Pb}$ (ppm) & Si (ppm) & Th (ppm) & $\mathbf{U}(\mathbf{p p m})$ \\
\hline 1 & Soln Std & & STD-B1-1 Cs & 1 & 1 & 19.4 & 0.005 & 0.04 & 0.005 & 4.1 & 9.79 & 83.1 & 0.01 & 50 & 0.05 & 0.1 \\
\hline 1 & NEPH3-42 & quenched & F52 & 1 & 2 & 11.616899 & 0.0083335 & 0.066668 & 0.0083335 & 6.783469 & 17.16701 & 85.66838 & 0.016667 & 113.00226 & 0.083335 & 3.00006 \\
\hline 1 & NEPH3-42ccc & $\mathrm{ccc}$ & F39 & 1 & 3 & 10.483543 & 0.0083335 & 0.066668 & 0.0083335 & 5.66678 & 17.33368 & 81.6683 & 0.016667 & 111.83557 & 0.083335 & 2.983393 \\
\hline 1 & ARM-1 & & F08 & 1 & 4 & 17.83369 & 0.0083335 & 0.066668 & 0.0083335 & 0.0033334 & 13.733608 & 39.00078 & 0.016667 & 64.50129 & 0.083335 & 0.16667 \\
\hline 1 & NEPH3-47 & quenched & F01 & 1 & 5 & 13.766942 & 0.0083335 & 0.066668 & 0.0083335 & 7.116809 & 23.00046 & 100.002 & 0.016667 & 114.33562 & 0.083335 & 2.83339 \\
\hline 1 & NEPH3-47ccc & $\mathrm{ccc}$ & F48 & 1 & 6 & 12.683587 & 0.0083335 & 0.066668 & 0.0083335 & 6.633466 & 25.50051 & 97.66862 & 0.016667 & 119.50239 & 0.083335 & 2.783389 \\
\hline 1 & blank & & F26 & 1 & 7 & 0.066668 & 0.0083335 & 0.066668 & 0.0083335 & 0.0033334 & 0.416675 & 0.4116749 & 0.016667 & 0.16667 & 0.083335 & 0.16667 \\
\hline 1 & NEPH3-46 & quenched & F25 & 1 & 8 & 11.733568 & 0.0083335 & 0.066668 & 0.0083335 & 7.100142 & 23.66714 & 73.50147 & 0.016667 & 120.83575 & 0.083335 & 2.83339 \\
\hline 1 & NEPH3-46ccc & $\mathrm{ccc}$ & F07 & 1 & 9 & 12.733588 & 0.0083335 & 0.066668 & 0.0083335 & 7.866824 & 26.50053 & 75.33484 & 0.016667 & 128.16923 & 0.083335 & 3.00006 \\
\hline 1 & NEPH3-41 & quenched & F37 & 1 & 10 & 9.083515 & 0.0083335 & 0.066668 & 0.0083335 & 6.966806 & 17.83369 & 74.83483 & 0.016667 & 117.66902 & 0.083335 & 3.416735 \\
\hline 1 & NEPH3-41ccc & $\mathrm{ccc}$ & F32 & 1 & 11 & 8.766842 & 0.0083335 & 0.066668 & 0.0083335 & 7.33348 & 17.66702 & 71.6681 & 0.016667 & 116.00232 & 0.083335 & 3.150063 \\
\hline 1 & Soln Std & & STD-B1-2 & 1 & 12 & 19.4 & 0.005 & 0.04 & 0.005 & 3.87 & 9.62 & 81.1 & 0.01 & 48.8 & 0.05 & 0.1 \\
\hline 1 & NEPH3-44 & quenched & F15 & 1 & 13 & 11.00022 & 0.0083335 & 0.066668 & 0.0083335 & 6.983473 & 15.266972 & 120.66908 & 0.016667 & 104.16875 & 0.083335 & 2.950059 \\
\hline 1 & NEPH3-44ccc & $\mathrm{ccc}$ & F36 & 1 & 14 & 11.400228 & 0.0083335 & 0.066668 & 0.0083335 & 5.066768 & 19.16705 & 124.33582 & 0.016667 & 110.83555 & 0.083335 & 2.566718 \\
\hline 1 & NEPH3-48 & quenched & F38 & 1 & 15 & 12.950259 & 0.0083335 & 0.066668 & 0.0083335 & 9.016847 & 22.16711 & 122.00244 & 0.016667 & 114.00228 & 0.083335 & 2.733388 \\
\hline 1 & NEPH3-48ccc & ccc & F47 & 1 & 16 & 20.0004 & 0.0083335 & 0.066668 & 0.0083335 & 5.233438 & 36.50073 & 137.16941 & 0.016667 & 138.3361 & 0.083335 & 3.266732 \\
\hline 1 & EA & & F50 & 1 & 17 & 625.00125 & 0.0833335 & 0.666668 & 0.0833335 & 0.0333334 & 183.3337 & 1716.6701 & 0.166667 & 883.3351 & 0.833335 & 1.66667 \\
\hline 1 & NEPH3-43 & quenched & F10 & 1 & 18 & 11.16689 & 0.0083335 & 0.066668 & 0.0083335 & 7.00014 & 16.83367 & 110.0022 & 0.016667 & 110.16887 & 0.083335 & 2.716721 \\
\hline 1 & NEPH3-43ccc & $\mathrm{ccc}$ & F34 & 1 & 19 & 11.450229 & 0.0083335 & 0.066668 & 0.0083335 & 8.566838 & 20.16707 & 109.00218 & 0.016667 & 118.50237 & 0.083335 & 3.16673 \\
\hline 1 & NEPH3-45 & quenched & F55 & 1 & 20 & 11.916905 & 0.0083335 & 0.066668 & 0.0083335 & 7.800156 & 25.66718 & 60.66788 & 0.016667 & 130.83595 & 0.083335 & 4.00008 \\
\hline 1 & NEPH3-45ccc & $\mathrm{ccc}$ & F28 & 1 & 21 & 12.00024 & 0.0083335 & 0.066668 & 0.0083335 & 7.200144 & 26.33386 & 61.33456 & 0.016667 & 132.16931 & 0.083335 & 3.466736 \\
\hline 1 & Soln Std & & STD-B1-3 & 1 & 22 & 19.4 & 0.005 & 0.04 & 0.005 & 3.9 & 9.71 & 82.4 & 0.01 & 49.4 & 0.05 & 0.1 \\
\hline 1 & Soln Std & & STD-B2-1 & 2 & 1 & 21.8 & 0.005 & 0.04 & 0.005 & 4.21 & 9.66 & 79 & 0.01 & 49.5 & 0.05 & 0.1 \\
\hline 1 & NEPH3-42 & quenched & F05 & 2 & 2 & 13.183597 & 0.0083335 & 0.066668 & 0.0083335 & 6.16679 & 18.16703 & 87.50175 & 0.016667 & 118.3357 & 0.083335 & 2.866724 \\
\hline 1 & NEPH3-42ccc & $\mathrm{ccc}$ & F30 & 2 & 3 & 11.683567 & 0.0083335 & 0.066668 & 0.0083335 & 6.300126 & 17.83369 & 81.33496 & 0.016667 & 114.83563 & 0.083335 & 2.850057 \\
\hline 1 & NEPH3-47 & quenched & F27 & 2 & 4 & 15.133636 & 0.0083335 & 0.066668 & 0.0083335 & 7.383481 & 23.50047 & 101.50203 & 0.016667 & 116.16899 & 0.083335 & 2.883391 \\
\hline 1 & NEPH3-47ccc & $\mathrm{ccc}$ & F03 & 2 & 5 & 13.866944 & 0.0083335 & 0.066668 & 0.0083335 & 6.750135 & 25.66718 & 95.0019 & 0.016667 & 120.83575 & 0.083335 & 2.783389 \\
\hline 1 & NEPH3-46 & quenched & F35 & 2 & 6 & 13.250265 & 0.0083335 & 0.066668 & 0.0083335 & 7.216811 & 23.66714 & 72.00144 & 0.016667 & 121.16909 & 0.083335 & 2.866724 \\
\hline 1 & NEPH3-46ccc & $\mathrm{ccc}$ & F19 & 2 & 7 & 14.083615 & 0.0083335 & 0.066668 & 0.0083335 & 7.83349 & 26.6672 & 72.50145 & 0.016667 & 128.50257 & 0.083335 & 3.050061 \\
\hline
\end{tabular}


Table E2. PSAL Measurements of the PCT Solutions for the Study Glasses After Appropriate Adjustments (continued)

\begin{tabular}{|c|c|c|c|c|c|c|c|c|c|c|c|c|c|c|c|c|}
\hline Part & Glass ID & $\begin{array}{c}\text { Heat } \\
\text { Treatment }\end{array}$ & Laboratory ID & Block & Seq & B (ppm) & Ba (ppm) & Cd (ppm) & $\operatorname{Cr}(p p)$ & $\mathrm{Fe}$ (ppm) & Li (ppm) & $\mathrm{Na}(\mathrm{ppm})$ & $\mathrm{Pb}(\mathrm{ppm})$ & Si (ppm) & Th (ppm) & U (ppm) \\
\hline 1 & NEPH3-41 & quenched & F09 & 2 & 8 & 10.250205 & 0.0083335 & 0.066668 & 0.0083335 & 6.533464 & 18.00036 & 71.16809 & 0.016667 & 119.00238 & 0.083335 & 3.716741 \\
\hline 1 & NEPH3-41ccc & ccc & F11 & 2 & 9 & 10.200204 & 0.0083335 & 0.066668 & 0.0083335 & 6.050121 & 18.00036 & 68.16803 & 0.016667 & 117.33568 & 0.083335 & 3.100062 \\
\hline 1 & ARM-1 & & F29 & 2 & 10 & 18.83371 & 0.0083335 & 0.066668 & 0.0083335 & 0.0033334 & 14.450289 & 39.50079 & 0.016667 & 66.33466 & 0.083335 & 0.16667 \\
\hline 1 & EA & & F53 & 2 & 11 & 638.33461 & 0.0833335 & 0.666668 & 0.0833335 & 0.0333334 & 185.00037 & 1683.3367 & 0.166667 & 895.00179 & 0.833335 & 1.66667 \\
\hline 1 & Soln Std & & STD-B2-2 & 2 & 12 & 20.7 & 0.005 & 0.04 & 0.005 & 4.02 & 9.7 & 79.2 & 0.01 & 50 & 0.05 & 0.1 \\
\hline 1 & NEPH3-44 & quenched & F24 & 2 & 13 & 12.550251 & 0.0083335 & 0.066668 & 0.0083335 & 7.650153 & 15.533644 & 120.16907 & 0.016667 & 105.33544 & 0.083335 & 2.716721 \\
\hline 1 & NEPH3-44ccc & $\mathrm{ccc}$ & F22 & 2 & 14 & 12.566918 & 0.0083335 & 0.066668 & 0.0083335 & 4.483423 & 19.00038 & 122.83579 & 0.016667 & 110.0022 & 0.083335 & 2.650053 \\
\hline 1 & NEPH3-48 & quenched & F14 & 2 & 15 & 14.550291 & 0.0083335 & 0.066668 & 0.0083335 & 9.200184 & 22.33378 & 120.0024 & 0.016667 & 115.33564 & 0.083335 & 3.033394 \\
\hline 1 & NEPH3-48ccc & $\mathrm{ccc}$ & F20 & 2 & 16 & 21.16709 & 0.0083335 & 0.066668 & 0.0083335 & 5.566778 & 36.16739 & 135.33604 & 0.016667 & 138.83611 & 0.083335 & 3.200064 \\
\hline 1 & NEPH3-43 & quenched & F49 & 2 & 17 & 11.600232 & 0.0083335 & 0.066668 & 0.0083335 & 9.00018 & 16.667 & 109.33552 & 0.016667 & 111.16889 & 0.083335 & 3.283399 \\
\hline 1 & NEPH3-43ccc & $\mathrm{ccc}$ & F44 & 2 & 18 & 12.350247 & 0.0083335 & 0.066668 & 0.0083335 & 8.933512 & 19.83373 & 106.33546 & 0.016667 & 117.66902 & 0.083335 & 3.116729 \\
\hline 1 & NEPH3-45 & quenched & F16 & 2 & 19 & 13.250265 & 0.0083335 & 0.066668 & 0.0083335 & 8.300166 & 25.83385 & 60.16787 & 0.016667 & 132.00264 & 0.083335 & 3.600072 \\
\hline 1 & NEPH3-45ccc & $\mathrm{ccc}$ & F02 & 2 & 20 & 13.016927 & 0.0083335 & 0.066668 & 0.0083335 & 8.650173 & 25.83385 & 59.00118 & 0.016667 & 131.83597 & 0.083335 & 3.633406 \\
\hline 1 & Soln Std & & STD-B2-3 & 2 & 21 & 19.8 & 0.005 & 0.04 & 0.005 & 4.1 & 9.55 & 79.6 & 0.01 & 48.8 & 0.05 & 0.1 \\
\hline 1 & Soln Std & & STD-B3-1 & 3 & 1 & 22.1 & 0.005 & 0.04 & 0.005 & 3.92 & 9.77 & 80.5 & 0.01 & 49.4 & 0.05 & 0.25 \\
\hline 1 & NEPH3-42 & quenched & F06 & 3 & 2 & 13.266932 & 0.0083335 & 0.066668 & 0.0083335 & 5.750115 & 17.66702 & 86.83507 & 0.016667 & 113.3356 & 0.083335 & 3.266732 \\
\hline 1 & NEPH3-42ccc & $\mathrm{ccc}$ & F23 & 3 & 3 & 12.233578 & 0.0083335 & 0.066668 & 0.0083335 & 6.366794 & 17.66702 & 87.00174 & 0.016667 & 111.6689 & 0.083335 & 3.16673 \\
\hline 1 & EA & & F46 & 3 & 4 & 581.66783 & 0.0833335 & 0.666668 & 0.0833335 & 0.0333334 & 168.33367 & 1530.00306 & 0.166667 & 800.0016 & 0.833335 & 1.66667 \\
\hline 1 & NEPH3-47 & quenched & F31 & 3 & 5 & 16.283659 & 0.0083335 & 0.066668 & 0.0083335 & 7.850157 & 23.00046 & 98.50197 & 0.016667 & 114.66896 & 0.083335 & 3.183397 \\
\hline 1 & NEPH3-47ccc & $\mathrm{ccc}$ & F43 & 3 & 6 & 14.816963 & 0.0083335 & 0.066668 & 0.0083335 & 7.16681 & 25.50051 & 96.16859 & 0.016667 & 118.66904 & 0.083335 & 3.016727 \\
\hline 1 & NEPH3-46 & quenched & F45 & 3 & 7 & 14.283619 & 0.0083335 & 0.066668 & 0.0083335 & 6.983473 & 23.83381 & 71.00142 & 0.016667 & 121.83577 & 0.083335 & 3.200064 \\
\hline 1 & NEPH3-46ccc & $\mathrm{ccc}$ & F56 & 3 & 8 & 14.800296 & 0.0083335 & 0.066668 & 0.0083335 & 8.083495 & 26.50053 & 71.83477 & 0.016667 & 129.33592 & 0.083335 & 3.383401 \\
\hline 1 & NEPH3-41 & quenched & F17 & 3 & 9 & 11.250225 & 0.0083335 & 0.066668 & 0.0083335 & 7.583485 & 18.00036 & 72.50145 & 0.016667 & 120.66908 & 0.083335 & 3.800076 \\
\hline 1 & NEPH3-41 ccc & $\mathrm{ccc}$ & F41 & 3 & 10 & 10.783549 & 0.0083335 & 0.066668 & 0.0083335 & 6.433462 & 18.00036 & 68.00136 & 0.016667 & 120.33574 & 0.083335 & 3.900078 \\
\hline 1 & blank & & F12 & 3 & 11 & 0.066668 & 0.0083335 & 0.066668 & 0.0083335 & 0.0033334 & 0.416675 & 0.066668 & 0.016667 & 0.16667 & 0.083335 & 0.16667 \\
\hline 1 & Soln Std & & STD-B3-2 & 3 & 12 & 20.4 & 0.005 & 0.04 & 0.005 & 3.96 & 9.62 & 79.8 & 0.01 & 49 & 0.05 & 0.1 \\
\hline 1 & NEPH3-44 & quenched & $\mathrm{F} 21$ & 3 & 13 & 13.066928 & 0.0083335 & 0.066668 & 0.0083335 & 8.133496 & 15.783649 & 121.00242 & 0.016667 & 105.50211 & 0.083335 & 3.433402 \\
\hline 1 & NEPH3-44ccc & $\mathrm{ccc}$ & F42 & 3 & 14 & 13.600272 & 0.0083335 & 0.066668 & 0.0083335 & 4.700094 & 19.50039 & 123.83581 & 0.016667 & 112.16891 & 0.083335 & 3.250065 \\
\hline 1 & NEPH3-48 & quenched & F18 & 3 & 15 & 15.050301 & 0.0083335 & 0.066668 & 0.0083335 & 9.400188 & \begin{tabular}{|l|}
22.16711 \\
\end{tabular} & 121.6691 & 0.016667 & 115.0023 & 0.083335 & 3.283399 \\
\hline 1 & NEPH3-48ccc & $\mathrm{ccc}$ & F33 & 3 & 16 & 22.00044 & 0.0083335 & 0.066668 & 0.0083335 & 5.716781 & 36.6674 & 134.00268 & 0.016667 & 140.33614 & 0.083335 & 3.516737 \\
\hline 1 & ARM-1 & & F13 & 3 & 17 & 20.66708 & 0.0083335 & 0.066668 & 0.0083335 & 0.0033334 & 14.750295 & 40.50081 & 0.016667 & 67.50135 & 0.083335 & 0.16667 \\
\hline
\end{tabular}


Table E2. PSAL Measurements of the PCT Solutions for the Study Glasses After Appropriate Adjustments (continued)

\begin{tabular}{|c|c|c|c|c|c|c|c|c|c|c|c|c|c|c|c|c|}
\hline Part & Glass ID & \begin{tabular}{c|} 
Heat \\
Treatment
\end{tabular} & Laboratory ID & Block & Seq & B (ppm) & Ba (ppm) & Cd (ppm) & Cr (pp) & $\mathrm{Fe}(\mathrm{ppm})$ & Li (ppm) & Na (ppm) & $\mathrm{Pb}(\mathbf{p p m})$ & Si (ppm) & Th (ppm) & U (ppm) \\
\hline 1 & NEPH3-43 & quenched & F54 & 3 & 18 & 12.016907 & 0.0083335 & 0.066668 & 0.0083335 & 8.900178 & 15.916985 & 103.16873 & 0.016667 & 106.6688 & 0.083335 & 4.083415 \\
\hline 1 & NEPH3-43ccc & $\operatorname{ccc}$ & F51 & 3 & 19 & 12.883591 & 0.0083335 & 0.066668 & 0.0083335 & 8.83351 & 19.50039 & 103.00206 & 0.016667 & 114.66896 & 0.083335 & 3.3334 \\
\hline 1 & NEPH3-45 & quenched & F40 & 3 & 20 & 13.750275 & 0.0083335 & 0.066668 & 0.0083335 & 9.450189 & 25.33384 & 58.83451 & 0.016667 & 128.3359 & 0.083335 & 3.83341 \\
\hline 1 & NEPH3-45ccc & $\mathrm{ccc}$ & F04 & 3 & 21 & 13.900278 & 0.0083335 & 0.066668 & 0.0083335 & 7.983493 & 26.00052 & 58.50117 & 0.016667 & 131.33596 & 0.083335 & 4.083415 \\
\hline 1 & Soln Std & & STD-B-3-3 & 3 & 22 & 20.5 & 0.005 & 0.04 & 0.005 & 3.89 & 9.62 & 80.1 & 0.01 & 49.6 & 0.05 & 0.1 \\
\hline 2 & Soln Std & & STD-B1-1 & 1 & 1 & 21.8 & 0.005 & 0.04 & 0.005 & 4.44 & 9.67 & 81 & 0.01 & 49.4 & 0.05 & 1.88 \\
\hline 2 & EA & & $\mathrm{H} 43$ & 1 & 2 & 643.33462 & 0.0833335 & 0.666668 & 0.0833335 & 0.0333334 & 183.3337 & 1628.33659 & 0.166667 & 886.66844 & 0.833335 & 1.66667 \\
\hline 2 & NEPH3-56ccc & $\mathrm{ccc}$ & H07 & 1 & 3 & 36.83407 & 0.0083335 & 0.066668 & 0.0083335 & 9.283519 & 74.50149 & 168.3367 & 0.016667 & 213.3376 & 0.1933372 & 3.016727 \\
\hline 2 & ARM-1 & & H09 & 1 & 4 & 21.16709 & 0.0083335 & 0.066668 & 0.0083335 & 0.0033334 & 15.150303 & 42.33418 & 0.016667 & 65.33464 & 0.083335 & 3.233398 \\
\hline 2 & NEPH3-54ccc & $\mathrm{ccc}$ & $\mathrm{H} 26$ & 1 & 5 & 15.883651 & 0.0083335 & 0.066668 & 0.0083335 & 15.250305 & 39.66746 & 91.16849 & 0.016667 & 161.50323 & 0.083335 & 2.866724 \\
\hline 2 & NEPH3-56 & quenched & H04 & 1 & 6 & 13.750275 & 0.0083335 & 0.066668 & 0.0083335 & 12.183577 & 25.50051 & 126.50253 & 0.016667 & 120.16907 & 0.083335 & 0.16667 \\
\hline 2 & NEPH3-52ccc & $\mathrm{ccc}$ & $\mathrm{H} 47$ & 1 & 7 & 14.400288 & 0.0083335 & 0.066668 & 0.0083335 & 6.916805 & 20.50041 & 144.66956 & 0.016667 & 121.50243 & 0.083335 & 2.633386 \\
\hline 2 & NEPH3-55 & quenched & $\mathrm{H} 23$ & 1 & 8 & 14.116949 & 0.0083335 & 0.066668 & 0.0083335 & 9.66686 & 26.33386 & 111.83557 & 0.016667 & 121.33576 & 0.083335 & 0.16667 \\
\hline 2 & NEPH3-54 & quenched & $\mathrm{H} 33$ & 1 & 9 & 13.416935 & 0.0083335 & 0.066668 & 0.0083335 & 8.866844 & 28.16723 & 81.83497 & 0.016667 & 130.0026 & 0.083335 & 3.600072 \\
\hline 2 & blank & & H19 & 1 & 10 & 0.4183417 & 0.0083335 & 0.066668 & 0.0083335 & 0.0033334 & 0.416675 & 0.083335 & 0.016667 & 0.16667 & 0.083335 & 5.133436 \\
\hline 2 & NEPH3-49 & quenched & H31 & 1 & 11 & 11.700234 & 0.0083335 & 0.066668 & 0.0083335 & 9.566858 & 18.16703 & 98.00196 & 0.016667 & 119.33572 & 0.083335 & 3.66674 \\
\hline 2 & Soln Std & & STD-B1-2 & 1 & 12 & 20 & 0.005 & 0.04 & 0.005 & 4.36 & 9.64 & 80.6 & 0.01 & 49.3 & 0.05 & 1.85 \\
\hline 2 & NEPH3-51ccc & $\mathrm{ccc}$ & $\mathrm{H} 40$ & 1 & 13 & 17.66702 & 0.0083335 & 0.066668 & 0.0083335 & 9.266852 & 24.16715 & 131.16929 & 0.016667 & 130.50261 & 0.083335 & 3.283399 \\
\hline 2 & NEPH3-50 & quenched & $\mathrm{H} 38$ & 1 & 14 & 12.716921 & 0.0083335 & 0.066668 & 0.0083335 & 9.933532 & 17.83369 & 114.00228 & 0.016667 & 119.66906 & 0.083335 & 3.83341 \\
\hline 2 & NEPH3-50 ccc & $\mathrm{ccc}$ & $\mathrm{H} 05$ & 1 & 15 & 12.866924 & 0.0083335 & 0.066668 & 0.0083335 & 8.250165 & 19.33372 & 109.50219 & 0.016667 & 120.50241 & 0.083335 & 3.716741 \\
\hline 2 & NEPH3-49ccc & $\mathrm{ccc}$ & $\mathrm{H} 53$ & 1 & 16 & 12.350247 & 0.0083335 & 0.066668 & 0.0083335 & 9.566858 & 19.83373 & 94.16855 & 0.016667 & 124.16915 & 0.083335 & 3.433402 \\
\hline 2 & NEPH3-53 & quenched & H37 & 1 & 17 & 13.100262 & 0.0083335 & 0.066668 & 0.0083335 & 11.100222 & 29.66726 & 71.33476 & 0.016667 & 136.83607 & 0.083335 & 0.16667 \\
\hline 2 & NEPH3-52 & quenched & $\mathrm{H} 42$ & 1 & 18 & 13.700274 & 0.0083335 & 0.066668 & 0.0083335 & 10.783549 & 17.66702 & 147.66962 & 0.016667 & 118.00236 & 0.083335 & 3.050061 \\
\hline 2 & NEPH3-53ccc & $\mathrm{ccc}$ & $\mathrm{H} 36$ & 1 & 19 & 16.83367 & 0.0083335 & 0.066668 & 0.0083335 & 23.00046 & 57.66782 & 88.50177 & 0.016667 & 216.671 & 0.083335 & 3.133396 \\
\hline 2 & NEPH3-51 & quenched & $\mathrm{H} 03$ & 1 & 20 & 13.450269 & 0.0083335 & 0.066668 & 0.0083335 & 8.683507 & 18.00036 & 130.16927 & 0.016667 & 118.3357 & 0.083335 & 5.400108 \\
\hline 2 & NEPH3-55 ccc & $\mathrm{ccc}$ & $\mathrm{H} 25$ & 1 & 21 & 18.66704 & 0.0083335 & 0.066668 & 0.0083335 & 9.183517 & 44.66756 & 126.6692 & 0.016667 & 158.3365 & 0.083335 & 3.133396 \\
\hline 2 & Soln Std & & STD-B1-3 & 1 & 22 & 19.7 & 0.005 & 0.04 & 0.005 & 4.28 & 9.66 & 82.4 & 0.01 & 48.7 & 0.05 & 2.06 \\
\hline 2 & Soln Std & & STD-B2-1 & 2 & 1 & 21.9 & 0.005 & 0.04 & 0.005 & 4.4 & 9.69 & 81.6 & 0.01 & 49.5 & 0.05 & 1.99 \\
\hline 2 & NEPH3-49ccc & $\mathrm{ccc}$ & $\mathrm{H} 52$ & 2 & 2 & 12.683587 & 0.0083335 & 0.066668 & 0.0083335 & 9.866864 & 20.33374 & 98.16863 & 0.016667 & 127.16921 & 0.083335 & 3.750075 \\
\hline 2 & NEPH3-54 & quenched & H15 & 2 & 3 & 13.350267 & 0.0083335 & 0.066668 & 0.0083335 & 8.816843 & 27.50055 & 84.83503 & 0.016667 & 127.83589 & 0.083335 & 2.983393 \\
\hline 2 & NEPH3-50ccc & $\mathrm{ccc}$ & $\mathrm{H} 22$ & 2 & 4 & 13.116929 & 0.0083335 & 0.066668 & 0.0083335 & 8.900178 & 19.33372 & 109.00218 & 0.016667 & 121.50243 & 0.083335 & 0.16667 \\
\hline
\end{tabular}


Table E2. PSAL Measurements of the PCT Solutions for the Study Glasses After Appropriate Adjustments (continued)

\begin{tabular}{|c|c|c|c|c|c|c|c|c|c|c|c|c|c|c|c|c|}
\hline Part & Glass ID & $\begin{array}{c}\text { Heat } \\
\text { Treatment }\end{array}$ & Laboratory ID & Block & Seq & B (ppm) & Ba (ppm) & Cd (ppm) & $\mathrm{Cr}$ (pp) & $\mathrm{Fe}(\mathrm{ppm})$ & Li (ppm) & $\mathrm{Na}(\mathrm{ppm})$ & $\mathrm{Pb}(\mathbf{p p m})$ & Si (ppm) & Th (ppm) & $\mathrm{U}(\mathbf{p p m})$ \\
\hline 2 & NEPH3-51 & quenched & H34 & 2 & 5 & 13.516937 & 0.0083335 & 0.066668 & 0.0083335 & 9.533524 & 18.00036 & 131.16929 & 0.016667 & 118.83571 & 0.083335 & 0.16667 \\
\hline 2 & NEPH3-54ccc & ccc & H18 & 2 & 6 & 13.733608 & 0.0083335 & 0.066668 & 0.0083335 & 9.283519 & 28.50057 & 85.50171 & 0.016667 & 132.00264 & 0.083335 & 3.100062 \\
\hline 2 & NEPH3-53ccc & ccc & H50 & 2 & 7 & 17.33368 & 0.0083335 & 0.066668 & 0.0083335 & 23.66714 & 57.00114 & 89.66846 & 0.016667 & 215.0043 & 0.083335 & 3.116729 \\
\hline 2 & NEPH3-55ccc & $\mathrm{ccc}$ & $\mathrm{H} 28$ & 2 & 8 & 20.33374 & 0.0083335 & 0.066668 & 0.0083335 & 10.0002 & 44.66756 & 128.83591 & 0.016667 & 159.33652 & 0.083335 & 3.083395 \\
\hline 2 & NEPH3-50 & quenched & $\mathrm{H} 24$ & 2 & 9 & 13.100262 & 0.0083335 & 0.066668 & 0.0083335 & 10.383541 & 18.16703 & 117.16901 & 0.016667 & 120.83575 & 0.083335 & 3.850077 \\
\hline 2 & NEPH3-52 & quenched & $\mathrm{H} 30$ & 2 & 10 & 13.3336 & 0.0083335 & 0.066668 & 0.0083335 & 13.533604 & 16.667 & 145.33624 & 0.016667 & 114.33562 & 0.083335 & 3.766742 \\
\hline 2 & NEPH3-53 & quenched & $\mathrm{H} 29$ & 2 & 11 & 14.033614 & 0.0083335 & 0.066668 & 0.0083335 & 10.766882 & 31.00062 & 77.83489 & 0.016667 & 142.66952 & 0.083335 & 5.350107 \\
\hline 2 & Soln Std & & STD-B2-2 & 2 & 12 & 20.7 & 0.005 & 0.04 & 0.005 & 4.32 & 9.68 & 83.8 & 0.01 & 49.7 & 0.05 & 2.14 \\
\hline 2 & EA & & H54 & 2 & 13 & 648.33463 & 0.0833335 & 0.666668 & 0.0833335 & 0.0333334 & 185.00037 & 1700.0034 & 0.166667 & 895.00179 & 0.833335 & 1.66667 \\
\hline 2 & NEPH3-56 & quenched & $\mathrm{H} 14$ & 2 & 14 & 14.583625 & 0.0083335 & 0.066668 & 0.0083335 & 10.866884 & 25.83385 & 132.83599 & 0.016667 & 121.33576 & 0.083335 & 3.50007 \\
\hline 2 & ARM-1 & & H17 & 2 & 15 & 21.83377 & 0.0083335 & 0.066668 & 0.0083335 & 0.0650013 & 15.450309 & 45.83425 & 0.016667 & 66.50133 & 0.083335 & 4.466756 \\
\hline 2 & NEPH3-49 & quenched & $\mathrm{H} 44$ & 2 & 16 & 12.200244 & 0.0083335 & 0.066668 & 0.0083335 & 9.733528 & 18.50037 & 105.66878 & 0.016667 & 121.33576 & 0.083335 & 0.16667 \\
\hline 2 & NEPH3-56ccc & ccc & H35 & 2 & 17 & 35.83405 & 0.0083335 & 0.066668 & 0.0083335 & 9.533524 & 75.16817 & 178.3369 & 0.016667 & 213.3376 & 0.1916705 & 0.16667 \\
\hline 2 & NEPH3-51ccc & ccc & H10 & 2 & 18 & 18.66704 & 0.0083335 & 0.066668 & 0.0083335 & 9.66686 & 24.50049 & 138.00276 & 0.016667 & 132.83599 & 0.083335 & 0.16667 \\
\hline 2 & NEPH3-52ccc & $\operatorname{ccc}$ & $\mathrm{H} 32$ & 2 & 19 & 14.250285 & 0.0083335 & 0.066668 & 0.0083335 & 7.033474 & 20.50041 & 153.16973 & 0.016667 & 123.83581 & 0.083335 & 4.016747 \\
\hline 2 & NEPH3-55 & quenched & H08 & 2 & 20 & 14.033614 & 0.0083335 & 0.066668 & 0.0083335 & 11.050221 & 26.6672 & 118.66904 & 0.016667 & 123.83581 & 0.083335 & 3.3334 \\
\hline 2 & Soln Std & & STD-B2-3 & 2 & 21 & 20.8 & 0.005 & 0.04 & 0.005 & 4.27 & 9.7 & 84.6 & 0.01 & 49.7 & 0.05 & 3.05 \\
\hline 2 & Soln Std & & STD-B3-1 & 3 & 1 & 21.2 & 0.005 & 0.04 & 0.005 & 4.26 & 9.72 & 80 & 0.01 & 48.8 & 0.05 & 1.82 \\
\hline 2 & NEPH3-49ccc & $\mathrm{ccc}$ & H55 & 3 & 2 & 12.800256 & 0.0083335 & 0.066668 & 0.0083335 & 9.700194 & 20.83375 & 94.16855 & 0.016667 & 126.6692 & 0.083335 & 0.16667 \\
\hline 2 & NEPH3-54ccc & ccc & $\mathrm{H} 21$ & 3 & 3 & 16.183657 & 0.0083335 & 0.066668 & 0.0083335 & 13.200264 & 40.66748 & 93.00186 & 0.016667 & 161.16989 & 0.083335 & 3.800076 \\
\hline 2 & NEPH3-51 & quenched & H39 & 3 & 4 & 13.933612 & 0.0083335 & 0.066668 & 0.0083335 & 7.966826 & 18.3337 & 128.50257 & 0.016667 & 118.3357 & 0.083335 & 5.233438 \\
\hline 2 & EA & & H11 & 3 & 5 & 650.0013 & 0.0833335 & 0.666668 & 0.0833335 & 0.0333334 & 185.00037 & 1651.66997 & 0.166667 & 896.66846 & 0.833335 & 37.000074 \\
\hline 2 & NEPH3-52 & quenched & H01 & 3 & 6 & 15.100302 & 0.0083335 & 0.066668 & 0.0083335 & 10.250205 & 18.16703 & 144.50289 & 0.016667 & 119.83573 & 0.083335 & 0.16667 \\
\hline 2 & NEPH3-55 & quenched & $\mathrm{H} 27$ & 3 & 7 & 14.900298 & 0.0083335 & 0.066668 & 0.0083335 & 12.433582 & 27.33388 & 109.33552 & 0.016667 & 126.83587 & 0.083335 & 2.916725 \\
\hline 2 & NEPH3-50ccc & $\mathrm{ccc}$ & $\mathrm{H} 41$ & 3 & 8 & 13.583605 & 0.0083335 & 0.066668 & 0.0083335 & 8.16683 & 20.0004 & 103.83541 & 0.016667 & 124.00248 & 0.083335 & 2.950059 \\
\hline 2 & NEPH3-53 & quenched & H13 & 3 & 9 & 14.616959 & 0.0083335 & 0.066668 & 0.0083335 & 10.916885 & 32.16731 & 71.6681 & 0.016667 & 147.33628 & 0.083335 & 3.266732 \\
\hline 2 & NEPH3-54 & quenched & $\mathrm{H} 20$ & 3 & 10 & 16.83367 & 0.0083335 & 0.066668 & 0.0083335 & 13.800276 & 40.0008 & 88.50177 & 0.016667 & 158.66984 & 0.083335 & 2.83339 \\
\hline 2 & ARM-1 & & $\mathrm{H} 49$ & 3 & 11 & 21.16709 & 0.0083335 & 0.066668 & 0.0083335 & 0.0033334 & 15.383641 & 41.00082 & 0.016667 & 66.668 & 0.083335 & 2.883391 \\
\hline 2 & Soln Std & & STD-B3-2 & 3 & 12 & 21 & 0.005 & 0.04 & 0.005 & 4.2 & 9.74 & 78.4 & 0.01 & 50.1 & 0.05 & 3.04 \\
\hline 2 & blank & & H56 & 3 & 13 & 0.4650093 & 0.0083335 & 0.066668 & 0.0083335 & 0.0033334 & 0.416675 & 0.083335 & 0.016667 & 0.16667 & 0.083335 & 0.16667 \\
\hline 2 & NEPH3-50 & quenched & $\mathrm{H} 46$ & 3 & 14 & 13.250265 & 0.0083335 & 0.066668 & 0.0083335 & 9.583525 & 18.50037 & 108.66884 & 0.016667 & 125.0025 & 0.083335 & 3.383401 \\
\hline
\end{tabular}


Table E2. PSAL Measurements of the PCT Solutions for the Study Glasses After Appropriate Adjustments (continued)

\begin{tabular}{|c|c|c|c|c|c|c|c|c|c|c|c|c|c|c|c|c|}
\hline Part & Glass ID & $\begin{array}{c}\text { Heat } \\
\text { Treatment }\end{array}$ & Laboratory ID & Block & Seq & B (ppm) & Ba (ppm) & Cd (ppm) & Cr (pp) & $\mathrm{Fe}(\mathrm{ppm})$ & Li (ppm) & $\mathrm{Na}(\mathrm{ppm})$ & $\mathrm{Pb}(\mathrm{ppm})$ & Si (ppm) & Th (ppm) & $\mathbf{U}(\mathbf{p p m})$ \\
\hline 2 & NEPH3-56 & quenched & $\mathrm{H} 48$ & 3 & 15 & 14.233618 & 0.0083335 & 0.066668 & 0.0083335 & 12.283579 & 26.50053 & 121.50243 & 0.016667 & 128.00256 & 0.083335 & 0.16667 \\
\hline 2 & NEPH3-55ccc & $\overline{\mathrm{ccc}}$ & H12 & 3 & 16 & 21.00042 & 0.0083335 & 0.066668 & 0.0083335 & 10.366874 & 46.33426 & 120.16907 & 0.016667 & 166.67 & 0.083335 & 0.16667 \\
\hline 2 & NEPH3-52ccc & $\mathrm{ccc}$ & H16 & 3 & 17 & 14.716961 & 0.0083335 & 0.066668 & 0.0083335 & 7.250145 & 20.0004 & 137.33608 & 0.016667 & 122.33578 & 0.083335 & 3.683407 \\
\hline 2 & NEPH3-49 & quenched & H06 & 3 & 18 & 13.016927 & 0.0083335 & 0.066668 & 0.0083335 & 10.066868 & 19.33372 & 95.83525 & 0.016667 & 128.3359 & 0.083335 & 3.250065 \\
\hline 2 & NEPH3-53ccc & $\mathrm{ccc}$ & $\mathrm{H} 02$ & 3 & 19 & 18.3337 & 0.0083335 & 0.066668 & 0.0083335 & 24.16715 & 58.83451 & 83.50167 & 0.016667 & 220.0044 & 0.083335 & 0.16667 \\
\hline 2 & NEPH3-51ccc & $\mathrm{ccc}$ & $\mathrm{H} 51$ & 3 & 20 & 18.83371 & 0.0083335 & 0.066668 & 0.0083335 & 9.316853 & 25.0005 & 128.3359 & 0.016667 & 137.50275 & 0.083335 & 2.616719 \\
\hline 2 & NEPH3-56ccc & $\mathrm{ccc}$ & $\mathrm{H} 45$ & 3 & 21 & 36.6674 & 0.0083335 & 0.066668 & 0.0083335 & 10.200204 & 76.50153 & 157.50315 & 0.016667 & 223.3378 & 0.1716701 & 3.650073 \\
\hline 2 & Soln Std & & STD-B-3-3 & 3 & 22 & 21.3 & 0.005 & 0.04 & 0.005 & 4.32 & 9.79 & 74 & 0.01 & 50.8 & 0.05 & 0.1 \\
\hline
\end{tabular}




\section{Exhibit E1. Laboratory PCT Measurements in Analytical Sequence for Study Glasses, EA, ARM, Blanks, and Solution Standards}
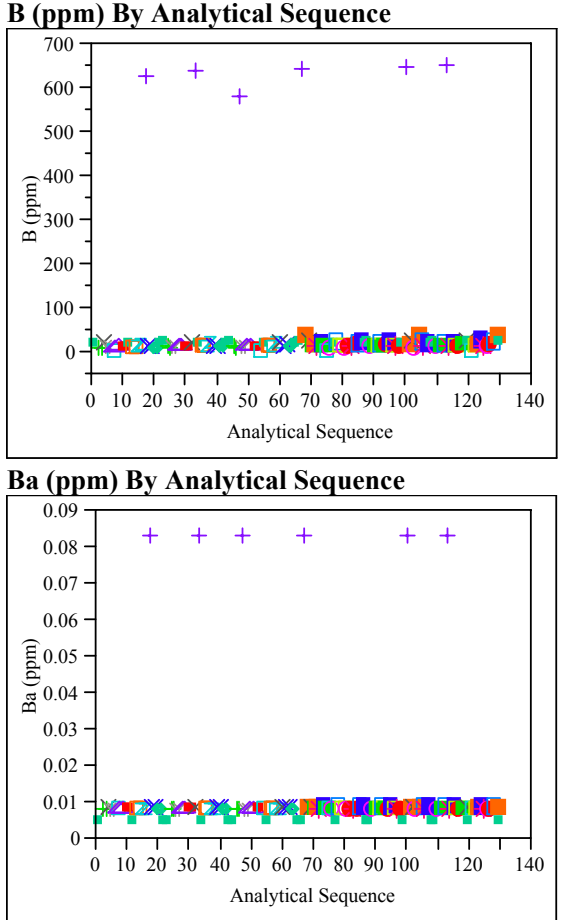

Cd (ppm) By Analytical Sequence

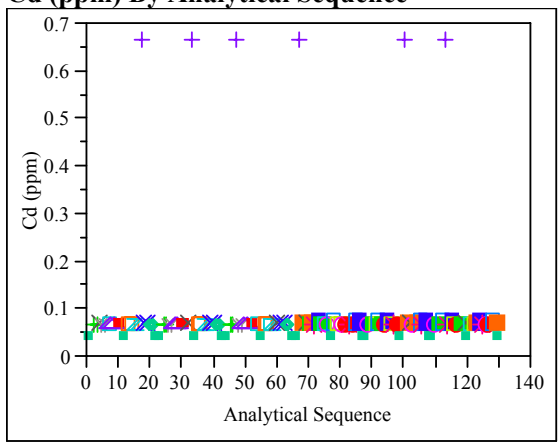

Cr (pp) By Analytical Sequence

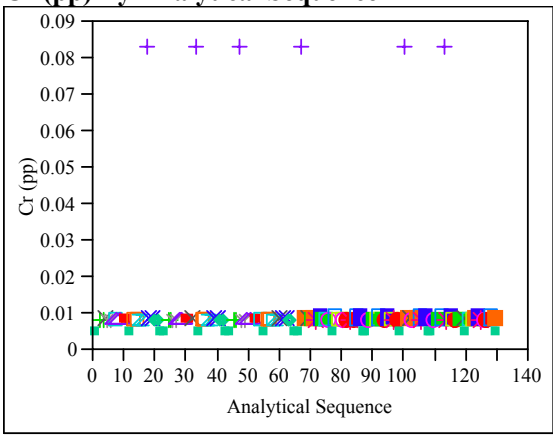

Fe (ppm) By Analytical Sequence

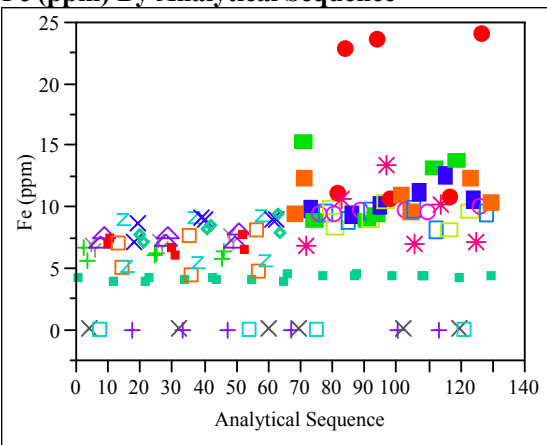

Li (ppm) By Analytical Sequence

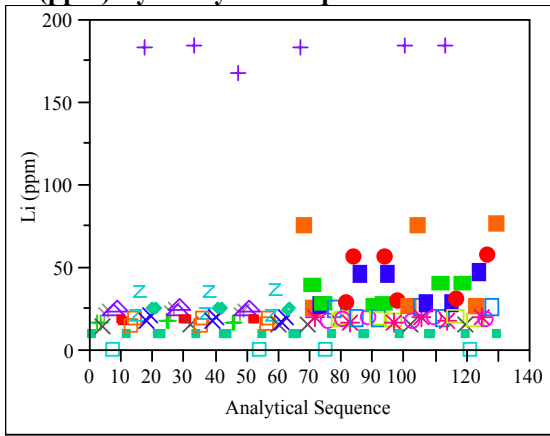

Na (ppm) By Analytical Sequence

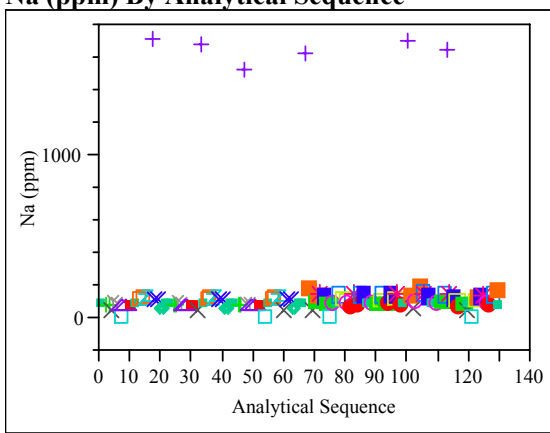

Pb (ppm) By Analytical Sequence

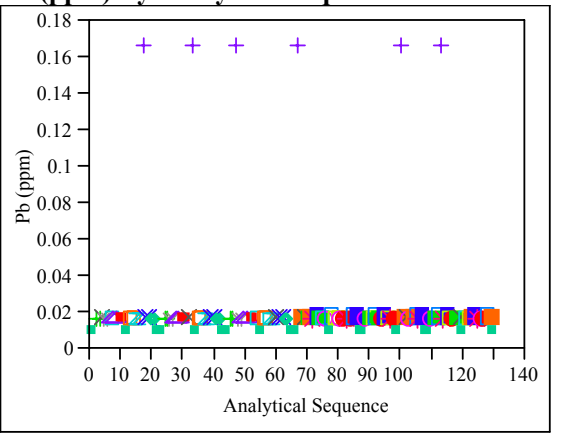

Si (ppm) By Analytical Sequence

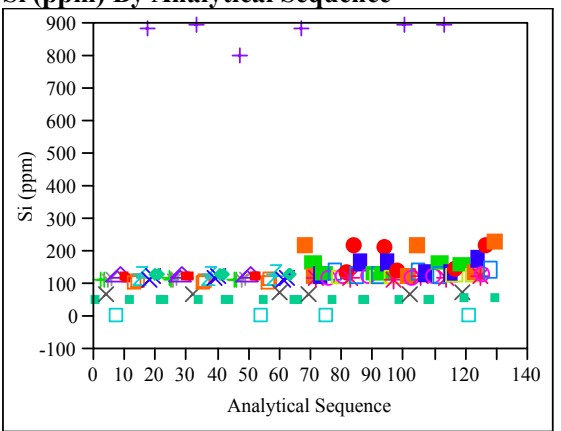

Th (ppm) By Analytical Sequence

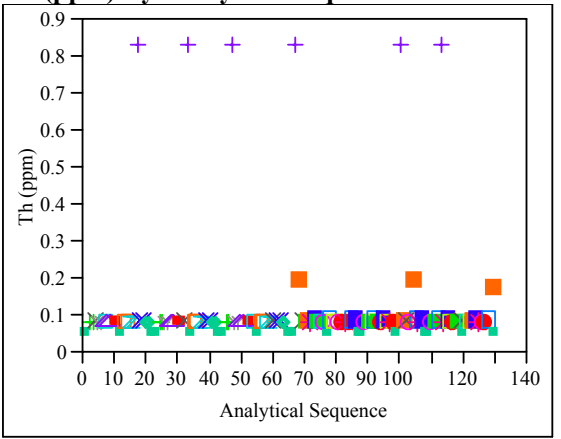

U (ppm) By Analytical Sequence

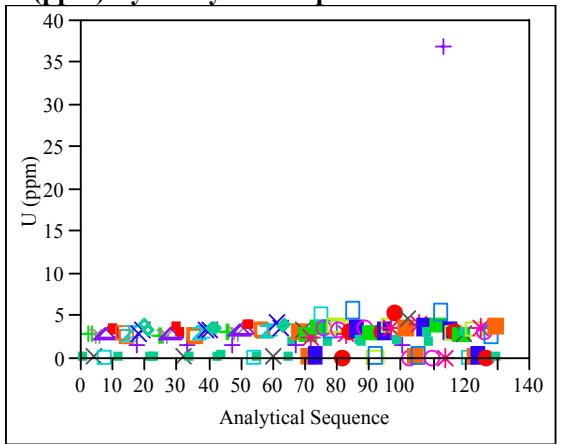




\section{Exhibit E2. Laboratory PCT Measurements in Analytical Sequence for Study Glasses}
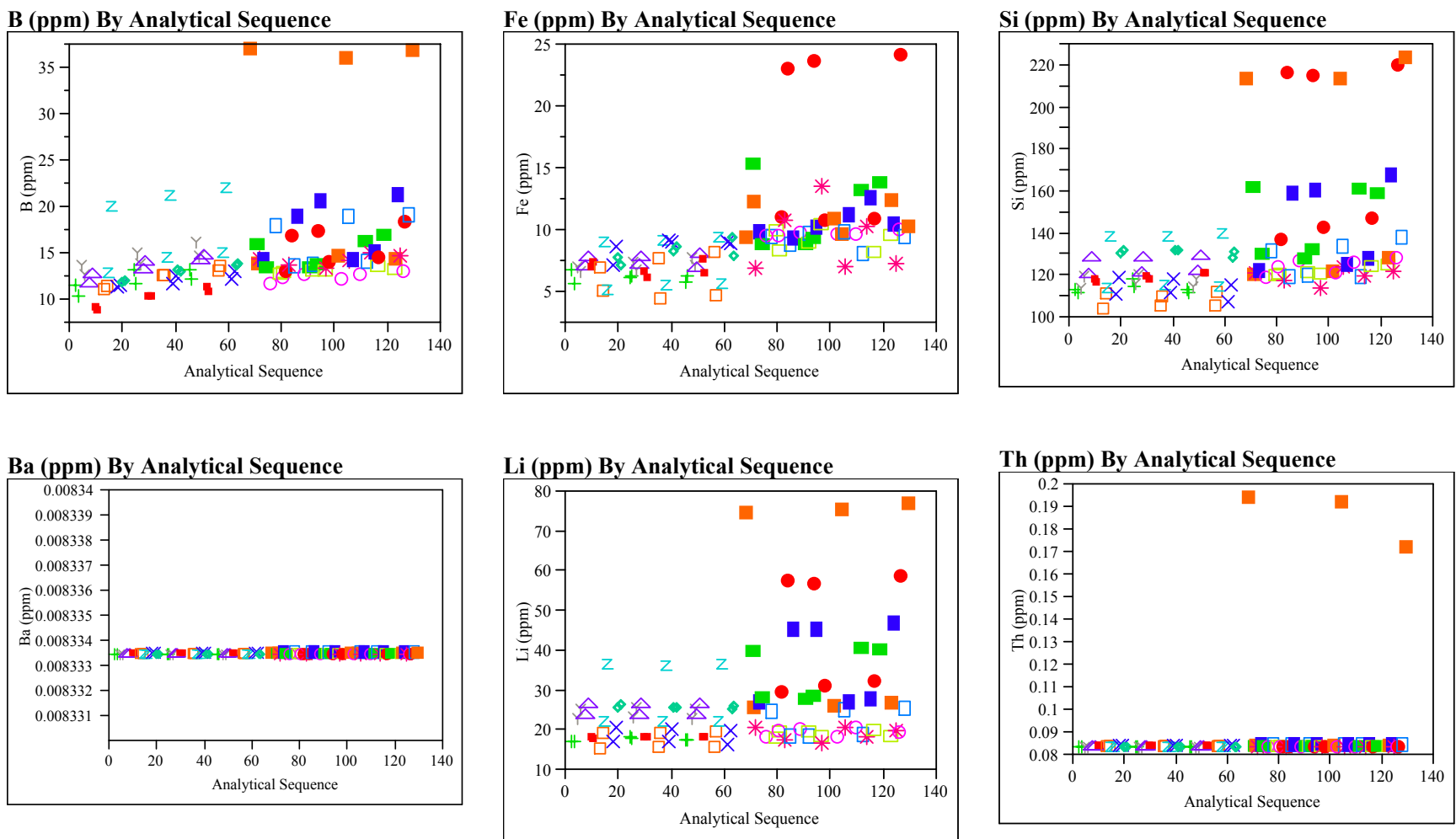

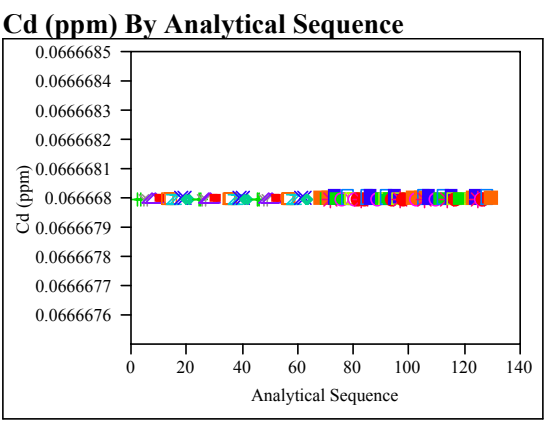

Cr (pp) By Analytical Sequence

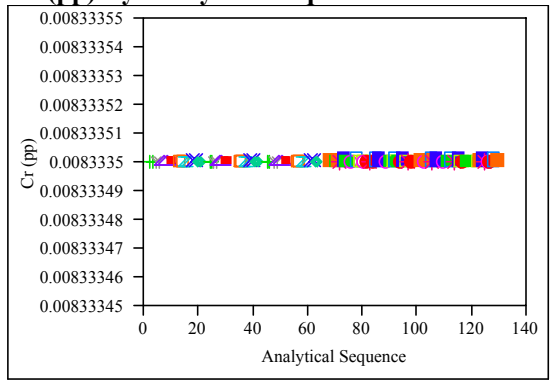

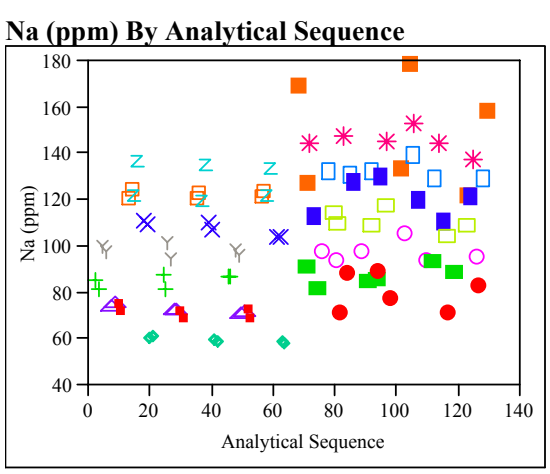

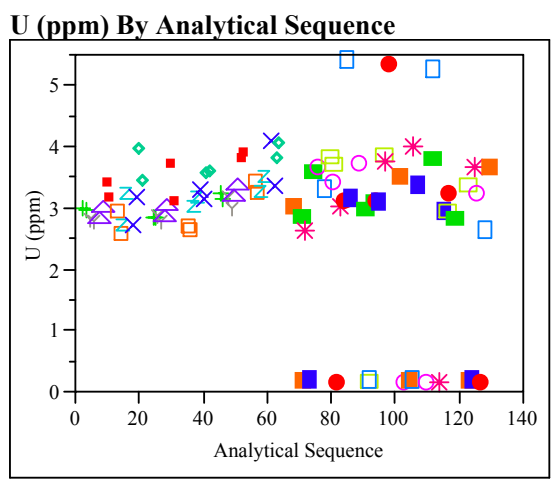

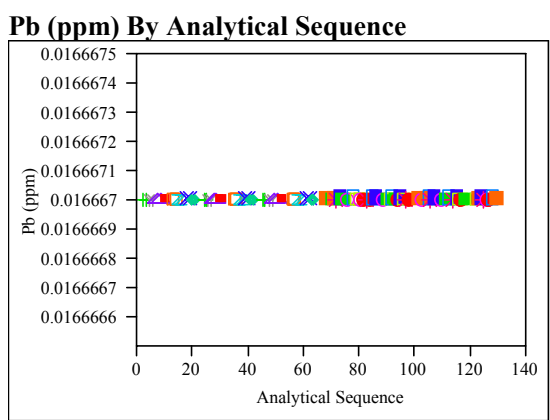




\section{Exhibit E3. Measurements of the Multi-Element Solution Standard}

\section{by Set and ICP Block}

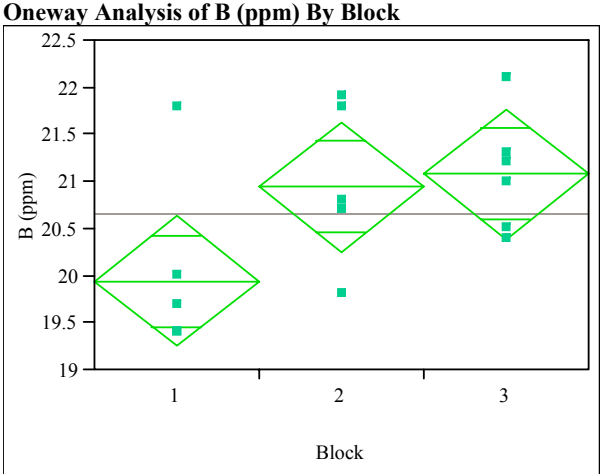

\section{Oneway Anova}

Summary of Fit

Rsquare

Adj Rsquare

0.328824

Adj Rsquare

0.239333

0.791553

Mean of Response

20.66111

Observations (or Sum Wgts)

Analysis of Variance

Source DF Sum of Squares Mean Square F Ratio Prob $>$ F

$\begin{array}{llllll}\text { Block } & 2 & 4.604444 & 2.30222 & 3.6744 & 0.0503\end{array}$

$\begin{array}{lrr}\text { Error } & 15 & 9.398333 \\ \text { C. } & 17 & 14.002778\end{array}$

0.62656

Means for Oneway Anova

Level Number Mean Std Error Lower 95\% Upper 95\%

$\begin{array}{llllll}6 & 6 & 19.9500 & 0.32315 & 19.261 & 20.639\end{array}$

$\begin{array}{llllll}1 & 6 & 19.9500 & 0.32315 & 19.261 & 20.639 \\ 2 & 6 & 20.9500 & 0.32315 & 20.261 & 21.639 \\ 3 & 6 & 21.0833 & 0.32315 & 20.395 & 21.772\end{array}$

Std Error uses a pooled estimate of error variance
Oneway Analysis of Ba (ppm) By Block

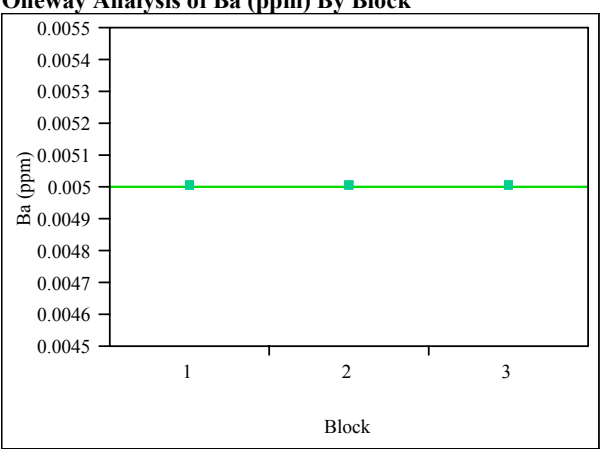

\section{Oneway Anova}

Summary of Fit

\section{Rsquare}

Adj Rsquare

Root Mean Square Error

Mean of Response

Observations (or Sum Wgts) 18

Analysis of Variance

Source DF Sum of Squares Mean Square F Ratio Prob $>$ F

$\begin{array}{llll}\text { Block } & 2 & 1.3542 \mathrm{e}-35 & 6.771 \mathrm{e}-36\end{array}$

$\begin{array}{lll}\text { Error } & 15 & 0\end{array}$

C. Total $17 \quad 1.3542 \mathrm{e}-35$

Means for Oneway Anova

Level Number Mean Std Error Lower 95\% Upper 95\%

$\begin{array}{lllllr}1 & 6 & 0.005000 & 0 & 0.00500 & 0.00500 \\ 2 & 6 & 0.005000 & 0 & 0.00500 & 0.00500\end{array}$

$\begin{array}{llllll}3 & 6 & 0.005000 & 0 & 0.00500 & 0.00500\end{array}$

Std Error uses a pooled estimate of error variance
Oneway Analysis of Cd (ppm) By Block

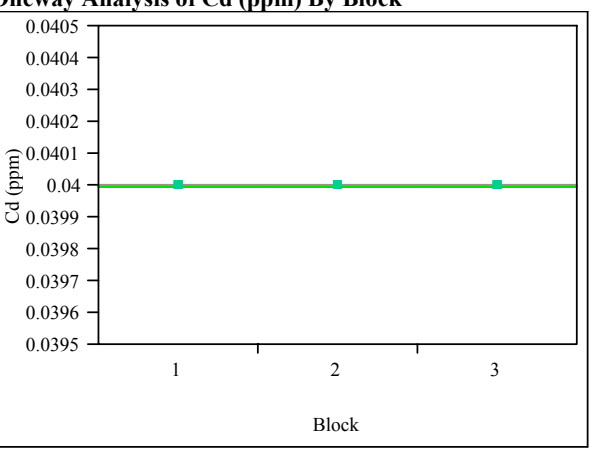

\section{Oneway Anova}

Summary of Fit

Rsquare

Adj Rsquare

Root Mean Square Error

Mean of Response

Observations (or Sum 0.04

Analysis of Variance

Source DF Sum of Squares Mean Square F Ratio Prob $>$ F $\begin{array}{lrrr}\text { Block } \quad 2 & 8.6667 \mathrm{e}-34 & 4.333 \mathrm{e}-34\end{array}$

$\begin{array}{lrr}\text { Error } & 15 & 0 \\ \text { C. Total } & 17 & 8.6667 \mathrm{e}-34\end{array}$

Means for Oneway Anova

Level Number Mean Std Error Lower 95\% Upper 95\%

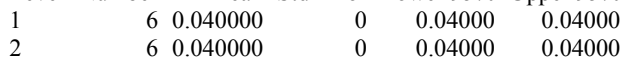

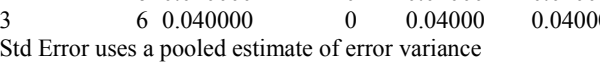




\section{Exhibit E3. Measurements of the Multi-Element Solution Standard} by Set and ICP Block (continued)

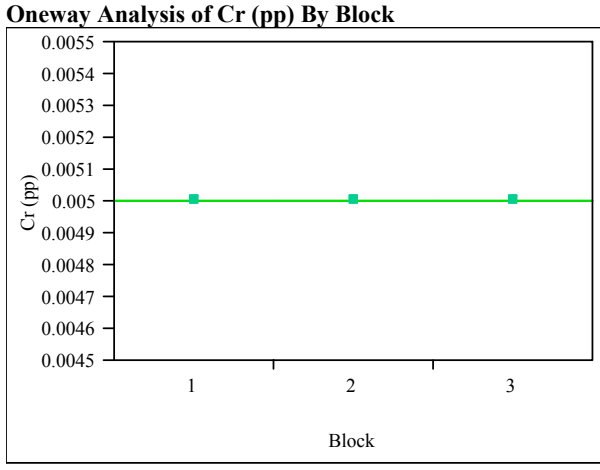

\section{Oneway Anova}

Summary of Fit

Rsquare

Adj Rsquare

Root Mean Square Erro

Mean of Response

Analysis of Variance

Source DF Sum of Squares Mean Square F Ratio Prob $>$ F

$\begin{array}{llll}\text { Block } & 2 & 1.3542 \mathrm{e}-35 & 6.771 \mathrm{e}-36\end{array}$

$\begin{array}{lrr}\text { Error } & 15 & 0 \\ \text { C. Total } & 17 & 1.3542 \mathrm{e}-35\end{array}$

Means for Oneway Anova

Level Number Mean Std Error Lower 95\% Upper 95\%

$\begin{array}{llllrr}1 & 6 & 0.005000 & 0 & 0.00500 & 0.00500 \\ 2 & 6 & 0.005000 & 0 & 0.00500 & 0.00500 \\ 3 & 6 & 0.00500 & 0 & 0.0050 & 0.0500\end{array}$

$\begin{array}{llllll}2 & 6 & 0.005000 & 0 & 0.00500 & 0.00500 \\ 3 & 6 & 0.005000 & 0 & 0.00500 & 0.00500\end{array}$

Std Error uses a pooled estimate of error variance

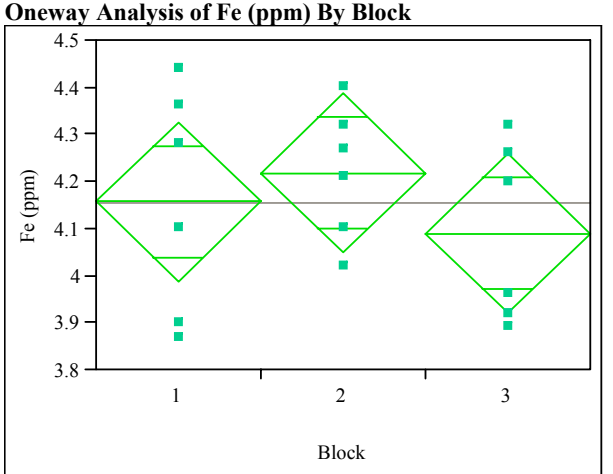

Oneway Anova
Summary of Fit

\section{Rsquare}

0.080171

Root Mean Square Error $\quad 0.194451$

Mean of Response 4.156667

Observations (or Sum Wgts) 18

Analysis of Variance

Source DF Sum of Squares Mean Square F Ratio Prob > F

$\begin{array}{lrrrrr}\text { Block } & 2 & 0.04943333 & 0.024717 & 0.6537 & 0.5343\end{array}$

$\begin{array}{llll}\text { Error } & 15 & 0.56716667 & 0.037811\end{array}$

C. Total $17 \quad 0.61660000$

Means for Oneway Anova

Level Number Mean Std Error Lower 95\% Upper 95\%

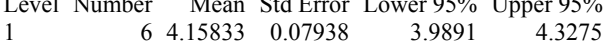

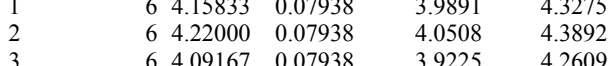

Std Error uses a pooled estimate of error variance
Oneway Analysis of Li (ppm) By Block

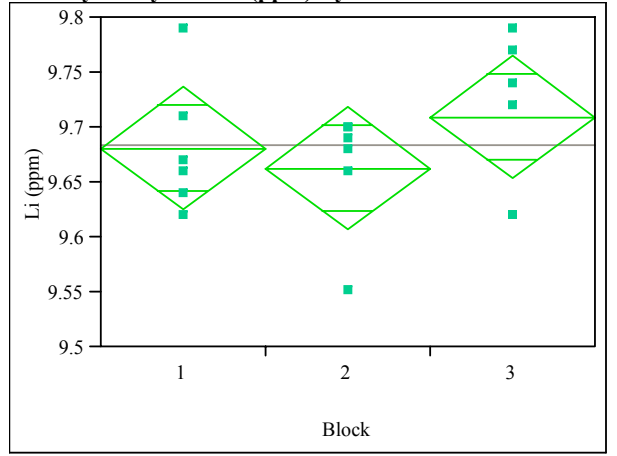

Oneway Anova

Rsquare $\quad 0.096066$

$\begin{array}{lr}\text { Adj Rsquare } & -0.02446 \\ \text { Root Mean Square Error } & 0.064507\end{array}$

Mean of Response Erer

Observations (or Sum Wgts) $\quad 18$

Analysis of Variance

Source DF Sum of Squares Mean Square F Ratio Prob $>$ F

$\begin{array}{lrrrrr}\text { Block } & 2 & 0.00663333 & 0.003317 & 0.7971 & 0.4688\end{array}$

$\begin{array}{lrll}\text { Error } & 15 & 0.06241667 & 0.004161\end{array}$

C. Total $17 \quad 0.06905000$

Means for Oneway Anova

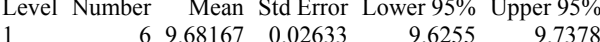
$\begin{array}{lllll}6 & 9.68167 & 0.02633 & 9.6255 & 9.7378 \\ 6 & 9.66333 & 0.02633 & 9.6072 & 9.7195 \\ 6 & 9.71000 & 0.02633 & 9.6539 & 9.7661\end{array}$

Std Error uses a pooled estimate of error variance 


\section{Exhibit E3. Measurements of the Multi-Element Solution Standard} by Set and ICP Block (continued)

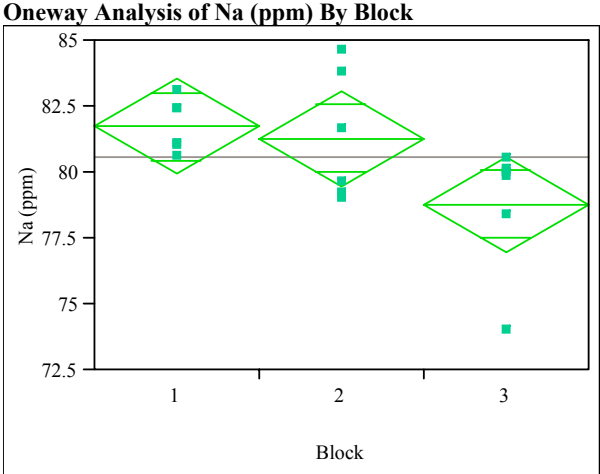

\section{Oneway Anova}

Summary of Fit

Rsquare

Adj Rsquare 0.319596

Root Mean Square Error $\quad 2.081879$

Mean of Response $\quad 80.62222$

Observations (or Sum Wgts)

Source DF Sum of Squares Mean Square F Ratio Prob $>$ F

$\begin{array}{llllll}\text { Block } & 2 & 30.537778 & 15.2689 & 3.5229 & 0.0557\end{array}$

$\begin{array}{lll}\text { Error } & 15 & 65.013333 \\ \text { C. } & & \end{array}$

4.3342

C.

Level Number Mean Std Error Lower 95\% Upper 95\%

$\begin{array}{lllll}6 & 81.7667 & 0.84992 & 79.955 & 83.578\end{array}$

$\begin{array}{llllll}1 & 6 & 81.7667 & 0.84992 & 79.955 & 83.578 \\ 2 & 6 & 81.3000 & 0.84992 & 79.488 & 83.112 \\ 3 & 6 & 78.8000 & 0.84992 & 76.988 & 80.612\end{array}$

Std Error uses a pooled estimate of error variance
Oneway Analysis of $\mathbf{P b}(\mathrm{ppm})$ By Block

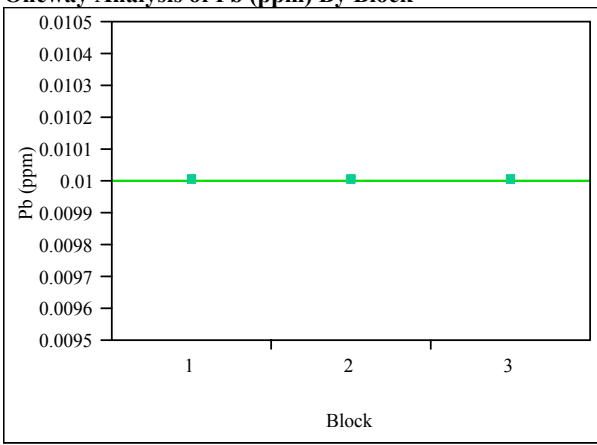

\section{Oneway Anova}

Summary of Fit

Rsquare

Adj Rsquare

Root Mean Square Error

Mean of Response

Observations (or Sum Wgts) 18

Analysis of Variance

Source DF Sum of Squares Mean Square F Ratio Prob $>$ F

$\begin{array}{llll}\text { Block } & 2 & 5.4167 \mathrm{e}-35 & 2.708 \mathrm{e}-35\end{array}$

$\begin{array}{llr}\text { Error } & 15 & 0\end{array}$

C. Total $17 \quad 5.4167 \mathrm{e}-35$

Means for Oneway Anova

Level Number Mean Std Error Lower 95\% Upper 95\%

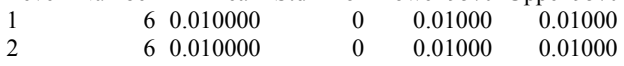

$\begin{array}{llllll}3 & 6 & 0.010000 & 0 & 0.01000 & 0.01000\end{array}$

Std Error uses a pooled estimate of error variance

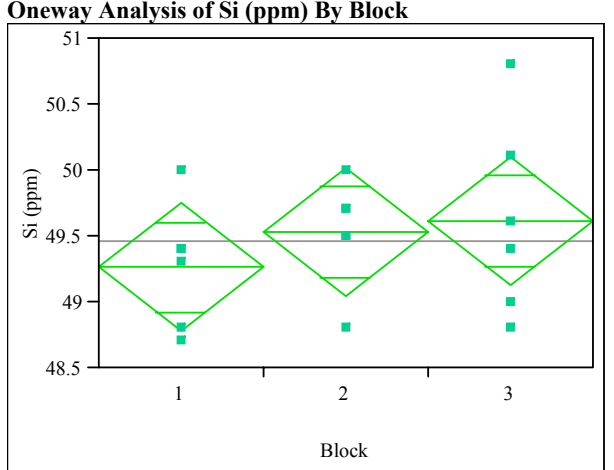

Oneway Anova

Summary of $\mathrm{Fit}$

Rsquare

0.079332

Adj Rsquare $\quad-0.04342$

Mean of Response 49.47222

Observations (or Sum Wgts) 49.47222

Analysis of Variance

Source DF Sum of Squares Mean Square F Ratio Prob $>$ F

$\begin{array}{lllllll}\text { Block } & 2 & 0.4011111 & 0.200556 & 0.6463 & 0.5380\end{array}$

$\begin{array}{lrll}\text { Error } & 15 & 4.6550000 & 0.310333\end{array}$

C. Total $17 \quad 5.0561111$

Means for Oneway Anova

Level Number Mean Std Error Lower 95\% Upper 95\% $\begin{array}{lllll}6 & 49.2667 & 0.22743 & 48.782 & 49.751 \\ 6 & 49.5333 & 0.22743 & 49.049 & 50.018\end{array}$ $\begin{array}{lllll}6 & 49.5333 & 0.22743 & 49.049 & 50.018 \\ 6 & 49.6167 & 0.22743 & 49.132 & 50.101\end{array}$

Std Error uses a pooled estimate of error variance 
Exhibit E3. Measurements of the Multi-Element Solution Standard by Set and ICP Block (continued)

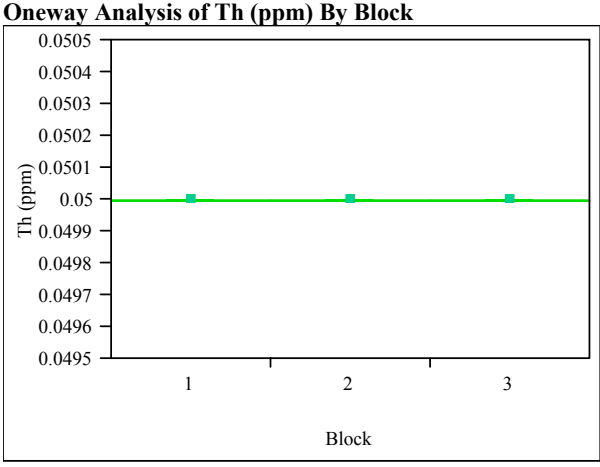

\section{Oneway Anova}

Summary of Fit

Rsquare

Adj Rsquare

$-0.13333$

Root Mean Square Error

Observations (or Sum Wgts)

$7.6 \mathrm{e}-18$

Source DF Sum of Squares Mean Square F Ratio Prob $>$ F $\begin{array}{llrrrr}\text { Block } & 2 & 0 & 0 & 0.0000 & 1.0000\end{array}$ $\begin{array}{llll}\text { Error } & 15 & 8.6667 \mathrm{e}-34 & 5.778 \mathrm{e}-35\end{array}$

C. Total $17 \quad 8.6667 \mathrm{e}-34$

Means for Oneway Anova

Level Number Mean Std Error Lower 95\% Upper 95\%

$\begin{array}{llllll}1 & 6 & 0.050000 & 3.103 \mathrm{e}-18 & 0.05000 & 0.05000\end{array}$

$\begin{array}{llllll}2 & 6 & 0.050000 & 3.103 \mathrm{e}-18 & 0.05000 & 0.05000\end{array}$

Std Error uses a pooled estimate of error variance

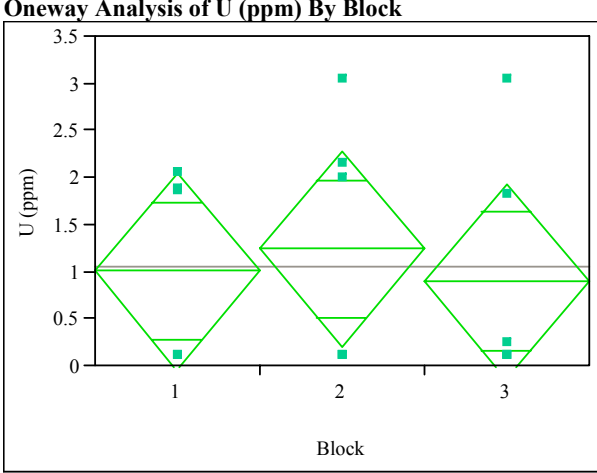

\section{Oneway Anova}

Summary of Fit

$\begin{array}{ll}\text { Rsquare } & 0.017072 \\ \text { Adj Rsquare } & -0.11398\end{array}$

017072

Root Mean Square Error $\quad 1.193448$

Mean of Response 1.054444

Observations (or Sum Wats) 1.05444

Analysis of Variance

Source DF Sum of Squares Mean Square F Ratio Prob $>$ F

$\begin{array}{lrrrrr}\text { Block } & 2 & 0.371078 & 0.18554 & 0.1303 & 0.8788\end{array}$

$\begin{array}{llll}\text { Error } & 15 & 21.364767 & 1.42432\end{array}$

C. Total $17 \quad 21.735844$

Means for Oneway Anova

Level Number Mean Std Error Lower 95\% Upper 95\%

$\begin{array}{llllll}1 & 6 & 1.01500 & 0.48722 & -0.0235 & 2.0535\end{array}$

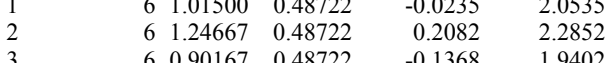

6 a pooled estimate of error variance 


\section{Exhibit E4. Laboratory PCT Measurements by Glass Number for Study Glasses and Standards \\ (100 - Solution Standard; 101 - EA; 102 - ARM; 103 - Blanks)}

B (ppm) By Glass \#

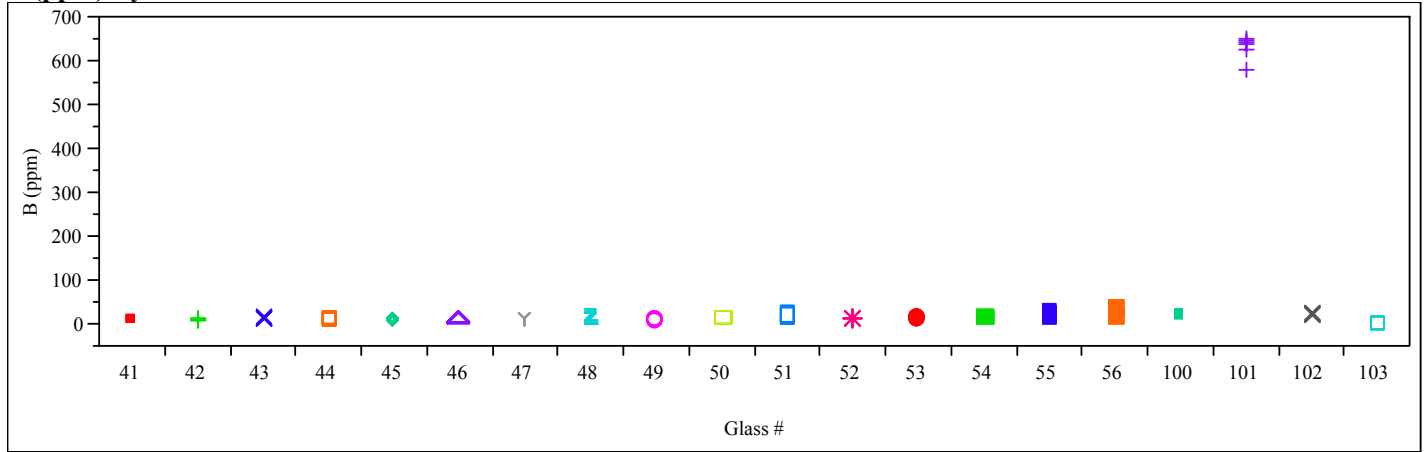

Ba (ppm) By Glass \#

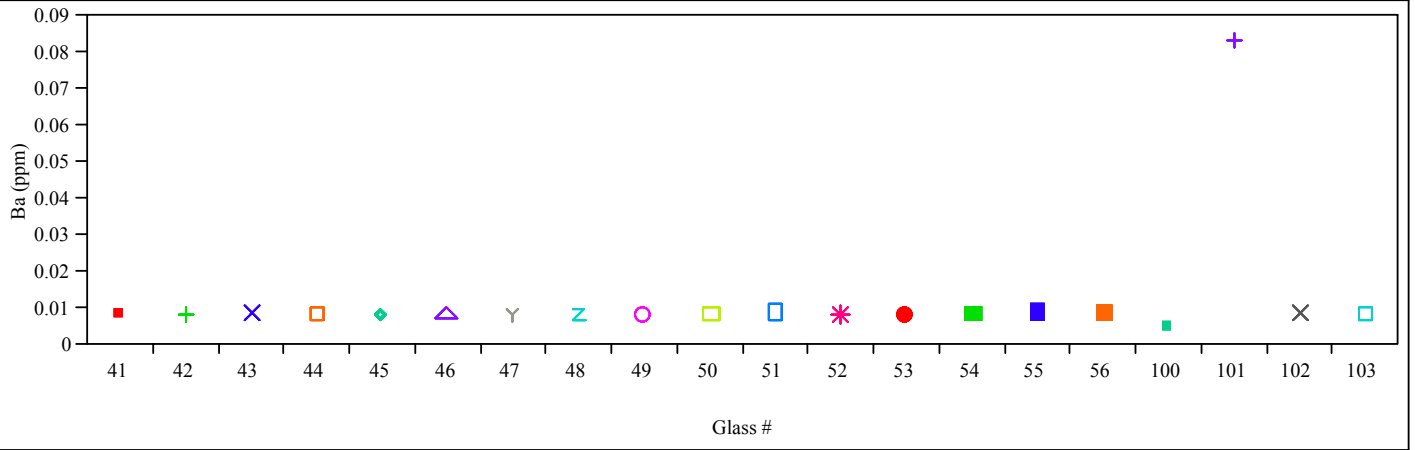

Cd (ppm) By Glass \#

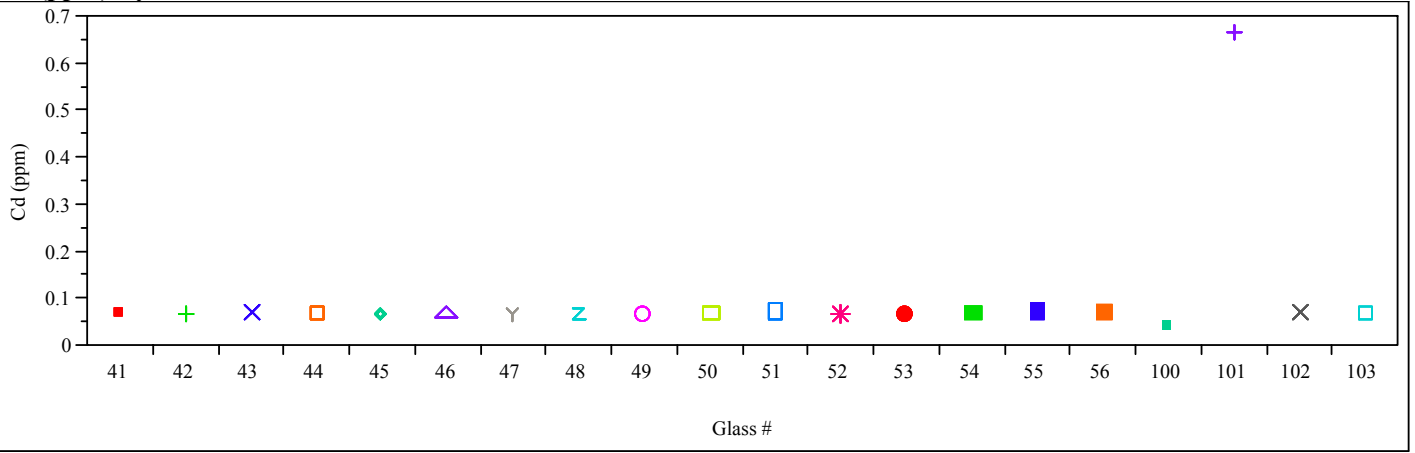

Cr (pp) By Glass \#

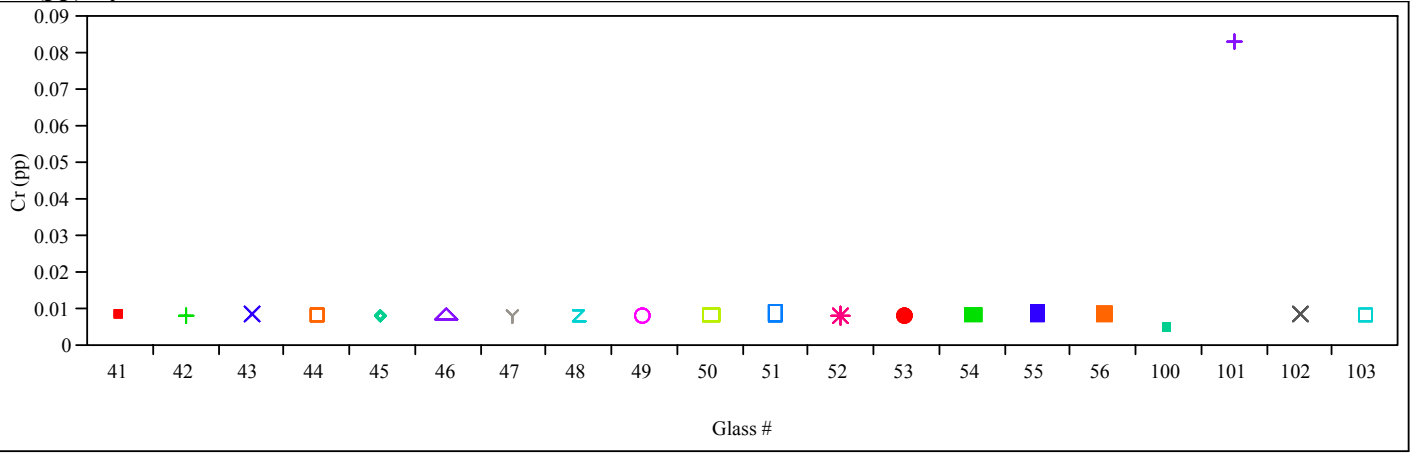


Exhibit E4. Laboratory PCT Measurements by Glass Number for Study Glasses and Standards (continued)

(100 - Solution Standard; 101 - EA; 102 - ARM; 103 - Blanks)

Fe (ppm) By Glass \#

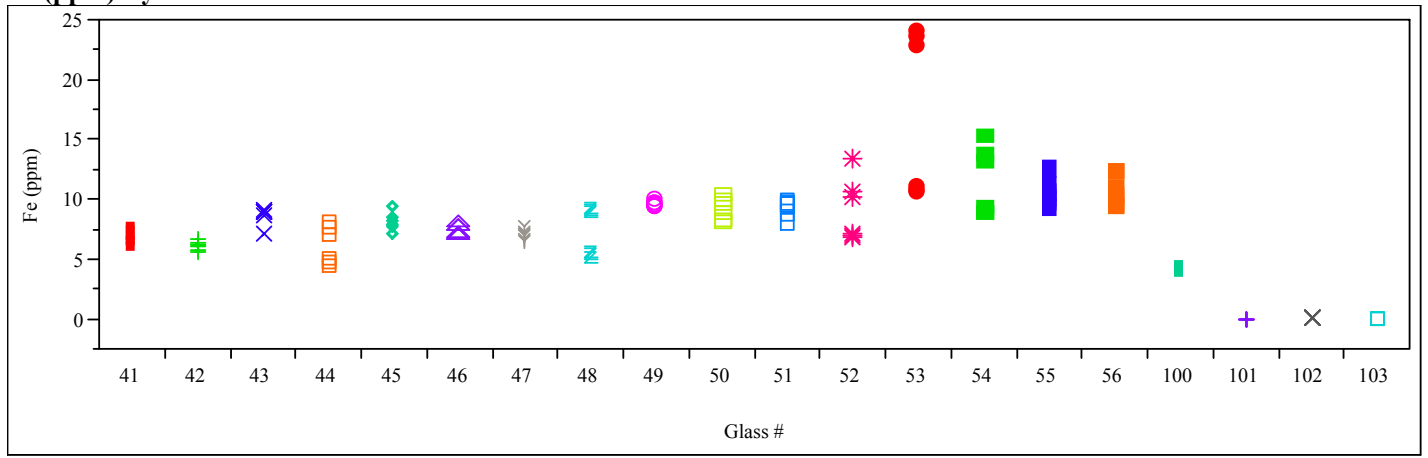

Li (ppm) By Glass \#

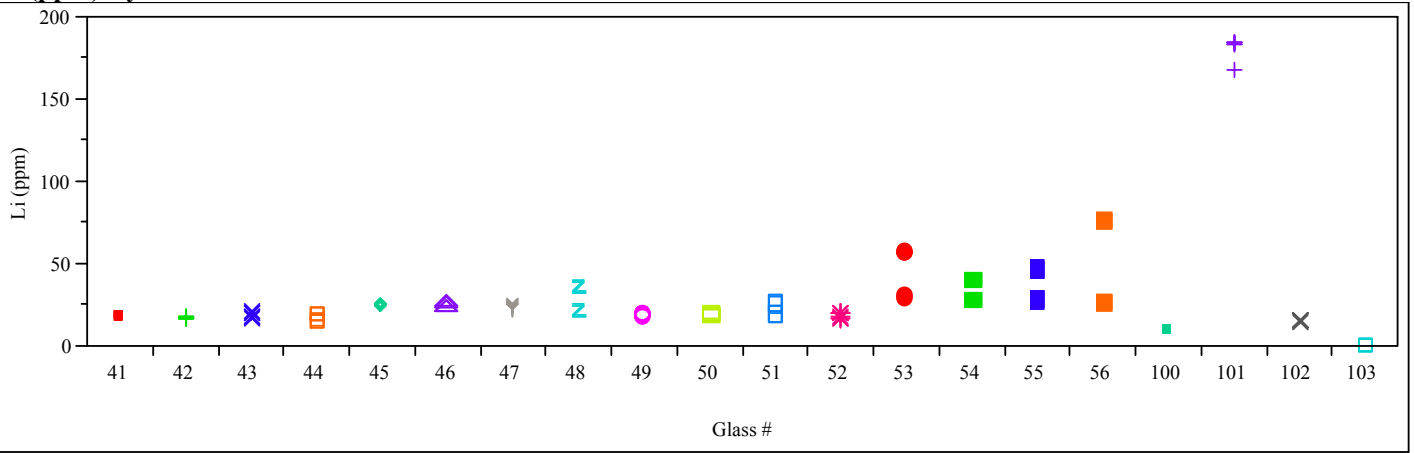

Na (ppm) By Glass \#

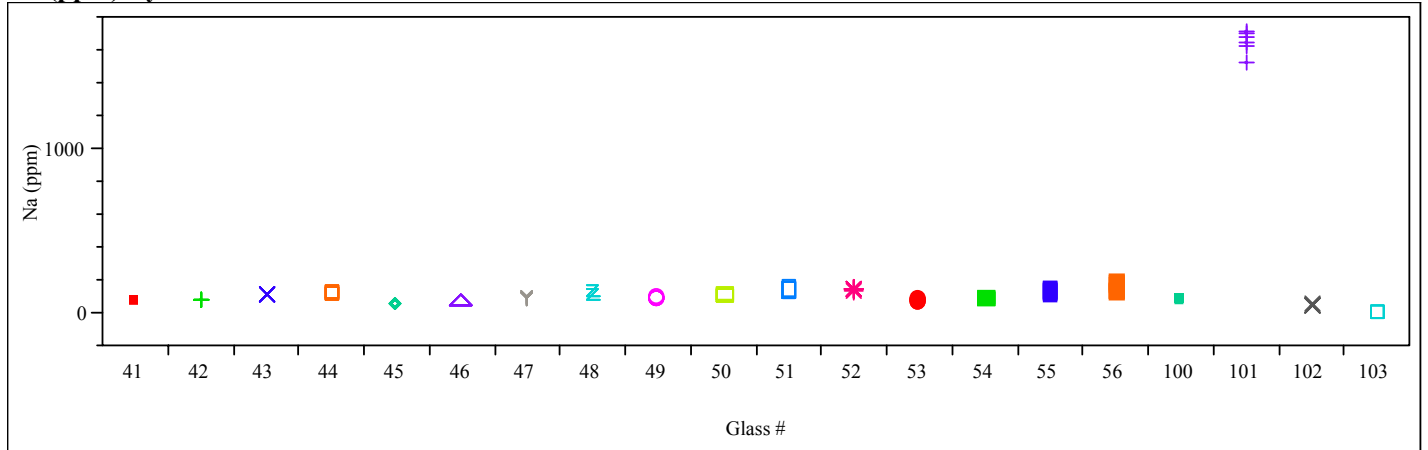

Pb (ppm) By Glass \#

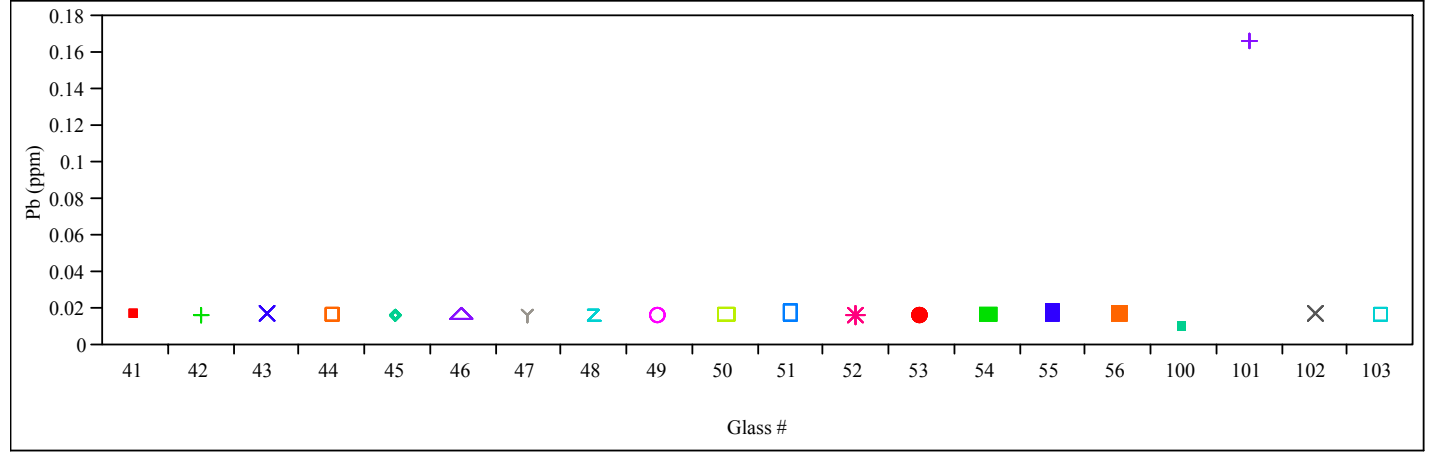


Exhibit E4. Laboratory PCT Measurements by Glass Number for Study Glasses and Standards (continued)

(100 - Solution Standard; 101 - EA; 102 - ARM; 103 - Blanks)

Si (ppm) By Glass \#

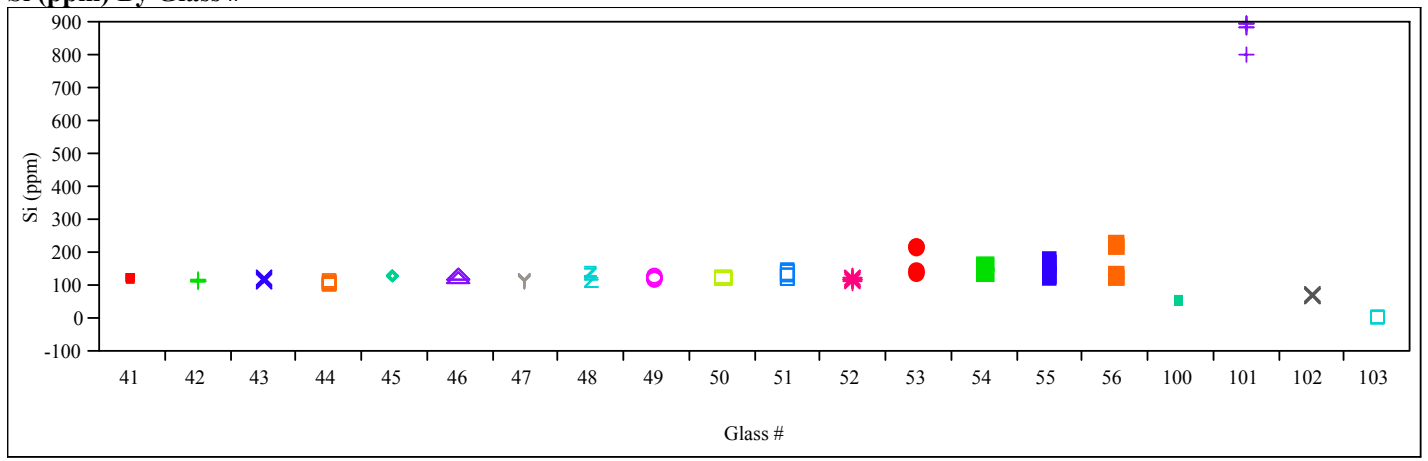

Th (ppm) By Glass \#

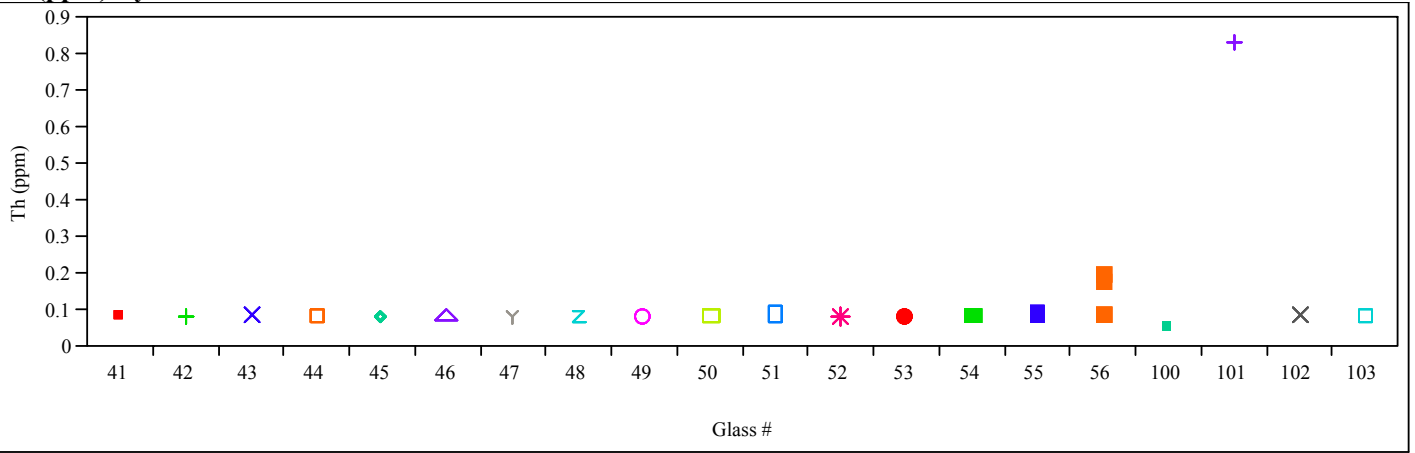

U (ppm) By Glass \#

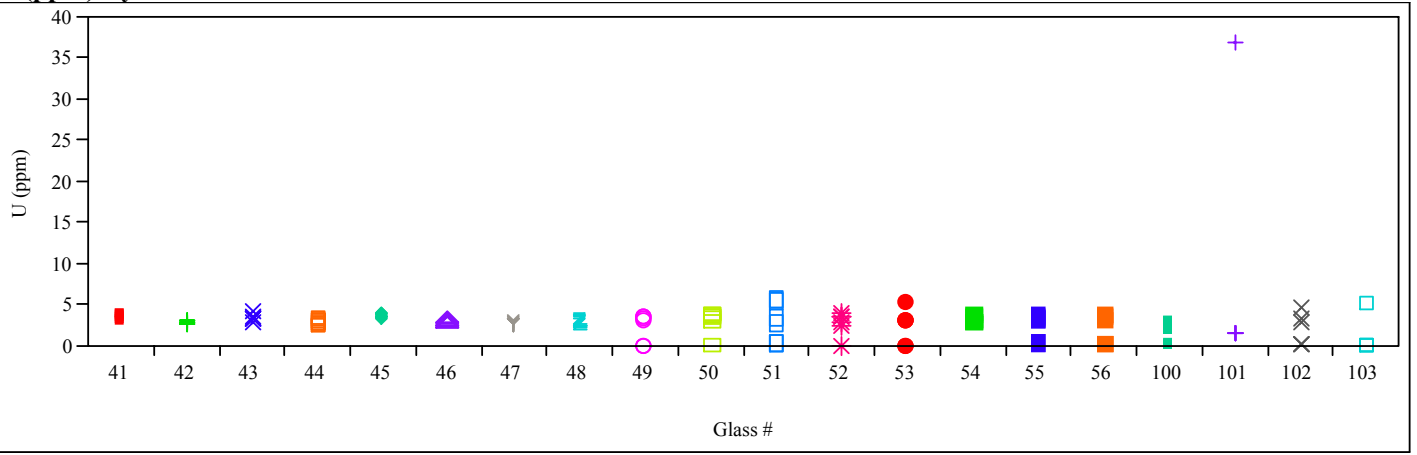




\section{Exhibit E5. Laboratory PCT Measurements by Glass Number for Study Glasses}
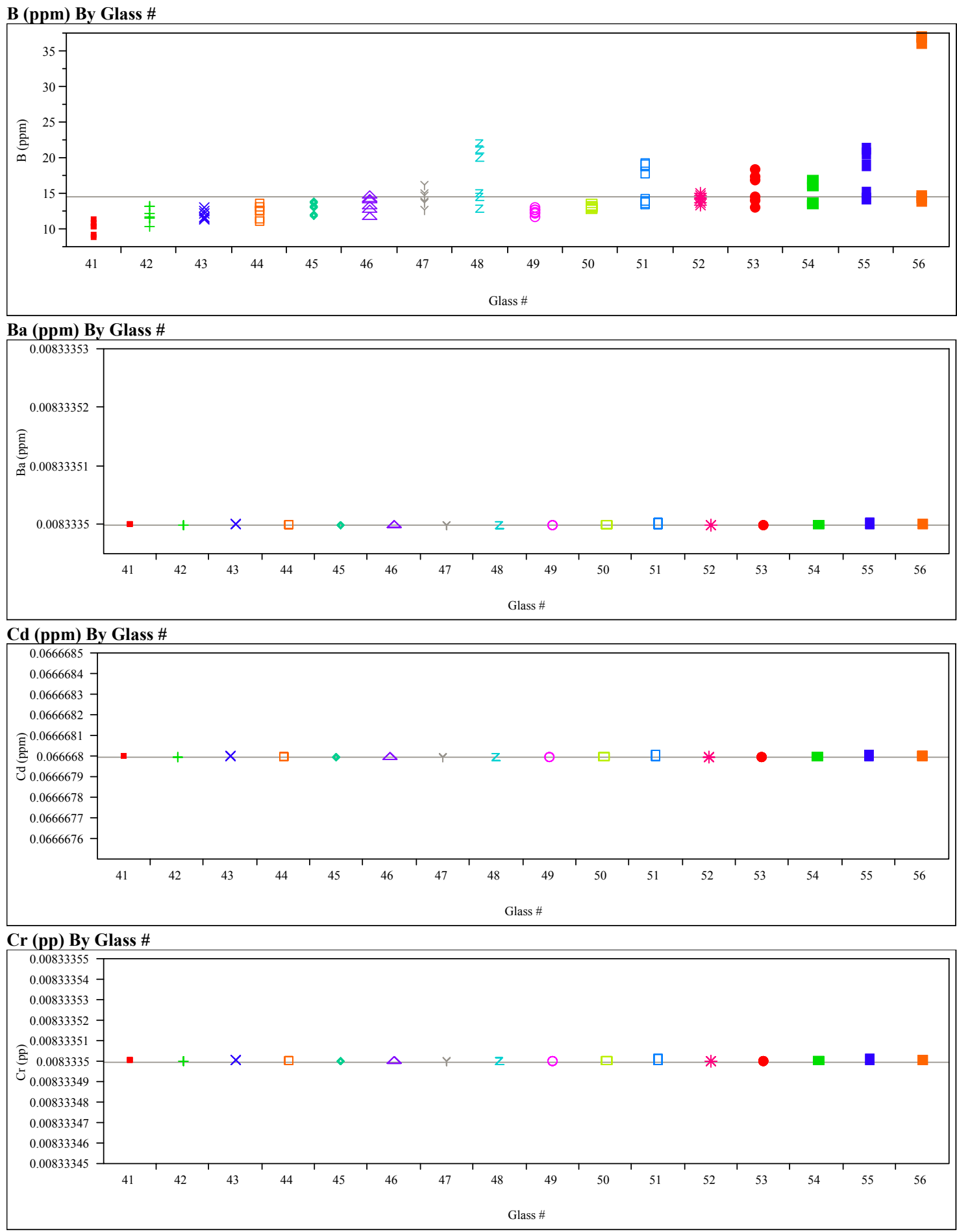


\section{Exhibit E5. Laboratory PCT Measurements by Glass Number for Study Glasses (continued)}
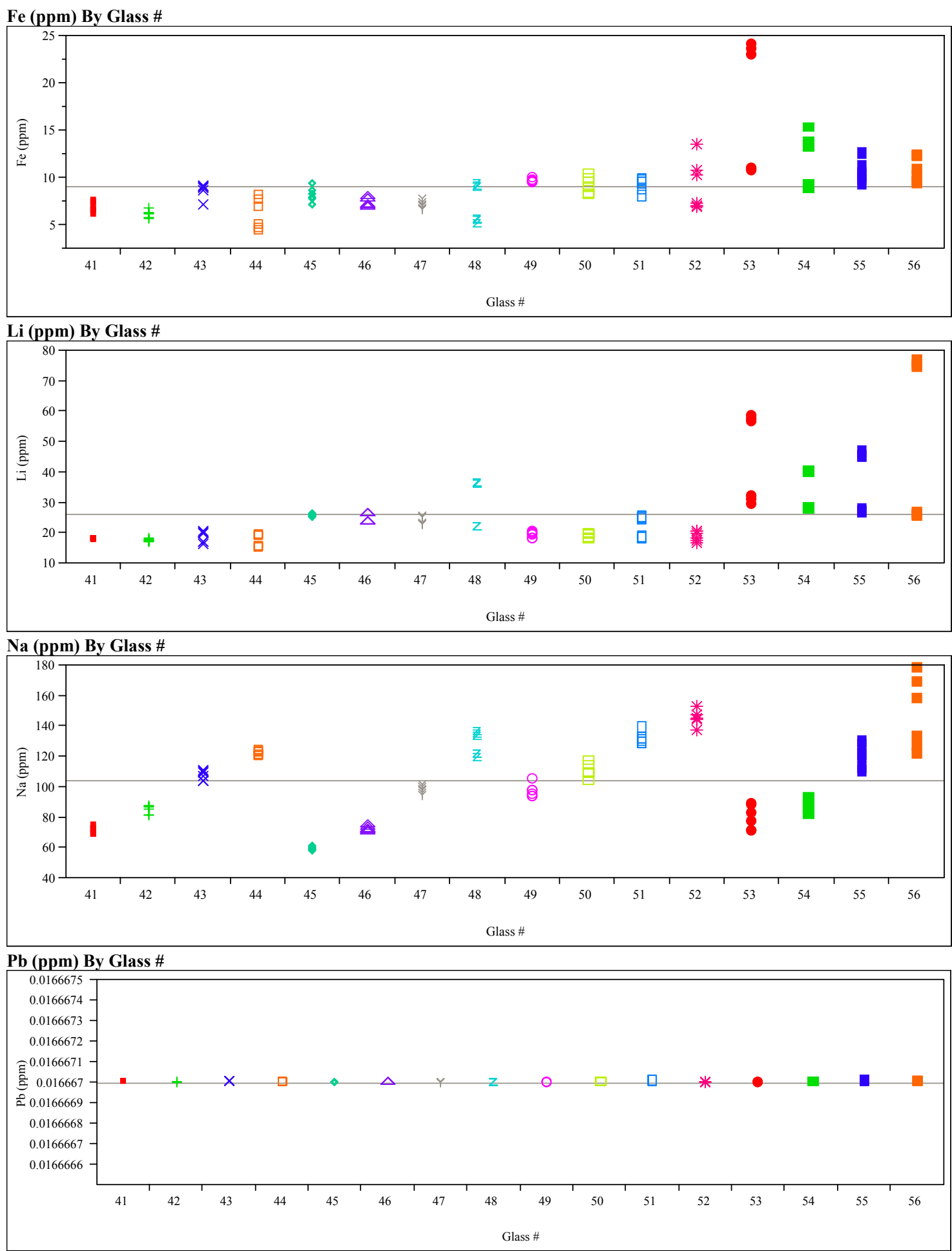


\section{Exhibit E5. Laboratory PCT Measurements by Glass Number for Study Glasses (continued)}
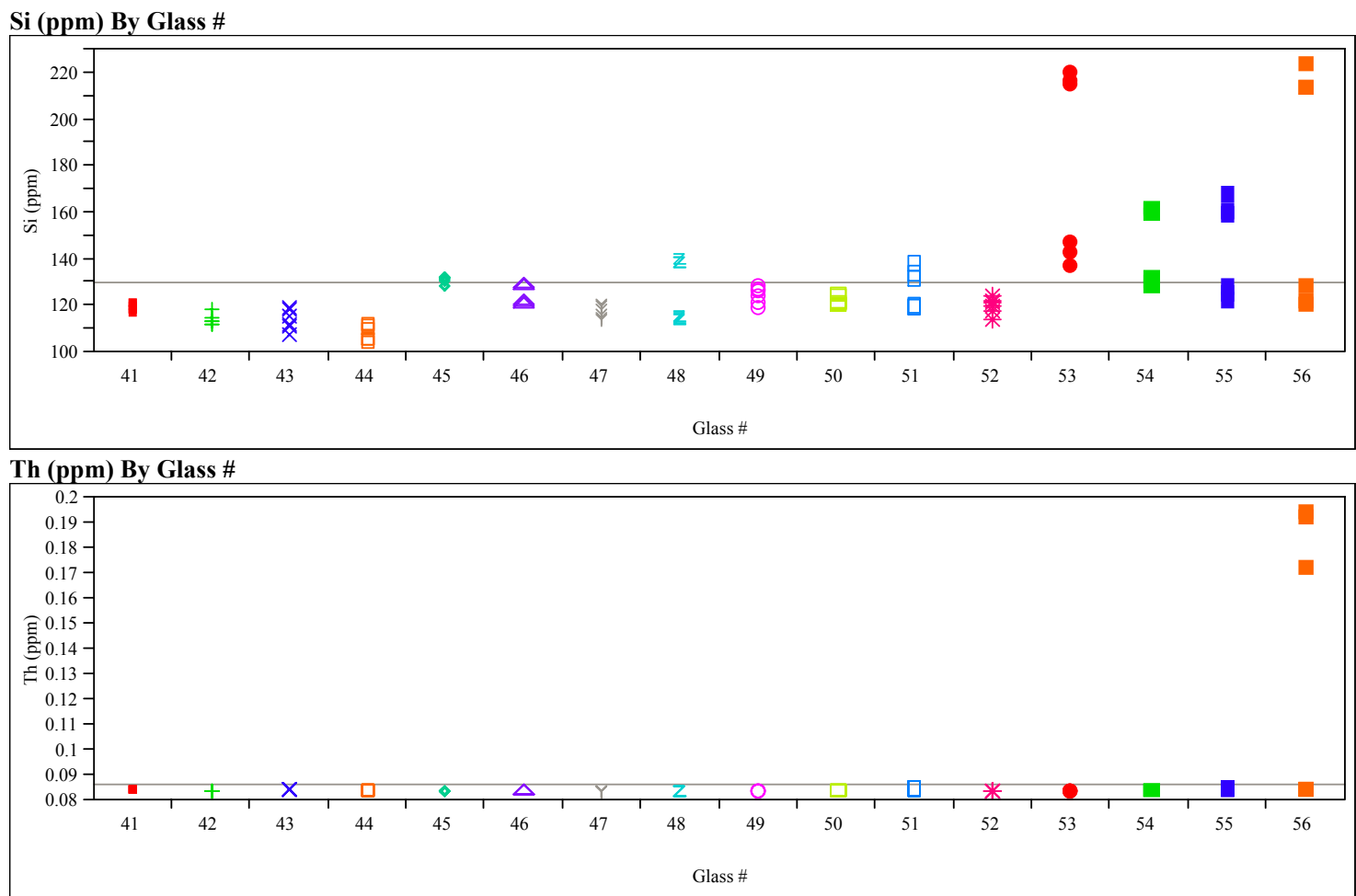

U (ppm) By Glass \#

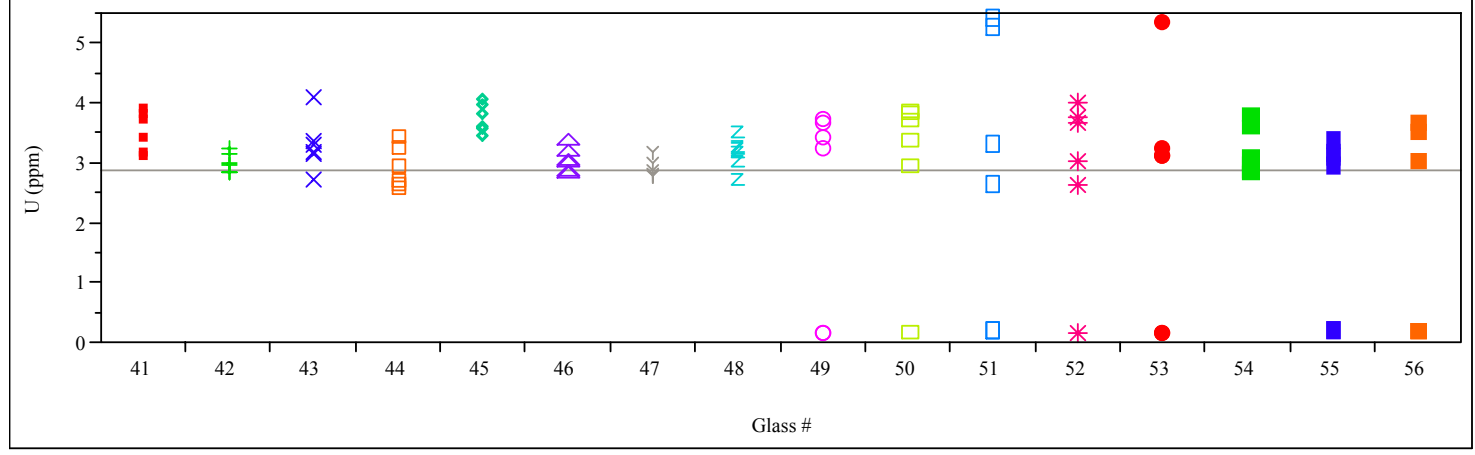




\section{Exhibit E6. Correlations and Scatter Plots of Normalized PCTs Over All Compositional Views and Heat Treatments}

Comp View/Heat Treatment=Measured bc-ccc

\section{Multivariate}

Correlations

$\begin{array}{lrrrr} & \log \mathrm{NL}[\mathrm{B}(\mathrm{g} / \mathrm{L})] & \log \mathrm{NL}[\mathrm{Li}(\mathrm{g} / \mathrm{L})] & \log \mathrm{NL}[\mathrm{Na}(\mathrm{g} / \mathrm{L})] & \log \mathrm{NL}[\mathrm{Si}(\mathrm{g} / \mathrm{L})] \\ \log \mathrm{NL}[\mathrm{B}(\mathrm{g} / \mathrm{L})] & 1.0000 & 0.9357 & 0.9432 & 0.9013 \\ \log \mathrm{NL}[\mathrm{Li}(\mathrm{g} / \mathrm{L})] & 0.9357 & 1.0000 & 0.8632 & 0.9877 \\ \log \mathrm{NL}[\mathrm{Na}(\mathrm{g} / \mathrm{L})] & 0.9432 & 0.8632 & 1.0000 & 0.8348 \\ \log \mathrm{NL}[\mathrm{Si}(\mathrm{g} / \mathrm{L})] & 0.9013 & 0.9877 & 0.8348 & 1.0000\end{array}$

\section{Scatterplot Matrix}

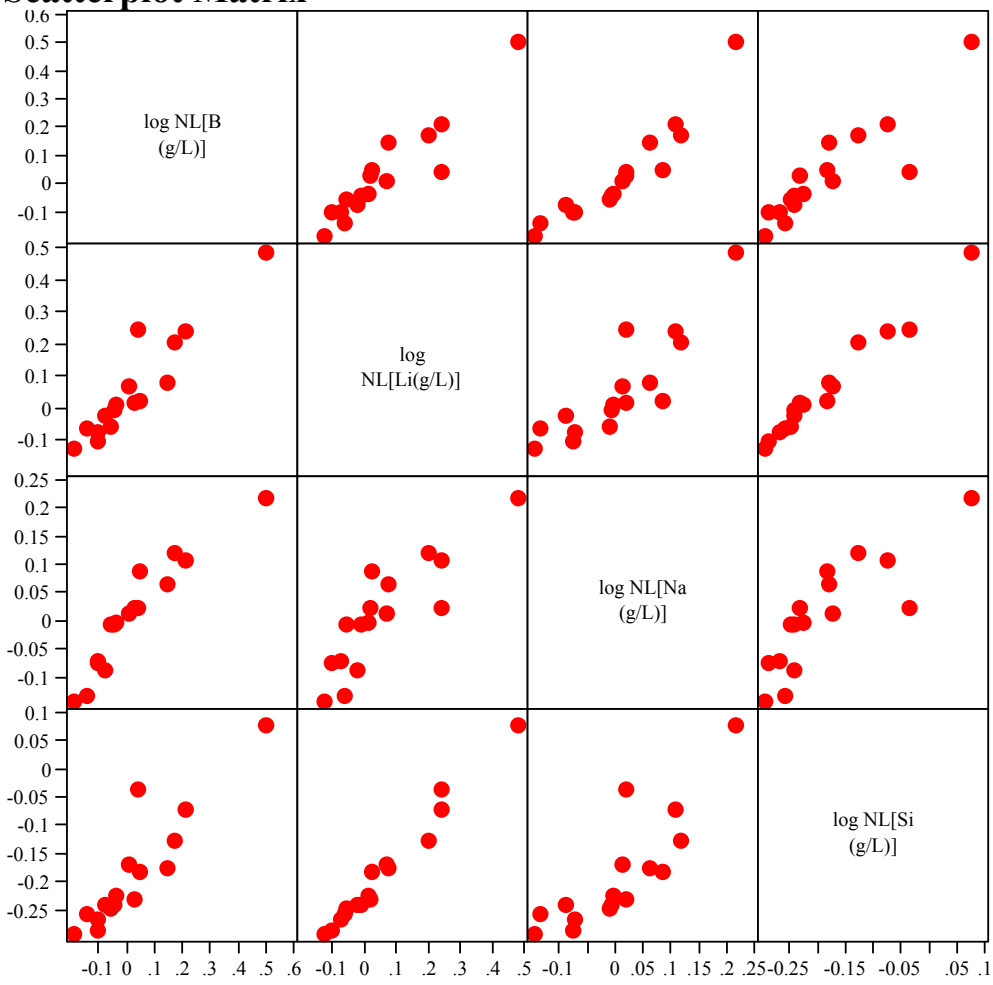

Comp View/Heat Treatment=Measured bc-quenched

\section{Multivariate}

\section{Correlations}

$\begin{array}{lrrrr} & \log \mathrm{NL}[\mathrm{B}(\mathrm{g} / \mathrm{L})] & \log \mathrm{NL}[\mathrm{Li}(\mathrm{g} / \mathrm{L})] & \log \mathrm{NL}[\mathrm{Na}(\mathrm{g} / \mathrm{L})] & \log \mathrm{NL}[\mathrm{Si}(\mathrm{g} / \mathrm{L})] \\ \log \mathrm{NL}[\mathrm{B}(\mathrm{g} / \mathrm{L})] & 1.0000 & 0.7638 & 0.9181 & 0.8431 \\ \log \mathrm{NL}[\mathrm{Li}(\mathrm{g} / \mathrm{L})] & 0.7638 & 1.0000 & 0.6183 & 0.9287 \\ \log \mathrm{NL}[\mathrm{Na}(\mathrm{g} / \mathrm{L})] & 0.9181 & 0.6183 & 1.0000 & 0.7764 \\ \log \mathrm{NL}[\mathrm{Si}(\mathrm{g} / \mathrm{L})] & 0.8431 & 0.9287 & 0.7764 & 1.0000\end{array}$

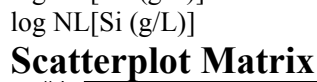

\begin{tabular}{|c|c|c|c|c|}
\hline $\begin{array}{r}-0.1- \\
-0.15\end{array}$ & $\begin{array}{c}\log N L[B \\
(\mathrm{g} / \mathrm{L})]\end{array}$ & 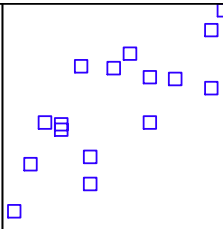 & 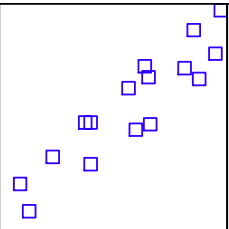 & 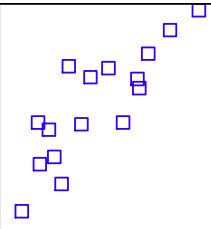 \\
\hline $\begin{array}{r}0.075- \\
-0.1\end{array}$ & 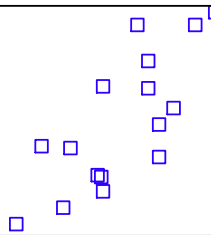 & $\begin{array}{c}\log \\
\mathrm{NL}[\mathrm{Li}(\mathrm{g} / \mathrm{L})]\end{array}$ & 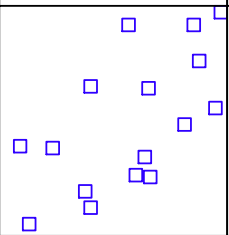 & 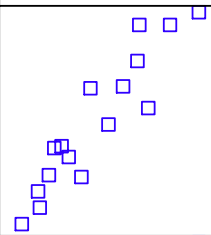 \\
\hline $\begin{array}{r}-0.05- \\
-0.1\end{array}$ & 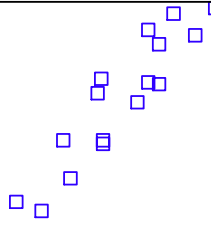 & 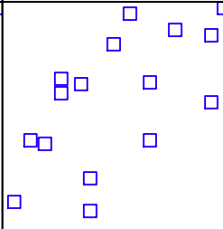 & $\begin{array}{c}\log \mathrm{NL}[\mathrm{Na} \\
(\mathrm{g} / \mathrm{L})]\end{array}$ & 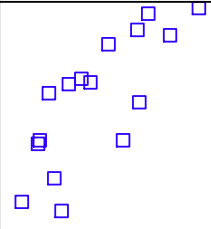 \\
\hline $\begin{array}{r}-0.225 \\
-0.25 \\
-0.275\end{array}$ & 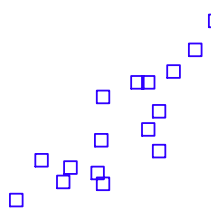 & 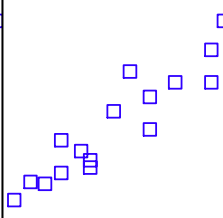 & 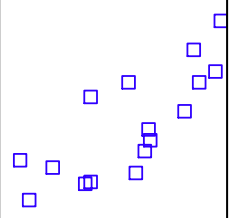 & $\begin{array}{c}\log N L[S i \\
(\mathrm{g} / \mathrm{L})]\end{array}$ \\
\hline
\end{tabular}


Exhibit E6. Correlations and Scatter Plots of Normalized PCTs

Over All Compositional Views and Heat Treatments (continued)

Comp View/Heat Treatment=Measured-ccc

Multivariate

Correlations

$\begin{array}{lrrrr} & \log \mathrm{NL}[\mathrm{B}(\mathrm{g} / \mathrm{L})] & \log \mathrm{NL}[\mathrm{Li}(\mathrm{g} / \mathrm{L})] & \log \mathrm{NL}[\mathrm{Na}(\mathrm{g} / \mathrm{L})] & \log \mathrm{NL}[\mathrm{Si}(\mathrm{g} / \mathrm{L})] \\ \log \mathrm{NL}[\mathrm{B}(\mathrm{g} / \mathrm{L})] & 1.0000 & 0.9384 & 0.9285 & 0.9049 \\ \log \mathrm{NL}[\mathrm{Li}(\mathrm{g} / \mathrm{L})] & 0.9384 & 1.0000 & 0.8623 & 0.9876 \\ \log \mathrm{NL}[\mathrm{Na}(\mathrm{g} / \mathrm{L})] & 0.9285 & 0.8623 & 1.0000 & 0.8397 \\ \log \mathrm{NL}[\mathrm{Si}(\mathrm{g} / \mathrm{L})] & 0.9049 & 0.9876 & 0.8397 & 1.0000\end{array}$

\section{Scatterplot Matrix}

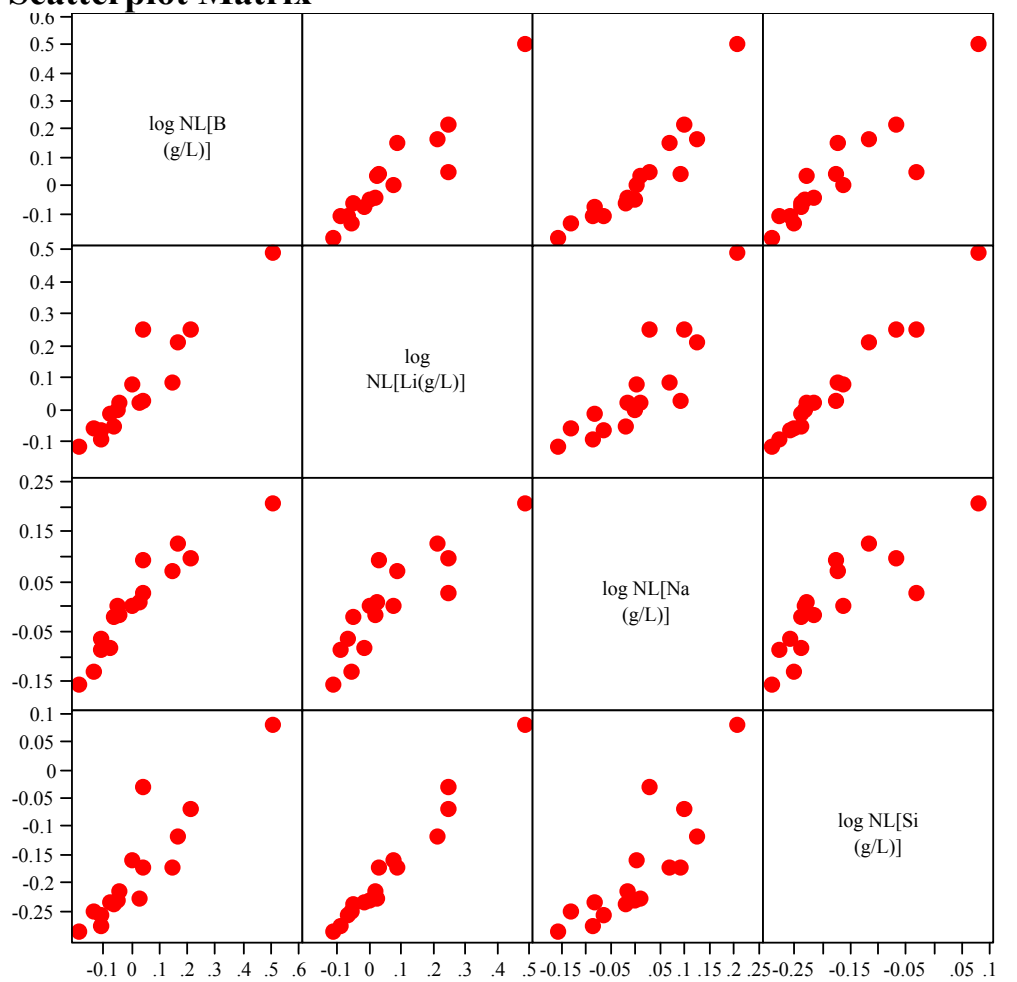

Comp View/Heat Treatment=Measured-quenched

\section{Multivariate}

Correlations

$\begin{array}{lrrrr} & \log \mathrm{NL}[\mathrm{B}(\mathrm{g} / \mathrm{L})] & \log \mathrm{NL}[\mathrm{Li}(\mathrm{g} / \mathrm{L})] & \log \mathrm{NL}[\mathrm{Na}(\mathrm{g} / \mathrm{L})] & \log \mathrm{NL}[\mathrm{Si}(\mathrm{g} / \mathrm{L})] \\ \log \mathrm{NL}[\mathrm{B}(\mathrm{g} / \mathrm{L})] & 1.0000 & 0.7708 & 0.8743 & 0.8491 \\ \log \mathrm{NL}[\mathrm{Li}(\mathrm{g} / \mathrm{L})] & 0.7708 & 1.0000 & 0.6077 & 0.9269 \\ \log \mathrm{NL}[\mathrm{Na}(\mathrm{g} / \mathrm{L})] & 0.8743 & 0.6077 & 1.0000 & 0.7856 \\ \log \mathrm{NL}[\mathrm{Si}(\mathrm{g} / \mathrm{L})] & 0.8491 & 0.9269 & 0.7856 & 1.0000\end{array}$

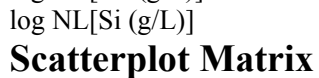

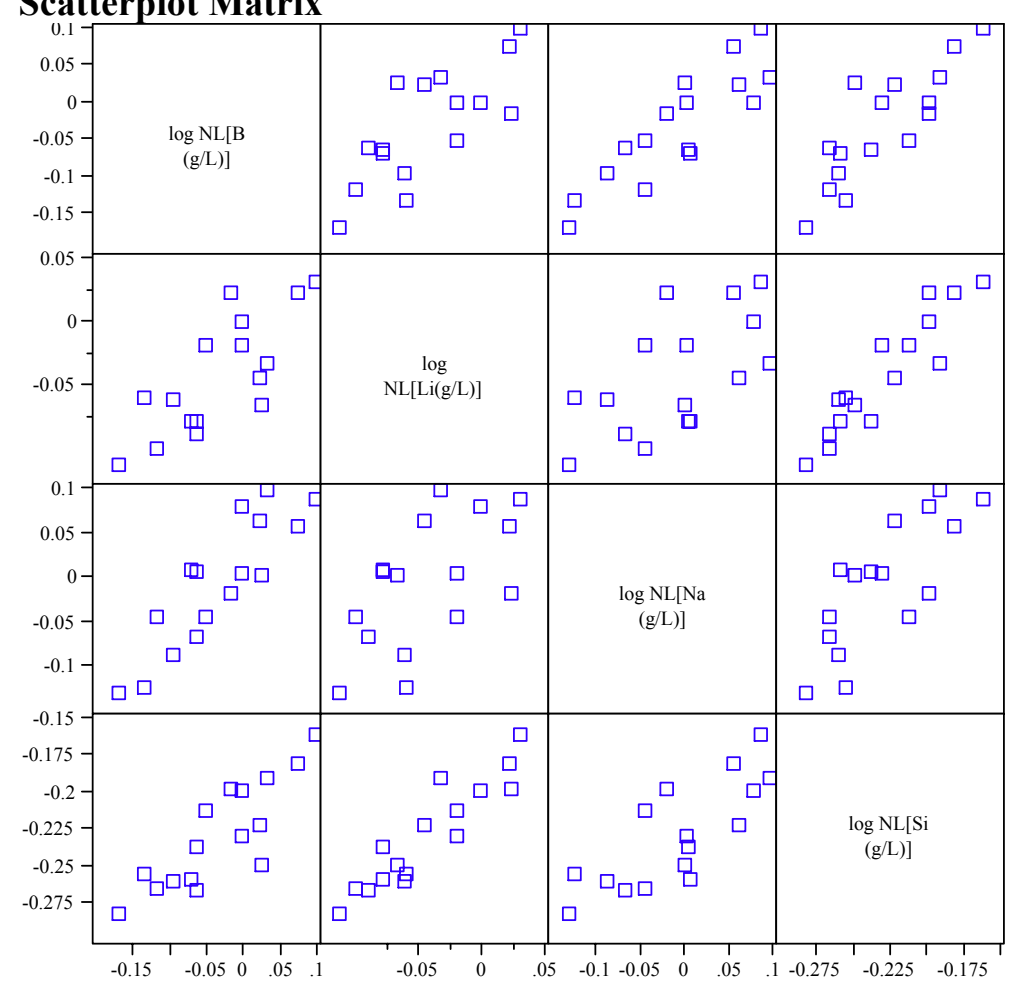




\section{Exhibit E6. Correlations and Scatter Plots of Normalized PCTs}

Over All Compositional Views and Heat Treatments (continued)

Comp View/Heat Treatment $=$ target-ccc

\section{Multivariate}

Correlations

$\begin{array}{lrrrr} & \log \mathrm{NL}[\mathrm{B}(\mathrm{g} / \mathrm{L})] & \log \mathrm{NL}[\mathrm{Li}(\mathrm{g} / \mathrm{L})] & \log \mathrm{NL}[\mathrm{Na}(\mathrm{g} / \mathrm{L})] & \log \mathrm{NL}[\mathrm{Si}(\mathrm{g} / \mathrm{L})] \\ \log \mathrm{NL}[\mathrm{B}(\mathrm{g} / \mathrm{L})] & 1.0000 & 0.9382 & 0.9459 & 0.9062 \\ \log \mathrm{NL}[\mathrm{Li}(\mathrm{g} / \mathrm{L})] & 0.9382 & 1.0000 & 0.8582 & 0.9903 \\ \log \mathrm{NL}[\mathrm{Na}(\mathrm{g} / \mathrm{L})] & 0.9459 & 0.8582 & 1.0000 & 0.8320 \\ \log \mathrm{NL}[\mathrm{Si}(\mathrm{g} / \mathrm{L})] & 0.9062 & 0.9903 & 0.8320 & 1.0000\end{array}$

\section{Scatterplot Matrix}

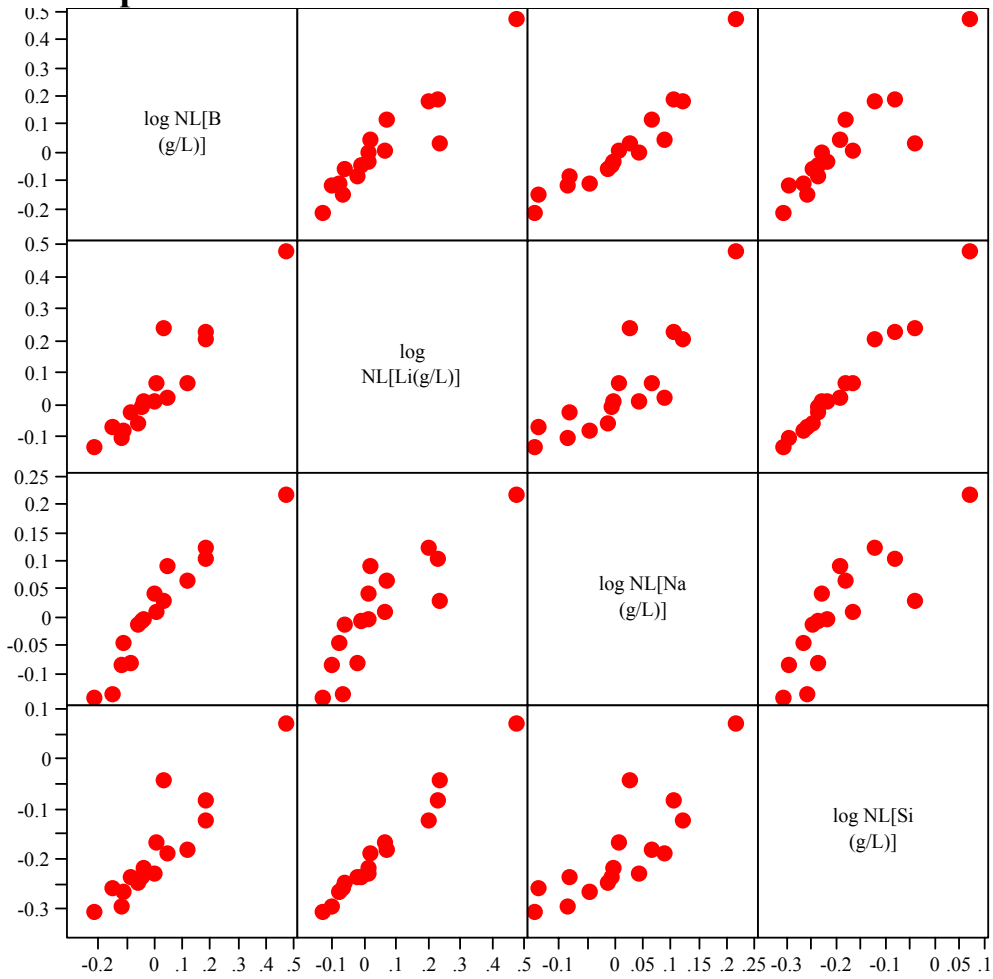

Comp View/Heat Treatment $=$ target-quenched

Multivariate

Correlations

$\begin{array}{lrrrr} & \log \mathrm{NL}[\mathrm{B}(\mathrm{g} / \mathrm{L})] & \log \mathrm{NL}[\mathrm{Li}(\mathrm{g} / \mathrm{L})] & \log \mathrm{NL}[\mathrm{Na}(\mathrm{g} / \mathrm{L})] & \log \mathrm{NL}[\mathrm{Si}(\mathrm{g} / \mathrm{L})] \\ \log \mathrm{NL}[\mathrm{B}(\mathrm{g} / \mathrm{L})] & 1.0000 & 0.7872 & 0.9162 & 0.8679 \\ \log \mathrm{NL}[\mathrm{Li}(\mathrm{g} / \mathrm{L})] & 0.7872 & 1.0000 & 0.5860 & 0.9460 \\ \log \mathrm{NL}[\mathrm{Na}(\mathrm{g} / \mathrm{L})] & 0.9162 & 0.5860 & 1.0000 & 0.7607 \\ \log \mathrm{NL}[\mathrm{Si}(\mathrm{g} / \mathrm{L})] & 0.8679 & 0.9460 & 0.7607 & 1.0000\end{array}$

$\log N \mathrm{~N}[\mathrm{Si}(\mathrm{g} / \mathrm{L})]$
Scatterplot Matrix

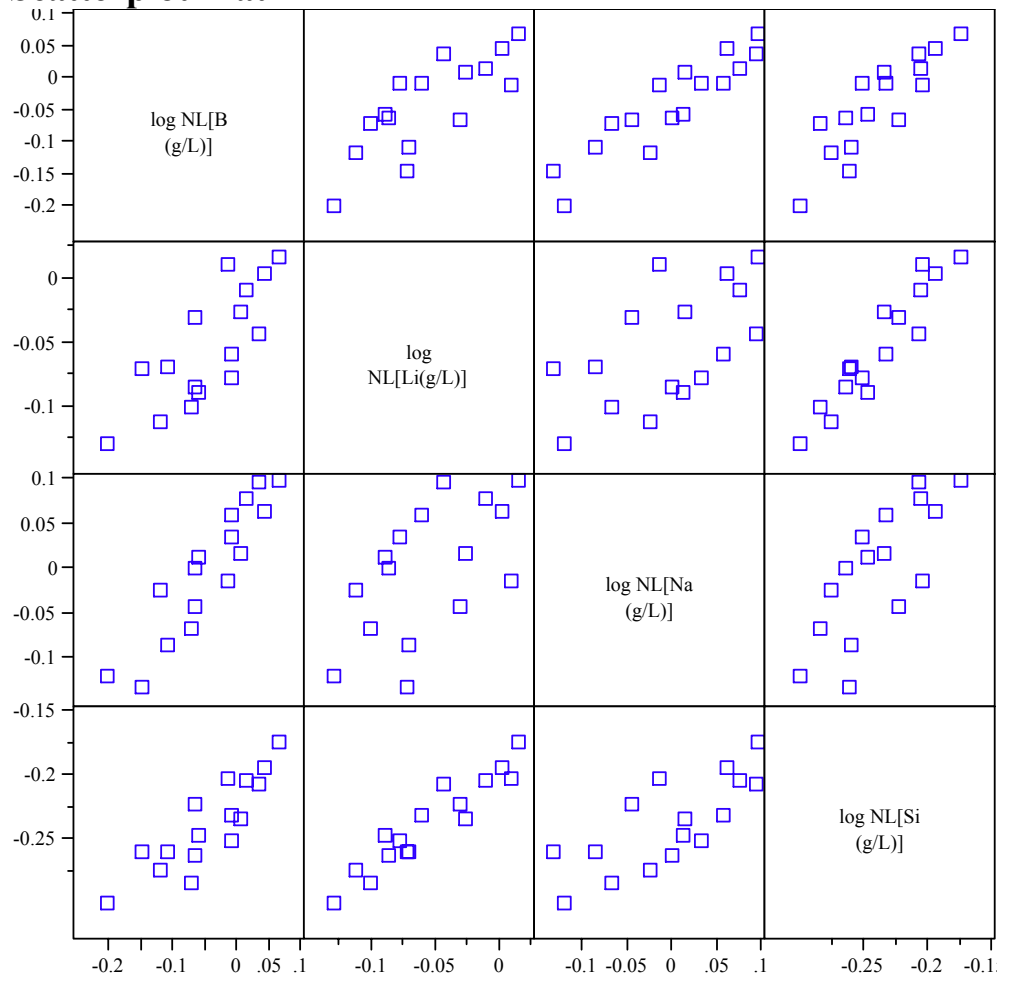




\section{Exhibit E7. Effects of Heat Treatment on PCT ppm-Response of Study Glasses}

Glass ID $=$ NEPH3-41

Oneway Analysis of $\log [\mathrm{B}$ ppm] By Heat Treatment

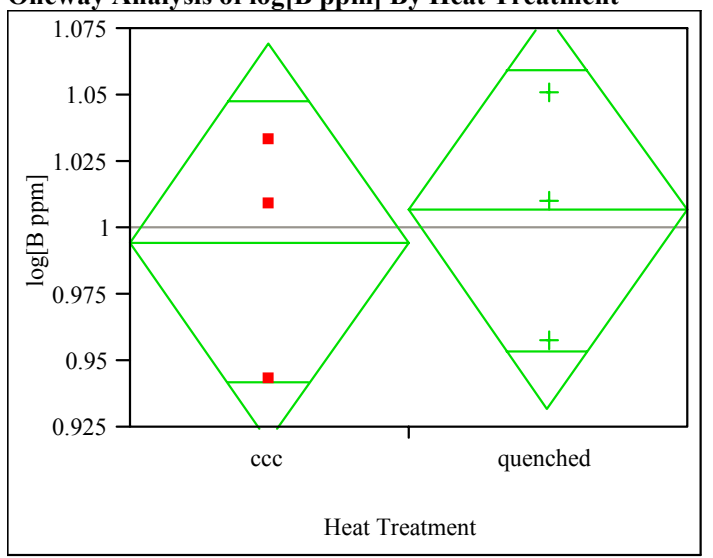

t Test

ccc-quenched

Assuming equal variances

Difference $\quad-0.01198$ t Ratio $\quad-0.31508$

Std Err Dif $\quad 0.03802$ DF 4

Upper CL Dif 0.09357 Prob $>|t| \quad 0.7685$

Lower CL Dif -0.11753 Prob $>t \quad 0.6158$

Confidence $\quad 0.95$ Prob $<\mathrm{t} \quad 0.3842$

Oneway Analysis of $\log [\mathrm{Li}$ ppm] By Heat Treatment

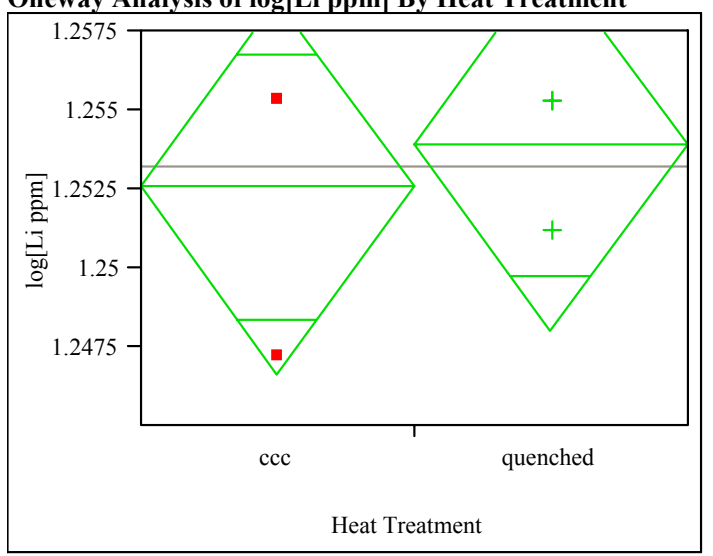

t Test

ccc-quenched

Assuming equal variances

Difference $\quad-0.00136$ t Ratio $\quad-0.44972$

$\begin{array}{lll}\text { Std Err Dif } & 0.00302 \text { DF } & 4\end{array}$

Upper CL Dif 0.00703 Prob $>|t| 0.6762$

Lower CL Dif - 0.00975 Prob $>t \quad 0.6619$

Confidence $\quad 0.95$ Prob $<\mathrm{t} \quad 0.3381$

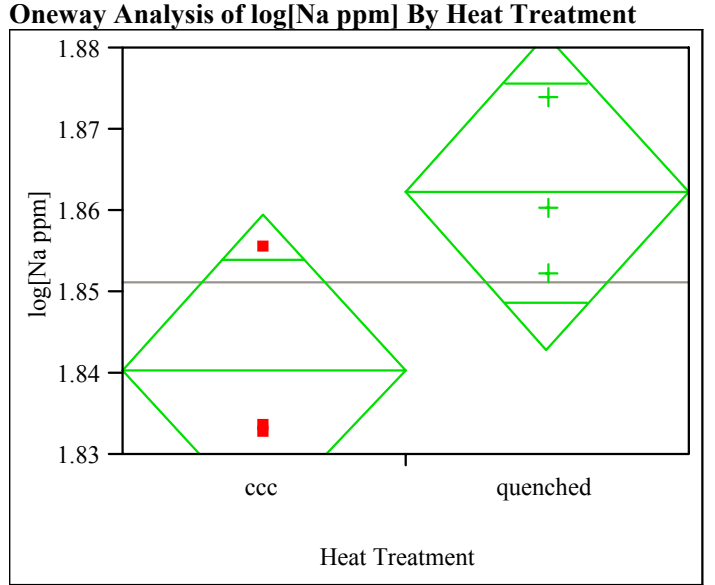

t Test

ccc-quenched

Assuming equal variances

$\begin{array}{lrlr}\text { Difference } & -0.02177 \text { t Ratio } & -2.2242 \\ \text { Std Err Dif } & 0.00979 \text { DF } & 4 \\ \text { Upper CL Dif } & 0.00541 \text { Prob }>|t| & 0.0902 \\ \text { Lower CL Dif } & -0.04895 \text { Prob }>\text { t } & 0.9549 \\ \text { Confidence } & 0.95 & \text { Prob }<\text { t } & 0.0451\end{array}$

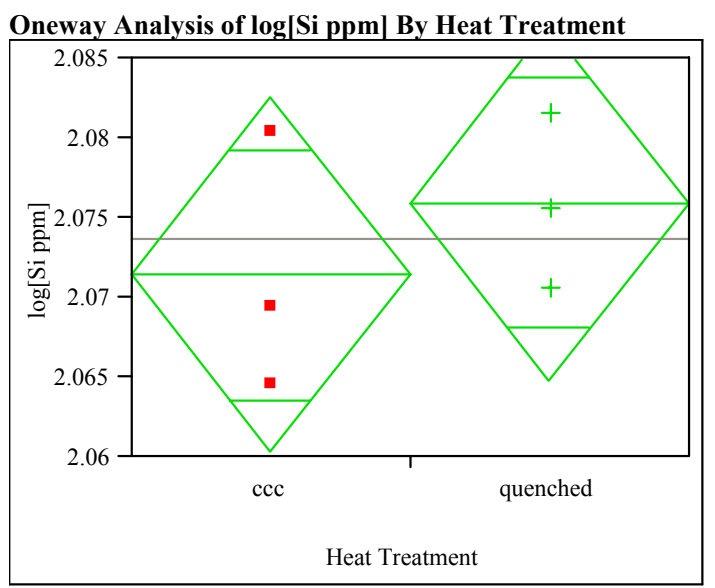

t Test

ccc-quenched

Assuming equal variances

$\begin{array}{lrlr}\text { Difference } & -0.00451 \text { t Ratio } & -0.79506 \\ \text { Std Err Dif } & 0.00567 \text { DF } & 4 \\ \text { Upper CL Dif } & 0.01123 \text { Prob }>|t| & 0.4711 \\ \text { Lower CL Dif } & -0.02025 \text { Prob }>\text { t } & 0.7645 \\ \text { Confidence } & 0.95 \text { Prob }<\mathrm{t} & 0.2355\end{array}$




\section{Exhibit E7. Effects of Heat Treatment on PCT ppm-Response of Study Glasses (continued)}

Glass ID $=$ NEPH3-42

Oneway Analysis of $\log [\mathrm{B}$ ppm] By Heat Treatment

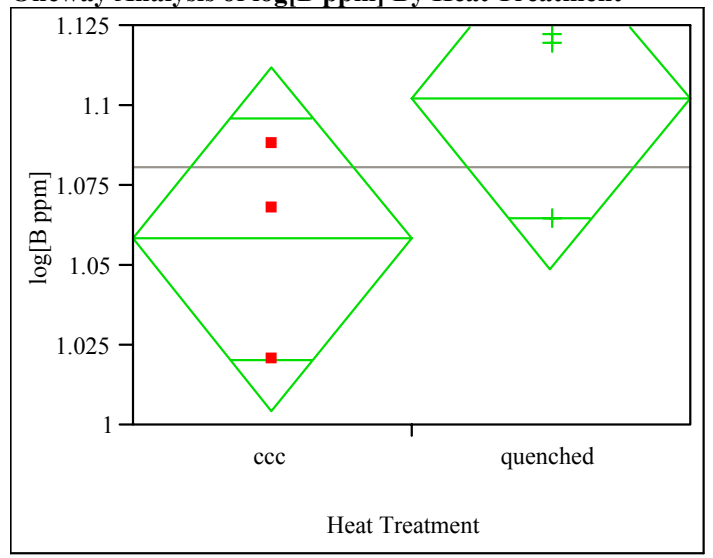

t Test

ccc-quenched

Assuming equal variances

Difference $\quad-0.04409$ t Ratio $\quad-1.61201$

Std Err Dif $\quad 0.02735$ DF 4

Upper CL Dif 0.03185 Prob $>|t| \quad 0.1823$

Lower CL Dif -0.12002 Prob $>t \quad 0.9089$

Confidence $\quad 0.95$ Prob $<\mathrm{t} \quad 0.0911$

Oneway Analysis of $\log [\mathrm{Li}$ ppm] By Heat Treatment

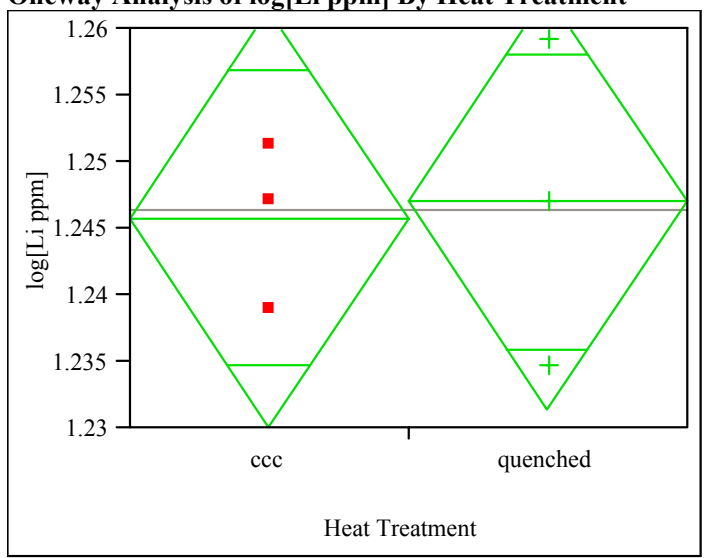

t Test

ccc-quenched

Assuming equal variances

Difference $\quad-0.00128$ t Ratio $\quad-0.16079$

Std Err Dif $\quad 0.00797$ DF 4

Upper CL Dif 0.02086 Prob $>|t| \quad 0.8801$

Lower CL Dif -0.02342 Prob $>\mathrm{t} \quad 0.5600$

Confidence $\quad 0.95$ Prob $<\mathrm{t} \quad 0.4400$

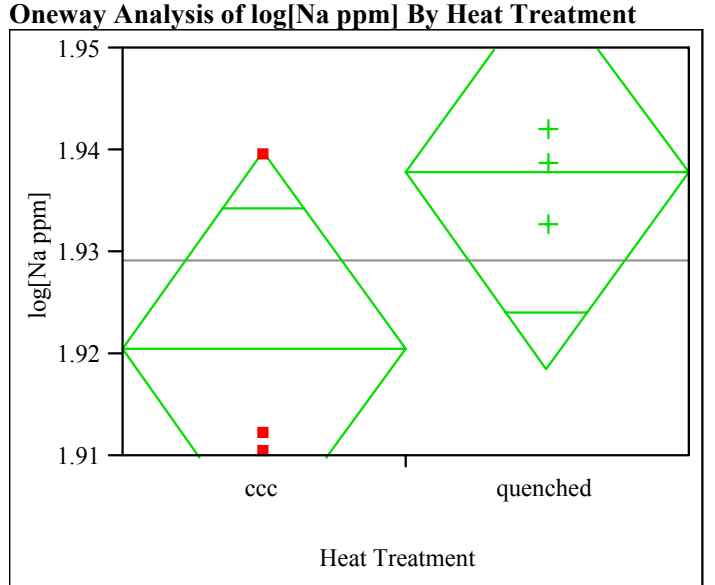

t Test

ccc-quenched

Assuming equal variances

$\begin{array}{lrlr}\text { Difference } & -0.01722 & \mathrm{t} \text { Ratio } & -1.75004 \\ \text { Std Err Dif } & 0.00984 \text { DF } & 4 \\ \text { Upper CL Dif } & 0.01010 \text { Prob }>|\mathrm{t}| & 0.1550 \\ \text { Lower CL Dif } & -0.04455 \text { Prob }>\mathrm{t} & 0.9225 \\ \text { Confidence } & 0.95 \text { Prob }<\mathrm{t} & 0.0775\end{array}$

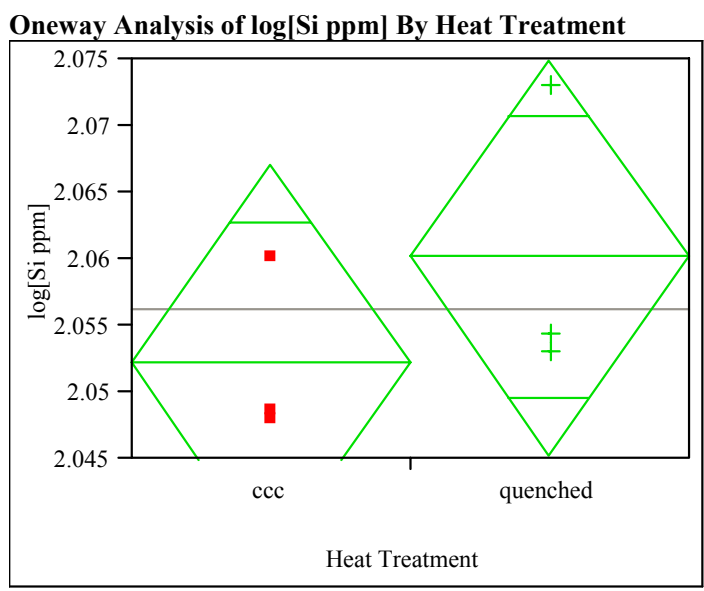

t Test

ccc-quenched

Assuming equal variances

Difference $\quad-0.00799$ t Ratio $\quad-1.05445$

$\begin{array}{lrr}\text { Std Err Dif } & 0.00758 \text { DF } & 4\end{array}$

Upper CL Dif 0.01305 Prob $>|\mathrm{t}| \quad 0.3512$

Lower CL Dif -0.02904 Prob $>$ t 0.8244

Confidence $\quad 0.95$ Prob $<\mathrm{t} \quad 0.1756$ 


\section{Exhibit E7. Effects of Heat Treatment on PCT ppm-Response of Study Glasses (continued)}

Glass ID $=$ NEPH3-43

Oneway Analysis of $\log [\mathrm{B}$ ppm] By Heat Treatment

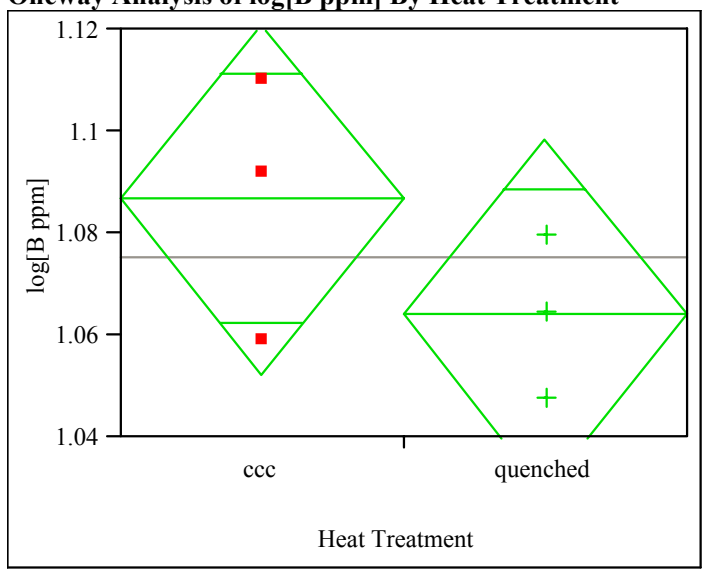

t Test

ccc-quenched

Assuming equal variances

Difference $\quad 0.02278$ t Ratio $\quad 1.295567$

$\begin{array}{lrrr}\text { Std Err Dif } & 0.01758 \text { DF } & 4 \\ \text { Upper CL } & 0.07159 \text { Prob }>|t| & 0.2648\end{array}$

$\begin{array}{lrl}\text { Upper CL Dif } & 0.07159 \text { Prob }>|t| & 0.2648 \\ \text { Lower CL Dif }-0.02604 \text { Prob }>t & 0.1324\end{array}$

$\begin{array}{lll}\text { Confidence } & 0.95 \text { Prob }<\mathrm{t} \quad 0.8676\end{array}$

Oneway Analysis of log[Li ppm] By Heat Treatment

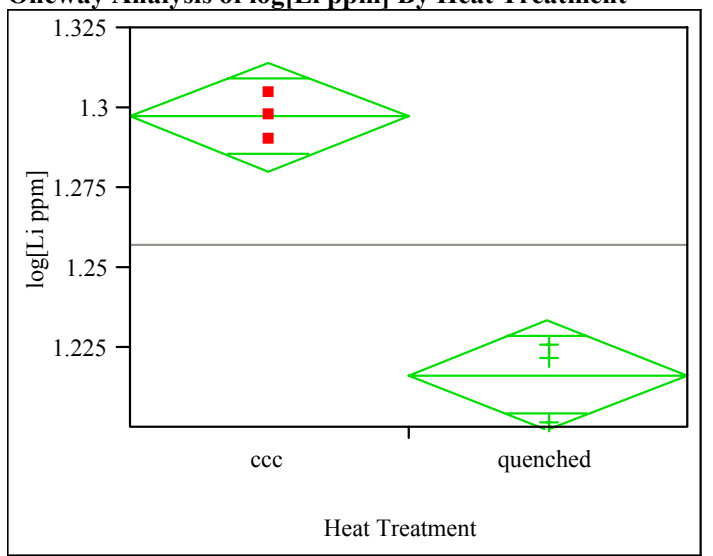

t Test

ccc-quenched

Assuming equal variances

Difference $\quad 0.080731$ t Ratio 9.393163

Std Err Dif $\quad 0.008595$ DF 4

Upper CL Dif 0.104594 Prob $>|t| \quad 0.0007$

Lower CL Dif 0.056869 Prob $>t \quad 0.0004$

Confidence $\quad 0.95$ Prob $<\mathrm{t} \quad 0.9996$

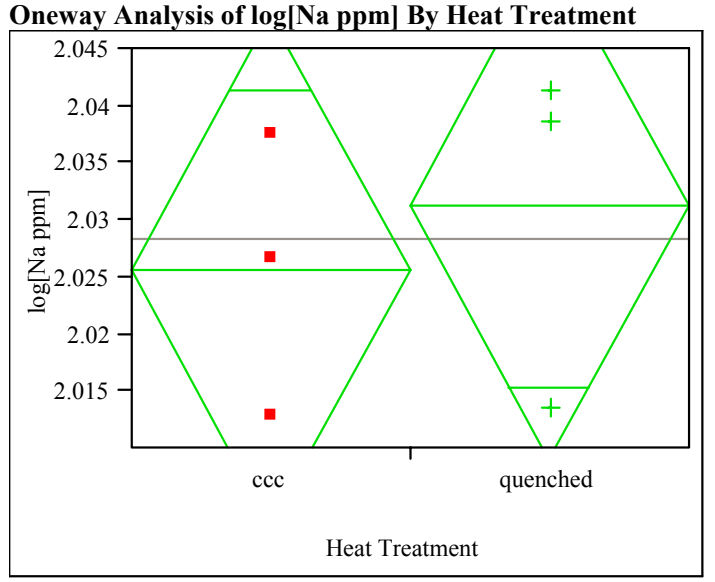

t Test

ccc-quenched

Assuming equal variances

$\begin{array}{lrlr}\text { Difference } & -0.00558 \text { t Ratio } & -0.49077 \\ \text { Std Err Dif } & 0.01138 \text { DF } & 4 \\ \text { Upper CL Dif } & 0.02601 \text { Prob }>|t| & 0.6493 \\ \text { Lower CL Dif } & -0.03717 \text { Prob }>t & 0.6754 \\ \text { Confidence } & 0.95 \text { Prob }<\mathrm{t} & 0.3246\end{array}$

Oneway Analysis of $\log [\mathrm{Si}$ ppm] By Heat Treatment

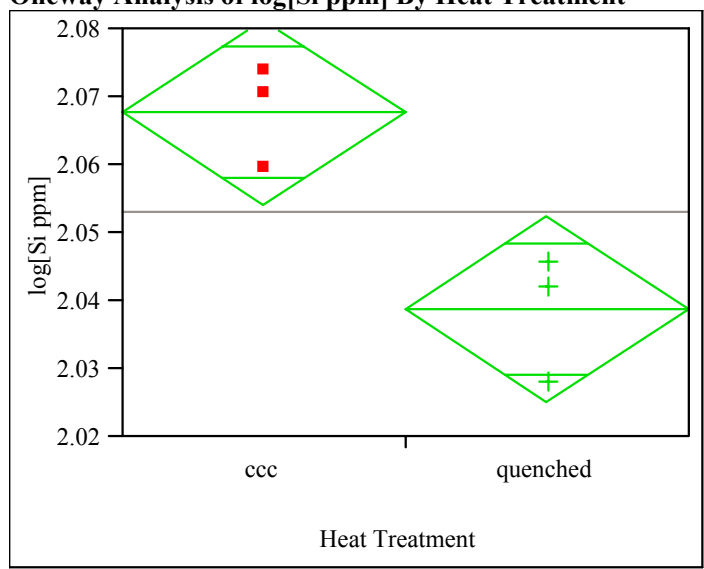

t Test

ccc-quenched

Assuming equal variances

Difference $\quad 0.029252$ t Ratio 4.199821

Std Err Dif $\quad 0.006965$ DF 4

Upper CL Dif 0.048590 Prob $>|\mathrm{t}| \quad 0.0137$

Lower CL Dif 0.009914 Prob $>$ t 0.0068

Confidence $\quad 0.95$ Prob $<\mathrm{t} \quad 0.9932$ 


\section{Exhibit E7. Effects of Heat Treatment on PCT ppm-Response of Study Glasses (continued)}

Glass ID $=$ NEPH3-44

Oneway Analysis of $\log [\mathrm{B}$ ppm] By Heat Treatment

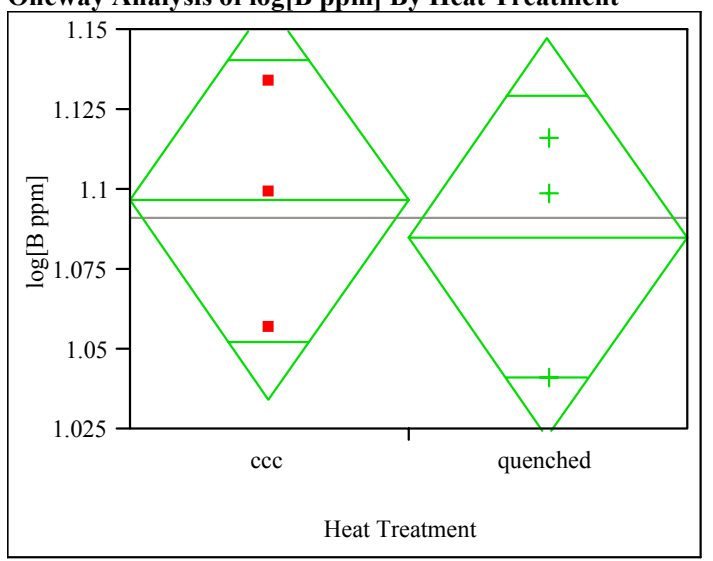

t Test

ccc-quenched

Assuming equal variances

Difference $\quad 0.01115$ t Ratio $\quad 0.352564$

Std Err Dif $\quad 0.03164$ DF 4

Upper CL Dif 0.09899 Prob $>|t| \quad 0.7422$

Lower CL Dif -0.07669 Prob $>t \quad 0.3711$

Confidence $\quad 0.95$ Prob $<\mathrm{t} \quad 0.6289$

Oneway Analysis of $\log [\mathrm{Li}$ ppm] By Heat Treatment

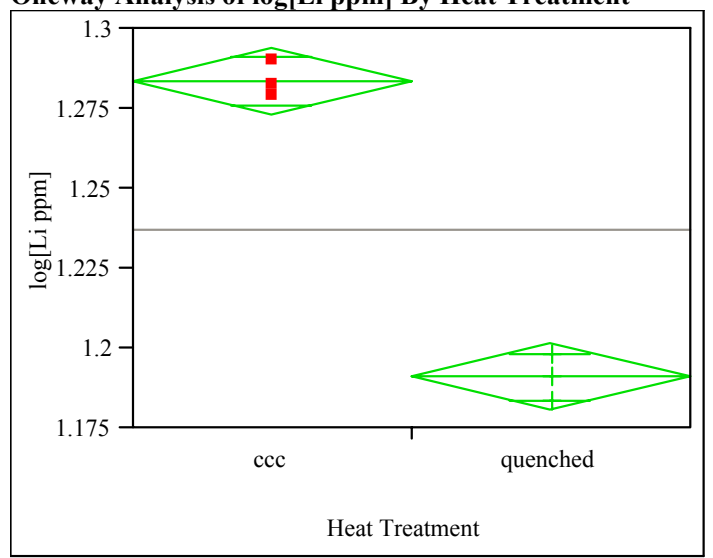

t Test

ccc-quenched

Assuming equal variances

Difference $\quad 0.092709$ t Ratio $\quad 17.39502$

Std Err Dif $\quad 0.005330$ DF 4

Upper CL Dif 0.107506 Prob $>|t|<.0001$

Lower CL Dif 0.077912 Prob $>t \quad<.0001$

Confidence $\quad 0.95$ Prob $<\mathrm{t} \quad 1.0000$

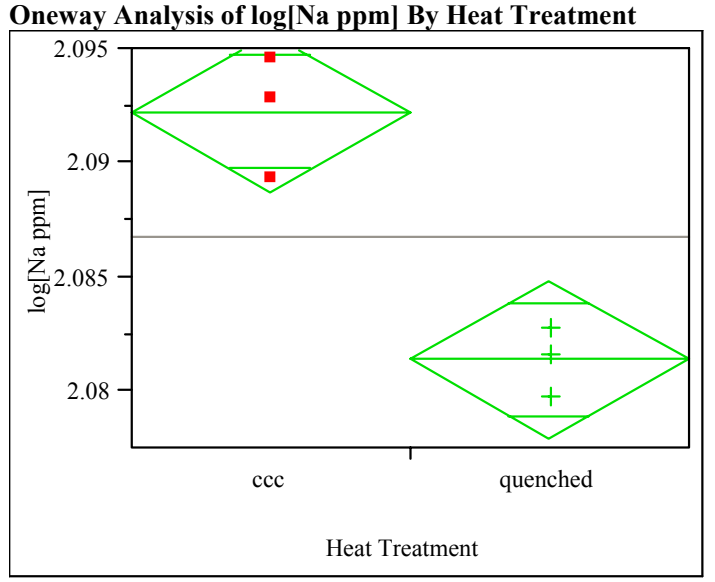

t Test

ccc-quenched

Assuming equal variances

$\begin{array}{lrlr}\text { Difference } & 0.010862 \text { t Ratio } & 6.106634 \\ \text { Std Err Dif } & 0.001779 \text { DF } & 4 \\ \text { Upper CL Dif } & 0.015800 \text { Prob }>|t| & 0.0036 \\ \text { Lower CL Dif } & 0.005923 \text { Prob }>t & 0.0018 \\ \text { Confidence } & 0.95 \text { Prob }<\mathrm{t} & 0.9982\end{array}$

Oneway Analysis of $\log [\mathrm{Si}$ ppm] By Heat Treatment

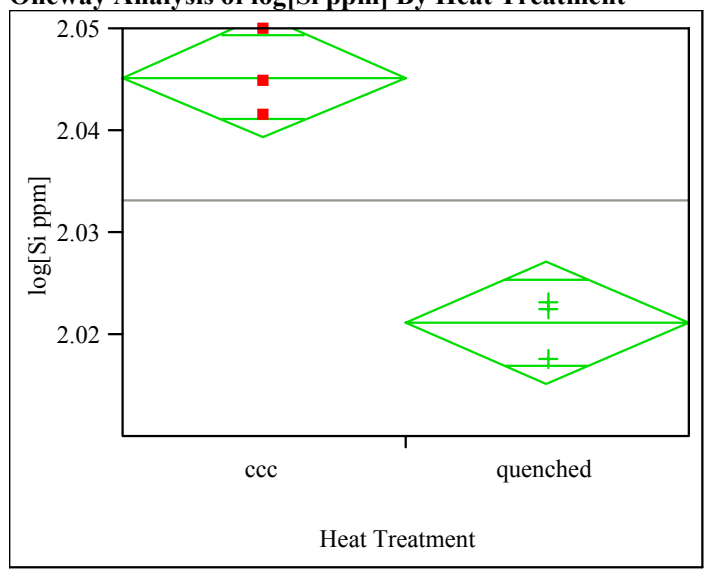

t Test

ccc-quenched

Assuming equal variances

Difference $\quad 0.024127$ t Ratio $\quad 7.996557$

Std Err Dif 0.003017 DF 4

Upper CL Dif 0.032503 Prob $>|t| 0.0013$

Lower CL Dif 0.015750 Prob $>$ t $\quad 0.0007$

Confidence $\quad 0.95$ Prob $<\mathrm{t} \quad 0.9993$ 


\section{Exhibit E7. Effects of Heat Treatment on PCT ppm-Response of Study Glasses (continued)}

Glass ID $=$ NEPH3-45

Oneway Analysis of $\log [\mathrm{B}$ ppm] By Heat Treatment

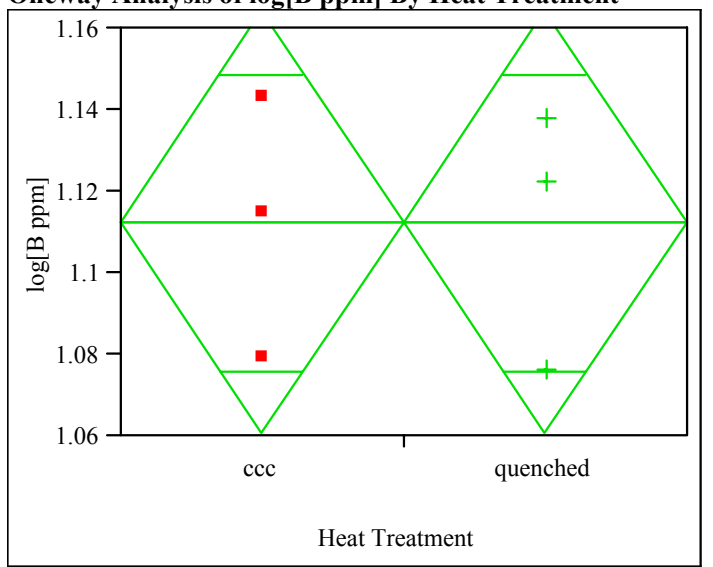

t Test

ccc-quenched

Assuming equal variances

Difference $\quad 0.000007$ t Ratio $\quad 0.000286$

Std Err Dif $\quad 0.02622$ DF 4

Upper CL Dif 0.07282 Prob $>|t| \quad 0.9998$

Lower CL Dif -0.07280 Prob $>t \quad 0.4999$

$\begin{array}{lll}\text { Confidence } & 0.95 \mathrm{Prob}<\mathrm{t} \quad 0.5001\end{array}$

Oneway Analysis of $\log [\mathrm{Li}$ ppm] By Heat Treatment

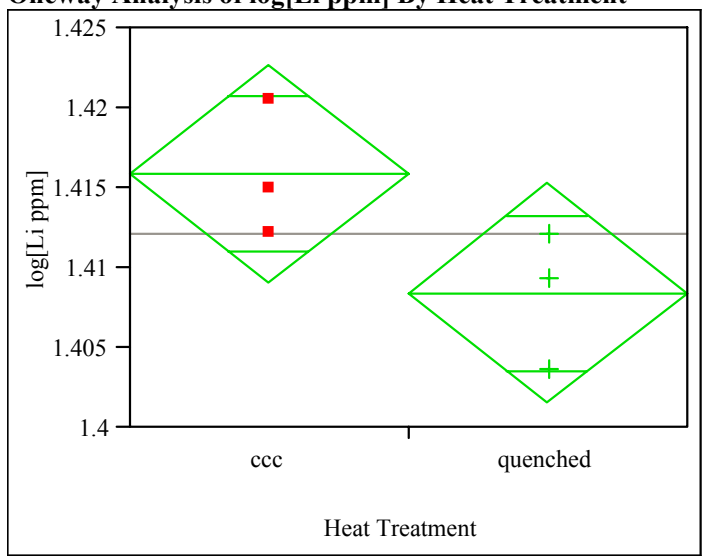

t Test

ccc-quenched

Assuming equal variances

Difference $\quad 0.00747$ t Ratio $\quad 2.137898$

$\begin{array}{lrr}\text { Std Err Dif } & 0.00350 \mathrm{DF} & 4\end{array}$

Upper CL Dif 0.01718 Prob $>|t| 0.0993$

Lower CL Dif -0.00223 Prob $>t \quad 0.0497$

Confidence $\quad 0.95$ Prob $<\mathrm{t} \quad 0.9503$

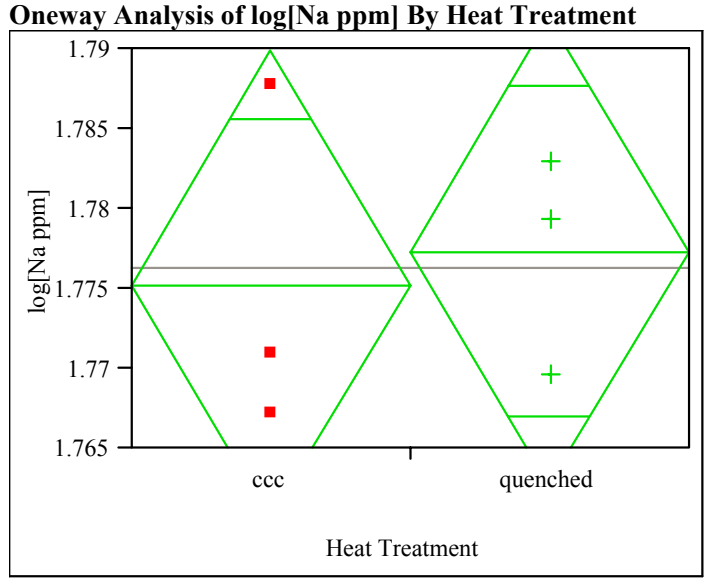

t Test

ccc-quenched

Assuming equal variances

$\begin{array}{lrlr}\text { Difference } & -0.00208 \text { t Ratio } & -0.27776 \\ \text { Std Err Dif } & 0.00747 \text { DF } & 4 \\ \text { Upper CL Dif } & 0.01867 \text { Prob }>|t| & 0.7950 \\ \text { Lower CL Dif } & -0.02282 \text { Prob }>t & 0.6025 \\ \text { Confidence } & 0.95 \text { Prob }<\mathrm{t} & 0.3975\end{array}$

Oneway Analysis of $\log [\mathrm{Si}$ ppm] By Heat Treatment

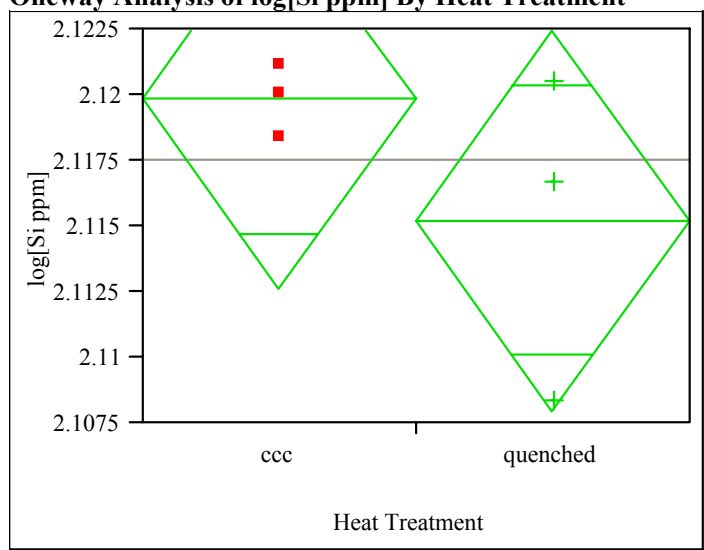

t Test

ccc-quenched

Assuming equal variances

Difference $\quad 0.00463$ t Ratio $\quad 1.251875$

Std Err Dif $\quad 0.00370$ DF 4

Upper CL Dif 0.01490 Prob $>|t| \quad 0.2788$

Lower CL Dif -0.00564 Prob $>$ t 0.1394

Confidence $\quad 0.95$ Prob $<\mathrm{t} \quad 0.8606$ 


\section{Exhibit E7. Effects of Heat Treatment on PCT ppm-Response of Study Glasses (continued)}

Glass ID $=$ NEPH3-46

Oneway Analysis of $\log [\mathrm{B}$ ppm] By Heat Treatment

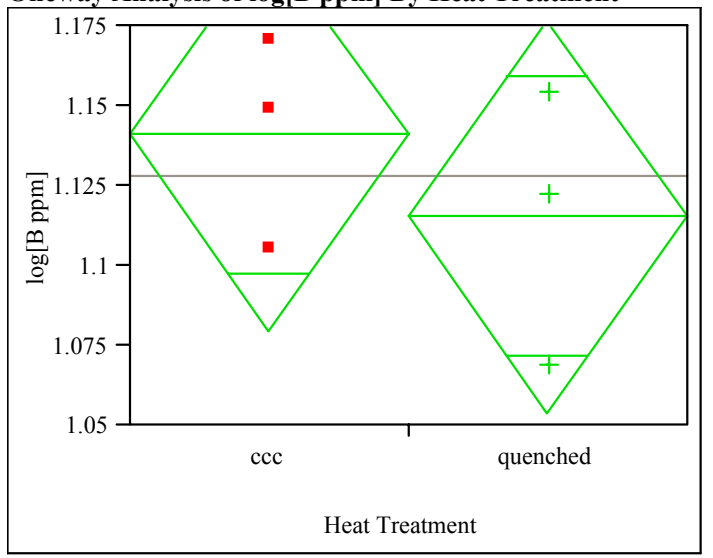

t Test

ccc-quenched

Assuming equal variances

Difference $\quad 0.02581$ t Ratio $\quad 0.821072$

Std Err Dif $\quad 0.03144$ DF 4

Upper CL Dif 0.11310 Prob $>|t| \quad 0.4577$

Lower CL Dif -0.06148 Prob $>t \quad 0.2289$

Confidence $\quad 0.95$ Prob $<\mathrm{t} \quad 0.7711$

Oneway Analysis of $\log [\mathrm{Li}$ ppm] By Heat Treatment

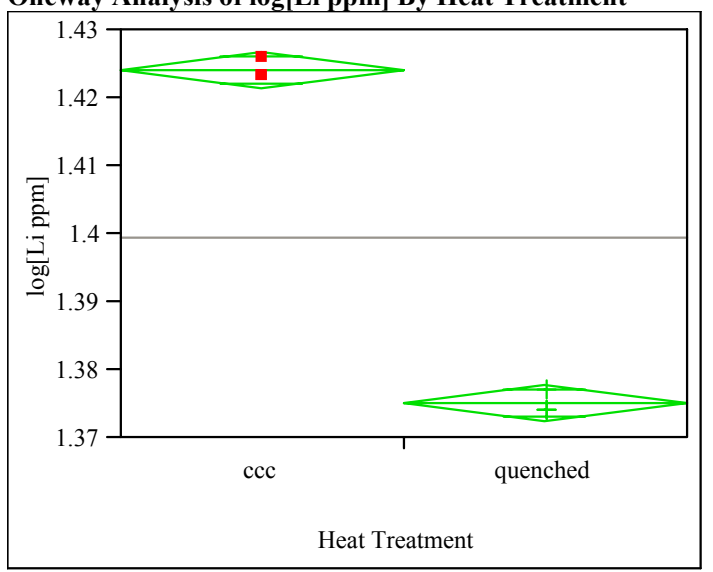

t Test

ccc-quenched

Assuming equal variances

Difference $\quad 0.049001$ t Ratio 35.96934

Std Err Dif $\quad 0.001362$ DF 4

Upper CL Dif 0.052783 Prob $>|t|<.0001$

Lower CL Dif 0.045218 Prob $>t \quad<.0001$

Confidence $\quad 0.95$ Prob $<\mathrm{t} \quad 1.0000$

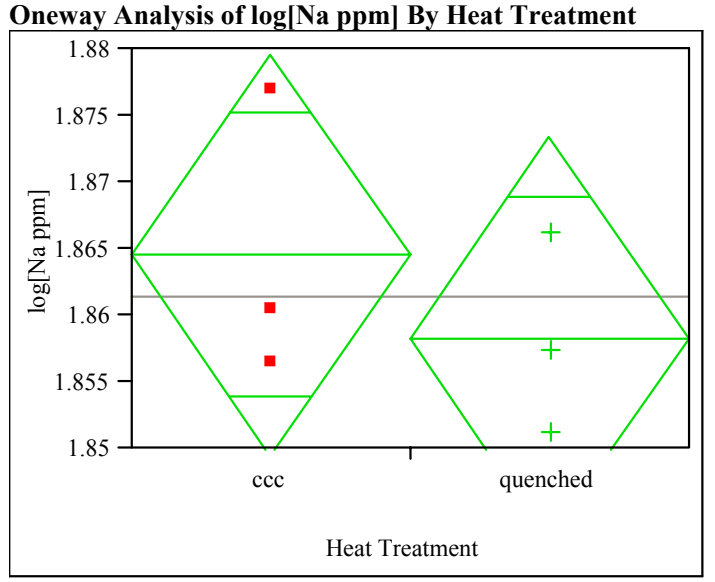

t Test

ccc-quenched

Assuming equal variances

$\begin{array}{lrlr}\text { Difference } & 0.00626 \text { t Ratio } & 0.814247 \\ \text { Std Err Dif } & 0.00769 \text { DF } & 4 \\ \text { Upper CL Dif } & 0.02760 \text { Prob }>|t| & 0.4612 \\ \text { Lower CL Dif } & -0.01508 \text { Prob }>t & 0.2306 \\ \text { Confidence } & 0.95 \text { Prob }<\mathrm{t} & 0.7694\end{array}$

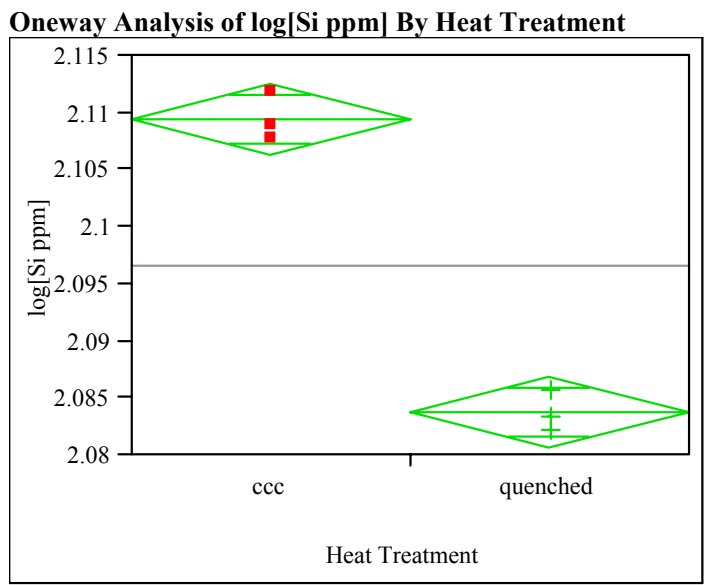

t Test

ccc-quenched

Assuming equal variances

Difference $\quad 0.025684$ t Ratio $\quad 16.32364$

Std Err Dif 0.001573 DF 4

Upper CL Dif 0.030053 Prob $>|t|<.0001$

Lower CL Dif 0.021316 Prob $>t<.0001$

Confidence $\quad 0.95$ Prob $<\mathrm{t} \quad 1.0000$ 


\section{Exhibit E7. Effects of Heat Treatment on PCT ppm-Response of Study Glasses (continued)}

Glass ID $=$ NEPH3-47

Oneway Analysis of $\log [\mathrm{B}$ ppm] By Heat Treatment

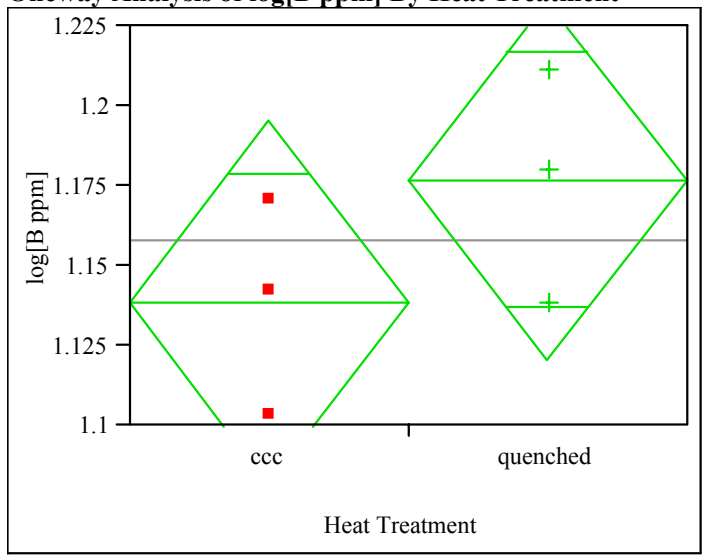

t Test

ccc-quenched

Assuming equal variances

Difference $\quad-0.03818$ t Ratio $\quad-1.32691$

Std Err Dif $\quad 0.02878$ DF 4

Upper CL Dif 0.04171 Prob $>|t| \quad 0.2552$

Lower CL Dif -0.11808 Prob $>t \quad 0.8724$

Confidence $\quad 0.95$ Prob $<\mathrm{t} \quad 0.1276$

Oneway Analysis of $\log [\mathrm{Li}$ ppm] By Heat Treatment

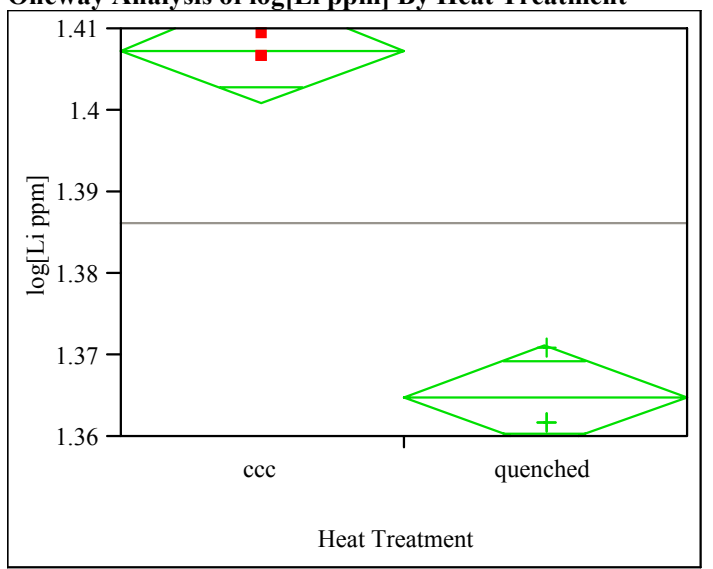

t Test

ccc-quenched

Assuming equal variances

Difference $\quad 0.042642$ t Ratio $\quad 13.10835$

Std Err Dif 0.003253 DF 4

Upper CL Dif 0.051674 Prob $>|t| \quad 0.0002$

Lower CL Dif 0.033610 Prob $>t \quad<.0001$

Confidence $\quad 0.95$ Prob $<\mathrm{t} \quad 0.9999$

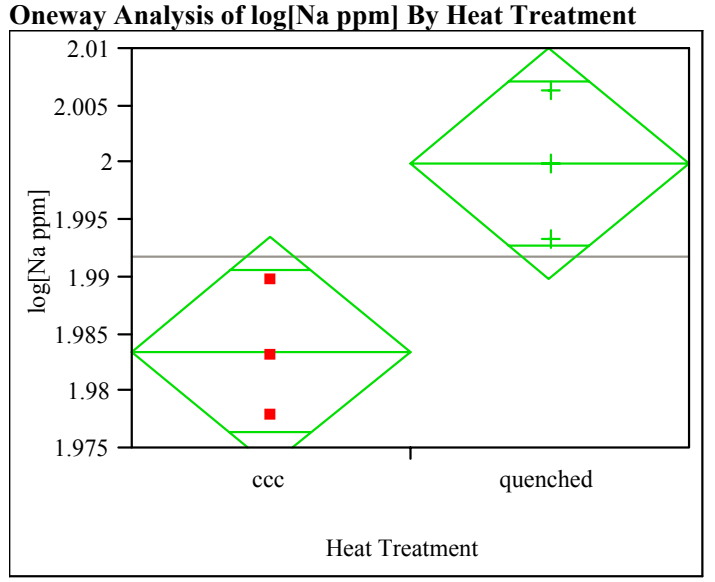

t Test

ccc-quenched

Assuming equal variances

$\begin{array}{lrlr}\text { Difference } & -0.01647 & \mathrm{t} \text { Ratio } & -3.21447 \\ \text { Std Err Dif } & 0.00512 & \text { DF } & 4 \\ \text { Upper CL Dif } & -0.00224 & \text { Prob }>|t| & 0.0325 \\ \text { Lower CL Dif } & -0.03069 & \text { Prob }>t & 0.9838 \\ \text { Confidence } & 0.95 & \text { Prob }<t & 0.0162\end{array}$

Oneway Analysis of $\log [\mathrm{Si}$ ppm] By Heat Treatment

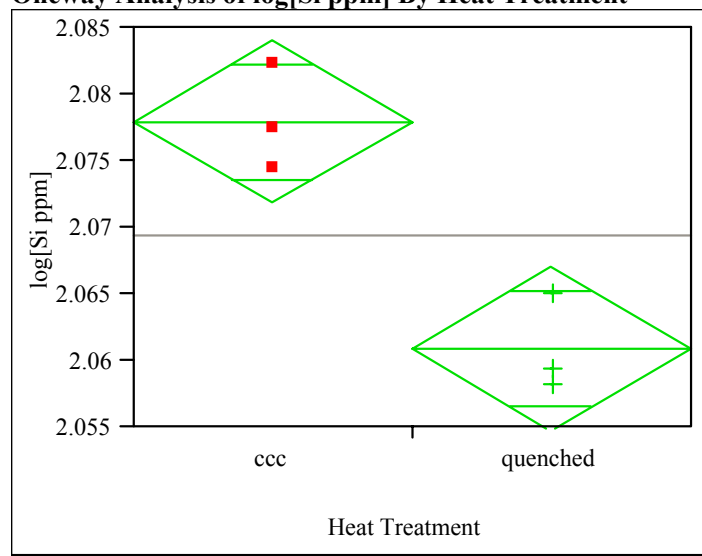

t Test

ccc-quenched

Assuming equal variances

Difference $\quad 0.017064$ t Ratio $\quad 5.466503$

Std Err Dif 0.003122 DF 4

Upper CL Dif 0.025731 Prob $>|t| \quad 0.0054$

Lower CL Dif 0.008397 Prob $>\mathrm{t} \quad 0.0027$

Confidence $\quad 0.95$ Prob $<\mathrm{t} \quad 0.9973$ 


\section{Exhibit E7. Effects of Heat Treatment on PCT ppm-Response of Study Glasses (continued)}

Glass ID $=$ NEPH3-48

Oneway Analysis of $\log [\mathrm{B}$ ppm] By Heat Treatment

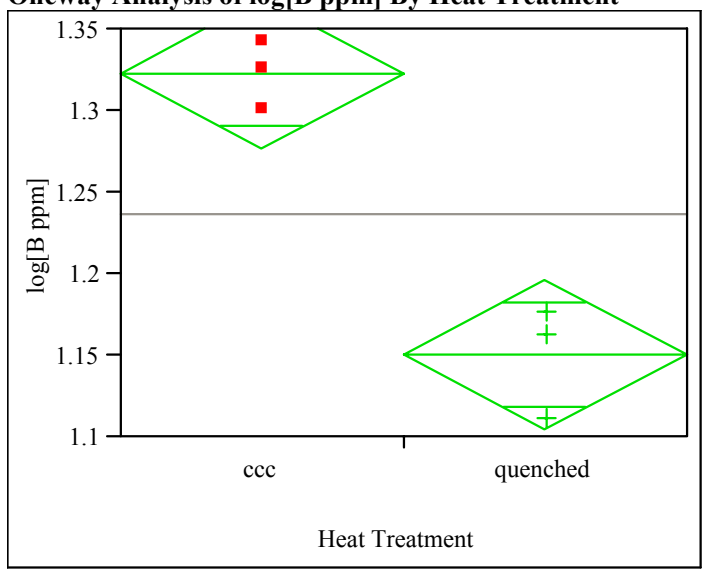

t Test

ccc-quenched

Assuming equal variances

Difference $\quad 0.172145$ t Ratio 7.44033

Std Err Dif $\quad 0.023137$ DF $\quad 4$

Upper CL Dif 0.236383 Prob $>|t| 0.0017$

Lower CL Dif 0.107907 Prob $>$ t 0.0009

Confidence $\quad 0.95$ Prob $<\mathrm{t} \quad 0.9991$

Oneway Analysis of $\log [\mathrm{Li}$ ppm] By Heat Treatment

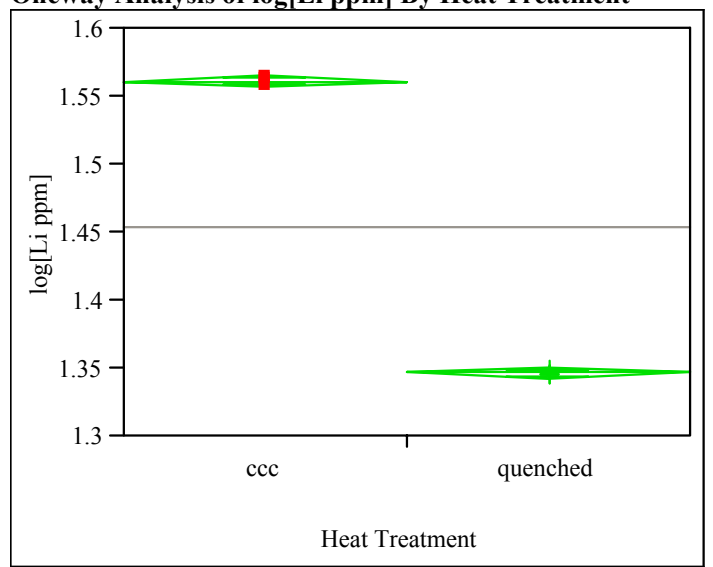

t Test

ccc-quenched

Assuming equal variances

Difference $\quad 0.214839$ t Ratio $\quad 104.2037$

Std Err Dif 0.002062 DF 4

Upper CL Dif 0.220564 Prob $>|t|<.0001$

Lower CL Dif 0.209115 Prob $>t \quad<.0001$

Confidence $\quad 0.95$ Prob $<\mathrm{t} \quad 1.0000$

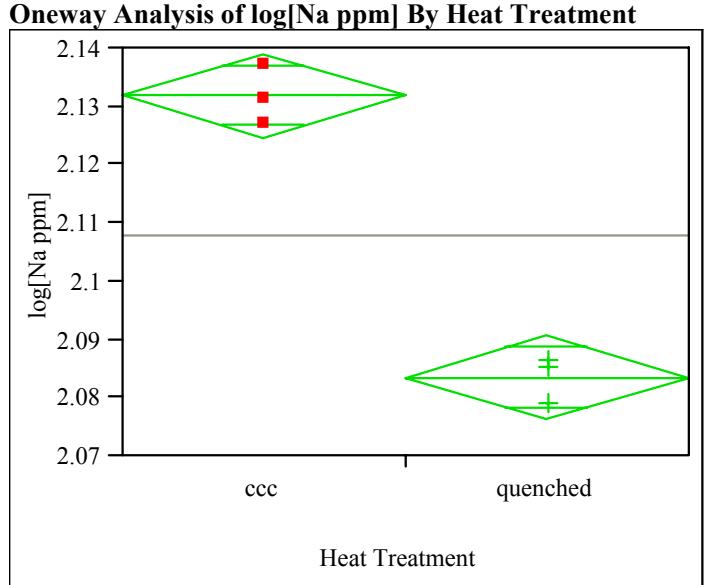

t Test

ccc-quenched

Assuming equal variances

$\begin{array}{lrlr}\text { Difference } & 0.048348 \text { t Ratio } & 13.122 \\ \text { Std Err Dif } & 0.003685 \text { DF } & 4 \\ \text { Upper CL Dif } & 0.058578 \text { Prob }>|t| & 0.0002 \\ \text { Lower CL Dif } & 0.038119 & \text { Prob }>\mathrm{t} & <.0001 \\ \text { Confidence } & 0.95 & \text { Prob }<\mathrm{t} & 0.9999\end{array}$

Oneway Analysis of $\log [\mathrm{Si}$ ppm] By Heat Treatment

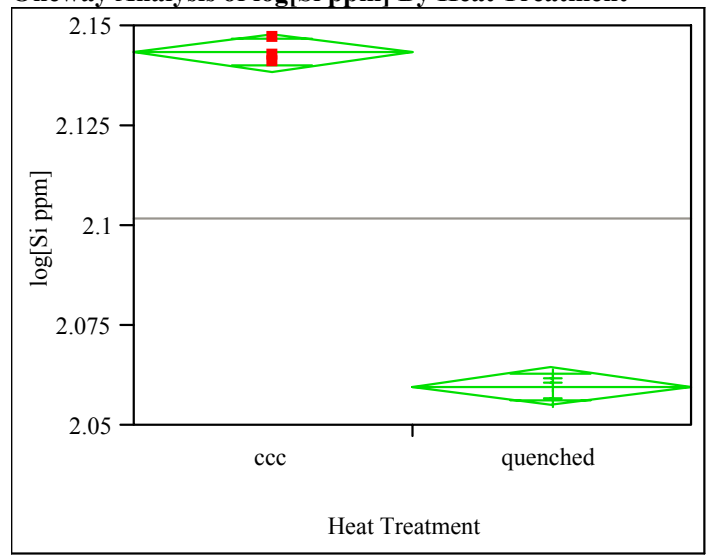

t Test

ccc-quenched

Assuming equal variances

Difference $\quad 0.083675$ t Ratio $\quad 34.71592$

Std Err Dif $\quad 0.002410$ DF 4

Upper CL Dif 0.090367 Prob $>|t|<.0001$

Lower CL Dif 0.076983 Prob $>t \quad<.0001$

Confidence $\quad 0.95$ Prob $<\mathrm{t} \quad 1.0000$ 


\section{Exhibit E7. Effects of Heat Treatment on PCT ppm-Response of Study Glasses (continued)}

Glass ID=NEPH3-49

Oneway Analysis of $\log [\mathrm{B}$ ppm] By Heat Treatment

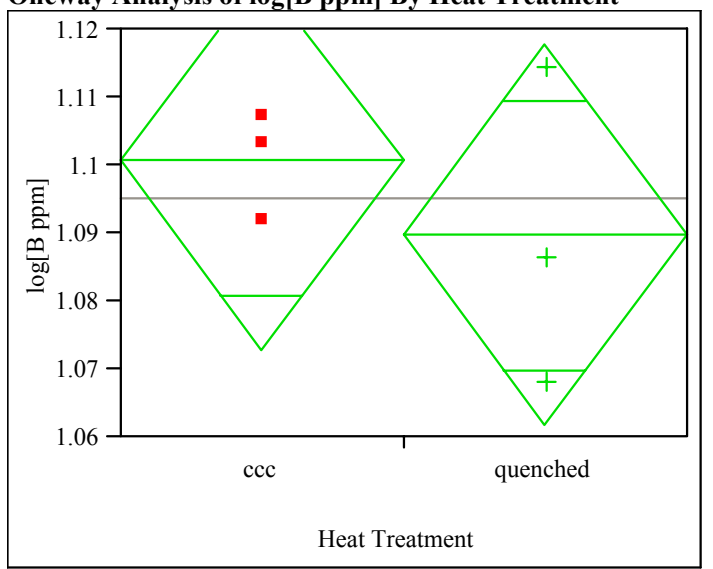

t Test

ccc-quenched

Assuming equal variances

Difference $\quad 0.01102$ t Ratio $\quad 0.77311$

$\begin{array}{lrrr}\text { Std Err Dif } & 0.01426 \text { DF } & 4 \\ \text { Upper CL Dif } & 0.05060 \text { Prob }>|t| & 0.4826\end{array}$

Lower CL Dif -0.02856 Prob $>\mathrm{t} \quad 0.2413$

Confidence $\quad 0.95$ Prob $<\mathrm{t} \quad 0.7587$

Oneway Analysis of $\log [\mathrm{Li}$ ppm] By Heat Treatment

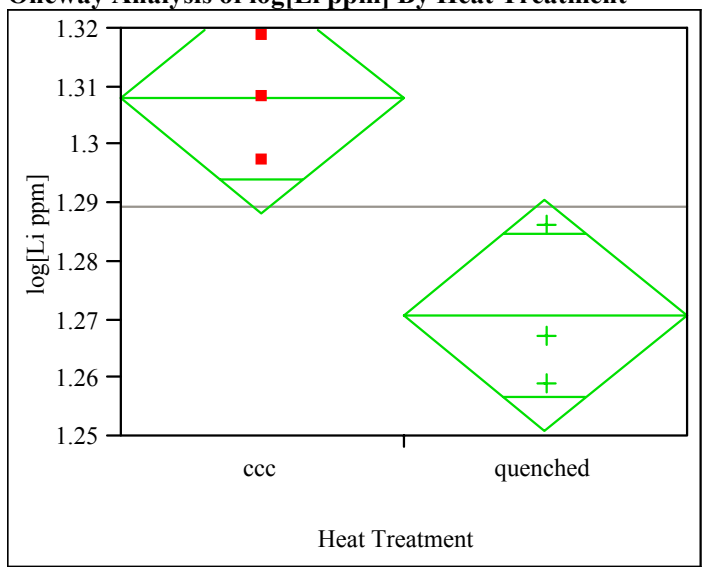

t Test

ccc-quenched

Assuming equal variances

Difference $\quad 0.037203$ t Ratio $\quad 3.675848$

Std Err Dif 0.010121 DF 4

Upper CL Dif 0.065303 Prob $>|t| \quad 0.0213$

Lower CL Dif 0.009103 Prob $>t \quad 0.0106$

Confidence $\quad 0.95$ Prob $<\mathrm{t} \quad 0.9894$

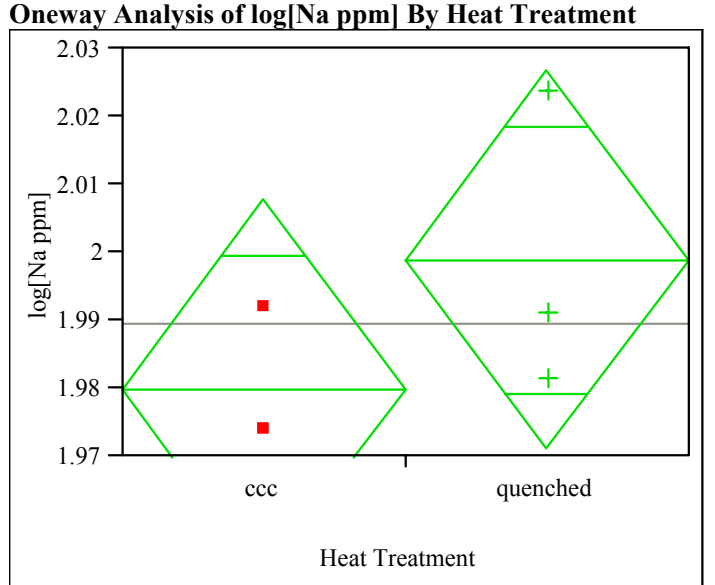

t Test

ccc-quenched

Assuming equal variances

$\begin{array}{lrlr}\text { Difference } & -0.01897 \text { t Ratio } & -1.33856 \\ \text { Std Err Dif } & 0.01417 \text { DF } & 4 \\ \text { Upper CL Dif } & 0.02038 \text { Prob }>|t| & 0.2517 \\ \text { Lower CL Dif } & -0.05833 \text { Prob }>\text { t } & 0.8741 \\ \text { Confidence } & 0.95 \text { Prob }<\mathrm{t} & 0.1259\end{array}$

Oneway Analysis of $\log [\mathrm{Si}$ ppm] By Heat Treatment

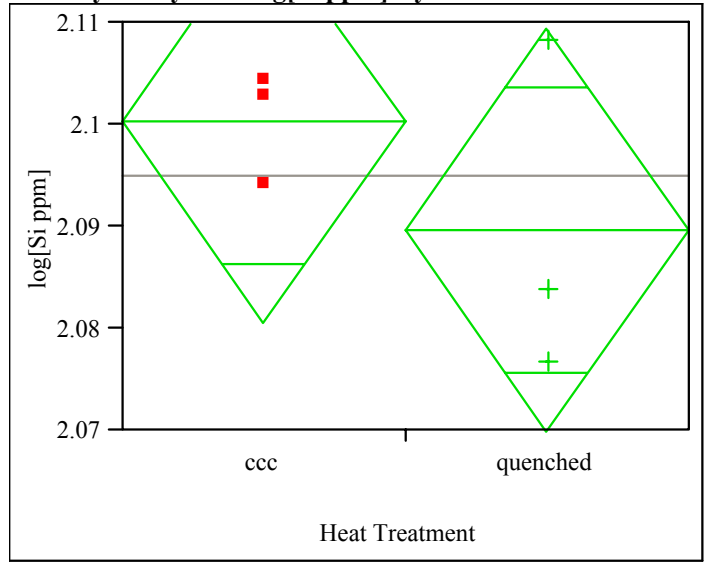

t Test

ccc-quenched

Assuming equal variances

Difference $\quad 0.01065$ t Ratio $\quad 1.057116$

Std Err Dif $\quad 0.01008$ DF 4

Upper CL Dif 0.03863 Prob $>|t| \quad 0.3501$

Lower CL Dif -0.01733 Prob $>\mathrm{t} \quad 0.1750$

Confidence $\quad 0.95$ Prob $<\mathrm{t} \quad 0.8250$ 


\section{Exhibit E7. Effects of Heat Treatment on PCT ppm-Response of Study Glasses (continued)}

Glass ID $=$ NEPH3-50

Oneway Analysis of $\log [\mathrm{B}$ ppm] By Heat Treatment

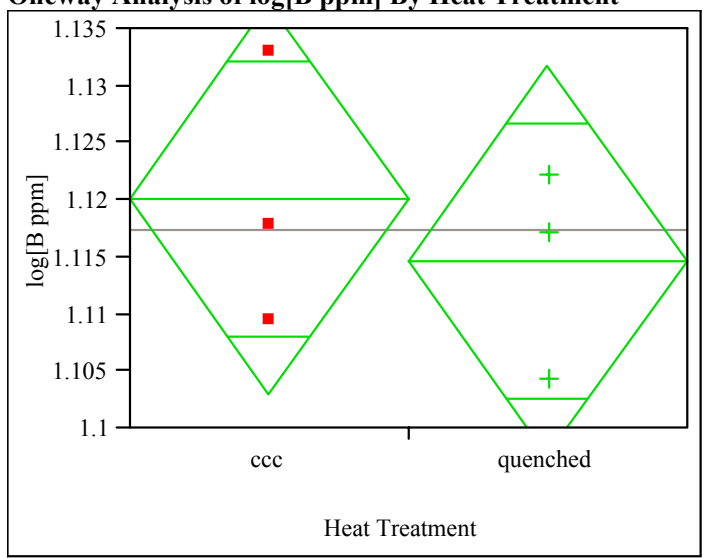

t Test

ccc-quenched

Assuming equal variances

Difference $\quad 0.00548$ t Ratio $\quad 0.629419$

Std Err Dif $\quad 0.00870$ DF 4

Upper CL Dif 0.02964 Prob $>|t| \quad 0.5632$

Lower CL Dif -0.01869 Prob $>t \quad 0.2816$

Confidence $\quad 0.95$ Prob $<\mathrm{t} \quad 0.7184$

Oneway Analysis of $\log [\mathrm{Li}$ ppm] By Heat Treatment

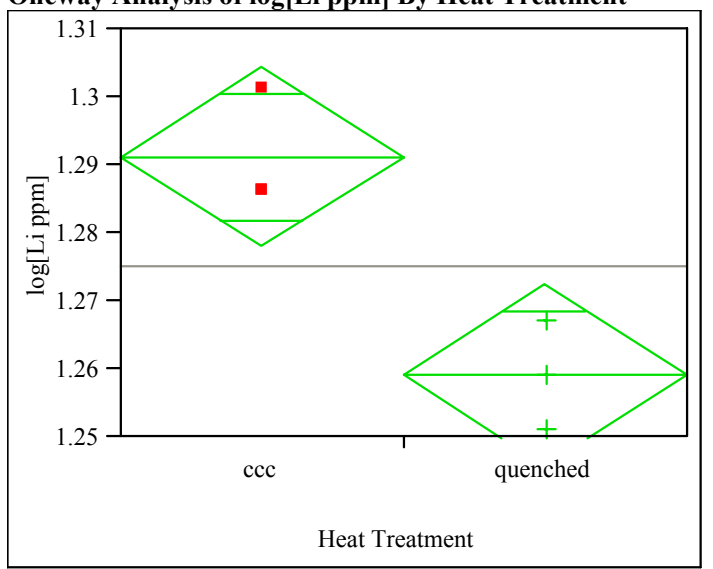

t Test

ccc-quenched

Assuming equal variances

Difference $\quad 0.031988$ t Ratio $\quad 4.75487$

Std Err Dif 0.006727 DF 4

Upper CL Dif 0.050666 Prob $>|t| 0.0089$

Lower CL Dif 0.013310 Prob $>$ t $\quad 0.0045$

Confidence $\quad 0.95$ Prob $<\mathrm{t} \quad 0.9955$

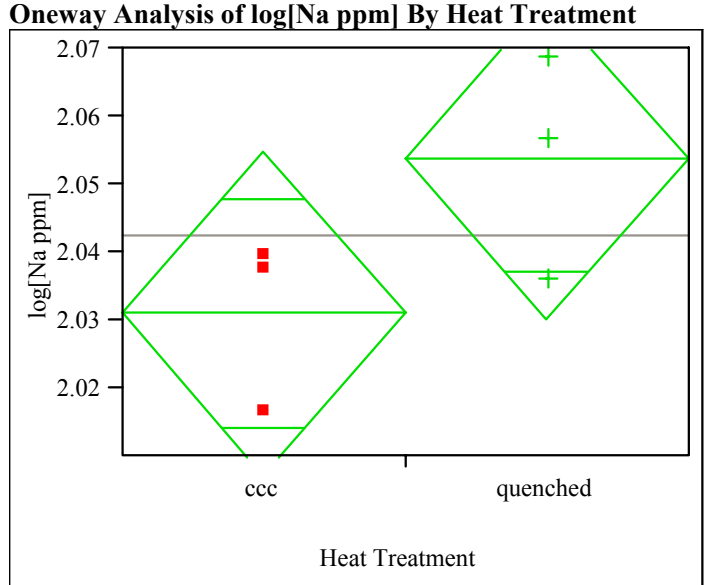

t Test

ccc-quenched

Assuming equal variances

$\begin{array}{lrlr}\text { Difference } & -0.02288 \text { t Ratio } & -1.89407 \\ \text { Std Err Dif } & 0.01208 \text { DF } & 4 \\ \text { Upper CL Dif } & 0.01066 \text { Prob }>|t| & 0.1311 \\ \text { Lower CL Dif } & -0.05641 \text { Prob }>t & 0.9344 \\ \text { Confidence } & 0.95 \text { Prob }<\mathrm{t} & 0.0656\end{array}$

Oneway Analysis of $\log [\mathrm{Si}$ ppm] By Heat Treatment

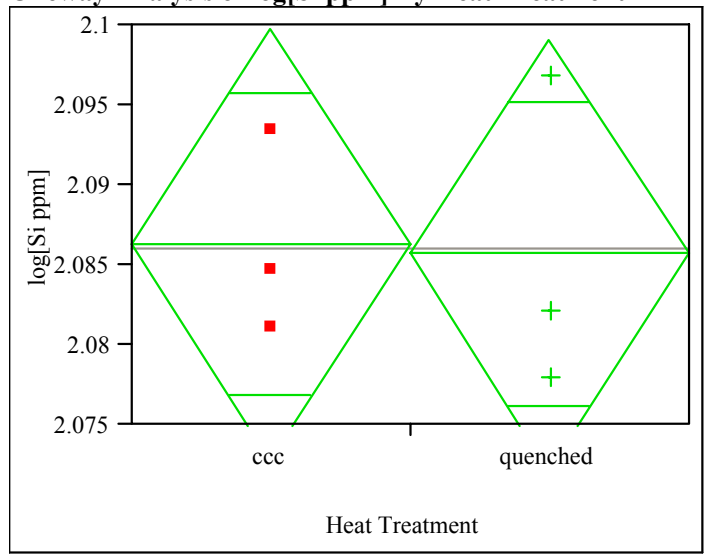

t Test

ccc-quenched

Assuming equal variances

Difference $\quad 0.00064$ t Ratio $\quad 0.093507$

$\begin{array}{lrr}\text { Std Err Dif } & 0.00683 \text { DF } & 4\end{array}$

Upper CL Dif 0.01959 Prob $>|t| \quad 0.9300$

Lower CL Dif -0.01832 Prob $>t \quad 0.4650$

Confidence $\quad 0.95$ Prob $<\mathrm{t} \quad 0.5350$ 


\section{Exhibit E7. Effects of Heat Treatment on PCT ppm-Response of Study Glasses (continued)}

Glass ID=NEPH3-51

Oneway Analysis of $\log [\mathrm{B}$ ppm] By Heat Treatment

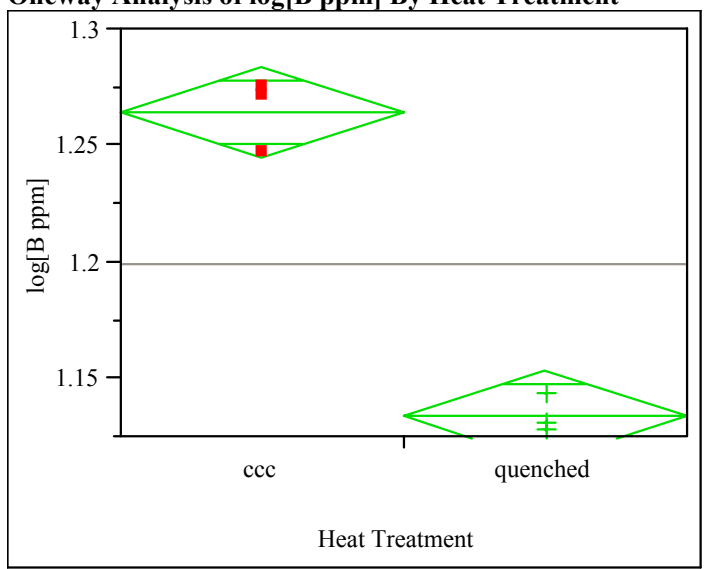

t Test

ccc-quenched

Assuming equal variances

Difference $\quad 0.129834$ t Ratio $\quad 13.08715$

$\begin{array}{lrrr}\text { Std Err Dif } & 0.009921 \text { DF } & 4 \\ \text { Upper CL Dif } & 0.157378 \text { Prob }>|t| & 0.0002\end{array}$

$\begin{array}{lll}\text { Upper CL Dif } 0.157378 \text { Prob }>|t| & 0.0002 \\ \text { Lower CL Dif } 0.102290 \text { Prob }>t & <.0001\end{array}$

$\begin{array}{lll}\text { Confidence } & 0.95 \mathrm{Prob}<\mathrm{t} \quad 0.9999\end{array}$

Oneway Analysis of log[Li ppm] By Heat Treatment

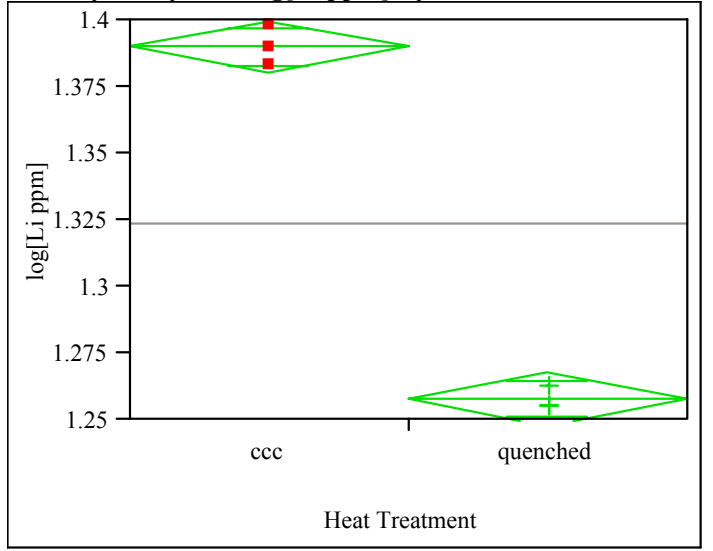

t Test

ccc-quenched

Assuming equal variances

Difference $\quad 0.132179$ t Ratio $\quad 26.25671$

Std Err Dif $\quad 0.005034$ DF 4

Upper CL Dif 0.146156 Prob $>|t|<.0001$

Lower CL Dif 0.118202 Prob $>t \quad<.0001$

Confidence $\quad 0.95$ Prob $<\mathrm{t} \quad 1.0000$

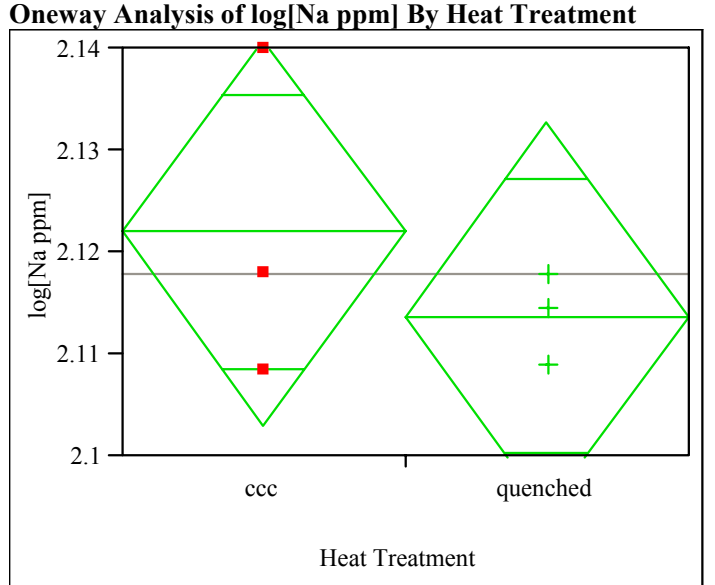

t Test

ccc-quenched

Assuming equal variances

$\begin{array}{lrlr}\text { Difference } & 0.00827 \text { t Ratio } & 0.852906 \\ \text { Std Err Dif } & 0.00970 \text { DF } & 4 \\ \text { Upper CL Dif } & 0.03520 \text { Prob }>|t| & 0.4418 \\ \text { Lower CL Dif } & -0.01866 \text { Prob }>t & 0.2209 \\ \text { Confidence } & 0.95 \text { Prob }<\mathrm{t} & 0.7791\end{array}$

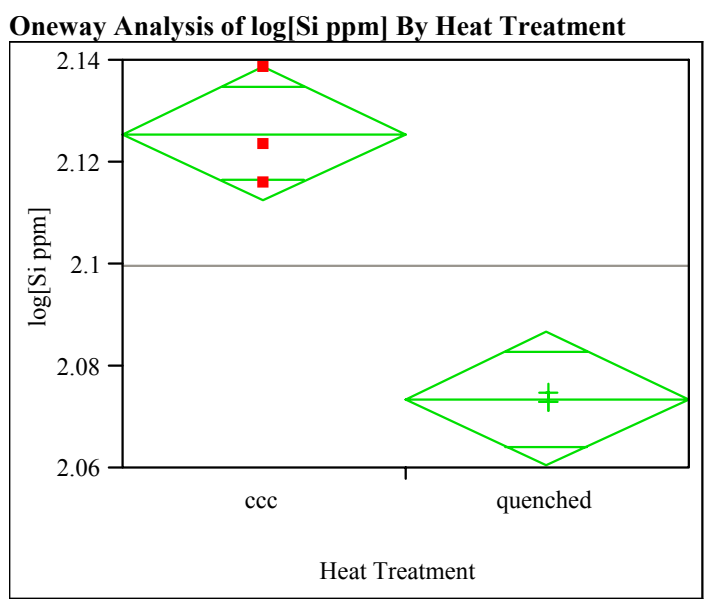

t Test

ccc-quenched

Assuming equal variances

Difference $\quad 0.052023$ t Ratio 7.775508

Std Err Dif 0.006691 DF 4

Upper CL Dif 0.070599 Prob $>|t| \quad 0.0015$

Lower CL Dif 0.033447 Prob $>t \quad 0.0007$

Confidence $\quad 0.95$ Prob $<\mathrm{t} \quad 0.9993$ 


\section{Exhibit E7. Effects of Heat Treatment on PCT ppm-Response of Study Glasses (continued)}

Glass ID $=$ NEPH3-52

Oneway Analysis of $\log [\mathrm{B}$ ppm] By Heat Treatment

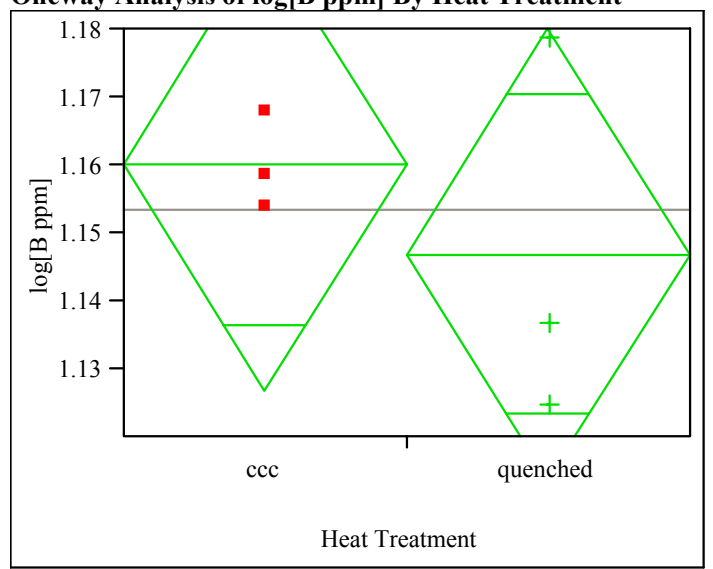

t Test

ccc-quenched

Assuming equal variances

Difference $\quad 0.01312$ t Ratio $\quad 0.775441$

$\begin{array}{lrlr}\text { Std Err Dif } & 0.01692 \text { DF } & 4 \\ \text { Upper CL } & 0.06008 \text { Prob }>|t| & 0.4814\end{array}$

$\begin{array}{lrl}\text { Upper CL Dif } & 0.06008 \text { Prob }>|t| & 0.4814 \\ \text { Lower CL Dif }-0.03385 & \text { Prob }>t & 0.2407\end{array}$

$\begin{array}{lll}\text { Confidence } & 0.95 \text { Prob }<\mathrm{t} \quad 0.7593\end{array}$

Oneway Analysis of log[Li ppm] By Heat Treatment

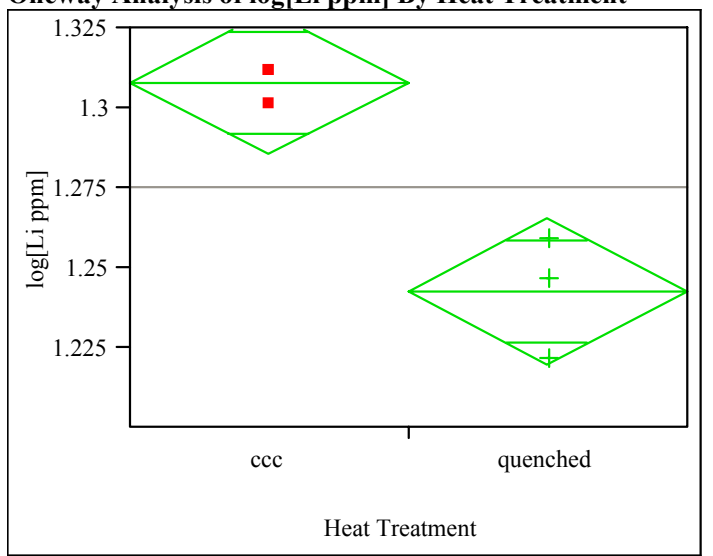

t Test

ccc-quenched

Assuming equal variances

Difference $\quad 0.065420$ t Ratio $\quad 5.644337$

Std Err Dif $\quad 0.011590$ DF 4

Upper CL Dif 0.097600 Prob $>|t| 0.0049$

Lower CL Dif 0.033240 Prob $>t \quad 0.0024$

Confidence $\quad 0.95$ Prob $<\mathrm{t} \quad 0.9976$

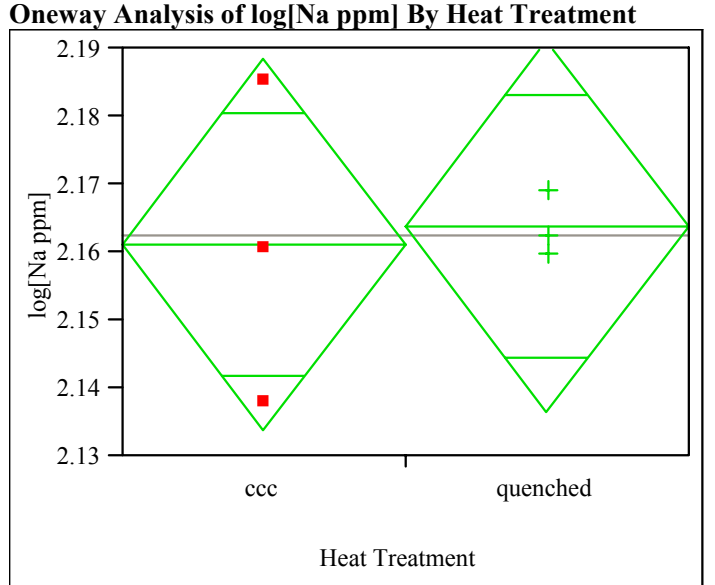

t Test

ccc-quenched

Assuming equal variances

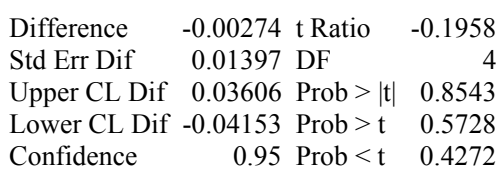

Oneway Analysis of $\log [\mathrm{Si}$ ppm] By Heat Treatment

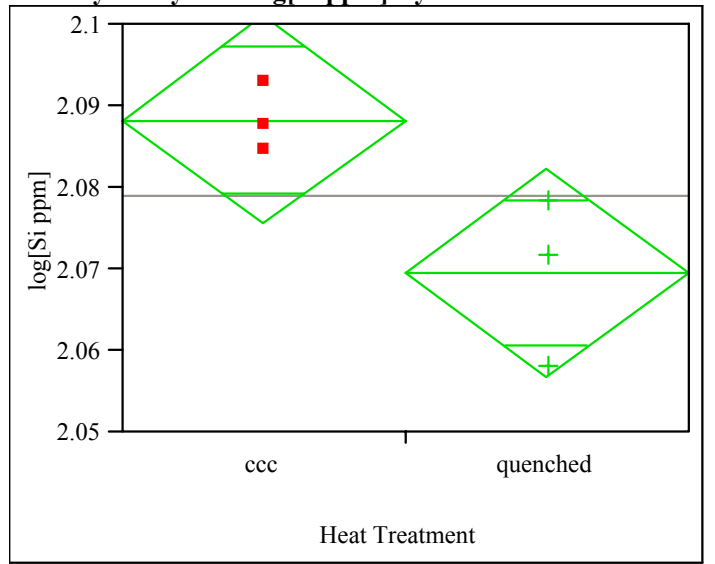

t Test

ccc-quenched

Assuming equal variances

Difference $\quad 0.018775$ t Ratio 2.900557

Std Err Dif 0.006473 DF 4

Upper CL Dif 0.036747 Prob $>|t| \quad 0.0441$

Lower CL Dif 0.000803 Prob $>t \quad 0.0220$

Confidence $\quad 0.95$ Prob $<\mathrm{t} \quad 0.9780$ 


\section{Exhibit E7. Effects of Heat Treatment on PCT ppm-Response of Study Glasses (continued)}

Glass ID $=$ NEPH3-53

Oneway Analysis of $\log [\mathrm{B}$ ppm] By Heat Treatment

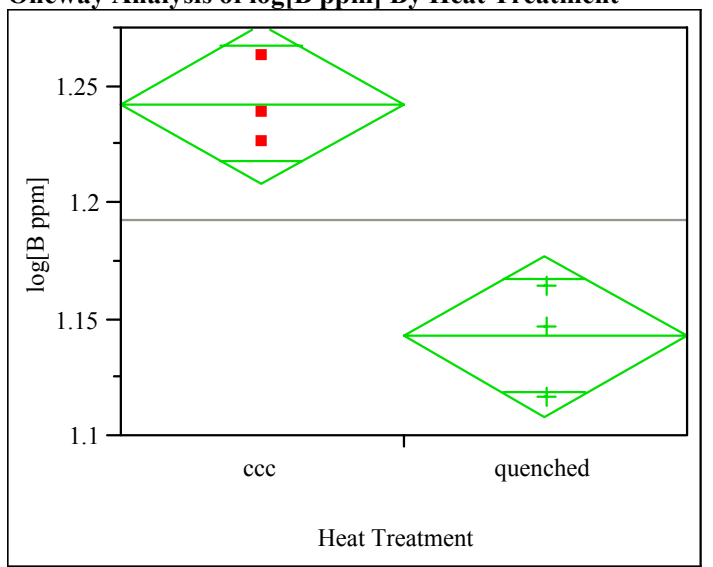

t Test

ccc-quenched

Assuming equal variances

Difference $\quad 0.099671$ t Ratio 5.651291

$\begin{array}{lrr}\text { Std Err Dif } & 0.017637 \text { DF } & 4 \\ \text { Upper CL } & 0.148639 \text { Prob }>|t| & 0.0048\end{array}$

$\begin{array}{lll}\text { Upper CL Dif } 0.148639 & \text { Prob }>|t| & 0.0048 \\ \text { Lower CL Dif } & 0.050703 \text { Prob }>t & 0.0024\end{array}$

$\begin{array}{lrr}\text { Lower CL Dif } & 0.050703 \text { Prob }>\mathrm{t} & 0.0024 \\ \text { Confidence } & 0.95 \text { Prob }<\mathrm{t} & 0.9976\end{array}$

Oneway Analysis of log[Li ppm] By Heat Treatment

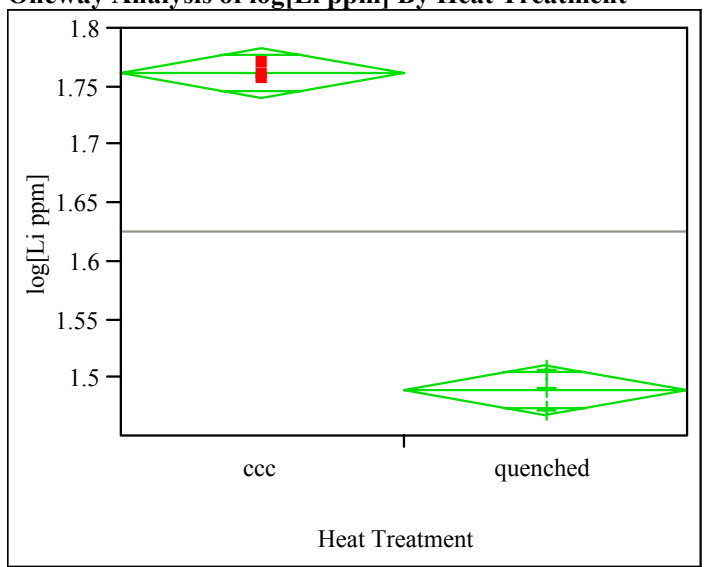

t Test

ccc-quenched

Assuming equal variances

Difference $\quad 0.271796$ t Ratio 24.88768

Std Err Dif $\quad 0.010921$ DF 4

Upper CL Dif 0.302117 Prob $>|t|<.0001$

Lower CL Dif 0.241474 Prob $>t \quad<.0001$

Confidence $\quad 0.95$ Prob $<\mathrm{t} \quad 1.0000$

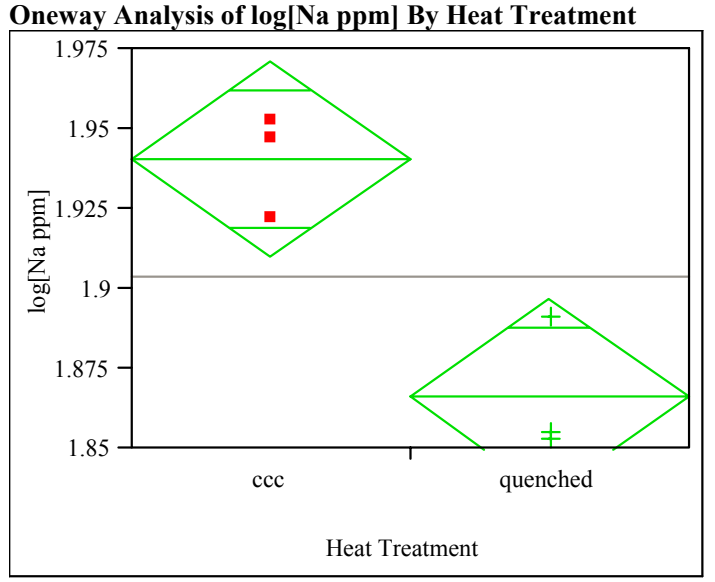

t Test

ccc-quenched

Assuming equal variances

Difference $\quad 0.073828$ t Ratio 4.74838

Std Err Dif $\quad 0.015548$ DF 4

Upper CL Dif 0.116997 Prob $>|t| \quad 0.0090$

Lower CL Dif 0.030660 Prob $>$ t 0.0045

Confidence $\quad 0.95$ Prob $<\mathrm{t} 0.9955$

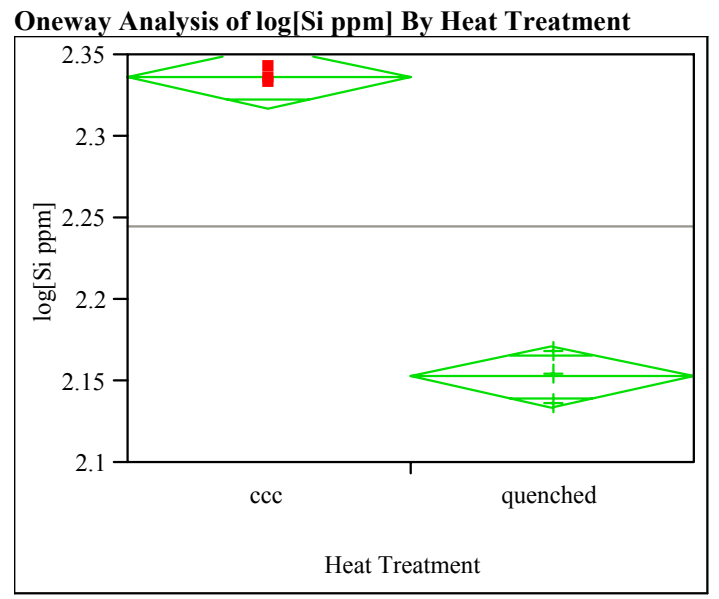

t Test

ccc-quenched

Assuming equal variances

Difference $\quad 0.183946$ t Ratio $\quad 18.87241$

Std Err Dif $\quad 0.009747$ DF 4

Upper CL Dif 0.211007 Prob $>|\mathrm{t}|<.0001$

Lower CL Dif 0.156884 Prob $>t \quad<.0001$

Confidence $\quad 0.95$ Prob $<\mathrm{t} \quad 1.0000$ 


\section{Exhibit E7. Effects of Heat Treatment on PCT ppm-Response of Study Glasses (continued)}

Glass ID $=$ NEPH3-54

Oneway Analysis of $\log [\mathrm{B}$ ppm] By Heat Treatment

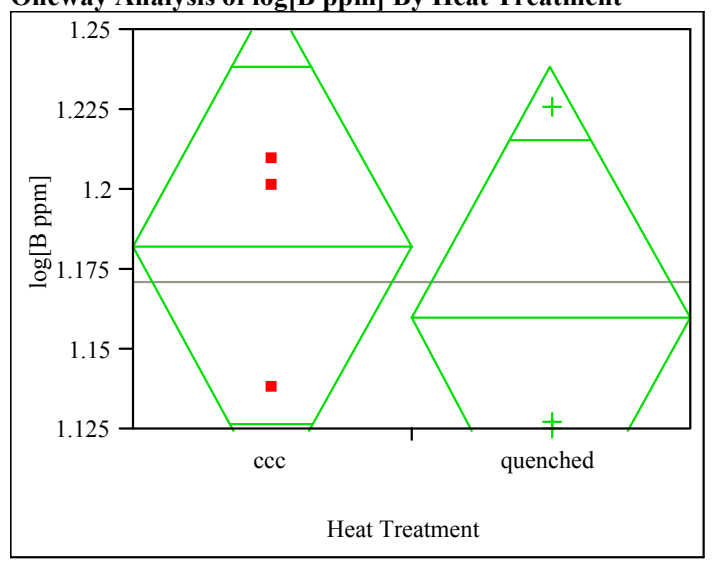

t Test

ccc-quenched

Assuming equal variances

Difference $\quad 0.02283$ t Ratio $\quad 0.568886$

Std Err Dif $\quad 0.04013$ DF 4

Upper CL Dif 0.13425 Prob $>|t| \quad 0.5999$

Lower CL Dif -0.08859 Prob $>t \quad 0.2999$

Confidence $\quad 0.95$ Prob $<\mathrm{t} \quad 0.7001$

Oneway Analysis of $\log [\mathrm{Li}$ ppm] By Heat Treatment

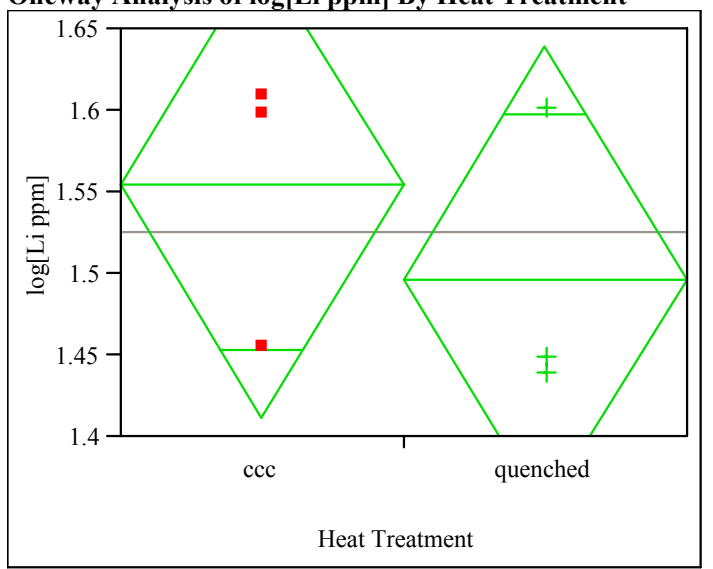

t Test

ccc-quenched

Assuming equal variances

Difference $\quad 0.05713$ t Ratio $\quad 0.789008$

Std Err Dif $\quad 0.07240$ DF 4

Upper CL Dif 0.25815 Prob $>|t| \quad 0.4742$

Lower CL Dif -0.14390 Prob $>t \quad 0.2371$

Confidence $\quad 0.95$ Prob $<\mathrm{t} \quad 0.7629$

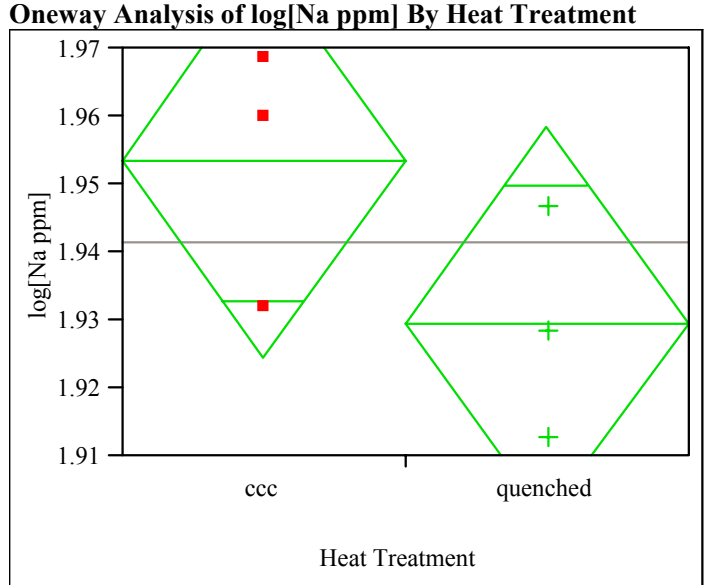

t Test

ccc-quenched

Assuming equal variances

$\begin{array}{lrlr}\text { Difference } & 0.02395 \text { t Ratio } & 1.621974 \\ \text { Std Err Dif } & 0.01476 \text { DF } & 4 \\ \text { Upper CL Dif } & 0.06494 \text { Prob }>|t| & 0.1801 \\ \text { Lower CL Dif } & -0.01705 \text { Prob }>t & 0.0901 \\ \text { Confidence } & 0.95 \text { Prob }<\mathrm{t} & 0.9099\end{array}$

Oneway Analysis of $\log [\mathrm{Si}$ ppm] By Heat Treatment

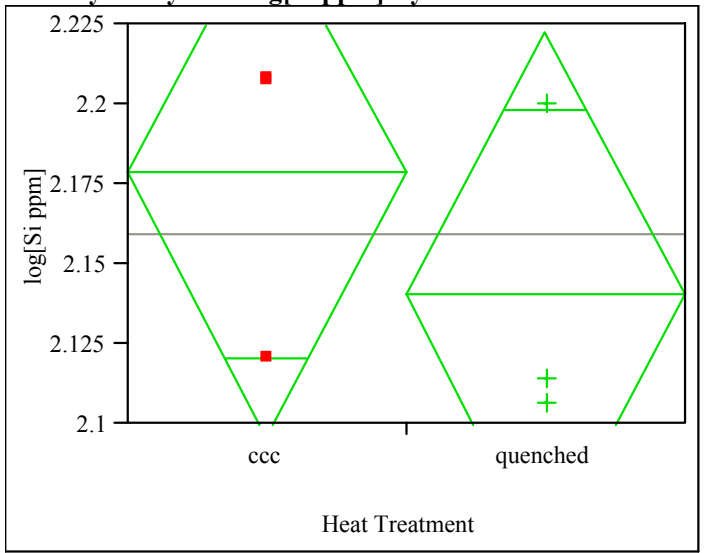

t Test

ccc-quenched

Assuming equal variances

Difference $\quad 0.03832$ t Ratio $\quad 0.915343$

$\begin{array}{lrr}\text { Std Err Dif } & 0.04186 \mathrm{DF} & 4\end{array}$

Upper CL Dif 0.15454 Prob $>|t| \quad 0.4118$

Lower CL Dif -0.07791 Prob $>$ t 0.2059

Confidence $\quad 0.95$ Prob $<\mathrm{t} \quad 0.7941$ 


\section{Exhibit E7. Effects of Heat Treatment on PCT ppm-Response of Study Glasses (continued)}

Glass ID $=$ NEPH3-55

Oneway Analysis of $\log [\mathrm{B}$ ppm] By Heat Treatment

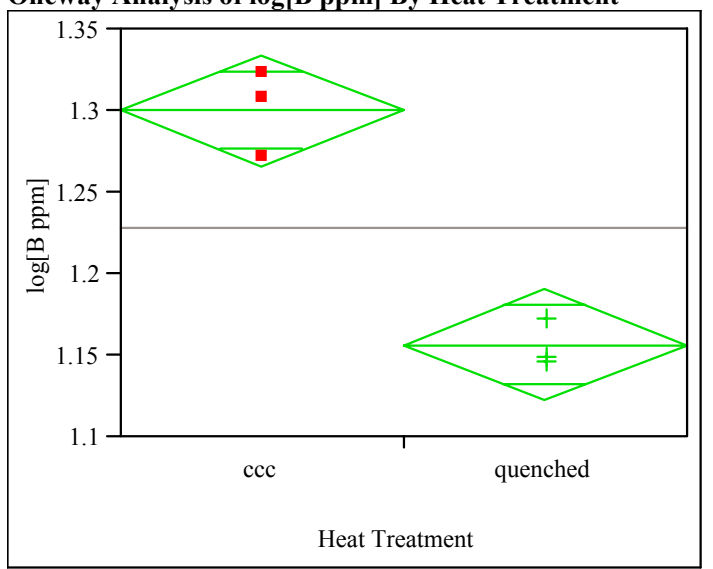

t Test

ccc-quenched

Assuming equal variances

Difference $\quad 0.143805$ t Ratio $\quad 8.282353$

Std Err Dif $\quad 0.017363$ DF 4

Upper CL Dif 0.192012 Prob $>|t| \quad 0.0012$

Lower CL Dif 0.095598 Prob $>$ t 0.0006

$\begin{array}{lll}\text { Confidence } & 0.95 \text { Prob }<\mathrm{t} \quad 0.9994\end{array}$

Oneway Analysis of log[Li ppm] By Heat Treatment

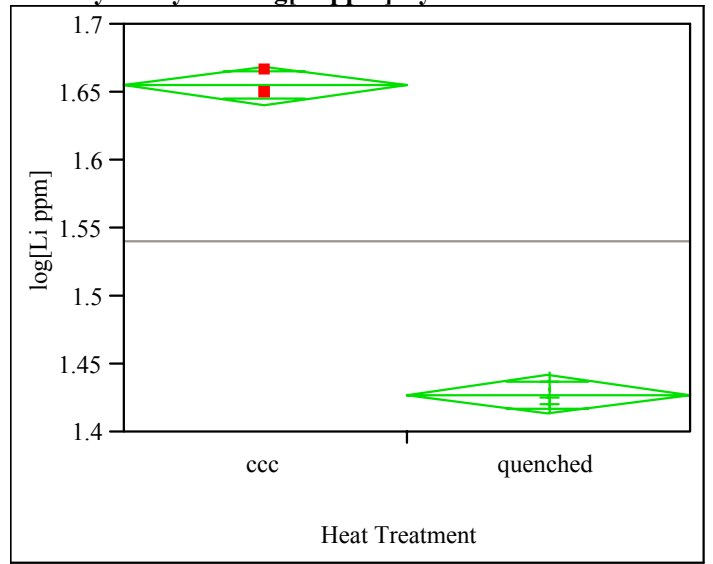

t Test

ccc-quenched

Assuming equal variances

Difference $\quad 0.227564$ t Ratio $\quad 31.95058$

Std Err Dif 0.007122 DF 4

Upper CL Dif 0.247339 Prob $>|t|<.0001$

Lower CL Dif 0.207790 Prob $>t \quad<.0001$

Confidence $\quad 0.95$ Prob $<\mathrm{t} \quad 1.0000$

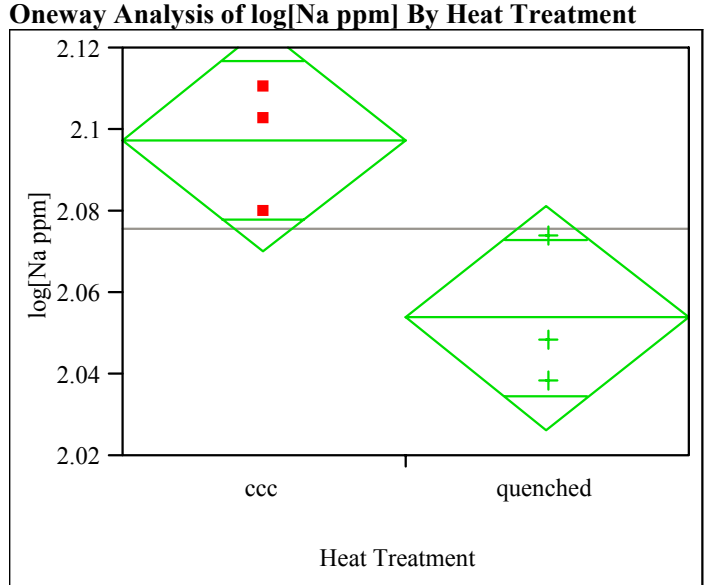

t Test

ccc-quenched

Assuming equal variances

$\begin{array}{lrlr}\text { Difference } & 0.043607 \text { t Ratio } & 3.119276 \\ \text { Std Err Dif } & 0.013980 \text { DF } & 4 \\ \text { Upper CL Dif } & 0.082422 \text { Prob }>|t| & 0.0356 \\ \text { Lower CL Dif } & 0.004793 \text { Prob }>t & 0.0178 \\ \text { Confidence } & 0.95 \text { Prob }<\mathrm{t} & 0.9822\end{array}$

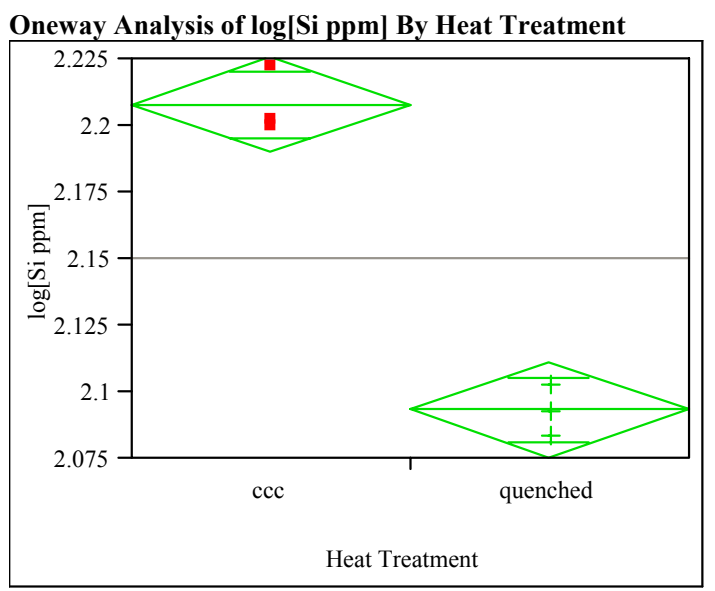

t Test

ccc-quenched

Assuming equal variances

Difference $\quad 0.114559$ t Ratio $\quad 12.79553$

Std Err Dif 0.008953 DF 4

Upper CL Dif 0.139417 Prob $>|t| 0.0002$

Lower CL Dif 0.089701 Prob $>$ t 0.0001

Confidence $\quad 0.95$ Prob $<\mathrm{t} \quad 0.9999$ 


\section{Exhibit E7. Effects of Heat Treatment on PCT ppm-Response of Study Glasses (continued)}

Glass ID $=$ NEPH3-56

Oneway Analysis of $\log [\mathrm{B}$ ppm] By Heat Treatment

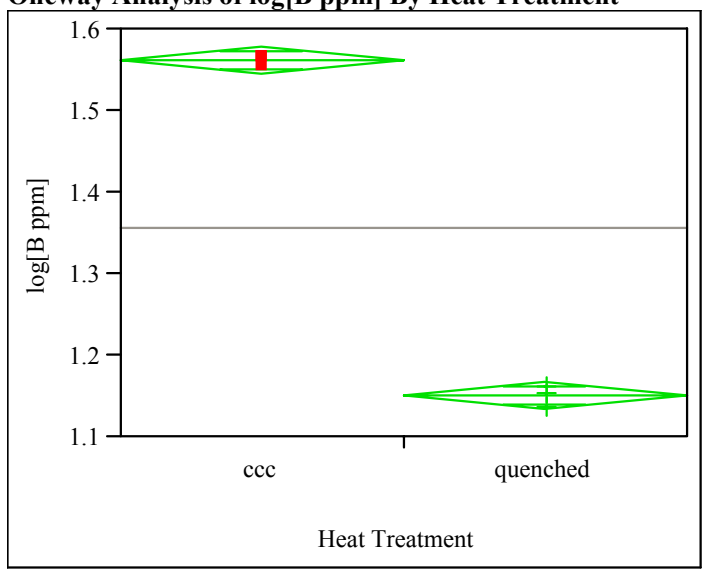

t Test

ccc-quenched

Assuming equal variances

Difference $\quad 0.409778$ t Ratio $\quad 49.45317$

$\begin{array}{lrr}\text { Std Err Dif } & 0.008286 \text { DF } & 4 \\ \text { Upper CL Dif } & 0.432784 \text { Prob }>|t| & <.0001\end{array}$

$\begin{array}{lll}\text { Upper CL Dif } & 0.432784 \text { Prob }>|t| & <.0001 \\ \text { Lower CL Dif } & 0.386772 \text { Prob }>t & <.0001\end{array}$

Confidence $\quad 0.95$ Prob $<\mathrm{t} \quad 1.0000$

Oneway Analysis of log[Li ppm] By Heat Treatment

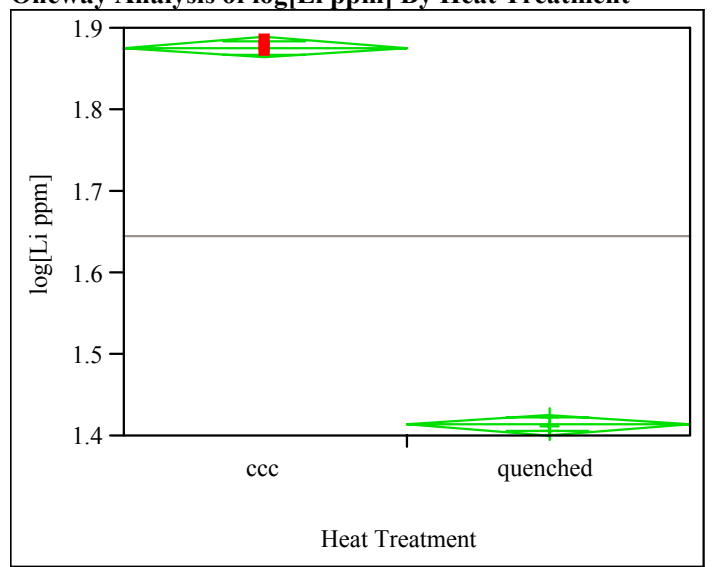

t Test

ccc-quenched

Assuming equal variances

Difference $\quad 0.463292$ t Ratio $\quad 77.75813$

Std Err Dif $\quad 0.005958$ DF 4

Upper CL Dif 0.479835 Prob $>|t|<.0001$

Lower CL Dif 0.446750 Prob $>t \quad<.0001$

Confidence $\quad 0.95$ Prob $<\mathrm{t} \quad 1.0000$

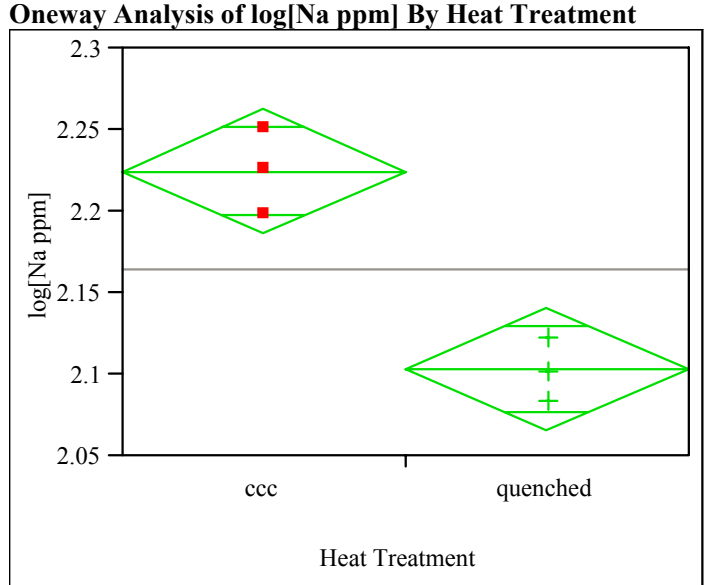

t Test

ccc-quenched

Assuming equal variances

$\begin{array}{lrlr}\text { Difference } & 0.121570 \text { t Ratio } & 6.33415 \\ \text { Std Err Dif } & 0.019193 \text { DF } & 4 \\ \text { Upper CL Dif } & 0.174857 \text { Prob }>|t| & 0.0032 \\ \text { Lower CL Dif } & 0.068282 & \text { Prob }>\mathrm{t} & 0.0016 \\ \text { Confidence } & 0.95 \text { Prob }<\mathrm{t} & 0.9984\end{array}$

Oneway Analysis of $\log [\mathrm{Si}$ ppm] By Heat Treatment

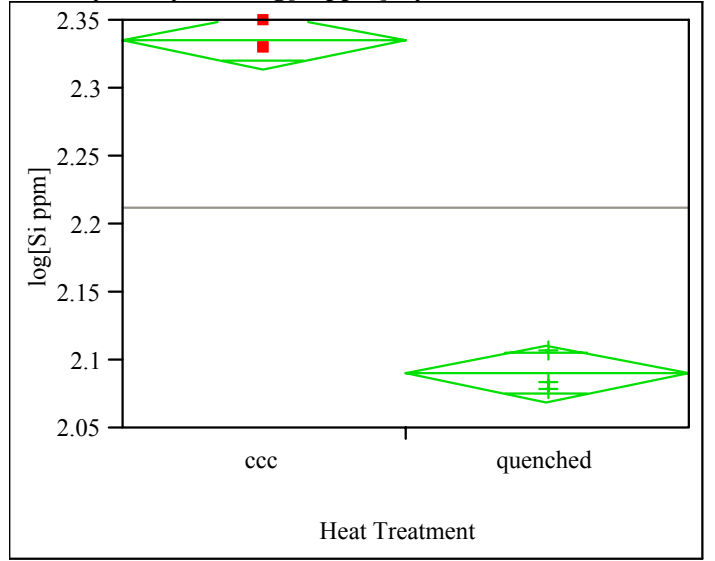

t Test

ccc-quenched

Assuming equal variances

Difference $\quad 0.245366$ t Ratio 22.7109

Std Err Dif 0.010804 DF 4

Upper CL Dif 0.275362 Prob $>|t|<.0001$

Lower CL Dif 0.215369 Prob $>t \quad<.0001$

Confidence $\quad 0.95$ Prob $<\mathrm{t} \quad 1.0000$ 


\section{Exhibit E8. Effects of Heat Treatment for Study Glasses by Compositional View}

\section{Comp View=Measured}

Variability Chart for $\log$ NL[B (g/L)]

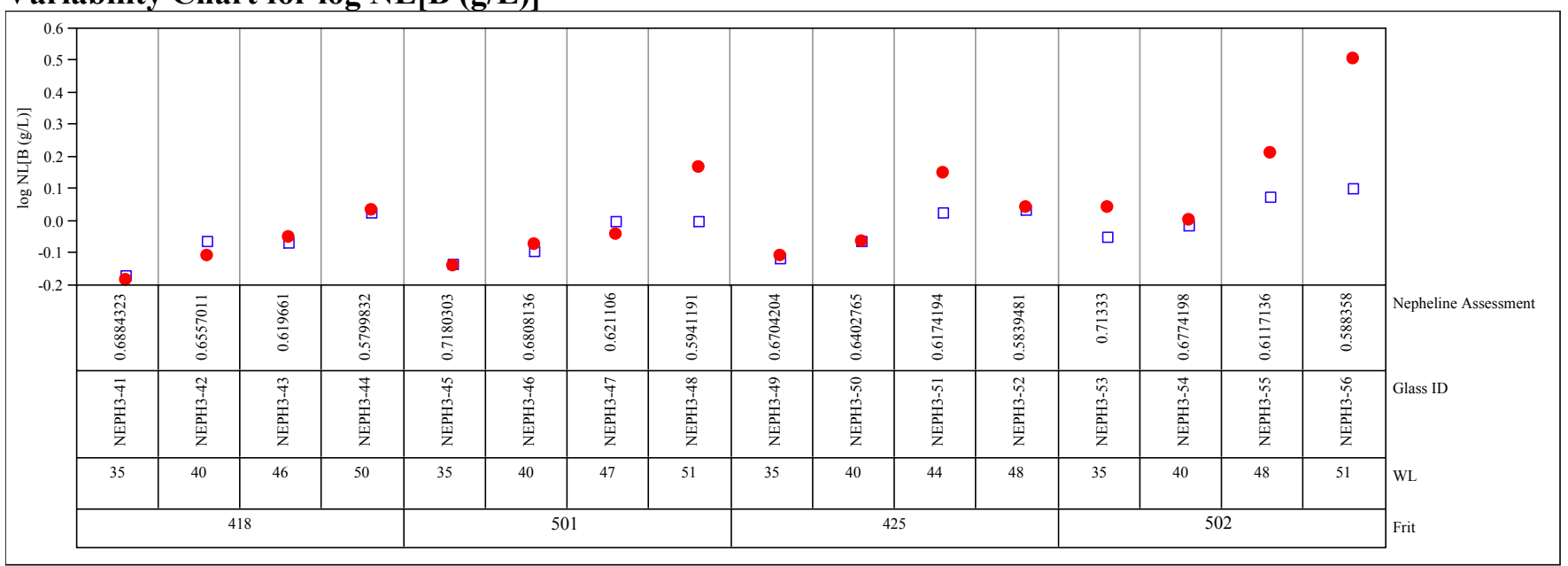

Variability Chart for log NL[Li(g/L)]

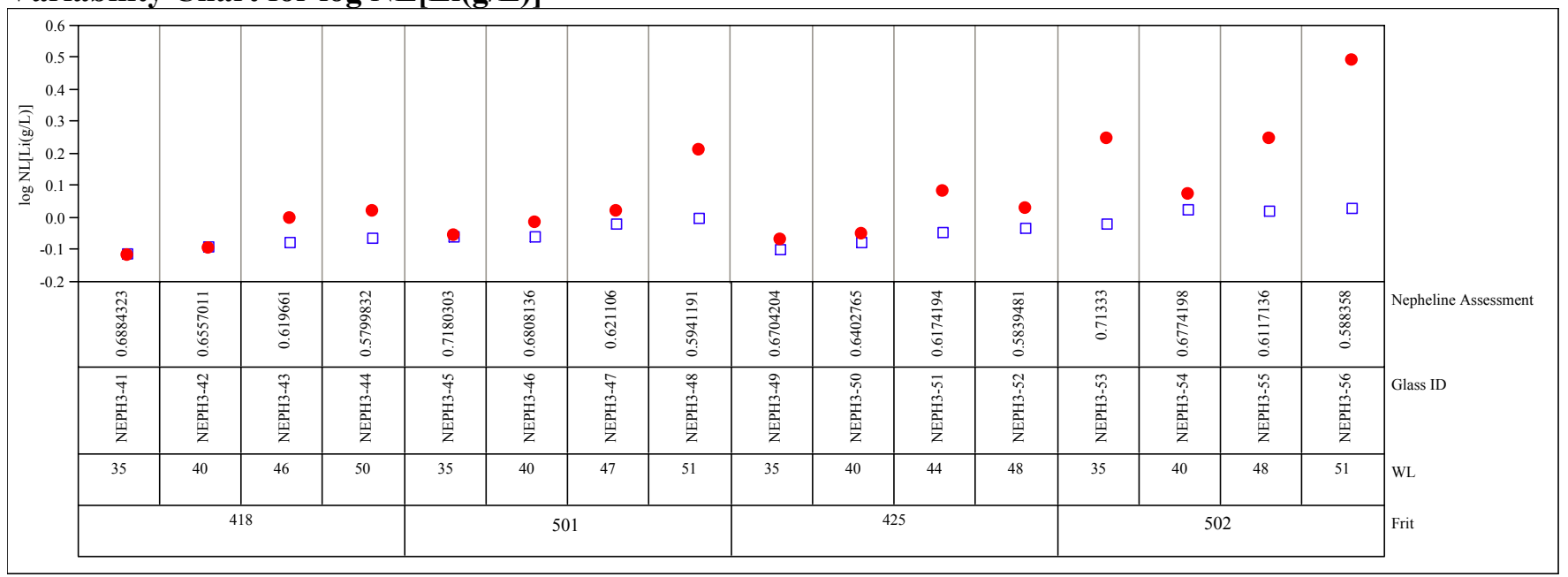




\section{Exhibit E8. Effects of Heat Treatment for Study Glasses by Compositional View (continued)}

Variability Chart for $\log$ NL[Na $(g / L)]$
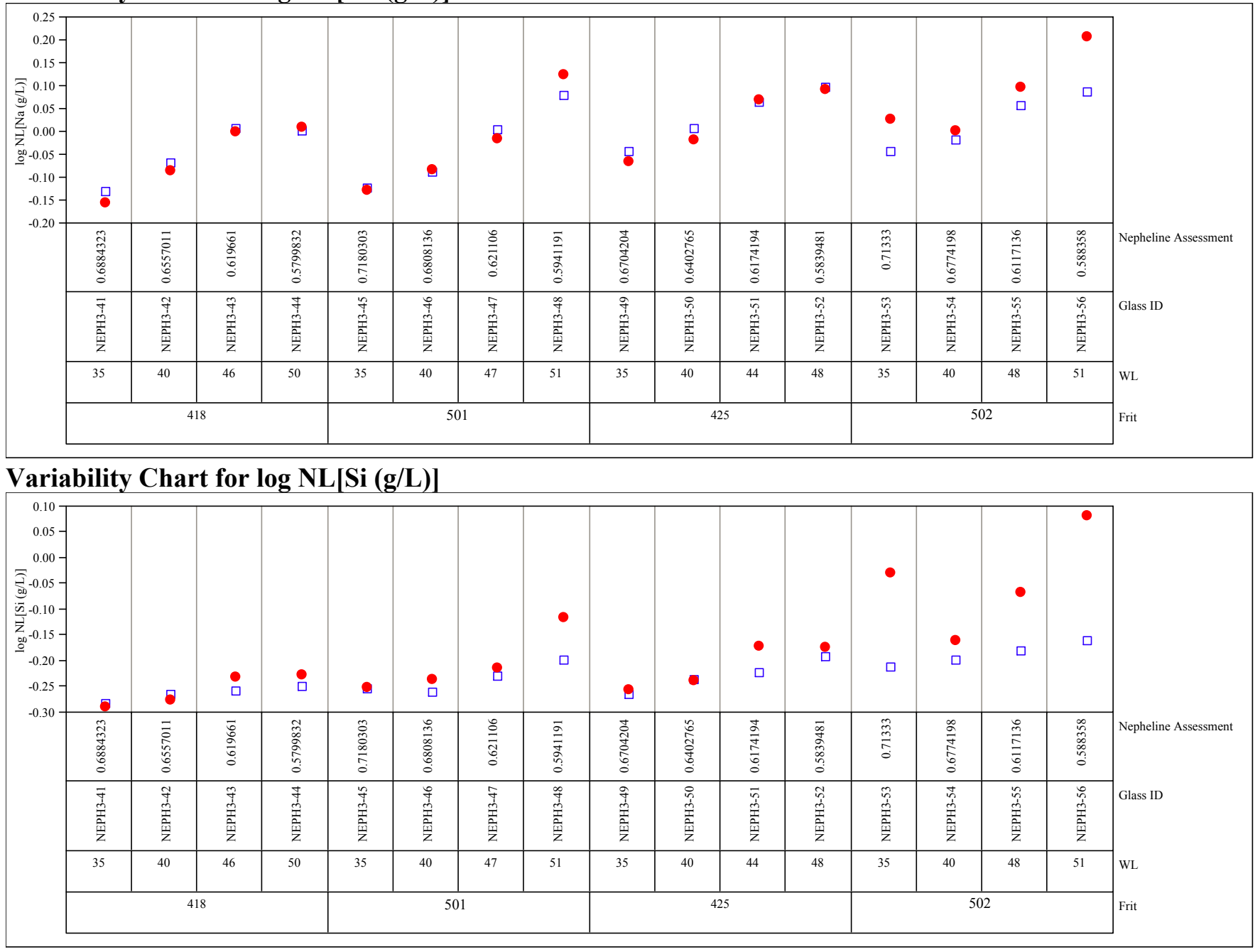


\section{Exhibit E8. Effects of Heat Treatment for Study Glasses by Compositional View (continued)}

\section{Comp View=Measured bc}

Variability Chart for $\log$ NL[B (g/L)]

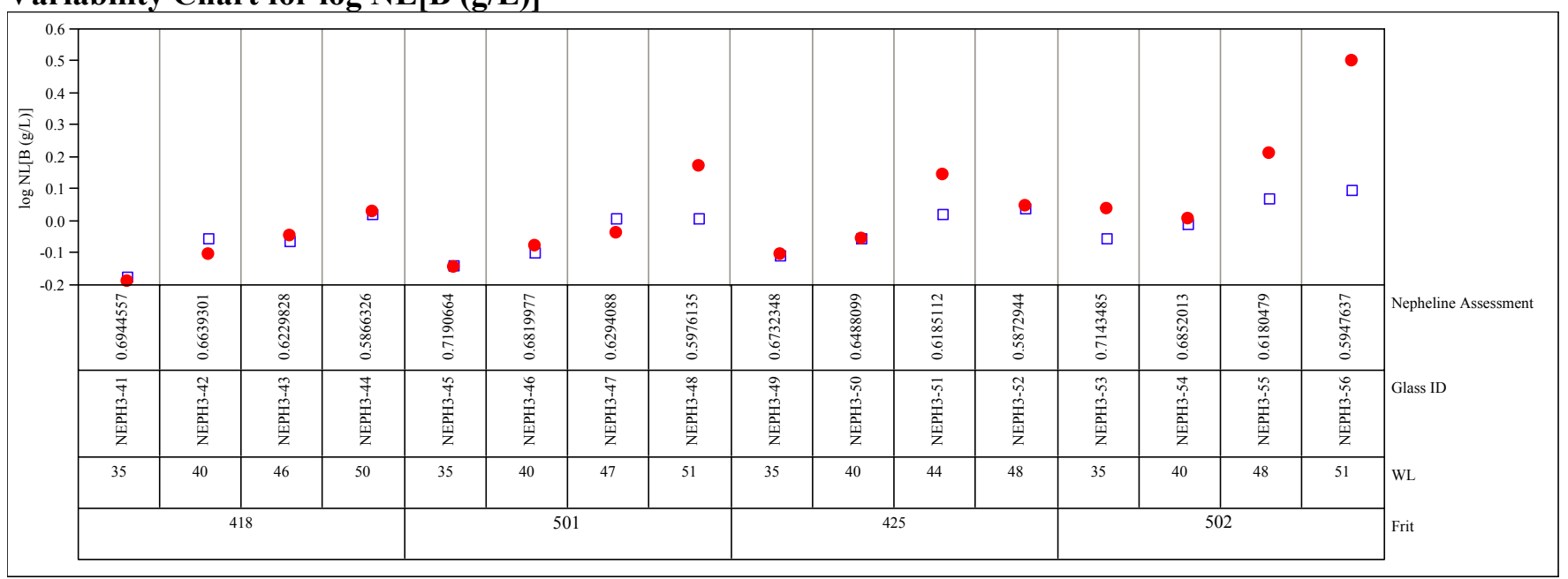

Variability Chart for log NL[Li(g/L)]

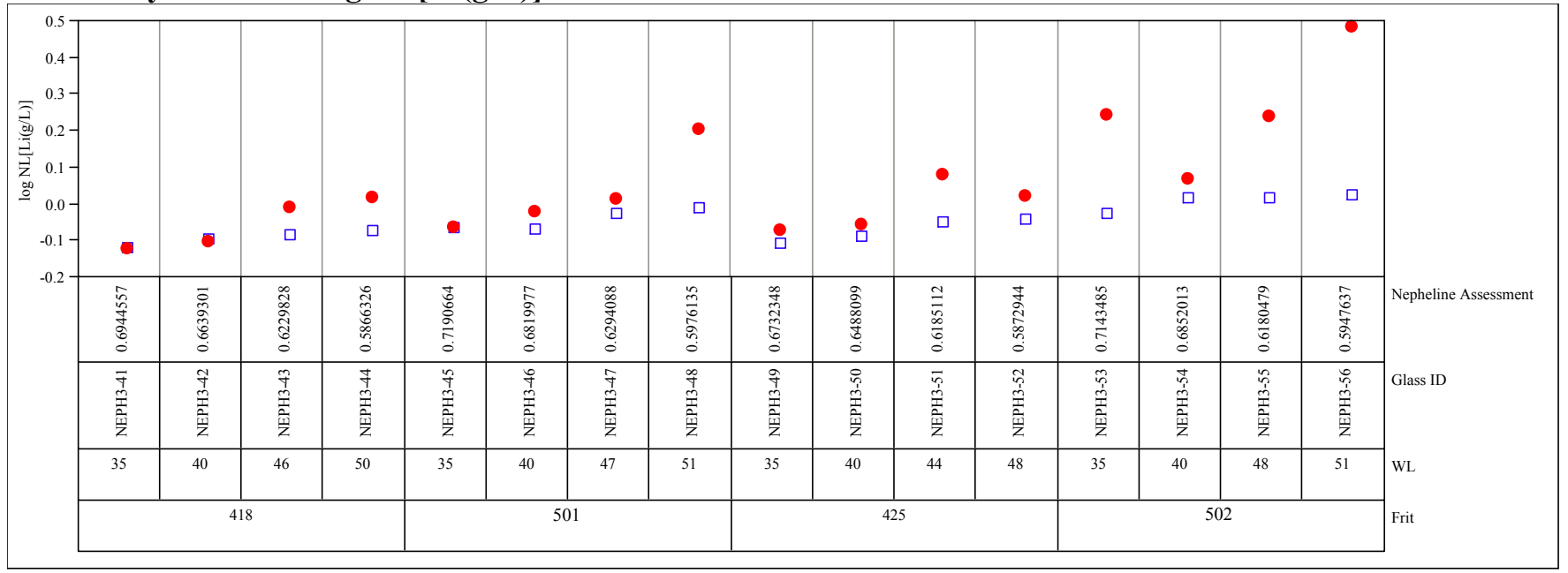




\section{Exhibit E8. Effects of Heat Treatment for Study Glasses by Compositional View (continued)}

Variability Chart for $\log \mathrm{NL}[\mathrm{Na}(\mathrm{g} / \mathrm{L})]$
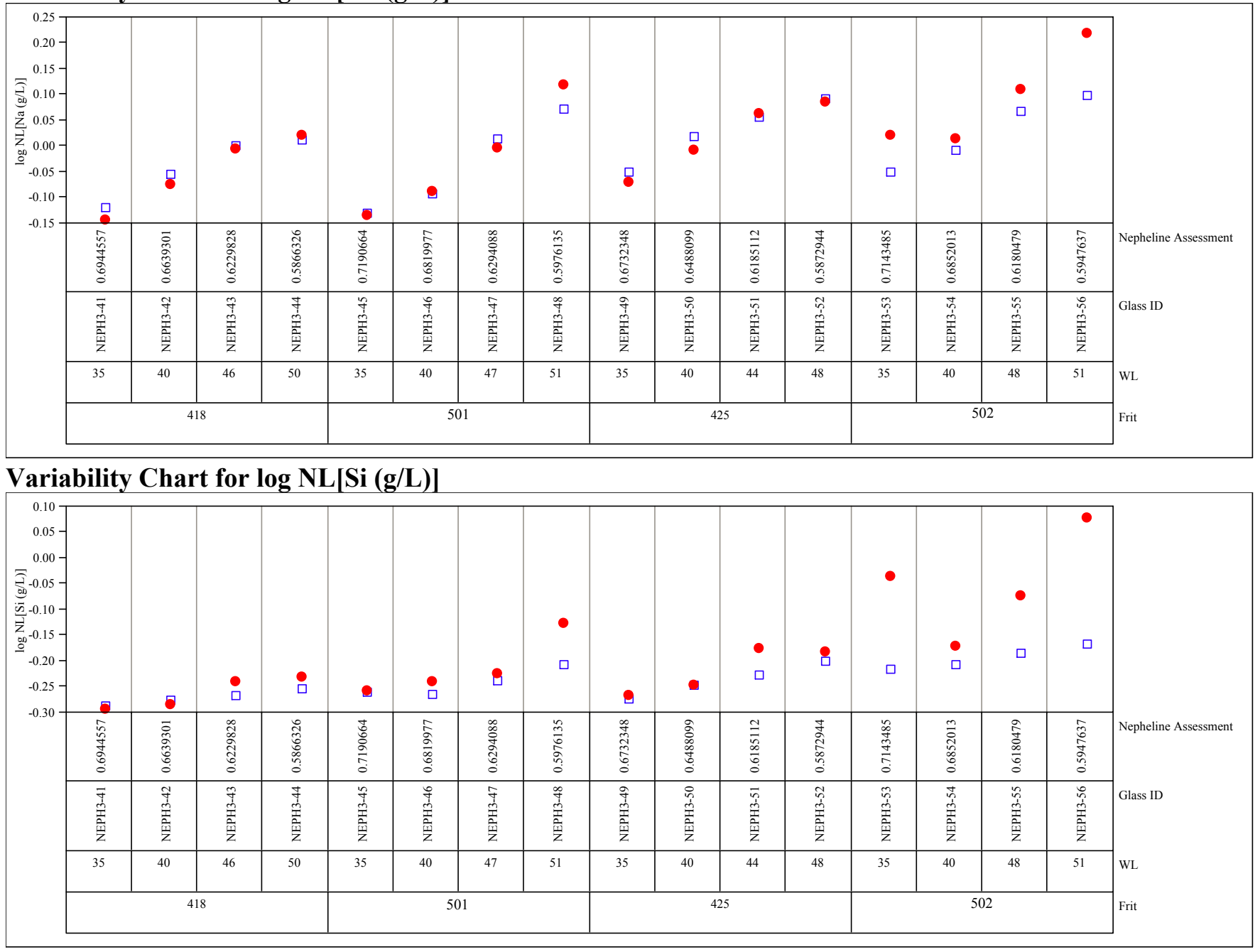


\section{Exhibit E8. Effects of Heat Treatment for Study Glasses by Compositional View (continued)}

\section{Comp View=target}

Variability Chart for $\log$ NL[B (g/L)]

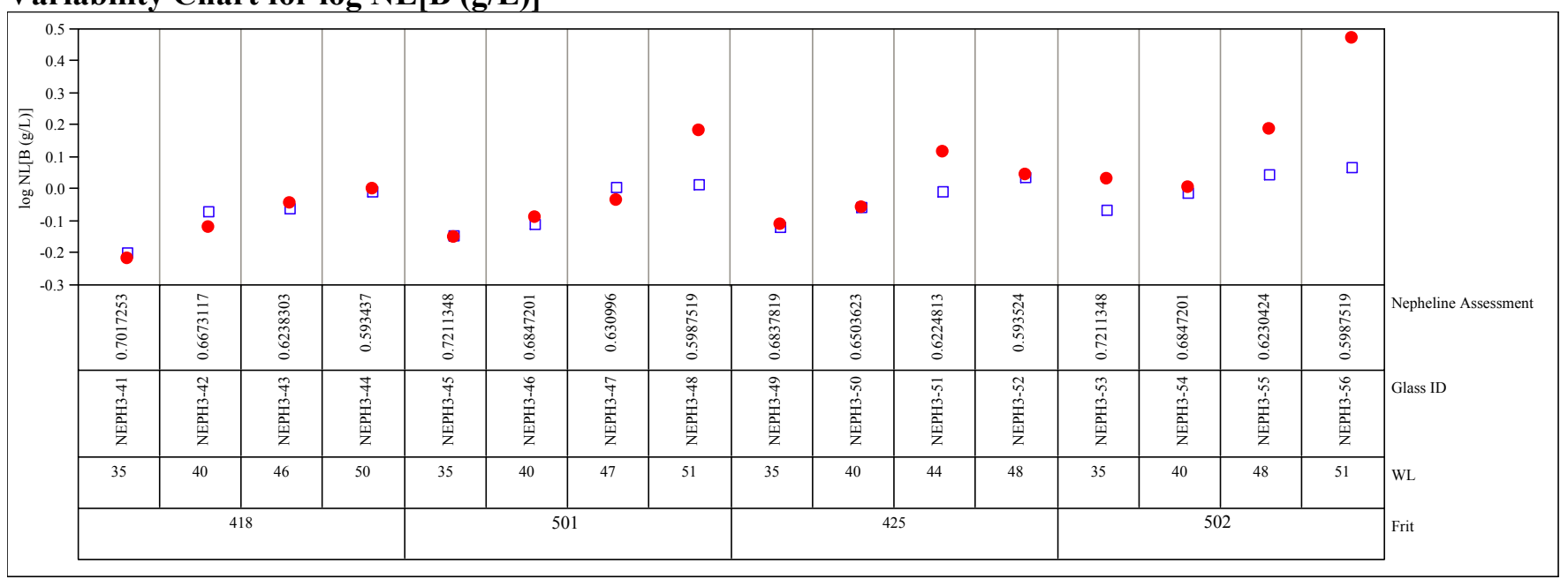

Variability Chart for log NL[Li(g/L)]

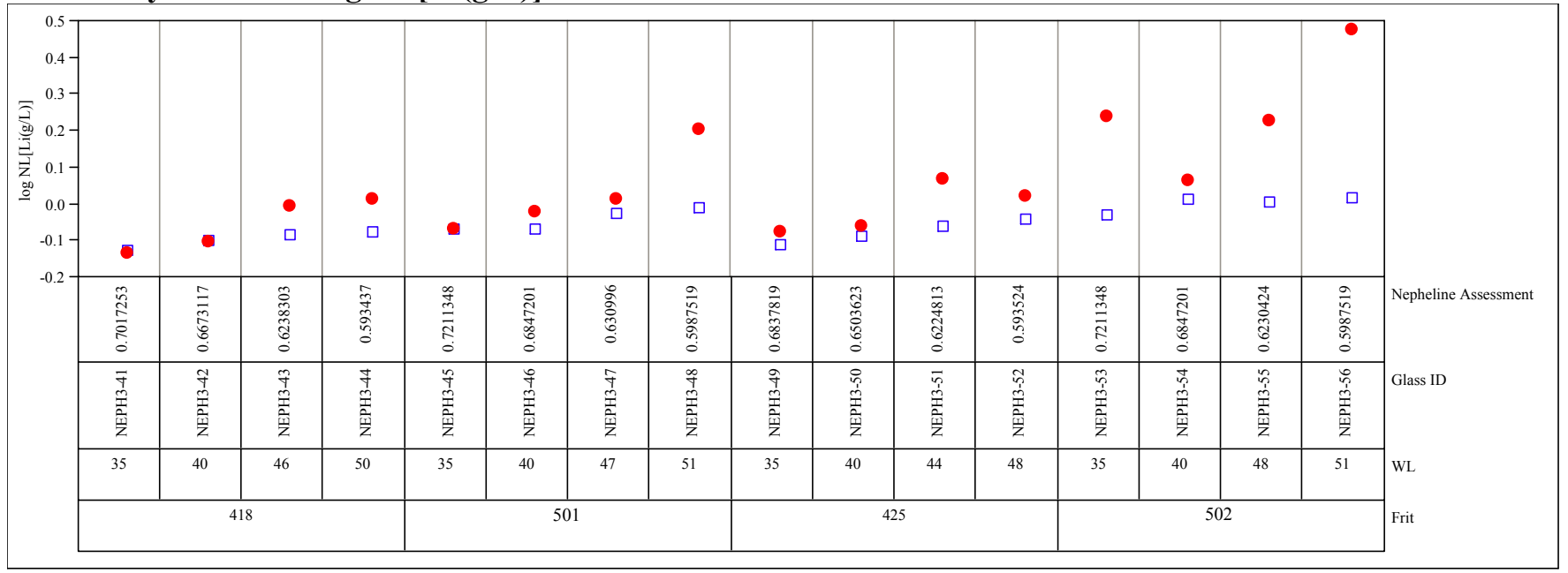




\section{Exhibit E8. Effects of Heat Treatment for Study Glasses by Compositional View (continued)}

Variability Chart for $\log$ NL[Na $(g / L)]$
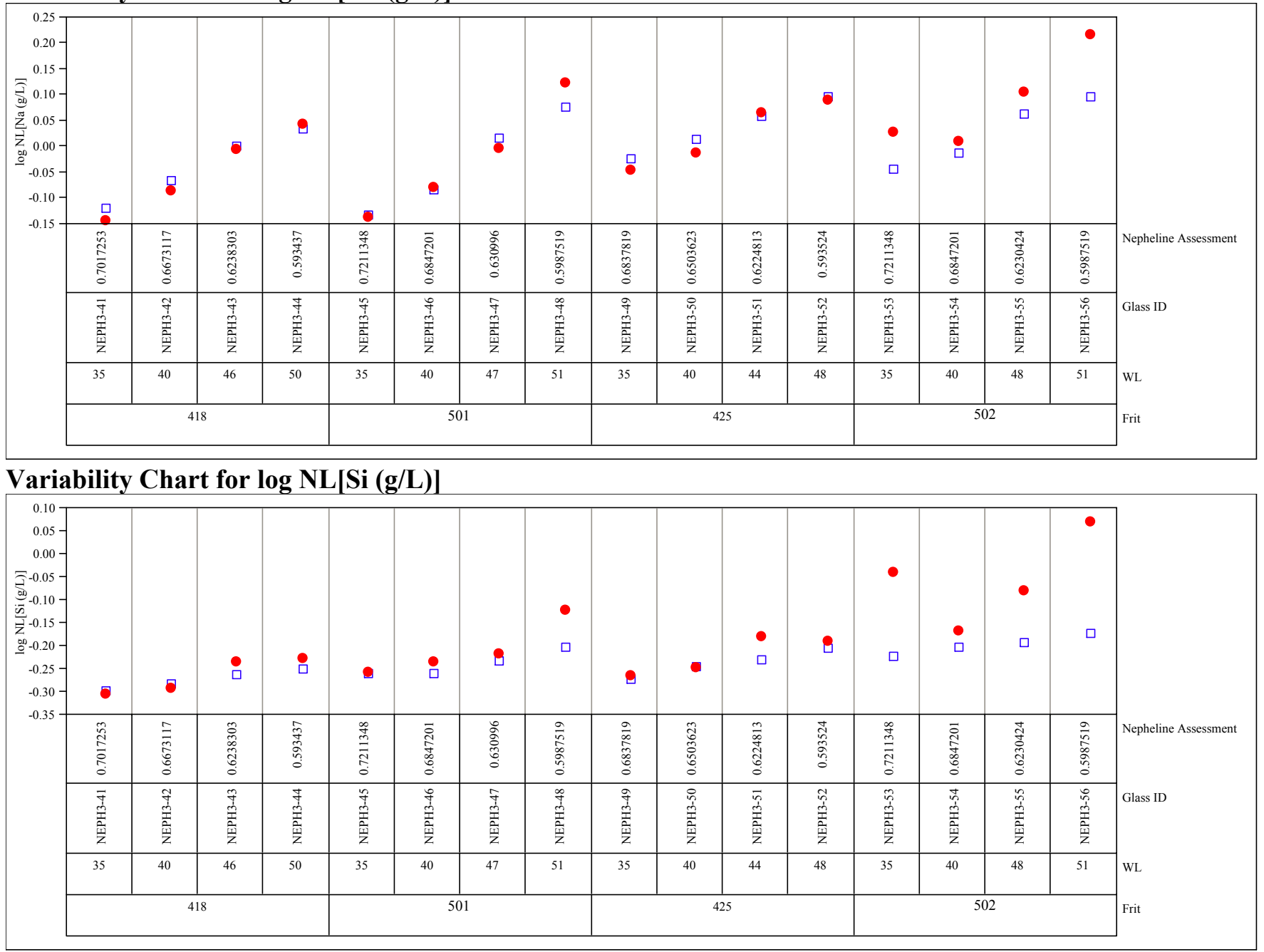
Exhibit E9. del $\mathbf{G p}\left(\Delta \mathbf{G}_{\mathrm{p}}\right)$ Predictions versus Common Logarithm Normalized Leachate $(\log \mathrm{NL}[]$.$) for B, Li, Na, and Si Over All Compositional Views and Heat Treatments$

Bivariate Fit of $\log$ NL[B (g/L)] By del Gp

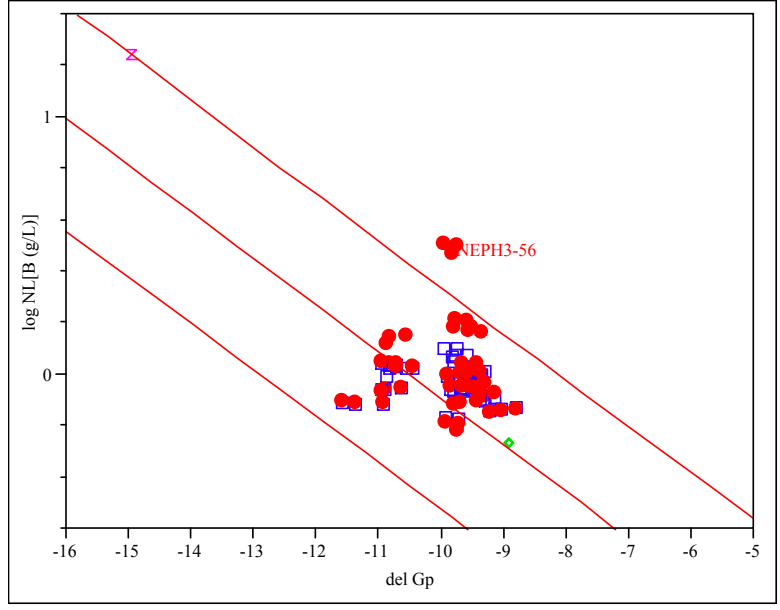

Linear Fit

Bivariate Fit of $\log \mathrm{NL}[\mathrm{Li}(\mathrm{g} / \mathrm{L})]$ By del Gp

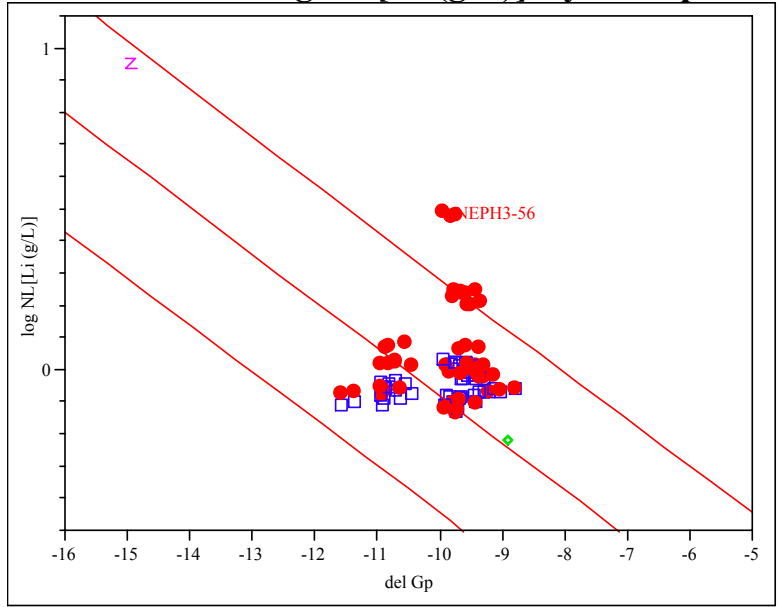

Linear Fit
Bivariate Fit of $\log \mathrm{NL}[\mathrm{Na}(\mathrm{g} / \mathrm{L})]$ By del Gp

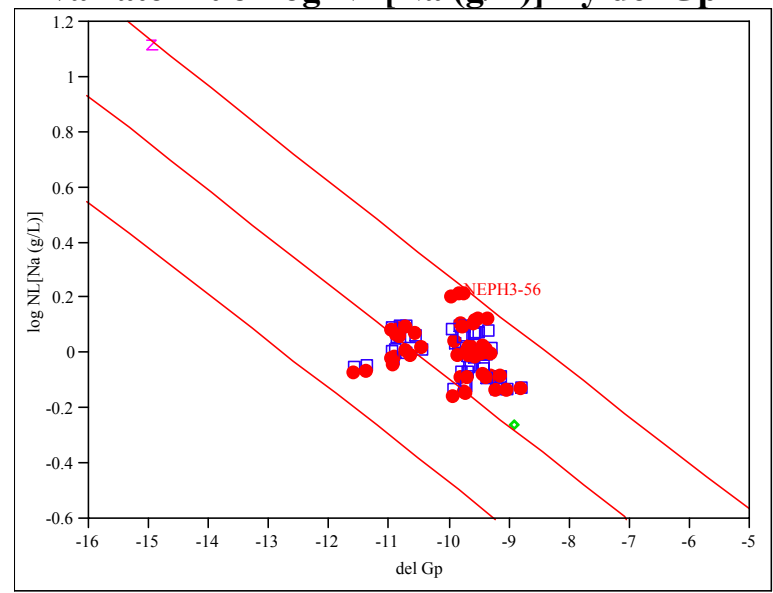

Linear Fit

Bivariate Fit of log NL[Si (g/L)] By del Gp

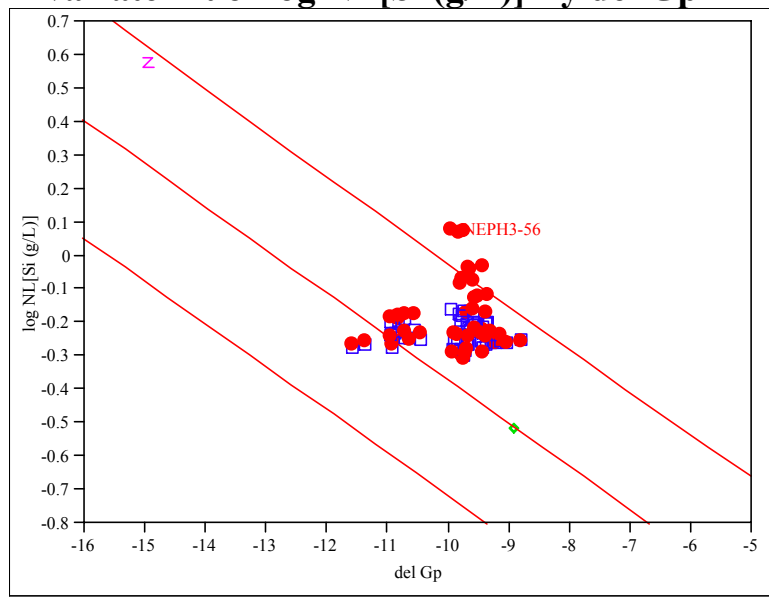

Linear Fit 


\section{Exhibit E10. del Gp $\left(\Delta G_{p}\right)$ Predictions versus Common Logarithm Normalized Leachate (log NL[.]) for $\mathrm{B}, \mathrm{Li}, \mathrm{Na}$, and $\mathrm{Si}$ Over All Compositional Views for Quenched Glasses}

Bivariate Fit of $\log$ NL[B (g/L)] By del Gp

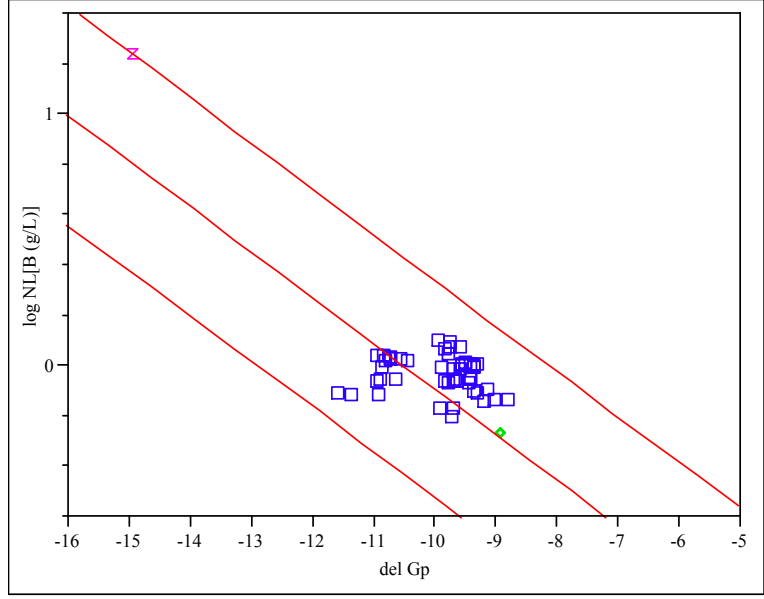

Linear Fit

Bivariate Fit of $\log \mathrm{NL}[\mathrm{Li}(\mathrm{g} / \mathrm{L})]$ By del Gp

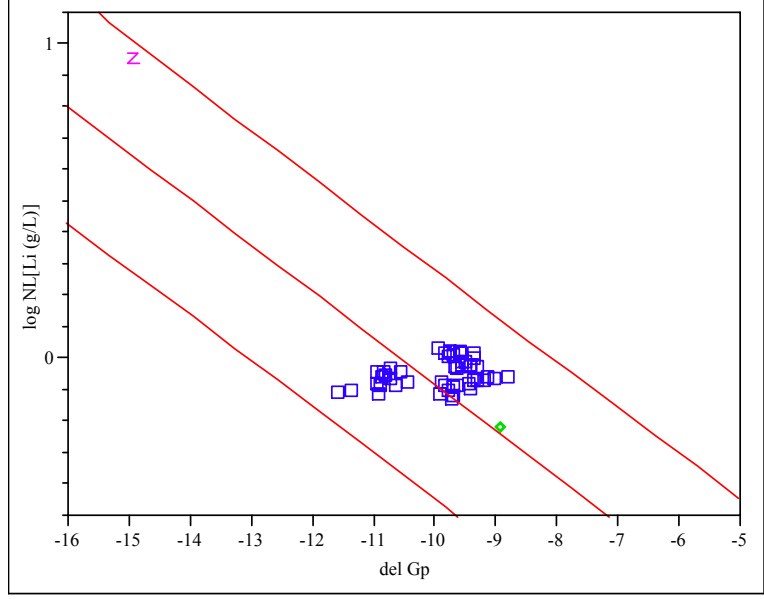

Linear Fit
Bivariate Fit of $\log$ NL[Na (g/L)] By del Gp

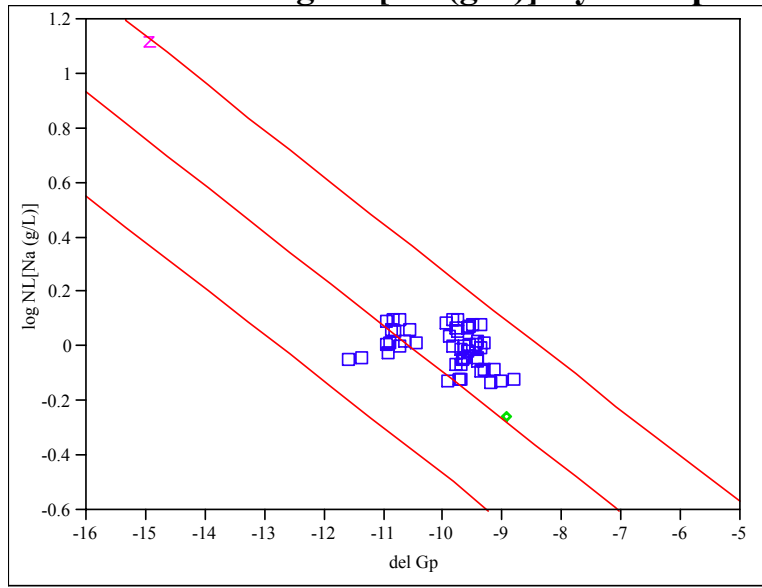

Linear Fit

Bivariate Fit of $\log \mathrm{NL}[\mathrm{Si}(\mathrm{g} / \mathrm{L})]$ By del Gp

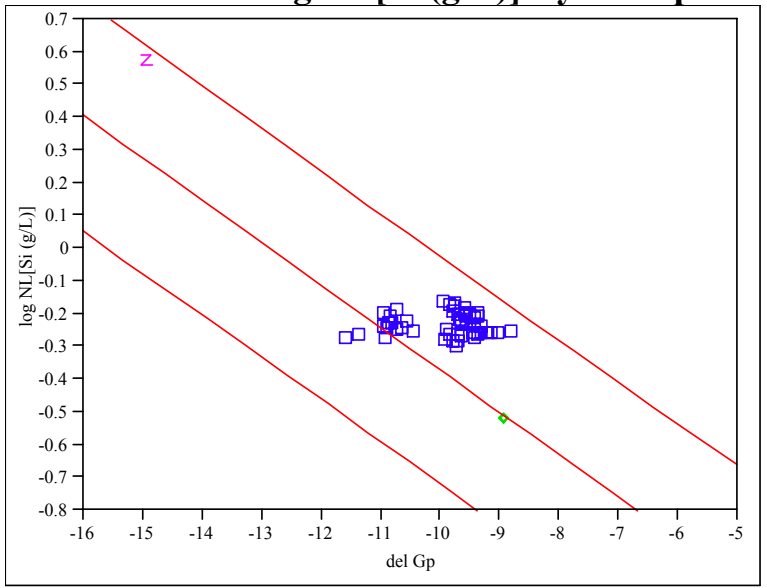

-Linear Fit 


\section{Exhibit E11. del Gp $\left(\Delta G_{p}\right)$ Predictions versus Common Logarithm Normalized Leachate (log NL[.]) for $\mathrm{B}, \mathrm{Li}, \mathrm{Na}$, and $\mathrm{Si}$ \\ Over All Compositional Views for ccc Glasses}

Bivariate Fit of $\log$ NL[B (g/L)] By del Gp

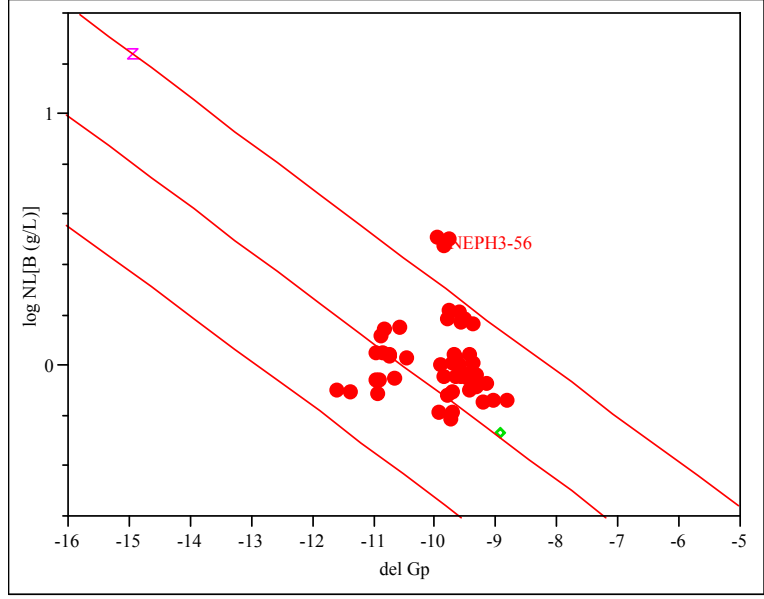

Linear Fit

Bivariate Fit of $\log \mathrm{NL}[\mathrm{Li}(\mathrm{g} / \mathrm{L})]$ By del Gp

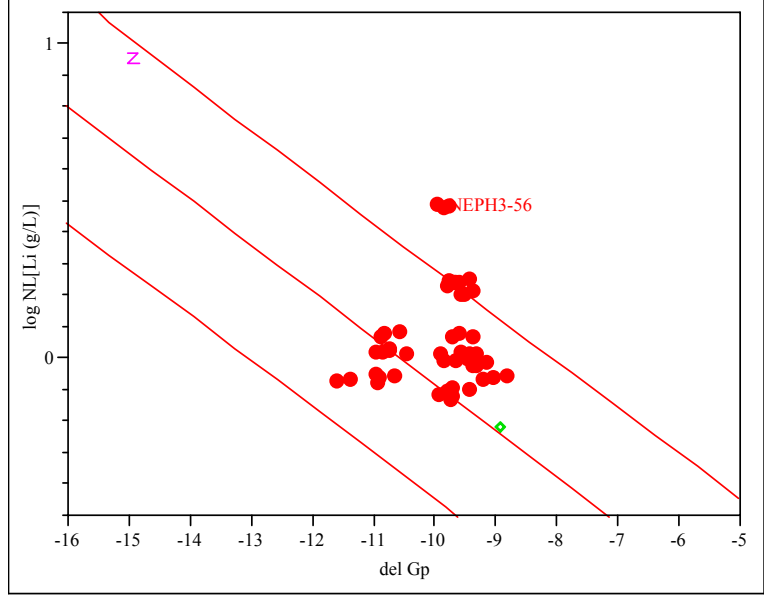

Linear Fit
Bivariate Fit of $\log$ NL[Na (g/L)] By del Gp

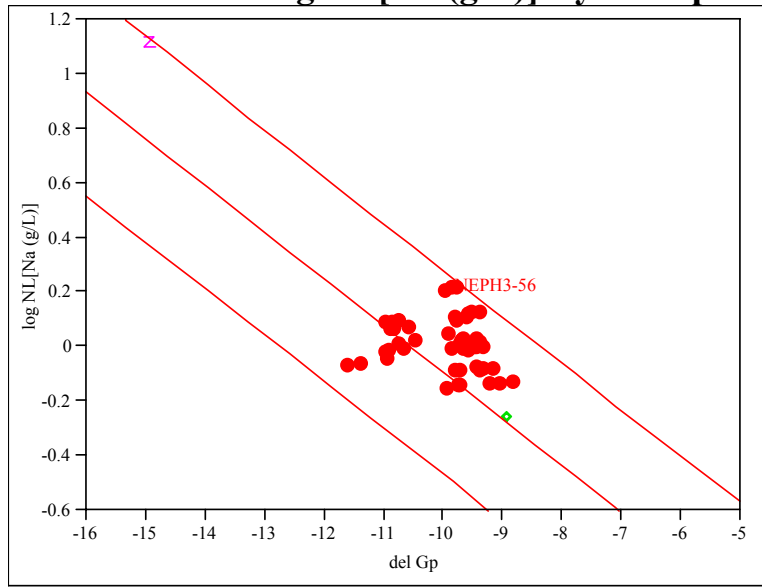

Linear Fit

Bivariate Fit of $\log \mathrm{NL}[\mathrm{Si}(\mathrm{g} / \mathrm{L})]$ By del Gp

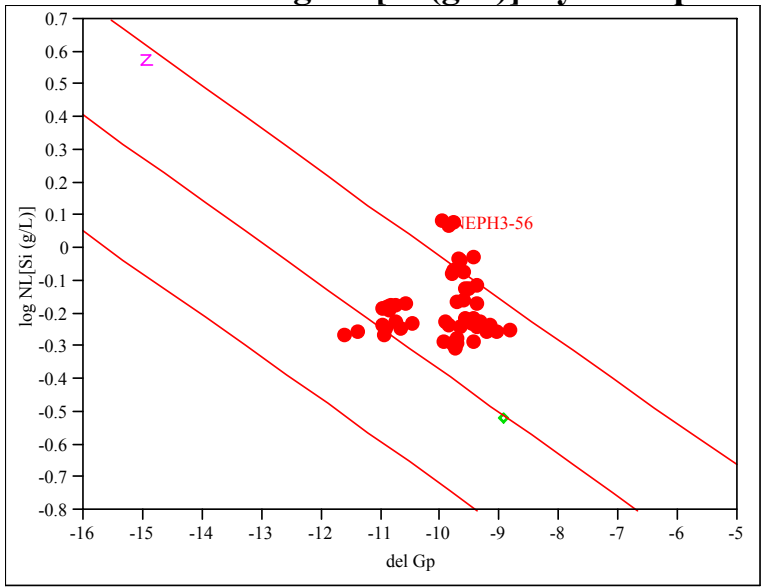

-Linear Fit 


\section{Distribution:}

J.E. Marra, SRNL

R.E. Edwards, SRNL

D.A. Crowley, 999-W

S.L. Marra, 773-A

T.B. Calloway, 999-W

D.B. Burns, 786-5A

G.T. Chandler, 773-A

N.E. Bibler, SRNL

C.M. Jantzen, SRNL

J.R. Harbour, 773-42A

G.G. Wicks, SRNL

R.C. Tuckfield, 773-42A

D.K. Peeler, 999-W

T.B. Edwards, 773-42A

K.M. Fox, 773-A

C.C. Herman, 773-42A
A.S. Choi, 999-W

M.E. Smith, 999-W

M.E. Stone, 999-W

D.H. Miller, 999-W

M.J. Barnes, 999-W

M.S. Miller, 704-S

J.E. Occhipinti, 704-S

T.M. Jones, 999-W

R.M. Hoeppel, 704-27S

B.A. Davis, 704-27S

P.M. Patel, 704-27S

J.F. Iaukea, 704-30S

J.W. Ray, 704-S

M.A. Rios-Armstrong, 766-H

J.M. Gillam, 766-H

H.B. Shah, 766-H 